ERDÉLYI TUDOMÁNYOS FÜZETEK

268

\author{
ZSEMLYEI BORBÁLA
}

\title{
KICSINYÍTŐ KÉPZŐK AZ ERDÉLYI RÉGISÉGBEN
}

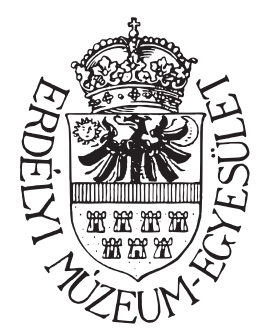

Kolozsvár, 2011 
A kötet megjelenését a Bethlen Gábor Alap és a Magyar Tudományos Akadémia
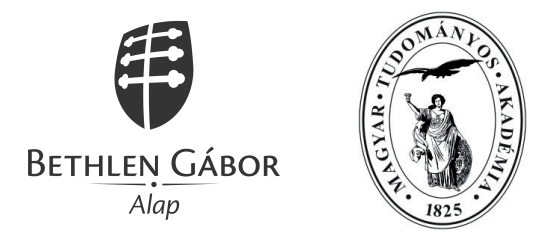

támogatta.

(C) Erdélyi Múzeum-Egyesület, 2011

(C) Zsemlyei Borbála

Felelős kiadó

BIRÓ ANNAMÁRIA

Korrektúra

FAZAKAS EMESE

Müszaki szerkesztés, tördelés

BODÓ ZALÁN

Nyomdai munkálatok

GLORIA, Kolozsvár

Felelős vezető

NAGY PÉTER

Descrierea CIP a Bibliotecii Naționale a României ZSEMLYEI, BORBÁLA

Kicsinyítő képzők az erdélyi régiségben / Zsemlyei Borbála. Cluj-Napoca: Societatea Muzeului Ardelean, 2011

Bibliogr.

ISBN 978-606-8178-24-0

811.511.141 
Szüleimnek 



\section{TARTALOM}

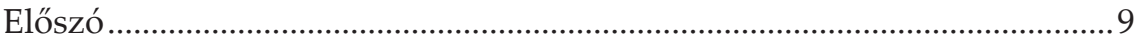

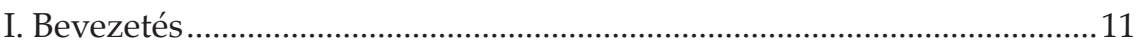

I.1. A kutatás tárgya, célja................................................................... 15

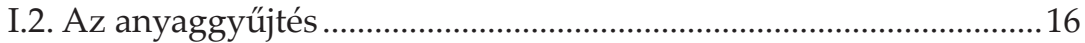

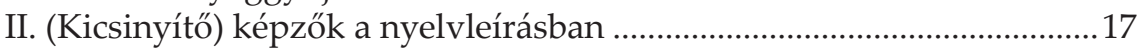

II.1. A terminológia kialakulásának története ...................................... 17

II.2. Képzőmeghatározások a mai magyar nyelvtanokban ...................20

II.3. Kicsinyítő képzők a régi grammatikákban ....................................22

II.4. Diminutívum-meghatározások a mai nyelvtanokban .................29

II.5. Képző-e a kicsinyítő képző? Terminológiai problémák.................30

II.6. Kísérlet a diminutívum meghatározására .................................... 34

III. A SzT.-ban szereplő kicsinyítő képzők kialakulásának története .........37

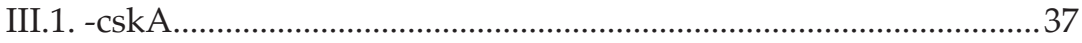

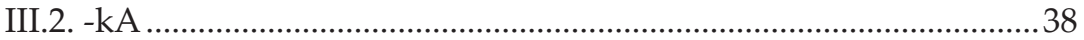

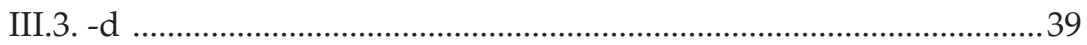

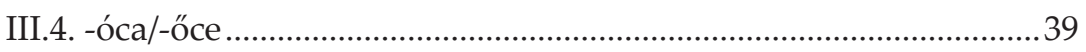

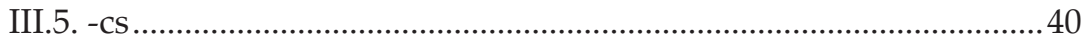

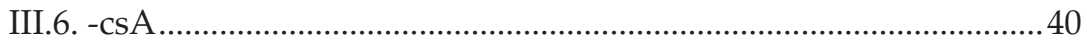

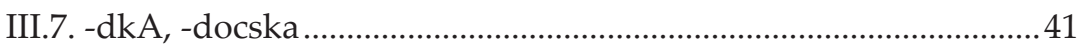

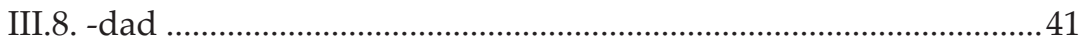

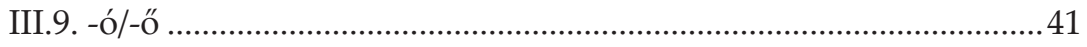

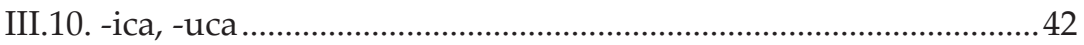

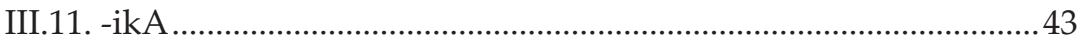

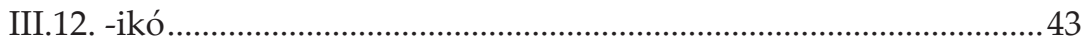

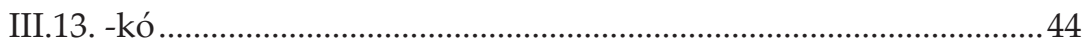

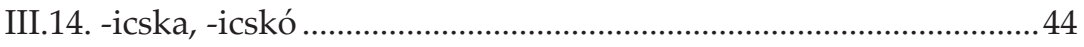

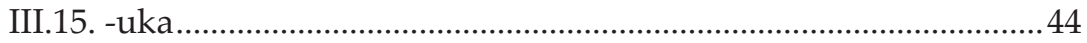

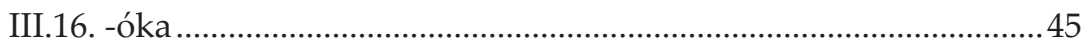

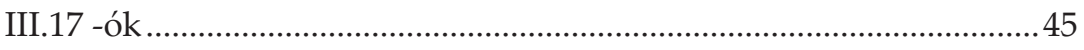

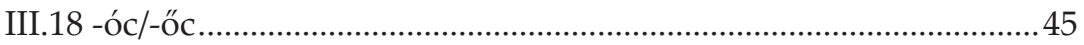


IV. A kicsinyítő képzők vizsgálatában alkalmazható szempontok ..............47

IV.1. A kicsinyítő képzős származékok szemantikája ..............................4 47

IV.2. A kicsinyítő képzők morfopragmatikai jellemzői............................63

IV.3. A kicsinyítő képzők szociolingvisztikai meghatározottsága .............75

IV.4. A kicsinyítő képzők kapcsolódásának szabályai ............................92

IV.5. A kicsinyítő képzők alaktani jellegzetességei ................................105

IV.6. A kicsinyítő képzők produktivitása ................................................124

IV.7. Kicsinyítő képzők és az alaptag szófaja ........................................128

IV.8. A kicsinyítő képzős származékok szintaktikai

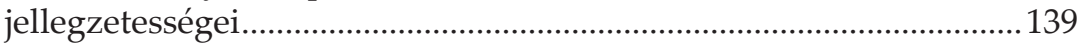

IV.9. A kicsinyítő képzők földrajzi megoszlása az erdélyi

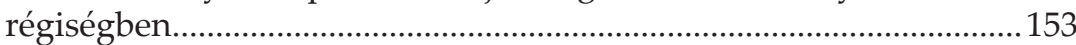

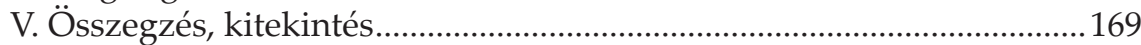

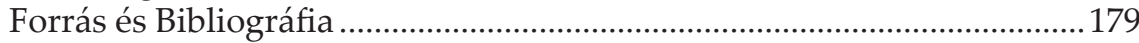

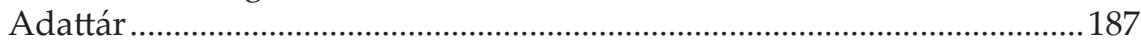

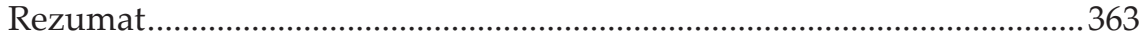

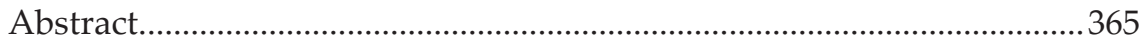




\section{ELŐSZÓ}

A Kicsinyitő képzók az erdélyi régiségben a 2009-ben megvédett doktori disszertációm szövegének módosított változata.

Vizsgálataim forrása az Erdélyi magyar szótörténeti tárnak a kutatás lezárásáig megjelent 12 kötete volt. Választásom azért esett erre a témára, mert a Tár szerkesztőjeként rádöbbentem, hogy ez a mü hihetetlenül gazdag nyelvi anyagot kínál: az adatok eredeti kontextusukban és pontos forrásmegjelöléssel jelennek meg, így a vizsgálat során lehetővé vált a képzőleírás hagyományos szempontjain túl olyanokat is figyelembe venni, mint a történeti szociolingvisztika, morfopragmatika vagy a történeti nyelvföldrajz. Azt remélem, hogy a történeti anyag alapján összeállított szempontok szerinti kutatás közelebb vihet a nyelvészeti leírás perifériájára szorult kicsinyítő képzők rendszerének alaposabb megismeréséhez.

Köszönettel tartozom Péntek János professzor úrnak, a doktori dolgozat irányítójának szakmai és emberi támogatásáért. Külön köszönet illeti Fazakas Emesét önzetlen tanácsaiért, hasznos útbaigazításaiért. Köszönöm doktori dolgozatom opponenseinek, Sárosi Zsófiának és Cs. Nagy Lajosnak értékes észrevételeiket, továbbá a kolozsvári BBTE Magyar és Általános Nyelvészeti Tanszék minden tagjának a szakmai és baráti segítséget. 



\section{BEVEZETÉS}

A kicsinyítő képzők, illetve az ezekkel ellátott származékok vizsgálata a nyelvészeti leírások perifériájára szorult. A magyar szakirodalomban igen kevés olyan tanulmány van, amely a denominális névszóképzők ezen részrendszerével foglalkozna.

A kicsinyítő képzők a denominális névszóképzők sajátos csoportját alkotják. Szerepük elsősorban nem új szónak a létrehozása, hanem jelentésbeli árnyalatnak a kifejezése, emiatt nem tipikus képzők. Kialakulásuk, megjelenésük a beszélők attitüdjében keresendő, abban a nyelvi igényben, amely a kifejezés szürkeségének elkerülésére törekszik. A kicsinyítés jellegzetessége pontosan a játékosságban rejlik, s ezért a mindenkori beszélők a rendelkezésre álló formánsokat számtalan lehetséges variációban összekapcsolják, állandóan változtatva, növelve e képzők állományát (Szegfü 1991: 207).

Ennek eredményeként a diminutívumok nagyon elterjedtek a különböző nyelvekben, bár használati gyakoriságuk, produktivitásuk, illetve rendszerszerüségük nyelvenként különbözik. Az angolban például viszonylag kevés a kicsinyítő képző szemben más európai nyelvekkel (spanyol, olasz, orosz), a svédben viszont egy néhány lexikalizálódott származékon kívül egyáltalán nincs is ${ }^{1}$. Másrészt a rendszer bonyolultságában is különböznek a nyelvek. A magyarban és németben egy-két formáns áll a beszélők rendelkezésére (-cska/-cske, -kal-ke; -lein, -chen), ezzel szemben az oroszban a diminutívumok bonyolult rendszert képeznek, a beszélők különböző szemantikai és pragmatikai jegyeik alapján válogatják ki a legmegfelelőbbet (Bronislava 1987, Dahl 2006: 594).

Mivel a nyelvekre általában jellemző a diminutívumok használata (függetlenül attól, hogy milyen mértékben), vannak olyan elméletek, amelyek szerint ezek fonetikai felépítése a különböző nyelvekben hasonló, hiszen

\footnotetext{
${ }^{1}$ Pl.: fossing 'lábacska' a fot tőből (1. Dahl 2006).
} 
ikonikus kapcsolat tételezhető alak és jelentés között², ugyanis a fizikai méret és a szótestben az azt jelölő fonetikai elemek között kapcsolat van. Ez egy 50 nyelvre kiterjesztett vizsgálat alaptézise volt (vö. Bauer 1996: 189-206). A nyelvek kiválasztásának kritériuma az volt, hogy különböző nyelvcsaládokba tartozzanak, azaz genetikailag egymástól távol essenek. Abból a feltételezésből indultak ki, hogy az elöl képzett magánhangzók, valamint a palatális mássalhangzók a diminutív szóelemekkel azért állnak ikonikus kapcsolatban, mert a nyelv és a szájpadlás közti keskeny rés a diminutívum által denotált kis méretet jelképezi. ${ }^{3} \mathrm{Az} 50$ nyelven végzett vizsgálat eredménye viszont az volt, hogy nem lehet semmiféle univerzálét feltételezni, egyes nyelvekre jellemző, másokra nem, és bármiféle hangszimbolizmus nyelv- és kultúraspecifikus, nem univerzális. ${ }^{4}$

A magyar nyelvtörténet folyamán a képzők változtak: az egyes nyelvtörténeti korszakokban ható hangváltozási tendenciák befolyásolták a képzők fonetikai felépítését. Egy másik változási tendencia a képzők jelentésének bővülését eredményezte. Harmadsorban egy kor képzőállománya egy másik korétól bizonyos formánsok megjelenésében, mások kiveszésében különbözik. A sok változás mellett a kicsinyítő képzők kategóriája viszonylagos állandóságot mutat: bár a nyelvtörténeti korok folyamán jelentek meg új elemek a kicsinyítés kifejezésére, tehát az állomány maga bővült, jelentésük alapjában véve ugyanaz maradt, esetleg árnyalati módosulások figyelhetők meg. E képzőcsoportnak másik sajátossága és érdekessége az, hogy az ősi formánsok sem vesztek ki, egy-két származékban, illetve bizonyos nyelvjárásokban ma is élnek. A-csa/-cse funkciója például az ómagyar kor második felétől becenevek létrehozására korlátozódott (pl.: Ancsa, Borcsa, Julcsa), a szlavóniai nyelvjárásban viszont a 20. század első felében is ez volt a leggyakoribb kicsinyítő képző (pl.: aprócsa, egércse, küszöbcse), sőt határozószókban sem volt ritka (pl.: nagyszerǘcsén) (Zsilinszky 2003: 181).

A különböző diminutívumok (-cskal-cske, -kal-ke, -d, -ikó stb.) alapjában véve sem szemantikai, sem pragmatikai szempontból nem különböznek egymástól (Kiefer 2004: 332), egymásnak a szúk értelemben vett szinoni-

2 „The frequent occurrence of diminutives of 'higher tonality, including high tones, high front vowels and fronted consonants' (Juraffsky 1996: 534) suggests an iconic link between meaning and form." (idézi Dahl 2006: 594).

${ }^{3},(\ldots)$ the general idea is that close vowels and palatal consonants are iconic with relation to diminutives because the close approximation of the tongue with the roof of the mouth reflects the small size denoted by the diminutive" (Bauer 1996: 191).

${ }^{4}$,There does not appear to be any universal principle of sound symbolism operating in markers of the diminutive and augmentative such that palatal articulation correlates with diminutives and not with augmentatives (...) The preference for close front vowels and palatal consonants, to the extent that it captures any real generalisation at all, seems to be restricted to particular language families, including Indo-European (...) Any patterns of sound symbolism seem to be language and culture specific not universal" (Bauer 1996: 202). 
mái. Megterheltségük különbözőségét egyrészt fonetikai ${ }^{5}$, másrészt nyelvtörténeti ${ }^{6}$ okok magyarázzák.

A diminutívumok használatával kapcsolatban a magyar nyelvi és nyelvű beszélőknek különböző elvárásai vannak, például gyakrabban fordulnak elő beszélt nyelvben, mint írottban, gyakoribbak a középkorú, kevésbé iskolázott, rurális környezetben lakó nők nyelvében, mint például a fiatal, egyetemet végzett, városi környezetben élő férfiak nyelvében (vö. Beeching 2007: 71). Ha valamelyik paraméter megváltozik, akkor valószínűleg valamilyen stratégiai meggondolásból használják a beszélők, hiszen a pozitív udvariassági elemek a társadalmi távolság csökkentésére alkalmasak (Brown-Levinson 1987: 130).

A diminutívumokkal ellátott alakok megjelenése nem jósolható meg, azt viszont meg lehet állapítani, hogy melyek azok a beszédhelyzetek, amelyek megengedik a kicsinyített alakok használatát (gyermekorientált beszédhelyzet, szerelmesek beszéde, kedvenc állat felé irányuló beszéd) (Kiefer 2004: 333). Ezekben a beszédhelyzetekben a diminutívumok gyengédséget, ragaszkodást, szeretetet fejeznek ki. A diminutívum használatát tehát a beszédhelyzet irányítja és szabja meg, amelyben a döntő szerep a beszédpartnerek közti viszonyé (Kiefer 2004: 338), ugyanis ez a képző elsősorban a beszélő érzelmeit képezi le (öröm, boldogság, szerelem/szeretet, ragaszkodás). Ha egy diminutívum felnőttek közti beszélgetésben jelenik meg (pl.: borocska, söröcske), akkor az azt mutatja, hogy köztük intim, közeli, informális a viszony. Intellektuális termékek, politikai vagy más szervezetek, valamint funkciók és foglalkozások neveinek diminutivizált alakja általában pejoratív jelentésű (pl.: újságocska, reformocska, pártocska, músorocska, elnököcske), az a pozitív viszonyulás, amely a diminutívumok megjelenését favorizáló beszédhelyzetekben jellemzően megjelenik, innen teljességgel hiányzik (Kiefer 2004: 338-9). Annak ellenére, hogy a 'kis, kicsi' jelentésjegy ezekben az alakokban is megvan, az inkább 'jelentéktelen, triviális' értelemben jelenik meg. Tehát a diminutívum ebben az esetben a jelöltnek nem méretbeli, hanem jelentőségbeli csökkenését okozza (Kiefer 2004: 339). A pejoratív jelentés mellékneveknél is előfordulhat akkor, ha valamilyen negatív jelentésű melléknévhez kapcsolódik a diminutívum (pl.: butácska, ostobácska). A beszélő nem minden esetben vállalja a negatív tulajdonság megnevezését, ezért különböző enyhítési stratégiákhoz folyamodhat, amelyeknek egyik lehetősége a diminutívum használata (Kiefer 2004: 340). A kicsinyítés (kicsiség) tehát stratégiai eszközként jelenhet meg eltérő beszédhelyzetekben. Ha a beszélő nem teljesen biztos beszédtársá-

\footnotetext{
${ }^{5}$ L. a kicsinyítő képzők kapcsolódási szabályait vizsgáló fejezet.

${ }^{6}$ A különböző formánsok megterheltségi foka nyelvtörténeti koronként változó.
} 
nak véleményében, a kicsinyítő képzővel saját véleményét is biztonságosan határozatlanná, homályossá teheti (Beeching 2007: 74).

A kicsinyítő képző funkciója tehát az, hogy az alapszó méretbeli csökkentését jelezze, az alapszó valamely más jelentésjegyét csökkentse, illetve a 'kis, kicsi' jelentésjegyet a teljes beszédszituációra kiterjessze. Ennek a szemantikai jegynek a teljes beszédszituációra való metaforikus kiterjesztése kb. annyit tesz, hogy: „ugyanúgy, ahogy a fizikai mérete lehet kicsi valaminek, az én kérésem is kicsi" (Beeching 2007: 82).

Problematikus lehet olyan főnevek elemzése, amelyek tartalmaznak ugyan egy -ka morfémát, de jelentésüknek olyannyira nincs közük történetileg sem a kicsiség fogalmához (tehát nem is lexikalizálódott származék), hogy felmerülhet annak a lehetősége, hogy ez a formáns (idegen nyelvi hatásra) egyszerüen főnévképző, nem áll összefüggésben a kicsinyítő képzővel, csak homoním azzal' . Ilyen például az oroszban a $-k a$, amely bizonyos származékokban egyértelmúen kicsinyítő képző (knižka 'könyvecske'), de ugyanez a morféma a nőnemü főnevek végződése is lehet (švedka 'svéd nő'), hasonló funkciója van a felvidéki magyar nyelvhasználatban elterjedt doktorka - $k a$ végződésének is, vagy akár általános főnevesítő képző: sotka, amelynek jelentése 'a százas számmal kapcsolatos'. Az Erdélyi magyar szótörténeti tárban ${ }^{8}$ ilyen például a magyarka, otthonka származék. Ezzel rokon jelenség az, hogy az erdélyi magyarban a román kölcsönszó végének tulajdonít a nyelvérzék kicsinyítő szerepet, bár az átadó nyelvben nincs meg ez a szerep. Ilyen például a SzT.-ban megjelenő subica, subika címszó, mindkettő 'kis suba' jelentésü, bár a román şubeică jelentése 'rövid bunda'. Az történik tehát, hogy egy olyan fonémacsoport értelmeződik morfémaként, amelynek az átadó nyelvben nincs ilyen szerepe. Benő Attila is rámutat, hogy „a román -că, -iță, -uță végű szavak a magyarban -ka, -ica, -uca szóvégűvé lettek, és némely esetben kicsinyítő képzőként értelmeződtek. Ezt a feltételezést egyértelműen igazolja a jelentésváltozások iránya: az ilyen szavak egy része jelentésszerkezetébe felvette a 'kis', 'apró' jelentésjegyet. Ezt szemléltetik a következő adatok: r. căruță 'kocsi, szekér' > m. karuca 1. kisebb ökörszekér, 3. kis szekér (stb.)" (Benő 2008: 103). A román szóvég kicsinyítő képzőként való értelmezését elősegíti az, hogy analóg képzésekről van szó, hiszen az említett fonémacsoportoknak a románban valóban lehet kicsinyítő képző funkciója is. Ezt támasztja alá a SzT. adatai közül a

7 "It is not always easy to distinguish here what is productive in a language from what is rather the frozen result of earlier processes, or what is universally available from what is a language-specific conventionalization. Moreover, morphemes that are used to form diminutives and augmentatives can also have various other functions that at least synchronically seem to have little to do with size, inviting the postulation of homonymy." (Dahl 2006: 594).

${ }^{8}$ A továbbiakban SzT. 
lunkuca 'rétecske' és pojenica 'kis erdei tisztás', amelyeknek eredeti jelentésük is hasonló: luncuță 'kis lanka, kis rét', poieniță 'kis (erdei) tisztás'.

\section{I.1. A kutatás tárgya, célja}

Kutatásom az Erdélyi magyar szótörténeti tár 16-19. századi kicsinyítő képzőinek, illetve kicsinyítő képzőkkel létrejött (esetleg lexikalizálódott) származékainak vizsgálatát célozza. A meghatározott korszak és régió tanulmányozása a kijelölt adatállomány alapján szervesen illeszkedik a nyelvtörténeti kutatások sorába, és kiegészíti azt, hiszen átfogó jellegű elemzés még nincs a denominális névszóképzők ezen részrendszeréről.

A kicsinyítő képzők vizsgálata a nyelvészeti kutatások igen kis szeletét képezi, amelyről látszólag - és a szakirodalom tanúsága szerint is - nem lehet túl sokat mondani. Az alaposabb vizsgálatok során azonban kiderült, hogy több elemzési szempont figyelembevételével részletes képet kaphatunk a kicsinyítő képzők erdélyi régiségben való használatáról. Az elemzés eredményei az említett időszak (nyelvtörténeti szempontból közép- és újmagyar kor) erdélyi regionális köznyelvére vonatkoznak, hiszen ahogy azt a SzT. címe is jelzi, a magyar nyelvterület keleti régiójának nyelvi anyagát tartalmazza.

A SzT.-ban a legkorábbi, kicsinyítő képzős származékot tartalmazó adalékok a 16. század első feléből származnak: a még latin nyelvű szövegben jelenik meg szórványként a magyar szó (1529: Cui dedi pro expensis fl. octo ac pro dolman Swpicza caligis et calceis ac sartori quinque et denarios 90 [Vh; MNy XXXI, 125]; 1531: panum michi pro una supicza seu tunica parva purgamal emere feci pro fl II $1 / 2$ [Vh; DomH 112]), hiszen a magyar írásbeliség a 16. század második felétől kezd terjedni. A 16-19. század közti időben, pontosabban a 18. század utolsó éveitől, de főleg a 19. században a felvilágosodás és a nyelvújítás döntően befolyásolták a nyelvhasználatot.

A vizsgálat tárgyának specifikus voltából adódik az az igény, hogy a témát minél alaposabban, minél több szempontból körüljárjam. Ebből következik, hogy a képzők hagyományos - elsősorban morfológiai szempontokra támaszkodó (l. hagyományos nyelvtanok, mint pl. MMNyR, MGr., StrGr.) - leírását kitágítsam, és figyelembe vegyem azok szociolingvisztikai meghatározottságát, pragmatikai jellemzőit, földrajzi elterjedtségét is.

A vizsgálat nem terjed ki a mai (erdélyi vagy magyarországi) nyelv kicsinyítő képzőire, illetve egyéb denominális névszóképzőkre sem.

Célom tehát az erdélyi régiségben (16-19. század) használt kicsinyítő képzők állományának feltérképezése, valamint kapcsolódási szabályaiknak, morfológiai, szintaktikai, morfopragmatikai, szemantikai jellemzőik- 
nek, szociolingvisztikai meghatározottságuknak, illetve földrajzi elterjedésüknek a megállapítása.

\section{I.2. Az anyaggyüjtés}

Az anyaggyüjtést megkönnyítette, hogy a SzT. a kicsinyítő képzős származékokat külön címszóként közli, ennek megfelelően a kutatás lezárásáig megjelent 12 kötet 1516 címszavának 5288 olyan adalékát vizsgálhattam meg, amely a kicsinyítő képzős származékot eredeti kontextusában közli . Az első kicsinyítő képzős származék a SzT. eddig megjelent köteteiben az ablacska, az utolsó a távolkábban.

Arra mindig figyeltem, amit Szabó T. Attila az I. kötet Tájékoztatójában (12.) kiemel: a Tár rendeltetése az, hogy „,a nyelvet úgyszólva hiteles közelségében, mindennapi kavargásában, lendületes mozgásában, változásában mutassa be". Anyaggyưjtésemet meghatározta az is: a 16-19. századból való adatok olyan változatos forrásokból származnak ${ }^{10}$, hogy az említett időszak nyelvhasználatáról átfogó képet kaphatunk. Természetesen nem feledkezhetünk meg az erdélyi köznyelvi adatokról sem (pl. különböző magánlevelezések), amelyek vizsgálata alkalmat nyújt a beszélt nyelv és a normatív nyelvváltozat összevetésére.

A vizsgálat lezártáig megjelent 12 kötet kicsinyítő képzős címszavainak kicédulázása után az adatokat a számítógépes Works programmal dolgoztam fel, amely lehetőséget adott arra, hogy szűrőkkel különböző szempontok szerint egyetlen gombnyomásra rendezni tudtam az anyagot. Például a földrajzi szórtság vizsgálatakor az adalékokat megyék szerint csoportosította, így meg lehetett állapítani, hogy megyénként milyen hasonlóságok és különbségek mutatkoznak a kicsinyítő képzők használatában.

\footnotetext{
${ }^{9}$ Itt jegyzem meg, hogy a Tárnak elöreláthatóan még 2 kötete lesz, amelyekből természetesen nem gyưjthettem. (A vizsgálat lezárása óta 2009-ben megjelent a XIII. kötet).

${ }^{10}$ Birtok- és szolgálat-összeírások, végrendeletek, osztálylevelek, kelengye- és tárgylajstromok, az élet legkülönbözőbb kérdéseiben tartott vallatások jegyzőkönyvi anyaga, csere- és adásvételi iratok, nyugták, költségjegyzékek, körlevelek, egyházlátogatási, törvénykezési, valamint városi tanácsi, falusi meg széki jegyzőkönyvek, anyakönyvek, jobbágykezeslevelek, naplók, elmélkedések, misszilisek stb.
} 


\section{II. (KICSINYÍTŐ) KÉPZŐK A NYELVLEÍRÁSBAN}

\section{II.1. A terminológia kialakulásának története}

Nyelvre vonatkozó feljegyzéseket már a rendszeres nyelvtanok megjelenése elött tettek, hiszen mindig megvolt az emberekben az igény, hogy a kommunikáció eszközét ne csak használják, hanem valamilyen módon le is írják, (tanulható/tanítható) szabályokba rendezzék minél nagyobb teljességre törekedve. Ennek eredményeként, a nyelv minden jelenségének leírása előbb-utóbb bekerült a grammatikákba.

A magyar szakirodalomban a ma már hagyományosnak számító felosztás szerint formális, funkcionális és esetenként szemantikai ismérvek alapján képzőket, jeleket és ragokat szokás elkülöníteni. E terminológia (képző - jel - rag) kialakulását és megszilárdulását elsősorban a magyar nyelvú munkák alapján tekintem végig röviden.

A korai grammatikák (16-17. század) bár felismerték a vulgáris magyar nyelv sajátosságait, mégis elsősorban latin grammatikai mintákat tartottak szem előtt, és még nem foglalkoztak a toldalékok részletes és következetes rendszerezésével.

Elsőként Szenczi Molnár Albert tárgyalja egymástól elkülönítve a névszóragozást és névszóképzést, valamint az igeragozást és igeképzést az 1610-ben megjelent latin nyelvú Novae Grammaticae Ungaricae... libri duo címü müvében.

A mai terminusok csírái a 17. században jelentek meg, a TESz. szerint 1645-től adatolható a szóvégi toldalék fogalmának jelölésére a raggaték kifejezés. A 18. század végétől hasonló jelentésben olyan kifejezések jelennek meg, mint pl. ragaszték szó, ragaszték, végezet végzet. Gyarmathy Sámuel használja először a toldalék szót az Okoskodva tanitó magyar nyelvmesterben (1794).

Ezzel szemben a Debreceni Grammatika (1795) szerzői nem különítették el a szóképzést és a ragozást. 'Toldalék' jelentésben a végezet és ragaszték szavakat használták. Annak ellenére, hogy tudatosan és expliciten nem 
tettek különbséget a képzés és ragozás között, megfigyelhető egy olyan törekvés, hogy igék mellett jobbára a végezet, névszók mellett a ragaszték elnevezést használták.

Kassai József Magyar nyelv-tanitó könyv (1817) című művében 'toldalék' értelemben a végezet és végszótska kifejezéseket használja, 'rag' értelemben a szó-ragaszték vagy suffixa műszavakat, a szóképzéssel viszont egyáltalán nem foglalkozik.

A szóképzés és ragozás megkülönböztetését Verseghy Ferenc tartotta elsőként fontosnak Magyar Grammatikájában (1818). Nála fordul elő először a képző nyelvészeti terminusként. Külön fejezetben fejti ki a szóképzéssel kapcsolatos véleményét, amely szerint a nyelvben az „eleven gyökérszavak" mellett vannak ,holt vagy néma gyökerek" (pl. ak, irg, til, figy, vigy, ev). "Ámde, ha hozzájuk bizonyos és mindenütt ösmeretes szótagok vagy betük függesztetnek, eleven és világos értelmü szavakká válnak, mint akaszt, irgalom, tilt, tilalom, figyelem, vigyáz, evez. E' szavakot a Szónyomozás formáltt gyökereknek, ama szótagokot és betüköt pedig, mellyeknek segedelmével a' holtt gyökerekbül elevenek válnak, szóképzöknek segedelmével az eleven és formáltt gyökerekbül is lehet megmeg új szavakot formálni, mellyek származékoknak neveztetnek, mint fás, szövevény, ágas, ásvány, várakozik, váras [...] söt még a' származékokból is lehet megmeg más származékokot csinálni, mint ágaskodik, várakoztat, városi [...]" (Verseghy 1818: 70). Verseghy tehát következetesen használja a képzö és származékszó müszavakat a mainak megfelelő értelemben, és különös fontosságot tulajdonít a szófajjelölő képzőknek.

Az első helyesírási szabályzatban, a Magyar helyesirás és szóragasztás fóbb szabályaiban - A' Magyar Tudós Társaság különös használatára (1832) a szerzők már egymástól következetesen különválasztva használják a rag és képző müszót. Itt elsősorban nyelvhelyességi és helyesírási szempontok miatt foglalkoznak a melléknévképzés néhány problémájával, valamint a fokozással.

A korabeli nyelvtanokban a mai értelemben használt képzó és rag fogalom, valamint a 'toldalék' jelentésű rag fogalmának összezavarása a nem egyértelmű műszóhasználat következménye.

Fogarasi János munkáját, a Müvelt magyar nyelvtan elemi részét (1843) is elsősorban a kettősség okozta bonyodalmak jellemzik. Van azonban egy olyan fontos lapalji jegyzete, amelyben a következő igen tanulságos mondatot olvashatjuk: „Grammatikai szók alakitásához minden nyelvtanulónak kell értenie, de szótári képzés nem minden ember dolga" (Fogarasi 1843: 64). Ez a mondat a grammatikai és lexikai szóképzés elkülönítésének az első megfogalmazása. A továbbiakban hosszú ideig a képzőmeghatáro- 
zások nem veszik figyelembe ezt az elkülönítést, és majd csak a 20. század második felében merül fel ismét e szétválasztásnak a szükségessége.

A'Magyar Nyelv' Rendszere (1846) már a nyelv ismeretén alapuló rendszeres nyelvtan, amely szerint a képző önálló lexikai egységet hoz létre: „Képzőnek neveztetik azon betü, vagy szótag, amellynek hozzáadásával élő vagy elavult gyökből, vagy tőszóból önálló szó vagyis beszédrész alkottatik".

Galgóczi Gábor Magyar nyelvtana (1848) terminológiai szempontból következetes, de az ő meghatározása szerint is a képző funkciója új szótári szó létrehozása: „Képzők, melyek által a’ tőszók önálló - az úgy nevezett szótári - szókká vagy beszédrészekké képeztetnek" (Galgóczi 1848: 108). Ő szól elsőként az igeragozási részen belül az igeidők és igemódok leírásával kapcsolatban a jegyekről, amelyeket elkülönít a ragoktól.

Szvorényi József Magyar nyelvtan tanodai használatra (1861) című munkájában háromféle szóelemet tart számon: gyök, képzö, rag.

A 20. századba való átlépés a toldalékok hármas tagolásának megerősödését hozza. Kis-Erős Ferenc A magyar nyelv rendszeres vizsgálata (1915) címú múvében megfogalmazza a képző - jel - rag kapcsolódási szabályait.

Gombocz Zoltán 1925-ben az egyetemi alaktani tárgyú előadásában a toldalékok hármas felosztását már magától értetődő tényként szögezi le, a jeleket a képzők alcsoportjaként mutatja be. Képzőmeghatározása a következő: „Az olyan végzetet, amelynek hozzátoldásával a szóból más szó lesz, képzőnek nevezzük" (Gombocz 1951: 4).

Ennek ellenére a 20. században sincs teljes egyetértés a toldalékok hármas tagolását illetően.

Horger Antal szerint például: „A szuffixumoknak képzőkre és ragokra való fölosztása nem nagyon fontos, mert az kétségtelen tény, hogy a nyelvtörténet folyamán egyik-másik képzőből rag lett és viszont, azt bizonyítja, hogy a közöttük levő válaszfal nem lehet valami erős" (Horger 1926: 84). Horger Antal itt olyan nyelvi jelenségre alapozza megállapítását, amelynek értelmében több esetben a szófajokat sem kellene elkülönítenünk egymástól, hiszen a szófajok között is vannak átfedések.

Balassa József A magyar nyelv könyvében (1943) sajátos módon tárgyalja a jelek problémakörét: „Vannak ezeken kívül olyan ragoknak nevezett szóelemek is, amelyek nem változtatják ugyan meg a szó jelentését, de lehet hozzájuk újabb ragokat függeszteni. Ilyenek a többesszám ragjai [...] és a birtokos személyragok [...]. Ezeket megkülönböztetésül jeleknek szoktuk nevezni" (Balassa 1943: 172).

Györke József Tó, képző, rag (1943) címú munkájában sem ért egyet a hármas felosztással, hiszen szerinte a jel nem önálló kategória, legfeljebb egyfajta képző. Így az idôképző és az idôjjel számára szinonimák. 
Tehát a 20. század első felének nyelvészei a jeleket vagy a ragokhoz hasonlatosként, vagy a képzőkhöz tartozókként határozzák meg.

Az 1950-es évektől az alaktani munkák azonban már következetesen a hármas felosztást fogadják el. Így a Tompa József szerkesztette akadémiai nyelvtan, a Mai Magyar Nyelv Rendszere, hivatalossá tette a toldalékok hármas felosztását.

\section{II.2. Képzőmeghatározások a mai magyar nyelvtanokban}

A toldalékok elhatárolása történhet szemantikai, funkcionális és formális ismérvek alapján. A különböző nyelvtanokban található meghatározások éppen abban térhetnek el egymástól, hogy mely szempontokra helyezik a hangsúlyt, illetve egyáltalán mely szempontokat veszik figyelembe az egyes toldalékosztályok jellemzőinek megállapításánál.

A Mai Magyar Nyelv Rendszere (1961) jelentésük és nyelvi funkciójuk szerint különbözteti meg a háromféle toldalékot. „A képzők a szótő jelentését többé-kevésbé határozottan megváltoztatják [...]. A szótő és a képző kapcsolatából támadt alakulat új szónak, új lexikai egységnek tekintendő. A képző új szót alkotó szóelem" (Károly 1961: 207).

Hasonló jellegű toldalékmeghatározások vannak a A mai magyar nyelv kézikönyvében (1971) is. A definíciók jelentéstani vonatkozásokkal kezdődnek, ezek alapján különítik el a toldalékokat egymástól. A kapcsolódás, sorrendi jegyek a meghatározás végére kerülnek. „A képző olyan mellék szóelem, amely a hangalak megváltoztatásával egyidőben megváltoztatja (emel + kedik, száll +ó, város $+i$, kér + és) vagy módosítja (jár + kál, ver + des, csap + kod) a szó értelmét. Kapcsolódási lehetőségeit tekintve pedig járulhat szótőhöz, követhet képzős (boldog $+u l+a ́ s)$, jeles $(n a g y+o b b+i t)$ vagy ragos (ön + ként +es), illetőleg jeles és ragos (él+jen +ez) alakot" (1971: 204). Ebben a definícióban tulajdonképpen megtörténik a lexikális és grammatikai szóképzés elkülönítése, a képző már nem csupán mint új szótári szót létrehozó elem jelenik meg.

Jelentéstani alapon különíti el a három toldalékfajtát a tanárképző fóiskolák számára írt Szóalaktan is, így a képző meghatározása a következő: „az alapjelentést (illetve általában jelentést) megváltoztató toldalékot képzőnek nevezzük" (Temesi 1963: 11).

A Kis magyar nyelvtan a funkciókülönbségre helyezi a hangsúlyt. „A szótőhöz hozzátoldott szóelemeknek háromféle szerepük lehet", ezek közül „a képző́k megváltoztatják a szó jelentését, gyakran szófaját is:

hall - hallgat: ige $\rightarrow$ ige

hang - hangos: fonnév $\rightarrow$ melléknév. 
A szótőhöz kapcsolódó képző tehát újabb szót (lexémát) alkot."11 (Rácz 1993: 97).

Antal László A magyar esetrendszer címú munkájában formális, kapcsolódási és pozicionális jegyeket vesz figyelembe: „Képzőnek nevezzük azokat a maguk mellett hasonló elemet, vagyis képzőt megtűrő kötött morfémákat, amelyek nem állhatnak soha szóeleji helyzetben, s amelyek nem követhetik a jeleket, mindig csak előttük állhatnak." (Antal 1961: 68).

Berrár Jolán a képzők funkcióját vizsgálva arra a következtetésre jut, hogy „a képző funkcióját vizsgálhatjuk: 1. morfológiai szinten, 2. szófaji szinten, 3. szintaktikai szinten, 4. szemantikai szinten. A képző definíciójába azonban csak az 1. és 2. szintű megállapítások kerülhetnek bele mint olyan jegyek, amelyek a többi toldaléktól megkülönböztetik" (Berrár 1974: 123). A morfológiai és szófaji funkciót együttesen tartalmazó képződefiníció ezek szerint így módosul: „új morfológiai szóegyedet hoz létre, amelynek saját paradigmája van" (i. m. 121). A szófaji funkció szempontjából nem kielégítő a szófajmeghatározó szerep elnevezés, hiszen a képzők csoportosíthatók aszerint, hogy I. szófajváltók, II. szófajtartók vagy III. szófajjelölők.

A Magyar leíró nyelvtani segédkönyv meghatározása szerint:

\section{„A képző}

Nem kötelező elem. Hiánya miatt nem veszünk fel morfémát.

Legbelsőbb helyzetű (a tő után következik).

Megtür maga mellett más képzőt.

Állhat utána jel és rag.

Nem köti meg a szóalak szófaját, nem akadályozza meg a további szófajváltást.

A képző lehet szófajtartó (halász), szófajváltó (zongorázik) és szófajjelölő (pattan).

Gyakran a képző határozza meg, hogy a szónak milyen bővítési lehetőségei vannak." (Berrár, Keszler, Rácz 1994: 9-41).

Kiefer Ferenc az Új magyar nyelvtanban arra a következtetésre jut, hogy a jelek és ragok esetében „,nincs értelme, hogy a kétféle inflexiós toldalék között terminológiai különbséget tegyünk." Ugy véli:

„A képző és az inflexiós toldalék megkülönböztetése fokozat kérdése.

A képzők és az inflexiós toldalékok egy skála két végpontján helyezkednek el. A tipikus képző új szót hoz létre, megváltoztatja a szintaktikai környezetet, szófajváltást okoz, nem minden tartományban termékeny, a

\footnotetext{
${ }^{11} \mathrm{~A}$ továbbiakban a ragok és jelek meghatározása következik.
} 
létrejött új szó hajlamos a lexikalizálódásra, és állhat utána más toldalék. A tipikus inflexiós toldalék ezzel szemben nem hoz létre új szót, nem változtatja meg a szintaktikai környezetet, nem okoz szófajváltást, teljesen termékeny, a vele toldalékolt szó nem lexikalizálódik, és nem állhat utána más toldalék (...).

Minél több képzőszerű tulajdonsággal rendelkezik egy toldalék, annál inkább képző, minél kevesebbel, annál inkább inflexiós toldalék" (Kiefer 1998: 195).

Kiefer meghatározása szerint tehát a becéző és kicsinyítő képzők nem helyezhetők el a tipikus képzők csoportjában, hiszen nem változtatják meg a szintaktikai környezetet, nem okoznak szófajváltást. Állhat utána viszont más toldalék. Ez az a tulajdonság, amely eltávolítja a tisztán inflexiós toldalékoktól. A képző inflexiós toldalék skálán tehát a kicsinyítő képzők valahol a középpont környékén helyezkednek el. ${ }^{12}$

A képzőmeghatározások többsége a képzőnek az új lexikális egységet létrehozó funkcióját emeli ki, pedig a képzők nagy hányada nem alkot új szót.

\section{II.3. Kicsinyítő képzők a régi grammatikákban}

A szóképzéssel mint a nyelv gazdagításának egyik legelterjedtebb módjával már a legkorábbi grammatikáink foglalkoztak. A képzőrendszeren belül a kicsinyítő képzők vizsgálata részletkérdésnek tűnik, ezért a korai nyelvtanok közül nem kerül be mindegyikbe. Így pl. Dévai Bíró Mátyás, Kövesdi Pál és Misztótfalusi Kis Miklós nyelvtanában nincs képzőkről szóló rész. Tsétsi János Observationes Ortographico-Grammaticae címü művében derivatum gyưjtőszó alatt mindenfajta toldalékról beszél, de mivel egy bibliafordítás margójára jött létre, ezért kicsinyítő képzőkről egyáltalán nincs szó benne.

Részletesebben tehát csak azokkal a grammatikákkal foglalkozom, amelyek valamilyen módon tárgyalják a kicsinyítő képzők problematikáját, és ezeknek nézeteit kronológiai sorrendben mutatom be. Ahol lehetséges, idézem a kicsinyítő képzőkről szóló részt, majd megjegyzéseket füzök hozzá.

Sylvester János az első magyar nyelvtan szerzője. 1539-ben jelenik meg a Grammatica Hungarolatina, amelyet Újtestamentum-fordításához előtanulmánynak szánt. Nyelvtanában a magyar nyelvnek azt a tulajdonságát emeli ki, hogy - a latinhoz hasonlóan - egy-egy középfokú melléknév kicsinyítő képzőt kaphat. Ebben a magyar nyelv fejlettségét látja. A példája:

\footnotetext{
${ }^{12}$ Erről részletesebben 1. a Képzö-e a kicsinyítő képző? Terminológiai problémák c. alfejezetet.
} 
„minusculus: küssebbedke” (idézi Szathmári 1968: 95). Ez az észrevétel a SzT. kicsinyítő képzőinek vizsgálata szempontjából is igen fontos, hiszen kevés adat van a -dke kicsinyítő képző előfordulására.

Szenczi Molnár Albert az első olyan szerző, akinek célja egy teljes magyar nyelvtan megírása volt (1610/2004. Novae grammaticae Ungaricae libri duo [Ford.: C. Vladár Zsuzsa]). A grammatika nyelve még mindig a latin, de magyar nyelvi jelenségeket mutat be. Például felismeri nyelvünknek a képzőkben, különösen a kicsinyítő képzőkben való gazdagságát (i. m. 166), és a kicsinyítés külön fejezetet foglal el, $A$ második nec végú névragozásról és A származás vagy összetartozás jelöléséról címü fejezetek között. Fontosnak tartom a teljes idevágó rész idézését:

\section{„XV. Fejezet}

\section{A Kicsinyitésról}

Ennyit a névszó esetek szerinti változásáról és a toldalékok körvonalazásáról, következik a névszó képzés és összetétel szerinti változása.

A képzés szerint a névszó vagy kicsinyítő képzős vagy származást, odatartozást jelölő képzős.

A kicsinyítő képzős az eredeti kicsinyítést jelöli, mint Lovaczka, equulus; ebeczke, caniculus, a.

Olykor egy alapszóból sok kicsinyítő képzős származik, mint a leány, puella szóból leánka, leancza, leanyoczka, puellula; a gyermec, puer szóból gyermekcze, gyermeczke, gyermekeczke, puerulus.

A kicsinyítő képzős főnevek és melléknevek közös végződései: $k a, c z k a$, $c z a$; ke, czke, cze, mint poharka, pocillum; házaczka, domuncula; ablaczka, fenestella; aranyaska, auroleus, a, inauratulus, a; rutaczka, turpiculus, a; nagyocz$k a$, grandiusculus, a; Legénke, adolescentulus; Szemeczke, ocellus; Szepeczke, pulcellus, a; Szegenyke, pauperculus; égyeczke, unicus, a.

Ezek mind a saját ragozási típusuk alanyeseteiből erednek, és a $k a, c z a$ végződésűek az első nac végű névragozásba; a ke és cze végződésúek az első nec végü névragozásba tartoznak.

Alig találsz olyan névszót a magyar nyelvben, amelyet ne lehetne ezekkel a végződésekkel kicsinyíteni.

Kicsinyíteni lehet a férfi tulajdonneveket, mint Janoska, Johannes parvus; Peterke, parvulus Petrus; Benedekcze, Benedictulus; a női neveket, mint az Ilonából Helena, Ilonka; Katuska, Catharinula; a népneveket, mint Magyarka, Ungarus parvus; Olaszka, Italus parvulus; Tótoczka, Slavicu- 
lus; Lengyelke, Polonulus; a czeh-ből Bohemus, Czeheczke, Bohemulus, a; Görögöczke, Graeculus." (180-181) ${ }^{13}$

Szenczi több terminust is használ a képzők megnevezésére: hol képzóként, hol végzódésként beszél róluk. Vladár Zsuzsa szerint is a fordítás egyik legnagyobb problémája a Szenczi által használt terminológia pontos visszaadása. ${ }^{14}$ A szövegből mégis az derül ki, hogy a két terminus technikus tulajdonképpen szinonim, a képző és végződés ugyanarra vonatkozik.

A képzést mint gyakori szóalkotási módot csak a különböző képzőtípusok bemutatása után határozza meg: „a képzés, amellyel névszó keletkezik az igéből, vagy ige keletkezik valami másból" Az igékbőll származó névszókról c. fejezetben (i. m. 309). Tehát annak ellenére, hogy külön fejezetben elemzi a kicsinyító képzőket, amelyek tipikusan nem eredményeznek szófajváltást, a képző alapvető funkciójának a szófajváltást tekinti. Kiemeli, hogy a névszóképzők rendszerén belül a kicsinyítő képzőknek jelentésmódosító, nem szófajváltó szerepük van.

Elemzése rendszeres: bemutatja a kicsinyítő képzők állományát, amelynek a ma is produktív -cska, -cske és -ka, -ke mellett a -csa, -cse is része volt. Példáiban párhuzamos képzéseket mutat, amelyekre a SzT.-ból is van adatunk. A gyermecske a SzT. egyetlen adalékában fordul elö, ezért úgy gondoltam, hogy vagy alkalmi szóképzés, vagy elírás eredménye lehet, de Szenczi grammatikájából kiderül: a -cska, -cske járulhat csonka tőhöz, amikor kiesik a tôvégi $k$, illetve kapcsolódhat a teljes tőhöz, ebben az esetben egy e kötőhangzó előzi meg. Ugyanakkor van egy olyan alak is, amelyben a teljes tövet egy -cse képző követi.

Nyelvtanában felismeri, hogy a főnevek mellett a melléknevek is produktívan elláthatók kicsinyítő képzőkkel. A mai nyelvleírásoktól eltér abban, hogy a kicsinyítést az igére is jellemzőnek tartja, bár itt kétségkívül arra érez rá, amire a későbbi nyelvtanok is felhívják a figyelmet, vagyis: van bizonyos szemantikai rokonság a kicsinyítő képzők és a gyakorító igeképzők között: „,Van néhány kicsinyítő képzős ige, melyek az eredeti szó jelentését kisebbítik, és vagy lic-re végződnek, mint czillaglic, micat instar stellae; fejérlic, albicat; zöldellik, virescit, vagy kál-ra végződnek, mint santikál, claudit; Hajozkál, naviculatur." (i. m. 309).

A képzők funkcióját nem taglalja részletesen, erre vonatkozó fél mondatában csak azt emeli ki, hogy a kicsinyítő képző szerepe az eredetinek a kicsinyítése.

\footnotetext{
${ }^{13}$ A szöveg idézésekor nem követtem húen az eredeti betűképet, a gótikus $f$-t kicseréltem s-re, az ö hang jelölését sem tartottam meg, hiszen úgy véltem, hogy ezek a képzők szempontjából nem relevánsak.

${ }^{14}$ Erről bővebben 1. Vladár Zsuzsa Szenczi terminológiájának fordítási kérdései (i. m. 23-5).
} 
Geleji Katona István abban különbözik elődeitől, hogy - bár nem rendszeres nyelvtant ír, hanem irodalmi munkássága közben, nyelvtannal és nyelvhasználattal kapcsolatban kialakult nézeteit szedi össze egy gyüjteménybe - ő volt az első, aki tulajdonképpeni nyelvmüvelőnek tekinthető. 1645-ben megjelent Magyar grammatikácskájában nem ad képzőmeghatározást. Bár szól a különböző képzőfajtákról (az igeképzők rendszerén belül például a gyakorító képzőkről), ezen toldalékok számára elsősorban a nyelvművelés szempontjából érdekesek. Kifejti, hogy a képzők segítségével a mondanivalót tömören lehet kifejezni. Külön rövid részt szentel a kicsinyítő képzőknek (diminutivumoknak): „XXXVIII. A' diminutivumokis mind verbumok, mind nomenek, s' mind adverbiumok azon módon kivált-képpen valo szokval mondathatnak ki. A' Verbumok. Mint: Eddegelek, iddogalok, járdogalok, szántdogalok etc. Az az: Kitsinyt-kitsinyt észem, iszom; lassan-lassan járok, szántok. A' Nomenek. Mint: Gyermek, gyermektse, vagy gyermetske; meny, menyetske; fiu, fiutska, vagy, fiatska; leány, leányka, vagy leányzó, leányzótska, ki azt láttatik jegyzeni, a'ki meg leányozik, a'vagy, a'kinek leányja lészen, etc. Az Adverbiumok pedig. Mint: Jobbatdskán, szepbetskén, ékesebetskén, lassabbatskán, gyorsabbatskán etc." ${ }^{15}$ (29-30).

A kicsinyítő képzőkről vallott felfogásának sajátossága, hogy - Szenczihez hasonlóan - a gyakorító képzők egy részét a kicsinyítő képzők közé sorolja, hiszen funkcionális és szemantikai hasonlóság van köztük, alapjelentésüket tekintve mindkettő valamilyen cselekvésnek vagy dolognak a kisebb voltára, kisebb intenzitására stb. vonatkozik. A kicsinyítő képzőket aszerint csoportosítja, hogy mi a származék szófaja, tehát az ilyen képzőket tartalmazó szavak lehetnek igék (verbumok), főnevek (nomenek), illetve határozószók (adverbiumok). Eredetisége és máig tartó érvényessége abban van, hogy észreveszi: a határozószókhoz is járulhatnak kicsinyítő képzők, hiszen a mai grammatikák sem említik, hogy kicsinyítő képző járulhat határozószóhoz, pedig - bár ma már nem termékeny ez a képzésmód - vannak ilyen származékok (pl. hátrábbacska, alábbacska stb.).

A SzT. adatai között is megjelenő gyermekcse, ill. a gyermecske kicsinyítő képzős származék Gelejinél - Szenczihez hasonlóan - kiemelt példaként szerepel, ami azt bizonyítja, hogy a 17. századi nyelvhasználatban elterjedt lehetett mind a -cse, mind pedig a -cske képzős származék.

Alig 10 évvel később, 1655-ben jelent meg Komáromi Csipkés Györgynek a Hungaria illustratája. Röviden ő is foglalkozik a magyar nyelv képzőrendszerével $A$ szóképzés (II.) címü fejezetben. Itt felsorolja a legfontosabb denominális és deverbális képzőket, többnek a funkcióit és alaktani sajátságait is. A nyelvi norma elég erős fokú meglétére enged következtetni

\footnotetext{
${ }^{15}$ A szöveg lejegyzésekor mai betűkészletet használtam, mert az nem befolyásolja a szöveg tartalmi vonatkozásait.
} 
az, amit a Tyukcsa, Gyermekcse-féle kicsinyített alakokról mond. Szerinte nyilván a mássalhangzó-torlódás miatt - ezek helytelen alakok. (Szathmári 1968: 280). Annak ellenére, hogy Komáromi műve csak tíz évvel jelent meg később Geleji Grammatikácskájánál, mégis helytelennek ítéli a -csa, -cse képzős alakokat. Természetesen az nem feltételezhetô, hogy tíz év alatt elavult volna, inkább nyelvjárási különbségről lehet szó.

Pereszlényi Pál a második, nemcsak teljes, hanem a nyelv sok részletjelenségét, apró finomságát rögzítő magyar nyelvtan szerzője. A Grammatica Lingvae Vngaricae 1682-ben jelent meg, és benne Pereszlényi felsorol több képzőt, hol csak példákkal illusztrálva, máskor viszont jelentésükre, jelentésárnyalatukra is rámutatva. Erősen érvényesül Szenczi hatása, olyanynyira, hogy a példák zömét, a tárgyalás- és felfogásmódot is tőle veszi át. A kicsinyítő képzők tárgyalása csak abban különbözik a Szencziétől, hogy Pereszlényi kissé másképp jelzi nyelvünk képzőbeli gazdagságát: „Non est omittenda gratiosa apud Vngaros diminutivorum observatio..." (427). Pereszlényi ugyanazokat a kicsinyítő képzős származékokat idézi példaként, mint Szenczi, különbség csak az írásképben van: a leányka, leánycsa, legényke a mai módon, ny-nyel fordul elő, s végül ő kevesebb példát vesz fel, mint Szenczi, de a Jánoska mellett szerepelteti a Janczi, Janczika becéző formát is (vö. Szathmári 1968: 313-4).

Bár nem lehet pontosan megállapítani, hogy mikor keletkezett a kézírásban maradt, Kolozsvári grammatika néven ismert nyelvtan (Lőrinczi 1998: 11-63), annyi valószínűsíthető, hogy valamikor a 18. század első felében. Ez a - kérdés-feleletre alapozó - nyelvtan érintőlegesen foglalkozik a szóképzéssel. Négy képzésfajtát nevez meg: elnevező, kisebbítést jegyző, verbumbeli és adverbiumbeli képzést. Annak ellenére, hogy a kicsinyítést külön képzésfajtaként különíti el, mégis csak érintőlegesen szól róla egy meghatározásban:

„Meg küssebittest jedczö az mely az maga Primitivumanak meg küssebbitteset jedczi hogy [rà ki()ralyotska, az kiralytol, ôtse az batyatol" (14v 24-26).

A meghatározásban egyetlen, -cska képzőt tartalmazó kicsinyítő képzős példa szerepel.

A 18. század végén, 1794-ben Kolozsváron jelent meg Gyarmathy Sámuelnek az Okoskodva tanító magyar nyelvmester címú nyelvtana, amely már teljes tudományos igényességgel készült: mindig hivatkozik az általa felhasznált forrásmunkákra. A magyar nyelv kicsinyítő képzőinek bemutatásának meglehetősen nagy teret szentel, és több olyan észrevételt tesz, amelyek elődeinél nem fordultak elő: 
„§. 28.

$\mathrm{A}^{\prime}$ Hasonlitásnak mintégy elleneiben tétetik a' Kitsinzés (diminutio) minthogy ezzel a' szóknak jelentése kitsidül. Ez ugy megyen véghez, hogy a' szók végibe toldatnak im ez hangotskák: $k a, k o$, atska, otska, ke, etske, ötske, p. o. jotska, ótska, rutatska, haragosotska, kitsinke, szépetske, bövetske, $e^{\prime} n y i t s k e, a^{\prime} n y i t s k a, m e ' n y i t s k e . A^{\prime}$ Magyar nelyben [elírás nyelvben h.] még a számlálokis kitsinyzödnek, p. o. egyetske, kettötske, százatska, söt még a' határozokis: régetske, reggeletske.

§. 29.

E’ben a' Kitsinzésben még-sokkal több részek van a' magán-értöknek, illyenek már ezek: léányka, legényke, Magyarka, ágatska, edényetske, ablakotska, idötske, tsirke, Péterke, Ilonka, fiutska, páltziko, fioka, anyoka, bahoka, háziko.

A' ki ezeknek formálását jol meg akarja tanulni, figyelmezzen azon Törvényekre, a' mellyeket alább a' 35. §. a' vádlo esetek formálásában adunk, mert vádlóból formálodik leghamarébb a' Kitsinzö, kiváltképen azon szókban, mellyek a'vonást a' vádloban el vesztik (quae perdunt accentum in Accusativo) p. o. kosárotska, kosárka, szamaratska, madaratska, kaszátska, szájatska, darabotska, tyukotska, horgotska, tulkotska, berketske, szekeretske, mesétske, sebetske, versetske, ködötske, tükrötske, vedretske, gödrötske.

Iegyzés: Még illyen formánis tsinályják némelly hellyeken a' Kitsinzöket: Ablatska léántsa, gyermektse, gyermetske, de a' jo nyelvhez szókott füleknek ez ám kedvetlenetske.

§. 30.

A' régi ösi igaz Magyarságban nem igy formálodtak a' Kitsinzök, a' mint ezt a'nak még égy néhány el nem tévellyedet maradvánnyábol ki-tanulhatjuk. Azok pedig im é kövedkezendök: Követs, kapots, forgáts, kovats, dugats, kulats, makats, bogánts, gubats, kats (Kitsin kéz, handlein, kezetske) totsa. Hanem ezeket el rontották lassanként Hazánknak Totosabb Vármegyéi, mellyek a' Magyar Kitsinzöket a' Totokéihoz kezdvén formálgatni, tsináltak: Követske, kapotska, kulatska 's több a' féle panitskákat. De már ezt meg nem lehet változtatnunk, hanem csak a' tudásával maradunk.

1. Iegyzés: Ide tartoznak a' Kisdedeknek neveiis, mellyeket a' Szülék édesgetöleg kitsinzenek p. o. Andris, Ferkö, Palko, Ianko, Iánoska, Gyurka, Istok, Katitza, Dsudsi.

2. Iegyzés: Hát vallyon ama szók nem ide tartoznaké, mellyek lék, dék, végüek? p. o. hulladék, maradék, töltelék, aprolék, ázalék, sepredék, töredék, tsötselék? Hiszem ezekis mind kitsinzések?" (60-62.)

Gyarmathy rendszeres elemzését adja a magyar kicsinyítő képzők rendszerének. Először is a kicsinyítő képzős szavak jelentésével foglalkozik, és kiemeli azt a szemantikai jegyet, amely minden kicsinyítő képzős 
származékra érvényes: 'kicsi/kis valami' . A kicsinyítő képzők állományába nyelvtana szerint a -ka, -ke és -cska, -cske, valamint a -kó képzők tartoznak (a -cska, -cske-nek felsorolja a különböző kötőhangzókkal bővülő változatait is). Egy megjegyzésében viszont megemlíti a -csa képzőt is, amelyről azt állítja, hogy a kiművelt beszélő nem használja. Példáiból kiderül, hogy kicsinyítő képző kapcsolódhat főnévhez (pl.: leányka, legényke, edényecske stb.), melléknévhez (pl.: kicsinyke, rútacska, szépecske stb.) - ahogy azt a korábbi grammatikák is tárgyalták -, valamint névmáshoz (pl.: ennyicske, annyicska, mennyicske), számnévhez (pl.: egyecske, kettősske, százacska) és határozószóhoz (pl.: régecske, reggelecske).

E munka nemcsak abban tér el az előzőektől, hogy sokkal alaposabb rendszerezését adja a kicsinyítő képzőknek, hiszen Gyarmathy több szempontból vizsgálja őket, hanem abban is, hogy nem pusztán szinkrón nyelvleírást ad. Példaként olyan szavakat említ, amelyek lexikalizálódtak, de amelyekben a szóvégi cs eredetileg kicsinyítő képző volt. Másik újszerü megállapítása az, hogy a kicsinyítő képzők erős elterjedése valószínúleg a szláv nyelvi hatással magyarázható.

Elemzésében van néhány zavarosabb rész, de ezeket csupán megválaszolandó kérdésként veti fel (pl. a -lék, -dék végü szavak kicsinyítő képzős volta).

A hiányosságok ellenére Gyarmathy mutatja be legteljesebben és legpontosabban kora kicsinyítő képzőinek rendszerét.

Egy évvel később, 1795-ben jelent meg a sokat és sokak által vitatott Debreceni grammatika, amely röviden szintén ír a szóképzésről, ám a kicsinyítő képzőket csak érinti. A -dad, -ded kicsinyítő képzőnek hasonlítást jelentő funkcióját emeli ki a kerekded és kisded példákban.

Összefoglalva tehát: a felsorolt grammatikák két okból is jelentősek. Nemcsak azért, mert különböző szempontú kicsinyítőképző-vizsgálatot adnak, hanem azért is, mert a különböző grammatikák példaanyagának összevetéséből kidomborodik a 16-18. század közti időszaknak a kicsinyítő képzőkben való gazdagsága, kiderül, hogy melyek voltak a termékeny képzők, illetve melyek kezdték elveszíteni produktivitásukat, és visszaszorulni egy-egy nyelvjárásba. Ugyanakkor kontrollanyagot biztosítanak a SzT. adatainak, ellenőrizni lehet, hogy az olyan kicsinyítő képzős származékok, amelyekre csak egyetlen adat került elő a SzT.-ból, megjelennek-e valamelyik grammatikában. Ha igen, azt jelenti, hogy az illető kicsinyítő képző még produktív lehetett, ha nem, azt, hogy elszigetelt jelenségről, véletlen szóalkotásról, netán elírásról stb. van szó. 


\section{II.4. Diminutívum-meghatározások a mai nyelvtanokban}

A mai leíró nyelvtanokban a diminutívumokkal való foglalkozás sokkal kisebb helyet kap, mint a régi grammatikákban. Ennek több oka is lehet: elsősorban valószínűsíthetô, hogy a régi nyelvben a diminutív képzésmodell produktívabb volt, mint a mai nyelvben ${ }^{16}$ (értem ezalatt a magyarországi sztenderdet, valamint az erdélyi regionális köznyelvet): sokkal több alapszóhoz járult diminutívum, illetve sokkal több beszédhelyzet megengedte használatukat, mint ma, másrészt akár amiatt is szorulhatott a nyelvleírás perifériájára ezen részrendszernek a leírása, mert több szempontból is problematikusnak bizonyult és bizonyul ma is.

A MMNyR. a képzőmeghatározásban általában alkalmazott szempontokat érvényesíti a kicsinyítő képzők meghatározásában is: 1. milyen szófajú szavakhoz járulhatnak (főnevekhez, melléknevekhez, számnevekhez és névmásokhoz), 2. milyen szófajú szót hoznak létre (a kicsinyítő képzők nem változtatják meg az alapszó szófaját), illetve 3. milyen irányba módosítják az alapszó jelentését (kicsinyítenek, a tulajdonság kisebb mértékét fejezik ki, kedveskedő jelentésárnyalatuk van, de némelykor gúnyos színezetük is lehet). ${ }^{17}$

A Magyar grammatika viszont már meg sem kísérli meghatározni a diminutívumokat, pusztán felsorolja őket. ${ }^{18}$

A kicsinyítő képzőknek az alapos bemutatása tehát hiányzik a leíró nyelvtanokból.

\footnotetext{
${ }^{16}$ Bár egy ilyen jellegű összehasonlító vizsgálat nem szerepelt e kutatás célkitűzései között, azt mindenképpen el kellene végezni valamikor.

17 „A denominális főnévképzők közt külön csoport a kicsinyítő-becéző képzőké. Elsősorban főnevekhez (köznevekhez vagy személynevekhez) vagy főnévi szerepű más névszókhoz járulnak. Ritkábban azonban nem főnévi szerepű melléknéven, számnéven, névmáson is jelentkeznek, de ilyenkor rendesen nem főnevet, hanem melléknevet, számnevet, névmást képeznek. A kicsinyítő képzős származékok szófaját tehát nem a képző, hanem inkább az alapszó határozza meg. Egyfelől kicsinyítenek: vkinek, vminek a kicsi vagy a szokottnál kisebb voltát, (melléknéven) a tulajdonság kisebb mértékét fejezik ki. Másfelől becézésre, becenevek, családias keresztnév-változatok képzésére használjuk őket. A származékoknak tehát gyakran kedveskedő jellegük - vagy olykor gúnyos, rosszalló színezetük - is van." (Ruzsiczky 1961: 400).

18 „Kicsinyítő, becéző képzők: -cskal-cske (-acskal-ocska/-ecske/-öcske): fiúcska, szánkócska, felhöcske, kanalacska, ablakocska, rögöcske; -kal-ke: asztalka, leányka, legényke; -i: Ági, Kati; -csi: Jancsi, repcsi; -ca: Teca; -ci: Anci; -u: Etu, apu; -us: Katus, apus; -ikó: házikó, ládikó; -csal-cse: Borcsa, tócsa, üvegcse; -kó: Palkó; -is: Andris; -ó/-ô: Kató, Petó; -dadl-ded: tojásdad, édesded(en)" (Keszler 2000: 316).
} 


\section{II.5. Képző-e a kicsinyítő képző? Terminológiai problémák}

A régi és újabb grammatikák képzőmeghatározásai után felmerül a kérdés, hogy a kicsinyítő képző melyik toldalékosztályba sorolható be, illetve hogy besorolható-e egyértelmúen valahova.

A klasszikus képzőmeghatározások a képzőknek általában azt a vonását emelik ki, hogy új szót (új lexéma új jelentéssel) hoznak létre. Az újabb nyelvtanok viszont - annak ellenére, hogy definíciót adnak - problematikusként, illetve nem minden képzőre érvényesként kezelik a meghatározást (vö.: Beard 1998: 44), ugyanis gyakran nem lehet elkülöníteni eléggé élesen az inflexiós eljárásokat a derivációsoktól. Erre Károly Sándor már egy 1965-ben megjelent tanulmányában felhívja a figyelmet. ${ }^{19}$

A probléma főként - a klasszikus besorolás szerint - képzőnek tartott toldalékok kapcsán merült fel, amelyek inflexiós tulajdonságokat mutatnak, pl. -hat/-het, -cskal-cske (vö.: Kenesei 1996, Kiefer 2003, 2004). Kenesei és Kiefer egyaránt három-három kritériumot sorolnak fel a két toldaléktípus elhatárolására, de nem ugyanazt a hármat.

Kenesei ${ }^{20}$ szerint a ragok és képzők elkülönítésében a következő kritériumok játszanak kulcsszerepet: 1. a tipikus inflexiós toldalékra jellemző az, hogy az adott szófaji kategória minden eleméhez hozzátehető, a képzőre nem; 2. a létrejött forma jelentése mindig kompozicionális a ragok esetében, a képzők esetében nem; 3 . a képzőt követheti más kötött morféma, a ragot viszont nem (1996: 92). Az első kritérium tehát a toldalék produktivitására vonatkozik, a második a szemantikájára, a harmadik pedig a pozíciójára.

Kiefer szintén központi szerepet tulajdonít a produktivitásnak mint tipikusan inflexiós tulajdonságnak, hiszen a képző́nek több akadályt kell legyőznie ahhoz, hogy az alapszóhoz tapadhasson. Keneseivel szemben Kiefer a képzőknek azt a tulajdonságát emeli ki, hogy tipikusan szófajváltó morféma, a ragnak nincs ilyen képessége. Illetve még azt tartja fontosnak megemlíteni, hogy az inflexió a szintaxis szolgálatában áll (a szintaxisra

19 "A szóragozást (illetőleg a deklinációt és konjugációt) nyelvtanaink általában úgy különböztetik meg a szóképzéstől (derivációtól), hogy a ragozást olyannak tekintik, amely a szó jelentését nem változtatja meg, hanem csak a mondattani szerepének a meghatározására való. Ezt a funkcióját úgy kapja meg, hogy a szónak csak az úgynevezett viszonyjelentését, vagy - úgy is szokták mondani - grammatikai jelentését változtatja meg, a lexikológiai jelentését nem. Ezzel szemben a szóképzés a szó lexikológiai jelentésének a megváltoztatására való, a szó mondattani viselkedése szempontjából közömbös. Ez a megkülönböztetés azonban nem elég szabatos. A nyelvtudomány ma már nem ilyen egyszerúen látja a kétféle morféma elhatárolásának kérdését" (Károly 1965: 273).

${ }^{20}$ Kenesei tanulmánya egész vitát indított el a Nyr. hasábjain, amelyhez Keszler Borbála (1997: 86-90) és Pete István (1997: 470-475) egyaránt hozzászóltak, majd mindkettejüknek válaszolt Kenesei (1998: 67-80). 
nézve vannak következményei), míg a képzés csak akkor válhat relevánssá a szintaxis számára, ha a szófajváltást figyelembe vesszük (2004: 327).

Mindenképpen szükség van olyan támpontokra tehát, amelyek kijelölik a tipikusan inflexiós toldalékok tulajdonságait, illetve a tipikus derivációs toldalékokét. Ezt az alapos elkülönítést Dressler végzi el (1989: 3-10), tanulmányában 20 olyan kritériumot fogalmaz meg, amelyek alapján meghatározhatók a fokozatbeli különbségek inflexió és deriváció között (idézi Kiefer 2003, 2004). Ennek értelmében azok a toldalékok, amelyek teljesítik a 20, inflexióra vonatkozó kritériumot, prototipikus inflexiós toldalékok, amelyek pedig a derivációra vonatkozó feltételeket teljesítik, prototipikus derivációs toldalékok. ${ }^{21}$ Ilyen prototipikus derivációs toldalékok például a deverbális névszóképzők (pl.: gondolkod-ás), denominális melléknévképzők (pl.: fá-s) stb. Természetesen nem lehet ennyire sarkítva felfogni a problémát, hiszen vannak olyan ragok, amelyek nem teljesítik az összes feltételt, és ugyanez érvényes a képzőkre is. Vagyis egy skálának két végén helyezkednek el a prototipikus inflexiós és derivációs toldalékok, az egyes toldalékok pedig aszerint, hogy a 20 feltételből mennyit teljesítenek, egyik vagy másik végéhez közelítenek. Nem prototipikus kategória például a kicsinyítő képző, ugyanis több tekintetben is közelebb áll az inflexiós toldalékokhoz, mint a képzőkhöz.

$\mathrm{Az}$ inflexiós és derivációs toldalékok elkülönítésének Dressler által meghatározott feltételei:

1. A képzők fő funkciója a szókincs gyarapítása, új szavakat hoznak létre, az inflexiós toldalékok nem. Bár van példa arra, hogy a kicsinyítő képzős származék lexikalizálódik (pl.: otthonka, magyarka stb.), ez nem jellemző. A származék jelentése általában levezethető a morfémák jelentéséből, vagyis kompozicionális: 'tőDIM' = 'tő' + 'DIM'.

2. Az inflexiós toldalékok mindig szintaktikai szerepet játszanak, vagyis a szintaktikai szerkezetek tagjai közti viszonyt speciális morfémákkal fejezik ki, a képzőknek nincs ilyen szerepük. Ezt a kritériumot a kicsinyítő képzők is teljesítik, ugyanis nincs semmiféle szintaktikai funkciójuk.

3. Egy szintaktikai szerkezeten belül kötelező az inflexiós toldalék megléte, a képző nem. Ebből a szempontból szintén képzőszerü tulajdonságot mutat a diminutívum: jelenléte egy szerkezetben nem kötelező, a nyelvtani struktúrát nem befolyásolja.

\footnotetext{
${ }^{21}$ „Most inflectional and derivational categories are prototypical” (Dressler 1989: 6).
} 
4. A biuniqueness ${ }^{22}$ iránti tendencia nagyobb szerepet játszik az inflexiós morfológiában, mint a derivációsban.

5. A szabályok variációja, illetve egymásmellettisége (l. szinonimitás a képzők körében ${ }^{23}$ ) a derivációnak tipikus vonása, az inflexiók esetében nem találkozunk ilyesmivel, hiszen egy rag egy nyelvtani kategóriát fejez ki.

6. A derivációnak nyelvspecifikus kategóriái sokkal számosabbak, mint az inflexióé, és változatosabb képet mutatnak a különböző nyelvekben.

7. Az inflexiós morfológiában nagyobb egység mutatkozik, mint a derivációsban.

8. Az inflexiós toldalékok jelentése elvontabb, mint a képzőké, ugyanis valamilyen nyelvtani relációt fejeznek ki.

9. A nyelvtani egyeztetés a ragokra jellemző (pl.: szám- és személybeli egyeztetés stb.), ritkán (a magyar nyelvben egyáltalán nem) figyelhető meg képzőknél.

10. Az inflexiós toldalék morfoszemantikai szempontból transzparensebb, mint a képző. Egy kicsinyítő képzős származék jelentése általában ${ }^{24}$ kompozicionális, a tô és a képző jelentésének az összege ('tö' + 'DIM' = 'származék').

11. Az inflexiós toldalékok tipikusan produktívabbak, mint a képzők. Ez azt jelenti, hogy szabályszerűen kapcsolódik különböző tövekhez (pl.: igeragozási rendszer, névszóragok). A kicsinyítő képzők közül a -cskal-cske teljesen produktívnak mondható, alig van olyan blokkoló szabály, amely gátolná valamely tőhöz való kapcsolódását. A -kal-ke kapcsolódását bizonyos fonetikai tényezők korlátozzák. ${ }^{25}$

12. A prototipikus inflexió nem változtatja meg az alapszó szófaját, a képzőnek viszont tipikusan szófajváltó szerepe van. A kicsinyítő képző ebből a szempontból sem tipikus képző, ugyanis nem az a funkciója, hogy egy tőnek megváltoztassa a szófaját, de még az sem, hogy valamely szófaji kategóriába besorolja (l. szófajjelölő képzők).

\footnotetext{
${ }^{22}$ A természetes morfológiában (natural morphology) az egy-egyértelmű megfelelés elvét jelenti, azaz egy alak - egy jelentés (Ladányi 2007: 31).

${ }^{23} \mathrm{Pl}$. a -cska/-cske és -ka/-ke szinonim képzők, jelentésükben nincs eltérés, kapcsolódásukat morfofonológiai tényezők szabályozzák (1. A kicsinyítő képzők kapcsolódási szabályai c. fejezetet).

${ }^{24}$ Kivételt képeznek a lexikalizálódott származékok, valamint a pragmatikai jelentéstöbblettel rendelkező származékok (1. A kicsinyítő képzók morfopragmatikai jellegzetességei c. fejezetet).

${ }^{25}$ L. A kicsinyítő képzók kapcsolódási szabályai c. fejezetet.
} 
13. Ez a kritérium azon strukturalista kritérium alapját képezi, amely az azonos osztályhoz tartozó morfémák egymással való felcserélhetőségére vonatkozik (pl. asztal-ka és asztal-ocska).

14. Egy alapszóhoz tipikusan több képző járulhat, de csak egyetlen rag. A kicsinyítő képzős származékokon egyetlen diminutívum jelenik meg. A -cskal-cske, -kal-ke képzőbokrok több, azonos funkciójú elemi képzőből állnak ugyan, de ezek az ősmagyar végén, ómagyar folyamán jöttek létre, az ómagyartól egységként fogja fel őket a nyelvérzék, és így kapcsolódnak az alapszavakhoz. ${ }^{26}$

15. A rag tipikusan kisebb mértékű jelentésváltozást okoz, mint a képző. A kicsinyítő képző sem hoz létre teljesen új jelentésű szavakat, hanem általában ${ }^{27}$ a 'kis, kicsi' szemantikai jeggyel egészíti ki a tő jelentését.

16. Az inflexiós toldalékok tipikusan paradigmatikus rendszerekbe rendeződnek, a képzők nem.

17. Az analógiás kiegyenlítődés sokkal erősebb a ragok esetében, mint a képzőknél. Ennek az a magyarázata, hogy a szoros paradigmába tartozó elemek nagyon könnyen hatnak egymásra.

18. A képzett szavak egységként raktározódnak el a mentális lexikonban, ezzel szemben a ragozott alakok nem.

19. A ragok periférikusabb helyet foglalnak el a szóalakban a képzőknél, tipikusan a képzők után helyezkednek el, és lezárják a szóalakot. $^{28}$

20. A morfémák közül bármely nyelvben a tövek mutatják a legnagyobb változatosságot (l. különböző tőalakok), a képzők kevésbé, a ragok pedig állandók a változatosság szempontjából.

Természetesen nem mindegyik kritérium alkalmazható a magyar nyelvre ${ }^{29}$, illetve nem mindegyik releváns a diminutívumok szempontjából. Mégis a felsorolt kritériumok alapján a kicsinyítő képzők bizonyos ragszerü tulajdonságokat mutatnak (jelentésük morfoszemantikai szempontból általában transzparens, produktívak, nem változtatják meg a tő szófaját, általában egy jelenik meg a tövön, nem feltétlenül raktározódik el

\footnotetext{
${ }^{26} \mathrm{~L}$. A SzT.-ban szereplő kicsinyítő képzők kialakulásának története c. fejezetet.

${ }^{27}$ Erről bővebben 1 . A kicsinyítő képzók szemantikája c. fejezetet.

${ }^{28}$ Ennek különböző okai vannak: 1 . a szóalakban a tőnek van a legkonkrétabb jelentése, a képző jelentése kevésbé konkrét, a ragé pedig a legelvontabb, ez az összefüggés metaforikusan az egyes morfémák egymáshoz viszonyított helyzetében mutatkozik meg; 2. a képzők új lexémákat hoznak létre, amelyek a maguk során ragozhatók, tehát a képzőnek meg kell elóznie a ragot; 3. a ragok szintaktikai szerpet töltenek be: egy szintaktikai struktúrán belül minél közelebb állnak azokhoz az elemekhez, amelyekre vonatkoznak, annál hatékonyabbak (vö. Dressler 1989).

${ }^{29}$ Vö. Mártonfi 2004: 65-66.
} 
egységként a mentális lexikonban), tehát nem lehet egyértelműen a tipikus képzők kategóriájába sorolni, az inflexiós-derivációs skálán az inflexiók felé mozdulnak el.

Ha az evaluatív morfológia ${ }^{30}$ szempontjait vesszük figyelembe, hasonló eredményhez juthatunk. Az első szempont a szemantikai változás. Ennek értelmében a diminutívum nem változtatja meg a tő jelentését (a tipikus képzőkkel szemben), hanem csak módosítja azt (pl.: szék - székecske 'kicsi szék'). Másodsorban (a képzőkhöz hasonlóan) nem zárják ki további, hasonló funkcióval rendelkező képzők hozzáadását az alapszóhoz (pl. a románban: mamă $\rightarrow$ mămică $\rightarrow$ mămicuță 'anya - anyuka - drága anyuka'). A mai magyar nyelvben ez nem fordul elő, de általában a kicsinyítő képzők kialakulási folyamatában ez a szabály igen fontos szerepet játszott (pl.: a -cska/-cske képző azonos funkciójú formánsok összetapadásából jött létre). Harmadsorban: az evaluatív toldalékok nem változtatják meg a tô szintaktikai kategóriáját, hiszen egy főnév, amelyet valamilyen (jelen esetben kis) méretüként fogunk fel, továbbra is főnév marad, a méretbeli csökkentés miatt nem változik meg a szófaji besorolása. Továbbá a tő bővítményeinek körét sem változtatják meg (vö.: Bauer 1997: 533-575), inkább a bővítmények jelentését jelölik ki ${ }^{31}$.

Tehát a kicsinyítő képzőknek az evaluatív morfológia szempontjai szerint való vizsgálata is azt mutatja, hogy ezek a képzők nem tipikus képzők, hanem bizonyos tulajdonságaikkal az inflexiós toldalékokhoz közelítenek.

Ennek terminológiai következménye lehet, ugyanis - ha a fenti szempontokat figyelembe vesszük - félrevezető a kicsinyitő képző terminusként való használata, hiszen a név olyan elvárásokat támaszt, amelyeknek a formáns nem tud megfelelni. A félreértés elkerülése végett talán jobb volna a diminutívum szakkifejezést használni helyette.

\section{II.6. Kísérlet a diminutívum meghatározására}

A fentebb jelzett problémák után (a diminutívumok több szempontból is eltérnek a tipikus képzőktől, emiatt valamely kategóriába való besorolásuk problematikus) igen nehéz pontos diminutívum-meghatározást adni.

\footnotetext{
${ }^{30} \mathrm{Az}$ evaluatív morfológia központi vizsgálati tárgya a diminutivizáció és az augmentáció, hiszen e két toldaléktípus gyakran nemcsak méretbeli módosítást fejez ki, hanem valamilyen emocionális többletjelentéssel ruházza fel az alapszót (egyetértés, ragaszkodás vagy éppen egyet nem értés és pejoráció) (Bauer 1997: 537).

${ }^{31}$ Erről bővebben 1. a A kicsinyítő képzős származékok bốvitményeinek jelentése c. alfejezetet.
} 
Robert Beard a diminutivizálást expresszív képzésnek tartja, amelyre az jellemző, hogy nem változtatja meg az alapszó referenciáját, illetve nem változtatja meg az alapszó lexikális kategóriáját (1998: 60), hanem valamilyen emotív jelentéstartalommal tölti fel a beszédhelyzetet.

Bronislav Volek diminutívum-meghatározásában szintén fontosnak tartja hangsúlyozni, hogy ez a formáns nem tipikus képző, hiszen nem hoz létre új lexémát, alapvető funkciójaként az érzelemkifejezést emeli ki (1987: 32). A toldaléknak az emotív potencialitása (emotive potency) attól függ, hogy az adott formáns milyen mértékben specializálódott az emotív származékok létrehozására (1987: 48), vagyis az emotív potencialitás mértéke attól függ, hogy a toldalék mekkora gyakorisággal eredményez emotív származékot.

A diminutív toldalékok alapfunkciója az, hogy az alapszóban kifejezett dolgot vagy tulajdonságot kicsinyítse. Emellett az alapszó jelentését befolyásolják: nagyobb részük képes emotív jelentést kölcsönözni annak a tőnek, amelyhez járul, csak nagyon kis részük nem rendelkezik ezzel a képességgel (elsősorban azok, amelyek lexikalizálódott származékban jelennek meg, illetve a pusztán kvantitatív jelentésűek) (1987: 50). Ennek értelmében a diminutívumokat jelentésük szerint három csoportba sorolhatjuk. Az elsőbe tartoznak azok, amelyeknek pusztán kvantitatív jelentésük van, a másodikba azok, amelyek pusztán emotív jelentésúek, a harmadikba pedig az emotív-kvantitatív jelentésűek (vagyis az olyan toldalékok, amelyek azon túl, hogy az alapszó méretbeli csökkentését eredményezik, valamilyen emotív jelentéstartalommal is feltöltik). Kisebb-nagyobb pontossággal az is megjósolható, hogy milyen tőhöz milyen típusú diminutívum kapcsolódik: az elvont jelentésú tő a diminutívumnak a pusztán emotív jelentését vetíti előre (pl.: hírnév - hírnevecske), a dolgot jelölő tövek viszont a diminutívumnak többféle értelmezését is lehetővé teszik (pl.: ágyacska 'kis ágy' vagy 'aranyos, kedves kis ágy') (1987: 51-2). 



\section{A SZT.-BAN SZEREPLŐ KICSINYÍTŐ KÉPZŐK KIALAKULÁSÁNAK TÖRTÉNETE}

A diminutív képzők rendszere a nyelvtörténetnek az egyik legdinamikusabb kategóriája, ami azzal magyarázható, hogy nem valamilyen grammatikai szükségszerűség, hanem a nyelvvel való játék, illetve a nyelvi játékosság iránti igény hívja életre őket. Már az ősi egyelemű képzők között is voltak olyanok, amelyeknek a funkciója a kicsinyítés, becézés volt, a későbbi korszakok folyamán pedig nagy számban keletkeztek a kicsinyítő képzők, amelyeknek produktivitása változott ugyan, de szinte mindegyik megmaradt valamelyik nyelvjárásban.

A SzT.-ban leggyakrabban előforduló kicsinyítő képző a -cskA, ezt követi a $-k A$ és sokkal kisebb százalékban van jelen a $-d$, -óca/-őce, -cs; -cs $A$, $-d k A$, $-d o c s k a,-d A d,-o ́,-o ̋,-i c a,-u c a,-i k a,-i k o ́,-i c s k a$, -icskó, -uka, -óka, óc/-öc.

\section{III.1. - cskA}

A -cskA a kései ómagyar korban keletkezett, és rövid időn belül az egyik leggyakoribb és legproduktívabb kicsinyítő képzővé vált a nyelvterület minden részén. Három, szintén kicsinyítő jelentésű formáns $(-c s+-k$ $+-a /-e)$ összeolvadásából jött létre ez a képzőbokor, és szinte minden megszorítás nélkül kapcsolható bármilyen alapszóhoz. Ma a legtermékenyebb kicsinyítő funkciójú toldalék. A kései ómagyar kor kezdetétől adatolható már, és ettől kezdve folyamatosan van rá példa: JókK. 32: hellecfken; 1450: Banyachka hn.; FestK. 34: hegechkeek; stb.

A SzT.-ban is ezzel a képzővel keletkezett a legtöbb kicsinyítős származék. Például: barmocska 'szarvasmarhácska' jelentésben 1584-ből: Zekel Balint vallia Eleyn barmochkat tartottam, de hogy twzert Ieót oda eze(n) Azzony, senkire $\mathrm{Ne}(\mathrm{m})$ gianithatta hogy barmanak el vezet Teye, hane $(\mathrm{m})$ ez Azzonra [Kv; TJk 4/1. 251]; alkalmatosságocska kicsinyítő jelentésben kb. 'kedvezés' 1689-ből: N. Boër Thamas, és B. Péter Uraimék Proponálva(n) az eo Ngok Fogarasi Felső Székin Felsŏ Venicei joszagokba(n) sokkeppe(n) valo meg bántodásokot, instaltak mi előttűnk kőzőnsegese(n) azo(n): hogy 
az iránt valo háborgattatásokba(n) ha mi alkalmatossagocskaval mi tőllünk kőzőnsegese(n) lehetne az iránt valo succursusunkot ne denegalnok [Fog.; Szád]; becsületecske 'kicsi becsület' jelentésben 1730-ból: az ország tellyes vala az Aszszony ream valo nehezsegevel s engemet kissebittö, s csak nem átokra fokado Szavaival, de én mind azokot hitetlenséggel, és jora valo magyarázáss s türessel palastoltam, söt ... azonn kész affextiomot tartom fenn az Aszszonyhoz (: kivált ha becsületecskemet tapasztalhatom :) melylyel ennek elötte viseltettem [Fehéregyháza NK; Ap. 2 gr. Haller István br. Apor Péterhez]; cselédházacska 'szolga-lakocska' jelentésben 1817-ből: A Kapun belől mindgyárt vagyon, egy kis cseléd házatska, mely bornábol vagyon ki rakva, és szalmával fedve [Kövesd NK; Kp V/319] stb.

\section{III.2. -kA}

A - $k A$ az ősmagyar kor folyamán keletkezett a - $k$ és az -a/-e kicsinyítő jelentésű formánsok összetapadásából. Az ezzel a képzővel létrejött szavak ősmagyar kori rétege szemantikailag jól körülhatárolható kategóriákba sorolhatók. A két nagy szemantikai kategória: a színnevek és az állatnevek csoportja. Ezek nagy részében a $-k A$ nem módosít számottevően az alapszó jelentésén, tehát a kicsinyítő funkció még nem eléggé erőteljes. Példák: TÖ.: Zeuke szn.; 1258: Zirku hn.; 1273 k.: Zurke szn.; VárReg. 166.: Tarca szn. Az állatnevek között magyar - $k A$ képzős származék kevés van: 1322: Chyrke szn.; JordK. 376: rokaknak (TNyt. I/243.).

A - $k A$ használati köre a kései ómagyar korban tovább bővült, a -cskA mellett a korszak legáltalánosabb kicsinyítő képzője volt. Főnévi alapszavakon a 14. századtól gyakori: JókK. 10: emberke; 1483: Azzonka hn. stb., mellékneveken a 16. században jelenik meg: 1577 k.: vekonka.

A SzT. adalékai is azt igazolják, hogy a $-c s k A$ mellett a $-k A$ volt a legproduktívabb kicsinyítő képző. Például: apróleányka 'szolgálóleányocska, szolgálócska, pesztonka' jelentésben 1666-ból: Az Apro leankaknak is hattam ... egy ŭnő tinőt (!) [Abafája MT; Told. 21], asszonyka 'asszonyocska' jelentésben 1582-ből: Mikor Menne az Ló és az Azzonyka Gereznaiaban vthanna siethe, Az gereznatole vag miteól vg Jyede meg az ló es ug Ruga fel [Kv; TJk IV/1. 114], bárányka 'bárányocska, fiatal juhocska' jelentésben 1750-ből: kŭldőttem bé ... őtt Csirkecskét, két Pipét, két ifju Nyulacskát, és ez oráig Annyát szopo két Kis Báránykát [O.csesztve AF; Ks 83], cipóka 'cipócska' jelentésben 1834-ből: A' kerti Szőllő megszedésekor Anyám teméntelen vendéget hivott ... Az üdő sanyarutska volta mellettís vigan mulattunk, a Tracta állot Czipoka, és lágy kenyérből [Kv; Pk 7 Pákei Krisztina lev.], csigafalatka '(húslevesbe való) csigatésztácska' jelentésben 1838-1845ből: a reszelt tésztából, ormos henger által egybesodort kis csigafalatkák, 
miket dara - vagy reszeltbe, mintegy előljárokul tesznek bé [MNyTK 107 rigó fütty al.] stb.

\section{III.3. - d}

A -d is ősi, egyelemű képzőink közé tartozik, és az ősmagyar kor legproduktívabb kicsinyítő képzője lehetett. A korai ómagyar korban is élnek még ezzel alakult derivátumok: TA.: holmodi rea; DömAd.: Apadi szn.; ÓMS.: eggedum, fyodum, urodū; 1300: Oprod szn. (OklSz.). A 14. században a - $d$ kicsinyítő funkcióban még produktívnak látszik, produktivitása a kései ómagyar kortól a nyelvterület kisebb részére korlátozódik (TNyt I/242.). Mára elavult toldalék, főleg helynevekben maradt meg (pl.: Cegléd, Fonyód, Ónód stb.), illetve egy-két személynévben (pl.: Árpád, Ond) (Zaicz 2006: 132).

A SzT. tanúsága szerint a - $d$ a magyar nyelvterület ezen régiójában később is viszonylag produktív maradt, több olyan származék tartalmazza ezt a formánst, amelyekben egyértelmü a kicsinyítő funkció. Az apród szónak például 'aprócska, kicsike' jelentése van a SzT.-ban egy 1778-ból származó adalékban: Marhái és Fakultásaira eset portioja én réám iratott mint el maradott õzvegjére Aprod gjermekeimmel egjütt [Agárd MT; Told. 8]. Egyéb, - $d$ képzővel létrejött származékok: jobbad 'jobbacska' jelentésben 1571-ből: egy jo paripat nem talalunk, lofeweknek sokaknak es keossegnek is kijet kijet jobbadnak hallottak nyayatul el üzettek [SzO II, 326], kevesed 'kevesecske' jelentésben 1826-ból: a praetendált jövedelemnek kevesed része az özvegyi kevés Joszágnak az igazi jővedelme [Ne; DobLev. V/1114. 9a], kicsid gyermekre vonatkoztatva 'kicsi, kicsike' jelentésben 1558-ból származó adalékban: Az melly Arwakat En Mostan tarthok mynd kyczydeket, mynd, Nagyokat azt Akarom hogy Meg Elegechek [JHbK XLIII/21 Mikola Ferencne Melyk Anna végr.] stb.

\section{III.4. -óca/-őce}

Az -óca/-őce a későn keletkezett képzők sorába tartozik, kicsinyítő funkciójú formánsok összetapadásából jött létre.

A SzT.-ban mindössze két származékot, a kakócát és a gyerkőcét hozta létre. Példák: a kakóca 'kiskakas' jelentésű lehetett, majd lexikalizálódott, és csupán helynevekben maradt fenn: 1820: A Kakotza erdő [Udvarfva MT; EHA], a gyerkőce származéknak 'gyermekecske' jelentése volt, egyetlen adalékban jelenik meg 1838-1845-ből: Prunkuj, porunkuj" (: a román "prunk, prunkuc = gyerkőcével egyeredetü" :) [MNyTK 107]. A SzT. csak 19. századi -óca/-őce képzővel létrejött származékokat tartalmaz. 


\section{III.5. -cs}

A -cs a korai ómagyar korban kicsinyítő jelentésben jelenik meg bizonyos származékokon. Például: [1237-1240]: Erech (Erecs <: ér 'kis patak') (PRT. 1: 782); 1268: Cuechesporog hn. (<: kövecs <: kó) (OklSz.). A képző ilyen jelentésű származékok létrehozásában a nyelvtörténet későbbi korszakai során nem vesz részt (TNyt I/244), kivételt képez a nyelvújítás kora, amikor olyan származékokat hoztak létre vele, mint a labdacs, szögecs, uracs (Zaicz 2006: 109).

A SzT. címszavai között két lexikalizálódott származék keletkezett a -cS képzővel: a kövecs (pl.: 1737: egj egj szekér porondot és követset vigjen vagj vitessen [Dés; Jk]; 1762: a Nagy Szamos ... ezen hellyet a midön el szakasztotta követtsel porondal és minden ágokkal megrakta [BSz; SLt XXIV. 6]) és a pakocs (1850 k.: piskota, makaroni pakocsban [Pk 2]).

\section{III.6. - csA}

A - $c s A$ az ősmagyar kor folyamán jött létre a szintén kicsinyítő jelentésű -cs és - $a$-e formánsok összetapadásából, és kedvelt kicsinyítőjévé vált ennek a kornak. Porduktivitása a kései ómagyar kortól csökkenőben van. A korai ómagyar korból kevés -csA képzős névszóra van példa: TÖ.: Keuueche szn.; VárReg. 16.: Scymcha (a szem alapszóból), 42.: Orocha szn.; 1322: Zarchazek hn. (Szárcsaszék). A vércse és tócsa szavak keletkezése is az ősmagyar korra tehető (1395 k.: verche (Gl.); JordK. 20.: tocfakra).

A kései ómagyar kor kezdeti szakaszából származó nyelvemlékekben még sok példa van -csA képzős származékokra: JókK. 62: fegencfe; BécsiK. 70: aiandokcsakat, 261: orozlancsaidat; stb. A későbbi időszakban már sokkal kevesebb -csA képzős adat található, szórványosan azonban még előkerülnek: NádK. 485: germokceiet; SzékK. 326: feeregcye, 339: haylokchaban; VirgK. 138: leanczayd. Mára teljesen elavult, csak néhány keresztnév becéző alakjában őrződött meg (pl.: Julcsa, Borcsa stb.) (Zaicz 2006: 109).

A SzT. is csak két -csA kicsinyítő képzős származékot tartalmaz: gyakorcsa valószínüsíthetően 'sürücske' jelentésben 1705-ből: ezen Falu határán Apró gyakorcsa nevü hellyen [Altorja Hsz; Borb. II], valamint gyermekcse 1688-ból: Egy itt quartelyozo Lutheranus Németnek, recens natus, és ige(n) beteg gyermekcsejét ... meg kereszteltem [Bethlen kör. SzD; UtI]. Ez utóbbi a régi grammatikák közül többen is előfordul példaként. ${ }^{32}$

\footnotetext{
${ }^{32}$ Vö. a Kicsinyitó képzók a régi grammatikákban c. fejezettel.
} 


\section{III.7. -dkA, -docska}

Azért kerülhet ez a két kicsinyítő képző egymás mellé, mert hasonló módon jöttek létre: pontosabban mivel a - $d$ kicsinyítő funkciója homályosulni kezdett, megtoldották még egy hasonló szerepü formánssal $(-d+-k A$ vagy $-d+-c s k a)$.

Több - $d k A$ képzős származék szerepel a SzT.-ban: alábbadka, jobbadka, nagyobbadka, nehezedke. Az alábbadka 'lejjebbecske' jelentésü (XVIII. sz. e. fele: Rétetskéje... van... Petlendi Puszta Falu helyen ${ }^{a}$ az elébbenivel egj sorba alábbatka [AbN. - ${ }^{a}$ Túr (TA) határában]), a jobbadka 'jobbacska' jelentésü (1694: Majorság-Szőlő ... Ennek két felől fel menő szelei ... igen pusztások, homolittatni kévánok: a közepe(n) jobbadka [Kisenyed AF; BfR néhai ifj. Bálpataki János urb.]), a nagyobbadka 'nagyocska' jelentésü (1644/1648 k.: egy Veres scarlat szűniegh nagiobbatka [Born. XXXVIII. 14]), a nehezedke 'sutácska, ügyetlenke' jelentésü (1796: Zsuzsi Urnaptol fogva a Gyapot mivelésel bajlodik, de nehezetke a' kezé hanem idŏvel tsak meg tanul [IB. Molnár György héderfáji ref. pap lev.]).

A -docska csupán a jobbadocskán származékban jelenik meg, jelentése 'jobbacskán', 1747-ből: Samuel Ur(am) ... beteges allapottal van, de most Jobbadocskán van [Buzd AF; Ks 96 Mikó Ferenc feleségéhez].

\section{III.8. -dad}

A - $d A d$ az ómagyar kor folyamán alakult ki a - $d$ kicsinyítő képző elemismétléséből. Korai példák: JókK. 39: kyfded; BécsiK. 171: ifiudad; GuaryK. 15: keregded; ÉrdyK. 50: tawoldaad, 519: ezesded; stb.

A SzT.-ban is van ezzel a képzőbokorral létrejött származék: hosszúdad ${ }^{33}$ 1864-ből: Várhegy, melly is egy felemelkedett hosszudad hegj [Nagyalmás K; KHn 316], kicsidded 'kicsiny' jelentésben 1585-ből: Talak kicsid(d)ed keozepzerewek vadnak Niolcz, tizenharmadfel font, tt f 2/7 [Kv; KvLt Vegyes $\mathrm{I} / 2-3]$.

\section{III.9. -ó/-ő}

A SzT.-ban is megjelenő -ó/-ő képző ősi, egyelemű képzőink sorába tartozik. Az -ó/-ő ( -ú/-ü) az ősmagyar kor jellegzetes és produktív kicsinyítő képzője volt (TNyt. I/242.), olyan származékokban, mint pl.: TA.: $m u$ norau; KTSz.: fiu; 1325: vezeus szn. (Zichy-Okm. 1:270); 1405 k.: zwmwlche (szemölcsé szemölcsó) (Gl.); A porK. 120: fellobe. Már ebben a korban vannak

\footnotetext{
${ }^{33}$ A SzT. nem adja meg ennek a származéknak a jelentését, azonban könnyen kikövetkeztethető, hogy jelentése 'hosszúkó, hosszúkás' lehetett.
} 
olyan származékok, amelyekben a képző jelentése elhomályosult (vesszó), illetve elhomályosulóban van (fiú, mogyoró), ami a képző csökkenő produktivitására utal. Világosan kielemezhető viszont például az anyó és apó származékokban. A TNyt. szerint (I/242.) az -ó/-ő ebben a kicsinyítő funkcióban a korai ómagyar kor végére elavult, személynevek becéző alakjában viszont még ma is előfordul (pl.: Kató, Janó stb.), illetve kedveskedőnek szánt megszólításokban újraéledni látszik (pl.: babó, nyuszó, bratyó) (Zaicz 2006: 582).

A SzT.-ban is van -ó képzős származék: agárkutyó ‘agárkölyök' jelentésben 1654-ből: praemendatt attam ... Haro(m) Agar kutjonak lib. nro 9 [Egeres K; Ks 70 Szám. 51], az ángyó becézésként rendszerint megszólításban fordul elö, például egy 1766-ból származó adalékban: le menvén Damokos Ferentz a' Battyahoz Damokos Janoshoz monda az Angyának Damokos Janosnénak jol mondotta ked Angyo (: mint hogy az elōtt valo estve ott volt :) hogj ne menyek el hanem hallyak itt mert valami bajom lész Azon beis tellyesedék rajtam [Szilágycseh; BfR 104/2] és a cserecsutkó 'tölgyfatönk/ csutak' jelentésben 1781-ből: ez oljan Sŭrŭ erdŏ volt nagy Csere tsutkok fák Tŏvis Fŭz rakotya es egyeb tseplesekkel ... rakva volt ... a Nagy Fakat Puska Porral hanyattatta el ... eŏ Nga [Balavásár KK; Ks 19/IV. 8]. Az elsőben a 'kis, kicsi' szemantikai jegy megvan, a másodikban a becéző funkció kerül előtérbe, a harmadikban pedig már elhomályosulóban van a kicsinyítő funkció, így lexikalizálódott.

\section{III.10. -ica, -uca}

Az -ica és -uca kicsinyítő képzők újabb keletkezésű toldalékok, elterjedésükre a hasonló szláv képzők hathattak. Az -ica elsősorban női nevek becéző alakjában jelenik meg (pl.: Ágica, Katica), ritkán azonban előfordul személyek kedveskedő említésére, megszólítására használt köznévből képzett szóalakokban is (pl.: hugica, tubica). Ma sem tekinthető teljesen elavult képzőnek, a játszi szóképzés egyik kedvelt formánsa (pl.: rókica 'kisróka', nyakica 'nyakacska') (Zaicz 2006: 325).

A SzT.-ban két ilyen képzővel létrejött származék szerepel címszóként, de ez voltaképpen nem az erdélyi magyar szóhasználatot tükrözi, hiszen az adalékok román anyanyelvűektől valók, azaz a románok kétnyelvűségére utal: lunkuca (<luncă) és pojenica (< poiană). A lunkuca 'rétecske' jelentésü, az adalék 1765-ből való: ezen Lunkutzát nem emlekezűnk reá hogy mikor és ki irtotta légyen ki [Hosszútelek AF; JHb XXVII. 25. 5], a pojenica pedig 'kis erdei tisztás' jelentésü 1782-ből: azt tudom hogy égy hellyetskét a Gorbai határon in vállyá Unguruluj nevezetű vőlgyben Pojáná Boldizsojénak hivják melly Pojenitzát én tudom, hogy olly kitsiny helly volt tsak 
az én emlekezetemre is, hogy alig termett meg rajta égy szekeretske széna ... de ezen Pojenitzát miért hivják annak, nem tudom [Paptelke SzD; JHbK VIII/18 Petrán Togyér Senior (72) jb vall.].

\section{III.11. -ikA}

Az -ikA a kései ómagyar korban keletkezett három egyelemü, kicsinyítő funkciójú képző összetapadásából $(-i+-k+-a /-e)$. Ilyen származékokban jelenik meg legkorábban: 1357: Karikad hn. (MNy. 10: 82) és vö. 1595: Palcfikakot (MNy. 62: 236). Ma is eleven képző, főleg személynevek becéző alakjának létrehozására használatos (pl.: Mártika, Erzsike, Klárika stb.), de dajkanyelvi szavakban is gyakori (pl.: hasika, husika stb.) (Zaicz 2006: 330).

A SzT.-ban nem tartozik a leggyakoribb képzők közé, de több származékban is megjelenik. Például: ládika 'ládácska, ládikó' jelentésben 1846ból: Egy ládika Klauzal Gabor képével [Dés; Berz. 20]; 1846: Egy papir lemez ládika [Dés; Berz. 20]; pálcika 'kicsiny pálca' jelentésben 1765-ból: Varga Gyŏrgy ... kezében lévŏ kis ujjomni pálczikával maga elŏtt Czivészlett, hogy valamiképpen belé ne szaladgyon Szabaszlai Ur(am) és meg ne foghassa [Szépkenyerüsztmárton SzD; Eszt-Mk Vall. 13] stb.

\section{III.12. -ikó}

Az -ikó kicsinyítő képzőbokor nem szerepel a TNyt-ben. Keletkezéséről elmondható, hogy két kicsinyítő funkciójú képző összeolvadásából jött létre (-i+-kó/-kó) az ómagyar korban. Gyakoribbá csak később, az -i-s becéző alakok elterjedésével vált (pl.: házikó, ládikó, Anikó). Magas hangrendű -ikő párja csak az újabb keletkezésü Enikő névben mutatkozik. A mai nyelvben új képzésekre már nem használatos, de főleg gyermekorientált beszédhelyzetben ma is elöfordul (pl.: ágyikó, lábikó, hasikó) (Zaicz 2006: 330).

A SzT.-ban három -ikó képzőt tartalmazó származék szerepel címszóként: házikó, ládikó és pálcikó, valamint olyan összetett szavak, amelyeknek elö- vagy utótagja a három említett szó egyike. A legkorábbi adalék a házikó címszó alatt szerepel, és 1640-ből van: vagi(on) ennek felette 19. muntanis Jőveveniek kiknek valami hazikoiokis vagio(n) szabadosak el menny vagi ot lakni [Szevesztrény F; UC 14/48. 78], az összes többi 18-19. századi adalék: ládikó 'ládácska' jelentésben 1849-ből: Kis ladiko finom cirkalmakkal 30 Rft [Görgénysztimre MT; Born. G. XXIVd]; pálcikó 'pálcácska' jelentésben 1765-bőll: az midŏn Varga Gyŏrgy az emlitett patzikoval hadarászot és hátra felé ment volná Szabaszlai uram beléje szaladván, akkoron érte azon 
pálczával az karját egyszer [Szépkenyerüsztmárton SzD; Eszt-Mk Vall. 13] stb.

\section{III.13. -kó}

A -kól-kő kicsinyítő képzőbokor, amely feltehetően az ősmagyar korban keletkezett a kicsinyítő - $k$ és a szintén kicsinyítő funkciójú -ó/-ő összetételéből. A régi nyelvben gyakoribb volt, ma elsősorban személynevek becéző alakjának létrehozásában játszik szerepet (pl.: Ferkó, Lackó, Jankó stb.), de néhány lexikalizálódott köznévből is kielemezhető (pl.: tarkó, szánkó, pejkó) (Zaicz 2003: 414).

A SzT. mindössze egy -kó képzővel létrejött származékot tartalmaz: szupujkó (1823-1830: a prussus huszároknak a csákójok is alol széles, a teteje szupujko volt [FogE 203]).

\section{III.14. -icska, -icskó}

Az -icska, -icskó képzőbokrok egy becéző és egy kicsinyítő funkciójú képző egymás mellé kerülésének eredménye. Újabb keletkezésű toldalékok.

A SzT.-ban egy-egy példa van ilyen képzőbokorral létrejött származékra: a házicska és a házicskó. Mindkét adalék 19. századi, és mindkét származék jelentése 'kicsi ház, házikó'. A házicska címszó alatt a következő adalék található: 1840: bátorságosabban bírhassam azon Hazitskat [Dés; DLt 1420], a házicskó alatt pedig: 1843: tetzet ... admoneáltatni hogy a Tegla vetŏ helyen fel epittetett Házatskát es egy kis veteményező Kertetskét elrontsam, holott az a Házitsko az egésség fen tartására ... szükséges képpen meg kelletik lenni ... méltoztasson azon Házitskot a maga valoságában meg hagyni [Dés; DLt 1358].

\section{III.15. -uka}

Az -uka képzőbokor elemei: a becéző funkciójú -u (1. anyu, apu, bátyu stb.) és a kicsinyítő -ka. Kérdés azonban, hogy a képzőbokornak van-e kicsinyítő funkciója, vagy egyszerūen egy becéző és egy kicsinyítő képző egymás mellé kerüléséről van szó.

A SzT.-ban két származékban szerepel: bátyuka 'bátya, bácsika, öreg' jelentésben 1598-ból: az en iozago(m)ba hazamba be fogatta $(\mathrm{m})$ valá magam otalmaert ... engemet, elessen es niugosso(n), tiztessegben tarczio(n) mint battiat ... de eö nem tekintette az Vristent sem az attiafiwsagot eö engemet tiztessegbe nem tarta, rutolt zidot kouetem az kegtek zekit Batiuka- 
nak lelek kuruanak es halallalis feniegetet engemet [UszT 13/117]. Ebben a szövegben a bátyukának gúnyos jelentésárnyalata van. A másik származék a mamuka, amelynek jelentése kb. 'ügyefogyott', és amelynek szintén csúfondáros, gúnyos jelentésárnyalata van. Az adalék 1812-ből származik: a Groffné nagyon indulatba jőtt, és a' Grofot nagyon kissebitetté sőt motskolta, gazolta mondván: Te Samuka, Mamuka, Mamujka, Tőkős [Héderfája KK; IB. Molnár György (58) ref. esp. vall.].

\section{III.16. -óka}

Az -óka két kicsinyítő funkciójú képzőből áll (-ó + -ka).

A SzT.-ban egyetlen származék jött létre ezzel a képzővel, a botóka, amelynek két jelentése van. Első jelentése 'botocska', és 17. századi adalékokban fordul elő: 1686: az tordai vitézek elrugazkodának, engem elszakasztának az lobonczok ... sokan vagdaltak hozzám, egy botokával hántam ellent [TT 1889.509 SzZsN], második jelentése 'csipke- v. receverő pálcika', és 18. századi adalékokban jelenik meg: 1761: őt darab szedett pántlika, mellynek szélin arany és ezüst botokan vert kőtésetske vagyon [Koronka MT; Told. 8].

\section{III.17 -ók}

Az -ók kicsinyítő képző két kicsinyítő funkciójú egyelemű formáns öszszekapcsolódásából jött létre. A TNyt csak a két egyelemű képzőt említi, az -ók képzőbokrot nem. A Zaicz-féle Etimológiai szótár a képzőbokor keletkezését az ősmagyarra teszi. A becézés mellett a régi nyelvben, valamint egyes nyelvjárásokban nagyítást is kifejezhetett, megnevezésekben sértő jelentésárnyalatot kaphatott (pl.: szemók 'nagy szemư', orrók 'nagy orrú'). Mára már teljesen elavult, személynevek becéző alakjában is régiesnek hat (pl.: Erzsók, Istók) (Zaicz 2006: 584).

A SzT. is csak egy olyan származékszót tartalmaz, amely ezzel a képzővel jött létre, vagyis nem tartozott a gyakori kicsinyítő képzők sorába. A szénafiók 'szénaboglyácska' jelentésű, már lexikalizálódott, egy 1824-ből származó adalékban jelenik meg: edgy Széna fiok alatt vártuk az esső elmulását [M.légen K; KLev. 9].

\section{III.18 -óc/-őc}

Az -őc képző keletkezése hasonló az -ók képzőéhez, amely a régi nyelvben is csak ritkán fordult elő (pl.: gombóc). A nyelvújítók néhány új származékot hoztak létre vele (pl.: bohóc) (Zaicz 2006: 96). 
A SzT.-ban egyetlen származékszóban jelenik meg, a gyerkőcben. A származékszó jelentése: 'gyermekecske', a képzőnek inkább becéző, mint kicsinyítő funkciója van: 1838-1845: járni kezdett a gyerkőc [MNyTK 107].

A kicsinyítő képzők e rövid történeti áttekintése azt mutatja, hogy a SzT. gazdag tárháza az ilyen formánsoknak, előkerültek olyanok is, amelyek a TNyt-ben nincsenek benne. Az ősi, egyelemű kicsinyítő funkciójú formánsok, valamint az egész nyelvterületen elterjedt képzők mellett az erdélyi régi nyelvben megjelennek olyan képzőbokrok, amelyeknek egyes elemei már önmagukban kicsinyítő képzők, de a funkció felerősítésére öszszetapadtak, továbbá olyanok, amelyek román közvetítéssel kerültek át a magyarba. 


\section{A KICSINYÍTŐ KÉPZŐK VIZSGÁLATÁBAN ALKALMAZHATÓ SZEMPONTOK}

\section{IV.1. A kicsinyítő képzős származékok szemantikája}

Amikor kicsinyítő képzős származékok szemantikájáról beszélünk, először is két fogalomnak a tisztázására van szükség. Meg kell határoznunk, hogy mit értünk morfoszemantikán és a morfológia lexikális szemantikáján.

Morfoszemantikán a morfológiai szabályok szemantikai jelentését értjük, vagyis a bemenet és kimenet közti szabályos jelentésváltozást (Dressler, Kiefer 1990: 69). Szóképzés esetén a bemenet a szótő, a kimenet pedig a képzett szó. A morfológia lexikális szemantikája pedig a morfológiailag komplex szavak jelentésére vonatkozik. Tehát egyrészt meg kell vizsgálni, hogy mi a kicsinyítő képző jelentése, másrészt azt, hogy a kicsinyítő képzővel létrehozott szó jelentése hogyan módosul az alapszó jelentéséhez viszonyítva.

A kicsinyítő képzőkről kialakult általános felfogás az, hogy 'kis, kicsi' szemantikai jeggyel egészítik ki az alapszó jelentését, mintegy lekicsinyítve azt. Emiatt a szakirodalomban a diminutív képzőket olyan szóbelseji kvantitatív eszköznek tekintik (Dressler-Merlini Barbaresi 1991, idézi I. Ştefănescu 1992: 332, Dahl 2006: 5944), amely a természetes nyelvekben megvan. Vagyis a kicsinyítő képző befolyásolja ugyan az alapszó jelentését, de ez a jelentésmódosítás csak egy kvantitatív skálán mozoghat. ${ }^{35}$

Első pillantásra úgy tünhet, hogy a jelentésbeli különbségek pusztán a tő lexikális vagy szemantikai kategóriájától függnek, például:

ház (fn) + -acska (DIM) 'kis fn (ház)'

magas $(m n)+$-acska (DIM) 'kevésbé/nem túl mn magas'.

\footnotetext{
${ }^{34}$ "Diminutives ... are words formed by derivational processes that add a semantic element having to do with size to the meaning of the word." (Dahl 2006: 594)

$35,(\ldots)$ as for the change of denotative meaning (i.e. of diminutives), this is restricted to a scale of quantity (or also corresponding to quality): diminutives involve a decrease in quantity." (Dressler\&Merlini Barbaresi 1994: 92)
} 
Ennek értelmében a kicsinyítő képző a tő szófaján nem változtat, jelentését is csak meghatározott irányba befolyásolja.

Egy másik megközelítésben:

$\left[{ }_{\text {dolog }}\right.$ ház $]+\left[_{\text {DIM }}\right.$ acska] 'kis dolog ház'

$\left[{ }_{\text {tulajdonság }}\right.$ magas $]+\left[_{\mathrm{DIM}}\right.$ acska] 'kevésbé/nem túl tulajdonság magas ${ }^{\prime 36}(1 . \mathrm{L}$. Gràcia, L. Turon 2000: 233), vagyis az osztályozás alapját nem az alapszó szófaja, hanem jelentése képezi. Ez azonban a lényegen nem változtat: a diminutív képző továbbra is az alapszó jelentésének csökkenését eredményezi.

A beszédhelyzettől függően viszont előfordulhat, hogy a kicsinyítő képző vagy tisztán pragmatikai jelentést kap, vagy - a denotatív jelentés mellett - bizonyos pragmatikai jelentésárnyalatot ${ }^{37}$ (1. Dressler, Kiefer 1990: 75). Így gyakran egyéb tényezőket is figyelembe kell venni a diminutívumot tartalmazó képzett szavak jelentésének a meghatározásában, hiszen - kontextustól függően - a származéknak több jelentése lehet (pl.: papocska - 1. kis termetú pap, 2. fiatal pap, 3. pejoratív értelemben rossz pap). Az első jelentés a ház szó kicsinyítő képzős származékához hasonlít, amikor a kicsinyítés méretbeli csökkentést jelent. A második esetben viszont a kicsinyítés a főnévnek egy másik jegyét érinti: itt már valamilyen időbeli vonatkozás csökkentéséről van szó, a harmadikban pedig a képző a főnévnek minőségi jegyét érinti. Tehát világos, hogy a papocska jelentése komplexebb, mint a házacskáé, ami arra enged következtetni, hogy olyan szemantikai jegyek meglétét feltételezhetjük, amelyek meghatározzák a szó jelentését. A képző képes ezeket a jegyeket külön-külön megváltoztatni, a képzett szó jelentése pedig árnyalatbeli különbségeket mutathat annak függvényében, hogy a diminutívum melyik jegyet módosítja.

A SzT.-ban legtöbb példa olyan származékra van, amelyek jelentése 'alapszó + DIM': házicskó 'ház + DIM': 1843: tetzet ... admoneáltatni hogy a Tegla vetŏ helyen fel epittetett Házatskát es egy kis veteményezõ Kertetskét elrontsam, holott az a Házitsko az egésség fen tartására ... szükséges képpen meg kelletik lenni ... méltoztasson azon Házitskot a maga valoságában meg hagyni [Dés; DLt 1358]; helyecske ‘hely + DIM': 1767: Nehai Ladányi legált 1000 For. Interessét, approbállya 'a Supr Consistorium hogy fordittassék Bibliotecha augmentatiojára, sőt hogy azon Testans emlékezetire 'a Bibliotecháb(a) kŭlŏn helyetskére tétessenek azok a kőnyvek mellyek ezzel vásároltatnak [Nsz; BK A kv-i ref. koll. csomója]; legényke 'legény + DIM': 1585: Marta Vekony Jstuanne vallia, Ez ersebet leany Vala,

\footnotetext{
${ }^{36}$ Más nyelvekben az igéhez is kapcsolható kicsinyítő képző (vö.: L. Gràcia, L. Turon 2000: 233).

${ }^{37}$ "Depending on the speech situation, the diminutive suffixes may acquire either a purely pragmatic meaning or, in addition to the denotative meaning, certain pragmatic overtones." (Dressler, Kiefer 1990: 75)
} 
es Az Gazdaya hon Nem vala, Egykor keseon estwe hat valamy leghenkek vadnak Az leannal ... es hat viragh eneket Mondank, de semmy gonozsagot $\mathrm{Ne}(\mathrm{m})$ latta $(\mathrm{m})$ hozza [Kv; TJk IV/1. 506]; reménységecske 'reménység + DIM'38: 1670: Gábor, hogy értett Ádámtúl, nem kétlem, mert éjjel-nappal csak együtt beszéltek, de nem hiszem, hogy az mi levelünk meritumát egészlen megmondhatta volna Ádám is, mivel bizony maga sem tudta, az modalitások mutogatásául mit írt Rottel, kihez képest Kegyelmednek is csak in generalibus terminis kell nekik mondani, hogy vagyon nyujtva valami jobb reménségecske most, mint eddig volt [TML V, 376 Bánfi Dienes Teleki Mihályhoz] stb.

Több adalékban azonban a származék jelentése nem 'alapszó + DIM', hanem beszédhelyzettől függően valamilyen jelentésárnyalattal egészül ki. Például: bátyuka alk. gúny 'bátya, bácsika, öreg': 1598: az en iozago(m)ba hazamba be fogatta $(m)$ valá magam otalmaert ... engemet, elessen es niugosso(n), tiztessegben tarczio(n) mint battiat ... de eö nem tekintette az Vristent sem az attiafiwsagot eö engemet tiztessegbe nem tarta, rutolt zidot kouetem az kegtek zekit Batiukanak lelek kuruanak es halallalis feniegetet engemet [UszT 13/117]; farkacska szitkozódásban: 1567: vxor Valentini dorotheam Dorkochka farkochka apellaset [Kv; TJk III/1. 9]; föemberecske gúny 'fönemesecske/uracska, inci-finci főnemes' 1736 u.: Ó mostani felfordult világ! egy nyomorult fó emberecske nem hogy más ember jobbágyaszszonyát de magát is jó nemesembert vagy annak gyermekeit szégyenlené atyafiának mondani, nemhogy valamivel succurálni olyan megszükült még közelről lévő atyafiának is [MetTrCs 481]; papocska lekicsinylően: 'jelentéktelen kis pap' 1772: ki szalada ... Popa Juanne Tamas Maria ... teli tarakkal kiáltván vár meg te Papotska mért te vével Tüzet, es Fel Gyujtád az Popa Házát [Ludvég K; KLev.] stb.

Arra is van példa, amikor a kicsinyítő képzős származék jelentése nem kompozicionális, nem lehet 'alapszó + DIM' szerint értelmezni, hanem teljesen más jelentést kap, azaz lexikalizálódik. A diminutívummal ellátott származékok esetében a lexikalizálódás azt jelenti, hogy az alapszó és toldalék együttese olyan származékot hoz létre, amelynek a jelentése nem motivált, nem lehet a morfémák jelentéséből levezetni, vagyis az alapszó és származék közti motiváció eltünik, a képző egy új, specializálódott jelentésben állapodik meg. ${ }^{39} \mathrm{~A}$ magyarka például nem 'magyar + DIM', hanem 'magyaros férfikabát', csak 19. századi adalékokban fordul elő: 1823:

\footnotetext{
${ }^{38}$ Ez utóbbi példa átmenetet képez az elvontabb jelentés fele, hiszen az alapszó maga sem konkrét főnév.

39 "The motivational relationship between the base and the derivative is lost and the derivative is either stabilized in a new, specialised meaning, different from the meaning of the base stem, or, on the contrary, it approximates the meaning of the base stem to the extent that it becomes its variant" (Volek 1987: 125).
} 
Mártonfi Simon ... Jár világos vadgalamb szin mellértes Magyarkában [DLt nyomt. kl]; 1838: Egy fekete uj Magyarka, seprö-szin merino bélléssel; hozzávaló gömbkötő munkáju láljbli (!) [RLt O. 1 Mike Sándor ellopott tárgyai közt]. Az otthonka jelentése 'háziruha', nem 'kis, kicsi otthon', az adalékok szintén 19. századiak: XIX. sz. köz.: Küldök 14 Zsemlet ... a Marika rozsaszin otthonkáját hozzá valo darabakkal [BLt 11 Cserei Róza férjéhez, Béldi Alberthez]; 1859: M Ujfalvi Sándor Natsága Részére ... Egy Egy othonkát vásárolt $16 \mathrm{f}$ [Kv; Újf. 1] stb.

Tehát amikor a kicsinyítő képzők, illetve a kicsinyítő képzővel ellátott szavak jelentéséről beszélünk, óvatosan kell fogalmaznunk, hiszen nem lehet általánosságban kijelenteni, hogy minden kicsinyítő képzős származék szemantikai szerkezete leírható a 'tő + DIM' képlettel, hanem egy olyan modellt kell találnunk, amelynek alapján megmagyarázhatók az eltérő jelentések.

L. Gràcia és L. Turon (2000: 234) szerint az értékelő szuffixumok ${ }^{40}$ (amelyek közé a kicsinyítő képzők is tartoznak) denotatív jelentése a következő kategóriákba sorolható: a képző vagy a tő denotátumának a kiterjedését módosítja, vagy pedig az intenzitását. Az első kategóriába főnevek, a másodikba melléknevek (és más nyelvekben igék ${ }^{41}$ ) tartoznak.

A főnévi alaptag jelentését négyféleképpen módosíthatja a kicsinyítő képző: a dolog fizikai kiterjedésének csökkentése (térbeli módosítás); egy (több összetevőből álló) dolog számbeli redukciója; apró, egymástól alig elkülöníthető egységekből álló dolgot jelentő főnevek fizikai kiterjedésének csökkentése; valamint az időbeli kiterjedés csökkentése. Ezek alapos elemzésével modellezhetô az, hogy a tô melyik jelentésjegyét módosítja a kicsinyítő képző (uők uo.).

\section{IV.1.1. A fizikai kiterjedés módosítása}

Mivel az első kategóriába olyan főnevek tartoznak, amelyekre a diminutívum úgy hat, hogy csökkenti a fizikai kiterjedésüket, természetesen ezt csak olyan főnevek engedik meg, amelyeknek van fizikai kiterjedésük: elsősorban konkrét főnevekről van szó (pl.: kert, autó, könyv stb.). A származék jelentése 'kis fn'. Jackendoff elmélete (idézi L. Gràcia, L. Turon 2000: 235) szerint ezek mind a dolog szemantikai kategóriájába tartoznak, és [+b, $-\mathrm{i}]^{42}$ fogalmi tulajdonságok jellemzik. Vagyis [+b], ugyanis ezek a fónevek

${ }^{40}$ Appreciative suffixes (L. Gràcia, L. Turon 2000: 231-247).

${ }^{41} \mathrm{~A}$ magyar nyelvben is találhatunk korlátozott számban példát diminutívummal ellátott igére, de ezek használata szigorúan a gyermekorientált beszédhelyzetre korlátozott (pl.: alukál, pisikál).

${ }^{42} \mathrm{~b}=$ bounded (térben korlátozott - fordítás tőlem, Zs. B.), i = internal structure (belső struktúra) (Jackendoff 1991: 9-45.) 
térben korlátozottak, és [-i], mert nincsenek belső alkotóelemei. Emellett dimenzionalitásuk is közrejátszik az elemzésben, hiszen pl. a vonal egydimenziósnak tekinthető, a felület kétdimenziós, a labda pedig három. Ha az ilyen típusú főnevekhez kicsinyítő képző járul, akkor a [+b] tulajdonságuk módosul, a dolog kiterjedése csökken. Ha a szóban forgó dolog nem egydimenziós, akkor általában mindegyik módosul (pl.: labdácska 'kis labda') kevés kivétellel: a könyvecske például nem jelent feltétlenül kis méretü, vékony könyvet, hanem vonatkozhat egy vastag, de kisebb méretü lapokból készült könyvre. Az élőlényt jelentő konkrét főnevek szintén ebbe a kategóriába sorolhatók, hiszen szemantikai szempontból ugyanúgy viselkednek, mint a fenti főnevek (van fizikai kiterjedésük, nincs belső szerkezetük: [+b, -i]). Összefoglalva az ilyen lexikális egységek jellemzőit: [+b(phys. dim.n. $\left.>0)^{43},-\mathrm{i}\right]$, vagyis van 0 -nál nagyobb fizikai kiterjedésük, és nincs belső szerkezetük. Ezek közül a szemantikai jegyek közül a kicsinyítő képző [ $+\mathrm{b}$ (phys.dim.n.>0)]-re hat, azaz a dolog fizikai kiterjedése csökken.

A SzT. adatai közül a legtöbb ebbe a kategóriába sorolható, pl.: ablakocska (1636: az kamoraczkan egy ablakoczka. Abbol viszont nylik mas egy fejer fel szer vas sarkos pantos aytó az kamora szekre, azon ket ablakoczka [Siménfva U; JHb Inv.]), agátoskó-pixisecske 'agát/achátszelencécske' (1714: Porn(a)k való keveles Agathoskó Pixisetke (!) [Nsz/Fog.; REkLt II. Apafi Mihály hagy. 10-1]), ágyacska 'kicsi ágy' (1675: Egy hársbol kőtőt edgyes rosz ágyacska [Dés; Borb. II]), boglárocska' boglárka, boglárdíszecske' (1591: az ezwst keozeot latek egi kis feier boglaroczkat [Kv; TJk V/1. 180]), boglyácska 'széna v. szalmarakásocska' (XVIII. sz. köz.: A Kis Simon végiben egj darabocska; mellyen mikor terem; egj kŏzönséges buglyácska lészen [Koronka MT; Told. 18]), csatocska (1818: Négy Sor nyakba való Gránát, a' végibe égy 4 szegeletü ezűst meg aranyozott csattotska, meger $15 \mathrm{Rf}[\mathrm{Kv}$; Pk 5]), cselédházacska 'szolga-lakocska' (1817: A Kapun belől mindgyárt vagyon, egy kis cseléd házatska, mely bornábol vagyon ki rakva, és szalmával fedve [Kövesd NK; Kp V/319]), deszkaajtócska (1744: Epittetett ... Gabonást ezen Gabonásnak az hijjara fel jaro deszka ajtocska bőr sarkakon forgo [Ádámos KK; JHbK XXVIII/10]), dombocska (1589: Thudom mikor en Zondj István zolgaia valek mikor ez feoldet Irtani kezdeok akkor egieb Azalt fa oott (!) nem volt hane (m) egy Domboczjkan van valami kewes [Szentkirály U; UszT]), edényke 'edényecske' (1738: két mázos edényke herbatének való [M.bikal K; Mohai lev.]), fakápolnácska'fatemplomocska' (1842: A magyarok telepedésekor Isten segitsen 1774-ben, Hadikfalván 1784ben, Andrásfalván 1785-ben épült fakápolnácskák, mind elromlottak, most árendált házokban tartatik az istentisztelet, Fogadj Istenben még állnak a kápolnácskák [WLt Egyház és iskola csomó. Bíró Mózes andrásfalvi ref. lelkész jel. Kelemen

\footnotetext{
${ }^{43}$ (phys.dim.n.>0) = a főnév fizikai kiterjedése nagyobb zérónál.
} 
Benjáminhoz, br. Wesselényi Miklós jószágigazgatójához]), gödröcske 'vápácska' (1779: (A) Széna Fŭnek szomszédgya ... Marton Ferencz ... Széna Fŭvecskéje, s, vagyon az Szélyiben egy ostormény Fa Bokorhoz csak két Lépésnyire egy Gŏdrŏcske [A.szovát (Később: M.szovát (K) egyik része) K; JHbK VI/17]), harangocska (1643/1687 k.: vagyon ă makfalvi Ecclab(an) ... ă Templom hijjánís ... égy kis harangocska [Makfva MT; MMatr. 187]), iróládácska 'írószeres ládika/ládikó' (1714: Egj dió fabul való Iro Ladatska, Ajtotskaja rezes Rosaval ékesitett, 8. tsiga formala (!) tsinalt labain áll. külombfele fiokokat foglalván magáb(an) fl. Hung. 15 [AH 55]), kádacska (1594: Az Somlioy maior hazban ... Soos viznek walo kadachka vagjon No 1 [Somlyó Sz; UC 78/7. 16-7]), konyhácska 'kis konyha, nyári konyha' (1750: elébb menvén egy kisség jobb kéz felé találtatott egj alkalmas konyhátska régi sendellyezéssel ujj foldozással, sőt még az fala is egj felől rosszatska [Szamosfva K; JHbK LVIII/4]), ládácska 'ládikó' (1647: Egj hitvan Ladaczka holmi dib dab egyetmasnak valo [Marosillye H; VLt 55/5415]), lajtorjácska 'létrácska' (1741: találtunk ... egj lajtorjártskát [Mezőbánd MT; LLt 146. B]), malmocska (1736: épithet ... azon Patakon egy Malmotskát [CU]), ólacska 'gazdasági építményecske (háziállatok számára)'(1743: Kriszta Iuon Teleke féle Puszta ... Ebbül ... Toma Ignat elfoglalt volt, es oklot, s valami olatskátis épitett rá [Kincsi KK; SLt 8. K. 15]), ösvényke 'kis ösvény' (1751/1753: a' Falu azon két ŏsvenyke nélkül kŏnnyen el lehet [Koronka MT; Told. 78]), rétecske 'kaszálócska, legelőcske' (1599: 1 Zakaz Zena niolcz eol. Az hawason es az reteczken eot boglia [Kv; Szám. 8/XV. 18]), serlegpoharacska 'kis serlegpohár' (1622: Egy kws sellek poharoczka nio(m)m. - p. 16 1/2 tt f. 4 d. 50 [Kv; RDL I. 119]), szegecske 'kis szeg' (1714: Ló szerszám barsonnjal buritott ès atzéljos halhéval rezes szegetskékkel, harom darabbul állo fl. Hung. 12. - [AH 22]), tálacska 'kis tál' (1584: Nagy Antal vallia ... a' zegeny fazakasne ezt kialta vala Az vargane Anniara ... Im vgmond az Eyel a' Bozorkany essez Curwa ennem hozot vala egy talachkaba [Kv; TJk IV/1. 280]) stb.

A felsorolt adalékokban olyan származékok vannak, amelyek rendelkeznek valamilyen fizikai kiterjedéssel, így értelemszerüen a diminutívum funkciója az, hogy ezt a fizikai kiterjedést csökkenti.

Sajátos helyet foglal el a felsorolt példák között a punktumocska származék, hiszen per definitionem a pont $t^{44}$, illetve punktum olyan dologra vonatkozik, amelynek a kiterjedése nem csökkenthető, tehát a diminutívum nem csökkentheti reálisan a dolog kiterjedését. Egyetlen olyan példa van, amelyben a matematikai értelemben vett punktum szó diminutívummal ellátott alakja szerepel: 1710 k.: a lineát helyesen ... definiálják a mathemati-

\footnotetext{
${ }^{44} \mathrm{~A}$ térnek igen kis kiterjedésű eleme, része. I Mat A térnek kiterjedés nélküli eleme (vö. ÉrtKSz. 1114).
} 
cusok, hogy sok punctumocskáknak öszvekötött lánca avagy kötele [BÖn. 449]. Mivel egyáltalán nem jellemző ennek a szónak a diminutivizálása, ezért két lexikalizálódott jelentése is kialakult: 'kisebb feltétel': 1668: Ez feljebb specificált punctumoknak megállására igírje magát ilyen formán, hogyha csak az kisebb punctumocskát által hágná is, tehát énnekem se püspököt, se ecclesiát ne kellessék érette keresnem, hanem lehessen szabados elválásom tőle [TML IV, 402 Szalánczy Krisztina Teleki Mihályhoz], valamint 'jelentéktelen részecske' 1782: Meltosagos Liber Báró és Gyeneralis Branyicskai Josika Joseff Ur ... meg emlekezvén ez boldog, és boldogtalan őrőkkevaloság kőzzé helheztetett, kitsiny Punktumotskánok az az ennek az Eletnek bizontalan voltarol ... Testamentumot tett [Kv; JHb V/9].

\section{IV.1.2. Az alkotó elemek számának módosítása}

A második kategóriába olyan főnevek (gyưjtőnevek) tartoznak, amelyek $[+b,+i]$ tulajdonsággal rendelkeznek: van fizikai kiterjedésük, és egymástól elkülöníthető elemekből állnak (pl.: csapat, testület, csokor stb.). Az ilyen főnevek fizikai kiterjedését az alkotó elemek száma határozza meg. Kicsinyítő képző hozzáadásával az alkotó elemek száma módosul. Például a csokrocska jelentése 'kis csokor', a diminutívum a [+b] jelentésösszetevőre hat. A csokrocska azonban olyan csokorra is vonatkozhat, amely kisebb virágokból áll, ebben az esetben a képző nem a csokor [+b] jelentésöszszetevőjét módosítja, hanem a virágét, az alkotó elemét. Vagyis az ebbe a kategóriába tartozó főnevek jelentése az alkotó elemek jelentéséből tevődik össze. Tehát az ilyen főnevek $[+b,+i]$ jelentésjegyekkel rendelkeznek, amelyekből a kicsinyítő képző a [+b]-t módosítja, amely lehet egyrészt a gyüjtőnév [+b(phys.dim.n.>0)] jelentésösszetevője, vagy az egyes elemeké külön-külön.

A SzT.-ban ilyen példákat találhatunk: alakorasztagocska (1723: Zab és Alakor Asztagocska [Holtmaros MT; EMLt]), árpaasztagocska (1760: égy Arpa Asztagotska is volt [TGsz 18]), asztagocska (1683: Buza Perceptioja Kalongyába(n) Asztagocskakban rakatott Kal(angya) [Szúv; UtI]), bokrétácska (1768: Egy Zamantzos bokrétátska 7 rosátskával 4 rubint benne és három jo féle győngy [Nsz; Ks 74. 56]), gabonácska (1722: Ha megis árra volna az Marhá(na)k, s Gabonácská(na)k mind szerezgetnék keveset kevesett [Fog.; KJ. Rétyi Péter lev.]), nádaska (1731: Nádaskában (sz) [Kászonimpérfva Cs; EHA]), tavaszbúza-asztagocska (1812: Egy Tavasz Buza Asztagotska [M.gyerőmonostor K; KCsl 11]). 


\section{IV.1.3. Az egyes összetevők fizikai kiterjesztésének módosítása}

A harmadik kategória főnevei abban térnek el a gyüjtőnevektől, hogy az alkotó elemek olyan kis fizikai kiterjedésüek, hogy azokat nem is lehet elkülöníteni egymástól (pl.: homok, esót5). Ezeknek nincs kiterjedésük, de belső struktúrával rendelkeznek: [-b, +i]. Következésképpen a kicsinyítő képző nem módosíthatja a fizikai kiterjedést, hanem - az előző kategóriához hasonlóan - az egyes összetevők fizikai kiterjedését csökkenti. Igy az esőcske jelentése (ha van ilyen) 'apróbb cseppü eső'. Vagyis az ilyen főnevek jelentését a kicsinyítő képző csak úgy módosíthatja, ha az alkotóelemek $[+b($ phys.dim.n. $>0)]$ jelentésösszetevőjére hat.

A SzT. kicsinyítő képzős címszavai közül a lisztecske, porocska és porondocska tünik ide illőnek. A lisztecske jelentése 'kevéske liszt', és ilyen értelemben nem is sorolható ebbe a kategóriába, vagyis a diminutívum a $[b$ (phys.dim.n.>0)] jelentésösszetevőjét módosítja ugyan az alapszónak, de mivel a három adalék közül egyben mennyiséget jelentő jelző áll a képzett szó előtt, mennyiségbeli csökkentést eredményez a kicsinyítő képző, és ugyanez a mennyiségbeli csökkentés feltételezhető a másik két adalékban is: 1740: Juhos Anna, lisztecskétt szallonnácskát, Czipot adogatott másoknak [Kük.; Mk IX Vall.]; 1747: láttam hogy ettzer mászszor hozott haza a Molnar Janosne Leanya egy egy Csomo Lisztecskét [Déva; Ks 101]; 1775: Borsai Nagy István Uram ... felesége ... a Jobbágy Aszszonyoknak is szŏ és fon lisztetskéért [Peselnek Hsz; HSzjP].

A másik két példában is ugyanez a jelenség figyelhető meg: bár olyan diszkrét alkotóelemekből állnak, amelyeknek egyenként - szabad szemmel látható - kiterjedésük nincs is; a magyar beszélők számára ezek egy homogén halmazzá állnak össze, mert számukra nem a lisztszem a fontos - mert önmagában nem hasznosítható, hanem az az egész, amit a sok-sok lisztszem alkot, és annak a mérete csökkenthető. Így inkább azt feltételezem, hogy a magyarban nem az egyes összetevők mérete csökken a kicsinyítő képzők következtében, hanem a kis (fizikailag észlelhetetlen) kiterjedésű elemekből álló egység mérete. És mivel annyira nem jellemző az ilyen típusú főnevek kicsinyítése, sokkal könnyebben lexikalizálódhatnak, a porocska jelentése 'kis orvosságpor-adag' (1735: kủltem az ŏ Ngă számára valami apro Porotskákat ... be kell adni tsets téjben ŏ Nganak [Ks Borosnyai N. Márton lev. Nsz-ből]; 1759: egj kis nyavalya tőres ellen valo port adott ... már ma vitális porocskát tőkéllették el hogj az Gyermeknek adgyanak [M.csesztve AF; Ks Mikes Antal lev.].), a porondocska 'porondszigetecskét' jelent (1812: Értem ... ennek az ágnak folyamattya hellyén egy kis poron-

\footnotetext{
${ }^{45}$ L. Gràcia, L. Turon példái (2000: 237).
} 
dotskát, mellyet a Viz Áradása okozott volt, de nagyon kitsi és száraz kopatz porondu hellyetske volt [Káptalan AF; DobLev. IV/943. 16a].).

\section{IV.1.4. Az időbeli kiterjedés módosítása}

A kicsinyítő képzők az időbeli kiterjedést is módosíthatják olyan főneveknél, amelyek korra vagy időtartamra vonatkoznak. Abban az esetben, ha a főnév élőlényt jelent, akkor a kicsinyítő képző hozzáadása korbeli csökkentést eredményez (l. papocska 'fiatal pap' jelentése). Ha élettelen dologra vonatkozik, akkor a diminutívum az időtartamot módosítja (pl. filmecske 'rövid film'). Az órácska-szerű származékok nem engednek kompozicionális értelmezést, hiszen az egészet alkotó elemek száma nem csökkenthető anélkül, hogy a fónév jelentése ne sérülne. Így a kicsinyítés az időtartamot érinti. Az élőlényt jelentő főnevek esetében a diminutívum a [+b] jelentésjegyet módosítja, ugyanis a korlátozottság nem kizárólag fizikai/térbeli lehet, hanem időbeli is: létezésük időben korlátozott. Mivel a kicsinyítő képző térbeli és időbeli kiterjedést is korlátozhat, ezért három lehetséges módja van a jelentésváltozásnak. Az első esetben a kicsinyítő képző csak a fizikai dimenziót érinti (pl.: nyulacska'felnőtt, de kis termetü nyúl'), a másodikban csak az időbeli dimenziót (pl.: öcsike'fiatalabb fiútestvér, de nem feltétlenül kis termetü'), végül előfordulhat az is, hogy mind a két dimenzióra egyszerre vonatkozik a diminutívum (pl.: inaska 'alacsony termetű fiatal inas'). Tehát az ide tartozó főnevek jelentésösszetevői közül a kicsinyítő képző a [+b(temp.dim. $\left.\left.{ }^{46}\right)\right]$-t csökkenti.

Sok olyan példát találunk élőlényt jelentő főnévre a SzT.-ban, amelyben a kicsinyítő képző nem a fizikai kiterjedés csökkentését eredményezi, hanem az időbeli kiterjedését. Ilyenek: bárányka 'bárányocska, fiatal juhocska' (1750: kŭldőttem bé ... őtt Csirkecskét, két Pipét, két ifju Nyulacskát, és ez oráig Annyát szopo két Kis Báránykát [O.csesztve AF; Ks 83]), bikácska 'fiatal bika' (1627: tauali kis bikaczka Nro 1 [Mezőrücs MT; BLt]; 1632: Egi taualy bikaczka [Hsz; LLt]; 1632: Bikátska 1 [Nagyercske MT; Told. 70]; 1756: Két esztendős Bikácska 1 [Déva; Ks 92. I. 32]), disznósüldőcske 'növendék/süldődisznócska' (1587: az harom faluban iutott dezmaban Swldeo diznochka 16 ... Ezekben az Dizno Swldeochkekben attunk el 8 fl. d. 62 [Kv; Szám. 3/XXXII. 7]), fácska ' fiatal fa' (1756: lattuk fát vágni ... sőtt enis Pap Gáspár egykor vágtam valami fátskákat az Vr Malmában vivén ŏrleni [Bácsi H; KB Casp. Pap (60) ns vall.]), füzfácska (XVIII. sz. e. f.: két fiatal Füz fátska mintegy gyalog karo vastagságuak [Petlend ${ }^{\mathrm{a}} ; \mathrm{AbN}$. $-{ }^{\mathrm{a}} \mathrm{A}$ Tordától Kv felé vezető út mellett egykor önálló település, ma kisebb házcsoport]), gyermeklovacska 'egy-hétéves hímcsikó' (1653 u.: Gyrokonak, ha ki akarja

\footnotetext{
${ }^{46}$ temp.dim. $=$ időbeli dimenzió.
} 
tőlteni az Inas esztendeit tartozzanak katonaságra felkésziteni: ha pedig nem, egy gyermek lovaczkat adgjanak nekj [JHbK XLII/3 Kovacsóczy Zsuzsánna végr.]; 1736: T. Biro Ur( $\mathrm{am})$ kezére ment fel fogott marhát modo legitimo adván Mlgos Bánffi Dénes Vrffi Tisztartaja egy seregély szürke szŏrŭ harmad fŭre meno Gyermeklovacskát, s azon Gyermek lovat T. Biro ur(am) az Város Menessére kŭldvén és ottan megtalálván Marton Birtalan Civisŭnk ... mind hárman ... fateallyák hogy a praedeclaralt Gyermeklo tulajdon Márton Birtalan igaz marhája [Kv; TJk XV/12. 40]), sógorka 'fiatal sógor' (1717: most ujjolag el kűldőttem edgy gyalmoczkámot Méhesre ha valamit tehetnének vélle, hogy Sogorkáimnak is succurálhatnék a bőjtre, itt pedig eppen Szúkösök vagyunk friss hal dolgabol [Darlac KK; ApLt 2 Haller János Apor Péterhez]).

Mivel a kicsinyítő képzők hatása meglehetősen ritkán irányul a főnevek jelentésösszetevői közül az időbeli kiterjesztésre, ezért gyakran lexikalizálódnak az ilyen származékok: agárkutyó 'agárkölyök' (1654: praemendatt attam ... Haro(m) Agar kutjonak lib. nro 9 [Egeres K; Ks 70 Szám. 51]), almafiatalocska 'almafacsemete' (1595: nap niugot feleol eg' arant eg' $\operatorname{vegb}($ en) vagion harom alma fiataloczka [Abrudbánya; Ks 42. B. 22]), cserefiatalocska 'tölgyfa-csemetécske' (1783: Csere Erdő mellyben tsak Szöllő Karoknak valo Csere Fiatalotskák találtatnak [Hosszútelke AF; Kath.]; 1821: egy erdő ... ritkás Csere fiatalotskákbol áll [Uzdisztpéter K; TGsz 18]), fiatalocska 'csemetécske' (1742: Sok féle virágok s fiatalotskak [Pókafva AF; JHb XXV/58]), morécska 'cigánygyermek' (1589: Hallottam bizonnial ki zemiuel latta egi Moreczka ki vgia(n) en zolgam volt [Dés; DLt 226]; 1592: meegh egyczer mikor ez vallo Iuhaz volt akkoron az Juhtul haza menth es hagiot egy Morechikat az Juhual [Dés; DLt 235]).

Az időtartamot jelentő főnevek kicsinyítésére is van néhány példa a SzT.-ban: hetecske 'valahány röpke hét' (1758: Barcsai Jánosnál laktomban mentem volt ki az asszonnyal Váradra az feredőre ... Négy hétig laktunk ott, de elmondhatom, hogy sohasem éltem olyan jól, mint ott azt a négy hetecskét [RettE 65]), időcske 'rövid idő' (1767: Kis Vaszij és Telegucza Juvonis ... bellyeb nem jővének hanem egy időcske mulva el menének onnon [Betlensztmiklós KK; BK. Demeter Ersok Forkos András Felesége (32) vall.]), órácska 'kb. egy órányi idő' (1786: alkanyadat után mint egy orátskával Házamhoz jöve a' Falubol három legény [KLev.]). Ugyanakkor ezen származékok úgy is értelmezhetők, hogy a kicsinyítő képző intenzitásbeli módosítást eredményez, és ilyen szempontból a következő (IV.1.5.) kategóriában is helyük lenne az adatoknak. 


\section{IV.1.5. Intenzitásbeli módosítás}

Egy diminutívum akkor módosíthatja valamely tő intenzitását, ha az melléknévi ${ }^{47}$ (ritkábban főnévi). Ennek értelmében a tulajdonság az a szemantikai kategória, amely intenzitásbeli csökkenésen megy át.

A melléknevek közül csak a fokozható melléknevek ${ }^{48}$ kicsinyíthetők (pl. magas, szép stb.), hiszen [+b] jelentésjegyük olyan tulajdonságra vonatkozik, amelynek kiterjedése és korlátozottsága egyaránt van. A magasnak például két határpontja van, és attól függően, hogy a skála melyik pontján helyezedik el, intenzívebb vagy kevésbé intenzív ez a tulajdonság. A kicsinyítés szemantikai hatása a fokozható melléknevekre az, hogy a skála alsó határához közelíti, például: magas + DIM = magasacska 'nem túl magas'.

A SzT. adatai azt mutatják, hogy a kicsinyítő képzővel ellátott melléknevek két csoportba sorolhatók aszerint, hogy kiterjedésre vonatkozó melléknévről van-e szó (pl.: magas, kicsi stb.), és ennek következtében konkrét határpontjai is vannak, vagy pedig olyan melléknevekről, amelyek skálázhatók ugyan, de átvitt értelemben (pl.: okos, buta, szép stb.).

Példák határpontos melléknevekre a SzT.-ból: aprócska ' kicsike' (1651: Harom oregh szem Gyengy Negy Aproczkab [Wass 27 Wass Judit kel.]), apród 'aprócska, kicsike' (1778: Marhái és Fakultásaira eset portioja én réám iratott mint el maradott őzvegjére Aprod gjermekeimmel egjütt [Agárd MT; Told. 8]), csekélyecske 'jelentéktelenecske' (1825: Az Egerpataki Bosa Jószág tsekélyetske [DLev. XIV. 5]), hosszabbacska (1748: mely le irt helység ha valamivel hoszszabatska lenneis az más rész atyafiak Erdejeknél, de sokkal keskenyeb, alá való és pusztáb [Kál MT; Berz. 2. 41/127]), hosszacska (1832: megkaptuk a kaptzáját a mely szŏr volt és égy krajtzárt, továbbatskát égy hoszszatska pipa szárt [Kv; KLev.]), hosszúcska 'hosszúkó' (1726: Vagyon Sővénnyel font perje fákra szalma fedél alatt készitett hosszutska disznó ól [Nagyfalu Sz; BfN Nagyfalusi csomó]), jókorácska 'jócskán nagy' (1749: vagyon ezen cinteremben egy fabul épített harangláb, melyben vagyon egy jókorácska harang [Nagyercse MT; ETF 107. 22]), kicsinyke 'kicsike, picike' (1560: Keth darab teoroth arany es egy kychynke azokkal Egywth [JHb QQ Temeswary János reg.]), magasacska 'nem nagyon magasra készített' (1823 -1830: Az első ülés vagyon benn a kocsi fenekében, a második középben az ajtónál, s ezek mind eléfelé fordulva, az harmadik ülés vagyon a középsővel szemben, ezeken kívül az első bakon volt még egy magasocska

\footnotetext{
${ }^{47}$ A magyar nyelvben az igék intenzitásának módosítása nem kicsinyítő képzőkkel, hanem más morfológiai eszközökkel, pl. gyakorító képzőkkel történik, amelyek szemantikailag pontosan emiatt rokoníthatók a diminutívumokkal.

${ }^{48}$ A nem fokozható mellékneveknek van ugyan [+b] jelentésjegyük, de 0 dimenziójuk miatt nem helyezhetők el egy skála különböző pontjain, a [+b] pedig nem csökkenthető, ha semmilyen szabály alapján nem lehet a dimenziót korlátozni (pl.: *élóke, *magyarocska stb.).
} 
ülés [FogE 253-4]), magasabbacska 'nagyobbacska' (1747: ezen katonáknak egyike ... kőpczős és nem igen magos ... az másiknak ... borzos verés kalpagja ... nem éppen olyan erős Compactióju mint az más de anál magasabacska termetŭ [A.hagymás SzD; Ks 27/XVIIb]) stb.

Nem határpontos melléknevek: alkalmasocska 'kics megfelelol' (1791: egy boronafábol készittetett és Náddal bé fedetett alkalmasotska Tselédház [T; CU]), alkalmatlanocska 'kics alkalmatlan' (1755: (A) nagy házbol ... két ajto nyilik ... edjiken nyitanak s.v. az Arnyék székre, mellynek ajtoja minthogy nintsen meg duplázva az házban lévő ágyhoz kŏzel esvén; alkalmatlanotska [Ludesd H; BK sub nr. 1020]), alkalmatosabbacska 'alkalmasabbacska' (1768: meltoztassek Ngtok I(ste)nesen meg tekinteni Szegényeket, hogj ok is a szolgálatra is alkalmatosabbatskák lehessenek [Esztény SzD; Told. 5a]), avatagocska 'avultacska' (1784: vagyon égy tizenkét őkőrre való marha pajta, mely avatagatska fábol készült szalmával fedve [Burjánosóbuda K; JHbK LX/18. 8]), barnácska 'barnás' (1805: Felvintzi iffiabb Kolosvári Mihálly ... barnátska, kerék Abrázatu [DLt nyomt. kl]), barnásocska 'barnásszerü' (1802: Püsokan Juon ... Barnásotska tiszta ábrázatu [DLt nyomt. kl]), butácska 'maflácska' (1841: Lakatos Ferencz ... egy kissé butácska [DLt 697 nyomt.]), csorbácska 'csorbás, csorbásocska' (1817: kivűl ezen kis malmon vagyon még ēgy csorbátska also malom kő, melly nagy Szűkségben adplicalhato lenne [Ördöngösfüzes SzD; ÖrmMúz. Conscr. 9]), durvácska 'egy kissé goromba' (1802: Déák Mihály, szármozásra Kolosvári ... durvátska beszédü [DLt nyomt. kl]), durvábbacska (1844: 14. Keszkenyő az durvábbatskábol is hasonlo képpen azan szerint van [Kv; IB Konetzni Ignátz takácsmester kezével]), együgyücske 'ügyefogyott' (1761: Bongardos Bálint és Iános Testvérek léven, publice notum, hogy ezen két Atyafí kivált Bálint együgyütske vólt, 's meg sem vóltak egymás kőzött osztozva, hanem mint ollyan együgyü Atyafiak ... mindeneket el adogatták [Kv; PolgK 45]), görbécske 'egy kissé görbe' (1820: Básta János ... Silesiai 38 esztendǒs ... hegyes görbetske orru [DLt nyomt. kl]), gyarlócska 'kb. ostobácska' (1764: Maradtanak gyermekei is ${ }^{\mathrm{a}}$, de gyarlócska lévén az aszszony, amint láttam neveléseket, nem hiszem egyik is apja fia legyen [RettE 178. - ${ }^{\mathrm{a}} \mathrm{Ti}$. a meghalt Simon János prókátornak és Ponori Krisztinának]), gyengécske 'kissé gyenge' (1806: delelöt gyengétske voltam delutannis, egyszer víszsza adták a Letzkémet [Dés; Ks 87 KMN 198]), gyérecske 'ritkácska' (1823: a' Rosunk gyéretske, de ha az Isten szemmel meg áldaná alkalmosint gyưlne gabonánk [Veresegyháza AF; Told. 7]), hegyesecske (1825: Romoselyi Nyikuláje Szimulyészk ... hegyesetske orru [DLt 767 nyomt. kl]) stb. A fenti melléknevek természetesen csak abból a szempontból viselkednek hasonlóan, hogy a kicsinyítő képző nem egy konkrét skálának az alsó határpontja felé való közelítést idéz elő, hanem egy elvont skálán való elmozdulást. Emi- 
att van az, hogy az egyébként teljesen más jelentéskategóriába sorolandó melléknevek egymás mellé kerülhettek (pl.: alkalmatlanocska, avatagocska butácska, együgyücske - barnácska, barnásocska stb.).

Bizonyos főnevek intenzitását is befolyásolhatják a diminutívumok. A térbeli és időbeli módosításon kívül néhány főnév esetében olyan értelmezés is elképzelhető, amely szerint a formáns a főnév intenzitását növeli/ csökkenti. Ez azért sajátos eset, mert ezeknél a főneveknél a kicsinyítő képző nem feltétlenül intenzitásbeli csökkentést eredményez, hanem akár az ellenkezőjét is (pl.: botocska, botóka bizonyos kontextusban nagy dorongot jelent, a férjecske származékban, amelynek jelentése lehet 'jó férj' is, a férji tulajdonság minőségét módosítja a képző pozitív irányba). Tehát a férj-típusú főnevek jelentése összetett szerkezetư: van egy másodlagos jelentésstruktúrájuk is, amely megegyezik a melléknevekével: a dolog jelentésjegy fizikai dologként (személy, férfi) definiálja a lexikai egységet, amelyhez egy másodlagos, valamilyen tulajdonságnak megfelelő, ezáltal a fokozható melléknevekhez hasonló struktúra rendelődik. A 'jó férj' jelentés a férji tulajdonság, nem pedig a fizikai kiterjedés vagy időbeli dimenzió módosításából származik.

A SzT. adatai között is találhatunk olyanokat, amelyekben a kicsinyítő képző nem az alapszó elsődleges jelentésének valamelyik összetevőjét módosítja, hanem a másodlagos, valamilyen tulajdonságot kifejező jelentésjegyet, vagyis éppen azt, amit elvárunk egy személytől ahhoz, hogy valaminek nevezzük őt ( $\mathrm{pl}$. ha valaki férj, elvárjuk, hogy a társadalom/közösség által elfogadott tulajdonságokkal rendelkezzen, és ezt változtatja meg a kicsinyítő képző). Azt az elvárást, miszerint a diminutívum pozitív irányba mozdítja el a jelentést, a SzT. következő adalékai nem igazolják, hiszen azt mutatják, hogy a jelentés negatív irányba tolódik el, és ebből a szempontból eltérnek a fentebb felsorolt példáktól. Pl.: autoritásocska 'kics (hivatali) hatalom, tekintély' (1678: eö keglmek sok helyeke(n) diffamalnak hogy Tiszt leve(n) ott, authoritasotskammal abutaltam, nyilvan valo kárommal, mint türtem s szenvedtem [Törzs. Osdolai Kun István a fej-hez]), bátyuka 'alk. gúny bátya, bácsika, öreg' (1598: az en iozago(m)ba hazamba be fogatta $(m)$ valá magam otalmaert ... engemet, elessen es niugosso(n), tiztessegben tarczio(n) mint battiat ... de eö nem tekintette az Vristent sem az attiafiwsagot eö engemet tiztessegbe nem tartá rutolt zidot kouetem az kegtek zekit Batiukanak lelek kuruanak es halallalis feniegetet engemet [UszT 13/117]), kurvácska 'ringyócska' (1570: Mond volt zabo Janosne Meny ky kwrwachka Mert Beled verem az kest [Kv; TJk III/2. 28]), nótáriusocska '(jelentéktelen) jegyzőcske' (1773: Gr. Bánffi Dénes tudna az igaz, de az is nagyon fractus: mely szerént tudom aféle nótáriusocskákkal, procuratorocskákkal fogják kipótolni a fogyatkozást, az aféle pedig maga ellen nem 
ír [RettE 304]). Az, hogy a kicsinyítő képző az alapszó jelentésstruktúráját negatív irányba befolyásolja, csak a kontextusból derül ki. Amennyiben csak a szót mondjuk vagy halljuk, gondolhatunk akár dimenzióbeli csökkenésre is, így az ilyen típusú kicsinyítő képzős szavak csak kontextusban fedik fel igazi értelmüket.

Ebbe a kategóriákba tartoznak olyan - nem kézzel fogható dolgot jelentő - főnevek is, mint a hang, nesz, zaj, szél stb. Kicsinyítő képzővel ellátott származékaik szintén csak akkor magyarázhatók meg, ha feltételezzük, hogy jelentésstruktúrájuk hasonlít a melléknevekéhez, a diminutívum pedig intenzitásbeli, nem kiterjedésbeli csökkenést eredményez (pl.: hangocska 'vékony hang', szelecske 'gyenge szél'). A SzT.-ból csak a szellőcske (lexikalizálódott származék) sorolható ide (1777: az Haztol az Istallora lengedezŏ szellŏtske [Majos MT; Told. 26/21]).

\section{IV.1.6. A kicsid származék szemantikai elemzése}

A kicsid származék jelentésstruktúrájának elemzése azért releváns, mert a SzT. - kétszófajú szó lévén - megkülönbözteti melléknévi és főnévi jelentését is, a jelentéselkülönítésben pedig az eddigiekben bemutatott modell rajzolódik ki: a különböző jelentésárnyalatok pontosan mutatják, hogy a diminutívum az alapszó melyik jelentésjegyére hat.

A kicsid melléknév első jelentésében ('kicsi, kis') a - $d$ diminutívumnak az a szerepe, hogy megerősítse az alapszó jelentését, de egyébként nem okoz méretbeli csökkenést: 1633: egi kiczid darabbal teòbnek talakozek az huss annal az menire Kornis Istua(n)ne megh fizetet uala, de Meszatos Georgi akkoris ugia(n) oda ada neki azt az kis darabocska hust is [Mv; MvLt 290. 139b]; 1636: egy fa keretes Ablaka, kiczid [Siménfva U; JHb Inv.]; 1710 k.: Külömben is dicsérék azt a hajót, hogy az kicsid ... csak úgy jár a vizen, mint egy tök vagy réce [BÖn. 589]; 1745: (A) Ház(na)k vad(na)k ónba foglalt ŭveg táblás három ablakai, egy tábla hijján, és egy kitsid csorbával [Marossztkirály MT; Told. 18] stb.

A származék 'apró, kicsinyke' jelentése azt mutatja, hogy a diminutívum a fizikai kiterjedés csökkentését eredményezi: 1776: Tizenhat kitsid, apró fejér zomántzos boglárotskák [M.köblös SzD; RLt Sombori Klára és Sándor lelt.]. Ennek az adaléknak további érdekessége, hogy a jelző és jelzett szó egyaránt diminutivizált származék.

A kicsid határpontos melléknévként viselkedik több adalékban is, és attól függően, hogy milyen jelentésű a jelzett szó, változik az a skála is, amelyen a diminutívum elmozdítja az alapszót. A következő adalékokban: 1632: az parta óuet latta(m), egi kiczid uala [Mv; MvLt 290. 105b]; 1765: adott el... egy pej szőrü kitsid Serényü Lovat [Fintoág H; Ks 113 Vegyes 
ir.], a származék jelentése 'rövid', vagyis egy legrövidebb ------- rövid skálán a diminutívum a származék jelentését az alsó határponthoz közelíti. A legkeskenyebb ------ keskeny skálán mozdul el a jelentés a diminutívum hatására a következő adalékban: 1630: aszt ${ }^{a}$ pedig kiczid ut nélkŭl nem lehet az hun az őrlő el Jarjon [Fehéregyháza NK; TGsz 51. - ${ }^{a}$ Ti. az egyezséget megkötni], valamint a legsekélyebb ------- sekély skálán a következőkben: 1632: kózbe(n) ki jöue Mihali mester az Malo(m) hazbol hazbol es mo(n)da Timar Janosnenak ne kósd ide, ugia(n) ne keosd ide az beoroket mert most kicsid az Viz es el fogiá az beor az malo(m) kereke alol az Viznek szebesseget [Mv; MvLt 290. 108a]; 1742: A Zsilipje most sem jo ă Malomnak, és ha kitsid ă viz, majd mind alatta foly el [Kv; AggmLt C. 12].

A kétdimenziós fizikai kiterjedés csökkentése figyelhetô meg a 'kis kiterjedésü' jelentésben. A diminutívummal ellátott melléknév területre vonatkozó főnevek jelzője a következő származékokban: 1583: Kun Caspar Rosaly... ielenti hogy az eó faluianak azokhoz kepest igen kichid hatara wagion [Gyf; WassLt, ETA V/2. 17 fej.]; 1679: Kesz To vagon. Nro 2 pokol üdö malmaval. Puszta To hely egy kiczid [Vajdakamarás K; Thor. 21/33]; 1751: Kováts János ... azt monda, hogy Moros székb(en) magánakis valami kitsid portiotskája vólna [Borbánd AF; Ks 83 Borbándi Szabó György lev.]; 1808: nyil után jutot kitsid kaszálo [Szárazpatak Hsz; Hr].

A területre vonatkozó főnevekhez hasonlóan viselkednek az élőlényt jelentő főnevek is, hiszen a diminutívumos származék a fizikai kiterjedés csökkentését jelenti. Ez igaz minden élőlényt jelentő fonnévre, függetlenül attól, hogy a SzT. szerkesztői több jelentésárnyalatot is elkülönítettek ('kis termetü, alacsony' 1606: Kychyd Thamas. Az Kiczjd Lukacz Leania marta [UszT 20/9, 20/107]; 1614: Kiczid Istwan lib. [Csomortán Hsz; UszLt VI/56, 3/8]; 1665: Kiczid Andras [Olosztelek U; UszLt X. 79]; 1748: Kitsid Mihaly [Egerpatak Hsz; Kp I. 166]; 'gyermekre von. kis, kicsike' 1558: Az melly Arwakat En Mostan tarthok mynd kyczydeket, mynd, Nagyokat azt Akarom hogy Meg Elegechek [JHbK XLIII/21 Mikola Ferencne Melyk Anna végr.]; 1627: Keőmives Jakab fia kiczid [Bibarcfva U; UszLt IV/50, 135]; 1794: akkor mi kitsidek lévén arra nem annyira űgyeltünk [Déva; Ks]; 'állatra von.' 1744: Kicsid Artány Malacz 5 Kicsid Eme Malacz 9 [Told. 18]).

Az időtartam csökkentését eredményezi a diminutívummal ellátott származék olyan főnevek mellett, amelyeknek van időbeli dimenziójuk is. Az idő főnév jelzőjeként megjelenő kicsid 'kis/rövid' jelentésü: 1590: Amy Nezy a faydalmas zywew vraim kewansagokat, halaztiak eo kgmek varosul $\mathrm{Ne}(\mathrm{m})$ az eo kgmek hozzusagara, hane(m) az Zas vraimnak tawol voltokert egy kichid Jdeigh [Kv; TanJk I/1. 140]; személyre vonatkozó főnév mellett pedig 'fiatal' jelentésú: 1589/XVII. sz. eleje: az kiknek Zálogiokat el adgiák es belŏlle az Ceh Igassagat ki vészik, efféle birsagolt szemeliek, se 
kiczid, se nagy, ez dologert az Ceh mesterekkel semminemw wdeőben ... ne perelhessenek [Kv; KőmCArt. 26-7]; 1653: a kastély falait az ácsokkal bérleni kezdik nagy cserefákkal belöll, és tölteni földel. Minden ember: bíróné, polgárné, papné, pap, bíró s polgár, nagy és kicsid, a ki életét szerette minden ember a míglen megkészüle, csak hozzája nyult akkor [ETA I, 97-8 NSz].

A kicsid általában akkor viselkedhet főnévként, ha egy jelzős szerkezet jelzőjeként a jelzett szó jelentését tapadással magára veszi (ilyen pl.: a ‘kicsi rész' és a 'kicsi baj/betegség', 'egy kis/rövid ideig' jelentés). Ilyenkor természetszerüleg a magába olvasztott főnév jelentésstruktúráját veszi át, tehát a 'kicsi rész' jelentésű kicsidben a diminutívum a fizikai kiterjedés csökkenését eredményezi: 1592: Thwdom hogy' fen a teteon egy kiczydet foglalt vala Domokos Mihaly be kertelte vala [UszT]; 1658: az kicsidis az mi közel kedvesebb [Beszt.; Ks 90 Cseffey László nyil.]; 1762: ada a ... joszagnak ... Del felől valo szegeletiből is egy egy kitsidet [Káposztássztmiklós MT; Told. 76]. Az 'egy kis/rövid ideig' jelentésű származékban a toldalék a jelentésösszetevők közül az idődimenziót módosítja: 1672: Visszatérvén az rácz, utánna kiált Bethlen Domokos: Várd még, úgy mond, egy kicsidig, hadd beszéljek veled [TML VI, 8 Naláczy István Teleki Mihályhoz]. A 'kicsi baj/betegség' jelentésű főnévnek az intenzitását csökkenti a diminutívum: 1584: Roma Janos vallia ... eg' delkort Aluzom vala, Megh erzem hogy a' Labom fayny kezde ... Masodnap igen meg Dagada ... kwldem felesegemet ez Catalin Azonyert ... Ezt monda Bizony zegien hogy eoregh ember lewe(n) oly kichiddel fekzik [Kv; TJk IV/1. 275].

\section{IV.1.7. Következtetés(ek)}

A kicsinyítő képző jelentésstruktúráját tehát a következő képletben lehet összefoglalni: $\left[\mathrm{DIM}\left(\left[\alpha^{49}+\mathrm{b}(\operatorname{dim} . n .>0)\right]\right)\right]$, vagyis a diminutívum a tő jelentésstruktúrájának $[+b]$ jegyére hat, amelynek a dimenzionális értéke nagyobb, mint 0 . Például az asztal jelentésstruktúrája így néz ki: $\left[_{\text {DOLOG }}\right.$ $+b$ (phys.dim.3), -i] 'asztal', a kicsinyítő képző hozzáadása ezt a jelentésstruktúrát módosítja: ${ }_{\text {DoLOG }}$ DIM (+b(phys.dim.3)), -i], azaz a fizikai kiterjedését csökkenti. Ha viszont egy többféleképpen értelmezhető kicsinyítő képzős származék jelentésstruktúráját vizsgáljuk, akkor azt vesszük észre, hogy a képző különböző jelentésjegyekre hat, és ennek függvényében változik a jelentés. Például a pap jelentéstruktúrájának a következő elemei vannak: háromdimenziós fizikai kiterjedése, valamint időbeli kiterjedése is van, nem rendelkezik belső struktúrával, van viszont olyan jelentésjegye, amely a papi tulajdonságot jellemzi. Attól függően, hogy ezek közül a

\footnotetext{
${ }^{49} \alpha$ = bármilyen fogalmi kategória (dolog, tulajdonság).
} 
jelentésjegyek közül mit változtat meg a kicsinyítő képző, változik a származék jelentése. Ha a háromdimenziós fizikai kiterjedésre vonatkozik a diminutívum, a származék jelentése 'kis/alacsony termetű személy, aki pap' (pl.: A papocska ki sem látszik az oltár mögül.). Ha az időbeli dimenziót módosítja, a származék jelentése 'fiatal személy, aki pap' (pl.: Az új papocskának ez az elsó istentisztelete, most végezte az egyetemet.), ha pedig a fokozható melléknevekre jellemző tulajdonság jelentésjegyre hat, akkor a származék jelentése 'olyan személy, aki rossz pap'. A SzT.-ban erre a jelentésre (így határozzák meg a szerkesztők, hiszen a szöveg hangneme is ezt sugallja: 'lekicsinylően: jelentéktelen kis pap') találunk adalékot: 1772: ki szalada ... Popa Juanne Tamas Maria... teli tarakkal kiáltván vár meg te Papotska mért te vével Tüzet, es Fel Gyujtád az Popa Házát [Ludvég K; KLev.].

Következésképpen megállapítható, hogy a kicsinyítő képzővel ellátott származékok jelentése annak függvényében módosul, hogy a kicsinyítés pontosan melyik jelentésösszetevőre vonatkozik. Hogy egy beszédhelyzetben melyik jelentés jelenik meg, mindig kontextusfüggő. Kontextus nélkül a fenti példáról (papocska) csak feltételezni tudjuk, hogy milyen jelentésárnyalatai lehetnek.

A SzT. adalékai lehetőséget adnak arra, hogy történetiségében vizsgálhassuk ezt a kérdést, ugyanis egyrészt a szerkesztői elvek közé tartozik, hogy olyan szövegkörnyezetbe ágyazva közöljék a címszavakat, amelyek megvilágítják a szó jelentését, másrészt pedig különös gondot fordítanak a szerkesztők a különböző jelentésárnyalatok aprólékos elkülönítésére. A fenti modell kategóriái szerint a SzT. diminutívummal létrehozott származékai szemantikai szempontból jellemezhetők, az viszont világos, hogy különböző beszédhelyzetekben különböző jelentést kaphat egy-egy származék pontosan a beszédhelyzetből adódóan, de ez már a pragmatika körébe tartozik. Ezen a ponton találkozik szemantika és pragmatika, és gyakran nem is lehet élesen elválasztani őket egymástól.

\section{IV.2. A kicsinyítő képzők morfopragmatikai jellemzői}

Mielőtt a diminutívumok (morfo)pragmatikai vizsgálatára sor kerülne, először kísérletet kell tennünk a szemantika és pragmatika elhatárolására. Erre vonatkozóan az általánosan elterjedt nézet az, hogy a szemantikai jelentés nem függ a kontextustól, hanem kiszámítható a lexikális jelentés, mondatkontextus és a szintaktikai struktúra alapján. Ezzel szemben a pragmatikai jelentés erőteljesen kontextusfüggő, és egyáltalán nem számítható ki (Kiefer 2004: 325). A külföldi szakirodalom hasonló eltérést tételez fel szemantika és pragmatika között: a szemantika azt tanulmányozza, hogy mit jelent egy nyelvi elem, míg a pragmatika azt, hogy mit jelent egy 
nyelvi elem a beszélőnek vagy hallgatónak adott beszédhelyzetben. Vagyis a szemantika a beszédszituációban résztvevőktől függetlenít, a pragmatika viszont a jelentést úgy vizsgálja, ahogy azt a beszélők interpretálják. ${ }^{50}$ Ennek értelmében a pragmatika fó feladata a kontextus által determinált jelentésnek a vizsgálata (Kiefer 2004: 326).

A morfopragmatika azt vizsgálja, hogy milyen szabályos pragmatikai változásokat eredményez egy toldalék (jelen esetben kicsinyítő képző) azon a tövön, amelyhez hozzákapcsolódik. Egy morfológiai szabálynak morfopragmatikai jelentése van, ha tartalmazza azt a pragmatikai változót, amely szükséges a jelentésének meghatározásában. Ebből következik, hogy az elemi pragmatikai jelentés nem redukálható egy szemantikai jelentésre (Dressler-Merlini Barbaresi 2001: 43, fordítás tőlem, Zs. B.). ${ }^{51}$

Dressler és Merlini Barbaresi a kicsinyítést evaluatív, értékelő (evaluation) folyamatnak tekintik (1994: 153). A kicsinyítő képzők különlegessége abban áll, hogy képesek a beszélőnek a beszédpartnerhez, a beszélgetés témájához, illetve a kommunikációs szituációhoz való viszonyát kifejezni. Például a beszélő olyan stratégiát alkalmaz, amellyel egy lehetséges sikertelenség veszélyét elhárítja magától, többek között azáltal, hogy az adott beszédhelyzetben saját felelősségét csökkenti. Vagy a beszélő azt is jelezheti, hogy a beszélgetés bizonyos részeit nem kell komolyan venni (i. m.: 234). Ennek egyik lehetséges módja a kicsinyítő képzők használata.

A diminutívumnak szintén pragmatikai szerepe lehet udvariassági beszédhelyzetben, ugyanis a kicsinyítő képző jelentésében pragmatikai jelentéseltolódás megy végbe: eltávolodik a konkrét fizikai valósággal való kapcsolatától (megszúnik a 'kis, kicsi', konkrétan méretre vonatkozó jelentésjegye), és a kommunikációs szituációban a beszélő szándéka és attitűdje válik meghatározóvá. Ennek értelmében a diminutívum úgy müködik, mint egy pragmatikai irányító, amely felhasználható arra, hogy enyhítse vagy gyengítse a megnyilatkozás illokúciós erejét, és ennek eredményeként hatékonyan müködik udvariassági jelölőként (Mendoza 2005: 164). Így a diminutívum az affekció, intimitás, értékelés kifejezője, és közeli, familiáris/baráti viszonyt feltételez, ami rögtön magyarázatot szolgáltat arra, hogy miért pont gyerekekkel, illetve kedvenc állatokkal való kommu-

\footnotetext{
50 “(...) semantics is the study of what a piece of language means; while pragmatics studies what a piece of language means to a given person - to the speaker or addressee in a given speech situation. In other words, the semantic structure of a sentence specifies what that sentence means as a structure in a given language, in abstraction from speaker and addressee; whereas pragmatics deals with that meaning as interpreted interactively in a given speech situation." (Leech 1980: 80).

51 "A morphological rule has a morphopragmatic meaning if it contains a pragmatic variable which is necessary within the description of its meaning. This implies that its basic pragmatic meaning(s) cannot be reduced to a semantic meaning." (Dressler-Merlini Barbaresi 2001: 43).
} 
nikációban olyan gyakori (Mendoza 2005: 165). Ugyanakkor a szimpátia és együttérzés kifejezői is lehetnek, valamint a beszélőnek a hallgató iránt érzett értékelésének és csodálatának a jelölői (uő. uo.).

A kicsinyítő képzők elsődleges funkciója az, hogy a nem-diminutív formával szemben hozzáadja a 'kicsi, kis, kisebb' szemantikai jegyet az alapszó jelentéséhez, emiatt akár a kis, kicsi melléknév szinonimájának tekinthető, ennek jelentését süríti egyetlen toldalékba. Mindemellett a kicsinyítő képző funkciója nem merül ki a 'kis, kicsi' jelentésben, hanem gyakran adott beszédhelyzetben a családiasság, informalitás, kedvesség/ kedveskedés megteremtésére is alkalmas nyelvi elem. Ilyenkor a kicsinyítő képző pragmatikai többletjelentést kap, a méretnek már nem kell reálisnak lennie, ugyanis a kicsinyítő képző nem minden esetben jelent méretbeli csökkenést ${ }^{52}$, bár általában kapcsolatban áll a szemantikai jelentéssel, és levezethető belőle.

A kicsinyítő képzők jelentésére vonatkozóan alapvetően két felfogás alakult ki a szakirodalomban: egy minimalista és egy maximalista felfogás.

A minimalista felfogást Dardano (idézi Dressler-Merlini Barbaresi 1994: 72) képviseli, aki szerint a kicsinyítő képzők morfoszemantikája ezeknek a jelentését magyarázza, a morfopragmatika pedig a jelentőségüket (vagyis hogy adott kontextusban milyen funkciót töltenek be). Minden pragmatikai hatás morfoszintaktikai eszközökkel generálódik, amely a maga során olyan általános pragmatikai stratégiákat tölt be, amelyek már függetlenek a morfológiától. Az általánosabb pragmatikai stratégiák mindig levezethetők a [kis] vagy [nem komoly] szemantikai jegyből. A minimalista felfogás szerint tehát minden kicsinyítő képzővel ellátott szó helyettesíthető volna egy 'kis + alapszó' szerkezettel, és fordítva: egy 'kis + alapszó' jelzős szerkezet helyettesíthetó volna egy 'alapszóDIM' származékkal.

Ezzel szemben a maximalista felfogás képviselői (Dressler-Merlini Barbaresi 1994) azt állítják, hogy vannak olyan pragmatikai szabályszerüségek, amelyek csak a kicsinyítő képzőkre érvényesek. A kicsinyítő képzők jelentését összetettnek fogják fel, elemei: a szemantikai [kis] jegy, valamint a morfopragmatikai [nem komoly] jegy. Tehát élesen elkülönítik a szemantikai és morfopragmatikai jelentésjegyet, nem mossák össze a kettőt, mint a minimalista felfogás képviselői.

A játék(osság) a beszélőnek természetes ösztöne, amely megteremti a mondat alaphangulatát. Ennek a kulcsa az, hogy a játékos képzők alapvetően nem felelnek meg semmilyen logikus kifejezési igénynek, nem is

\footnotetext{
${ }^{52}$ L. még ezzel kapcsolatban a A kicsinyitő képzők szemantikája c. fejezetet.
} 
tapadnak szorosan egyetlen szóhoz. $\cdot^{53}$ Alonso Amada szerint a kicsinyítő képzőknek nem a 'kis, kicsi' szemantikai jegynek az alapszóhoz való hozzáadása a lényegük, hanem a különböző emocionális értékek kifejezése, amelyeknek pontos jelentése és hatása függ a kontextustól, a beszélők attitűdjétől, valamint magától a beszédtettől. Továbbá Amada a kicsinyítő képzők stratégiai használatáról beszél, ugyanis szerinte ezeknek egyik alapvető funkciója a captatio benevolentiae (idézi Dressler 1994: 87).

A kicsinyítő képzők általános morfopragmatikai jelentése a [nem komoly]. A [nem komoly] vonás hozzáadása egy szóhoz stratégiai fogás, mégpedig az a célja, hogy a beszélő felelősségét csökkentse a beszédtettel kapcsolatban, pontosabban, hogy csökkentse a beszélő felelősségét a beszédtett illokúciós erejével szemben. Vagyis a beszélő a kommunikációs szituációt nem-komolynak értékeli, ami megengedi a kicsinyítő képzők használatát (i. m. 144). Így akár a kicsinyítő képzők metaforikus használatáról is beszélhetünk, hiszen mintegy konnotálja egy beszédszituációban a nem komoly jelleget. Ezáltal a pragmatikai jelentés már nem korlátozódik egy szóalakra, hanem átterjed a teljes kommunikációs szituációra.

A [nem komoly] vonás különböző beszédhelyzetekben realizálódhat. A játékos jelleg játékos beszédhelyzetekben jelenik meg. A potenciálisan kellemetlen beszédhelyzeteken (pl. kérések, utasítások vagy fenyegetések stb.) a kicsinyítő képzők stratégiai használata enyhít. A diminutív szóképzés másik fontos színtere a gyermeknyelv. Az ilyen kommunikációs szituációban a gyermek lehet beszélő, címzett vagy a beszédhelyzet résztvevője, illetve a felnőttek közti beszélgetés tárgya. Ez értelmezhető egyrészt a [kis, kicsi] denotatív vonás pragmatikai alkalmazásaként, vagy a [nem komoly] pragmatikus vonás realizációjaként. A szerelmesek közti kommunikációban a kicsinyítő képzőknek érzelmi színezete van, ezek kifejezhetnek örömet, boldogságot, kötődést, meglepetést, csodálatot, érdeklődést, szimpátiát stb.

Vannak olyan megszorítások, szabályozó tényezők, amelyek a kicsinyítő képzőknek kedvező beszédhelyzetek létrejöttét segítik, illetve gátolják. A kicsinyítő képzők megjelenését bizonyos beszédhelyzetben favorizálja a családiasság és intimitás, ami arra vonatkozik, hogy a címzett, valamint a résztvevők között közeli vagy távoli a viszony. A szimpátia és empátia olyan beszédhelyzetnek a velejárója, amelyben gyengédség, ragaszkodás, kötődés vagy egyéb pozitív személyes attitűd fejeződik ki.

53 "The ludic instinct is a mood of the speaker's which creates the ground of the sentence, the key: the playfully attached suffixes originally do not correspond to any logical expressive need, they do not stick to that specific word" (Spitzer, idézi Dressler 1994: 86). 
A diminutív képzés modellje a következő: a [nem komoly] pragmatikai vonás a kicsinyítés segítségével hozzáadódik a beszédtetthez és/vagy a kommunikációs szituációhoz. A diminutív képzés mindig értékelő jellegü, ami azt jelenti, hogy a kicsinyítő képző az értékelő értékelési intenciójának, perspektívájának és normáinak megfelelő értékelést vagy ítéletet fejez ki. Az értékelés egy olyan mentális múveletként definiálható, amely felméri egy dolognak vagy eseménynek az értékét. Vagyis ilyen szempontból az érték nem más, mint egy dolognak vagy eseménynek többé-kevésbé megbecsült volta, amely megfelel a beszélő által az illető dolognak vagy eseménynek tulajdonított fontosságnak. Az értékelés szubjektív, ugyanis a beszélő viszonyulását fejezi ki egy dologhoz/eseményhez (i.m. 153). Az értékelés aktusát explicit vagy impilicit beleegyezés vagy elutasítás követi a hallgató részéről. Ezek szerint egy értékelés kimondása kockázatos, mert a beszéd partner akár el is utasíthatja azt, így a beszélő megpróbálhatja csökkenteni az elutasítás veszélyét például a kicsinyítő képzők használatával (i.m. 153-4).

Kicsinyítő képzők különböző beszédhelyzetekben fordulhatnak elő, egyes szövegtípusokra jellemzőbbek, mint másokra (pl. megjelenése valószínübb gyermeknyelvi szövegben, mint egy hivatalos okiratban). Ennek értelmében Dressler és Merlini Barbaresi (1989, 1991, 1994) a kicsinyítő képzőknek következő fajtáit különítik el: diminutivum puerile, diminutivum sociale, diminutivum modestum és diminutivum ironicum.

A kicsinyítő képzők nagyszámú használata a gyermekorientált (childcentered) beszédszituációra jellemző: a beszédtárs gyerek, illetve a beszédtársak gyerekekről tárgyalnak. Erre a szakirodalomban a diminutivum puerile terminust alkalmazzák (l. fentebb). Általában a gyermek világának a komponensei kicsinyíthetők: testrészei (pl. Hol van a szemecskéd?), ruhái (pl.: Vegyük fel a blúzocskát!), ételei (pl.: Egyél ebből a finom leveskéből!), játékai (pl.: Hova tetted a macikát?) stb. Egyrészt ilyenkor a diminutívum méretbeli csökkenést/csökkentést jelent (a világ dolgait mintegy a gyermek méreteihez szelidíti a beszéló), másrészt mindenképpen hozzákapcsolódik egy affektív elem, az ilyen kicsinyítő képzőknek affektív jelentésárnyalatuk van. Dressler és Merlini Barbaresi (1994) az olasz nyelvből olyan példákat is idéznek, mint: elefantino ('elefántocska'), rivoltella giocatollo ('játékpisztolyocska').

A gyermekorientált beszédszituációból a kicsinyítő képzők metaforikusan átterjedhetnek a szerelmesek beszédére (lover-centered). Ezekben a helyzetekben a kicsinyítő képzőkre nem annyira a [kis, kicsi] vagy [komolytalan] jegy a jellemző, hanem inkább az affektív jelentésárnyalat kerül előtérbe (pl.: szívecském, galambocskám stb.). 
A diminutivum sociale esetében a családiasság az elsődleges feltétel (pl.: nem mindenkivel beszélhetünk asztalkáról, telecskéről stb.). Általában az ilyen beszédszituációban pozitív hozzáállás figyelhető meg minden kommunikációs fél részéről (pl.: Iszunk még egy kis borocskát?). Gyakran ez a diminutivum sociale fordul elő kérésekben, indítványokban, ahol a kicsinyítő képző funkciója az, hogy a kérést, indítványt indirektebbé tegye, és ezáltal az esetleges visszautasítás veszélyét elhárítsa (pl.: Lenne egy javaslatocskám. - értsd: 'Van egy javaslatom, de nem baj, ha nem fogadjátok el'). Itt már nem a szó jelentését változtatja meg a képző, hanem az egész mondatét, illetve az egész beszédhelyzetét. A diminutívum ugyanis egy alternatív vagy kiegészítô választási lehetőséget kínál más szintaktikai vagy lexikai stratégia helyett.

A diminutioum modestum nem feltétlenül egy intim kommunikációs szituáció része. Szintén az a stratégia, hogy a beszélő saját felelősségét csökkentse a beszédhelyzetben, így a lehetséges visszautasítást már eleve kivédi (pl.: Amennyire a pénzecskémböl futja, igyekszem a számlákat kifizetni. értsd: 'Elég kevés pénzem van, fennáll az esélye, hogy nem tudom a számlákat kifizetni').

A diminutivum ironicum használata esetében mindig egy rejtett konfliktus húzódik meg a kommunikációs szituációban a valóság és a kicsinyítő képző denotátuma között, vagyis a kicsinyítő képző teljesen elveszíti a [kicsi, kis] szemantikai jegyet, másat jelent (pl.: Micsoda poétácska vált XY-ból, már öt verse jelent meg. - értsd: 'Öt vers még nem tesz valakit költővé').

Az említett beszédhelyzetekben a szimpátia, empátia, családiasság, informalitás, intimitás, irónia, eufemizmus, illetve a beszélő személyének a „lekicsinyítése" jelenik meg szabályozó faktorként.

A konstitutív és szabályozó tényezők együtt megnövelik a kicsinyítő képzők használatának esélyét adott beszédhelyzetben. Természetesen morfológiai (l. kapcsolódási szabályok) és lexikai megszorítások is szerepet játszanak a kicsinyíthető szó, illetve a megfelelő kicsinyítő képző kiválasztásában.

A SzT.-ban nagyon sok olyan adalék van, amelyben a kicsinyítő képzőnek/kicsinyítő képzős származéknak nincs pragmatikai jelentése, azaz pragmatikai szempontból semleges. Funkciója annyi, hogy a [kis, kicsi] szemantikai jegyet hozzáadja az alapszóhoz: ablakocska (1636: az kamoraczkan egy ablakoczka. Abbol viszont nylik mas egy fejer fel szer vas sarkos pantos aytó az kamora szekre, azon ket ablakoczka [Siménfva U; $\mathrm{JHb}$ Inv.]), ajtócska (1692: ezen haznak padgyara fel jaro kis vas sarkas, pantos, reteszes, reteszfüs ajtocska vagyon [Görgénysztimre MT; JHb Inv.]), almafácska (1736: ezen le irt metátol edgy Stucz lŏvesnyire edgy alma fácska mellé erigaltatot edgy fŏld halom [K; SLt F. 40]), fatornyocska (1745: A' 
Palotákra mennek bé faragott kŏ gráditsos, és faragott kŏ padimentomos Folyóson ... mindenik felŏl ... sendély fedél alatt, mely Sendelyezésnek-is a' kŏzepe táján vagyon egy kis sendelyes fa-tornyotskája [Marossztkirály MT; Told.]), házacska (1803: égy Classis(na)k való kisded Kamarátska vagy Házatska égy kis Tanulo Házatska vagy Kamarátska [Désfva KK; UnVJk 183]), pártaövecske (1588: Az Orsik Reze. Wagion egy kisded partha eowechke fekete visselt Mayczon Niom Maiczostol, 16 boglar rayta, M 1 p. 16 [Kv; KvLt Vegyes I/2. 23]) stb.

A gyerekekről/gyerekekhez szóló beszédhelyzetben gyakori a kicsinyítő képzők használata. Ezekben a [kis, kicsi] szemantikai jegy affektív jelentésmozzanattal egészül ki. A SzT. adalékaiban a diminutivum puerile elsősorban a gyermekekről szóló kommunikációs szituációban jelenik meg: fiacska (1681: Zarandvarmegyeben Bethlenǒsŏn lako szegeny emberek ... Bethlen Domokos vrunknak egy darab idŏk alatt mint ŏs ŏrŏkŏs iobbagyi adot fizettenek, de Bizonyos idŏktol fogva nem adozvan, mostan meg irt vrnak neveletlen arva Ficskaianak Tekt Nemzetes Iktari Betlen Istvan vrunknak Tutora Tekintetes Nemzetes Véér Kristina Aszszony eo kge ... szofogadatlansagokert katonak altal hozatvan fel azon Betlenŏs nevŭ falubol ket nŏtelen legenyeket [IB. Thuroczi András közbíró Désfalván lakó vall]), gyermecske (1603: Zabo Miklos ... vallia ... Nyreo Mathenak az eo tercialitassaba adiudicaltak volt az Arbiterek f 15 d. 66. Ezenkeowl ezen azzontul valo Nyreo Mathenak germechikeienek portioiat [Kv; TJk VI/1. 645]), gyermekecske (1681: Udvarhelyszéki Uarosfalui Cziki Balas es Cziki Janos Lofŭ szemelyek ... szollanak òkis Biro Istuan Urunknak, hogy ... adna megh eo Kegyelme anny penzt, az menyuel edgy borius tehenet uehetnenek azon Marko Borbaratol aruasaghra hagyatott kiczin gyermekeczke tartasara [Borb. II]; 1724: Rusz alias Hafrik Mihállynak az Anya ... bé jŏ az Atyám házáb(a) egj kis csecsszopo Gyermekecskével a karján, es kérdi az Anyam ... hol vetted menyecske ezen kis Gyermeket [Nagykájon SzD; BK Kiskájoni lev. Czermure Iuon (46) jb vall.]), leányka (1603: Budaky Georgy Vramnakis Ke(gyelme)d, mondia Zolgalatomat es az mely Leankatt ennekem Commendalt uala itt az en gyermekim keozeott io Egessegbe vagion ... Him warraastis az en lyankammal egywtt tanulnak [Dés; BesztLt 65 Th. Szabo dési városbíró G. Frank beszt-i esküdt polgárhoz]) stb.

Sokkal kevesebb olyan szöveg van, amelyekben felnőtt-gyerek beszédszituációban, a gyerekekkel való kommunikáció részeként jelenik meg a kicsinyítő képző: fiacska (1771: hallottam a Száva Marján Szájábol ezeket beszélleni ... hogj az Utrizáns Bágjuléknak attját Bágj (!) Juont az ŏ édes attja hozta, vagj szőktette ell Vintzről, ide Csákljára, ekképpen hitegetvén őtet, gjere ell édes fiatskám én velem mert én meg ruházlak, s felnevelnevellek (így!), s gondodat viselem [Girbó AF; JHb Nikoje Patru (70) jb vall.]), 
leányka (1724: kérdettem a Leánkát An(n)ya előtt, ki leánykája vagy [Náznánfva MT; BK. Roska Nyisztor (45) jb vall.]).

Egy adalékban a gyermekről és a gyermekkel való beszéd, illetve ezekben a kicsinyítő képző́k használata érdekesen kombinálódik: a gyermekről való beszédhelyzetben az alapszónak a kicsinyítő képzős alakja jelenik meg (leányka), a gyermekkel való párbeszédben viszont ugyannak az alapszónak képző nélküli változata: 1597: Simon Janos wallia ... hiwa egizer eleombe Sardine az leankat, monda neki hallode te leany mond megh az gazda eleot mit chelekedet az vrad veled [Kv; TJk VI/1. 95].

A diminutivum puerile általában olyan alapszavakon jelenik meg, amelyek konkrétan a gyerekre vonatkoznak (1. gyermekecske, gyermekcse, fiacska, leányka), nagyon kevés olyan adalék van, amelyben a gyermeki világ egyéb dolgait (ruhadarabokat, állatokat, játékokat) megnevező szavak vesznek fel kicsinyítő képzőt. Ilyenek: ágyacska (1736: Gyermeknek valo kŏzŏnséges ágyotska [CU]), ágyúcska (1714: Mas Gyermek(ne)k valo két Agjutska rezes apparatussal egjütt [Nsz/Fog.; REkLt II. Apafi Mihály hagy. lelt. 26]), csizmácska (1769: Gyermeknek valo viseltes két pár Csizmacska [Nagyercse MT; Told. 19]).

Az alábbi példában az affektivitást, illetve szimpátiát az is felkelti, hogy nem egyszerúen egy gyermekről van szó, hanem egy beteg gyermekről: ételecske (1791: 4szer ételetskeje ${ }^{\mathrm{a}}$ légyen gyénge savanyuságu korpa Cibre, vagy megyből készitett Levesetske [Dés; DLt. - ${ }^{a}$ Beteg gyermeknek]).

Ugyanígy a gyerek tulajdonában álló állatok is a gyermek világához idomulnak a kicsinyítő képzők segítségével: lovacska (1705: Ugyan ma jött volna a kurucoktól egy trombitás és egy kisgyermek párducbőrösön, kinek hozzávaló kis lovacskája volt és aranyos forgója, kik is délután jüvén ki, estére ismét kimentenek [WIN I, 501]).

A diminutivum sociale alkalmazásának feltétele a familiaritás, azaz a beszédtársak meglehetôsen jól kell hogy ismerjék egymást ahhoz, hogy az egymással való kommunikációban kicsinyítő képzős származékokat használjanak. Az ilyen kicsinyítő képzők mindig közvetlen beszédhelyzetben jelennek meg, leginkább beszélt szövegekre jellemzők. Mivel a SzT. írott korpuszt tartalmaz, ez a közvetlen beszédhelyzet általában levelezésben valósulhat meg, így a legtöbb példa levelekből került elő: ajándékocska (1701: Ezen bizonyos emberitül Kegyelmednek Az mint Szegény ifiu legenységemtúl telik, egy kis ajándékocskát kültem [Gyeke K; Ks 96 Kornis István Gyeröfi Borbálának]), csirkécske (1760: Azonban ezen Talyigán két Zsák szárnyas majorságnak valo buza rostaalyát kŭldőttem bé, Holnap Napra penig, őtt Csirkécskét, két Pipét, két ifju Nyulacskát és ez oráig Anynyát szopo két Kis Báránykát [O.csesztve AF; Ks 83 Szabó István lev.]), forintocska (1788: Ha az Ur I(ste)n Békeséget parantsol, reménlyhettyuk 
az Aszszu-szolo Borának arrábol a' Nyereséget; ha az 1000. s' valamivel többetske vederb(e) Ngd béverte vagy 200. Forintotskáját, de ide hátrébb azt lehetne legalább 6000-forintokon distrahalni, a' Nyereség ... szépetske lenne [Kercsesora H; TL. Málnási László ref. konz. pap gr Teleki Józsefhez.]), lágyacska (1817 k: az uj Birorol Nagyságos Groff Ur annyít írhatok, hogy lágyotska, de talám meg szokik, mert külőmben eléggé űgyel a parantsolatra [Héderfája KK; IB]), levelecske (1667: Édes Komám uram, aszszonyunknak ír Nemes János uram egy kis levelecskét; öt-hat szóból állott [TML IV, 248 Naláczi István Teleki Mihályhoz]; 1729: hoszszasobban most az Asz(szonyo)m(na)k nem udvarolhatok, hanem kivánom ez levelecském találhassa az Asz(szo)nt örvendetes friss jo egességbe [ApLt I gr. Haller János gr. Kálnoki Borbárához Nsz-ből]).

A diminutivum sociale alcsoportját képezik az olyan kicsinyítő képzők, amelyek különböző ügyekben hivatalos szervekhez intézett kérésekben jelennek meg. Ilyenkor a kicsinyítő képzőnek az a stratégiai szerepe, hogy az esetleges visszautasítás veszélyét elhárítsa, hiszen a kérést eleve kevésbé fontosnak állítja be: cselédecske (1742: Király Biro Ur(am) kedre törvenyes napot indicalt, s edgy Jobbágjomot halálra keresik; s ha lehetne Comparealnék annak az Törvényin, mint hogy Cseledetskemet tartozom defendalni [Zalán Hsz; Ap. 2]), fizetésecske (1752: Fizetésetském irántis igen alázatosan, de tellyes bizalommal instálok, ha kegyes szivére nem vészi a' Mlgs Ur igen bajosan Subsistalhatok [Szentdemeter U; Ks 83]), fundusocska (1671: Bál Pataki János kőnyőrőg ... Kgls Aszszonyom ... Házammal altal ellenben Borberekben ${ }^{a}$ vettem vólt egj szegenj nemes Aszszontol egy kis paraszt Fundust ... az én kezemmel ket kőből buza alá valo földetskevel több utánna nintsen ... meltoztassek Nagd azt az egy Fundusotskat cum appertinent(iis) nekem, felesegem(ne)k es ket agon lévő maradványaim(na)k őrőkőssen adni, meg-is nemessitteni [Törzs.]), házacs$k a$ (1843: tetzet ... admoneáltatni hogy a Tegla veto helyen fel epittetett Házatskát es egy kis veteményező Kertetskét elrontsam, holott az a Házitsko az egésség fen tartására ... szükséges képpen meg kelletik lenni ... méltoztasson azon Házitskot a maga valoságában meg hagyni [Dés; DLt 1358.]), húgocska (1630: Nagodnak müis Agnes nevü kis Hugocskánkal edgyütt, mint Keglmes Urunk(na)k kŏnyŏrgŭnk ... méltoztassék azon Negy Falucskainkrol Nova Donatiot Conferalni [JHbK LVII. 31. - ${ }^{\mathrm{a}}$ Ti. a fej-nek $\left.{ }^{54}\right)$, sertésecske (1721: alazatoson még szolgalom az Mlgos Urnak ha nekém is ég sértesecskét küld ézen meszét le vivő talyigan tavaj nem busitotam az Mlgos Urat mivel vot de most égyecsket őletem vot mind aprolikja mind

\footnotetext{
${ }^{54}$ Ebben az adalékban a kicsinyítő képzős származékkal a beszélő szánalmat szándékszik kelteni, hiszen a mögöttes jelentése az lehetne, hogy meg kell az illetőt szánni, mert fiatal, még gyerek. Ugyanezt a stratégiát erősíti fel a kis minőségjelző is.
} 
szalonaja mind egy falatig el fogot (!) [Szentpál K; TK1 Mihály Deák Teleki Pálhoz]) stb.

A diminutivum sociale csoportján belül sajátos alcsoportot képvisel a diminutivum modestum. Ezek egyrészt a diminutivum socialek közé tartoznak, hiszen a beszédszituációra a familiáris jelleg jellemző. Eltérnek viszont tőlük abban, hogy a diminutívum jellegzetesen a beszélőre vonatkozik: önmagát, illetve a tulajdonában álló javak értékét csökkenti azzal a céllal, hogy a visszautasítás veszélyét kivédje.

A beszélő saját személyének lekicsinylésére használhat kicsinyítő képzőket, ilyenkor ezzel alázatosságát, saját személyének másokhoz viszonyított jelentéktelenebb voltát emeli ki: állapotocska (1656: Az temetés pedigh, tsak az en csiekely allapotoczkamhoz kepest legien, tudgiak ki voltam en [Ádámos KK; Bál. 93 végr.]), autoritásocska (1678: eö keglmek sok helyeke(n) diffamalnak hogy Tiszt leve(n) ott, authoritasotskammal abutaltam, nyilvan valo kárommal, mind türtem s szenvedtem [Törzs. Osdolai Kun István a fej-hez]), becsületecske (1730: az ország tellyes vala az Aszszony ream valo nehezsegevel s engemet kissebittö, s csak nem átokra fokado Szavaival, de én mind azokot hitetlenséggel, és jora valo magyarázáss s türessel palastoltam, söt ... azonn kész affextiomot tartom fenn az Aszszonyhoz (: kivált ha becsületecskemet tapasztalhatom :) mellyel ennek elötte viseltettem [Fehéregyháza NK; Ap. 2 gr. Haller István br. Apor Péterhez]; 1793: Ngod parantsolattya ellen kezem alatt lévén Az Apámnak sem kedveznék, menynyivel inkább ennek a' valoságos Akasztofára valonak, aki betsületecském Nsgod altal valo nagy Sérelmére okott szolgáltatott mikoron cselekedném [Kályán K; JF 36 Lev K Vég Mihály pref. lev.]), fóemberecske (1736 u.: Ó mostani felfordult világ! egy nyomorult fó emberecske nem hogy más ember jobbágyasszonyát de magát is jó nemesembert vagy annak gyermekeit szégyenlené atyafiának mondani, nemhogy valamivel succurálni olyan megszükủlt még közelről lévő atyafiának is [MetTrCs 481]) stb.

A beszélő személyes tulajdonában álló dolgok értékének lekicsinyítésére is használhat kicsinyítő képzőket: aranyacska (1631: tudom hogi volt az Aniadnak penze, arra azt felelte hogi hagiot edes koma(m) Aszony ... hagjot ennekem szegeny egi nehany araniaczkat [Mv; MvLt 290. 259a]), árucska (1586: Ieowe hozzam Igiarto Giorgi az kamoracikaban Azhon ennekem Arwcikam vagion [Kv; TJk IV/1. 618-9]), barmocska (1839: Ǔgyekezetem utánn az Isten vagy két Barmotskát rendelt ... azon Barmotskáimnak olyan alkalmatlan hajlékok vagyon, - hogy teljességgel nem képes abban ki telelnem ('́gy!) [Szentdemeter U; Told. 39]), falucska (1663: oly falucskáimra vetettenek az passák számára minden hétre tizenöt-öt szán szénát s öt szán fát az mely falucskámból egyikből-egyikből két ekénél vagy szánnál több ki nem jöhet [Szentdemeter U; SzO VI, 282 özv. Gyulaffi Lászlóné 
Balássi Erzsébet Bornemissza Anna fejedelemasszonyhoz]), hasznocska (1625: My Varostol ualaztotot Djrectorok Teolczeres Nagy Tamas es Hannes Eppel szamado Regestumunkat be aduan, ezen eztendöben valo keues haznoczkaual, mely az Varosra zallot Maradot kezunknel f 19 [Kv; Szám. XXXIII/16. 25]), költségecske (1712: Bőer (!) Samuel Uram és Feleséghe Nzts Bároczi Christina Aszszony ... jelenté, hogj az mostani közelebb el múlt haborusághos ŭdőkb(en) min(en) marhájokbol nagjobbára ki pusztultak vólna, ugj hogj ... akarnák el adni ... Nagylakon lévŏ portiojoknak egj részét és abból kevés kŏlcségecskét abbéli szŭkségekre szerzeni [Hari AF; DobLev. I/75]), vagyonocska (1792: magam tulajdon Sok faratságom s helylyes ŭgyekezetem által szereztetett vagyonotskaimbol, az Én Istenem Ladajaban el rendeltem egy Filleretskét vetni; Az az Hagjok és Testalok a' ... KolosVári Unitarium Collegium Szŭkségire ŏrŏkŏsŏn ... Hung fr. 10000, az az Tiz Ezer Magyar forintokot [Héjjasfva NK; SLt XLIII. 17 Felső Dobofalvi Marothi István kezével]) stb.

A diminutivum ironicumra jellemző rejtett ellentmondás a valóság és a képző denotátuma között a SzT. adatai szerint kétféle módon manifesztálódhat: egyrészt olyan beszédhelyzetekben, amelyekben a beszédpartner lekicsinylését, becsmérlését fejezi ki a kicsinyítő képző, például szitkozódásban, sértegetésben jelenhet meg, másrészt a másik típust azok a származékok képviselik, amelyekben a kicsinyítő képző 'kis, kicsi' jelentése ellentétben, olykor akár ellentmondásban is állhat a származék jelentésével.

A szitkozódást tartalmazó kontextusban megjelenő kicsinyítő képzők mindig személyt jelentő szavakhoz járulnak: bátyuka (1598: az en iozago(m)ba hazamba be fogatta $(m)$ vala, magam otalmaert ... engemet, elessen es niugosso(n), tiztessegben tarczio(n) mint battiat ... de eö nem tekintette az Vristent sem az attiafiwsagot eö engemet tiztessegbe nem tartá rutolt zidot kouetem az kegtek zekit Batiukanak lelek kuruanak es halallalis feniegetet engemet [UszT 13/117]), kurvácska (1570: Mond volt zabo Janosne Meny ky kwrwachka Mert Beled verem az kest [Kv; TJk III/2. 28]), kurvanőcske (1568: Anna consors Stephani Nagy ... fassa e(st), Ezt hallotta(m), hogy ... az leant ... Jgy zida, kurúa nọchke, veryelek, de egzer se(m) wtte [Kv; TJk III/1. 185]), legényecske (1630: fel haniua(n) az szenat Istua(n) Deak lata(m) hogi ez az Leani egy Inassal fekszik vala, kiket fel pirongatua(n) az Inasnak monda(m), jai iō fiam illien Iffiu Legenieczke leuen bezzeg nagj korpa hwuelihez fogtal volt [Mv; MvLt 290. 197b]), legényke (1879: Csekélyebb legényke a kis Kálmán, semhogy számot tegyen nekem az, mit ő felőlem elmond [PLev. 43 Petelei István Jakab Ödönhöz]), papocska (1772: ki szalada ... Popa Juanne Tamas Maria ... teli tarakkal kiáltván vár meg te Papotska mért te vével Tüzet, es Fel Gyujtád az Popa Házát [Ludvég K; KLev.]). 
A diminutivum ironicum második alcsoportjába olyan kicsinyítő képzők tartoznak, amelyek elsősorban dolgok neveihez járulnak, és ellentét vagy ellentmondás van a képző és a származék jelentése között: botocska (1574: Mond az Kĕwer Marton, Al hattrab te Azzony ... orrodat Aiakastwl ely Mecchem azt ely higged, egi Botochka volt Nala Meg feniegeteis veleh [Kv; TJk III/3. 365]), botóka (1686: az tordai vitézek elrugazkodának, engem elszakasztának az lobonczok ... sokan vagdaltak hozzám, egy botokával hántam ellent [TT 1889. 509 SzZsN]), csákányka (1634: Kerekes Ianos ... ki ragadva(n) cziakankajat monda: Ez az en Atyamfia, megh lattia ki bant [Mv; MvLt 291. 2b]), pálcácska (1748: Tasnádiné Aszszonyomot ... egy kis páltzátskával veri vala [F.karácsonfva KK; Told. 56]; 1761: Lupéj Vaszali őtootis a' főldhőz tsapta, Blidár Gligoris oda jőtt, s kezéb(en) lévő páltzatzkával kétzer meg ütőtte Krisán Vonult, de el-választván őkőt egy mással meg békéllettek [Illyésfva Sz; BfR 45/9 Farkas Makari (46) zs vall.]), pálcika (1584: Sos Jstwan ... wallia ... hallek kialtast ... Hatra tekintek es hat Dauid Ianos es Sardi Ianos Ieo vtanna(m) Ez zora kialtasra felele igy Sardi Ianos, Jhol Neste lelek Curwa fy lasd meg Minemeo palczika vagion en Nallam [Kv; TJk IV/1. 348]; 1599: az Vduaron faraczkal vala Deak Peter, egi palczachikat veon kezebe kj mene, de azt ne(m) latta(m) mjkor verthe [UszT 14/39]).

A SzT. adalékai tehát azt igazolják, hogy - az alapszó mértékbeli csökkentésén kívül - a kicsinyítő képzőnek gyakran pragmatikai funkciója van, bizonyos beszédhelyzetekben használatuk stratégiai fontosságú. A Dressler-Merlini Barbaresi-féle csoportosítást követve a kicsinyítő képzőket pragmatikai funkciójuk szerint négy nagy csoportba lehet sorolni, bár a SzT. adalékai alapján ezt az osztályozást tovább lehet árnyalni. Az első módosítás a négy föcsoportot érinti, hiszen a SzT. adalékai alapján a diminutivum modestum a diminutivum sociale alcsoportját képezi. Ezen belül két további alcsoport különíthető el attól függően, hogy a beszélő saját személyét vagy a tulajdonában álló javakat kicsinyíti-e. A diminutivum ironicum kategóriáján belül pedig szintén két alosztály különíthető el: az egyikbe azok a kicsinyítő képzők sorolhatók, amelyek becsmérlést, szitkozódást tartalmazó beszédszituációban jelennek meg, a másikba pedig azok a származékok, amelyekben a kicsinyítő képző és a származék jelentése között ellentét (esetenként akár ellentmondás is) van. 


\section{IV.3. A kicsinyítő képzők szociolingvisztikai meghatározottsága}

A nyelvtörténeti vizsgálatok középpontjában általában a grammatikai rendszer valamely elemének diakróniai változása áll, teljesen elvonatkoztatva attól a szociokulturális környezettől, amelyben a szöveg mint kommunikációs egység elhangzott/megíródott. Már a 60-as évektől viszont többen felfigyeltek arra, hogy a saussure-i álláspontot, vagyis a nyelven belüli és nyelven kívüli tényezők éles megkülönböztetését fel kell adni, hiszen ezek megbonthatatlan szerves egységet alkotnak. Ettől a pragmatikai fordulatként ${ }^{55}$ számontartott nyelvészeti paradigmaváltástól világossá vált, hogy a nyelv nem pusztán szabályokba foglalandó grammatikai rendszer, hanem leírásakor nem hagyható figyelmen kívül a humán faktor, a beszélőknek a vizsgálata sem. ${ }^{56}$ Nyugat-Európában is többen képviselik ezt az álláspontot, többek között Susan Romaine, aki szerint több nyelvnek is újra meg kellene vizsgálni a textuális hagyományait, mégpedig úgy, hogy a hangsúly ezúttal a szocio-kulturális, valamint szocio-történelmi aspektusra helyeződjék. ${ }^{57}$ Hutterer Miklós szerint „amennyiben a történeti szempontot (...) ismét érvényre kívánjuk juttatni a nyelvtudományban (...), fokozottabb figyelmet kell szentelnünk az úgynevezett határtudományoknak" (1967: 169), amelyek közül elsődleges fontosságúként a szociológiát emeli ki, mint annak a közegnek a vizsgálatával foglalkozó tudományágat, amely nélkül az emberi kommunikáció nem jöhet létre.

A történeti szociolingvisztika fő feladata a nyelvi változási folyamatok rekonstruálása oly módon, hogy a folyamatokat a maguk társadalmi beágyazottságában tárja fel (Zelliger 2002: 304).

A nyelv tehát nem a külvilágtól hermetikusan elzárt rendszer, nem vonatkoztathatunk el attól a közegtől minden szereplöjével együtt, amelyben létrejött. Ebből a kontextusból még akkor sem ragadhatjuk ki a beszédmüvet, ha az régebbi korban keletkezett, és emiatt a szövegkörnyezet nehezen rekonstruálható. Egy szociopragmatikai irányultságú nyelvtörténet feladata a nyelv kommunikatív aktusként való értelmezése (Maitz 2000), azaz

\footnotetext{
${ }^{55}$ „A 20. század második felében - köztudottan - egy új paradigma jelent meg a nyelvtudományban, amelyet ma "pragmatikai fordulatként« tartunk számon." (Maitz 2000: 501)

56 "A nyelv innentől kezdve már nem pusztán, illetve nem elsősorban grammatikai rendszer, hanem funkcionálisan definiált társadalmi jelenség, egy nyelvi közösség kommunikációs eszköze, a nyelvhasználat kommunikatív cselekvés, és mint ilyen, csak társadalmi és kommunikatív pragmatikus kontextusában írható le, fogható meg lényének egészében." (uő.: uo.)

57 " There is a great need for re-examining the textual traditions of many languages in greater depth and for paying attention to the location of texts in their socio-historical context, i.e. where they fit into the registers available at the time." (Romaine 1988: 1463)
} 
a történeti (szocio)pragmatika a nyelvhasználat és a nyelv összefüggéseit vizsgálja a történetiségben, különös tekintettel a két vagy több résztvevős interakciókra és azok kontextusára (Sárosi 2003). Vagyis a hagyományos nyelvleírással szemben (amely a nyelvnek valamely rendszerét önmagában, az egészből kiragadva vizsgálja) a dimenzionális nyelvszemléletet kellene követni, ami azt jelenti, hogy szerves egységbe épül a nyelvi müködés három fő dimenziója: a térbeli, időbeli és a humán dimenzió (Juhász 2002: 165).

Azon túl tehát, hogy a grammatikai rendszer egy elemének a rendszeren belüli változását kutatjuk, azt is meg kell vizsgálnunk, hogy ki, kinek, mikor és milyen körülmények között mond/ír valamit, ugyanis a változások nem minden esetben a nyelvi rendszerből fakadó változások, hanem ezeknek gyakran külső okai lehetnek ${ }^{58}$ Ez a kérdés Vandenbussche és Willemyns tanulmányában a történeti szociolingvisztika központi problémájaként fogalmazódik meg, de valamivel szűkebb értelemben: Ki kinek, mikor és mit ír? ${ }^{59}$ Természetes, hogy a különböző nyelvtörténeti korokból csak írott anyag maradt meg, de az sok esetben tükrözi az élő beszédet is. A középmagyartól kezdődően olyan szövegtípusok jelennek meg (pl. tanúvallomási jegyzőkönyvek stb.), amelyekből beszélt nyelvi jelenségekre vonatkozó következtetések is levonhatók. A SzT. rendkívül gazdag forrásanyagából ha csak a kolozsváriakat emeljük ki (pl. Kolozsvár törvénykezési jegyzőkönyvei, a város költségeiről vezetett számadáskönyvek és a várost vezető tanács közgyưléseinek jegyzőkönyvei), akkor hiteles képet kaphatunk a korabeli nyelvhasználatról. „Ezek egyrészt híven tükrözik, határozataikkal, törvénykezésükkel szabályozzák a város életvitelét, és a lakosok nemzedékeinek sokezernyi személyes sorsáról szólnak, másrészt a várost érintő országos dolgokkal is foglalkoznak. Következésképp a közéleti - s ezen belül a hivatali, törvénykezési, államelméleti, politikai nyelvhasználat mellett a városi krónikás és az egyéni nyelvhasználat sokféle árnyalata keveredik bennük" (B. Gergely 2002: 189) ${ }^{60}$.

Hegedüs Attila problémafelvetése szerint a nyelvtörténésznek azt kell kimutatnia, hogy a nyelv hogyan hordozza magán az adott kor történeti, társadalmi változatait/vonásait (1986: 441). A SzT. alapján nem biztos, hogy ez alkalmazható, csak a fordítottja: Van-e valamilyen különbség a

${ }^{58}$ „A mósosulást közvetlen előidéző tényezők rendkívül változatosak lehetnek, mindenekelőtt lehetnek rendszeren belüliek, de lehetnek rendszeren kívüliek is, azaz létrejöhetnek a beszédaktusban résztvevők testi-lelki állapotával, adottságaival kapcsolatosan, lehetnek a nyelvi aktusok domináns környezetéhez, szocio-kulturális jellegzetességeihez kötöttek, s lehetnek e tényezők bonyolult kötegei." (Herman 2001: 402)

59 "Wer schreibt was für wen und wann?" (Vandenbussche \& Willemyns 1999: 145)

${ }^{60} \mathrm{~B}$. Gergely több tanulmányában is foglalkozik a SzT. adalékaiban vizsgálható írott és beszélt nyelv viszonyával (1997: 65-74, 1999: 323-31, 2000: 41-51). 
kicsinyítő képzős származékok használatában abból a szempontból, hogy ki, mikor, milyen kontextusban használja őket? Azaz arra voltam kíváncsi, hogy a SzT. adalékainak vizsgálatában valóban lehet-e történeti szociolingvisztikai szempontokat alkalmazni, pontosabban a grammatikai rendszer egy részrendszerében, a kicsinyítő képzős származékokban kimutatható-e valamilyen szociolingvisztikai meghatározottság. Egy ilyen jellegü vizsgálat központi kérdése az, hogy milyen társadalmi háttere volt a 16-19. századok közti időszakban a kicsinyítő képzős származékok használatának. Ha leíró szempontból közelítenénk meg a problémát, akkor a nem, társadalmi pozíció, korcsoport tényezőket figyelembe véve elmondható, hogy a kicsinyítő képzők inkább a nők nyelvhasználatára jellemzőek, mint a férfiakéra, inkább a középső és alsó társadalmi osztály kedveli őket, mint a felső, és inkább a középkorú és idős beszélők körében elterjedt, mint a fiatalok körében.

Az a kérdés, hogy ez visszavetíthető-e a régi nyelvre is, valóban létezik-e valamilyen nemi, társadalmi funkcióbeli, illetve életkor szerinti meghatározottság a kicsinyítő képzők használatában.

Másrészt mindenképpen szem előtt kell tartani azt a tényt, hogy - mivel történeti anyagról van szó - egy ilyen vizsgálatnak korlátai vannak, sok esetben nem ellenőrizhető az adatok hitelessége (lokalizáció, datálás, szövegközlő személye), gyakran az egykori kontextust, valamint ennek összetevőit nehéz rekonstruálni. Vagyis egy ilyen korpuszt csak megfelelő óvatossággal lehet kezelni.

A SzT. célja, hogy a 16-19. századok közti időszak Erdélyének élő nyelvét mutassa be: „A Tár anyagának egybegyűjtője és az anyag szerkesztője ilyenformán arra törekedett és törekedik a továbbiakban is, hogy e szótári munkában a nyelvet úgyszólva életes közelségében, mindennapos kavargásában, lendületes mozgásában, változásában mutassa be" (Szabó T. 1975: 12). Az adalékok olyan változatos forrásokból származnak, hogy a legváltozatosabb beszédszituációk rekonstruálhatóak. A SzT. előnye, hogy ahol csak lehet, szögletes zárójelben megjelenik az adatközlő neve, társadalmi státusa, kora: „A forrásjelzetek után nem ritkán - valamilyen formában - a forrásszerkesztő, misszilisek esetében a levélíró és sokszor a levél címzettjének, a vallomásokból kijegyzett szövegrészek esetében a vallomástevő neve, ( )-ben életkora, rövidített formában társadalmi helyzetére, esetleg foglalkozására való utalás is szerepel" (i. m. 18), így szociolingvisztikai következtetések is levonhatók.

A SzT. nyelvi anyagának vizsgálatakor figyelembe kell vennünk azt a történelmi tényt, hogy a magyar nyelv Erdélyben vált először államnyelvvé. Ezáltal a magyar nyelv nemcsak a közemberek közti kommunikáció nyelve, hanem „,az erdélyi fejedelemség hivatalos nyelvének rangjá- 
ra emelkedik, amelyet a helyi ügyintézéstől a fejedelmi tanácsig vagy az erdélyi országgyưlések végzéséig a közélet minden fórumán hivatalosan és elsődlegesen használtak" (B. Gergely 2002: 187). Ez az adott korban az anyanyelv presztízsének gyors emelkedését eredményezhette.

Az eddig megjelent 12 kötet megvizsgált adalékai alapján három nagy kategória rajzolódik ki: legtöbb esetben nincs semmilyen információ a kommunikációban résztvevő felekről, ezek általában tárgylajstromokból, leltárakból stb. kiragadott részletek (pl.: 1576: Wagion egy weres tereok Ingh taffota kereol A galyran igen zep gyngye (!) Aranyos hymechke [Szamosfva K; JHbK XVIII/7. 4]; 1693: Szănto fŏldek ... Az Bŭdŏs kutnál négy holdatska [Ne; DobLev. I/37]; 1699: az Ablak tablai vas pantocskakon s horgocskakon forgok [Boroskrakkó AF; BfN VI]; 1761: Hegedüske [Kiskászon Hsz; SzNM Eml. 61]; 1774: (Az erdőből) hordott jotskán Gyertján ágat [Csóka MT; Ks 31. XXIXb] stb.).

A második kategóriába azokat az adalékokat soroltam, amelyek után zárójelben ugyan nem jelenik meg az adatközlő neve, de a szövegből kirajzolódik az a kontextus, amelyben a kommunikáció zajlott (az ilyen adalékok elsősorban pragmatikai szempontból relevánsak) (pl.: 1630: Nagodnak müis Agnes nevü kis Hugocskánkal edgyütt, mint Keglmes Urunk(na)k kŏnyŏrgŭnk ... méltoztassék azon Négy Falucskainkrol Nova Donatiot Conferalni [JHbK LVII/31]; 1662: Kun Gergelj vram Algiogon és ott kőzel léuö két három falukban levŏ husz ház iobbagiocskámot Ngodtol ... megh kérte volt uolna, melj portiocskát ... conferalt volt [KJ]; 1683: Az Szakacs, es Janos nevú inaska dolgat az mi illeti, mivel Uram magame s Atyam Uramis magam szamara tanittatta az szakacsot; az inast pedigle(n) magam tartottam őrokbe; mint jo Uramat kerem alazatosan kegyelmedet, ha tovab nem, bar csak harom vagy negy esztendeig, mig edgyet tanitana engedgye ide, mivel kegyelmednek szakacsokat eleget adott [Diód AF; Incz. V. 20]; 1748: Nézze kgld az én kétt iker Fiacskáim micsoda nagyott nőtek már [Aranyosrákos TA; LLt]; 1779: a husz pénznek ... interesse egy pénznél valamivel tŏbbecske, viszontag ajállom a Tekintetes Aszszonynak, hogy azon interesetskét méltosztassék ez alkolmatossaggal meg fizetni [Bő MT; Sár.] stb.).

A harmadik kategóriába azok az adalékok kerültek, amelyek után pontos információt kapunk az adatközlő személyéről (pl.: 1600: En mindenkor Fekete Balaseknak tuttam azt a helechket ... eók kazaltak [UszT 15/87 Iswanffy Isthwan, Kaidichfalui, Zabad Zekely vall.]; 1600: Én Gyeörgyffi Martont, mindenkor Gyeörgyffi Balint fianak tuttam ... a mikor el wetekezek hazulis az Marton io kora inaska wala, nekem hagya, s az apiawal eggiott mi tartuk oztan [Zetelaka U; UszT 15/38 Gyeörgyffi Thamas Ersebet lib. vall.]; 1695: Bánfi Mihály Uram(na)k egy idegen arva Inaskábúl alló 
('́gy!) Szakács Inassa Tekei Tivadar tőbb lator Complices társaival egyűtt az eo klgmek ... Sz: Királyi pinczejét egy néhány izbe(n) fel vervén, nem kevés karokat tőtt [Marossztkirály AF; WassLt Sz:Győrgyi Mihally sch(ola) mester vall.] stb.).

A szociolingvisztikai vizsgálatba csak azokat az adalékokat vontam be, amelyek után a szögletes zárójel tartalmaz az adatközlő személyére vonatkozó információt, ugyanis ebből a szempontból ezek relevánsak. Egyéb adalék esetén is elképzelhető, hogy ki lehetne nyomozni a kommunikációs felek kilétét, de ez történeti anyagon igen bonyolult feladat volna. Bár a SzT. szerkesztési elvei közé tartozik az adalék minél pontosabb behatárolása (település, megye, levéltár, adatközlő), gyakran nem lehet mindegyiket pontosan megállapítani, emiatt az adatközlő személye sok adalékban nem deríthető ki. A következő táblázat azt szemlélteti, hogy az összes kicsinyítő képzős származékot tartalmazó adalékhoz viszonyítva milyen azoknak az aránya, amelyekben az adatközlő személye is azonosítható.

\begin{tabular}{|c|c|c|}
\hline Kötetszám & $\begin{array}{c}\text { Kicsinyítő képzős származékot tartal- } \\
\text { mazó adalékok száma }\end{array}$ & $\begin{array}{c}\text { Azonosítható } \\
\text { szövegközlő }\end{array}$ \\
\hline I. & 598 & 35 \\
\hline II. & 558 & 55 \\
\hline III. & 248 & 26 \\
\hline IV. & 599 & 64 \\
\hline V. & 549 & 109 \\
\hline VI. & 535 & 58 \\
\hline VII. & 491 & 51 \\
\hline VIII. & 98 & 15 \\
\hline IX. & 361 & 26 \\
\hline X. & 398 & 34 \\
\hline XI. & 397 & 42 \\
\hline XII. & 456 & 60 \\
\hline
\end{tabular}

Összesítve a számadatokat kiderül, hogy az 5288 adalékból 576-ban lehet azonosítani az adatközlőt, ami 10,9\%-ot jelent.

A beszédaktus résztvevői alapvetően két szövegtípusban azonosíthatók: egyik a levél (levélíró és címzett), a másik az élet legkülönfélébb kérdéseiben tartott vallomási jegyzőkönyvek szövege. Itt elsősorban a beszélő azonosítható, a beszédtárs nem mindig. Ezeknek a vallomási szövegeknek az az előnyük, hogy a beszélt nyelvhez állnak közel, az adatközlőről pedig pontos információkat nyújtanak: nevén kívül általában a korát, valamint a társadalmi funkcióját is közlik. 
Attól függően, hogy az adalék utáni szögletes zárójel, illetve a TJk, TanJk esetében a szövegben megjelenő „XY fassa/fassus est” kezdetű adalékok milyen információkat közölnek az adóról, több kategóriát különíthetünk el:

I. Az első csoportba olyan adalékok tartoznak, amelyek csak az adatközlő nevét tartalmazzák (pl.: 1719: Almakerékről, vagy negy Általagocskámat ŭrmŏs(ne)k és veres(ne)k el kŭldem [Ebesfva KK; KJMiss. Rétyi Péter lev.]; 1759: az Gyermeknek az Bal kezecskéje keze fején alol tsudálatos mozgásban van, minden inai erecskéiben ollyan rángotás formalag mozog ugyan tsak az kezecskeit az Gyermek nem fájlolta, kivált az hűvelykecskeivel, s mutato ujjával az Gyermek kolcsokatis meg fogott, s tartottis [M.csesztve AF; Ks Mike Antal lev.]; 1759: im küldom tojocskaban v. ferslogocskaban a Specimeneket [Komlód K; WLt Árva Daniel Polixéna lev.]; 1760: Azonban ezen Talyigán két Zsák szárnyas majorságnak valo buza rostalyát kŭldőttem bé, Holnap Napra penig, őtt Csirkécskét, két Pipét, két ifju Nyulacskát és ez oráig Annyát szopo két Kis Báránykát [O.csesztve AF; Ks 83 Szabó István lev.] stb.).

II. A nembeli megkülönböztetés mellett a korcsoportok szerinti elkülönítést teszik lehetővé azok az adalékok, amelyekben az adatközlő kora is megjelenik (pl.: 1795: Lorinczi Joseff Uram ... a Fiatskajat ki edgygyetlen edgy meg vérte [M.köblös SzD; RLt Ládár Dávidné Vanna (30) vall.]; 1843: látván hogy a Bakkan Kupfer van ... fel bontattuk, gyengetske Lakatját ő a kezivel le fotsarván, kŏvetkezőleg a ... talált portékákat ki vettŭk [Bágyon TA; KLev. Török István (26) vall.]; 1844: Balog Mosinak az Szallannája el veszvén meg Matoztotta s nállam egy Kis Kosárba talált egy darabatskát a Matozo Hütesség [Bágyon TA; KLev Nutzuj János (21) vall.] stb.).

III. A harmadik csoportba tartoznak a név mellett a társadalmi funkciót vagy foglalkozást feltüntető adalékok (pl.: 1572: Nadasy balynth zamara valo foldetis Egy darabochykath byrnak [Gyerömonostor K; KP Thamo (?) Mate jb vall.]; 1576/1577: Egy kys fiaczkayays Maradot Az Azzonnak Thorozkay Christophtol [Torda/Kv; Thor. VI/4. Gr. Zabo de Dengelegh ns vall.]; 1644/1785: az Ur Isten ... az én Szerelmes Attyámfiát Nyagu Borbárát rendelte Házas társul ... Haza Törvénye szerint a micském van nagyobbára vélle együtt szerezvén őtet illetné [BfN Kémeri Huszti Menyhárt erdélyi főharmincados végr.]; 1798: Kádár János ö kegyelme Cserében adot Joszágan egy Haziko vagyan ... Tar János ö kegyelme Feleségének Kadár János által, lett Csere Joszágban lévő házikónak amig hasznát lehet venni vegje hasznat [Csegez TA; Borb. I Csegezi Csongvai Pál Hütös assessor kezével] stb.).IV. A negyedik csoport az előző háromnak a kombinációja, vagyis az adalék utáni szögletes zárójelből információt kapunk az adatközlő nevére, korára és társadalmi funkciójára vonatkozóan (pl.: 1730: az én Jnaskám 
Tőrők, s - az Fiacskám haza jővé(n)ek s - mondák hogy Szakács Máttyás áskált azon Jószágon [Altorja Hsz; Borb. Donát Jánosné Aszsz(ony)m Ilona (46) ns vall.]; 1756: lattuk fát vágni ... sőtt enis Pap Gáspár egykor vágtam valami fátskákat az Vr Malmában vivén ŏrleni [Bácsi H; KB Casp. Pap (60) ns vall.]; 1759: Néhai Alb Tyiron ... egy F. Fentősi Menyecskét szeretvén ... egy alkalmatossággal a' Fentősiek rajta kapták bujálkodásokan és azon cselekedeteiért adta vólna a Fentősiek(ne)k ezen csegellj földecskét [F.fentős Szt; TL. Buttyán Petre (66) nb vall.] stb.).

A negyedik csoport egy alegységét azok az adalékok képezik, amelyekben a névből arra is lehet következtetni, hogy az adatközlő milyen nemzetiségű (pl. a következő adalékokban román az adatközlő: 1744: A Lunka Kinyipa helységetskét ... Gánya Petru birta ... s háza volt ott [Nagyalmás H; BK sub nro 181 Szidera Filip (58) jb vall.]; 1759: Martinnak is vagjnak három kisded Fiatskái [Girbó AF; JHb Valászie Muntyán (99) zs vall.]; 1766: hellyetskéjin [Szentegyed SzD; WassLt Öreg Pop Iuon (76) zs vall.]; 1831: az magam Nemesi Erdőtském meg visgálására menvén ki egyszer csak hallok valami őkrőket hajtani [Hosszúfalu Szt; TKhf Drágos Dumitru (72) ns vall.] stb.).

V. Az ötödik csoport azért sajátos, mert ide írott szövegek, levelek tartoznak, amelyekben a kommunikáció mindkét résztvevőjére, az adóra és vevőre is van információ (pl.: 1701: Ezen bizonyos emberitül Kegyelmednek Az mint Szegĕny ifiu legenysĕgemtűl telik, egy kis ajándékocskát kültem [Gyeke K; Ks 96 Kornis István Gyeröfi Borbálának]; 1730: Az tegnapi halasztatas Ur(am) En rajtam el nem mult - harom Csukacskat harmincz Karaszt Kilenc vén Rakokat fogtak [Szentpál K; TKl Mihály Deák Teleki Pálhoz]; 1749: Angjom Aszszony(na)k irtam volt egy Invitatoriat a 9um p(rae)sentis meg akarván kereszteltetni az Fiatskánkat [Zsibó Sz; WLt Wesselényi István Wesselényi Ferenchez]; 1766: Pap Stefán ... egy kis darabotska Irottvánt kezdet volt [Szentegyed SzD; Wass Molduván Kratsun (80) zs vall.]; 1842: A magyarok telepedésekor Isten segitsen 1774ben, Hadikfalván 1784-ben, Andrásfalván 1785-ben épült fakápolnácskák, mind elromlottak, most árendált házokban tartatik az istentisztelet, Fogadj Istenben még állnak a kápolnácskák [WLt Egyház és iskola csomó. Bíró Mózes andrásfalvi ref. lelkész jel. Kelemen Benjáminhoz, br. Wesselényi Miklós jószágigazgatójához] stb.).

VI. Az utolsó kategóriába olyan adalékok tartoznak, amelyekből az adatközlő személyén kívül a szöveg funkciója is kiderül (végrendelet, utasítás stb.) (pl.: 1598: hattam az Gazda Azzonnak, egj eoregh Serleget, kin az en magam neuem es Czimere(m) rajta vagion egj rottiaz (!) ezwst Kannaczykat, es egj eozue Jaro Aranyas kupaczykat [Gerend TA; Törzs. Gerendj Pál végr.]; 1631: Agoston Falvanak hason felit ... hagyom ... az kis 
neveletlen hugoczkam(na)k Petki Katának ... el ne vegyék tŏlle az eŏ rész jószágottskájaval edgjüt [Nagyteremi KK; Ks L. 5 Sükősd György végr.]; 1643: Mivel ... azon ioszagoczkamnak jeovedelmebeol egyebüttis az decimat ki szoktam vetetni ... Azert az mi kiczin az ott valo ieovedelmeczkeből jut annak mind exigalasabol s mind erogatiojabol ehez tarcza magat [ETA V/2. 75 I. Bethlen István ut. a bethlenősi dézma felhasználása felől]; 1784: Tŏrvénytelen, és Calumniosa a' Querulansok(na)k procedurajok, mert elsobben Malmunk(na)k gatatskaját potentiose el vagták, tollalták $\mathrm{s}$ annak utánna kivánnyák a' differentiát Sopiáltottni [Szováta MT; Jeremiás György és Lőrinc folyamodványa (Mt)] stb.).

Ezen adalékokat szociolingvisztikai szempontból két nagy csoportban lehet vizsgálni. Minden adalék bevonható abba a vizsgálatba, amely arra irányul, hogy kinek a nyelvhasználatában fordul elő kicsinyítő képzős származék. Arra vonatkozólag, hogy kihez szól a szöveg, vagyis milyen kommunikációs helyzetben kerülhetnek a szövegbe kicsinyítő képzős származékok, csak azok az adalékok elemezhetők, amelyek a beszédtárssal kapcsolatos információt is tartalmaznak.

A kicsinyítő képzős származékok előfordulásának nemek szerinti megoszlását a következő táblázat szemlélteti:

\begin{tabular}{|c|c|c|}
\hline Kötet & Férfi & Nő \\
\hline I. & 31 & 4 \\
\hline II. & 50 & 5 \\
\hline III. & 22 & 4 \\
\hline IV. & 59 & 6 \\
\hline V. & 94 & 15 \\
\hline VI. & 52 & 6 \\
\hline VII. & 47 & 4 \\
\hline VIII. & 13 & 2 \\
\hline IX. & 26 & - \\
\hline X. & 29 & 5 \\
\hline XI. & 39 & 3 \\
\hline XII. & 54 & 6 \\
\hline Összesen & 516 & 60 \\
\hline
\end{tabular}

A táblázatban szereplő adatok azt mutatják, hogy kicsinyítő képzős származék használata sokkal gyakoribb férfiak beszédében, mint női adatközlők szövegében, a százalékos megoszlás: $89,58 \%$ a férfi, $10,42 \%$ a nő. Látszólag ez teljesen ellentmond a szinkrón állapotnak, hiszen a mai beszélők közül úgy tünik, hogy inkább nők használnak kicsinyítő képzőket, mint férfiak - bár erre vonatkozó felmérés még nem készült. Ebből a szempontból viszont a SzT. anyaga (de akármilyen más történeti forrásra is gon- 
dolhatunk) nem teljesen megbízható, ugyanis egyrészt a 16-19. században az írás elsősorban a férfiak privilégiuma volt (a férfiaknak nagyobb hozzáférésük volt az intézményes keretek között működő oktatáshoz, így körükben sokkal több volt az írástudó, mint a nők körében), másrészt a különböző vallatások tanúi is inkább férfiak voltak. Így a 89,58\% nem azt mutatja, hogy kicsinyítő képzős származékokat szinte kizárólag férfiak használtak, hanem azt, hogy a korabeli szövegek elsősorban férfiaktól származnak.

Kevesebb adalék vonható be a kicsinyítő képzős származékok használatának korcsoportonkénti vizsgálatába, mert nem minden adatközlőről van a korára vonatkozó információ is. Az ilyen irányú elemzés ráépül a nemek szerinti vizsgálatra, kiegészíti azt. Összesen 157 adatközlőnek ismert a kora. Nyolc korcsoportot (10 éves korig, 11-20, 21-30, 31-40, 41-50, 51-60, 61-70, 70-) különítettem el a táblázatban (10 éves intervallumokat), mert úgy gondolom, hogy ha ennél nagyobb időszakot tekintenék egy egységnek, az már nem volna releváns, hiszen például egy 7 és egy 17 éves adatközlő nyelvhasználatában nagyobb eltérések mutatkoznak, mint egy 21 és 25 éves beszédében.

\begin{tabular}{|c|c|c|}
\hline Kor & Férfi & Nő \\
\hline-10 & - & 1 \\
\hline $11-20$ & 2 & 1 \\
\hline $21-30$ & 13 & 4 \\
\hline $31-40$ & 36 & 4 \\
\hline $41-50$ & 32 & 2 \\
\hline $51-60$ & 33 & 4 \\
\hline $61-70$ & 17 & 3 \\
\hline $71-$ & 14 & 1 \\
\hline
\end{tabular}

A táblázatba foglalt adatok elemzéséből kiderül, hogy itt is jóval több férfi adatközlő kora ismert, mint nőé, amelynek ugyanaz a magyarázata, ami miatt általában több férfi adatközlő azonosítható, mint nő. Az adatközlők szignifikáns többsége (79,04\%) 31 és 70 év közötti, vagyis ez azt jelenti, hogy elsősorban az ilyen korúak nyelvhasználatában fordulnak elő kicsinyítő képzős származékok. Arra is van példa viszont, hogy nagyon fiatalok vagy nagyon idősek vallomásában szerepel kicsinyítő képzős származék (20,96\%). A legfiatalabb adatközlő egy 7 éves kislány (1603: En is akkor abbany Az hazachykabany voltam, Az Echyetes Altalaghy mellett wleok vala [Kv; TJk VI/1. 666 Varga Caspar leania Sophika (7) vall.]).

A másik végletet az idősek nyelvéből idézhető kicsinyítő képzős származékok jelentik. A legidősebb adatközlő 99 éves, de van adatunk 98, 97, illetve 94 éves adatközlőtől is (1759: Martinnak is vagjnak három kisded 
Fiatskái [Girbó AF; JHb Valászie Muntyán (99) zs vall.]; 1770: a' Szasz Regenieknek azon altal járo Kis Hidasotskája a Mellyet ... a' viz által gyakorta el rontatott pallo helyibe tsináltattanak [Szászrégen MT; Born. XVI/79-80 Kiss Márton (98) vall.]; 1792: azon kis Zállogos joszágotska ... minekutánna ki váltatatt, azon szerzemény-joszág árrát el osztották három felé [Borb. II Agillis Andreás Kedei ez M. Sákod ${ }^{a}$ (97) vall. - ${ }^{a}$ U]; 1731: Fát tudom hogy Kolosvárra ... Sz. Pálrol, és Vajdaházárol hordatott a Nagy Ura , innen minden nap két szekérrel vittenek, mely miá nehány kor nagy tsonkulásais esett a Gazdaság folytatásban, az eŏ Nga kủlőnŏs Joszágábol pedig még tsak edgy szálatskát sem vittenek egyszeris [Szentpál K; TKl. - ${ }^{a}$ Gr. Teleki Pál Bara András (94) jb vall.]).

Ennek a táblázatnak az adatai leginkább azt mutatják meg, hogy a különböző peres ügyekben, illetve a törvénykezési folyamatban tanúként az aktív korosztály vett részt, azaz kb. a 30-tól 60 évesig, az ezen a csoporton kívül esőket csak ritkán idézték a törvény elé vallomást tenni. Ebből tehát természetszerúleg következik, hogy ennek a korosztálynak a nyelvhasználatából van a legtöbb példa kicsinyítő képzős származékra: (1714: Avram Csilyé Eszt monda en csak Evel az küs palczacskaval vagyok nem ugy jöttem hogy harczallyak, nem is vala nagy bott hanem csak Edgy küs palczaczka vala kezeben [Tamáspatak H; BK sub nro 261 Aramia Koszteszkuly (50) falusbíró vall.]; 1758: monda Udvar Istvánné Aszszonyom: Iuana ha sŭtŏttél vólna adnál nékem egy Kis kenyeret ... mellyre én mondék: Jó szivel én Aszszonyom, tsak hogy bizony szegényetske a' kenyerem [Bethlensztmiklós KK; BK. Farkas Juana cons. providi Vintilla Petre (32) vall.]; 1793: az Asszony eŏ Nga felöl nem felelek ... hogy szokott kegyességétöl viseltetve conventiotskátis nem adott nékie, de ebben bizonyos nem vagyok [Kémer Sz; TKhf St. Dombi (60) zs vall.]; 1795: Lorinczi Joseff Uram ... a Fiatskajat ki edgygyetlen edgy meg vérte [M.köblös SzD; RLt Ládár Dávidné Vanna (30) vall.]; 1829: a Falus Biro egy egy Szál Gyümőlts Fát le vágotatt s vitetett Rectificator Urhoz ... egy egy Szekeretskével [Mezőkölpény MT; TSb Fartzádi Márton (46) vall.] stb.).

A kicsinyítő képzős származékok társadalmi osztályok és ezen belül különböző mesterségek szerinti megoszlása igen változatos képet mutat. A társadalom legalsóbb rétegéhez tartozók nyelvhasználatától (pl. jobbágyok) a legmagasabb réteg képviselőinek nyelvhasználatáig (pl. a fejedelem) van példa kicsinyítő képzőkre. ${ }^{61}$

A SzT. adalékaiban megjelenő társadalmi funkciókat és mesterségeket a társadalomban elfoglalt helyük szerint három rétegbe sorolhatjuk: alsó, közép- és felső réteg. Az alsóbb társadalmi osztályba tartoznak a

\footnotetext{
${ }^{61}$ A vizsgálatba azokat az adalékokat vontam be, amelyek után szögletes zárójelben megjelenik az adatközlő mestersége, ill. valamilyen információ a társadalmi helyzetére nézve.
} 
jobbágyok, zsellérek és szolgáló emberek, a középréteghez a takácsmesterek, sáfárpolgárok, libertinusok, lakatosok, jószágigazgatók, méhészek, tiszttartók, deákok, mérnökök, kántorok, malombírók, gyalogos katonák, hivatali segédek, beszerzők stb. ${ }^{62}$ A felső társadalmi réteghez tartozónak tekintem a közigazgatásban és igazságszolgáltatásban dolgozókat (bírók, ügyvédek), az egyházhoz tartozó személyeket (papok, lelkészek, káptalanok, esperesek), valamint a nemesség képviselőit (nemesek, grófok, bárók, lófó emberek).

Az adatok mennyiségét tekintve, legtöbb kicsinyítő képzős származék az alsó réteghez tartozók vallomásaiból került elő (46,22\%) (pl.: 1757: a meg nevezet ŏrŏkségnek ... nagjobb részit a viz mosta el, s a mi a viztŏl meg maradot edgj darabacskát latván az Mgŏs Groff Bethlen Dávid Vr eŏ Nga Bohoroj Juon nevŭ jobbágya hogj senki semmi kőzit hozzá nem tartya, a maga őrőkségihez applicalta [F.borgó BN; BK Orbanás Iuon (60) jb vall.]; 1771: hallottam a Száva Marján Szájábol ezeket beszélleni ... hogj az Utrizáns Bágjuléknak attját Bágj (!) Juont az ó édes attja hozta, vagj szőktette ell Vintzről, ide Csákljára, ekképpen hitegetvén őtet, gjere ell édes fiatskám én velem mert én meg ruházlak, s felnevelnevellek ('́gy!), s gondodat viselem [Girbó AF; JHb Nikoje Patru (70) jb vall.]; 1782: Groff Székely Adám Vr ... Praefektussa ... az Also Suki Lakosokkal, a' Nemes Suki és Also Suki Határok kŏzé ki menvén ... bizonyos fŏld halmotskákat Vagyis métàzásokat tsinalt az emlitett két Faluk hatàraik kőzőtt [F.zsuk K; SLt XLII. 5. 15 Moldován alias Marosán Alexa (36) zs vall.]; 1777: egy főldetskének a vegire tsinált volt Nehai Pap Gábor eŏ klme egy Juhász Házikot azután a maga Nemes Curiáját ugj vitte azon földek végeiben valo nyilatskara [Marossztgyörgy MT; MkG 36. 5/5 Bojtos Todor (63) zs vall.]; 1807: a midőn azon hely még szabad hely volt, egy kis Strázsa házatska volt réá építve [Apahida K; RLt O. 5 Moga Von (50) col. vall.]; 1813: Groff Korda Anna Vr Aszszony ... fogattatott fel egy jo darab fiatalos Erdŏt ... ugy hallottam, hogy az akkori Udvari Tiszt az eŏ Nga emberei által fogattatta fel már régetskén ... imitt amott a régi fogásnak jelei és valoságos kereszt jegyei a Fákon találtatnak [F.berekszó Sz; BfR III. 12/9 Fluerás Mikás Vonucz (40) col. vall.]; 1843: akkor pedig a' Deresztés a' Jovábol egy darabotskát magának felszántott, 's ugy használta [Bodola Hsz; BLt 12 Molnár Györgye (60) szolgáló ember vall.] stb.).

A kicsinyítő képzős származékok előfordulásának gyakoriságát tekintve második helyen a felső társadalmi osztály áll (36,02\%) (pl.: 1600: En mindenkor azt a darab zena fwwechket Fekete Balaseknak hallotta(m), en masenak ne(m) hallotta(m) [UszT 15/87 Miklos Ferencz Kaidichfalui Lofeö

\footnotetext{
${ }^{62}$ Megjegyzem, hogy a középrétegen belül a mesterségek és társadalmi funkciók felsorolásában nincs rangsorolás.
} 
ember vall.]; 1661: Az odabocsátott német kapitánnal egyértelemből, ha tetszenék neki is, az istáló körül kellene valami jó erősségecskét csinálni, árokkal is bekeriteni, úgy hogy az várból is lehetne defensioja [SzO VI, 235 a fej. Fog. főtiszteihez]; 1728: Az Feleségem ... csak nem épülhet ki nyavalyájából, ha három négy nap jobbacskán vagyon, megint harom nap roszszabbul ... most megint tegnaptol fogva roszszabbacskán vagyon [ApLt 1 gr. Haller János gr. Kálnoki Borbárához Nsz-ből]; 1790: Rutkai Vr(am), látom magais igen szereti Tŏvisset, s nem örőmest válna meg tölle, de kéntelen, mert szegény; Hunyad Vármegyéb(en) szándékozik meg fészkelödni, s ha módja lenne benne, ott valamivel a' Tŏvissi Részinek árrával kŭllyebetske terjeszkedni, mert nem capax szegény feje ideis tovais figyelmezni [Celna AF; TL. Málnási László ref. főkonz. pap gr. Teleki Józsefhez]; 1806: Azon által járo pallo hellyett keszittetett Hidasotska jol lehet akkora legyenis, hogy azzal ket lovat a' Vizen altal lehessen vinni ... csupán a' gyalog valo járás engedtetik meg [Radnótfája MT; Born. XVI. Csavasi Mihály (34) ns vall.]; 1820: En regtŏl fogva betegesetske allopottol vagyok [Mv; Borb. II. Mátyás Sámuel ügyvéd lev.]; 1831: az magam Nemesi Erdőtském meg visgálására menvén ki egyszer csak hallok valami őkrőket hajtani [Hosszúfalu Szt; TKhf Drágos Dumitru (72) ns vall.] stb.).

Legkevesebb kicsinyítő képzős származékot tartalmazó szöveg a középréteghez tartozó adatközlőktől került elő (17,74\%) (pl.: 1776: Onnan ira ... ŏ Ngă egy Leveletskét a' Mlgs Praepost Urnak, mellyben ... nagyon kérte, hogy meg ne eskettené Mlgs B. Henterrel a' Kis Aszszony ŏ Ngát [Kóród KK; GyL. Geor. Vizi (30) rk kántor vall.]; XVIII. sz. v.: Esmet hozat az jáger ... egy kis flintátskat melnek egy által járo szeget csinaltam $[\mathrm{Kv}$; $\mathrm{BK}$. Gyarmathi Sámuel lakatos kezével]; 1816: a' Balás János Méhészinél vagyon égy karotska Szénája [Mezőmadaras MT; Born. XVb Puro Juvon (50) méhész vall.]; 1844: 14. Keszkenyő az durvábbatskábol is hasonlo képpen azan szerint van [Kv; IB Konetzni Ignátz takácsmester kezével]; 1847: a' 2ik viz keréknek kalátsai-bérlései, és ládátskái oly roszszak, hogy a' miatt ezen keréknek hasznátis alig vehetni [Kv; KmULev. 2 László János mérnök kezével] stb.).

Ha a három vizsgálati szempont (nem, kor, társadalmi funkció) eredményeit egy táblázatba foglaljuk, csak azok az adalékok vehetők figyelembe, amelyek után szögletes zárójelben mindhárom információ szerepel (név, kor, foglalkozás vagy társadalmi státus). Emiatt az eredményeket kellő óvatossággal kell kezelni. 


\begin{tabular}{|l|l|c|c|c|}
\hline \multirow{2}{*}{ Nem } & Kor & Alsó réteg & Középréteg & Felső réteg \\
\hline \multirow{3}{*}{ Nő } & Fiatal & 1 & - & - \\
\cline { 2 - 5 } & Középkorú & 2 & - & 3 \\
\cline { 2 - 5 } & Idős & - & - & - \\
\hline \multirow{3}{*}{ Férfi } & Fiatal & 30 & 7 & 4 \\
\cline { 2 - 5 } & Középkorú & 42 & 6 & 16 \\
\cline { 2 - 5 } & Idős & 8 & - & 2 \\
\hline
\end{tabular}

A táblázat adataiból az derül ki, hogy kicsinyítő képzős származékok leggyakrabban az alsó társadalmi réteghez tartozó középkorú férfiak nyelvében fordulnak elő, de általában ennek a rétegnek a nyelvi adataiban van a legtöbb példa ilyen származékszavakra, függetlenül a korosztálytól. Ez valószínúleg kapcsolatban áll azzal a pragmatikai ténnyel, hogy a beszélő (ezúttal alacsony réteghez tartozó) csökkenti saját felelősségét a kommunikációs szituációban, illetve alázatát fejezi ki. Arányaiban a következő helyen a felső réteghez tartozó (középkorú) férfiak nyelvhasználata áll. Nők szövegeiből általában jóval kevesebb került a SzT.-ba, mint férfiakéiból (a fentebb említett okok miatt), és ezt igazolják a táblázat adatai is. A legkevesebb adat a középréteghez tartozóktól származik (egyetlen női adatközlőtől sincs példa, férfiaktól is kevés).

Ezen adatok alapján bizonyos következtetések levonhatók ugyan a 16-19. század erdélyi nyelvre vonatkozóan (például az, hogy kicsinyítő képzős származékok elsősorban az alsó réteghez tartozó középkorú férfiak nyelvében fordultak elő), mégis hangsúlyoznunk kell, hogy ezek az adatok csak megfelelő óvatossággal kezelhetők, hiszen - bár követelmény volt a tanúk szavainak hiteles lejegyzése - mindenképpen figyelembe kell venni egyrészt, hogy lejegyzett szövegekkel dolgozunk, amelyeket a leírás során az íródeákok módosíthattak, másrészt azt, hogy nem minden társadalmi, illetve korcsoport vett részt a törvénykezési folyamatban egyenlően.

Szociolingvisztikai szempontból ki kell még térnünk az olyan kommunikációs szituációk elemzésére, amelyekben mindkét résztvevő (az adó és a vevő egyaránt) ismert. Főként levélrészletek esetén jelenik meg szögletes zárójelben a levél írójára és a címzettre vonatkozó információ is.

Több eset különíthető el aszerint, hogy mit tudunk meg a beszédhelyzet szereplőiről.

Az első csoportba azokat az adalékokat sorolom, amelyekből csak a beszédhelyzet résztvevőinek nevét ismerjük meg (ennek alapján elemezhető a kicsinyítő képzős származékoknak a nemek szerinti kommunikációban való megoszlása) (pl.: 1701: Ezen bizonyos emberitül Kegyelmednek Az mint Szegĕny ifiu legenysègemtül telik, egy kis ajándékocskát kűltem [Gyeke K; Ks 96 Kornis István Gyeröfi Borbálának]; 1730: Az tegnapi ha- 
lasztatas Ur(am) En rajtam el nem mult - harom Csukacskat harmincz Karaszt Kilenc vén Rakokat fogtak [Szentpál K; TK1 Mihály Deák Teleki Pálhoz]; 1755/1805: most Sz. György napjára akarnék váltani ki egy darabatska Joszágot [F.zsuk K; SLt XLVI. 7 Suki János Ferentzi Györgyhöz] stb.).

\begin{tabular}{|c|c|}
\hline $\begin{array}{c}\text { A kommunikációs partnerek nemek } \\
\text { szerinti megoszlása }\end{array}$ & Adatok száma \\
\hline Nő $\rightarrow$ férfi & 1 \\
\hline Férfi $\rightarrow$ nő & 7 \\
\hline Nő $\rightarrow$ nő & 2 \\
\hline Férfi $\rightarrow$ férfi & 45 \\
\hline
\end{tabular}

A táblázat adatai szerint kicsinyítő képzős származékok leggyakrabban olyan kommunikációs szituációban fordulnak elö, amelyekben az adó férfi, ezen belül is gyakoribb a férfi $\rightarrow$ férfi irányú beszédhelyzetben (pl.: 1670: had lenne bárcsak egy tisztességes lovacskám; úgy adom meg az árát, valamint Kegyelmed kivánja [TML V, 11 Ispán Ferenc Teleki Mihályhoz]; 1743: mivel e nyári szoross idő s tsekély oeconomiatskánk lovainkot distrahállya, meltoztassék Nagysagtok egy szekér iránt parantsolni [Hatolyka Hsz; ApLt 5 Pótsa Lázár Apor Józsefhez]; 1884: Tavaszi Józsinak meghalt a felesége. Március végén új asszonyt visz a házhoz ... (Zárjel közt ide írom, hogy a tavaly a fecském elvesztette a feleségét, amelyikkel együtt rakták a fészket, egy hét múlva más nőcskét hozott a házacskába) [PLev. 110 Petelei István Jakab Ödönhöz] stb.).

Férfi által nőhöz intézett levélből is került elő kicsinyítő képzős származék (pl.: 1728: az Aszszony sajtal s Fürjeszecskével valo kedveskedését alázatoson vettem [Darlac KK; Ap. gr. Haller János gr. Kálnoki Borbálához]; 1730: bízom Ngod gratiajában ís vagy egy kőblőtske szalad iránt ... Felesegem fözŏn sert s kerjen fa hozo kalákát [Somlyó Cs; ApLt 4 So János deák Apor Péternéhez]; 1737: két rend bili Sertesek beritis kérik Erőssen tőllem ... En nekem nincs miből meg fizetnem ha Gabanacskabol meg nem fizetek ez utan [Somlyó Cs; Ap. 2 Léstyán János Apor Péternéhez] stb.).

Női adatközlőtől származó szövegben (attól függetlenül, hogy nő-e vagy férfi a címzett) szinte alig van példa kicsinyítő képzős származékra (1668: Ez feljebb specificált punctumoknak megállására igírje magát ilyen formán, hogyha csak az kisebb punctumocskát által hágná is, tehát énnekem se püspököt, se ecclesiát ne kellessék érette keresnem, hanem lehessen szabados elválásom tőle [TML IV, 402 Szalánczy Krisztina Teleki Mihályhoz]; 1723: ma Szintén Uram eő kgme fel menvén ... a Mlgos Vajdanét kőszőntötte ... hozodott elé Kgd Atyafiságos io akarattyábol mely 
szép fejedelmi czipokkal szokott volt Kgd Uram eő kgmének kedveskedni ... és mely Szép gyenge pogácsácskákot kalácsokat s tőbb afféle gyenge sütőgeteseket Szokott Kgd készittetni [ApLt 5 gr. Ferratiné gr. Kálnoki Ágnes Apor Péterné Kálnoki Borbárához Jászvásárból]; 1824: Reád haraghatnánk, édes Máriskó a feredőn még jobbacska voltál, de Branyitskan, Illjén felénk sem jöttél [Kv; EM XVII, 173 Csáki Rozália Lázár Benedekné Bethlen Máriához.]).

A második kategóriába azok az adalékok kerültek, amelyekben a beszédtársak közül vagy az egyiknek vagy mindkettőnek konkrétan megjelenik a társadalmi funkciója a szögletes zárójelben, és ezáltal (általában) megállapítható a köztük lévő viszony (ennek alapján vizsgálható a kicsinyítő képzős származékok megoszlása a különböző társadalmi kategóriák közti kommunikációban) (pl.: 1661: Az odabocsátott német kapitánnal egyértelemből, ha tetszenék neki is, az istáló körül kellene valami jó erősségecskét csinálni, árokkal is bekeriteni, úgy hogy az várból is lehetne defensioja [SzO VI, 235 a fej. Fog. fötiszteihez]; 1673: Kls Aszonyom az mely helyre hitván majoromot Epitette(m) ig(en) sáros szoros hely leve(n) ninczen hova egy hitvan csŭrüczket czinaltassak [Fog.; Törzs. Cserej János a fejedelemasszonyhoz]; 1722: én Ncsagas Uram csak dolgacskaimat végézhessem fél mégyék runkra [Kéménd H; JHb XIII/39 Váradi András br. Jósika Imréhez]; stb.).

\begin{tabular}{|c|c|}
\hline $\begin{array}{c}\text { A kommunikációs partnerek társadalmi pozíció } \\
\text { szerinti megoszlása }\end{array}$ & Adatok száma \\
\hline Alacsonyabb rangú $\rightarrow$ magasabb rangú & 22 \\
\hline Magasabb rangú $\rightarrow$ alacsonyabb rangú & 5 \\
\hline Azonos társadalmi pozíció & 1 \\
\hline
\end{tabular}

Az adatok szerint leggyakrabban olyan beszédszitációban elhangzó szövegben fordul elő kicsinyítő képzős származék, amelyben egy alacsonyabb rangú személy szólít meg egy magasabb társadalmi osztályhoz tartozót (pl.: 1663: hitván falucskáim emberim nélkủl, pusztán maradnak [Szentdemeter U; SzO VI, 282 özv. Gyulaffi Lászlóné Balássi Erzsébet Bornemissza Anna fejedelemasszonyhoz]; 1678: eö keglmek sok helyeke(n) diffamalnak hogy Tiszt leve(n) ott, authoritasotskammal abutaltam, nyilvan valo kárommal, mind türtem s szenvedtem [Törzs.; Osdolai Kun István a fej-hez]; 1790: Rutkai $\operatorname{Vr}(\mathrm{am})$, látom magais igen szereti Tŏvisset, s nem örőmest válna meg tölle, de kéntelen, mert szegény; Hunyad Vármegyéb(en) szándékozik meg fészkelödni, s ha módja lenne benne, ott valamivel a' Tŏvissi Részinek árrával kŭllyebetske terjeszkedni, mert nem 
capax szegény feje ideis tovais figyelmezni [Celna AF; TL. Málnási László ref. főkonz. pap gr. Teleki Józsefhez]; stb.).

A fordított irányú beszédhelyzetre (magasabb rangú $\rightarrow$ alacsonyabb rangú) sokkal kevesebb példa van (pl.: 1603: Budaky Georgy Vramnakis Ke(gyelme)d, mondia Zolgalatomat es az mely Leankatt ennekem Commendalt uala itt az en gyermekim keozeott io Egessegbe vagion ... Him warraastis az en lyankammal egywtt tanulnak [Dés; BesztLt 65 Th. Szabo dési városbíró G. Frank beszt-i esküdt polgárhoz]; 1661: Az odabocsátott német kapitánnal egyértelemből, ha tetszenék neki is, az istáló körül kellene valami jó erősségecskét csinálni, árokkal is bekeriteni, úgy hogy az várból is lehetne defensioja [SzO VI, 235 a fej. Fog. főtiszteihez]; 1842: A magyarok telepedésekor Isten segitsen 1774-ben, Hadikfalván 1784ben, Andrásfalván 1785-ben épült fakápolnácskák, mind elromlottak, most árendált házokban tartatik az istentisztelet, Fogadj Istenben még állnak a kápolnácskák [WLt Egyház és iskola csomó. Bíró Mózes andrásfalvi ref. lelkész jel. Kelemen Benjáminhoz, br. Wesselényi Miklós jószágigazgatójához] stb.).

Az azonos társadalmi pozícióban lévők közti szövegekből pedig egyetlen példa került elő kicsinyítő képzős származékra (1730: az ország tellyes vala az Aszszony ream valo nehezsegevel s engemet kissebittö, s csak nem átokra fokado Szavaival, de én mind azokot hitetlenséggel, és jora valo magyarázáss s türessel palastoltam, söt ... azonn kész affextiomot tartom fenn az Aszszonyhoz (: kivált ha becsületecskemet tapasztalhatom :) melylyel ennek elötte viseltettem [Fehéregyháza NK; Ap. 2 gr. Haller István br. Apor Péterhez]).

A harmadik csoportba azok az adalékok tartoznak, amelyek után a szögletes zárójelben közölt információ a beszédfelek közti családi vagy rokoni kapcsolatra derít fényt (így lehetőség van a kicsinyítő képzős származékok megoszlását vizsgálni a rokonok közti kommunikációban) (pl.: 1595: küldtem Dyák Mihálytól 3 ezüst karikát, két darab lapos ezüstöcskét ... 1 aranyat, 2 tallért [SzO V, 159 Fejes Mihály alsócsernátoni ember lev. feleségéhez a havaselvi hadakozásból]; 1724: Laczika csak fajtattya az Lepit bizony gyengecskén vagyon [Nyújtód Hsz; ApLt 2 Apor Péter feleségéhez]; 1725: Az Fijacskát első napján az Innepnek a Jesuvitakhoz küldétték misére [Darlac KK; Ap. 2 gr Haller János apósához] stb.). 


\begin{tabular}{|c|c|}
\hline $\begin{array}{c}\text { A kommunikációs partnerek rokoni } \\
\text { viszony szerinti megoszlása }\end{array}$ & Adatok száma \\
\hline Gyermek $\rightarrow$ anya & 3 \\
\hline Anya $\rightarrow$ gyermek & 1 \\
\hline Férj $\rightarrow$ feleség & 15 \\
\hline Feleség $\rightarrow$ férj & 4 \\
\hline Testvér $\rightarrow$ öccséhez & 2 \\
\hline Vö $\rightarrow$ após & 1 \\
\hline Vó $\rightarrow$ anyós & 1 \\
\hline Rokon $\rightarrow$ rokon & 1 \\
\hline
\end{tabular}

Leggyakrabban kicsinyítő képzős származék a férj és feleség közti beszédben fordul elő (pl.: 1595: küldtem Dyák Mihálytól 3 ezüst karikát, két darab lapos ezüstöcskét ... 1 aranyat, 2 tallért [SzO V, 159 Fejes Mihály alsócsernátoni ember lev. feleségéhez a havaselvi hadakozásból]; 1687: Ha elombe ki jŏvel, az szep nimet hintocska szinten ma fog altal jŏni az maramarosi havason, s azon édgjüt mehetnénk haza [ApLt 6 Kálnoki Sámuel feleségéhez Nagybányáról]; 1703: az ki penig az kalapot veszi, nagyotska karimajut vegyen [Ks 96 Kornis István feleségéhez] stb.).

Sokkal kevesebb példa van feleség által férjhez intézett szövegben előforduló kicsinyítő képzős származékra (pl.: 1717: I(ste)n(ne)k hála az Gyermekeim jobbacskán vadnak ... igazán meg vallom hogj féjtem őköt [ApLt 2 Kálnoki Borbála férjéhez, Apor Péterhez Szu-ről]; 1852: a' Lelkem Anyám egy nap jobbatskán van másnap fekszik [Kv; Pk 6 Pákei Krisztina férjéhez] stb.).

A szük értelemben vett családon belüli kommunikációban (szülők és gyerekek, illetve testvérek között) meglehetősen kevés példa van kicsinyítő képzős származékra (pl.: 1664: Énnekem is Kegyelmed ez kis íráskámról meg bocsásson és ne tartson idegennek [TML III, 328 Teleki János ${ }^{63}$ atyjafiához, Teleki Mihályhoz]; 1701: edes Anyam Aszszony ... ha az ökröt el adgya kegjelmed fizessem meg kegjelmed az kinek ados ha penig tartani akarja fogadgjon egj inaskat hogy gondot tudgyan viselni az ökörre [Ne; BLt 9 Toth István a koll-ból édesanyjához Angyalosra (Hsz)]; 1780: külgyen édes Aszszony Anyam egy kis tzédulátskát s tudam hogy őkegyelme szolgál a kenyérrel [Kp III. 203 Újdófalvi Sámuel anyjához]; 1801: A’ Páltzát vettem Sombori által - nagyotska, de ha lehet elébb adok rajta, mert ŏtsém Uram(na)k még inkább nem valo, minthogy nem éppen modi az illyen nagy páltza [Kv; SLt 17 P. Horváth Miklós öccséhez] stb.).

\footnotetext{
${ }^{63}$ Teleki János Teleki Mihály apja volt.
} 
A nagyobb családon belüli kommunikációban előforduló kicsinyítő képzős származékra egy-egy példa került elő (pl.: 1723: most esmét ... harmadnaptol fogva esmét szep üdök kezdének fordulni, de az etczakák hüvesecskék, s kivált az el mult etczaka ugyan hüves vala [Darlac KK; ApLt 1 gr. Haller János anyósához]; 1725: Az Fijacskát első napján az Innepnek a Jesuvitakhoz küldétték misére [Darlac KK; Ap. 2 gr Haller János apósához]).

A SzT. adalékainak szociolingvisztikai vizsgálata alapján a kicsinyítő képzős származékok használatáról elmondható, hogy elsősorban az alacsonyabb társadalmi kategóriába tartozó középkorú férfiak nyelvében gyakori, a kétrésztvevős kommunikációs szituációban is. Nőktől származó szövegekben sokkal ritkábban fordul elő. A mai nyelvállapothoz viszonyítva (ahol kicsinyítő képzős származékok nagyobb számban a középkorú, középosztályhoz tartozó nők nyelvében gyakoribbak) az erdélyi régiségben tehát pontosan fordított volt a helyzet.

\section{IV.4. A kicsinyítő képzők kapcsolódásának szabályai}

\section{IV.4.1. Fonológiai blokkoló szabályok}

E fejezet célja megvizsgálni, hogy milyen fonetikai szabályok irányítják a kicsinyítő képzők kapcsolódását, mikor jöhetnek létre párhuzamos képzések (azaz: egy alapszóhoz mikor járulhat több kicsinyítő képző is) a SzT. tanúsága szerint. Pontosabban: azt vizsgáltam, hogy hogyan irányítja az alapszó utolsó hangja a kicsinyítő képző kiválasztását, illetve hogy ebből a szempontból - a mai nyelvállapothoz képest milyen specifikumai vannak az erdélyi régi nyelvnek.

Ladányi Mária (2004: 52-64) ezt a kérdést a mai nyelvállapot kicsinyítő képzőire vonatkoztatva vizsgálja a Strukturális magyar nyelvtan vonatkozó részeit felhasználva (Kiefer 2000: 164-214), esetenként nyelvtörténeti magyarázatot is ad. A tanulmányában megfogalmazott szabályszerűségeket ellenőrzöm az erdélyi régiség kicsinyítő képzős származékaiban. A szabályok közül csak azokkal foglalkozom, amelyek a szótagszámmal és hangkörnyezettel összefüggő korlátozásokra térnek ki.

Mind a mai nyelvben, mind az erdélyi régi nyelvben párhuzamos képzések előfordulhatnak, de a $-k A$ használatát a szótagszámmal, illetve a hangkörnyezettel kapcsolatos megszorítások korlátozzák. A Strukturális magyar nyelvtanra alapozva, Ladányi Mária szerint $-k A$ nem fordulhat elő:

- egyszótagú szavakkal (pl. *lábka, *fogka stb.); 
- zárhangra végződő többszótagú szavakkal ( ${ }^{*} c s a l a ́ d k a, ~ * b e s z e ́ d k e$, *oszlopka stb.), bár Ladányi szerint ez kétségbevonható, a többi mássalhangzó esetében mindkét képző lehetséges;

- ale végü szavakkal ("zergéke, *keféke, *almáka stb.).

A két képző, illetve párhuzamos képzés esetén a két különböző képzős szó közötti választást a következő tényezők befolyásolják:

- A magánhangzóra végződő szavak többnyire a -cskA-t kapják (kígyócska, autócska, tetősske stb.), kivéve az i végúeket, amelyek inkább -kA-t (nénike, kocsika stb.). Mindig lehetnek párhuzamos alakok, ha ezt a már említett korlátozások nem zárják ki (tepsike - tepsicske).

A SzT.-ban megjelenő kicsinyítő képzők kapcsolódási szabályainak vizsgálatára két táblázatot állítottam össze: az első a magánhangzóban végződő (egy- és többszótagú) szavakat, a másik a mássalhangzóban végződő (egy- és többszótagú) szavakat tartalmazza. Hat olyan származék van a SzT.-ban, amelyek a lexikalizálódás olyan fokán állnak, illetve román kölcsönszó (l. butuja), hogy (még) felismerhető ugyan bennük a kicsinyítő képző, jelentésükben is megvan a 'kis, kicsi' szemantikai jegy, de az alapszó nem szerepel önálló címszóként: butuja ${ }^{64}$ 'hordócska', pántlika 'szalagocska', szénafiók 'szénaboglyácska', szurdi-burdi 'kis termetü', illetve a szóvég egybeesik valamilyen kicsinyítő képzővel, de a 'kis, kicsi' jelentés már nincs benne: szárika 'posztó guba, suba', szárikás 'kb. gubás, subás'.

1. táblázat: Magánhangzóban végződő szavak

\begin{tabular}{|c|c|c|c|c|c|c|c|c|c|c|c|}
\hline & cskA & kA & d & Acs & dAd & ó & ica & uca & ika & Uka & ikó \\
\hline $\mathbf{a}$ & 206 & 1 & & & & 2 & 1 & 1 & 7 & 1 & 3 \\
\hline e & 38 & & & & & & & & & & \\
\hline é & 3 & & & & & & & & & & \\
\hline $\mathbf{i}$ & 8 & & 5 & & 1 & & & & & & \\
\hline ó & 103 & 5 & 4 & & & & & & & & \\
\hline ő & 64 & & & 1 & & & & & & & \\
\hline $\mathbf{u}$ & 11 & & & & 1 & & & & & & \\
\hline $\mathbf{u}$ & 21 & 1 & & & 1 & & & & & & \\
\hline ü & 17 & & & & & & & & & & \\
\hline \hline
\end{tabular}

\footnotetext{
${ }^{64}$ A butuja a román butoiaş átvétele lehet, a magyar nyelvérzék a -(j)a szóvéget kicsinyítő képzőnek érezte.
} 
Az első táblázatban összesen 506 szó szerepel, amelyekhez a kicsinyítő képzők a következő arányban kapcsolódnak: -cskA 471 (93,08\%), -kA 7 $(1,38 \%)$, más 28 (5,53\%). Érdekes, hogy a magánhangzós végú címszavaknál gyakoribb a - $d$ képzős, mint a $-k A$ (pl. kicsid, apród), és ezeknek a továbbképzett származékai (kicsidell, kicsidít, kicsidség, apródonként, apródonkénti).

A táblázat szerint magánhangzóban végződő szóhoz (legyen az egyvagy többszótagú) - $k A$ képző csak ritkán kapcsolódhat. Elsősorban ó végü szavak engedik meg ezt a képzőt: pl. cipóka (de van cipócska is), fenyődeszkatolóka, fenyőfa-tolóka, folyóka, húzóka, járóka stb. A felsorolt származékok nagy része lexikalizálódott (ilyen a tolóka, húzóka, járóka), amely alátámasztja Ladányi Mária észrevételét, miszerint a képzőbokrok nagyobb produktivitást mutatnak, mint azok a képzők, amelyek összekapcsolódásából előálltak (a -cskA magában foglalja a $-k A-t)$, hiszen az azonos funkciójú formánsokat egyesítő képzőbokrok erőteljesebben képviselik az adott funkciót, mint az egyes komponensek külön-külön (i. m. 55). Magánhangzóra végződő szóhoz kapcsolódhat még -ika (hártyika, ládika, pálcika stb.), -ó (agárkutyó), -dAd (kicsidded, hosszúdad), -uka (bátyuka), -ikó (ládikó, pálcikó).

Az egyszótagú, magánhangzóban végződő szavak között egy példa van -cs kicsinyítő képzőre (kövecs), ez természetesen lexikalizálódott származék.

A mássalhangzóban végződő szavaknál (a mássalhangzókat a képzés módja szerint rendeztem el: b-től k-ig zárhangok, v-től h-ig réshangok, c-cs zár-réshangok, r pergőhang, nem vettem fel külön j-t és ly-t) sokkal nagyobb a megoszlás, főleg a többszótagúaknál.

Összesen 1004 címszóból 829 tartalmaz -cskA képzőt (82,57\%), 132 -kA-t (13,15\%), más kicsinyítő képzőt 43 (4,28\%).

A mássalhangzóban végződő szavak többsége -cskA-t vesz fel, mégis vannak olyan szóvégek, amelyeket más képző követ. Természetesen ennek az is lehet a magyarázata, hogy ezek a magyar nyelvnek ritkább mássalhangzói, és kevés ilyen végü szó van. Nincs példa egyszótagú ny-ben, egy- és többszótagú zs-ben, illetve egy- és többszótagú ty-ben, valamint többszótagú v-ben és $f$-ben végződő szóhoz kapcsolódó -cskA képzőre.

Az egyszótagú mássalhangzóban végződő szavak között csupán a rab$k a$, szánka, szipka és a tálka - $k A$ képzős (nagyrészt lexikalizálódott) származékok. Nincs példa olyan egyszótagú $m, d, t, n y, g, k, v, f, z, s z, z s, s, j(l y), h$, $g y, t y, c, c s, r$ végü szavakra, amelyekhez - $k A$ kapcsolódna.

A mássalhangzóban végződő többszótagú szavak között szintén a -cskA a gyakoribb, de itt már nagyobb a megoszlás. A SzT. adatai azt mutatják, hogy az erdélyi régiségben az ny végű szavak többsége (60,65\%-a) -kA kicsinyítő képzőt vesz fel (pl.: ártányka, asszonyka, bárányka, leányka stb.), valamint $n$ végü szavak (36,96\%, pl.: bodonka, kalánka, paplanka, topán- 


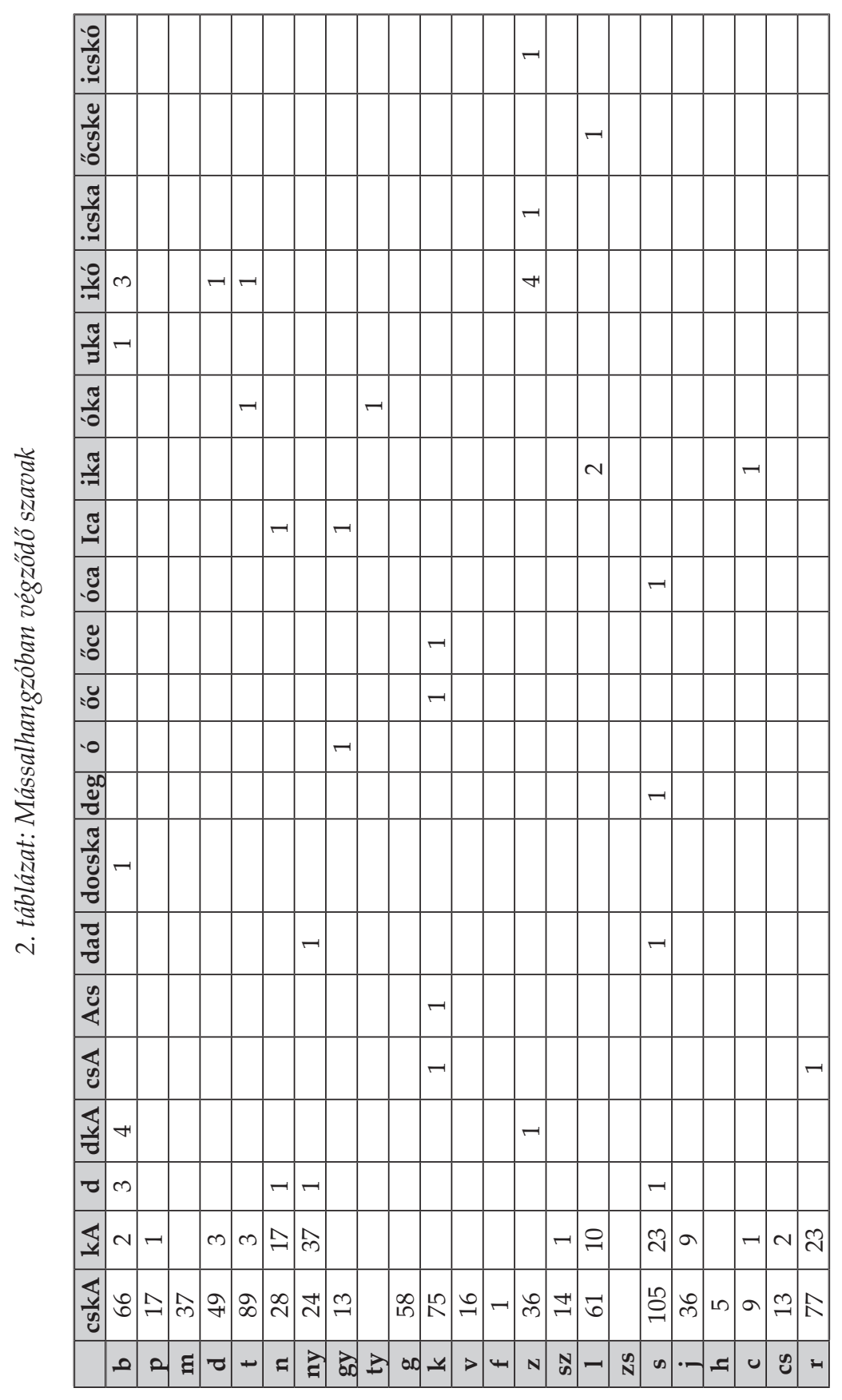


ka stb.). Szintén magas arányban kapcsolódik a $j$ végű szavakhoz $(37,15 \%$, pl.: derékaljka, paszulyka, rostélyka stb.), ezt követik a $c$ végűek $(33,33 \%$, pl.: malacka), a $d$ végüek (30\%, pl.: árpádka, beszédke, rövidke), az $r$ végúek (27,71\% pl.: kosárka, madárka, mocsárka stb.), az l végúek (23,68\%, pl.: asztal$k a$, levélke, oldalka stb.), a cs végűek (22,22\%, pl.: grádicska, kapocska), az s végüek (20,17\%, pl.: nádaska, nyáraska, papiroska stb.), az sz végüek (12,5\% pl.: rekeszke), de kapcsolódhat $-k A$ a $t(7,69 \%$, pl.: csigafalatka, falatka, huncfutka) és $b(2,27 \%$, pl.: darabka) végü szavakhoz is. Ez nem jelenti azt, hogy az ilyen mássalhangzókban végződő szavak kicsinyítő képzős származékai csak - $k A$ képzővel jöhetnek létre, ezek körében igen gyakoriak a párhuzamos képzések, vagyis -csk $A$ és - $k A$ egyaránt járulhat hozzájuk (pl.: ártányka, ártányocska; asztalka, asztalocska; bárányka, bárányocska; boglárka, boglárocska; cipócska, cipóka; cseberke, csebrecske; csegelyecske, csegelyke; csuporka, csuprocs$k a$; darabka, darabocska; stb.). Csak az ny végü szavaknál figyelhető meg, hogy a kicsinyített származék létrehozásában gyakrabban szerepel a $-k A$ képzö, mint a -cskA.

A SzT. adatai alapján nem járulhat - $k A$ képző többszótagú szavakhoz, ha azok $p, m, g, k, v, f, z, z s, h, g y$, ty végúek.

A többi kicsinyítő képző csak egy-egy származékban jelenik meg. Az egyszótagú mássalhangzóban végződő szavakhoz még a következő kicsinyítő képzők kapcsolódhatnak: -d (jobbad és a továbbtoldalékolt származékaiban: jobbadik, jobbadon), -dka (jobbadka), -docska (jobbadocska), -ded (kisded), -deg (kisdeg), -ó (ángyó), -óka (botóka), -óke (pintyóke), -ikó (ládikó, fabotikó, házikó), valamint olyan összetételekben, amelyeknek utótagja a házikó kicsinyítő képzős főnév (darabontházikó, juhászházikó, parasztházikó), -ika (porcika), -icska (házicska), -icskó (házicskó), -őcske (szellöcske), -ocs (pakocs 'csomagocska').

A többszótagú mássalhangzóban végződő szavakhoz még a következő kicsinyítő képzők járulhatnak: -d (kicsind), $-d k A$ (alábbadka, nagyobbadka, nehezedke), -dAd (kicsinyded), -ika (ángyelika), -csa (gyakorcsa), -óc (gyerkóc), -ica (pojenica), -öce (gyerkóce), -óca (kakóca).

Mivel ezek a képzők csak egy-egy származékot hoznak létre, nem lehet fonetikai szabályszerüséget feltételezni kapcsolódásukban. A felsorolt alapszavak többségéhez más kicsinyítő képző is járulhat. Például -cska/-ikó képzők váltakozása figyelhető meg a következő származékokban (darabontházacska/darabontházikó, kardocska/kardikó, parasztházacska/parasztházikó). A -cska -dka képzőbokorral váltakozik (alábbacskal alábbadka, nagyobbacskal nagyobbadka). Mindkét esetben középfokú melléknév, illetve határozószó kicsinyítő képzős alakjáról van szó. Egy-egy esetben a következő variánsokra találunk példát: -cskal-óka (botocska/botóka), -d/-ded (kicsid/kicsidded), és -ical-ika (subica/subika). 
Vannak olyan címszavak a SzT.-ban, amelyek három különböző kicsinyítő képzővel jönnek létre: -cskal-ikal-ikó (ládácska/ládika/ládikó és pálcácskal pálcika/pálcikó). Mindkét fónévnek ugyanaz a hangtani felépítése: $\mathrm{C}+a++C+a$. Ezzel magyarázható, hogy ugyanazokat a képzőket veszik fel. Egy-egy példa van a következő kombinációkra: -icska/-icskó/-ikó (házicska, házicskó, házikó), -cskal-dl-dka (jobbacska, jobbad, jobbadka), -cskel-dl-ke (kevesecske, kevesed, kevéske), -ded/-cskel-ke (kicsinyded, kicsinyecske, kicsinyke). ${ }^{65}$

Két alapszónak több, mint három kicsinyítő képzős származéka szerepel a vizsgált anyagban: gyerek/gyermek (gyerekecske, gyerkő́c, gyerkő́ce; gyermecske, gyermekcse, gyermekecske), valamint hosszú (hosszacska hosszúcska, hosszúdad, hosszúka, hosszúkás, hosszúkó, hosszúkós).

A SzT. adatai alapján tehát a Ladányi Mária által megállapított kapcsolódási szabályokat a következőképpen módosíthatjuk:

- a - $k A$ előfordulhat egyszótagú szavakkal, de ezek a származékok már lexikalizálódtak, vagy a lexikalizálódás útján állnak (szipka, rabka, szánka, tálka);

- zárhangra végződő többszótagú szavakhoz is kapcsolódhat $-k A$ az erdélyi régiségben (darabka, árpádka, beszédke, rövidke, csigafalatka, falatka, huncfutka), kivéve, ha az illető zárhang $m, g$ vagy $k$;

- $\quad a$ és $e$ végü szavak az erdélyi régiségben sem kaphattak $-k A$ képzőt;

- A SzT. adatai is azt bizonyítják, hogy az erdélyi régiségben a magánhangzóra végződő szavak többnyire a -cskA-t kapták. A mai nyelvben kivételnek az $i$ végüek számítanak, amelyek inkább $-k A-\mathrm{t}$ vesznek fel. Ezzel szemben a SzT.-ban nyolc olyan -cskA képzős címszót találtam, amelyek alapszava $i$-re végződik, és egy példa sincs arra, hogy $i$ végü szóhoz - $k A$ képző kapcsolódna (amicske, annyicska, holmicska, kocsicska, lájbicska, mántlicska, régicske, stelázsicska). Tehát ez a blokkoló szabály nem vetíthető vissza a régi nyelvre.

A -cskA és -kA képzőn kívül az erdélyi régiségben más kicsinyítő képzők is hozhattak létre származékokat, bár ezek már a vizsgált időszakban sem voltak produktívak (-d, -ócal-öce, -csal-cse, -dkal-dke, -dad/-ded, -docska, -deg, -ó, -ö, -ica, -őce, -óca, -ika, -ikó, -icska, -őcske, -icskó, -uka, -uca, -ók, -őc).

\footnotetext{
${ }^{65}$ Erről bővebben 1 . a köv. alfejezetet.
} 


\section{IV.4.2. Több kicsinyítő képzőt felvevő szavak}

A korpusz vizsgálata során feltünt, hogy több olyan alapszó is van, amelyhez nem csak egy, hanem több kicsinyítő képző is kapcsolódhat. Kérdés az, hogy van-e valamilyen eltérés (alaki, szemantikai, pragmatikai stb.) az egyes származékok között. A nyelvről szóló tudás azt diktálná, hogy mindenképpen különbségnek kell lennie az egyes származékok között, mert abszolút szinonimák a nyelvi ökonómia miatt nem léteznek (sem a lexémák, sem a morfémák szintjén).

A SzT. adatállománya szerint a következő szavakhoz járul több kicsinyítő képző: ablak (ablacska, ablakocska), alább (alábbacska, alábbadka), ártány (ártányka, ártányocska), asztal (asztalka, asztalocska), bárány (bárányka, bárányocska), boglár (boglárka, boglárocska), bot (botocska, botóka), cipó (cipócska, cipóka), cseber (cseberke, csebrecske), csegely (csegelyecske, csegelyke), csupor (csuporka, csuprocska), darab (darabka, darabocska), darabontház (darabontházacska, darabontházikó), derékalj (derékaljacska, derékaljka), diófaasztal (diófaasztalka, diófaasztalocska), edény (edényecske, edényke), erkély (erkélyecske, erkélyke), ezüstboglár (ezüstboglárocska, ezüstboglárka), ezüstkalán (ezüstkalánka, ezüstkalánocska), fogas (fogaska, fogasocska), fundus (funduska, fundusocska), gabonás (gabonáska, gabonásocska), grádics (grádicska, grádicsocska), gyalogszán (gyalogszánka, gyalogszánocska), gyerek (gyerekecske, gyerkőc, gyerkóce, gyermecske, gyermekcse, gyermekecske), határ (határka, határocska), ház (házicska, házicskó, házikó), hegyes (hegyesecske, hegyeske), hitvány (hitványka, hitványocska), hosszú (hosszacska, hosszúcska, hosszúka, hosszúkás, hosszúkó, hosszúkós), inas (inaska, inasocska), írás (íráska, írásocska), irotvány (irotványka, irotványocska), jobb (jobbacska, jobbad, jobbadka), kalán (kalánka, kalánocska), kard (kardikó, kardocska), kastély (kastélyka, kastélyocska), kávéskalán (kávéskalánka, kávéskalánocska), keskeny (keskenyecske, keskenyke), kevés (kevesecske, kevesed, kevéske), kicsi (kicsid, kicsidded), kicsiny (kicsinyded, kicsinyecske, kicsinyke), kosár (kosaracska, kosárka), kőkémény (kókéményecske, kőkéményke), kötés (kötésecske, kötéske), láda (ládácska, ládika, ládikó), leány (lányka, leányocska), legény (legényecske, legényke), levél (levelecske, levélke), malac (malacka, malacocska), nagyobb (nagyobbacska, nagyobbadka), ösvény (ösvényecske, ösvényke), pálca (pálcácska, pálcika, pálcikó), papiros (papiroska, papirosocska), paplan (paplanka, paplanocska), parasztház (parasztházacska, parasztházikó), piros (piroska, pirosocska), pohár (poharacska, pohárka), pojána (pojánácska, pojánka, pojenica), rekesz (rekeszecske, rekeszke), rostély (rostély$k a$, rostélyocska), rövid (rövidecske, rövidke), sovány (soványka, soványocska), suba (subica, subika), szán (szánacska, szánka, szánocska), szebb (szebbecskén, szebbedkén), szegény (szegényecske, szegényke), szekér (szekerecske, szekérke), széles (szélesecske, széleske), tál (tálacska, tálka). 
Összesen 70 alapszónak szerepel két, három vagy több kicsinyítő képzős származéka a SzT.-ban. Az alapszavaknak túlnyomó többsége, 85,71\%-a két, 11,43\%-a három (ház, jobb, kevés, kicsiny, láda, pálca, pojána, szán), 2,86\%-a pedig háromnál több (gyerek, hosszú) kicsinyítő képzővel hoz létre származékot.

A két kicsinyítő képzőt felvevő alapszavak többsége, 43, százalékos arányban 67,18\% a -cska/-cske -kal-ke képzővel ellátott alakjukban válnak címszavakká (pl.. asztalka/asztalocska: 1636: egy hitua(n) asztalka [Siménfva U; JHb Inv.]; 1652: Egy kereszt lábon Asztalocska benne [Görgényi vár MT; Törzs Inv. 19], bárányka/bárányocska: 1750: kŭldőttem bé ... őtt Csirkecskét, két Pipét, két ifju Nyulacskát, és ez oráig Annyát szopo két Kis Báránykát [O.csesztve AF; Ks 83]; 1714: Meg aranyozott ezüst Pohár Krisztus Vrunk Kinszenvedésit reprezentalo harom figurakkal ékesitett, hasonlo fődéllel, melly(ne)k a tetejen Bárányotska vagjon [Szb/Fog.; REkLt II. Apafi Mihály hagy. lelt. 28], csegelyecske/csegelyke: 1724: egy küs cseglecsketöl fogva az Sombari Ur(am) reszin valok be szántottak volna harom őlnyit közönséges ember ölivel [M.zsombor K; Told. 2]; 1793: egy darab bokros tsegelyke ... tsak úgy méretlen maradott [O.palatka K; RLt O. 2], hegyesecske/hegyeske: 1821: Monka (!) János ... hegyesetske orru [DLt 631 nyomt. kl]; 1835: A Hegyeskékben (sz) [Nyén Hsz; EHA], poharacska/pohárka: 1635/1650: Az Iffiú Mesterek keozeonsegessen ennek eleotte czinaltak volt magok számokra egy Cristal forma mereo(n) aranyozot poharoczkat ... az vtolsó az ki ideieben az pohar keszwlt, az Kolczyos mester tisztit el erte [Kv; ÖCJk]; 1650: az ezűst poharaim kőzőtt vagyon egy tőrpe szeles poharka aztis agyak az monostori Pater kezében az teóbbiuel egyűtt [Kv; JHb III/7] stb.). Két példában a -cskal-cske a hangzóhiányos tőváltozathoz járul: cseber + -cske $\rightarrow$ csebrecske (1652: egy hosszu szabásu Jégnek valo Csebrecske [Görgény MT; EMLt]), csupor + -cska $\rightarrow$ csuprocska (1733: Mazos tsuprotska 2 [Marossztkirály $\mathrm{AF} ;$ Told. 2]). A -ka/-ke képző előtt viszont nincs semmilyen változás a tőben, a szótári tőhöz kapcsolódik: cseber $+-k e \rightarrow$ cseberke (1756: Egy tsŏjŭ Lombikhoz valo kis Cseberke réz tsŏ egj benne [Somkerék SzD; Ks gr. Bethlen Imre lelt.]), csupor + -ka $\rightarrow$ csuporka (1740: A’ Kamara hijján egy Láda, mellyben vagyon egy viseltes bőr vánkos. Egy derekaj rajta lévő vereses kőz vászon hajjal együtt. Két Fringysia. Egy kis tsuporka [Hermány U; Ap. 5 Apor Péterné lelt.]). Az ablak tő sajátosan viselkedik, ugyanis mindkét származéka a -cska kicsinyítő képzővel jött létre, egyik esetben viszont a tő $k$-ja kiesik a képző előtt: ablak + -cska $\rightarrow$ ablacska. Ez lehet véletlen elírás eredménye is, hiszen csak egyetlen adat van rá a SzT.-ban, bár a gyermecske 
alak alátámasztja létezését. (1692: Ló Istálló ... ennek két kis ablacskai (!) [Mezőbodon TA; BK 4. - ${ }^{a}$ Nem merö elírás ablakocska h.?] $\left.{ }^{66}\right)$.

Három származékban $(4,68 \%)$ a -cska/-ikó képzők váltakozása figyelhetô meg (darabontházacska/darabontházikó: 1647: Az porkolab haza rendiben harom Drabant hazaczkak, fabol eppittetek, ajtajok mindeniknek jó ketteiben sővinj kemencze Egjikben Szekelj Janos az Drabant rakatott volt kemenczet. Hejazattjok semmire nem jo [Marosillye H; VLt 55/5415]; 1744: boronafábol rakott kis ded Darabont háziko Sendelj fedél alatt [LLt Fasc. 67], kardocska/kardikó: 1700: Egy kis Zŏld aranyos Gyermek(ne)k valo kardocska [Hr I/20]; 1738: Az úrfi Kardikoját ki hozattam Bányárul [Nagysomkút Szt; TLMiss.], parasztházacska/parasztházikó: 1763: belső antiquă Colonialis Sessio ... Vagyon a' Falu kòzepiben, hajdon Kosztándin Bárb Jobbágy Mosiájanak hivattatot, melyen egy paraszt Házatska lévén; lakik benne egy Alexandru Muntyán nevü Sellér [Rákovica Szb; Born. XXIXa. 19 néhai Hortobágyi Gergély György conscr. 58]; 1774: Zŏld Uram aban az Ŭdŏben a Falun kivŭl egy oldalban az Uraság fŏlgyin egy paraszt Hazikot epitetett [Mocs K; Ks Conscr. 31]). Kettőben (3,12\%) a -cska a -dka képzőbokorral váltakozik (alábbacska/alábbadka: 1762: azon nevezetŭ hellyben allabbotska [Backamadaras MT; CsS]; XVIII. sz. e. fele: Rétetskéje ... van ... Petlendi Puszta Falu helyen az elébbenivel egj sorba alábbatka [AbN. - ${ }^{\mathrm{a} T u ́ r}$ (TA) határában], nagyobbacska/nagyobbadka: 1658: Kett Eőregh lada Est f $1 \mathrm{~d}$ 60 Kett masfel singes lada Est $\mathrm{f} 1$ Egy singes es mas nagiobaczka [Kv; KJ]; 1644/1648 k.: egy Veres scarlat szőniegh nagiobbatka [Born. XXXVIII. 14]). Mindkét esetben középfokú melléknév, illetve határozószó kicsinyítő képzős alakjáról van szó. Egy-egy esetben a következő variánsokra találunk példát: -cskal-óka (botocska/botóka: 1574: Mond az Kewer Marton, Al hattrab te Azzony ... orrodat Aiakastwl ely Mecchem azt ely higged, egi Botochka volt Nala Meg feniegeteis veleh [Kv; TJk III/3. 365]; 1636: ezt az fogoly legent ... Nagy Zabo Istvan karon foghta vala, es ugy vonza uala ... nyerges Istvanis utanok ballagh uala az botokaual [Mv; MvLt 291. 68a]), -d/-dded (kicsid/kicsidded: 1633: egi kiczid darabbal teòbnek talakozek az huss annal az menire Kornis Istua(n)ne megh fizetet uala, de Meszatos Georgi akkoris ugia(n) oda ada neki azt az kis darabocska hust is [Mv; MvLt 290. 139b]; 1585: Talak kicsid(d)ed keozepzerewek vadnak Niolcz, tizenharmadfel font, tt f 2/7 [Kv; KvLt Vegyes I/2-3]), és -ical-ika (subica/subika: 1529: Cui dedi pro expensis fl. octo ac pro dolman Swpicza caligis et calceis ac sartori quinque et denarios 90 [Vh; MNy XXXI, 125]; XVIII. sz. v.: Egy veres Subika ... Egy ramas Aszony Embernek valo Czima (!) [Borb.]).

\footnotetext{
${ }^{66} \mathrm{Az}$ is elképzelhető, hogy ezekben a szavakban hangátvetés történik, ugyanúgy, mint a szökcse - szöcskében, amely a szök- (l. szökik) tőből jön, és a fonémaszerkezete hasonló az ablak - ablacska, gyermek-gyermecske szavakhoz.
} 
Több alapszónak szerepel három-három kicsinyítő képzős alakja. Csak két esetben fordul elő ugyanaz a kombináció: -cskal-ikal-ikó (ládácska/ládikal ládikó: 1647: Egj hitvan Ladaczka holmi dib dab egyetmasnak valo [Marosillye H; VLt 55/5415]; 1846: Egy ládika Klauzal Gabor képével [Dés; Berz. 20]; 1849: Kis ladiko finom cirkalmakkal 30 Rft [Görgénysztimre MT; Born. G. XXIVd] és pálcácska/pálcika/pálcikó: 1599: az Vduaron faraczkal vala Deak Peter, egi palczachikat veon kezebe kj mene, de azt ne(m) latta(m) mjkor verthe [UszT 14/39]; 1584: Sos Jstwan ... wallia ... hallek kialtast ... Hatra tekintek es hat Dauid Ianos es Sardi Ianos Ieo vtanna(m) Ez zora kialtasra felele igy Sardi Ianos, Jhol Neste lelek Curwa fy lasd meg Minemeo palczika vagion en Nallam [Kv; TJk IV/1. 348]; 1733: Bricz Stéphán főbe üte egj patzikoval Gligort [Szentmargita SzD; Ks 15. LXXVIII. 6]). Mindkét fönévnek ugyanaz a hangtani felépítése: $C+a ́+C+a$. Ezzel magyarázható, hogy ugyanazokat a képzőket veszik fel. Egy-egy példa van a következő kombinációkra: -icska/-icskó/-ikó (házicska/házicskó/házikó: 1840: bátorságosabban bírhassam azon Hazitskat [Dés; DLt 1420]; 1843: tetzet ... admoneáltatni hogy a Tegla vetǒ helyen fel epittetett Házatskát es egy kis veteményező Kertetskét elrontsam, holott az a Házitsko az egésség fen tartására ... szükséges képpen meg kelletik lenni ... méltoztasson azon Házitskot a maga valoságában meg hagyni [Dés; DLt 1358]; 1640: vagi(on) ennek felette 19. muntanis Jóveveniek kiknek valami hazikoiokis vagio(n) szabadosak el menny vagi ot lakni [Szevesztrény F; UC 14/48. 78]), -cska/-d/-dka (jobbacska/jobbad/jobbadka: 1699: edgyik ${ }^{a} . .$. jobbatska [O.csesztve AF; LLt Litt. C. ${ }^{a}$ Bárka]; 1571: egy jo paripat keoztunk nem talalunk, lofeweknek sokaknak es keossegnek is kijet kijet jobbadnak hallottak nyayatul el üzettek [SzO II, 326]; 1694: Majorság-Szőlő ... Ennek két felől fel menő szelei ... igen pusztások, homolittatni kévánok: a közepe(n) jobbadka [Kisenyed AF; BfR néhai ifj. Bálpataki János urb.]), -cske/-d/-ke (kevesecske/kevesed/kevéske: 1663: Erdélyben az mi kevesecském ezelőtt volt ... azokhoz való jutásimat is ő nagyságok tellyességesen meggátolták [TML II, 570 Teleki Mihály Bánfi Dieneshez]; 1826: a praetendált jövedelemnek kevesed része az özvegyi kevés Joszágnak az igazi jővedelme [Ne; DobLev. V/1114. 9a]; 1589 k.: Az Demeter deakott penigh tudom hogj foglalt egj keueskett az attia birodalma vtan Vgian ott az szeken valo feoldben [Szu; UszT]), -ded/-cskel-ke (kicsinyded/kicsinyecske/kicsinyke: 1584: Cathalin Borbely Ianos felesege Vallia ... Lattam esmeg Arany forintokatis Nalla eg kichinded fekete keskeny Sachkoba [Kv; TJk IV/1. 389]; 1812: ezen Fok nevezetü fiatalos Berek gyermekségemtől fogva őrőkké a' Nagy Laki Eklesiájé volt, e' nevelte ekkorára, mert én tudom mikor a fák kitsinyetskékis voltak [Nagylak AF; DobLev. IV/943. 25b]; 1560: Keth darab teoroth arany es egy kychynke azokkal Egywth [JHb QQ Temeswary János reg.]). 
Két alapszónak pedig több, mint három kicsinyítő képzős származéka szerepel a vizsgált anyagban: gyerek/gyermek (gyerekecske/gyerköc/gyerköce; gyermecske/gyermekcselgyermekecske), valamint hosszú (hosszacska hoszszúcskal hosszúdad/hosszúka/hosszúkás/hosszúkó/hosszúkós).

A gyerek, ill. gyermek főnév legkorábbi kicsinyítő képzős származéka a SzT.-ban 1570-ből való: Bak Matthias ... vallya, hogy egy nap Regwel haza Ment volt, es egy gyermechke $e^{67}$ eo zolgaya Mongia Neky ${ }^{a}$ KVv; TJk III/2. 18. 130c. - ${ }^{a}$ Köv. a nyil.]. Úgy tünik, hogy ez a kicsinyító képzős alak volt az elterjedtebb a 16-18. századig, azaz: a gyermek alapszóhoz a -cske képzőt illesztették, amelyből sajátos hangalakú származék jött létre: gyermecske. Az történhetett, hogy a beszélők a - $k+-$-cske egymás mellé kerülésével keletkező mássalhangzó-torlódást úgy oldották fel, hogy a szóvégi $k$ és a kicsinyítő képző $k$ hangjának szerepét összemosták, a szóvégi $k$-nak ráértéssel kicsinyító értelmet tulajdonítottak, és emiatt elég volt egyetlen $k$ a szóban. 1603-ból ilyen adatunk van: Zabo Miklos ... vallia ... Nyreo Mathenak az eo tercialitassaba adiudicaltak volt az Arbiterek f 15 d. 66. Ezenkeowl ezen azzontul valo Nyreo Mathenak germechikeienek portioiat [Kv; TJk VI/1. 645], 1732-ből: János nevű gjermecskejeis ott lévén ugj meg ijedett hogj talan Ember Soha nem lészen belőlle [Dés; Jk]. Más magyarázata is lehet a szóvégi $k$ kisesésének: elképzelhető, hogy a szabálytalan rövidülés a felgyorsult beszédtempó következménye, vagy a rövidített alak jobban kifejezi a kicsinyítést. Továbbá hangátvetés is történhetett (l. a 66-os lábjegyzetet).

Szintén korai, 17. századi adatunk van a -cse képzőre: gyermek + -cse $\rightarrow$ gyermekcse: 1688: Egy itt quartelyozo Lutheranus németnek, recens natus, és ige(n) beteg gyermekcsejét ... meg kereszteltem [Bethlen (SzD) kör.; UtI].

Arra is van példa, hogy a gyermek alapszóhoz -(e)cske képző járul. 1681: Udvarhelyszéki Uarosfalui Cziki Balas es Cziki Janos Lofŭ szemelyek ... szollanak òkis Biro Istuan Urunknak, hogy ... adna megh eo Kegyelme anny penzt, az menyuel edgy borius tehenet uehetnenek azon Marko Borbaratol aruasaghra hagyatott kicsin gyermekecske tartasara [Borb.II]; 1791: a' gyermekecskét magamhoz hivtam [Bács K; RKA]. Szókapcsolatokban: csecsemô/szopó . 1724: Rusz alias Hafrik Mihállynak az Anya ... bé jŏ az Atyám házáb(a) egj kis csecsszopo Gyermekecskével a karján, es kérdi az Anyam ... hol vetted menyecske ezen kis Gyermeket [Nagykájon SzD; BK Kiskájoni lev. Csermure Iuon (46) jb vall.]. Egyszer a gyerek alapszóhoz járul az -(e)cske képző: 1800: azonn gyereketskének fürt haja ... kezébenn maradatté? [Dés; DLt].

\footnotetext{
${ }^{67}$ Kiemelés tőlem.
} 
19. századi adalékokban két kicsinyítő képző fordul elő: az -őc és az -ôce. 1838-1845: járni kezdett a gyerkőc [MNyTK 107] I „Purkuj, porunkuj” (: a román „prunk, prunkuj=gyerkőcével egyeredetü":) [uo.].

A gyerek, gyermek fónévhez tehát a ma is gyakori, termékeny képzők közül a -cske kapcsolódott, a -cse mára elavult, az -ốc, -ôce pedig csak a 19. századi nyelvhasználatban bukkan fel, ma csak bizonyos kontextusban fordul elö.

Szemantikai szempontól a -cske, -ke képzők kicsinyítést fejeznek ki, a származékok a gyermek korára utalnak. Ez fóleg azokból az adalékokból derül ki, amelyekben valamilyen jelző áll a képzős alak mellett: 1681: kicsin gyermekecske, 1724: kis csecsszopo Gyermekecskével. Az -ő́c szintén korra utaló kicsinyítő képző: az 1838-1845-ös adalékban: járni kezdett a gyerkőc. Mai nyelvérzékünk inkább becéző jelentést tulajdonít a képzőnek ebben a származékban. A gyerkő́ce származékkal egy román szónak a magyar fordításában találkozunk, így valószínü, hogy a román diminutívum (prunkuc) hatott a megfelelő magyar képző kiválasztására: 1838-1845: prunk, prunkuc = gyerköce.

A hosszú melléknévnek hét kicsinyítő képzős alakja található meg a SzT.-ban. Ezek közül a hosszacska és hosszúcska úgy tünik, hogy szabad variánsok, egymás mellett éltek. Egyik esetben a -cska képző a teljes tőhöz kapcsolódik (hosszú +-cska). 1726: Vagyon Sővénnyel font perje fákra szalma fedél alatt készitett hosszutska disznó ól [Nagyfalu Sz; BfN Nagyfalusi csomód; 1788: Úvegnek valo kitsin tojokás Ferslog ... Egy hoszszutska fejér Tojoka [Mv; TSb 47]; 1845: Egy hosszucska fenyőfa asztal [Doboka; Mk]. A másik esetben viszont a véghangzóhiányos tőhöz járul a képző: hosszú + -cska $\rightarrow$ hosszacska: 1698: edgy hoszszacska asztal [Kóród KK; LLt 72]; 1766: egy hoszszatska régi fogass a' falon Szegezve [Hosszútelke AF; Kath.]; 1832: megkaptuk a kaptzáját a mely szŏr volt és égy krajtzárt, továbbatskát égy hoszszatska pipa szárt [Kv; KLev.].

A két származék között nincs jelentésbeli különbség, mindkettő alakra vonatkozik, és 'hosszúkó' jelentésű. Időben is ugyanaz a megoszlásuk, azzal az eltéréssel, hogy a hosszacska korábbról, 1698-ból adatolható. Mindkettő előfordul a 18. és 19. században is. Földrajzi elterjedtségükre vonatkozóan sem állapítható meg különbség, hiszen Erdélyszerte előfordul mindkét alak: hosszacska - Kis-Küküllő megye, Alsó-Fehér megye, Kolozs megye; hosszúcska - Szilágy megye, Maros-Torda megye, Fejér megye. Különbség csak abban van, hogy csak a hosszacskát követi határozórag: hosszacskán, a hosszúcskát nem. A hosszacskán alaknak két jelentése van: 1. vminek a hoszsza mentén: 1739: a miolta én értem minden esztendőben használtak a Sz: Benedeki Révészek égy darabotska rétet a Révre menő uton alol hoszszatskán és keskenyen a Viz le mentére [Dés; Ks 28. V]; 2. hosszacska ideig tar- 
tó: 1765/1783: Hogyha ... a' Venditorok ... azon Csekelaki Portiot valamely praegnans impedimentum miatt által nem adhatnák, és által adása hoszszatskán terjedne ... tehát azontul egész az által adásig legalis Interesse, az ŏ Nsgok fel adott penzek(ne)k currályon [Kv; DobLev. III/574].

A hosszúka időben ugyanolyan elterjedtséget mutat, mint az előző kettő: az első adat 1693-ból való, egy-egy adalék van a 18., illetve a 19. századból. Az adatok alapján úgy tűnik, hogy szemantikai különbség van közöttük: a hosszacska és hosszúcska inkább nagyobb méretü, belső vagy külső berendezési tárgyakkal kapcsolatos, a hosszúka pedig az emberi külsőre, illetve az ember által viselt ruhadarabok hosszára vonatkozik. 1693: Tizenhat aranyas hoszszuka Dolmanra valo gombok Szives formak pikkel [Ne; DobLev. I/38. 8b]; 1710 k.: Termetem sem hoszszú, sem kurta ... ábrázatom hosszúka, barnaszeg, piros [BÖn. 491]; 1838: Kadár János ... égy kevéssé hosszuka halavány ábrázatú [DLt 264]. Helynevekben viszont csak ez az egy alak fordul elö, a hosszacska és hosszúcska nem. 1637/1778: Hoszszuka mezŏ (sz) [Erdősztgyörgy MT; EHA]; 1774: a Hoszszuka Mező Pataka [Erdősztgyörgy MT; EHA].

Szintén az alaptag alakjára vonatkozó jelentése van a hosszúkás, hoszszúkó, hosszúkós és hosszúdad származékoknak, szemantikai különbség nincs közöttük. Az egyes alakok használatában időbeli eltérés mutatkozik. Legkorábbi a hosszúkó, az első adalék 1726-ból származik: Ördőgharapást ${ }^{a}$ nem kủldhettem ... elég vagyon Gyergyoban, a hol Sovány határok vadnak, a Levele hoszuko mint egy petyegetet, az koroja magassan nő fel, a tetein

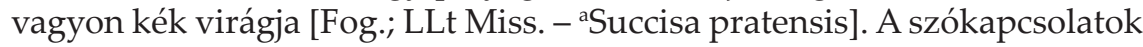
között egy 17. századi adalék is van: 1697: nyolcz hoszszuko fejér, fekete, s kék Zomanczos boglár [Szentmargita SzD; KGy]. Főnévi használata még korábbról adatolható: 1655: Tudom azt hogy egy olykor, jövenek hozzám két Olāhok ... mutogàtvàn nèkem hosszukób(an) darab aranyat $[\mathrm{Kv}$; CartTr]. A 19. századtól párhuzamosan mind a négy változat megjelenik. A nyelvérzék számára már nem volt elegendő a -kó képző a jelentés kifejezésére, ezért megtoldotta egy -s melléknévképzővel. 1819: Knittel Jóseff ... hoszszukós hegyes orru I dringa Gyŏrgy ... hoszszukos fekete ábrázatu [DLt 610, 732 nyomt. kl]; 1854: zöld hosszukos mente [Újf. 78]. Másik megoldás az, hogy a hosszúka alakot toldja meg a nyelvérzék egy -s melléknévképzővel: 1811: Felesége hoszszukás tiszta ábrázatu [DLt 166 nyomt. kl]; 1846: Kirilla Nadrás ... hosszukás ábrázatu, szabatos orru [Kv; DLt 1200]. A hosszúdad szintén 'hosszúkó, hosszúkás' jelentésű. A -dad képző az ősi -d elemismétléséből jött létre. 1864: Várhegy, melly is egy felemelkedett hoszszudad hegj [Nagyalmás K; KHn 316]. 
1. ábra. Tótípusok
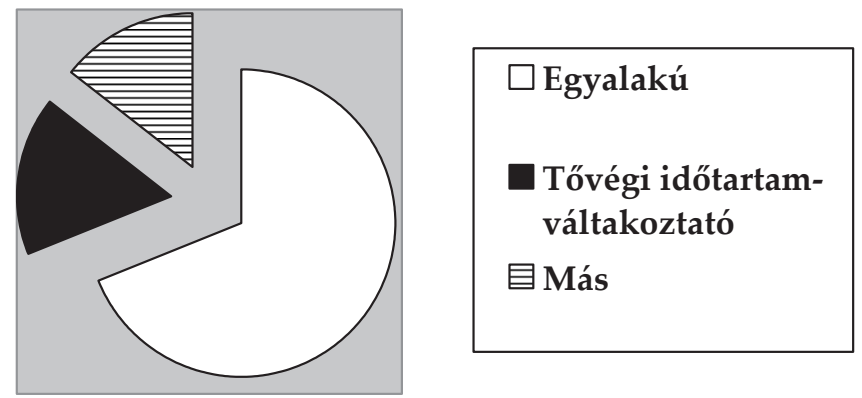

A párhuzamos képzések esetében tehát viszonylag ritka az az eset, amikor semmilyen különbség nincs az egyes alakok között. Ha időbeli vagy jelentésbeli eltérés nem is figyelhető meg, akkor morfológiai felépítésükben igen.

\section{IV.5. A kicsinyítő képzők alaktani jellegzetességei}

A kicsinyítő képzők alaktani jellegzetességeinek tárgyalásakor két szempontot kell figyelembe vennünk. Egyrészt azt, hogy milyen tőhöz kapcsolódhat: egyalakú vagy többalakú tőhöz. Másrészt meg kell vizsgálnunk, hogy a kicsinyítő képző milyen helyet foglal el a szóalakban: milyen morfémák előzhetik meg, illetve milyen morfémák követhetik.

\section{IV.5.1. A kicsinyítő képzős származékok tövei}

A SzT.-ban megjelenő kicsinyítő képzős származékok töveinek megoszlása arányaiban megközelítőleg megegyezik a mai névszőtövekével ${ }^{68}$, vagyis leggyakoribb az egyalakú tő $(68,77 \%)$, ezt követi a tővégi időtartamot váltakoztató tőtípus $(16,69 \%)$, majd csökkenő sorrendben: tőbelseji időtartamot váltakoztató $(4,71 \%)$, hangzóhiányos $(3,56 \%)$, hangszínt és időtartamot váltók (1,81\%), véghangzóhiányos $(1,08 \%)$, hangszínt és időtartamot váltakoztató v-s tő $(0,94 \%)$, időtartamot váltakoztató v-s tő $(0,87 \%)$, változatlan tőhangzős v-s tő $(0,2 \%)$, hangzóhiányos változatú v-s tő $(0,07 \%)$, valamint van néhány olyan származék, amelyiken felismerhető ugyan a kicsinyítő képző, de a tő önállóan nem él (1,27\%) (1. 1. ábra).

\footnotetext{
${ }^{68}$ Vö. Kádár 2007: 62-66.
} 
A SzT. adatai alapján a kicsinyítő képző olyan egyalakú tövekhez járul, mint pl.: ártány + -ka $\rightarrow$ ártányka (1681: Artányka nrō 20. [Szúv; UtI]), bónum + -cska $\rightarrow$ bónumocska (1732: hazi eszközökből álló Bonumocskák [Kémer Sz; Bölöni L., A Bölöni család tört. 28]), csekély + -cske $\rightarrow$ csekélyecske (1825: Az Egerpataki Bosa Jószág tsekélyetske [DLev. XIV. 5]), dolmány + -ka $\rightarrow$ dolmányka (1748: volt egy Dolmánkája [Torda; Borb.]), együgyü +-cske $\rightarrow$ együgyücske (1761: Bongardos Bálint és Iános Testvérek léven, publice notum, hogy ezen két Atyafi, kivált Bálint együgyütske vólt, 's meg sem vóltak egymás kőzött osztozva, hanem mint ollyan együgyü Atyafiak ... mindeneket el adogatták [Kv; PolgK 45]), feles + -ke $\rightarrow$ feleske (1754: Idvezult edes Anjátol feleske Edjetmásokkal Vitéz Ersébethnek adatott Ládák [Gernyeszeg MT; TGsz 33]), gát + -cska $\rightarrow$ gátacska (1751: János Pap úr Gáttya nevezetü Gátotska [Koronka MT; Told. 31/4]), hasáb + -cska $\rightarrow$ hasábocska (1764: Künn a' Mezőbenn Cserélt ... egynehány hasábocska főldet [Csüdőtelke KK; Told. 8]), ingváll + -cska $\rightarrow$ ingvállacska (1629: Egy hitua(n) Jng vál ... d. 50 Más, Egi hitua(n) Ingh vállaczika ... d. 10 [Kv; RDL I. 132]), jobbágy + -cska $\rightarrow$ jobbágyocska (1657: Bojér Simon nevü bortöltő szolgája mellett instálék, hogy Fogarasföldén Kopacselen valahány jobbágyocskát adna neki; kire felelé van azonféle jószág Gitás nevű faluban, azt neked adom. Ekképpen ada szegény kéretlen azt az joszagocskat [KemÖn. 97]), kémény + -cske $\rightarrow$ kéményecske (1736: a konyha ... sŏvénybŏl font tapaszos Kéményetskéje [CU]), lakat + -cska $\rightarrow$ lakatocska (1736: Boros pintzén állo nagy Bétsi lakat 1. Aprobb Lakatotskák 4 [Mikefva KK; CU XIII/1. 171]), minden + -cske $\rightarrow$ mindenecske (1663: Ha idegeny uraim mellett nem szántam sok izben mindenecskémet elhagynom, bizony készebb leszek Nagyságtok mellett ... mindent elszenyvednem [TML II, 474 Teleki Mihály Bornemisza Annához]), nép +-cske $\rightarrow$ népecske (1710 k.: (Audenciakor) A házában... egy darab által volt rekesztve ... aranyos fa orsókkal, övig ... ő azon belöl állott ... a rekesszel ellenben seregel a sok supplicans ... aki mikor érkezett ... aszerént szólították, és elément a rekeszen belől; ki csak supplicatiót adott s elment, némely ... beszéllett is, de nem igen nagyon, úgy hogy az ... ott jelenlévő népecske nem hallotta [BÖn. 593-4]), nyomorú +-cska $\rightarrow$ nyomorúcska (1768: azon Csikkot mikor edgyüt teleltünk volt tavasz felt be hozták Moldovába meg pokrotzal takarták volt bé hogy Nyomorutska volt [Kovászna Hsz; SzentkGy Stojka Ráduly (40) zs vall.]), oltár + -cska $\rightarrow$ oltárocska (1732: Ezen kápolnában találunk, egj kicsinj arannjos oltárocskát, és erre függesztett aprolék pergament (!) ŭvegbe foglalt, aranyos rámás képeket tizennégyet, három ŭvegbe foglalt más képeket irottakot [Kv; Ks 40. XXVIIIc néhai gr. Kornis Zsigmond kv-i házának conscr.]), ösvény +-ke $\rightarrow$ ösvényke (1751/1753: a' Falu azon két ŏsvenyke nélkül kŏnnyen el lehet [Koronka MT; Told. 78]), polc + -cska $\rightarrow$ polcocska (1746: Paraszt Fogas 1 Potzoska 1 [Borsa K; Told. 
49]), reménység + -cske $\rightarrow$ reménységecske (1670: Gábor, hogy értett Ádámtúl, nem kétlem, mert éjjel-nappal csak együtt beszéltek, de nem hiszem, hogy az mi levelünk meritumát egészlen megmondhatta volna Ádám is, mivel bizony maga sem tudta, az modalitások mutogatásául mit írt Rottel, kihez képest Kegyelmednek is csak in generalibus terminis kell nekik mondani, hogy vagyon nyujtva valami jobb reménségecske most, mint eddig volt [TML V, 376 Bánfi Dienes Teleki Mihályhoz]), sajt + -cska $\rightarrow$ sajtocska (1596: 1. Sajtoczkat vöttem vala p(er) d 14 hogy az el kele hosszú Ianos Wram küldöt 1. Saitot [Kv; Szám. 6/XXV. 8]), szántó + -cska $\rightarrow$ szántócska (1787: parlagban hagyott egy Szántotska [Désakna; Hr 1/22]), tallér + -cska $\rightarrow$ tallérocska (1704: még lévén száz tallérocskám, abból vöttem ki tízet [WIN 225]) stb.

A többalakú tőváltozatok közül a tővégi magánhangzó-időtartamot váltakoztató tôtípus a leggyakoribb a SzT. adatai szerint, pl.: csésze + -cske $\rightarrow$ csészécske (1710: egj Cseszetske [Told. 19]), deszka + -cska $\rightarrow$ deszkácska (1582: zekerche fokkal valo w thesys vagion az Ayto mellet valo dezkachkan [Kv; TJk IV/1. 9]), eklézsia + -cska $\rightarrow$ eklézsiácska (1693: En Iffiabbik Czegei Vas György ... Vitettem el egy Harangot Csaszari kicsid Ecclesiacskamb(a) [RLt 1]), fejsze + -cske $\rightarrow$ fejszécske (1812: Egy Fejszétske ... égy jobbatska fejsze [M.gyerőmonostor K; KCsl 11]), gúnya + -cska $\rightarrow$ gúnyácska (1727: az én halalos betegsegemb(en) mellettem forgolodo s hiven serenkedő Cseledim(ne)k legjek szabados Testalni Tiz Tizenkét farintokat, vagj egjeb Gunyácskát [Gyf; JHb XVI/1]), história + -cska $\rightarrow$ históriácska (1736: Gondolod talám, ez az utolsó két-három históriácska nevetésre való; de bizony nem nevetésre, hanem nagy oktatásodra vagyon, kedves olvasóm, ha jól meggondolod [MetTr 420-1]), instancia + -cska $\rightarrow$ instanciácska (1819: egy egy Instantiatskát irogattam [Fog.; Konstantinus lev.]), kalangya + -cska $\rightarrow$ kalangyácska (1808: Hát arra emlékeziké a Tanu, hogy azon Hetven kalangyátskákat is ... nem a maga csürihez, hanem az erszény Lupujéhoz rakatta? [Erked K; LLt vk]), lecke + -cske $\rightarrow$ leckécske (1807: magam egy sovány Letskétskét mondottam [Dés; KMN 360]), mente + -cske $\rightarrow$ mentécske (1616: egj ... csonka vjŭ Mentechke [Kv; RDL 1. 101 Andreas Junck kezével]), osztováta + -cska $\rightarrow$ osztovátácska (1793: egy prém szövö rosz osztovatatska [TL Conscr.]), párna + -cska $\rightarrow$ párnácska (1816: A’ Cselédek 2. pokrotza és 4. párnátskája ... 6 Rf [Kv; Born. IV. 41]), róka + -cska $\rightarrow$ rókácska (1711: (A kászon úffalusiak) most is oda fogytok (!) Kegdhez egj rokaczkaval [Újfalu Cs; BCs]), summa + -cska $\rightarrow$ summácska (1613: mely Summaczykanak hatra maradot Tizen hat forintiat my eleottwnk veüe fel ... es igy Aztalos Miklos vallast teon my eleottwnk, hogy Radnothy Jstua(n) vram Jmmar Egy penzeuel sem uolna eó nekj ados [Kv; RDL I. 92]), szóke + -cske $\rightarrow$ szókécske (1813: Rákosi Hodra Danilla ... szŏkétske [DLt 890 nyomt. kl]), tábla + -cska $\rightarrow$ táblácska (1804: Egy Szám vető tablátska [Borosbenedek AF; SLev.]) stb. 
A SzT. adatai között ilyen példákat találunk a tőbelseji időtartamot váltakoztató tőtípusra: ér + -cske $\rightarrow$ erecske (1640: A szena rett hazul felül egy ereczkere jeö labbal [Ne; DobLev. I. 10]), híd + -cska $\rightarrow$ hidacska (1585: (Az ölfa) Egy Rezet az kezep kapún belol walo hidachkara Raktak. Hogy ez hidachkat megh Chinalta az Korcholiasz Negied Magaúal fizettem ... d. 25 [Kv; Szám. 3/XVIII. 26a]), kéz + -cske $\rightarrow$ kezecske (1759: az Gyermek ... azon reszketö kezecskéit Feleségem Kánforos Spiritussal mosogatván tegnap semmi ollyas felettébb valo nagy változása nem volt az Gyermeknek [M.csesztve AF; Ks]), levél + -cske $\rightarrow$ levelecske (1765: néhai Veres Daniel Ur(am) és mi voltunk a Divisorok, nekűnk ... valami Leveletskéket mutogattak, de mikről valók vóltanak már meg fejtettűk [Kökös Hsz; Kp I. 225 Sam. Sigmond sen. (46) gy. kat. vall.]), nyúl + -cska $\rightarrow$ nyulacska (1705: Ma voltam kinn nyulászni Disznód felé lovon ... egy nyulacskát is fogatánk [WIN I, 114]), rúd +-cska $\rightarrow$ rudacska (1647: Egj mecznek valo Vas serpenyő negj rudaczkán [Marosillye H; VLt 55/5415]), szekér + -cske $\rightarrow$ szekerecske (1748: volt két Lova, s, egy szekeretskéje [Torda; Borb.]) stb.

Hangzóhiányos tövek közül a következőkre van példa a SzT. adatai között: árok + -cska $\rightarrow$ árkocska (1572: Byzonnyal Twggia az Kys Arkochka desy hathar [Dés; DLt 184]), barom + -cska $\rightarrow$ barmocska (1584: Zekel Balint vallia Eleyn barmochkat tartottam, de hogy twzert Ieót oda eze(n) Azzony, senkire $\mathrm{Ne}(\mathrm{m})$ gianithatta hogy barmanak el vezet Teye, hane(m) ez Azzonra [Kv; TJk 4/1. 251]), csupor + -cska $\rightarrow$ csuprocska (1733: Mazos tsuprotska 2 [Marossztkirály AF; Told. 2]), dolog + -cska $\rightarrow$ dolgocska (1722: én Ncsagas Uram csak dolgacskaimat végézhessem fél mégyék runkra [Kéménd $\mathrm{H} ; \mathrm{JHb}$ XIII/39 Váradi András br. Jósika Imréhez]), fatorony + -cska $\rightarrow$ fatornyocska (1745: A' Palotákra mennek bé faragott kŏ gráditsos, és faragott kŏ padimentomos Folyóson ... mindenik felŏl ... sendély fedél alatt, mely Sendelyezésnek-is a' kŏzepe táján vagyon egy kis sendelyes fa-tornyotskája [Marossztkirály MT; Told.]), gödör + -cske $\rightarrow$ gödröcske (1779: (A) Széna Fŭnek szomszédgya ... Marton Ferencz ... Széna Fŭvecskéje, s, vagyon az Szélyiben egy ostormény Fa Bokorhoz csak két Lépésnyire egy Gŏdrŏcske [A.szovát (Később: M.szovát (K) egyik része) K; JHbK VI/17]), horog + -cska $\rightarrow$ horgocska (1699: az Ablak tablai vas pantocskakon s horgocskakon forgok [Boroskrakkó AF; BfN VI]), jövedelem + -cske $\rightarrow$ jövedelmecske (1621: Zam veweőket zoktanak valaztanj, kik az varosnak kewes Jeöwedelmeczkejenek exitusarol, es mindenfele erogatiokrol az Tiztviseleő vrainktol zamot zoktanak vennj [Kv; TanJk II/1. 335]), kapocs + -cska $\rightarrow$ kapcsocska (1585: Ersebet Sarlay Ambrusne vallia ... Agya es leple haz ezkeoze vala Az Azzonnak es keosseontuye, kapchochkaia, es egy Eowechkeyeis [Kv; TJk IV/1. 428]), malom + -cska $\rightarrow$ malmocska (1736: épithet ... azon Patakon egy Malmotskát [CU]), orom + -cska $\rightarrow$ ormocska (1746: a describalt helység 
felsŏ oldalának vicinussa házának kapujanak also részitŏl fogva, egj essŏ csinálta árkacskán alol lévŏ kis Ormocskán le a fen álo kert Szegeleteig ... volt is valami kis káposztás kertecskéje [Monor BN; Ks 7. XX. 19]), ökör + -cske $\rightarrow$ ökröcske (1595: Jo eóchejm ket eòkrechket hizem adhattok tizen hat eŏkerbeól az gazda aszon(n)ak, de ne adgiatok az Joúaba, hane(m) adgiatok ket eókrechket [UszT 10/59]) stb.

Hangszínt és időtartamot váltó tövekre ilyen példákat találunk a SzT.ban: ajtó + -cska $\rightarrow$ ajtócska (1636: tyuk oll hoszan ket szakaszban ... ket aytoczka raytok, uas, retezesek [Siménfva U; IHb Inv.]), erdó + -cske $\rightarrow$ erdöcske (1575: Zegenieknek az Zent lelek Espotalyaba zakaztasson Byro vram egy darab Erdeoczket otth hwl Az varos hazahoz vagnak [Kv; TanJk V/3. 110b]), mezö+-cske $\rightarrow$ mezőcske (1714: az melly darab mezöcsket fuz fakal ... tegnap ültetet be ... arolis tiltatom eő Kegelmet [Abafája MT; Born. V. 36]), süldődisznó + -cska $\rightarrow$ süldődisznócska (1587: Maradott Nyolcz dizno Swldeo dezmaban. Mindenesteol fogua az harom faluban iutott dezmaban Swldeo diznochka 16 ... Ezekben az Dizno Swldeochkekben attunk el 8 fl. 3 d. 62 [Kv; Szám. 3/XXXII. 7]) stb. Ennél a tőtípusnál a kicsinyítő képző mindig a szótári tőhöz járul, és nem a hangszínt és időtartamot változtatott tőhöz.

Véghangzóhiányos tövekre példák a SzT.-ból: borjú + -cska $\rightarrow$ borjacska (1681: Az Milványi megh holt jobbágy(omnak) ... maradott eökre négy két borjacska égyik őkőr másik űsző [RLt 1]), ifjú + -cska $\rightarrow$ ifjacska (1753/1781: néhai idŏsb osdolai Kun Miklós Ur(na)k ǒzvegyét kiis sok pénzŭ és nagy Joszágu volt, noha ŏreg is vólt, B, Jósika Imre pedig igen iffiatska lévén, nem is igen gazdag vólt maga el vetté a kitŏl nagy gazdagságot nyére, erôsen meg gazdagula [Nagyrápolt H; JHb LXXI/3. 332-3 Komán Togyer (50) jb vall.]), suba $+-i k a \rightarrow$ subika (XVIII. sz. v.: Egy veres Subika ... Egy ramas Aszony Embernek valo Czima (!) [Borb.]) stb.

A SzT. kicsinyítő képzős származékai között a v-s tövek százalékos aránya összesen alig teszi ki az 1\%-ot. Hangszínt és időtartamot váltakoztató v-s tövekre példa a hó +-cska $\rightarrow$ havacska (1738: itten az vetések igen szépen, essöis bövecskén kezdet lenni ugy az hovasokon hovacskák, melyeknekis gyakor hoharmati vadnak [Szamosfva K; Ks 99 Kornis Antal lev.]), szó + -cska $\rightarrow$ szócska (1665: Naláczi uram ő kegyelme jelenté, Uram, nekem, hogy nehezen esett volna Kegyelmednek egy szócska az asszonyunk ő nagysága levelében, melyben írja ő nagysága, hogy ajándék nélkül nem volt az Kapi uram ő nagysága dolga stb., alítván, hogy Kegyelmedet értené ő nagysága [TML III, 541 Székhalmi András Teleki Mihályhoz]) stb. Időtartamot váltakoztató v-s tőre példa: kő + -cske $\rightarrow$ kövecske (1714: Baraczk szin Seljembol valo Dolmanj, nagjob részrül kek Atlas Materiaval béllett, a' mellyén 15 , s az uyan penig 16 aranj fonal gombotskakkal, és annyi követskékkel ékesitett fl. Hung. 24 [AH 51-2]), lé + -cske $\rightarrow$ levecske (1632: az az Annok 
... hoza egj kis labasba(n) egj kis sarga leueczket az piaczra s azt ugia(n) sokan eueök ot megh [Mv; MvLt 290. 94b]), ló + -cska $\rightarrow$ lovacska (1670: had lenne bárcsak egy tisztességes lovacskám; úgy adom meg az árát, valamint Kegyelmed kivánja [TML V, 11 Ispán Ferenc Teleki Mihályhoz]) stb. Változatlan tőhangzós v-s tôre példa a bövebb + -cske $\rightarrow$ bövebbecske (1768: Enyeden bővebbetske szüret volt [TLMiss.]), valamint hangzóhiányos v-s töre példa a falu + -cska $\rightarrow$ falucska, de - amint látszik - az alapváltozathoz járul a képző (1618: Ngos Boczkoj Miklos vrünk(na)k az mjnemö faluczkaia itt ben Erdeljben most vagjon ... hatta es engette vsq(ue) bene placitüm (!) [Kv; Törzs.]).

Külön kategóriába kerültek azok a származékok, amelyeken a nyelvérzék felismeri ugyan a kicsinyítő képzőt, de a tő önállóan nem él a magyar nyelvben $^{69}$. Ennek egyik oka az, hogy a diminutív képzésmodellel lexikalizálódott származék keletkezik, amely csak ebben a formában marad meg a nyelvhasználatban. Ilyen lexikalizálódott származékok vannak a SzT.ban: mányika (jelentése '(bélelt) kesztyü' 1699: Egy veress boitos barsony aszony embernek valo kesztyü vagy manyika tetszin pantlikak raita, az pantlikak vegein mind io féle győngy [Szárhegy Cs; LLt Fasc. 150]), szalmapántlika (jelentése 'szalmából font pántlika' 1711: 12 Vég Szalma Pántlika ... 8 // 16 [ApLt 5 Apor Péter inv.]), szárika (jelentése kb. '(posztó)guba, suba' 1739: Szárikámot az nyakambol kivetvén, mondám az Öcsemnek, Lőjjed ... mert el kell vesznünk [Kézdisztlélek Hsz; HSzjP St. Hodor (49) pp vall.]) és ennek továbbképzett származéka a szárikás (jelentése kb. 'gubás, subás' 1796: jöttenek hozzá oda ki valo szárikás isméretlen emberek [Hidvég Hsz; HSzjP Támpa István (60) col. vall.]), szénafiók (jelentése 'szénaboglyácska' 1824: edgy Széna fiok alatt vártuk az esső elmulását [M.légen K; KLev. 9]), szipka (jelentése 'fúvóka' 1823: Egy pár ezŭst aranyozot trombita kővekkel ki rakva veres sejem sinorral, égyik Szipka nélkül [Szentbenedek SzD; Ks 38. V Clenodia fam.]), szkédácska (jelentése 'cédulácska' 1600: Die 18 Decembris exhibealt egy schedachkat (!) kiben mutogat regestumanak be Adassa vthan valo buza ky oztast Cub 51 1/2 tt az Arra fl 257/50 [Kv; Szám. 9/IX. 14]), szodomika (jelentése 'fajtalankodó' 1683: eo kglme Felesegevel nem az tiszta Szent hazassagnak rendi szerent élt, hanem tilalmas sodomika eletet Kővetet [Dés; Jk]), szupulyka, szupujkóo (két jelentése van: 1. 'karcsúan elvékonyodó' 1823-1830: a prussus huszároknak a csákójok is alol széles, a teteje szupujko volt [FogE 203]; 2. 'lapos' 1792: a' Székelyeknél ... szupulyka orru, az az lapos orru [MNy LXIX, 283]).

${ }^{69}$ Pontosabban a SzT.-ban nem jelenik meg címszóként a képző nélküli változat.

${ }^{70}$ A TESz.-ben szupojkó alakban jelenik meg, az első adat 1655-ből való: „Szupolyka-húsu” (A-Csere: Enc. 352: NySz.). A szó ismeretlen eredetü, a -ka -kó szóvég kicsinyítő-becéző képzőnek látszik. Eredeti jelentése és jelentéseinek fejlődése az ismeretlen eredet miatt bizonytalan. Erdélyi nyelvjárási szó. (TESz. III/805). 
Másik oka az, hogy jövevényszó lévén, a kicsinyítő képzős származék használatos az erdélyi magyar nyelvben a SzT. adatai alapján, az alapszó nem. Több jövevényszó ilyen alakban került át a magyarba, és a szóvégződésnek - mivel az alakját tekintve megegyezett a kicsinyítő képzővel - ráértéssel kicsinyítő funkciót tulajdonítottak. Ilyen az ángyelika (két jelentésben szerepel a SzT.-ban: 1. többszínü könyvkötő-papiros 1750: a Tabellakot mind ujjolag kellett compingáltatnom Angelicába igen szépen [Ap. 3 Rétyi Antos István lev.]; 2. ? angyalgyökér/fü; Angelica ${ }^{71}$ 1757: Postára orvosságra Angyelikára és egjéb edgyet másra Rfr 02 xr 4 [TL. Teleki Ádám költségnaplója]), apródutka (jelentése '(három) garasos ércpénz-érmecske' 1628/1635: Egj hozzu sakban negj zaz forint arra apro dutka [Bodok Hsz; BLt]), butuja $a^{72}$ (jelentése 'hordócska' 1743: kŭldŏttem ... Egy butuja Tejfelt [A.árpás F; EMLt Váradi Zsigmond gr. Teleki Ádámhoz]), mántlicska (jelentése '(gyolcs) köpenyke' 1788: Galléros gyolts mántlitska égy és gallératlan négy [Mv; TSb 47]), szádok-budunka (jelentése 'hársfából készült bödön' 1840: Juh fejő 2. Krinta 1 és 2 Turos Désa R. for. 3. ... 2. Zádag vagy hársfa Budunka R. for. 2 [Várhegy MT; TLt Közig. ir. 1042 Bencze Illyés lelt.]), szerviánka (jelentése 'rövid női kabát, ujjas' 1849: 12. sing kartont ... Egy Szerviánka ... égy fel duczet kés, és villa [Dés; DLt]).

Vannak olyan származékok is, amelyeken tisztán felismerhető ugyan a kicsinyítő képző, de a SzT. adalékaiból nem derül ki a jelentése. Ilyenek a himocska ('?' 1692/XVIII. sz. köz.: Nyulasra menŏ utt mellett egj darab himocska szánto fŏld [Told. 36]), holocska ('?' 1778: a Vajatis küldöm Holotskával még ha, lehet fogatok $\mathrm{s}$ magam bé viszem $\mathrm{Na}$ (go)dnak [Nagyida K; Told. 6]), hornyocska ('?' 1729: Marhák lábához valo hornyotska [Tarcsafva U; Pf]). Továbbá megjelenik egy játszi szóalkotással létrehozott ikerszó, amelynek morfológiai szerkezetében az -i becézőképző ismerhető fel: szurdi-burdi (jelentése 'kis termetü' 1758: Magaa is hozzám eljött volna, de a leveleimet mind elfogták, még csak egy sem ment kezébe, amint annak utána maga, minekutána már Fosztó Zsigmondhoz ment volna, mondotta, ki is egy szurdi-burdi, kopasz ember [RettE 73-4. - 'Boér Krisztina]). Az idézett adalékok nagy része a XVIII. és XIX. századból származik, kevés kivétellel, ami azt bizonyítja, hogy a nyelvújítás korában a kicsinyítő képzőmodell is kedvelt módszer volt új szavak létrehozására.

A kicsinyítő képzős származékok tövei tehát bármelyik tőosztályba tartozhatnak, nincsen semmi erre vonatkozó korlátozó szabály. A többalakú tövek esetében viszont meg kell azt is vizsgálni, hogy a szótári tőhöz vagy éppen valamelyik tôváltozathoz kapcsolódik-e a kicsinyítő kép-

\footnotetext{
${ }^{71}$ A román nyelvben a második jelentés terjedt el: angelică 1 . Plantă erbacee aromatică, cu frunze mari şi cu flori alb-verzui, a cărei rădăcină se întrebuințează în farmacie, 2. Băutură alcoolică preparată din această plantă.

${ }^{72}$ A román butoi, butoiaş átvétele.
} 
ző. A kicsinyítő képző a megváltozott hangalakú tövet hívja elő minden esetben a SzT. adalékainak bizonysága szerint a következő tőtípusoknál: tővégi magánhangzó-időtartamot váltakoztató, tőbelseji magánhangzóidőtartamot váltakoztató, hangzóhiányos, időtartamot váltakoztató v-s és változatlan tőhangzós v-s. A többalakú tövek közül csak a hangszínt és időtartamot váltakoztató tövekben, valamint a hangzóhiányos v-s tőben (falucska) nem történik változás a kicsinyítő képző elött, ez a szótári tőhöz kapcsolódik minden adalékban. A véghangzóhiányos, illetve a hangszínt és időtartamot váltakoztató tövek egy részének megváltozik, más részének nem változik meg a hangalakja a kicsinyítő képző előtt (borjúcska tőtípusát tekintve véghangzóhiányos, a képző viszont a teljes tőhöz járul, de ifjacska). A hangszínt és időtartamot váltakoztató v-s tövek közül külön megemlítendő a havacska származék, amely a SzT. adalékában hovacskaként jelenik meg, és így - bár erre más adat nincs - itt időtartamot változtató v-s tőként viselkedik.

\section{IV.5.2. A kicsinyítő képző helye a szóalakban}

A klasszikus képzőmeghatározások szerint a kicsinyítő képző közvetlenül a tőhöz vagy más képzőhöz kapcsolódhat, jelek és rag követheti. Mivel viszont a diminutívum nem tekinthető minden szempontból tipikus képőnek ${ }^{73}$, ezért a szóalakban sem feltétlenül a tő vagy más képző után áll, hanem előfordulhat az is, hogy például jel előzi meg.

A kicsinyítő képzős származék leggyakrabban T + DIM felépítésü a SzT. adatai alapján. Például: ágynemü + -cske $\rightarrow$ ágynemúcske (1791: Néhai Lukáts Mihálynénak meghalálozásakor maradot ... valami ágynemütskéje [Déva; Ks 79. XXVI. 8]), akó + -cska $\rightarrow$ akócska (1761: (Lopott) Papuk Péter ... Szurdukán Juontol egj akócska vagj buria pálinkát [Fazsacel H; Ks 113 Vegyes ir.]), ami +-cske $\rightarrow$ amicske (1791: a' mitske vagyonis a ketskék által el rágatot [Doboka SzD; MkG]), apró + -cska $\rightarrow$ aprócska (1651: Harom oregh szem Gyengy Negy Aproczkab [Wass 27 Wass Judit kel.]), arany $+-c s k a \rightarrow$ aranyocska (1754: Aproság Aranyotskák Flor. hung. 9 [Nsz; Told. 19 Oszt. 16]), árok +-cska $\rightarrow$ árkocska (1572: Byzonnyal Twggia az Kys Arkochka desy hathar [Dés; DLt 184]), balta +-cska $\rightarrow$ baltácska (1801: Vagyon egy kis Baltátska vj Nyellel fel keszitve [Vargyas U; CsS]), bástya + -cska $\rightarrow$ bástyácska (1623: legyen ... az Zegeten Egy zep Bastaczyka mostani forman kiben 25 puskas legeny feryen Zw(kse)gnek Jdeyen [Törzs. Bethlen Gábor gazd. ut.]), birtok + -cska $\rightarrow$ birtokocska (1806: ezen birtokocskát Sebess Uram birta [Nagymon Sz; Bál. 68]), boglár + -cska $\rightarrow$ boglárocska (1591: az ezwst keozeot latek egi kis feier boglaroczkat [Kv; TJk V/1. 180]), bokréta + -cska $\rightarrow$ bokré-

\footnotetext{
${ }^{73}$ L. a Képzö-e a kicsinyitó képző? c. alfejezetet.
} 
tácska (1768: Egy Zamantzos bokrétátska 7 rosátskával 4 rubint benne és három jo féle győngy [Nsz; Ks 74. 56]), bolt + -cska $\rightarrow$ boltocska (1742: (A) rab háznak az Délre nézŏ vegiben vagjon egy kis boltocska [Gyeke K; Ks 4. VII. 1]), cáp + -cska $\rightarrow$ cápocska (1639: Cziapoczka ez idey nro 2 [Hsz; LLt]), cédula +-cska $\rightarrow$ cédulácska (1780: külgyen édes Aszszony Anyam egy kis tzédulátskát $s$ tudam hogy őkegyelme szolgál a kenyérrel [Kp III. 203 Újfalvi Sámuel anyjához]), címer + -cske $\rightarrow$ címerecske (1733: Az ajto felett egj czimerecske felette vadaszoknak képe [Hacecsel $\mathrm{H}$; JHb Jósika Zsigmond udvarházában]), cipó + -cska $\rightarrow$ cipócska (1773: midön ezen Oláh Fenesi Udvar épittetett szoktak volt három három Czipotskát adatni Napjáb(an) [O.fenes K; JHb II/3]), cseber + -ke $\rightarrow$ cseberke (1756: Egy tsŏjŭ Lombikhoz valo kis Cseberke réz tsŏ egj benne [Somkerék SzD; Ks gr. Bethlen Imre lelt.]), csegely + -cske $\rightarrow$ csegelyecske (1724: egy küs cseglecsketöl fogva az Sombari Ur(am) reszin valok be szántottak volna harom őlnyit közönséges ember ölivel [M.zsombor K; Told. 2]), csekély + -cske $\rightarrow$ csekélyecske (1825: Az Egerpataki Bosa Jószág tsekélyetske [DLev. XIV. 5]), csikó + -cska $\rightarrow$ csikócska (1807: egy két esztendŏs, barna Csitkocska [DLt 391 nyomt. K1]), cső + -cske $\rightarrow$ cső́cske (1803: a' ... négy virágzat a' Pohár szárához a' virágokot felyül és aloll égyben foglaló tsőtskéken áll [Nagyteremi KK; UnVJk 203]), darab + $-k a \rightarrow$ darabka (1589: Enis Irtottam ez peres feoldbe(n) ... egy darabkat [Szentkirály U; UszT]), dolog +-cska $\rightarrow$ dolgocska (1710: magam dolgocskám [Cssz; BCs]), durva + -cska $\rightarrow$ durvácska (1802: Déák Mihály, szármozásra Kolosvári ... durvátska beszédű [DLt nyomt. kl]), eb +-cske $\rightarrow$ ebecske (1597: B. V. kwlde Zekel Martont Vi Varban Egy kis Ebechikeert [Kv; Szám. 7/XII. 56 Filstich Lőrinc sp kezével]), egy + -cske $\rightarrow$ egyecske (1721: alazatoson még szolgalom az Mlgos Urnak ha nekém is ég sértesecskét küld ézen meszét le vivő talyigan tavaj nem busitotam az Mlgos Urat mivel vot de most égyecsket őletem vot mind aprolikja mind szalonaja mind egy falatig el fogot (!) [Szentpál K; TK1 Mihály Deák Teleki Pálhoz]), ember + -cske $\rightarrow$ emberecske (1827: Szegény sokgyermekü, nyomoru Emberetske [K; KLev.]), észak + -cska $\rightarrow$ északocska (1746: Azon életskén tul lévő eszakotskát fel méretvén ... hoszszusága ... huszonhárom kötel [Mezőbodon TA; JHb XI/22. 6]), ezüst + -cske $\rightarrow$ ezüstöcske (1595: küldtem Dyák Mihálytól 3 ezüst karikát, két darab lapos ezüstöcskét ... 1 aranyat, 2 tallért [SzO V, 159 Fejes Mihály alsócsernátoni ember lev. feleségéhez a havaselvi hadakozásból]), falu + -cska $\rightarrow$ falucska (1630: tób Jozagot ne(m) vetett szalogb(an) az tot faluczkanal [Gálfva MT; Told. Huszár lev. 17a]), fáta + -cska $\rightarrow$ fátácska (1715: hallottam ... it egy faluban két olha (!) fataczkat [Bethlen SzD; BK]), fedö + -cske $\rightarrow$ fedốcske (1733: Uj Fedŏtske 5 mazos tserép tálatska 5 [Marossztkirály AF; Told. 2]), fegyver +-cske $\rightarrow$ fegyverecske (1782: Egy kis Spanyol fegyveretske [Mv; NkF]), fejsze + -cske $\rightarrow$ fejszécske (1812: Egy Fejszétske ... égy 
jobbatska fejsze [M.gyerőmonostor K; KCsL 11]), fiú + -cska $\rightarrow$ fiúcska (1748: voltanak gyermekei ... egy Fiucska s egy Leányotska [Aranyosrákos TA; LLt]), folyosó + -cska $\rightarrow$ folyosócska (1699: vagyon nyolcz cserifa köteses oszlopokon allo foljosocska karfa nélkült [Szentdemeter U; LLt]), gabona + -cska $\rightarrow$ gabonácska (1808: a' Désen lévő kévés gabonátskám [Kackó SzD; DLt 622]), görbe +-cske $\rightarrow$ görbécske (1820: Básta János ... Silesiai 38 esztendŏs ... hegyes görbetske orru [DLt nyomt. kl]), gúnya + -cska $\rightarrow$ gúnyácska (1845: a' mi gunyátskát ... szerezhetett [Dés; DLt 591]), gutta + -cska $\rightarrow$ guttácska (1851: Sala Farkas is tegnap eret vágatott magán ... mint ha nyelvét valami kis guttátska legyintette volna meg, alig tudott hebegni [Kv; Pk 7]), gyarló + -cska $\rightarrow$ gyarlócska (1764: Maradtanak gyermekei isa ${ }^{a}$ de gyarlócska lévén az aszszony, amint láttam neveléseket, nem hiszem egyik is apja fia legyen [RettE 178. - ${ }^{a}$ Ti. a meghalt Simon János prókátornak és Ponori Krisztinának]),gyémánt+-cska $\rightarrow$ gyémántocska(1652:Egy Kisveressskatulyacskab(an), ket arany gyŭrŭk egyikb(en) ket gyemántocskák [Nsz; IB X. 2 Bethlen István lelt.]), gyér + -cske $\rightarrow$ gyérecske (1803: Ezen szőllő csutkos gyeretske, nem igen jól mivelt [Koronka MT; Told. 23]), gyerek + -cske $\rightarrow$ gyerekecske (1800: azonn gyereketskének fürt haja ... kezébenn maradatté? [Dés; DLt]), gyürü +-cske $\rightarrow$ gyürücske (1628: egy gyureocyke p. f. $3 / 50$ [Kv; RDL I. 123]), halom + -cska $\rightarrow$ halmocska (1592/1633: (A földnek) egy feleol hatara az hegjen fen egy kis halmoczka [Gyeke K; Ks 90]), hambár + -cska $\rightarrow$ hambárocska (1763: 1 Hambarotska [Kv; TJk XVII/1. 17]), határ + -ka $\rightarrow$ határka (1614 e.: Határka pataka [Mezőbánd MT; EM XLVII, 313]), ház +-ikó $\rightarrow$ házikó (1748: Házikót magok épittetnek [Ákosfva MT; Told. 8]), hitvány +-ka $\rightarrow$ hitványka (1749: Tavallyi ... okŏr bornyu 2 Az edgyik hitvánka [Marossztgyörgy MT; Ks 23. XXIIb]), hüvely + -cske $\rightarrow$ hüvelyecske (1625: Ezüst es arany marhak szama ... Egy ezüsteos hiuelyeczkeis [Kv; RDL I. 126]), idő + -cske $\rightarrow$ időcske (1791: ez kitsiny idŏcske alatt hozzánk érkezének [Szucság K; RKA]), inas + -ka $\rightarrow$ inaska (1760: Hallottam valami inaskáktol ... hogy ... etczakának idején iffiu Boda Juvonnét egy kertben látták egj Férfival [Kóród KK; Ks 17. XXXI]), istálló + -cska $\rightarrow$ istállócska (1740: Vagyon ... edgy négy Lónak valo jó istállócska ... fedele szalma, és igen meg avúltt, hidlás is vagyon benne [Szentkirály TA; Ks 89 Inv. 8]), isten + -ke $\rightarrow$ istenke (1832: ugy láttzik, hogy ez a' Fia az Istenkéje [JHb Br. Jósika Jánosné gr. Csáky Rozália fiához, Samuhoz]), ital + -cska $\rightarrow$ italocska (1785: magamnak eledeletskéért vagj italatskáért ... fizettem [Kv; Pk 7]), jó + -cska $\rightarrow$ jócska (1710: jotska viseltes ŏreg gombok [Told. 19]), jószág + -cska $\rightarrow$ jószágocska (1757: küsded Joszágotskához tartozo kétt Főldetskei [Vacsárcsi H; Sándor conscr.]), juh + -cska $\rightarrow$ juhocska (1659: ez fekete juhoczkanak meghalt az barania [HSzj fekete al.]), juss + -cska $\rightarrow$ jussocska (1774: leven ... egy harmad részni Jussotskaja [Bölön Hsz; Berecz lev.]), kád +-cska $\rightarrow$ kádacska (1621: Veŏttwnk egy kadachkat sos 
viznek p(ro) d 28 [Kv; Szám. 15b/VII. 25]), kalán +-ka $\rightarrow$ kalánka (1744: Lapos nyelü ezüst régi vásott kalánkak 2 [Szentdemeter U; LLt Fasc. 67]), kard + -ikó $\rightarrow$ kardikó (1738: Az úrfi Kardikoját ki hozattam Bányárul [Nagysomkút Szt; TLMiss.]), karó + -cska $\rightarrow$ karócska (1849: Rostéllyos kertnek valo hegyes karotskák [Somkerék SzD; Ks 73/55]), kereszt + -cske $\rightarrow$ keresztecske (1816: a kapu teteinek két szélyin cserefábol keszitett két keresztecske tiszteltetik [Jobbágyfva MT; BálLt 67]), kevés $+-d \rightarrow$ kevesed (1826: a praetendált jövedelemnek kevesed része az özvegyi kevés Joszágnak az igazi jővedelme [Ne; DobLev. V/1114. 9a]), láda + -ika $\rightarrow$ ládika (1846: Egy ládika Klauzal Gabor képével [Dés; Berz. 20]), lakat + -cska $\rightarrow$ lakatocska (1736: Boros pintzén állo nagy Bétsi lakat 1. Aprobb Lakatotskák 4 [Mikefva KK; CU XIII/1. 171]), lecke +-cske $\rightarrow$ leckécske (1806: egy Letzkétskét tanultam a diák Aríthmetikából [Dés; KMN]), levél + -ke $\rightarrow$ levélke (1758: Drótra hajba tsinált győngyős levélkék, egyikben 27 győny (így!) [Nsz; TSb 21]), linea + -cska $\rightarrow$ lineácska (1817: a' kis pad széket két liniátskat a Diariummal edgyütt vettem [Hidalmás K; TSb 11]), málé + -cska $\rightarrow$ málécska (1743: Adott vala Isten ő felsége ... annyi gabonácskát, mely csinosan költve s málécskával elegyitve ... talán elegendő lett volna [HalmágyiNIr. 450]), medál + -cska $\rightarrow$ medálocska (1668: Egy kis Medaloczka Zomanczos smaragd benne [Mk 10 Kapi György lelt.]), medence + -cske $\rightarrow$ medencécske (1793: egy kís mosdo csipkés szelü medentzetske [TL Conscr.]), minden + -cske $\rightarrow$ mindenecske (1663: Ha idegeny uraim mellett nem szántam sok izben mindenecskémet elhagynom, bizony készebb leszek Nagyságtok mellett ... mindent elszenyvednem [TML II, 474 Teleki Mihály Bornemisza Annához]), munka + -cska $\rightarrow$ munkácska (1794: Eleget mesterkedtem benne hogy Ngōd parantsolattya szerént de otiori Juris cursu valo Munkátskát bé küldhessem, de sohol sem lelem [Hosszúfalu Szt; TKhf Jakab Gábor gr. Teleki Imréhez]), muzsika + -cska $\rightarrow$ muzsikácska (1681: Tŏrŏk sip uj Nro 2 ... Virgina ... Orosz Musikaczka, ighen kiczin, fa Tokostol Nro 1 [Vh; VhU 539]), nagy + -cska $\rightarrow$ nagyocska (1733: (A) Bástyában vagyon edgy nagyoczka fejér láda [Marossztkirály AF; Told. 25]), nyelv + -cske $\rightarrow$ nyelvecske (1759: az nap kezdett gyengén észre venni az Gyermeknek nyelvecskéin szájánis hasanlo mozgást, ugyan tsak ezek mellett az gyenge étkecskéit meg ette, mulatott, jádzott [M.csesztve AF; Ks Mikes Antal lev.]), nyoszolya +-cska $\rightarrow$ nyoszolyácska (1694: Ebben az hazba(n) va(gyo)n egy nyoszolyacska labostol es egy sing vason allo zőld mazu kemenczeje [Kővár Szt; JHb Inv.]), nyúl + -cska $\rightarrow$ nyulacska (1705: Ma voltam kinn nyulászni Disznód felé lovon ... egy nyulacskát is fogatánk [WIN I, 114]), nyuszt + -cska $\rightarrow$ nyusztocska (1743: Egy Rokas Téli Süveg. Egy Nusztotska [O.fenes K; JHbK XXIX/28]), oldal $+-k a \rightarrow$ oldalka (1795: A' meleg oldalka [Szénaverős KK; EHA]), olló +-cska $\rightarrow$ ollócska (1671: Ket Aranyos oloczkakert egy forint [Gyf; UtI]), óra + -cska $\rightarrow$ órácska (1724: 
vettŭnk ki... egy bontakozott orácskát [Koronka MT; Told. 29/15]), oszlop + -cska $\rightarrow$ oszlopocska (1850: a kissebb Lo Istáloba a Zablo hellyen vagyon a földbe ásva 3 kurta oszlopotska [Gyéressztkirály TA; DE 5]), osztováta + -cska $\rightarrow$ osztovátácska (1793: egy prém szövö rosz osztovatatska [TL Conscr.]), öl + -cske $\rightarrow$ ölecske (1765: ő Naga emberei a Fejérvári Kristina Aszszony részében vágtanak vólt két vagy három őlecske vesszőt [Hosszútelke AF; $\mathrm{JHb}$ XXVII/25. 3]), öreg + -cske $\rightarrow$ öregecske (1685: Egy ŏregecske Réz ŭst [UtL]), ösvény +-ke $\rightarrow$ ösvényke (1751/1753: a' Falu azon két ŏsvenyke nélkül kŏnnyen el lehet [Koronka MT; Told. 78]), óz + -cske $\rightarrow$ ózecske (1785 k.: Elég légyen ez néhány versecske; Néked írom te dali őzecske [EM XX. 501 Balás kódex. - A vén lány panasza]), pajta +-cska $\rightarrow$ pajtácska (1736: kis Sővényből font pajtátska [Bongárd BN; CU]), pakk +-cska $\rightarrow$ pakkocska (1839: Dánielnének ezen pakotskát... kérem, sietve juttassa át [Kv; Pk 7]), pálca + -ikó $\rightarrow$ pálcikó (1733: Bricz Stéphán főbe üte egj patzikoval Gligort [Szentmargita SzD; Ks 15. LXXVIII. 6]), pénz + -cske $\rightarrow$ pénzecske (1743: én egy kevés pénzetskét.... Borbol Congeráltam s pálinkábol [A.árpás F; TKl Váradi Zsigmond Teleki Ádámhoz]), pince + -cske $\rightarrow$ pincécske (1748: Vagyon Szalma fedél alat egy kisded pintzétske [Nyárádsztbenedek MT; Told. 79]), puttony + -ka $\rightarrow$ puttonyka (1758: Egy putonka káposztának valo valora den. 36 [HSzj puttony al.]), rajz + -cska $\rightarrow$ rajzocska (1881: Kétségbe vagyok esve, Ödön! Nem tudok bár egyetlen vidám rajzocskát írni. Nem fog a pennám [PLev. 89 Petelei István Jakab Ödönhöz]), ráma +-cska $\rightarrow$ rámácska (1656: Az fal mellett egi darab deszka polcz jvegh ablakhoz valo ramaczkák nro 6 [Fog.; UF II, 162]), rekesz + -ke $\rightarrow$ rekeszke (1694: Ezen Folyoso vagy Tornacz vegen viszont van egy Kis Rekeszkeis, kinek sem Ajtaja, sem egjeb nincsen semmis benne [Kövár Szt; JHb Inv.]), rigó + -cska $\rightarrow$ rigócska (XVII. sz. v.: Rigottskám, Rigottskám tsatsogo szajkotskám [ETF 20. 7 Thoroczkay Zsigmond daloskönyve 13b]), ruha + -cska $\rightarrow$ ruhácska (1790: Egy Csengetü ... Két oltárra valo ruhátska [Déva; Ks 76. IX. 24]), rút + -cska $\rightarrow$ rútacska (1806: Az írás rutatska volt [Dés; KMN 189]), seb +-cske $\rightarrow$ sebecske (1749: a nyakán egj Sebetske lévén [Ohába AF; Told. 3]), smaragd + -cska $\rightarrow$ smaragdocska (1697: Gyŭrŭ, melyben vagyon négy rubintocska, és az közepin egy kis Smaragdocska [KGy]), sovány + -ka $\rightarrow$ soványka (1746: égy soványka Domb [Nagyida K; Told. 9]), summa + -cska $\rightarrow$ summácska (1842: kötelesek ... a' fenn irt sum(m)átskát Czéhbe állásokkor mindjárt le-fizetni [Kv; ÖCLev.]), süket + -cske $\rightarrow$ süketecske (1830: Nutza Sófi ... kevéssé sűketetske Fejérnép [DLt 1025 nyomt. kl]), szalonna +-cska $\rightarrow$ szalonnácska (1589: Ket Zalonnachka, es egy darab [Kv; KvLt Vegyes I/2. 70]), szántó +-cska $\rightarrow$ szántócska (1787: parlagban hagyott egy Szántotska [Désakna; Hr 1/22]), szegény + -ke $\rightarrow$ szegényke (1851: kitsi Titi is mostanság mind beteg volt el van pusztulva, féltŭnk hogy el veszessük szegénykét [Kv; Pk 6 Pákei Krisztina férjéhez]), 
szelíd + -cske $\rightarrow$ szelídecske (XIX. sz. eleje: Mondám néki szelidetske Léány vagy e vagy menyetske Én sem Léány sem menyetske vagyok oh te szelidetske [AbN]), szív + -cske $\rightarrow$ szívecske (1714: egy haj kenönek valo Pixisetske, egj haj Tő egy szivetske ezüstes [AH 32, 55]), szürke + -cske $\rightarrow$ szürkécske (1822: Pipa Antal ... szŭrkétske himlŏhelyesetske ábrázatu [DLt 73 nyomt. kl]), tábla + -cska $\rightarrow$ táblácska (1804: Egy Szám vető tablátska [Borosbenedek AF; SLev.]), tál + -cska $\rightarrow$ tálacska (1623: ket kis vy kannaczka es egj Talaczka niomnak Lib. 8 [Kv; RDL I. 121]), tallér +-cska $\rightarrow$ tallérocska (1704: még lévén száz tallérocskám, abból vöttem ki tízet [WIN 225]), tarack + -cska $\rightarrow$ tarackocska (1620: Az Chyath hazban Taraczkochyka No. 1 [Kővár Szt; Borb. II]), távol + -cska $\rightarrow$ távolacska (1749: en mint hogj tavulotska voltam nem ŭsmerhettem kik légjenek [Balavásár KK; Ks 15. LXXVIII. 17]) stb.

A kicsinyítő képzős származékok tovább is képezhetők, különféle szuffixumok járulhatnak hozzájuk, a szóalak felépítése: T + DIM + K. A kicsinyítő képzőt követő szuffixum általában szófajváltó. Leggyakoribb az az eset, amikor a kicsinyítő képzős származékból - $(V) n$ képzővel határozószó jön létre: bőv + -cske + -(V)n $\rightarrow$ bốvecskén (1738: itten az vetések igen szépek, essōis bővecskén kezdet lenni ugy az hovasokon hovacskák, melyeknekis gyakor hoharmati vadnak [Szamosfva K; Ks 99 Kornis Antal lev.]), buta + -cska + -(V)n $\rightarrow$ butácskán (1807: (A szökött rab) beszédjét ugy ejti, mint a' vastag nyelvŭek tudniillik butátskán 's keményen, egyeb aránt folytában 's akadozás nélkŭl, bátran beszéllŏ [DLt 674 nyomt. kl]), csinos $+-c s k a+-(V) n \rightarrow$ csinosacskán (1736: Az ... udvarrol ... vagyon ... aditus ... Csinosotskán faragott ... fenyő deszka kapun rajta lévő kis Csekélly két vas Sorkokon forgó vas reteszszel zarlodo gyalog ajtotskával egyetemben [Várhegy MT; CU]), drága + -cska + -(V)n $\rightarrow$ drágácskán (1756: Fyat falván levő kis portziotskájának nékem engedését az Aszszonynak, noha drágatskán, de meg is Szivemnek telyes háládatosságával kőszőnőm ... egész igyekezettel rajta vagyok, hogy hová hamarább meg Szerezhessem [Bonyha KK; JHbK XXIV/10]), gyenge + -cske + -(V)n $\rightarrow$ gyengécskén (1822: Vére el folyása miat Gyengétskén talaltam [KLev. 15]), gyér + -cske + - (V)n $\rightarrow$ gyérecskén (1813: egy Csür vagy szekér szin, az oldalai sővénnyel gyéretskén bè fonva [Koronka MT; Told. 18]), hossz + -cska + -(V)n $\rightarrow$ hosszacskán (1739: a miolta én értem minden esztendőben használtak a Sz: Benedeki Révészek égy darabotska rétet a Révre menő uton alol hoszszatskán és keskenyen a Viz le mentére [Dés; Ks 28. V]), ifj + -cska + -(V)n $\rightarrow$ ifjacskán (1629/1676: Nagj Erdéllyi Miklos is megh halvá(n), igen Ifiacská(n) maradott Bátyá(m) [Somkerék SzD/Sv; WassLt St. Erdelly vall.]), jó + -cska + -(V)n $\rightarrow$ jócskán (1715: némellyek nékem jocskán adossok [BSz; JHb I/23]), kemény + -ke + -(V)n $\rightarrow$ keménykén (1736: Tőmlecz Tartoi kŏtelességheis kénszeritetté hogj keménykén visellye magát, az elegy belegy személlyekbŏl allo Rabokhoz 
[Kv; TJk XV/12. 5]), késő + -cske + -(V)n $\rightarrow$ későcskén (1718: enjim let volna a kŏtelesség hogj a Groffnak eléb inserviállyak, de késŏcskén érkezvén kevés Szŭretemen vagjok occupatus [Postelke KK; Ks 96 Székely Ádám lev.]), magas + -cska + -(V)n $\rightarrow$ magasacskán (1700: ha pedig magossacskán kőtődik az gát ugy híszszűk hogy nem lészen kára nélkűl Vas Daniel Ur(amn)ak [Dob.; WassLt]), meleg + -cske + -(V)n $\rightarrow$ melegecskén (1843: a füszereket mustba meg főzve, melegecskénn be önteni a hordóba [KCsl 13]), mély + -cske + -(V)n $\rightarrow$ mélyecskén (1864: a' porondköves hegy méjjecskén be van vágva [Váralmás K; KHn 316]), nehez + -cske + -(V)n $\rightarrow$ nehezecskén (1755: Klmes Asz(onyo)m eo Excellya ... egyedúl lévén, mostanáb(an) ide bé, nehezetskén tőlti idejit [Ks 96 Baló Antal lev. Nsz-ből]), nyers + -cske + $-(V) n \rightarrow$ nyersecskén (1855: Én se kértem ... nyersecskén nyilatkozni [ÚjfE 283]), rég +-cske + - (V)n $\rightarrow$ régecskén (1712: nem emlekezem jol rea mivel regeczken volt [Dés; Hr 6/28]), rossz + -cska $+-(V) n \rightarrow$ rosszacskán (1809: Czitrom árulo Társa roszatskán lévén le fekszik [Dés; DLt]), sok + -cska + -(V) $n \rightarrow$ sokacskán (1738: ittenis hagymázban sokacskán kezdettek betegeskedni egy nehanyon holtakis meg [Gyeke K; Ks 99 Kornis Antal lev.]), szép + -cske + -(V)n $\rightarrow$ szépecskén (1710 k.: Az kész pénzen kűlis hólmi naturálétok gyült öszve nállam szépetskén [CsV]), távol $+-k a+-(V) n \rightarrow$ távolkán (1657: Erre én a fejedelemmel ugyan pirongató kemény szókkal is írattam, de addig halogatá, hogy az ellenség is megértvén ugyan az én szerencsi földvárnál lételemet is, igyekezik vala reám jüni, de azonban nyelvet fogván az Ibrányi hadából, minden állapotjának végére ment, mind az helynek alkalmatosságának, rossz vigyázásának és tőlem is távolykán lételének [KemÖn. 257]) stb. Jóval kisebb számú példa van más képzővel létrejövő származékokra: -nyi: boglya + -cska + -nyi $\rightarrow$ boglyácskányi (1732: Egy mezei buglyácskáni ${ }^{\mathrm{a}}$ [Göcs MT; Berz. 15. XXX/7. - ${ }^{\mathrm{a}}$ Ti. a széna]), folt +-cska +-nyi $\rightarrow$ foltocskányi (1808: az Szekely Győrgytöl acquirált kitsin fotostskanyi (!) Joszag 11 Forintal acquiraltatot es ... az 11 Forintal vasarlot Joszagotska az Szekely Boldisar kezére ment [Harasztos TA; Borb. II]), öl + -cske + -nyi $\rightarrow$ ölecskényi (1784: installŭnk az Urnakis hogy a sz: Eccla tsak egy ŏlŏtskeni szelessegŭt ${ }^{a}$ penzŭnkert adgyon [Kőrispatak U; Pf. - ${ }^{a}$ Ti. földet]); -júl-jü: (két)remek + -cske + -jü $\rightarrow$ kétremekecskéjü (1719: Egy huszan òtt remekbŏl allo nyak szorito rubintos. Egy husz remekből allò huszan négj smaragdos nyak szorito két remekecskeu [WassLt Wass Dániel saját kézzel írt inv.]), odor + -cska + -jú $\rightarrow$ odrocskájú (1722: egy közönséges két odrocskáju Csür [HSzj odor al.]); -nként: apró +-d +-nként $\rightarrow$ apródonként (1584: az mit hozza kezdeth aprodonkenth Jomodon felúette rezeth es elmenth [Kv; TJk 4/1. 292]); -nként + -i: apró + -d + -nként + -i $\rightarrow$ apródonkénti (1837: az a felett fekvő meredek hegyek aprodonkénti le le süllyedezések [Dés; DLt 631]); -beli: jószág +-cska +-beli $\rightarrow$ jószágocskabeli (1581: wagion az Sohoz tartozo hawas 
allat egy nagy kazalo mezzeó ... az En Jozagochkambeli zegeny Jobbagimis onnat Eltenek minden fele mwhebe (!) walo fakkal ... barmokotis ott tarthatta [Gyf; Törzs Szentpáli Kornis Mihály a fej-hez]); -dég: kicsi +-d +-dég $\rightarrow$ kicsiddég (1638: latam az ladat hogi egi kiczidegh fel uala szakadva az sarka [Mv; MvLt 291. 123b]); -ll: kicsi $+-d+-l l \rightarrow$ kicsidell (1763: ha a ket Sézás Lo nagjab let volna ugjan ada Sütném mast Tudi (!) Sigmand Urnak, de kitsidelli [Kóród KK; Ks CII. 18 Szarka József tt lev.]); -it: kicsi + -d + it $\rightarrow$ kicsidít (1690: Ha az károkat kicsiditene ... mondgja azt reá, hogy ... ha vala holott valamit fizetnekis tsak semmi, őtőd, hatod, meg tized reszet sem adgyak [Ebesfva; Törzs. Bethlen Sámuel fej-i instr-ja]); -ség: kicsi $+-d$ + -ség $\rightarrow$ kicsidség (1795: Ferentz eő kegyelmét tudom kicsidségétől fogva, hogy szolgált [Ozsdola Hsz; HSzjP Ito Mihály (70) gy. kat. vall.]); -szerü: nagy +-cska +-szerü $\rightarrow$ nagyocskaszerü (1791: Egy nagyotska szerŭ Kávé ŏrlŏ avatég [Mv; MvLev.]).

Több olyan összetett szó van a SzT.-ban, amelyekben az első taghoz kapcsolódik a diminutív képző, a szóalak felépítése tehát: T1 + DIM + T2 ${ }^{74}$ : ajtó +-cska + hely $\rightarrow$ ajtócskahely (1741: a padláson fenn ki bontottak egy régi ajtotska hellyet [Meggyesfva MT; Ks 184. LXXXVIII]), árok + -cska + torok $\rightarrow$ árkocskatorok (1572: egy Arkochka Thorokban egy hathar kew wolt [Dés; DLt 184]), bársony + -cska + láda $\rightarrow$ bársonyocska-láda (1768: Barsonyotska Ládába talaltattak ... Kŏnyvetskék 3 [Marossztgyörgy MT; Ks 23 XXIIb]), borjú + -cska + bör $\rightarrow$ borjúcskabör (1757: 2 hitván bornyucska kicsin bőr adatot el [Kiskend KK; Ks 71. 52 Szám.]), cáp + -cska + bör $\rightarrow$ cápocskabör (1684: Ez idej Czápocska Bōr nro 8. [Déva; UtI]), inas + -ka + köpönyeg $\rightarrow$ inaskaköpönyeg (1798: Vitt magával ell a' Kotsis egy Inaska köpenyeget és ugyan azon Inaskának holmi fejérnémúit [DLt nyomt. kl]), jobbágy + -cska + zsellér $\rightarrow$ jobbágyocska-zsellér (1747: az Falu nem mind eŏ Ngaje mert az Szabad emberekbŏl állo derékos Falu, hanem tsak udvarháza van eŏ Nganak abban az Faluban tiz tizenkét Jobbágjotska Sellérekkel édgyŭt hozzá [Gagy U; Ks 83 Péterffi Sándor lev.]), kád + -cska + forma $\rightarrow$ kádacskaforma (1820: Egy talpon állo Czirádás szélü, és viragos fedelű Nád méz tarto ... égy kádacska forma fedeles és ovalis figuraju más Nád méz tartó mind a kettő F. T. betükkel jegyezve [Felőr SzD; BetLt 5 Fráter Theresia kel.]), láb + -cska + föld $\rightarrow$ lábacska-föld (1788: Vagyon a' Kőblős Lászlo ur udvara felett valo Hegyen kivúl fetske farku Lábatska Főld [Melegföldvár SzD; SLt XLI]), leány +-ka + gyermek $\rightarrow$ leánykagyermek (1595: Az Adam Janos Swteo hazaban egi Arva leanka gyermeknek vettunk egi Czondorat f - / 32 [Kv; Szám. 6/ XIII. 34]), major + -cska + hely $\rightarrow$ majorocskahely (1776: egy kitsiny Majorotska hellye [Mv; Told. 21]), patak + -cska + forma $\rightarrow$ patakocskaforma (1812: ez elött is volt az én értekemre egy kis patakotska forma kis Maros Ág, de ez

\footnotetext{
${ }^{74}$ Ennek valószínűleg szemantikai oka van.
} 
olly kítsín volt, hogy által lehetett lépni [Koppánd AF; DobLev. IV/943. 18a Petrutz György (70) jb vall.]), tábla + -cska + forma $\rightarrow$ táblácskaforma (1787: Vr Asztalára valo elegyes Sejemmel arannyal Ezústel Táblatska formákra varrott Abrasz [M.fodorháza K; RLt]) stb.

A SzT. adatai szerint a kicsinyítő képző előtt állhat valamilyen más képzö, a szóalak felépítése: T + K + DIM: -ság/-ség: adó + -ság + -cska $\rightarrow$ adósságocska (1733: hogy nékem se légyen semmi panaszom, a mint hogy nem sok adósságocskám lévén hátra ... tehát azokat fizesse meg az Vr Battyám vram [TK1 Teleki Sámuel lev.]), erős + -ség + -cske $\rightarrow$ erôsségecske (1653: Ilyen nagy vigyázással kellett a sok félelmes nép között oltalmaznunk magunkat a kicsiny parányi erősségecskében ${ }^{\mathrm{a}}$ [ETA I, $77 \mathrm{NSz}$ - - ${ }^{\mathrm{a}} \mathrm{Mv}$ nagytemploma körüli erődítményben, a Kastélyban]), föld + örök- + -ség + -cske $\rightarrow$ földörökségecske (1748: fŏld őrőkségetskéimet ... őrőkősön birhassák [Komjátszeg TA; AbN]), gazda + -ság + -cska $\rightarrow$ gazdaságocska (1793: azon alázatossan instálok Nsgodnak gazdaságotskájok fojtathatásában Méltoztassék hozzájok grátiát Mutatni [Kályán K; JF 36 LevK]), hely + -ség + -cske $\rightarrow$ helységecske (1744: A Lunka Kinyipa helységetskét ... Gánya Petru birta ... s háza volt ott [Nagyalmás H; BK sub nro 181 Szidera Filip (58) jb vall.]), költ + -ség + -cske $\rightarrow$ költségecske (1675: Batjam vram; ha mi kŏlcsegecskeje volna kglmednek valakinel mondana meg kgld [Szotyor Hsz; BLt]), major + -ság + -cska $\rightarrow$ majorságocska (1669: mihelt az kevés majorságocskámnak takarítását ... hacsak valami részében is végezhetem, az jószág árának felvételéért bemegyek Kegyelmedhez [TML IV, 505 Ispán Ferenc Teleki Mihályhoz]), örök- + -ség + -cske $\rightarrow$ örökségecske (1660: Sas Balasnenak egy Darab eöreöksegeczkeje, itt Szárhegyen, az Eőttsiuel, Orsolyaual Edgyütt [LLt Fasc. 152]), remény + -ség + -cske $\rightarrow$ reménységecske (1670: Gábor, hogy értett Ádámtúl, nem kétlem, mert éjjel-nappal csak együtt beszéltek, de nem hiszem, hogy az mi levelünk meritumát egészlen megmondhatta volna Ádám is, mivel bizony maga sem tudta, az modalitások mutogatásául mit írt Rottel, kihez képest Kegyelmednek is csak in generalibus terminis kell nekik mondani, hogy vagyon nyujtva valami jobb reménségecske most, mint eddig volt [TML V, 376 Bánfi Dienes Teleki Mihályhoz]); -s: barna + -(V)s + -cska $\rightarrow$ barnásocska (1802: Püsokan Juon ... Barnásotska tiszta ábrázatu [DLt nyomt. kl]), beteg $+-(V) s+-c s k e \rightarrow$ betegesecske (1820: En regtŏl fogva betegesetske allopottol vagyok [Mv; Borb. II. Mátyás Sámuel ügyvéd lev.]), gaz + -(V)s + -cska $\rightarrow$ gazosocska (1761: a' Rét nehol gazosotska lévén irtógattam ... egy Bogjatska szénára valot [Illyésfva Sz; BfN 45/9 Brállya Maftyéj (48) zs vall.]), hiba + $-(V) s+-c s k a \rightarrow$ hibásacska (1785k.: Kata ugyan mégis nem oly hibásacska: Dolgaiban serény, sokkal is jobbacska, Alattomban ő is akaratosocska [EM XX, 503 Balás-kódex]), puszta + -(V)s + -cska $\rightarrow$ pusztásocska (1769: hogy ha munkát tétet eő Nagysága azon szőlőb(en) (: mint hogy pusztásotska ${ }^{a}$ ) 
verificalodvan, menyi munka ment reá; aztis a szőlő mellé todván tartaz(z)am meg forditani éô Nagyságának [Ádámos KK; MbK IX. 39. - 'Tollvétség pusztásocska h.]), rongy + -(V)s + -cska $\rightarrow$ rongyosocska (1747: Egy Bibliaja magyar de Rongyosocska [LLt 3. B]) stb.; -atlan: szok- +-atlan +-cska $\rightarrow$ szokatlanocska (1798: Szokatalnotska a dolog ${ }^{a}$ [MNy XLVI, 157. Gyarmathi Sámuel Aranka Györgyhöz Göttingából - ${ }^{\mathrm{a}} \mathrm{Az}$ ifjú gr. Bethlen Elek hirtelen házassága]); -atos + -ság: alkalm- + -atos - + -ság + -cska $\rightarrow$ alkalmatosságocska (1689: N. Boer Thamas, és B. Péter Uraimék Proponálva(n) az eo Ngok Fogarasi Felső Székin Felsŏ Venicei joszagokba(n) sokkeppe(n) valo meg bántodásokot, instaltak mi előttünk kőzőnsegese(n) azo(n): hogy az iránt valo háborgattatásokba(n) ha mi alkalmatossagocskaval mi tőllünk kőzőnsegese(n) lehetne az iránt valo succursusunkot ne denegalnok [Fog.; Szád]); -ás/-és: elnyíl- + -ás + -cska $\rightarrow$ elnyílásocska (1793: az Uttza feloll lévő Falnak a' Bót-hajtás végétől lett elnyílásatskáját tapasztalok [Kv; Pk 2]), fizet + -és + -cske $\rightarrow$ fizetésecske (1742: ă két szolgálo kevés fizetésetskéje esztendeig 17 forint [Kv; Aggm. C. 12]), homlít + -ás + -cska $\rightarrow$ homlitásocska (1667: maga Monostori Uram egy homlitásotskát megh fogván fel huza [Kv; RDL I. 148e Stephanus Fekete alias Szeots jur. centum vir Colosvariensis (67) vall.]), ir + -ás + -cska $\rightarrow$ írásocska (1632: noha k(ne)k ualazt irattam mind az altal ket harom szoual magamis ez reouid irasochkammal akaram kdet biztatni keöztunk ualo bekeseges alkalom es eggiesegh feleöl [Kv; Ks 41. D. 20 Lud. Bornemisza lev.]), irt + -ás + -cska $\rightarrow$ irtásocska (1643: Uagion egi iritasoczjka [Szentsimon Cs; BLt]), rak + -ás + -cska $\rightarrow$ rakásocska (1763: Lattam Bereczki Gábornális Farkas Dombi fát jo rakásotskát egy vagy két teréből állót [Zágon Hsz; Szentk. Sam. Domokos (58) pp vall.]) stb.

Több olyan melléknévre és határozószóra van példa, amelyek alaktani felépítésében a középfok jele a kicsinyítő képző előtt áll ${ }^{75}$, a szóalak felépítése: T + J + DIM: alá + -bb + -cska $\rightarrow$ alábbacska (1762: azon nevezetŭ hellyben allabbotska [Backamadaras MT; CsS]), alá $+-b b+-d+-k a \rightarrow$ alábbadka (XVIII. sz. e.: fele Szánto fold van alábbatka azon Sorba ${ }^{a}\left[\mathrm{AbN}\right.$. $-{ }^{\mathrm{a}}$ Túr (TA) határában]), bő + -bb+-cske $\rightarrow$ bövebbecske (1768: Enyeden bővebbetske szüret volt [TLMiss.]), durva $+-b b+-c s k a \rightarrow$ durvábbacska (1821: Egy kisség durvábbatska ujj Kender Lepedők [Backamadaras MT; CsS]), elé + -bb + -cske $\rightarrow$ elébbecske (1767: Ugyon ott elébbecske oldalas Sovány hellyen ... széna fü [Kincsi KK; LLt Fasc. 129]), fel + -bb +-cske $\rightarrow$ feljebbecske (1732/1793: a' Szász ut mellett egy hold ... felyebetske egy fél ál [Albis Hsz; BartosLev.]), fenn + $-b b+$-cske $\rightarrow$ fennebbecske (1714: Váltó szántok ... Ugyantsak ot fennebbetske [Borberek AF/Mv; RLt O. 3]), gazdag + -bb + -cska $\rightarrow$ gazdagabbacska (1760: SzántoFőldekre, és Széna retekre nézve mellyik részre jutott jobban nem

\footnotetext{
${ }^{75} \mathrm{Ez}$ (többek között) erős érv arra vonatkozóan, hogy a diminutívumot nem lehet egyértelmüen képzőnek tekinteni (1. bővebben a Képzö-e a kicsinyítő képző c. alfejezetet).
} 
tudjuk. De Marhásabb és gazdagabbatskák, és jobb Gazdák mentenk (!) Mlgos Groff Bethlen Győrgy Vr ö Nagys(á)g(ána)k [Somkútpataka/Kővár Szt; KS r. tanú vall.]), hátra + -bb + -cska $\rightarrow$ hátrábbacska (1813: Hátrébbotska az Erdö ... bütüjibe foglalt Keresztesi István is mint egy 16 vékásnyi helyet [Koronka MT; Told. 22]), hosszú + -bb + -cska $\rightarrow$ hosszabbacska (1803: (A ház) fedelire kének (!) még fel őlni hoszszuságunál hoszszabbatska bűkfa Dranitza 50 szál [Kőrisbánya H; Ks 108 Vegyes ir.]), jó + -bb + -cska $\rightarrow$ jobbacska (1699: edgyik ${ }^{\mathrm{a}} .$. jobbatska [O.csesztve AF; LLt Litt. C. - ${ }^{\mathrm{a}}$ Bárka]), jó + -bb+-d $\rightarrow$ jobbad (1571: egy jo paripat keoztunk nem talalunk, lofeweknek sokaknak es keossegnek is kijet kijet jobbadnak hallottak nyayatul el üzettek [SzO II, 326]), jó + -bb + -dka $\rightarrow$ jobbadka (1694: Majorság-Szőlő ... Ennek két felől fel menő szelei ... igen pusztások, homolittatni kévánok: a közepe(n) jobbadka [Kisenyed AF; BfR néhai ifj. Bálpataki János urb.]), késő + -bb + -cske $\rightarrow$ késóbbecske (1844: későbbetske vissza hozták Szŏllősi Jozsit is [Torda; KLev.]), kevés $+-b b+-c s k e \rightarrow$ kevesebbecske (1730: az Portiot nem fizetők legyenek az elsőbb Classisb(an) mind egy iránt, Az masodik Classisbeliekre kevesebbecske Az 3dik Classisbeliekre a legszegényebbekre annális kevesebb [Dés; Jk 401b]), kinn + -bb + -cske $\rightarrow$ kijjebbecske (1790: Rutkai Vr(am), látom magais igen szereti Tŏvisset, s nem örőmest válna meg tölle, de kéntelen, mert szegény; Hunyad Vármegyéb(en) szándékozik meg fészkelödni, s ha módja lenne benne, ott valamivel a' Tŏvissi Részinek árrával kŭllyebetske terjeszkedni, mert nem capax szegény feje ideis tovais figyelmezni [Celna AF; TL. Málnási László ref. főkonz. pap gr. Teleki Józsefhez]), kis $+-b b+$ -cske $\rightarrow$ kisebbecske (1733: Egj borona kissebbecske [Kv; Pk 6]), középnagy + $-b b+$-cska $\rightarrow$ középnagyobbacska (1729: Egy kőzép nagyobbatska jukas üst [Tarcsafva U; Pf]), lenn + -bb + -cske $\rightarrow$ lejjebbecske (1796: Antiqua Populosa Sessio ... a Falu Derekánál lejjebbetske [Cikud TA; WassLt]), magas + -bb+ -cska $\rightarrow$ magasabbacska (1819: Szolga Biro Buda Simon Ur állott fel egy magosabbatska hellyre [Sárosmagyarberkesz Szt; Ks 67. 47. 28]), messze + -bb + -cske $\rightarrow$ messzebbecske (1782: (A föld) meszebecske vagyon [Kászonújfalu Cs; MvLev. Vegyes anyag 8]), nagy +-bb+-cska $\rightarrow$ nagyobbacska (1658: Kett Eöregh lada Est $\mathrm{f} 1 \mathrm{~d} 60$ Kett masfel singes lada Est $\mathrm{f} 1$ Egy singes es mas nagiobaczka [Kv; KJ]), nagy + -bb +-dka $\rightarrow$ nagyobbadka (1692: Apro Tekenŏ no. 4 nagyobbatka. no. 2 [Mezőbodon TA; BK Inv. 13]), olcsó + -bb + -cska $\rightarrow$ olcsóbbacska (1739: Mlgs Gróff Fő-Ispán Urunk ő Ngának igért 50. Köböl Zabn(a)k penzen lejendö meg-vétettetésére, mig ólcsobbacska lészen a' zab, facultáltatik Hadnagj atyánkfia ő kglme [Dés; Jk 523a]), rossz + -bb + -cska $\rightarrow$ rosszabbacska (1735: Jo üres Meh Kosár nrŏ 151 Roszszabbatska Meh Kosár nro 7 [Mezősztjakab TA; JHb XI/9. 10]), sötét + -bb + -cske $\rightarrow$ sötétebbecske (1807: Az Harmadik Kantza setétebbetske Pely [DLt 234 nyomt. kl]), szép +-bb +-cske $\rightarrow$ szebbecske (1747: a Hámbárnak edgyik rekeszszében 
találtunk ... szebbetske buzát Cub: 3 metr. 3 [Spring AF; JHb XXV/88. 5]), széles $+-b b+$-cske $\rightarrow$ szélesebbecske (1754: az egész épúletnek hoszsza 16 1/2 Szeless 3 ől és helyenn szelesebbetskeis [Uzdisztpéter K; CU]), távol + -bb + -cska $\rightarrow$ távolabbacska (1820: Thorda harmadfél postányi Kolosváron tul rakott uttal járhat, vagyon Gyalu távulobbatska [Bács K; KmULev. 2]) stb.

A kicsinyítő képzővel ellátott középfokú melléknév továbbképezhető, a szóalak felépítése: $\mathrm{T}+\mathrm{J}+\mathrm{DIM}+\mathrm{K}:$ bő + -bb + -cske + - $(V) n \rightarrow$ bö́vebbecskén (1758: csak adgjon Isten bŏvebecskén mint Karkoban ${ }^{\mathrm{a}}$ [TLMiss. - ${ }^{\mathrm{a} B o-}$ roskrakkó AF]), hosszú + -bb + -cska + -(V)n $\rightarrow$ hosszabbacskán (1700: Takarodot estve avval ${ }^{a}$ harangozzanak hoszszabbacska(n) mint eddig [Dés; Jk 311a. - ${ }^{a} \mathrm{~A}$ Dési Diószegi István adományozta kis haranggal]), jó + -bb+-cska + -(V)n $\rightarrow$ jobbacskán (1742: Az Orvosság vétel után jobacskán érzi magát [BálLt 1 Gyulaffi László lev. Bécsből]), jó + -bb+-d+-(V)n $\rightarrow$ jobbadon (1589/ XVII. sz. eleje: az Legeny rend ez Varosbol el mehet iobbadon valo tanulasnak okaert idegen mesterekhez, orszagokat iarhat az tudomany kedueert [Kv; KömCArt. 7-8]), kemény + -bb +-cske + -(V)n $\rightarrow$ keményebbecskén (1732: csag (!) eppen aszt láttam vona leg szükségesebbnek lenni, hogy az M: Ur ot létiben ö Nganak kemenyebbecskén szollat vona, és tanácsával is éltette vona a M: Ur, ŏ Ngát [Kóród KK; Ks 99 Kornis Ferenc Kornis Istvánhoz]), késő + -bb + -cske + -(V)n $\rightarrow$ késóbbecskén (1670: jobb későbbecskén lenni az dolognak jól, hogy sem futva rosszabbul [TML V, 264 Teleki Mihály Bethlen Jánoshoz]), rég + -bb + -cske + -(V)n $\rightarrow$ régebbecskén (1767: Az ide valo Possessor Urak közül mostanában, vagy régebbetskenis a kőzőnséges falu földibŏl ... mennyit fogtanak fel? [K; JHbK XLVIII/1. $8 \mathrm{vk]),} \mathrm{rossz} \mathrm{+} \mathrm{-bb} \mathrm{+}$ $-c s k a+-(V) n \rightarrow$ rosszabbacskán (1728: Az Feleségem ... csak nem épülhet ki nyavalyájából, ha három négy nap jobbacskán vagyon, megint harom nap roszszabbul ... most megint tegnaptol fogva roszszabbacskán vagyon [ApLt 1 gr. Haller János gr. Kálnoki Borbárához Nsz-ből]), szép + -bb + -cske $+-(V) n \rightarrow$ szebbecskén (1748: miolta Ferenczi Uramhoz ment férjhez, az ólta maga szebbetskén jár, mint az elŏtt [Torda; Borb.]), szép + -bb +-dke + -(V)n $\rightarrow$ szebbedkén (1670: Uram, én nem bánnám, bár maga írna, mert talám még valamivel kevesebbet írna, csak írna egy kevéssé szebbedkén, ne kelletnék oly fötöréssel elolvasnom [TML V, 5 Naláczi István Teleki Mihályhoz]), széles $+-b b+-c s k e+-(V) n \rightarrow$ szélesebbecskén (1733: Minthogy az hegy teteje felé meg rŏvidult az láb, potoltuk azzal hogy szelesebbetsken mertük fellyŭl, mint aláb [Kiskerék AF; JHb XXVI/44]) stb.

Egyetlen olyan kicsinyítő képzős származék van a SzT. adatai között, amelynek alaktani felépítésében a középfok jele követi a kicsinyítő képzőt: $\mathrm{T}+\mathrm{DIM}+\mathrm{J}+\mathrm{K}:$ távol + -ka + -bb + -(V)n $\rightarrow$ távolkábban (1663: Kérem, tovább is ha mit érthet, tudósítson, távulykábban lételemben is [TML II, 614 Teleki Mihály Kászoni Mártonhoz]). 


\section{IV.6. A kicsinyítő képzők produktivitása}

\section{IV.6.1. A produktivitás fogalma}

Bármely nyelvben egy képző akkor tekinthető produktívnak, ha új szavak hozhatók létre vele adott szintaktikai és szemantikai feltételek között. A képzőproduktivitás szorosan összefügg a képzőjelentéssel, ugyanis termékeny képzésnél a képzett szó jelentése mindig kompozicionális: 'tö' + 'képző' (Keszler 2000: 309, Ladányi 2001: 236). Ha egy képzett szó lexikalizálódik, nem jelenti azt automatikusan, hogy nem produktív képzésmóddal jött létre, hiszen a produktivitásnak nem kizáró kirtériuma az, hogy a származékok nem lexikalizálódhatnak. Egy képző akkor veszti el produktivitását, ha a nyelvi rendszerben egyetlen új származék sem hozható létre vele. Tehát a képzőproduktivitás a diakróniában értelmezhető fogalom: ahogy egy képző belép a nyelv képzőrendszerébe, egyre több származékot hoz létre, ezáltal produktivitása növekszik, majd bizonyos származékokban megállapodik (amelyek lexikalizálódhatnak is), fokozatosan elveszti produktivitását, nem hoz létre új származékokat. Előfordulhat viszont, hogy egy lexikalizálódott származék képzőjével új szavak alkothatók, ennek értelmében nem lehet azt állítani, hogy ha egy képző lexikalizálódott szóalakban szerepel, nem produktív.

Tágabb értelemben vett produktivitásról abban az esetben beszélhetünk, ha egy szabályba foglalható nyelvi minta korlátozás nélkül használható új nyelvi formák létrehozására (Ladányi 2001: 232).

A természetes morfológiában a produktivitás skálázható fogalom. Annak függvényében, hogy a képzésmód mekkora nehézségeket képes leküzdeni, kisebb vagy nagyobb a produktivitása. Vagyis: minél nagyobb nehézségek ellenére is képes múködni egy bizonyos képzésmód, annál termékenyebbnek tekinthető (Ladányi 2001: 234). Ennek alapján a termékenységnek a következő fokozatai különíthetők el:

1. Legproduktívabbak azok a képzésmódok, amelyekkel az idegen szavakat is rendszerbe lehet illeszteni.

2. A következő fokozatot azok a képzésmódok képviselik, amelyek az eredetileg is megfelelő tulajdonságokkal rendelkező vagy már beilleszkedett idegen szavakon végezhetők, ugyanis az ilyen szavakkal kapcsolatban - mivel már a rendszer részei - nem merülnek fel nagy nehézségek.

3. Harmadik nehézségi fokozat az, hogy az adott képzésmód müködik az illető nyelvben keletkezett rövidítéseken, betűszavakon.

4. A negyedik fokozatot a képzésen belül egy másik alosztály irányába való elmozdulás képviseli. 
5. A legalacsonyabb fokozat az, ha a képzésmód működik az adott nyelvben keletkezett neologizmusokon (i.m. 237-8).

A kicsinyítés mint az evaluatív morfológia vizsgálati tárgya a legproduktívabb képzésmódokhoz tartozik, sőt az inflexiós eljárásokhoz hasonlóan és szemben a tipikus derivációs folyamatokkal ${ }^{76}$, valószínűleg teljesen produktív (Bauer 1997: 551).

A -cskA és - $k A$ képző produktivitásának mértéke a természetes morfológia kritériumrendszere alapján a következő táblázatban foglalható össze (Ladányi 2007: 156-157):

\begin{tabular}{|c|c|c|c|}
\hline & & $-\operatorname{csk} A$ & $-k A$ \\
\hline 1. & idegen szavak beillesztése & - & - \\
\hline 2. & $\begin{array}{l}\text { beillesztett idegen szava- } \\
\text { kon }\end{array}$ & $\begin{array}{l}\text { blog-ocska, } \\
\text { lúzer-ecske }\end{array}$ & $\begin{array}{l}\text { *blog-ka, } \\
\text { lúzer-ke }\end{array}$ \\
\hline 3. & $\begin{array}{l}\text { rövidítéseken, betüszava- } \\
\text { kon stb. }\end{array}$ & $\begin{array}{l}\text { kft-cske, tsz-ecske, } \\
\text { sztk-cska, } \\
\text { maszek-ocska }\end{array}$ & $\begin{array}{l}\text { ?kft-ke, tsz-ke, } \\
\text { ?sztk-ka, } \\
\text { ?maszek-ka }\end{array}$ \\
\hline 4. & $\begin{array}{l}\text { alosztályváltás az érintett } \\
\text { képző javára }\end{array}$ & $\begin{array}{l}\text { nagynéni-cske, } \\
\text { csoki-cska, } \\
\text { öcsi-cske (a } \\
\text { nagynéni-ke, } \\
\text { csoki-ka, öcsi-ke } \\
\text { mellett) }\end{array}$ & $\begin{array}{l}\text { *fröccs-ke vs. } \\
\text { fröccs-öcske } \\
\text { *kapá-ka vs. } \\
\text { kapá-cska }\end{array}$ \\
\hline 5. & magyar alapszavakon & & \\
\hline a. & $\begin{array}{l}\text { potenciális alapszavakból } \\
\text { (intermediate false steps) }\end{array}$ & $\begin{array}{l}\text { ?fogyás-osdi-cska } \\
\text { ?tornáz-dá-cska }\end{array}$ & $\begin{array}{l}\text { ?fogyás-osdi-ka } \\
\text { *tornáz-dá-ka }\end{array}$ \\
\hline b. & $\begin{array}{l}\text { lexikai akadályozódás elle- } \\
\text { nére aktualizálódó potenci- } \\
\text { ális alakok }\end{array}$ & $\begin{array}{l}\text { *járó-cska, } \\
\text { *nyaló-cska, } \\
\text { *üló-cske (a járó-ka, } \\
\text { üló-ke mellett) }\end{array}$ & $\begin{array}{l}{ }^{*} \text { fogó-ka, *bújó-ka, } \\
{ }^{*} \text { fózó-ke (a } \\
\text { fogó-cska, } \\
\text { bújó-cska, föző-cske } \\
\text { mellett) }\end{array}$ \\
\hline c. & $\begin{array}{l}\text { potenciális szavak nem } \\
\text { standard aktualizációi }\end{array}$ & bosszú-cska & vendég-ke \\
\hline d. & $\begin{array}{l}\text { összetett morfológiai szer- } \\
\text { kezetű magyar neologiz- } \\
\text { musokból }\end{array}$ & $\begin{array}{l}\text { másoldá-cska, } \\
\text { ?elnökösdi-cske }\end{array}$ & $\begin{array}{l}\text { *másoldá-ka, } \\
\text { ?elnökösdi-ke }\end{array}$ \\
\hline e. & $\begin{array}{l}\text { nem összetett morfológiai } \\
\text { szerkezetű magyar neolo- } \\
\text { gizmusokból }\end{array}$ & puff-ocska & ${ }^{*} p u f f-k a$ \\
\hline
\end{tabular}

\footnotetext{
${ }^{76}$ L. bővebben a Képző-e a kicsinyitő képző alfejezetet.
} 


\begin{tabular}{|c|l|l|l|}
\hline f. & $\begin{array}{l}\text { régóta elfogadott, már ha- } \\
\text { gyományosnak tekinthetó } \\
\text { szavakból }\end{array}$ & $\begin{array}{l}\text { asztal-ocska, } \\
\text { szék-ecske, } \\
\text { gép-ecske }\end{array}$ & $\begin{array}{l}\text { asztal-ka, *szék-ke, } \\
\text { *gép-ke }\end{array}$ \\
\hline g. & $\begin{array}{l}\text { a derivátum létrejöttét } \\
\text { idegen szó motiválja }\end{array}$ & $?$ & $\begin{array}{l}\text { Fontos-ka (kisasz- } \\
\text { szony) }\end{array}$ \\
\hline
\end{tabular}

${ }^{\dagger}$ „,A lexikalizálódott jelentésű alakok rögzítettek, esetükben (azonos jelentésben) egyik irányból sincs felcserélési lehetőség." (Ladányi 2007: 156).

A táblázat tehát azt mutatja, hogy mindkét kicsinyítő képző produktívnak mondható a mai nyelvben. Bár idegen szavak beillesztésében nem vesznek részt (a kicsinyítő képző általában nem viselkedik honosító képzőként), a nyelvi rendszerének részévé vált szavakon viszont már mind a -cskA, mind a $-k A$ megjelenhet. Rövidítések és betüszók diminutivizálásában a -cskA egyértelműen részt vesz, a $-k A$ is elképzelhető, de a Ladányi által vizsgált korpuszban nem fordult elő. A -cskA produktivitását az is alátámasztja, hogy - a kapcsolódási szabályok szerint - $-k A$ képzőt preferáló alapszavakból is létrehozható diminutivizált származék -cskAval. A fordított irányú elmozdulásra viszont nincs példa. A neologizmusok kicsinyítésére általában nincs sok példa. A potenciális alapszavakhoz (5: a-e) kapcsolható kicsinyítő képzők kiválasztását szintén a kapcsolódási szabályok irányítják. A régóta elfogadott és már hagyományosnak tekinthető szavakból mindkét képző hoz létre származékokat, viszonylag kevés esetben járulhat mindkét képző ugyanahhoz az alapszóhoz. ${ }^{77}$ A derivátum létrejöttének idegen szó általi motiváltsága fordításokban figyelhető meg leginkább: pl. egy más nyelvből fordított mese szövegében megjelenik a táblázatban is idézett Fontoska név, amely aztán más szövegkörnyezetben is elterjedt.

A táblázatban szereplő adatok alapján az a következtetés vonható le, hogy a mai nyelvben a -csk $A$ kicsinyítő képzőnek nagyobb a produktivitása, mint a - $k A$-nak, de hangsúlyoznunk kell, hogy ennek gyakran fonetikai okai vannak.

\section{IV.6.2. A kicsinyítő képzők produktivitása a SzT. adatai alapján}

A SzT. adatai azt mutatják, hogy a -cska/-cske képzőnek a legnagyobb a produktivitása, szinte minden alapszóhoz kapcsolódhat: bármilyen névszó, sőt néhány határozószó mellett is megjelenik, használatát semmi nem korlátozza. Kicsinyít főnevet (pl.: madzagocska 'spárgácska, kötőcske' jelentésben 1584-ból: Angalit Razman Palnę vallia, Ez hus hagiatba ez Minapiba meg betegeswlek, hiwan hozzam Zabo Catot, es megh kene, vegre fel

\footnotetext{
${ }^{77}$ L. a Több kicsinyitó képzôt felvevő szavak c. alfejezetet.
} 
keonniebedem, Es mikor hazamat seprenęm, Az kemencze Alat talalek egy darab sot, es harom Mazagal vala Altal keoteozve rajta, ige(n) Zep feier So vala, es az harom mazagochkan harmincz keotes és chomo vala [Kv; TJk IV/1. 217] stb.), melléknevet (pl.: magasacska 'nem nagyon magasra készített' jelentésben 1766: a Szegeletben Magosotska ... régi Kementze [Hoszszútelke AF; Kath.]; 1806/1818: 1 Fiokos tükör magassotska [Mv; Told.]; 1823-1830: Az első ülés vagyon benn a kocsi fenekében, a második középben az ajtónál, s ezek mind eléfelé fordulva, az harmadik ülés vagyon a középsővel szemben, ezeken kívül az első bakon volt még egy magasocska ülés [FogE 253-4]; 1833: Magossatska Tüz helj [Nyárádsztanna MT; MvLev. 8]), határozószót (pl.: feljebbecske 'fennebbecske, fentebbecske' XVII. sz. köz.: (A földnek) vicin(usa) ... kívül a Gáton felyül mindjárt az Uraság Diszno Dinnyének fogott főldje felyebbetske a' kerülőjében .... a réája rugo Főldek vége [Mezőbánd MT; Wass]; 1754: az Utrumb(an) Specificalt Sz. fŏldet Vládék ... fogtak volt fel tŏvisbŏl es gyepbŏl Koszta Mihally is rajtak feljebbetske belé szurta volt magát [Erdőalja KK; Ks 39/XI. 11]), de névmást is - igaz, hogy fónévi jellegú használatban - (pl.: amicske 'amennyicske, amennyikó' 1644/1785: az Ur Isten ... az én Szerelmes Attyámfiát Nyagu Borbárát rendelte Házas társul ... Haza Törvénye szerint a micském van nagyobbára vélle együtt szerezvén őtet illetné [BfN Kémeri Huszti Menyhárt erdélyi főharmincados végr.]) és számnevet (egyetlen példa van rá a SzT.-ban: egyecske, főnévi használatban: 1721: alazatoson még szolgalom az Mlgos Urnak ha nekém is ég sértesecskét küld ézen meszét le vivő talyigan tavaj nĕm busitotam az Mlgos Urat mivĕl vot de most égyecsket őletem vot mind aprolikja mind szalonaja mind egy falatig el fogot (!) [Szentpál K; TK1 Mihály Deák Teleki Pálhoz]).

A - $k A$ kicsinyítő képző produktivitása kisebb, mint a -cskA képzőé, megjelenését bizonyos alapszavakon blokkoló szabályok korlátozzák. Például nem jelenik meg egyszótagú, valamint a/e végü szavakon. ${ }^{78}$ Vannak viszont olyan tövek, amelyek (az utolsó hang függvényében) a - $k A$ képzőt kedvelik. Ilyen például az asszonyka, jelentése: 'asszonyocska', 1582-ből: Mikor Menne az Ló és az Azzonyka Gereznaiaban vthanna siethe, Az gereznatole vag miteól vg Jyede meg az ló es ug Ruga fel [Kv; TJk IV/1. 114]; kisleányka 'leányocska' jelentésben 1583-ból: Vaida Andras vallia hallomassal ... hallotta ezt(is) Biro Mihalnak es Mostany felesegeteol hogy kialtotta az vchan Biro Mihal feleól hogy Az kis leankan kapta volna az vrat [Kv; TJk IV/1. 140] stb.

Ezzel szemben vannak olyan kicsinyítő képzők is, amelyek már a 16-19. században sem mondhatók produktívnak, a SzT.-ban is csak egyegy származékban jelennek meg. Például: a -cs $A$ képző (amennyiben nem

\footnotetext{
${ }^{78}$ Erről bővebben 1. a A kicsinyítő képzők kapcsolódási szabályai c. alfejezetet.
} 
hangátvetésről van szó) a gyermekcsében, az adalék 1688-ból való: Egy itt quartelyozo Lutheranus Németnek, recens natus, és ige(n) beteg gyermekcsejét ... meg kereszteltem [Bethlen kör. SzD; UtI]; az -őc a gyerkő́cben 1838-1845-ös adalékban: járni kezdett a gyerkőc [MNyTK 107]; az -ốce a gyerkócében szintén 1838-1845-ös adalékban: Prunkuj, porunkuj" (: a román „,prunk, prunkuc=gyerkőcével egyeredetü” :) [MNyTK 107] stb.

Összefoglalásként egy képzésmód akkor tekinthető termékenynek, ha a minta alapján tetszőleges számú szemantikailag transzparens új szó hozható létre, a SzT. adatai alapján az erdélyi régiség produktív diminutív képzője a -cskal-cske.

\section{IV.7. Kicsinyítő képzők és az alaptag szófaja}

Valamely képző, illetve szóképzési mód alapvető jellemzői közé tartozik, hogy milyen szófaji kategóriába tartozik az az alapszó, amelyhez a képzési folyamat során valamely képző járul, valamint az, hogy a képzési folyamat eredményeként létrejövő derivátum milyen szófaji kategóriába sorolható (Ladányi 2007: 69). A produktív képzők alapvetően csak a nagy lexikai kategóriákba ${ }^{79}$ tartozó szavakhoz járulhatnak.

Laurie Bauer (1997: 533-575) egy hierarchiát állapított meg arra vonatkozóan, hogy milyen szófajú tövekhez mennyire jellemzően járulhat diminutív toldalék. Ennek értelmében a hierarchia csúcsán a főnév áll, a következő szinten a melléknév és az ige ${ }^{80}$, a harmadik szinten a határozószó, számnév, névmás, indulatszó, a legalsó szinten pedig az utalószók állnak (Bauer 1997: 540). Ez kis mértékben tér el az Ettinger által megállapított hierarchiától (1974: 162), amelyben a legmagasabb szinten a főnév áll, ezt követi a melléknév, harmadik szinten a határozószó és az ige, majd a névmás és legvégül az indulatszó. Mindkettőre érvényes, hogy minél lennebb haladunk a hierarchiában, annál kevésbé jellemző a kicsinyítés.

Ha egy - a magyar nyelvre - érvényes hierarchiát próbálnánk megállapítani, meglehetősen más eredményre jutnánk: a Bauer- és Ettinger-féle rendszerrel abban egyezne meg, hogy a legfelső fokon a fónév áll, ezt követi a melléknév, alsóbb szinten a határozószó, majd a névmás és a számnév (ez utóbbi kettőhöz ma már nem produktív módon kapcsolódik ${ }^{81}$ ), illetve a hierarchia legalján az ige, amely a magyar nyelvben csak nagyon

\footnotetext{
${ }^{79}$ Nagy lexikai kategóriának (major lexical category) a főnevet, az igét, a melléknevet és a határozószót tekintik (vö. Ladányi 2007: 69).

${ }^{80}$ Megjegyzendő, hogy ezt a hierarchiát egy több nyelvre kiterjesztett vizsgálat eredményeként állította fel.

${ }^{81}$ "Az alapszófajokat helyettesítő szófajokba tartozó szavak, azaz a névmások közül a főnévi és melléknévi névmások ragozhatók, de nem lehetnek produktív képzési szabályok bemenetei." (Ladányi 2007: 70)
} 


\section{2. ábra. Az alapszó szófaja}

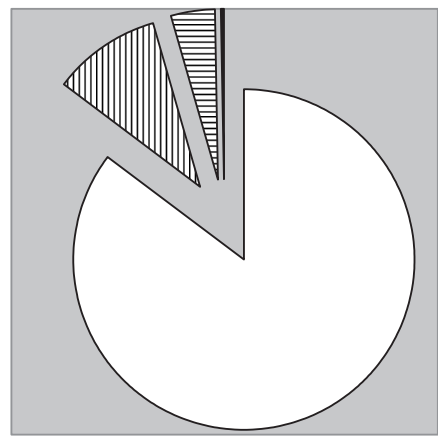

$\square$ Főnév
四 Melléknév
目Határozószó
$\square$ Más

korlátozottan, kizárólag gyermekorientált beszédhelyzetben fordulhat elő. A többi szófaji kategória pedig teljességgel hiányzik a hierarchiából.

Ennek értelmében a kicsinyítő képzők a denominális névszóképzők egyik népes csoportjaként, elsősorban főnévi alaptagon termékenyek, bár - mivel a kicsinyítő képzős mellékneveknek vannak rendszeres pragmatikai funkciói - ezeknek a pragmatikai funkcióknak a betöltéséhez a megfelelő mellékneveket elő kell tudni állítani (Kiefer 2003: 102), tehát ez a szófaji kategória is gyakran kicsinyíthető. A SzT. adatai viszont azt mutatják, hogy lényegében (ha nem is teljesen produktívan) járulhatnak bármilyen névszóhoz, valamint a fokozható határozószókhoz is.

Az egyes szófaji kategóriákba való tartozás a szóképzési szabályokban előforduló korlátozásoknak ${ }^{82}$ csak egyik típusát jelentik, „,vagyis a megfelelő szófaji kategóriába való tartozás szükséges, de nem elégséges feltétele annak, hogy egy szóból egy adott képzésmóddal a megfelelő derivátumot létrehozhassuk: a szóképzési szabályok nem működhetnek az adott kategóriába tartozó szavak bármelyikén" (Ladányi 2007: 71).

A SzT. eddig megjelent 12 kötetében összesen 1516 diminutív képzéssel létrejött származék található. Ezek alapszófajának százalékos megoszlási aránya a következő: 85,30\%-a főnév, 10,04\%-a melléknév, 4,27\%-a határozószó, 0,35\%-a más (1. 2. ábra). A más kategóriába konkrétan egy diminutív képzésmodellel létrehozott számnév (egyecske), valamint két névmás (amicske, annyicska) tartozik. Szintén ide soroltam azt a két igét, amelynek a morfológiai felépítésében kicsinyítő képző is szerepel, bár ezek voltaképpen diminutívummal ellátott melléknevek, s ezekhez járul az igeképző (kicsidell, kicsidit).

\footnotetext{
${ }^{82}$ Más korlátozástípusra vonatkozóan 1 . később.
} 


\section{IV.7.1. Kicsinyítő képzős főnevek a SzT.-ban}

A SzT. kicsinyítő képzős címszavai azt mutatják, hogy ezek a képzők elsősorban főnevekhez járulnak, a Bauer- és Ettinger-féle hierarchiáknak megfelelően.

Többek között a következő fonnévi alaptagú kicsinyítő képzős származékokra találunk példákat a SzT.-ban ${ }^{83}$ : acélláncocska (1668: Egy kis fekete Aczel Lanczoczka [Mk Kapi György lelt.10]), ágynemúcske (1791: Néhai Lukáts Mihálynénak meghalálozásakor maradot ... valami ágynemütskéje [Déva; Ks 79. XXVI. 8]), általagocska (1585: Regy zokas zerent az Atalagochkanak feneket ky wagattak volna es a' bort a feoldel emesztettek volna megh [Kv; TanJk. I/1. 7]), bárdocska (1679: Sindelyezéshez valo régi bárdocska nro 1 [Uzdisztpéter K; TL Bajomi János inv. 72]), birodalmacska (1678/1638: jllik azert ... magokra igen vigiazniak ... kiket kőzűletek ... Ez Erdelj Birodalmocskaban Is(ten) megis tovabra tartvan helheztet, s, helheztetet [Ks Kornis Gáspár kezével]), csákányka (1634: Kerekes Ianos ... ki ragadva(n) cziakankajat monda: Ez az en Atyamfia, megh lattia ki bant [Mv; MvLt 291. 2b]), csirkécske (1760: Azonban ezen Talyigán két Zsák szárnyas majorságnak valo buza rostaalyát kŭldőttem bé, Holnap Napra penig, őtt Csirkécskét, két Pipét, két ifju Nyulacskát és ez oráig Annyát szopo két Kis Báránykát [O.csesztve AF; Ks 83 Szabó István lev.]), csontládácska (1674: Vagyon egy kis Csont ládácska melyben vagyon oh pénz és egy Nihány tallér [Beszt.; Wass 72/6]), darabontházikó (1744: boronafábol rakott kis ded Darabont háziko Sendelj fedél alatt [LLt Fasc. 67]), elóruhácska (1576: Egy eleo Rwhachkaro walo zederies Aranyas zel mynth egy Syng [Szamosfva K; JHbK XVIII/7. 13a]), énekecske (1808: Igen nagyon emelné betsületét nyelvünk(ne)k az is, ha ahoz értő emberek szednék Nemzeti nyelvünkben lévő szebb szebb Eneketskéket [Kemény, Coll. Manuscr. Tom. XXX. Varia XII]), erkélyke (1692/1737: Szen Peteren az Imátkozo Erkelykéb(en) ... láttom az Asztalotskáján sok kűlőm külőm arany müveket [Szilágycseh; EMLt]), faedényecske (1742: egy fa edényetskéb(en), hat darab fūlbe valo gombok és egy ezűst gyürü [Kisborszó SzD; TL. Kifor fam. lelt. 42]), fazekacska (1696: Volt ennekem ... egy egy keves penzem fazekacskaban [Dés; Jk]), fejszécske (1812: Egy Fejszétske ... égy jobbatska fejsze [M.gyerőmonostor K; KCsL 11]), fenyóajtócska (1742: mentünk fel ... törpe fenyŏ Ajtotskán [Pókafva AF; $\mathrm{JHb}$ XXV/58]), feredóházacska (1629: iutot ... Egy Boltos konyha feredeo hazaczikaual Egiwtt [Kv; RDL I. 132]), fésúcske (1729: Az árvák számára valo küs fésücskékért d 6 [Szentbenedek SzD; Ks 26. XIV. 1]), fogadócska (1799: a' Kérei ${ }^{a}$ Hágo innenső allyáb(an) valo Fogadon innétvalo Fogadotskával szemben bé érték [Dés; DLt. - ${ }^{\mathrm{a}} \mathrm{A}$ Kérő (SzD) határában levő]), gallérocs-

\footnotetext{
${ }^{83}$ Kötetenkét $5-5$ példát emelek ki.
} 
ka (1576: Egy kamoka hímel waroth kys galerochka [Szamosfva K; JHbK XVIII/7. 15]), hibácska (1772: ezen Malomnak, a' mint láttam, némely apro hibátskái vadnak [Ádámos KK; JHb LXVII/2. 313]), hordócska (1645: egj kis hordoczkais uala [Szárhegy Cs; LLt Fasc. 120]), imádságoskönyvecske (1596: In 16. Imatsagos keonywechke Nemetewl [Kv; RDL I. 65]), ingvállacska (1629: Egy hitua(n) Jng vál ... d. 50 Más, Egi hitua(n) Ingh vállaczika ... d. 10 [Kv; RDL I. 132]), juhocska (1599: Iffiú koromba(n)is volt Juhoczkank es ott a' taiban tartottak neha [UszT Antonius Thorniau de Zataloka (!) (60) pp vall.]), kádacska (1594: Az Somlioy maior hazban ... Soos viznek walo kadachka vagjon No 1 [Somlyó Sz; UC 78/7. 16-7]), kalánocska (1700: Harom fejer kis kalánocska [Hr 1/20]), kancsócska (1698: edgj zŏld kancsocska [Kóród KK; LLt Fasc. 72]), kehelyecske (1728: Egj on kehelyetske Brassai Kis Gjŏrgjne Collatuma [Gidófva Hsz; SVJk]), kisasztalka (1756: Négj szegeletŭ kis Asztalkák [Somkerék SzD; Ks gr. Bethlen Imre lelt.]), kocsicska (1710 k.: Ratisbonában mü egy kocsicskát fogadánk ketten, Norimbergáig, alkudtuk két tallérban [BÖn. 571-2]), kosaracska (1773: egy kűs kosárotskába belé tette [Szárhegy Cs; LLt Fasc. 69]), ládácska (1647: Egj hitvan Ladaczka holmi dib dab egyetmasnak valo [Marosillye H; VLt 55/5415]), lepedöcske (1738: Egy elegyes sellyemmel varrott lepedŏtske [DobLev. I/171]), lövóbástyácska (1664: az csonka bástya végében csináltatott egy kis lövő bástyácskáta [TML III, 95. Katona Mihály Teleki Mihályhoz - ${ }^{a}$ Kóváron]), majorocskahely (1776: egy kitsiny Majorotska hellye [Mv; Told. 21]), malmocska (1736: épithet ... azon Patakon egy Malmotskát [CU]), marhapajtácska (1778: egy egy Marha Pajtátskát vagy egy kis Gabonásotskát tsináltak [Pósa Sz; Ks 34. VI. 1]), medálocska (1668: Egy kis Medaloczka Zomanczos smaragd benne [Mk 10 Kapi György lelt.]), méheskertecske (1736: ezen Méhes kertetskének ajtaja tsak Sŏvénybŏl valo [CU]), mosdócska (1615: Egj Teörreödeözeöt Sarga mosdochka f - d. 12 [Kv; RDL I. 97 Junck András kezével]), nyársacska (1750: egj vas kalány, vas fogó s egj kis Nyársotska [Szamosfva K; JHbK LVIII/4. 2]), oldalbástyácska (1694: Az Kapun belől Balkez felől egj oldal Bastyacska va(gyo)n [Kővár Szt; JHb Inv.]), ónpalackocska (1634: Egy ohn palaszkoczka [Kv; RDL I. 105]), órapárnácska (1842: Csengettyű három rézbŏl valok, két párnátskával ... égj ora párnátska [Dés; Újf. 3 Újfalvi György hagy.]), osztovátácska (1793: egy prém szövö rosz osztovatatska [TL Conscr.]), ösvényke (1751/1753: a' Falu azon két ŏsvenyke nélkül kŏnnyen el lehet [Koronka MT; Told. 78]), pakkocska (1839: Dánielnének ezen pakotskát ... kérem, sietve juttassa át [Kv; Pk 7]), patikaládácska (1698: Patika ládácska vagy iskatulya [MNy XXXVIII, 206]), rámácska (1656: Az fal mellett egi darab deszka polcz jvegh ablakhoz valo ramaczkák nro 6 [Fog.; UF II, 162]), részjószágocska (1582: Az eo Rez Ioszagoczikajat ... Varadi Pal deaknak es Az eo felesegenek ... ada eoreok aro(n) [Mv; BálLt 55]), rudacska (1842: egy két 
águ rudátskát találtam [Dés; DLt 916]), sebforradásocska (1805: a' bal Pofáján vagyon egy Seb forradásotska [DLt nyomt. kl]), szalonnácska (1589: Ket Zalonnachka, es egy darab [Kv; KvLt Vegyes I/2. 70]), szapulókádacska (1770: Szapullo kádatska [Esztény SzD; Told. 29]), székecske (1631: azon beleöl uagyon ... egy szekecsyke [Fog.; UF I, 401]), szíjacska (1719 k.: szerszámhoz valo darad szijatskak [LLt Fasc. 115]), tafotavánkosocska (1700: Egj Kis Kopot, Tengerszin Tafata vankosocska [Ebesfva; UtI]) stb.

\section{IV.7.2. Kicsinyítő képzős melléknevek a SzT.-ban}

Kiefer szerint (Kiefer 2003: 102) a kicsinyítő képzős melléknevek valamilyen pragmatikai funkciót töltenek be, jelentésük elszakad az 'alapszó + DIM' képlettől. A SzT. adatai viszont pontosan azt igazolják, hogy gyakran a kicsinyített melléknévnek nincsen különösebb pragmatikai funkciója.

Többek között ilyen példák vannak melléknévi alaptag kicsinyítő képzős származékára a SzT.-ban ${ }^{84}$ : alkalmasocska (1745: az vanyolohoz egy vedres üst, 1 vizmelegitő alkalmasotska [EMLt]), alkalmatlanocska (1755: (A) nagy házbol ... két ajto nyilik ... edjiken nyitanak s.v. az Arnyék székre, mellynek ajtoja minthogy nintsen meg duplázva az házban lévő ágyhoz kŏzel esvén; alkalmatlanotska [Ludesd H; BK sub nr. 1020]), alkalmatosabbacska (1768: meltoztassek Ngtok I(ste)nesen meg tekinteni Szegényeket, hogj ok is a szolgálatra is alkalmatosabbatskák lehessenek [Esztény SzD; Told. 5a]), csekélyecske (1825: Az Egerpataki Bosa Jószág tsekélyetske [DLev. XIV. 5]), csorbácska (1817: kivül ezen kis malmon vagyon még ēgy csorbátska also malom kö, melly nagy Szükségben adplicalhato lenne [Ördöngösfüzes SzD; ÖrmMúz. Conscr. 9]), dagadtacska (1836: a Gróf Kendefi féle kancza csíkónak hátulsó bal lába hasonló sértődést kapván ezis dagattocska [Zsibó Sz; WLt Nagy Lázár kezével]), fejérecske (1812: Misztrai Álexa ... fejéretske, kerek abrázatú [DLt 506 nyomt k1]), feleske (1754: Idvezult edes Anjátol feleske Edjetmásokkal Vitéz Ersébethnek adatott Ládák [Gernyeszeg MT; TGsz 33]), fiatalocska (1797: Hargos magu Szilva fák Nro 203 ezek kŏzŭl némelyik fiatalotskákis találtatnak de nagyobbára régi meg vénhedettek [Kőrispatak U; Pf]), gazdagabbacska (1760: Szánto Főldekre, és Széna retekre nézve mellyik részre jutott jobban nem tudjuk. De Marhásabb és gazdagabbatskák, és jobb Gazdák mentenk (!) Mlgos Groff Bethlen Győrgy Vr ö Nagys(á)g(ána)k [Somkútpataka/Kővár Szt; KS r. tanú vall.]), gazosocska (1761: a' Rét nehol gazosotska lévén irtógattam ... egy Bogjatska szénára valot [Illyésfva Sz; BfN 45/9 Brállya Maftyéj (48) zs vall.]), hegyesecske (1821: Monka (!) János ... hegyesetske orru [DLt 631 nyomt. kl]), hiányosocska (1798/1812: egy ujj, de héjánosotska Conscriptio [Msz; HG Conscr.

\footnotetext{
${ }^{84}$ Kötetenként 3-3 példát emelek ki.
} 
222]), hibásacska (1785k.: Kata ugyan mégis nem oly hibásacska: Dolgaiban serény, sokkal is jobbacska, Alattomban ő is akaratosocska [EM XX, 503 Balás-kódex]), keményecske (1778: Jo az igen bádgyatt és álmosságba, hagymázba merült betegnek a' két szárok ikrájára ... Kovásszal és meg tört mustár maggal s' kevés etzettel tsinált keményetske tésztát kötni egy gallérni nagyságra, hogy verességet, vagy hojjagot szivjon [MvÁLt, Mátyus, ConsSan. gub. - L. Színi Karola kijegyzése]), keményke (XVIII. sz. köz.: ha szintén magok kőzt kemenyke szo eset vagy eshetettis [Nsz; Told. 2]), keskenyecske (1744: Zazor vőlgyin valami keskenjecske hellyen [Vécke U; LLt Fasc. 67]), kopottacska (1803: Egy Sőtét zőld festékű kopottatska rostélyos scriptorium szegeletes négy Lábakon [Ne; DobLev. IV/858. 1a]), középnagyobbacska (1729: Egy kőzép nagyobbatska jukas üst [Tarcsafva U; Pf]), középnagyocska (1829: Schütz Márton ... közép nagyotska termetü [DLt 977 nyomt. kl]), magasabbacska (1747: ezen katonáknak egyike ... kőpczős és nem igen magos ... az másiknak ... borzos verés kalpagja ... nem éppen olyan erős Compactióju mint az más de anál magasabacska termetŭ [A.hagymás SzD; Ks 27/ XVIIb]), magasacska (1853: A hegy meredek és magasotska [Kv; KmULev. 4]), mérgesecske (1846: Annyi igaz hogy Ifj: Imre Mihály mérgesetske ember [Kakasd MT; DE 2]), nagykorácska (1750: A cinteremben vagyon egy tisztességes fábol épült fatorony, melyben vagyon két nagykorácska harang [Marosvécs MT; ETF 107. 22]), nagyobbadka (1644/1648 k.: egy Veres scarlat szüniegh nagiobbatka [Born. XXXVIII. 14]), öregecske (1685: Egy ŏregecske Réz ŭst [UtL]), parasztocska (1823-1830: Vettem volt már egy lovat ... E parasztocska kanca volt, de fiatal, sebes és iramló [FogE 282]), piroska (1846: teli piroska ábrázatu [KLev.]), régicske (1771/1817: Cseléd ház ... fedele régitske [Kardicsfva U; Mk Török-Rhédei transmiss.]), romlottacska (1806: Weress Samuel Ur ... kéntelenittetett ... egy fél Arkus Albat Subscribálni, mellyet Déakul akarván meg tenni Nevének első Sillabáját az S. leis írta, a' midön mük meg szollitottuk, hogy ... Magyarúl kelletik Subscribalni, igy oztan az S böl egy romlottatska Vét tsinált [Szék SzD; RLt O. 2 Kasza József keze írása]), rongyosocska (1747: Egy Bibliaja magyar de Rongyosocska [LLt 3. B]), szebbecske (1747: a Hámbárnak edgyik rekeszszében találtunk ... szebbetske buzát Cub: 3 metr. 3 [Spring AF; JHb XXV/88. 5]), szegényecske (1758: monda Udvar Istvánné Aszszonyom: Iuana ha sŭtǒttél vólna adnál nékem egy Kis kenyeret ... mellyre én mondék: Jó szivel én Aszszonyom, tsak hogy bizony szegényetske a' kenyerem [Bethlensztmiklós KK; BK. Farkas Juana cons. providi Vintilla Petre (32) vall.]), szélesebbecske (1754: az egész épűletnek hoszsza 16 1/2 Szeless 3 ől és helyenn szelesebbetskeis [Uzdisztpéter K; CU]) stb. 


\section{IV.7.3. Kicsinyítő képzős határozószók a SzT.-ban}

A diminutivizálható szófajok hierarchiájának következő fokán azok a határozószók állnak, amelyek fokozhatók, és ezáltal szoros rokonságban állnak a melléknevekkel. A nem fokozható határozószók nem szolgálhatnak képzés alapszavául (vö. Ladányi 2007: 69).

A SzT.-ban szereplő határozószók két nagy csoportba oszthatók aszerint, hogy az alapszó már eleve határozószó-e, vagy pedig melléknévből képzett.

Az első csoportba tartozó határozószók alaktani felépítése: T + közéfok jele + DIM: alábbacska 'lejjebbecske, egy kissé lejjebb' (1767: Ugyan abban a Sorban vagyon alábbatska a falunak kōzepe fele [Pocsfva KK; LLt Fasc. 129]), alábbadka 'lejjebbecske' (XVIII. század első fele: Rétetskéje ... van ... Petlendi Puszta Falu helyen az elébbenivel egj sorba alábbatka [AbN. - ${ }^{\mathrm{a} T u ́ r}$ (TA) határában]), feljebbecske 'fennebbecske, fentebbecske' (XVII. sz. köz.: (A földnek) vicin(usa) ... kívül a Gáton felyűl mindjárt az Uraság Diszno Dinnyének fogott főldje felyebbetske a' kerúlőjében ... a réája rugo Főldek vége [Mezőbánd MT; Wass]), hátrábbacska 'hátrácskább, egy kissé/vmivel hátrább' (1813: Hátrébbotska az Erdö ... bütüjibe foglalt Keresztesi István is mint egy 16 vékásnyi helyet [Koronka MT; Told. 22]), későbbecskén 'egy kissé később' (1670: jobb későbbecskén lenni az dolognak jól, hogy sem futva rosszabbul [TML V, 264 Teleki Mihály Bethlen Jánoshoz]), kijjebbecske 'egy kissé messzebbre/távolabbra' (1790: Rutkai $\operatorname{Vr}(\mathrm{am})$, látom magais igen szereti Tŏvisset, s nem örőmest válna meg tölle, de kéntelen, mert szegény; Hunyad Vármegyéb(en) szándékozik meg fészkelödni, s ha módja lenne benne, ott valamivel a' Tŏvissi Részinek árrával kŭllyebetske terjeszkedni, mert nem capax szegény feje ideis tovais figyelmezni [Celna AF; TL. Málnási László ref. főkonz. pap gr. Teleki Józsefhez]), lejjebbecske 'lennebbecske' (1796: Antiqua Populosa Sessio... a Falu Derekánál lejjebbetske [Cikud TA; WassLt]), messzebbecske 'kissé messzebbre' (1782: (A föld) meszebecske vagyon [Kászonújfalu Cs; MvLev. Vegyes anyag 8]), távolabbacska 'messzebbecske' (1810: Margita esik mint egy' őkőr szekérrel négy ora alat meg járhato tavulságra, más hely Tasnádon (!), mely távulabbacska vagyon [Pacal Sz; Ks 76. 444 Conscr.]) stb., illetve ritkábban T + DIM: későcskén' (egy kissé) későre' (1718: enjim let volna a kŏtelesség hogj a Groffnak eléb inserviálylyak, de késŏcskén érkezvén kevés Szŭretemen vagjok occupatus [Postelke KK; Ks 96 Székely Ádám lev.]), messzecske 'meglehetős távolságban' (1747: a kaljániak Marhákat legeltettek ottan, de meszszetske lévén tőllők egyet sem ismértem kőzüllök [Báré K; Székely lev. Supl. 28-39 Marosán Gligor (38) zs vall.]), távolacska 'kissé messzebb' (1728: mihellyen az Vrfi ... Czirmai nevŭ Szolgája, és iffiabbik Szotyori Ferencz Vram érkeztek, mindgjárást ă 
Sertéseket lŏdŏzni kezdették, s még akkor az vrffi távullocska volt [Hidvég Hsz; Mk I Joan. Barabás (56) jb vall.]), távolkán 'kissé távolabb' (1657: Erre én a fejedelemmel ugyan pirongató kemény szókkal is írattam, de addig halogatá, hogy az ellenség is megértvén ugyan az én szerencsi földvárnál lételemet is, igyekezik vala reám jűni, de azonban nyelvet fogván az Ibrányi hadából, minden állapotjának végére ment, mind az helynek alkalmatosságának, rossz vigyázásának és tőllem is távolykán lételének [KemÖn. 257]).

A második csoportba a melléknévből szófajváltó képző segítségével létrehozott határozószókat soroltam. Ezek alaktani felépítésében az - a klasszikus nyelvtanok által esetragnak (Keszler 2000: 218), az újabb nyelvleírások szerint szófajváltó képzőnek (Kádár 2007: 154) tartott--(A)n toldalék közép- és felsőfokban a fokjel után áll, és foktól függetlenül a kicsinyítő képző megelőzi. Tehát a határozószók ezen csoportjában voltaképpen az történik, hogy a melléknév diminutivizálódik, majd ez a diminutivizált melléknév egy szófajváltó képző hozzáadásával határozószóvá válik. Attól függően, hogy alapfokú vagy fokozott melléknévhez járul a kicsinyítő képző, két csoportot különíthetünk el: az első csoportba tartozó határozószók morfológiai felépítése: tő + kicsinyítő képző + szófajuáltó képzó: butácskán 'kb. maflácskán' (1807: (A szökött rab) beszédjét ugy ejti, mint a' vastag nyelvŭek tudniillik butátskán 's keményen, egyeb aránt folytában 's akadozás nélkŭl, bátran beszéllŏ [DLt 674 nyomt. kl]), csinosacskán 'szépecskén' (1736: Az ... udvarrol ... vagyon ... aditus ... Csinosotskán faragott ... fenyő deszka kapun rajta lévő kis Csekélly két vas Sorkokon forgó vas reteszszel zarlodo gyalog ajtotsával egyetemben [Várhegy MT; CU]), drágácskán 'drágábbacska áron' (1756: Fyat falván ${ }^{a}$ levő kis portziotskájának nékem engedését az Aszszonynak, noha drágatskán, de meg is Szivemnek telyes háládatosságával kőszőnőm ... egész igyekezettel rajta vagyok, hogy hová hamarább meg Szerezhessem [Bonyha KK; JHbK XXIV/10. - ${ }^{a}$ Fiátfva U]), gyérecskén 'ritkásan' (1813: egy Csür vagy szekér szin, az oldalai sővénynyel gyéretskén bè fonva [Koronka MT; Told. 18]), ifjacskán 'fiatalocskán' (1629/1676: Nagj Erdéllyi Miklos is megh halvá(n), igen Ifiacská(n) maradott Bátyá(m) [Somkerék SzD/Sv; WassLt St. Erdelly vall.]), ittasacskán 'kapatosan' (1778: mint egy ittasotskán mondotta ezeket alattomba sugva [K; KLev.]), hosszacskán 'vminek a hossza mentén' (1739: a miolta én értem minden esztendőben használtak a Sz: Benedeki Révészek égy darabotska rétet a Révre menő uton alol hoszszatskán és keskenyen a Viz le mentére [Dés; Ks 28. V]), keménykén 'keményecskén, egy kissé keményen' (1736: Tőmlecz Tartoi kŏtelességheis kénszeritette, hogj keménykén viselylye magát, az elegy belegy személlyekbŏl allo Rabokhoz [Kv; TJk XV/12. 5]), melegecskén 'langyosan' (1778: A' kiknek a' Torkok, oldalok, vagy mejjek 
fáj, azok mindent melegetskén igyanak [MvÁLt Mátyus, ConsSan. gub.]), nehezecskén 'üggyel-bajjal, döcögve' (1790: A' Szarvas Marhák itt mostis dŏglenek, és tilalom alatt vagyunk... melly miá az ott valo oeconomia nehezetskén foly [Sztrézakercesora F; TL. Wesselényi Dániel gr. Teleki Józsefhez]), nyersecskén 'meglehetős gorombán' (1855: Én se kértem ... nyersecskén nyilatkozni [ÚjfE 283]), rosszacskán 'rossz egészségi állapotban, betegecskén' (1724: En is Isten engedelméből, holnap ki fogok menni, csak Köleséri Ur(a)m(ma)l conferalhassak, mivel az estve is roszszatskán vala ${ }^{a}$ [ApLt 1. - ${ }^{a}$ Ti. a felesége gr. Haller János anyósához Nsz-ből]), szépecskén 'elegendő számban, mennyiségben' (1722: ki adta(m) kevés pénzetskémet dolog feiben, az által folj az oeconomia(m), amaz nagy szŭkségben szépecskén $\operatorname{adta}(\mathrm{m})$ el Gabonácskát, abbol teremptettem vala pénzetskét [KJ. Rétyi Pál lev. Fog-ból]) stb. Olyan származékra is van példa, amelyben a kicsinyítő képzőt és a szófajváltó képzőt fokjel előzi meg, a határozószó morfológiai felépítése: tô + fokjel + kicsinyitó képző + szófajváltó képzó: bövebbecskén 'bőségesebbecskén' (1758: csak adgjon Isten bŏvebecskén mint Karkoban ${ }^{a}$ [TLMiss. - 'Boroskrakkó AF]), felesebbecskén 'többecskén' (1725: ugy történhetik, hogy ha az alatt felesebbecskén jüne penz kezem közi, egészlen is meg maradhatna [Darlac KK; Ap. 2 gr. Haller János Apor Péterhez]), keményebbecskén 'kissé erélyesebben' (1732: csag (!) eppen aszt láttam vona leg szükségesebbnek lenni, hogy az M: Ur ot létiben ö Nganak kemenyebbecskén szollat vona, és tanácsával is éltette vona a M: Ur, ŏ Ngát [Kóród KK; Ks 99 Kornis Ferenc Kornis Istvánhoz]), régebbecskén 'kissé régebben' (1761: Galambadon a menyi Drágány vagyon mind edgy féle, ennek az itt valonak Szamontzája... régebbetskén jőttek volt Galambadra, mert ez sokat budoklott imit, amot [Mezőcsávás MT; TL. Burdusán Gligor (60) jb vall.]), szebbecskén 'vmivel szebben' (1748: miolta Ferenczi Uramhoz ment férjhez, az ólta maga szebbetskén jár, mint az elŏtt [Torda; Borb.]), szebbedkén 'kibetưzhetőbben' (1670: Uram, én nem bánnám, bár maga írna, mert talám még valamivel kevesebbet írna, csak írna egy kevéssé szebbedkén, ne kelletnék oly főtöréssel elolvasnom [TML V, 5 Naláczi István Teleki Mihályhoz]), szélesebbecskén 'kissé szélesebben, szélesebbkén' (1733: Minthogy az hegy teteje felé meg rŏvidult az láb, potoltuk azzal hogy szelesebbetsken mertük fellyŭl, mint aláb [Kiskerék AF; JHb XXVI/44]) stb.

A melléknév és határozószó tehát rokon vonásokat mutatnak a diminutívum szempontjából. Ha melléknévi és határozószói tőhöz kicsinyítő képző kapcsolódik, akkor ennek funkciója az, hogy jelentését gyengítse (pl. magasacska 'kevésbé magas', csúnyácska 'kevésbé csúnya', feljebbecske 'nem egészen fel'), és általában olyan beszédhelyzetben jelennek meg, amelyben a beszélő ódzkodik a puszta tövet kimondani, hiszen nem akarja, hogy udvariatlannak tekintsék (Mendoza 2005: 166). Történetileg a melléknév- 
hez és határozószóhoz illesztett diminutívum eredeti funkciója pontosan a tő jelentésének gyengítése, enyhítése volt, ugyanis természeténél fogva kicsinyítést fejez ki (uő. uo.). A nyelvtörténet folyamán metaforikus jelentésváltozáson ment át: alapjelentésében a kicsiség fizikai fogalom, amely a fizikai világról való tudás alapján alakult ki, és olyasmire vonatkozik, ami a beszélő számára pontosan mérhető. Az ilyen konkrét jelentéshez viszonyítva, melléknévi és határozószói tőhöz kapcsolódva, a diminutívum metaforikus jelentést kap, és a tőben jelölt attribútum vagy minőség gyengítését fejezi ki. ${ }^{85}$

\section{IV.7.4. Kicsinyítő képzős névmások a SzT.-ban}

A SzT.-ban két olyan névmás van, amelyhez kicsinyítő képző járul: az amicske és az annyicska. Annak ellenére, hogy nem gyakori a kicsinyítő képzős névmás, mégsem tekinthető kivételes képzésmódnak, hiszen a névmás alapvető funkciója a helyettesítés, ,, toldalékolhatósága, mondatrészszerepe megegyezik a helyettesített szófaj tulajdonságaival" (Kugler-Laczkó 2000: 165) (a fónévi névmások például főnévre jellemző toldalékokat vehetnek fel, és főnévre jellemző mondatrészszerepeket tölthetnek be stb.).

A két kicsinyítő képzős névmás értelmezése a SzT.-ban amiatt nem megfelelö, mert a helyettesítő funkciót emeli ki, holott ez a szófajnak a sajátossága.

Az amicskének például főnévi és melléknévi jelentését különíti el, bár valójában arról van szó, hogy ez a névmás mindkét szófajt helyettesítheti: fónévi jellegű használatban jelentése 'amennyicske, amennyikó', az adalékok 1644/1785-ből: az Ur Isten ... az én Szerelmes Attyámfiát Nyagu Borbárát rendelte Házas társul ... Haza Törvénye szerint a micském van nagyobbára vélle együtt szerezvén őtet illetné [BfN Kémeri Huszti Menyhárt erdélyi főharmincados végr.], 1710 körülről: az szebeni nyomoruságos Estendők alatt ki vesztegettem vala kevés Pinzemet, a' mittske meg maradhatott az terhes kŏltésimböl [Cs. Vajda lev.], 1748-ból: a' mitskéje volt, el takaritatta [Ne; Told. 56]; 1782: Veress Samuel ... házasságának oly éretlen idejiben oka a' volt, hogy arván maradván a' mitskéje, két felé osztva maradott ne pusztulyon el [Torda; KW], 1791-ből: a' mitske vagyonis a ketskék által el rágatot [Doboka SzD; MkG], illetve a XVIII. század végéről származnak: a' mitském vagyon, mind a' Szegény Anyám Aszszony Jussán vagyon $[\mathrm{AbN}]$. Melléknévi jellegű használatban jelentése 'ami kevéske', az

85 "In its fundamental sense, the concept of smallness is a physical notion, anchored in our experience of the real world, and refers to that which we can sensorially perceive and/or measure. From such concrete basis, the diminutive, when applied to adjectives and adverbs, come to indicate an attenuation of their meaning, a weakening of the degree to which the relevant quality or attribute is present" (Mendoza 2005: 166). 
egyetlen adalék a XVIII. század végéről való: a'mitske Joszagotskám vagyon mind a' Néhai b.e. Szaniszló Sigmond Uram Joszágibol valo [AbN].

Az annyicska címszó jelentése a SzT. szerint 'akkorácska', bár tulajdonképpen ez csak a kontextusból adódó jelentés. A mutató névmásnak (mint a többi névmásnak is) nincs önálló jelentése. A távolra mutató névmás egy speciális grammatikai (konnexiós) használatra kötődött le, mégpedig az utalószói szerepre (Kugler-Laczkó 2000: 166), ami azt jelenti, hogy ezt az üres jelentésű szót a mellékmondat tölti fel jelentéssel. Az adalék 1813-ból való: ugy gondolkodtam, hogy kedves Bátyám Uramat meg instáljam arra, mely szerént Kedves Bátyám Uram a' maga Földgyéből keresztúl annyitska helyet a'mennyi egy kőzőnséges Fogadonak szúkséges ... által adni méltoztassék [Dicsősztmárton; RLt O. 3 Gyárfás Ferenc Weress Sámuelhez].

\section{IV.7.5. Kicsinyítő képzős számnév}

A SzT. eddig megjelent 12 kötetében egyetlen példa van diminutívummal ellátott számnévre ${ }^{86}$, bár ennek az adott mondatban aktuálisan főnévi szerepe van (fónévi esetraggal van ellátva, fônévre jellemző szintaktikai funkciót tölt be): 1721: alazatoson még szolgalom az Mlgos Urnak ha nekém is ég sértesecskét küld ézen meszét le vivő talyigan tavaj nèm busitotam az Mlgos Urat mivèl vot de most égyecsket őletem vot mind aprolikja mind szalonaja mind egy falatig el fogot (!) [Szentpál K; TK1 Mihály Deák Teleki Pálhoz]. Grammatikailag semmi nem látszik indokolni a SzT. által megadott melléknévi jelentést: 'kicsinyke'.

\section{IV.7.6. Kicsinyítő képzőt tartalmazó igék}

A magyarban nagyon kevés olyan ige van, amelyhez diminutívumot lehetne kapcsolni, és azok használata a gyerekorientált beszédszituációra korlátozódik (alukál, pisikál), szemben más nyelvekkel (pl.: a szláv nyelvek), ahol az igék diminutivizálása termékeny képzésmodell.

Ez a kategória azért tér el a többitől (pl. a főnévtől és melléknévtől), mert nem az igéhez mint alapszófajhoz járul a diminutívum, hanem a kicsinyített melléknévből denominális igeképzővel jön létre az ige. Morfológiai felépítésük: tô + kicsinyitő képző + igeképző. Mégsem soroljuk ezeket a származékokat a melléknevekhez, hiszen a diminutívum az ige alakjához mindenképpen hozzátartozik, még akkor is, ha különösebb jelentésmódosítást nem okoz.

${ }^{86}$ A számnév mint önálló szófaj problematikusságával kapcsolatban vö. Keszler 2000: $70-1$. 
Mindössze két származék sorolható ide: a kicsidell, amelynek jelentése 'kicsinek tart' (1763: ha a ket Sézás Lo nagjab let volna ugjan ada Sűtném mast Tudi (!) Sigmand Urnak, de kitsidelli [Kóród KK; Ks CII. 18 Szarka József tt lev.]; 1776: azon Bikát az Falu tellyesseggel nem szerette azert hogy kicsidelt es maskentis disztelen, nem szep faju Bika [Szentháromság MT; Sár.]), illetve a kicsidit 'kisebbít' jelentésben (1690: Ha az károkat kicsiditene ... mondgja azt reá, hogy ... ha vala holott valamit fizetnekis tsak semmi, őtőd, hatod, meg tized reszet sem adgyak [Ebesfva; Törzs. Bethlen Sámuel fej-i instr-ja]).

\section{IV.8. A kicsinyítő képzős származékok szintaktikai jellegzetességei}

A kicsinyítő képzős származékok szintaktikai vizsgálatakor két aspektust kell figyelembe vennünk: egyrészt az a kérdés, hogy milyen mondatrészszerepet töltenek be, másrészt pedig az, hogy befolyásolja-e a kicsinyítő képző az illető szó bővíthetőségét (ugyanolyan bővítményeket vehet-e fel, mint az alapszó, vagy leszúkíti, módosítja a kicsinyítő képző a bővítmények körét).

\section{IV.8.1. A kicsinyítő képzős származékok mondatrészszerepe}

A kicsinyítő képző - mivel nem szófajváltó képző - alapvetően nem változtatja meg az alapszó szintaktikai szerepét, vagyis a származék ugyanolyan mondatrész lehet, mint az alapszó.

Az erdélyi régiségben a SzT. adatai szerint a kicsinyítő képzős származékok leggyakrabban (41,13\%) alanyi szerepben fordulnak elő (pl.: 1667: Ez Várban mennek bé nap kelet felöl három öregh kapun, kiknek a' külsö kapujan vagyon a' kapu oszlopjában szegezve egy kis lánczocska ${ }^{87}$, mellyel az nagy kaput, és kis ajtot öszve foglalván zárhatni be [UF II, 334]; 1669: Ezen pinczeben vagyon ... Egy cziknak valo ŭres hordoczka [Királyhalma NK; Ks. 67. 46. 24a]; 1704: Pekriné asszonyomtól valamely kicsi kutyácska adattatott volna az asszonynak [WIN I, 269] stb.), ezt követi a tárgy (13,75\%) (pl.: 1570: Latthya hogy egy leankat az leorinch deak leaniat ky tollyak az Ayton mynd az kyssebyk gyermekel egetembe [Kv; TJk III/2. 28]; 1729: Az Ur erdejeből vagtam ... egj Kapu ally fát, s egj agasocskat [A.karácsonyfva AF; Told. 31]; 1757: minek utánna ki hordatik néholt a' Bányábol ki jővő, néholt pedig Tokbol a' Bánya, szájáhaz csatornákan dirigált vizre harom arasz szélességú és négy arasz hoszszuságu ládátskát tsinálúnk, a' fede-

\footnotetext{
${ }^{87} \mathrm{Az}$ adalékokban dőlten szedem a különböző szintaktikai funkciókban megjelenő kicsinyítő képzős származékot.
} 
lét sűrűn meg furdallyuk [Zalatna AF; JHb Borsai István kezével] stb.), a minőségjelző (11,13\%) (pl.: 1585: Jlona Damakos Mathiasne vallia, Nallam lakik vala az Ersebet mint egy tizenket eztendeos leanka vala, hat vagy huzon eot penzt gywteogetet volt az Zonzed Azzonyhoz, kenyeret fatis Adot volt oda ... ez kisded vetket tudom hozza [Kv; TJk IV/1. 506]; 1732: az Samsondi territoriumon ... egj kis kender főld orotványbol valo ... Ezen felyül más orotvány ... megis e mellet más kicsinke orotvany [Mezősámsond MT; Berz. 5. 42. S. 59]; 1803: Egy Sőtét zőld festékú kopottatska rostélyos scriptorium szegeletes négy Lábakon [Ne; DobLev. IV/858. 1a] stb.), a helyhatározó $(7,45 \%)(1657$ : Erre én a fejedelemmel ugyan pirongató kemény szókkal is írattam, de addig halogatá, hogy az ellenség is megértvén ugyan az én szerencsi földvárnál lételemet is, igyekezik vala reám jüni, de azonban nyelvet fogván az Ibrányi hadából, minden állapotjának végére ment, mind az helynek alkalmatosságának, rossz vigyázásának és tôlem is távolykán lételének [KemÖn. 257]; 1736: négy agosotskára epitett, perellyere fedett az két oldalába ragasztott kis Szekér szin vagy Arnyék [Noszoly SzD; CU]; 1790: Rutkai $\operatorname{Vr}(\mathrm{am})$, látom magais igen szereti Tŏvisset, s nem örőmest válna meg tölle, de kéntelen, mert szegény; Hunyad Vármegyéb(en) szándékozik meg fészkelödni, s ha módja lenne benne, ott valamivel a' Tŏvissi Részinek árrával kŭllyebetske terjeszkedni, mert nem capax szegény feje ideis tovais figyelmezni [Celna AF; TL. Málnási László ref. főkonz. pap gr. Teleki Józsefhez] stb.), a mennyiségjelzó (7,26\%) (1761: (Lopott) Papuk Péter ... Szurdukán Juontol egj akócska vagj buria pálinkát [Fazsacel H; Ks 113 Vegyes ir.]; 1826: a praetendált jövedelemnek kevesed része az özvegyi kevés Joszágnak az igazi jővedelme [Ne; DobLev. V/1114. 9a]; 1847: a' játzintok elvitelével nem akartam alkalmatlankodni, mert sokatska pak, hanem mihelyt lesz kitől, elkűldőm [Kv; Pk 7] stb.), az állítmány (4,29\%) 1755: (A) nagy házbol ... két ajto nyilik ... edjiken nyitanak s.v. az Arnyék székre, mellynek ajtoja minthogy nintsen meg duplázva az házban lévő ágyhoz kŏzel esvén; alkalmatlanotska [Ludesd H; BK sub nr. 1020]; 1772: mi ezt eszre nem vehettük ben a házban külömben is már akor borosatskák voltunk [Sályi TA; Mk V. VII/17] stb.), az aszemantikus határozó (2,47\%) (1579: Igen nagy insegbe, es zwkelkedesbe volt az zegenyseg mostanis mely sok zwksege vagio(n) e kewes borochkara kynek az hire nagiob hogy sem mint Az Summaia [Kv; TanJk V/3. 203b]; 1582: semmikeppen milto nem volna az eó faluia dezmaczkaiatol azokkal egi arant walo arendat fizetni [Gyf; ETA V/1. 17]; 1765: Az Udvarb(an) meg kivantato Ajtocskákra tŏb szŭkséges helyekre... erog(altam) Nro 239 [Nagybarcsa H; Ks 71.52 Szám.] stb.), a birtokosjelzó (2,32\%) (pl.: 1613: mely Summaczykanak hatra maradot Tizen hat forintiat my eleottwnk veúe fel ... es igy Aztalos Miklos vallast teon my eleottwnk, hogy Radnothy Jstua(n) vram Jmmar Egy penzeuel sem uolna 
eó nekj ados [Kv; RDL I. 92]; 1662: ez a gyermek oly nagy szopható, hogy ugyan mód nélkül vagyon. Egyébaránt nem aránszom szegénykének semmi nyavalyáját [TML II, 242 Veér Judit Teleki Mihályhoz]; 1759: az midőn le akartunk volna takaradni jobbanis ell álmosodván az Gyermek, azon szájocskája nyelve reszketése erőssebben réá jőtt [M.csesztve AF; Ks Mikes Antal lev.] stb.), a társhatározó (1,95\%) (pl.: 1698: egj Tornacz ... ajtocskaval edgjütt [Kóród KK; LLt fasc. 72]; 1732: a Tabernaculum asztalos munkával aranyozva ... kicsiny vas sarkokon fordulo ajtocskájával [Kóród KK; Ks 12/I] stb.), az állapothatározó (1,63\%) (pl.: 1683: Buza Perceptioja Kalongyába(n) Asztagocskakban rakatott Kal(angya) [Szúv; UtI]; 1700: Az gabona ... asztagocskaban, es Csürbeli odorb(an) vagion [Bál. 71]; 1724: Rusz alias Hafrik Mihállynak az Anya ... bé jŏ az Atyám házáb(a) egj kis csecsszopo Gyermekecskével a karján, es kérdi az Anyam ... hol vetted menyecske ezen kis Gyermeket [Nagykájon SzD; BK Kiskájoni lev. Czermure Iuon (46) jb vall.] stb.), valamint a módhatározó (1,11\%) (pl.: 1584: az mit hozza kezdeth aprodonkenth Jomodon felúette rezeth es elmenth [Kv; TJk 4/1. 292]; 1599: Az Eoregh Marok Vasnak szama ... 4762, keolt el benne 469 ... aprodonkent attuk kit alab kit fellieb az mit èrt [Kv; Szám. 8/XI. 27]; 1754: vagyon erdő árrábol gyưldőgelt penze ${ }^{\mathrm{a}}$ szepetskén [Dés; DREmLt Conscr. III. 51. - ${ }^{a}$ A ref. eklézsiának] stb.).

Az egyéb szintaktikai szerepben megjelenő kicsinyítő képzős származék nem éri el az 1\%-ot, ilyen az alárendelt alany (pl.: 1733: hogy nékem se légyen semmi panaszom, a mint hogy nem sok adósságocskám lévén hátra ... tehát azokat fizesse meg az Vr Battyám vram [TK1 Teleki Sámuel lev.]; 1753: az fen megh irt Erdŏhez tartazvan megh egj darabacska, az melljetis ... attunk ŏ kegjelmenek ... husz vonas forintakban [Torockó; Bosla]; 1807: ezen ... puszta hely mellett a Szamosnak egy kis ágotskája fojván el egy Pallo vagyon épitve [Apahida K; RLt 0. 5] stb.), a részeshatározó (pl.: 1654: praemendatt attam ... Haro(m) Agar kutjonak lib. nro 9 [Egeres K; Ks 70 Szám. 51]; 1666: Az Apro leankaknak is hattam ... egy ŭnő tinőt (!) [Abafája MT; Told. 21]; 1722 k.: Ennek az Ekklésiátskának égy darab szŏlŏje van [Unoka MT; GörgJk 161] stb.), az eszközhatározó (pl.: 1686: az tordai vitézek elrugazkodának, engem elszakasztának az lobonczok ... sokan vagdaltak hozzám, egy botokával hántam ellent [TT 1889. 509 SzZsN]; 1765: Varga Gyŏrgy ... kezében lévŏ kis ujjomni pálczikával maga elŏtt Czivészlett, hogy valamiképpen belé ne szaladgyon Szabaszlai Ur(am) és meg ne foghassa [Szépkenyerüsztmárton SzD; Eszt-Mk Vall. 13]; 1783: égy sebet ejtven Kálo Miskán, egy Pátzikoval, mellyet kutya ŭtni vett volt kezéb(en) [Koronka MT; Told. 19/81] stb.), a partitivusi határozó (pl.: 1777: Elsŏ Tábla ... a mint az Aranyos teriről a' vőlgy fel menyen a fenn lévő három águ gödrŏk vagy vŏlgyetskék kŏzt lévŏ három bértzetskék kŏzŭl, a' felsŏ, vagy nap nyugott 
felŏll valo bértzin fel mindenűtt a tetŏre [Magura TA; Ks 89]), a hasonlító határozó (pl.: 1710: ugar sém maradott tőb két darabocskánál [Cssz; BCs]; 1731: nem is volt edgy kis fako Lovatskájánál tobb de aztis el vitte mikor él ment [Kendilóna SzD; TK1 St. Szakáts (40) lib., aulicus et conventionatus coquus vall.]; 1762: mikor én ide szármoztam akkor a szamos egészen innét Magosmart felöl fojt ... s tul Közepfalva felöl a hol most az Exp(onens) urfi malma vagyon semmi árka vagy nyoma nem volt egyéb egy kis viz nélkül valo Ergétskénél ... lévén ottan az elöttis valamely kitsin száraz viz nélkült valo Ergétske s abbol kapott osztég a viz oda [Virágosberek SzD; SLt XXIV. 5] stb.), a fok- és mértékhatározó (pl.: 1739: szomoru és véletlen actusok volt az Nagy Táboron lèvöknek, vgy mint Mascherozván Orsova fele alá Landorfejerváron jocskaval alab ... az exploratorokot az fak melöl harmincz ezerig valo jancsár puska szokal excipialtak [Ks 99 Kornis Antal lev.]; 1769: az ország uttya ... a' mostani hidon felyül égy darabocskával ki tért [Apahida K; JHbK XLII/24]; 1843: a pank egy darabotskával bennebb esik a határnál [Körtvélyfája MT; LLt] stb.), az idóhatározó (pl.: 1783: Megnyugodni látszatott égj darabotskáig az eŏ nyughatatlan elméjek [Torockó; Thor. XX/5. 42]; 1786: a' kőzelebb el-mult télen egy darabotskáig Szappany Utzában Pós Thrésiánál laktam [Kv; KLev.]; 1809: most késöttskén vagyan (: s A Pappiros Malmunk késŏre lett le készíttése miatt :) a kivánt két kötés Pappirassat előre küldem, oly alázatos kérelem mellett, hogy a Rongyok által kŭldésében nem késni méltoztassék [Bogát NK; UszT 1600] stb.), a célhatározó (pl.: 1597: B. V. kwlde Zekel Martont Vi Varban Egy kis Ebechikeert [Kv; Szám. 7/XII. 56 Filstich Lőrinc sp kezével]; 1777: leváltam ujra őtt Magyar forintokot 8 Den az Ns Küküllő vármegyei Erdő allyai fundusotskára [Kük.; Ks 66. 45. 17d] stb.), az eredethatározó (pl.: 1772/1812: Bikfa keskeny Deszkatskákbol öszve rakott s fa Sorkokon járo Kapu [Kál MT; HG Conscr. 128]; 1795: ezen Háznak padlása vagyon hat darab Gerendákra rakott, és helyheztettett Bükfa Deszkátskákbol [Algyógy H; Ks 74/56 Conscr. 9-10]; 1825: egy ügyes jo nagyobb Marhatarto Istállo ... felső Deszka padlózattja dirib darabotskábol [Dés; DLt 595] stb.), a számállapot határozó (pl.: 1738: ittenis hagymázban sokacskán kezdettek betegeskedni egy nehanyon holtakis meg [Gyeke K; Ks 99 Kornis Antal lev.]; 1831: kettetskén által mentưnk Ábelhez a Fogadóshoz, és egy fertály Páinkát nálla meg ittunk [Dés; DLt 332. 4]), a nuncupatious (pl.: 1761: Az alsó Contignatioban ... vagyon egj egj németes oldalú egj contiguitásban lévŏ Stukaturás három kisded alkalmatosság, mellyek jollehet Stukaturások, mind az által Boltotskáknak neveztettnek [Szászvessződ NK; JHbK LXVIII/1. 211]; 1803: szánto főlgyeitis tudom ... de azok kőzzúll kevesett mondhatok csak jótskánakis, nagyobb része el soványodott majd a haszonvehetetlenségig [Márkod MT; BetLt 5 Emericus Kováts (53) ns vall.]), az eszközlő határozó (pl.: 1630: az szomszed 


\section{3. ábra. Szintaktikai szerep}
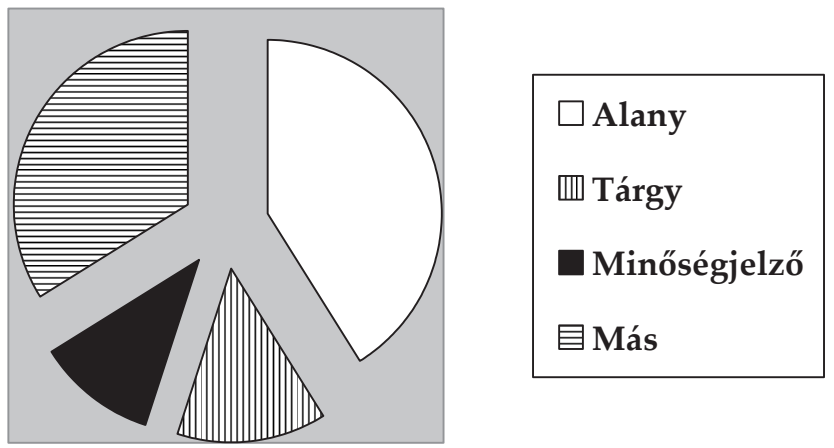

... Azzoni ... hiuata engemet az Leanioczkaiaual altal hozzaia az paitaba [Mv; MvLt 290. 187b]), a jelzői értékú határozó (pl.: 1778: Vagyon egy fábol ki mettzett Apálcza (!) kép egy kisdeddel [Csapó KK; Berz. 4. 8. C. 18]), a kijelöló jelző (pl.: 1789: (A föld) alábbatska levŏ szellyessége ... [Kisadorján MT; Sár.]; 1800: Ezen Kedekistirol (!) Malmokon alábbatska levő Sos Forrás penig ma nincs meg [Indal/Mikes TA; JHb]; 1831: azon adosságnak jobbatska részit tsipegve tsupogva per partes $170 \sim$ száz hetven Rforintokban s 20 Xrokban, kezemhez vettem [Hagymásbodon MT; Pf Pogány Sándor lev.] stb.) és az értelmező jelző (pl.: 1653: a kastélya falait az ácsokkal bérleni kezdik nagy cserefákkal belöll, és tölteni földel. Minden ember: bíróné, polgárné, papné, pap, bíró s polgár, nagy és kicsid, a ki életét szerette minden ember a míglen megkészüle, csak hozzája nyult akkor [ETA I, 97-8 NSz. - aA mv-i templomváréit]; 1653: Vet magahoz ... Egi Cziatlo lanczot kisdeget [Ilencfva MT; DLev. 1/II. B]; 1710 k.: Bort kevesecskét mindenkor, sert eleget ittunk [BÖn. 575] stb.). Továbbá több adalékban is a kicsinyítő képzős származék megszólítás, így nem szerves része a mondatnak (pl.: 1568: Anna consors Stephani Nagy ... fassa e(st), Ezt hallotta(m), hogy ... az leant ... Jgy zida, kurúa nochke, veryelek, de egzer se(m) wtte [Kv; TJk III/1. 185]; 1766: le menvén Damokos Ferentz a' Battyahoz Damokos Janoshoz monda az Angyának Damokos Janosnénak jol mondotta ked Angyo (: mint hogy az elōtt valo estve ott volt :) hogj ne menyek el hanem hallyak itt mert valami bajom lész Azon beis tellyesedék rajtam [Szilágycseh; BfR 104/2]; 1806: jőjen kend Ángyo szoporán lásson ujjságot [Dés; DLt 250/1808] stb.), illetve két olyan adalék van, amelyekben idegen (pontosabban latin) nyelvü szövegben jelenik meg a diminutívummal ellátott szó, ezért nem lehet mondatrészszerepet tulajdonítani neki (pl.: 1529: Cui dedi pro expensis fl. octo ac pro dolman Swpicza caligis et calceis ac sartori quinque et denarios 
90 [Vh; MNy XXXI, 125]; 1531: panum michi pro una supicza seu tunica parva purgamal emere feci pro fl II 1/2 [Vh; DomH 112]).

A kicsinyítő képzős származék tehát főleg alanyi szerepet tölt be az erdélyi régiségben, ezt követi a tárgy és a minőségjelző, a többi szintaktikai szerep pedig együttvéve nem éri el az alany arányszámát (1. 3. ábra) ${ }^{88}$. Az adatok tehát azt mutatják, hogy voltaképpen semmi blokkoló szabály nem állapítható meg a régi nyelvben, amely a diminutívumoknak a mondatbeli szabad elhelyezkedését gátolná, ez pusztán az alapszófajtól függ, és ezen a kicsinyítő képző semmit sem változtat.

\section{IV.8.2. A kicsinyítő képzős származékok bővíthetősége}

\section{IV.8.2.1. A kicsinyítő képzős származékok bővítményei}

A kicsinyítő képzős származékok szintaktikai viselkedésének vizsgálata során az a kérdés merül fel, hogy befolyásolja-e a képző a származék bővítményeinek körét (pl. csökken-e az adott szófajú szó lehetséges bővítményeinek száma), megszabja-e, hogy milyen bővítménye lehet az illető alaptagnak, illetve kizár-e másokat a szintaktikai vonzásteréből.

A SzT. adalékai azt mutatják, hogy a kicsinyítő képzős származék ugyanúgy bővíthető, mint az alaptag. A kicsinyítő képző inkább a bővítmények jelentését szükíti, ugyanis blokkoló elemként müködik olyan bővítményekkel szemben, amelyek a 'nagy' jelentésmezejébe tartoznak.

Az erdélyi nyelvben - a SzT. adalékainak mennyiségi vizsgálata szerint - a kicsinyítő képzős származék leggyakrabban bővítmény nélkül fordul elő, tipikus bővítménye valamilyen jelző (főként mennyiség- ${ }^{89}$ és minőségjelző), de - az alaptag szófajától függően - alanyi vagy határozói bővítménye is lehet.

Az adalékok 28,30\%-ában nincs bővítménye a kicsinyítő képzős származéknak (pl.: 1759: Egy ablakocska eleibe valo tarka Sellyem superlátot [Nsz; Tsb 7]; 1763: ablakotskái dészkával bé tsinálva vadnak [Hortobágyfva Szb; Born. XXIXa]; 1765: az Executorok Biráinkat szidták verték ... ha pedig ajjándékocskát adhattak Biráink nékik, s az intertentio dolgabanis kedveskedhettek, akkor tsendesebben viselték magokat [Szeszcsor H; Eszt-Mk Vall. 251] stb.). Mennyiségjelző az adalékok 18,66\%-ában kapcso-

\footnotetext{
${ }^{88}$ Hasznos volna a mai nyelvben használt kicsinyítő képzős származékok szintaktikai szerepét is megvizsgálni, és összehasonlítani a SzT. adatai alapján kirajzolódott képpel. Bár nincs számszerü adatom erre vonatkozóan, mégis azt feltételezem, hogy kicsinyítő képzős származék sokkal kevesebb szintaktikai szerepben jelenik meg a mai magyarban, mint a régi nyelvben.

${ }^{89}$ A mennyiségjelző ilyen nagyfokú gyakorisága a szövegtípussal magyarázható, ugyanis nagyon sok adalék valamilyen összeírásból, leltárjegyzékből származik.
} 
lódik az alaptaghoz (pl.: 1636: az kamoraczkan egy ablakoczka. Abbol viszont nylik mas egy fejer fel szer vas sarkos pantos aytó az kamora szekre, azon ket $^{90}$ ablakoczka [Siménfva U; JHb Inv.]; 1729: Az Ur erdejeből vagtam ... egj Kapu ally fát, s egj agasocskat [A.karácsonyfva AF; Told. 31]; 1733: hogy nékem se légyen semmi panaszom, a mint hogy nem sok adósságocskám lévén hátra ... tehát azokat fizesse meg az Vr Battyám vram [TK1 Teleki Sámuel lev.] stb.). Megközelítően azonos a minőségjelző előfordulásának aránya is (18,20\%) (pl.: 1679: Puszta ablakocskaja nro 2 [Uzdisztpéter K; TL Bajomi János lelt. 26]; 1694: az felso Hazacskajab(an) nemet lakik, üveg Ablakocska rajta [Kővár; JHb Inv.]; 1699: vagyon zŏlden festet ajtocskaju almariumocska a falban [Boroskrakkó AF; BfN] stb.). Az adalékok 10,51\%ában mennyiségjelző és minőségjelző egyaránt bővíti az alaptagot (pl.: 1667: az meg nevezett édes Urátol maradott egyetlen egy árva Agacska ugy mint Lázár Imreh ur(am) [LLt 70/13]; 1692: Ló Istálló ... ennek két kis ablacskai $\left(\right.$ !) ${ }^{a}$ [Mezőbodon TA; BK 4. - ${ }^{\mathrm{a} N e m}$ merő elírás ablakocska h.?]; 1772: egy négy szegeletü Ablakatska ... Ezen Ajto felett égy szakadozott Ablakatska láttatik [Kv; BKt Mikes conscr.]; 1803: vékony patyolat nagy keszkenő ... szélein égy égy kissebb ágatskák szkofiummal varrattattak [UnVJk] stb.), 9,17\%-ában több minőségjelző járul ugyanahhoz az alaptaghoz (pl.: 1679: Onban foglalt, kivül vas keresztes, paraszt uveges ablakocskaja [Uzdisztpéter K; TL Bajomi János lelt. 26]; 1681: Innen elébb menvén, vagyon az vas hámor gáttyára nyíló, fenyő fábul csinált mellyékü vastag deszkákbul álló, ugyan afféle deszkákkal meg fedett, fa kilincsetlen fél szeres kapucska [CsVh 90]; 1692: ezen haznak padgyara fel jaro kis vas sarkas, pantos, reteszes, reteszfüs ajtocska vagyon [Görgénysztimre MT; JHb Inv.]; 1790: Ezen Kamarának ... vagyon egy kisdég kerek ablakotskája [MNy XXXVIII, 208]; 1800: ezen erdő hellyen, mit-sem erő apro agotskák vagynak [Csekelaka AF; EHA]; XVII. sz. m. f.: hajra valo hajlott Agaczka [Klobusitzky lev.] stb.). A többi bővítmény az adalékok kevesebb mint $5 \%$-ában fordul elő. Ezek csökkenő sorrendben a következők: alany (3,18\%) (pl.: 1745: az vanyolohoz egy vedres üst, 1 vizmelegitő alkalmasotska [EMLt]; 1746: minthogy az Urfi ö Nga része alábbatska Való ennek gyengesége expleáltatik a felső To felett lévo szakodasban lévő kis foltotskával [Mezőbodon TA; JHb XI/22. 8]; 1755: (A) nagy házbol ... két ajto nyilik ... edjiken nyitanak s.v. az Arnyék székre, mellynek ajtoja minthogy nintsen meg duplázva az házban lévő ágyhoz kŏzel esvén; alkalmatlanotska [Ludesd H; BK sub nr. 1020] stb.), mennyiségjelző és több minőségjelző (3,1\%) (pl.: 1668: Egy kis fekete Aczel Lanczoczka [Mk Kapi György lelt.10]; 1668: Egy kis gyenge Arany Lanczocska, ŏt Arany benne [Mk Kapi György lelt.]; 1788: Két kitsin fejér ajtótska [TSb 47] stb.), kijelölő jelző (2,93\%) (pl.: 1737: a Kapus Bérczecskék mellett [Nagyida

\footnotetext{
${ }^{90} \mathrm{~A}$ kicsinyítő képzős származék bővítményét emelem ki dőlt betütípussal.
} 
K; EHA]; 1806: ezen birtokocskát Sebess Uram birta [Nagymon Sz; Bál. 68]; 1838/1845: A pseudoorvos egy sarlot vagy kést vévén elő, a kelés körül és felett jártatja, mintha éppen aratna, mialatt $e$ beszédkét szavalja el ... [MNyTK 107] stb.), birtokos jelzö (1,38\%) (pl.: 1585: Nemeth Menyhart Arany Gywreochkeye vagion zalagba [Kv; Szám. 3/XIX. 3]; 1692: Tisztarto Háza ... ajtócskája vas sorkokon pántokon járó fūrész Deszkabol valo [Mezőbodon MT; BK Inv. 6-7]; 1750 k./1811: A Csik Sz. Mártoni Janka Miklos Bonumotskái következnek eszerint ... [HG] stb.), kijelölő és minőségjelző (1,05\%) (pl.: 1633: oda ada neki azt az kis darabocska hustis [MvLt 290. 139b]; 1774: Ezen occludált Demonstratiotskat Curiosusabbatskan comportaltam volna az egész Confusioba voltam [Sáros KK; SLt XL Kŏrmŏtzi Joseff Suki Jánoshoz]; XVIII. sz. v.: Azan kis Birodalmotska mellyet ... Arenda titulus alat bir [Usz; Pf] stb.).

A kicsinyítő képzős származékhoz kapcsolódó többi bővítmény (illetve bővítmény-kombináció) nem éri el az 1\%-ot. Ennek értelmében kicsinyítő képzős alaptagnak lehet ${ }^{91}$ fok-mérték határozója (pl.: 1821: Egy kisség durvábbatska ujj Kender Lepedők [Backamadaras MT; CsS]; 1841: Lakatos Ferencz ... egy kissé butácska [DLt 697 nyomt.]; é.n.: Az itt valo Pék fortelyoskodik mivel jó elegjetske a' Buzánk ne(m) igen akarja bé venni [Fog.; KJ Rétyi Péter lev.] stb.), kapcsolódhat hozzá birtokos jelző és minőségjelzó (pl.: 1708: Commendans u(ramna) $\mathrm{k} \breve{~} \mathrm{Ng}(n a) \mathrm{k}$ penig csecsemŏ fiacskaja meg halva(n) ma Temettek el [Fog.; KJ. Fogarasi János lev.]; 1725: néhai Déési János Arva Fiacskáját Pap Gyŏrgytől el vévén ... eo kgle vegye kezéhez és Scholaztatván tanittassa [Dés; Jk 376b]; 1790: Eresztevényi Elek testvér Etsémnek árva fiatskáját ... segitetvén [Eresztevény Hsz; HSzjP] stb.), kijelöló jelzó és mennyiségjelző (pl.: 1630: Nagodnak müis ... mint Keglmes Urunk(na)k kŏnyŏrgŭnk ... méltoztassék azon Negy Falucskainkrol Nova Donatiot Conferalni [JHbK LVII. 31. - ${ }^{a}$ Ti. a fej-nek]; 1751: A' Tsür helly nevezetü gődrős helly ... azon két eletskéknek közepéig hoszszára gondoltatván, keresztúl két egyenlő részekre szakadott [Koronka MT; Told. 31/4]; 1803: tekintse meg ezen két fiutskáinkat, kikért tőrekedűnk [Ebesfva; Pk 4] stb.), birtokos jelzö és mennyiségjelző (pl.: 1629: (Az árváknak) Az Anyai harmadot Excidalnok, Es Jnuentariumba(n) Czinalnok, hogy ieöendeoben eokis tudnak az eo keues Jouaczkaiokat mi volna [Kv; RDL I 146]; 1669: nyoltzad fel nehezek ezwstit ... eleven az Ceh ladajab(a) teotte az Inasnak ket gywrwczkejevel egyŭt [Kv; ÖCJk]; 1757: a Hegjnek két bérczetskéje [Kissolymos U; Márkos lev.] stb.), hasonlító határozó (pl.: 1798: egj Fekete Fodor Fátyol félviseltesnél jobbatska 3//6 [Kv; Pk 6 Pázmány Hedviga hagy.]; 1803: (A ház) fedelire kének (!) még fel ôlni hoszszuságunál hoszszabbatska bűkfa

\footnotetext{
${ }^{91} \mathrm{Az}$ 1\%-ot el nem érő bővítményeket gyakorisági sorrendjük szerint soroltam fel, a százalékos arány feltüntetése nélkül.
} 
Dranitza 50 szál [Kőrisbánya H; Ks 108 Vegyes ir.]; 1841: a kŏ rakástol92 fejjebbetske ésmet le rogyot a tsiko és az edgyik hid alol valo posvány végébe beleesett az iszapba [Dés; DLt 1541. 8a] stb.), birtokos jelzó és több minőségjelző (pl.: 1681: Zarand varmegyeben Bethlenŏsŏn lako szegeny emberek ... Bethlen Domokos vrunknak egy darab idŏk alatt mint ŏs orrŏkŏs iobbagyi adot fizettenek, de Bizonyos idŏktol fogva nem adozvan, mostan meg irt vrnak neveletlen arva Ficskaianak Tekt Nemzetes Iktari Betlen Istvan vrunknak Tutora Tekintetes Nemzetes Véér Kristina Aszszony eo kge ... szofogadatlansagokert katonak altal hozatvan fel azon Betleniŏs nevŭ falubol ket nŏtelen legenyeket [IB. Thuroczi András közbíró Désfalván lakó vall.]; 1688: Egy itt quartelyozo Lutheranus Németnek, recens natus, és ige(n) beteg gyermekcsejét ... meg kereszteltem [Bethlen kör. SzD; UtI]; stb.), kijelölő jelzó és több minőségjelzó (pl.: 1621: azon Thorda es Colosz (!) warmegieben leueo kiczin Jozagoczkayat birhassak [Gyf; LLt Fasc. 155]; 1770: a' Szasz Regenieknek azon altal járo Kis Hidasotskája a Mellyet ... a' viz által gyakorta el rontatott pallo helyibe tsináltattanak [Szászrégen; Born. XVI/79-80 Kiss Márton (98) vall.]; 1771: Tavaj Ugarláskor ugy esik, hogy Kis Istvánnál lévő akkori Tímár Inaskát Enyedi Marczit el kérvén Timár Istvántol hogy ott az Ekét hajtaná ki addig a Béla hegy alá és ott étesse a marháját ... a Gyermek Inas fel ment a Béla Hegy tetőre ... ott étette az Ŏkrŏkket Imbrefi Ferentz is hogy ki jŏve azt mondá az Inaskának hat te mért butál el előlem hogy idejöjj Lantzas Diszno Ordog Menkŏ Kutya Teremtette? [Dés; DLt 321. 39b-40a] stb.), kijelölő jelzö, mennyiségjelzó és minőségjelzö (pl.: 1747: azon két kisded fundusotskán a' Nemes var(me)gye Postalis Commoditasokot epithessen, és birhassa pacifice [Déva; Ks 73. III. 18 1/2]; 1796: Ezen ket utolso rétetske a Falu kŏzŏnséges réttyébŏl jár a házok utan [Szentgothárd SzD; WassLt]; 1880: Emlékezel-e arra, mikor Klasszit felküldtem a Főv. Lapoknak, s onnan írták azt a gonosz három sorocskát [PLev. 83 Petelei István Jakab Ödönhöz]), több mennyiségjelzố3 (pl.: 1715: keözöttünk lako némely egyházi rendeknek lévén nemes vármegyében ... két vagy harom jobbágyocskája ... mégis velünk együtt contribuálni nem akarnak [SzO VII, 207 a székely nemzet kívánalmai a gub-hoz]; 1747: az Falu nem mind eŏ Ngaje mert az Szabad emberekbŏl állo derékos Falu, hanem tsak udvarháza van eŏ Nganak abban az Faluban tiz tizenkét Jobbágjotska Sellérekkel édgyŭt hozzá [Gagy U; Ks 83 Péterffi Sándor lev.]), értelmező jelző (pl.: 1591: Mindeneket

\footnotetext{
${ }^{92} \mathrm{Az}$ erdélyi régi nyelvben az adalék tanúsága szerint a középfokú melléknév hasonlító határozói vonzatának a ragja -tól/-től is lehetett. Mára ez a toldalékos alak a köznyelvből a nyelvjárásokba szorult vissza.

${ }^{93}$ Több mennyiségjelző akkor kapcsolódhat egy alaptaghoz, ha közöttük mellérendelő (elsősorban választó) viszony van.
} 
4. ábra. Kicsinyitő képzős származékok bővitményei

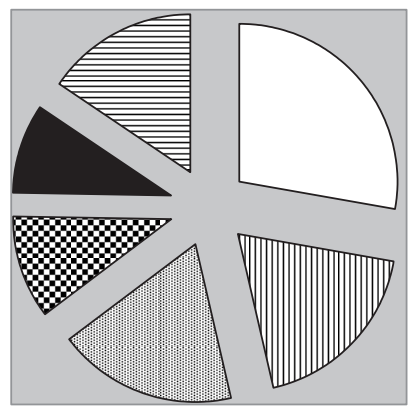

\begin{tabular}{|l|}
\hline 0 bővítmény \\
血 Mennyiségjelző \\
Minőségjelző \\
Q Mennyiség- és \\
minőségjelző \\
Több minóségjelző \\
目 Más
\end{tabular}

hagiok ... kis leankamnak Frusinnanak [Gyf; BálLt 93] ${ }^{94}$; 1783: az legénke Tanko Andris is oda futot [Lengyelfva U; EMLt]); birtokos jelzó, minőségjelzó és értelmező jelző (pl.: 1660: Baczy Katha asz(ony) ugy mint Tutrix Iffiabik Baczy István kis Fiaczkajanak Petinek Sos Martont vallia Procuratoranak Buday Mihaly ellen [Kv; TJk VII/3. 309]; 1690: Néhai Nemzet(es) Kolosvári Mislei Péter Hajadon Léánykájának Annisnak ... házoknál ... szidalmazta az Ac(tort) [Kv; TJk XIII/1. 444]); birtokos jelző, minőségjelzô és mennyiségjelzó (pl.: 1662: a hatalmas nemzet minden tanácsát arra kezdé forditani, hogy ... Erdélynek ... nyakát kedve szerint megnyomhassa, s Magyarországnak megmaradott kevés részecskéjének holdoltatásához és foglalásához is nagyobb kaput nyithasson [SKr 531]), minőségjelzó és értelmező jelzó (pl.: 1662: Rudnai Anna Aszszony, monda: Myuel engemet Unoka Leankam(m)al Baczi Kis Annaval edgyut ez haborusagos ideőben ellensegh elött ualo futasba(n) ez varosba ualo szorulasban, penzeuel tartot, s taplalt, Papay Imreh vra(m) ... adom, vallom, es kótóm megh neuezet Leankammal edgyut ... Pintek neueŏ Faluba(n) való puzta haz helyeimet [Dés/Beszt.; RLt O. S]) és időhatározó (pl.: 1772: mi ezt eszre nem vehettük ben a házban külömben is már akor borosatskák voltunk [Sályi TA; Mk V. VII/17]).

A SzT. adatai azt mutatják, hogy - az alaptag szófajából adódóan ${ }^{95}$ leggyakrabban valamilyen jelző bővíti a kicsinyítő képzővel ellátott alaptagot, csak ritkán alany, határozó stb (1. 4. ábra).

\footnotetext{
${ }^{94} \mathrm{Az}$ adalék a kisleányka címszó alatt jelenik meg, tehát nem jelzős szerkezet, hanem öszszetett szó.

${ }^{95}$ Bővebben 1 . Az alaptag szófaja c. alfejezetben.
} 
5. ábra. Kicsinyitő képzős származékok bövitményeinek jelentése

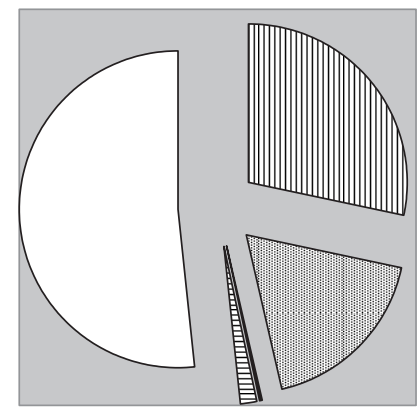

\begin{tabular}{|c|}
\hline 四 Nincs bővítmény \\
\hline $\begin{array}{l}\text { 'Kis, kicsi' jelentésí } \\
\text { bővítmény }\end{array}$ \\
\hline $\begin{array}{l}\text { 'Nagy' jelentésü } \\
\text { bővítmény }\end{array}$ \\
\hline $\begin{array}{l}\text { 目 Negatív jelentésü } \\
\text { bővítmény }\end{array}$ \\
\hline $\begin{array}{l}\square \text { Más jelentésű } \\
\text { bővítmény }\end{array}$ \\
\hline
\end{tabular}

\section{IV.8.2.2. A kicsinyítő képzős származékok bővítményeinek jelentése}

Azon túl, hogy milyen bővítményei lehetnek egy kicsinyítő képzős származéknak, fontos megvizsgálni ezen bővítmények jelentését is (a bővítmények jelentésmegoszlására vonatkozóan 1. 5. ábra). A vizsgálat alapján kimutatható, hogy a bővítmények 18,07\%-a a 'kis, kicsi' jelentéskörbe tartozik, azaz a 16-19. századi erdélyi beszélők szükségét érezték a képző jelentését valamilyen egyéb elemmel ('kis, kicsi' jelentésü minőség- és mennyiségjelző, valamint fok-mérték határozó) felerősíteni. Vagyis nem elég az, hogy a képző maga a 'kis, kicsi' szemantikai jegyet adja hozzá az alaptaghoz, hanem ezt a bővítmény is felerősíti, és így redundánsnak tünő szerkezetet hoz létre, amely a következő képlettel írható le: 'kis, kicsi' + alaptagDIM.

A következő (ebbe a jelentéskörbe tartozó) szavak fordulnak elő a kicsinyítő képzős származék bővítményeként: apró: 1800: ezen erdő helylyen, mit-sem erő apro agotskák vagynak [Csekelaka AF; EHA]; apróbb: 1801: Aprobb Boros Hordotskák [Vargyas U; CsS]; aprólék: 1611: Ezwst teö tarto valamj aprolek kapsochkaual ... f. 1 [Kv; RDL I. 88]; aprólékos: 1826: Ifjab Ajtai Moses ... né mely aprolékos hibátskákért büntettetett tsak három ezüst forintokig [Kv; ÖCJk]; apróság: 1763: Három Lántz végire valo Kapots Uagy holmi aprosag kaptsotskák nro 24 [Nsz; Szer. özv. Harsányi Sámuelné Tisza Ágnes lelt.]; csekély: 1656: Az temetés pedigh, tsak az en csiekely allapotoczkamhoz kepest legien, tudgiak ki voltam en [Ádámos KK; Bál. 93 végr.]; csekélyebb: 1879: Csekélyebb legényke a kis Kálmán, semhogy számot tegyen nekem az, mit ő felőlem elmond [PLev. 43 Petelei István Jakab Ödönhöz]; diónyi: 1852: egy vílágos piros pelyparipa ... hasa közepén ... egy dionyi tsomotska [Dés; DLt 1066]; kevés számú: 1710: Anno 1710. Die 5 July Szamlalvan meg keves Szamu arany marhacskamat 
mellyis kŏvetkezik a Szerint [Wass 11]; kevés: 1755: Husvéthi Innep napon szokásunk szer(ént) mulatván Falunkbéli Iffjaink ... Falunkban el járo utasokkal is jádzo modon szoktak bánni, hogy valami kevés ajándékocskát nyerjenek [Balsa H; Gy]; kevéssé: 1759: Hatházi Czilika ... hogy a' rudat ezen földre le ne fektethesse, egy kevéssé gyengécskénn mellybe megtaszitotta ... Marusán Gavrila [Árpástó SzD; BK]; kicsi: 1816: Egy Sárga festékű gyermeki kitsi Hintotska [Bányabükk TA; MkG]; kicsid: 1776: Tizenhat kicsid, apró fejér zomántzas boglárotskák [M.köblös SzD; RLt Sombori Klára és Sándor lelt.]; kicsind: 1760: Az Száraz Pataki és Kantai Kitsind portiotskák még inventálatlan vadnak [Feltorja Hsz; LLt]; kicsiny: 1732: a Tabernaculum asztalos munkával aranyozva... kicsiny vas sarkokon fordulo ajtocskájával [Kóród KK; Ks 12/I]; kicsinyég: 1702: ŏ kglme egj kitsineg tavolkábban ült [Tarcsafva U; Pf]; kicsit: 1827: égy kicsit Tavulatska husztom volt meg magamat az Malamtol [Szind TA; EMLt Mészkői cs. lev.]; kis: 1692: Ló Istálló ... ennek két kis ablacskai (!)a [Mezőbodon TA; BK 4. - ${ }^{a}$ Nem merő elírás ablakocska h.?]; kisded: 1697: Ezen hazbol vagyon egy kis kamaráb(a) ki nyilo bérlett fenyo Deszkábol állo vas sarkokon fuggó kisded ajtocska [O.brettye H; Born. XXIXa 2]; kisdég/kisdeg/küsdeg: 1790: Ezen Kamarának ... vagyon egy kisdég kerek ablakotskája [MNy XXXVIII, 208]; 1816: vagyon egy kisdeg fijatskája [Torda; KvAkLt Mss 363]; 1831: Vaszi meg halálozván egy küsdeg fiatskája maradott árván [Szentdemeter U; Told. 39]; kisebb: 1803: vékony patyolat nagy keszkenő ... szélein égy égy kissebb ágatskák szkofiummal varrattattak [UnVJk]; kissé: 1841: Lakatos Ferencz ... egy kissé butácska [DLt 697 nyomt.]; kisség: 1821: Egy kisség durvábbatska ujj Kender Lepedők [Backamadaras MT; CsS]; legkisebb: 1738: (Marján kocsist) meg nehezedvèn, meg nèzettem az batyaval ha pestisbe vagyonè, de leg kisebb csomocskajais nem volt [Gyeke K; Ks 99 Kornis Antal lev.]; néhány: 1631: tudom hogi volt az Aniadnak penze, arra azt felelte hogi hagiot edes koma(m) Aszony ... hagjot ennekem szegeny egi nehany araniaczkat [Mv; MvLt 290. 259a]; nem sok: 1733: hogy nékem se légyen semmi panaszom, a mint hogy nem sok adósságocskám lévén hátra ... tehát azokat fizesse meg az Vr Battyám vram [TK1 Teleki Sámuel lev.]; parányi: 1653: Ilyen nagy vigyázással kellett a sok félelmes nép között oltalmaznunk magunkat a kicsiny parányi erôsségecskében ${ }^{\mathrm{a}}$ [ETA I, $77 \mathrm{NSz}$. - ${ }^{\mathrm{a}} \mathrm{Mv}$ nagytemploma körüli erődítményben, a Kastélyban]; rövid: 1672: Ebesfalvi Kastélyban eddig bé iöt Majorság, dézma, és egyéb gyülevész borokrol valo rövid Extraktusocska [UtI]; semmi: 1830 k.: lèszen Ur Bátyam oly Jo hogy meg nem Neheztel reám hogy alkalmatlan lészek ezen Semmi Pénzetskémért [Mocs K; BetLt 1 Henter Farkas Vajna Istvánhoz]; törpe: 1742: mentünk fel ... törpe fenyŏ Ajtotskán [Pókafva AF; JHb XXV/58]; vékony: 1757: (A) Bányais ... négy esztendőkig (: belé hagyatván :) pusztánn állótt, akkor a’ Mgos Gróff 
Exp(one)ns Vr kezdette ujra dolgoztatni, és ... igen vékony hasznotskáját latni [Nagyalmás H; BK ad nro 144].

Előfordul olyan eset is, amikor több, azonos jelentésű jelző bővíti a kicsinyítő képzővel ellátott alaptagot: kis, apró: 1798: vagjon ... ŏ nganak ... szep allodialis szallos tsefas (!) Erdeje melynek deli szomszedcságaban nekem is vagjon egy kis apro tsere nyilatskam [Ádámos KK; JHb XIX/58. 25]; kicsiny, parányi: 1653: Ilyen nagy vigyázással kellett a sok félelmes nép között oltalmaznunk magunkat a kicsiny parányi erősségecskében ${ }^{a}$ [ETA I, 77 NSz. - ${ }^{a} \mathrm{Mv}$ nagytemploma körüli erődítményben, a Kastélyban]; kisded kis: 1754: Egy pár rezes kápáju kisded kis Mordajotska [Nsz; Told. 19].

Bár értelemszerüen 'nagy' jelentésű bővítmény nem járulhatna a kicsinyítő képzős származékhoz, az adalékok 0,33\%-ában mégis ebbe a jelentéskörbe tartozó szavak bővítik az alaptagot: igen ('nagyon'): 1725: igen bővőcskén elte(ne)k őkglmek Kolosvárat ... innen az magunkébő (!) kellet ki potolni [K; TKl]; jó ('jókora, nagy'): 1694: egj jo darabocska Szőlős Kert [Kővár; JHb inv.]; jókora: 1742: egj ebedre csengetŏ Jókora csengetyű harangotska [Pókafva AF; JHb XXV/58. - Tomai László kijegyzése]; jókorácska: 1750: Vagyon itt ... a felső falu végin egy tisztességes alkalmas magasságú fatorony és abban két jókorácska harangocska [M.fülpös MT; ETF. 107. 21]; nagy: 1816: Egy nagy Kapotska ... Egy kupás, és egy tollas véső [Varsolc Sz; Born. IV. 41 Bornemisza Krisztina conscr.] (a kicsinyítő képzős származék lexikalizálódott, jelentése: 'ácskapocs'); nagyobb: 1748: Kissebb, s nagyobb kasocskák, melljekb(en) gyümőlcsőt Tojást, és egyebb e' félét Szoktak tartani, és hordani Nro 9 [Ks XXVIII. 8. 5]; 1756: én látván hogj nagyobb hasznacskát vehetnék azon helységről, magam két részemre Malmot építettem [Ribicsóra H; Ks LXII/7]; öreg (hordócska) 'nagy hordócska' jelentésben: 1720: egy vak ablakban egy ŏreg hordotska [Köröspatak Hsz; HSzjP]; sokkal: 1785 k.: Kata ugyan mégis nem oly hibásacska: Dolgaiban serény, sokkal is jobbacska. Alattomban ő is akaratosocska, Titkon lappang, mint az alá néző macska [EM XX, 503 Balás-kódex].

A harmadik ${ }^{96}$ kategóriába azok a bővítmények sorolhatók, amelyek valamilyen negatív jelentésárnyalatot hordoznak. Ez az adalékok 1,58\%ában fordul eló: árva: 1667: az meg nevezett édes Urátol maradott egyetlen egy árva Agacska ugy mint Lázár Imreh ur(am) [LLt 70/13]; avatag: 1736: Az Úr Házáb(an) ... Fejér hajas avatag derekallyka 1 [Várhegy MT; CU XIII/1. 103]; dirib-darab: 1788: Holmi díríb darab rongy, ezzel édgyŭtt valami hulladék gáz végek. Holmi díríb darab formátskák és példák [Mv; TSb 47]; elromlott: 1735: ezen Tornácznak bal kéz felől valo vegiben, vagjon egj el romlott Kő Kamaracska [Ó-Torda TA; JHb XI/9. 54-5]; félszeg: 1818:

\footnotetext{
${ }^{96}$ A bővítmények körében kirajzolódó jelentéskategóriákra vonatkozóan 1. a bővebb magyarázatot a A kicsinyítő képzós származékok szemantikája c. fejezetben.
} 
egy leán, félszeg vagyon ... Ezen félszeg leánykának ... egy tehénye vagyon [Jenőfva Cs; RSzF 244]; gonosz: 1880: Emlékezel-e arra, mikor Klaszszit felküldtem a Fôv. Lapoknak, s onnan írták azt a gonosz három sorocskát [PLev. 83 Petelei István Jakab Ödönhöz]; gyarló: 1753: A’ Margita felől való Plágán vagyon egy erdő ... minthogy igen el vágták gyarló erdőcske, mogyoró és gyertyán veszsző is terem rajta [M.décse SzD; EHA]; gyenge: 1668: Egy kis gyenge Arany Lanczocska, ŏt Arany benne [Mk Kapi György lelt.]; hitvány: 1812: Más hitvány általagotska [M.gyerőmonostor K; KCsl 11]; kopott: 1745: egy kopott on tányérotska [Sárd KK; UnVJk 115]; lyukas: 1744: Edgy lyukas ón tálatska [Szentdemeter U; LLt Fasc. 67]; mit sem éró: 1800: ezen erdő hellyen, mit-sem erő apro agotskák vagynak [Csekelaka AF; EHA]; nyomorult: 1736 u.: Ó mostani felfordult világ! egy nyomorult fő emberecske nem hogy más ember jobbágyasszonyát de magát is jó nemesembert vagy annak gyermekeit szégyenlené atyafiának mondani, nemhogy valamivel succurálni olyan megszűkűlt még közelről lévő atyafiának is [MetTrCs 481]; ringy-rongy: 1766: (A szolgáló) holmi ringj rongj egjetmasatskáinal egjebet az Udvarbol szekeremen nem vitt [O.kocsárd KK; Ks 8. XXV. 18]; rongyos: 1841: egy rongyos Házikó [Torda; HG]; rossz: 1675: Egy hársbol kőtőt edgyes rosz ágyacska [Dés; Borb. II]; semmirekellő: 1749: Egy semmire kellő rosz agyácska [Királyhalma KK; Ks 23/XXIIb]; sovány: 1745: (Egy föld) mégyen az ellenb(en) lévő Sovány Dombotskára [Nagyida K; Told. 9]; szakadozott: 1772: egy négy szegeletü Ablakatska ... Ezen Ajto felett égy szakadozott Ablakatska láttatik [Kv; BKt Mikes conscr.]; szegény: 1672: Isten Kegyelmeteket továbbra is oltalmazza, az asszonyt penig gyógyítsa. Szegény kisdedecske teste csak azt kívánta: ő jó helyen van [TML VI, 163 Bánfi Dienes Teleki Mihályhoz]; viseltes: 1769: Gyermeknek valo viseltes két pár Csizmacska [Nagyercse MT; Told. 19].

Az adalékok között több olyat is találunk, amelyekben a diminutív toldalékkal ellátott származékoknak több, nem szinonim, de hasonló (negatív) jelentéskategóriába tartozó bővítményük van: alázatos, szegény: 1740: maradok G(róf) U(ramna)k alazatos szegeny szolgátskaja Mohaj Moses mpr [TK1 Mohai Mózes Teleki Ádámhoz]; megrongyollott és elpusztult: 1775: az alatta lévő Kő pintze Gátorja felett, egy kis Sendely fedél alatt lévő, mind fedelire mind oldal Deszkaira nézve meg rongyollot és el pusztult filegoriátska [Buza SzD; LLt Csáki-per 107. L. 14]; szegény, neveletlen, árva: 1651: szegjnj neveletlen arva fjaczkam [Körtvélyfája MT; Bál. 1]; szegény, sokgyermekü, nyomorú: 1827: Szegény sokgyermekü, nyomoru Emberetske [K; KLev.]. Ezekben az adalékokban maga a kicsinyítő képző is inkább negatív jelentésárnyalatot sugall, tehát tulajdonképpen a bővítmény felerősíti a negatív jelentést. 


\section{IV.9. A kicsinyítő képzők földrajzi megoszlása az erdélyi régiségben}

\section{IV.9.1. Nyelvföldrajz - történeti nyelvföldrajz}

A nyelvföldrajz vizsgálati módszer és szemlélet, a nyelvtudománynak az az ága, amely a nyelv térbeliségét vizsgálja, vagyis a nyelvi variabilitást térben ábrázolja, a nyelvi jelenségeket térképekre vetíti. Ennek értelmében a nyelvföldrajzi kutatás feladatai közé tartozik az egymással többnyire érintkező nyelvjárások egyezéseinek és különbségeinek a magyarázata is (Kiss 1972: 346).

A történeti nyelvföldrajz a nyelvtörténet különböző korszakai nyelvi jelenségeinek földrajzi megoszlását kutatja. Szemben a mai nyelvállapot nyelvföldrajzi vizsgálatával, a történeti anyag esetén különböző nehézségekbe ütközünk. Elsősorban azzal kell szembesülnünk, hogy írott nyelvi anyag áll rendelkezésünkre, amely tükrözi ugyan a beszélt nyelvet, de az írott betű nem adja vissza minden esetben pontosan a hangzó beszédet. Tehát annak ellenére, hogy a SzT. adatai változatos forrásokból származnak és erős földrajzi szórtságot mutatnak, csak kellő óvatossággal kezelhetők. Mégis Kósa megállapítja, hogy „,a Tárbeli szavak földrajzi megoszlása többnyire elég arányos. Ezt mutatják a székely és mezőségi nyelvjárásterület különböző pontjairól, tájegységeiről való adatok. Viszont jóval kevesebb adat képviseli az északkeleti nyelvjárásterületet, például a Szilágyságot. Ez vagy az ehhez hasonlók - tudjuk - azzal magyarázhatók, hogy a gyúijtő munkáját olykor kénytelen-kelletlen befolyásolta a számára hozzáférhető forrásanyag mennyisége és milyensége" (Kósa 1976: 106).

Az adatokkal kapcsolatban még az is felmerülhet, hogy az adat keletkezési helye nem egyezik meg az író születési helyével, akár misszilisről, akár magánjellegú vagy hivatalos okiratról van szó. Ennek értelmében az iratok keletkezési helye írójának tartózkodási helyéről, nem feltétlenül s nem mindig lakóhelyéről vagy származási helyéről tanúskodik (Papp 1961: 18). Előfordulhat például, hogy a Székelyföldről a mezőségi nyelvjárás jellegzetességeit mutató nyelvi adat kerül elö, vagy a szövegen belül keveredik az író anyanyelvjárása tartózkodási helyének nyelvjárásával.

A hivatalos iratokkal azért is kell óvatosan bánnunk, mert adott sablonok alapján készültek. A végrendeletek például nem minden esetben megbízhatóak - hasonlóan más hivatalos irattípushoz -, hiszen kialakult kezdő- és záróformulákat tartalmaznak, amelyeket az íródeákok készen kaptak, így ez az egyéni/helyi nyelvhasználat vizsgálhatóságát gátolja. Ehhez társul az a nehézség is, hogy gyakran bonyodalmat okozhat az író személyének azonosítása, mert sokszor a számos aláíró tanú közül nehéz 
eldönteni, hogy ki volt a szövegező. Tehát egy szöveg nyelvjárásának helyhez kötésekor fontos az író származási helyének meghatározása. Magán- és hivatalos levelek esetén - Deme László terminológiáját alkalmazva - el kell választanunk a fejet, aki a fogalmazó, diktáló személy, a kéztől, aki a diktálás után író vagy másoló személy. A kettő lehet azonos, de különbözhetnek is egymástól, és ilyenkor kérdés, hogy a levélben a fej vagy a kéz nyelvjárása jelenik-e meg (Deme 1959: 7). Még akkor is, ha sikerül megállapítani az író személyét, előfordulnak olyan esetek, amikor egy szövegen belül is nyelvjárási ingadozások vannak. Ennek oka lehet, hogy a szövegek írói nem beszéltek teljesen tisztán egy bizonyos nyelvjárást, hiszen nem egy helyen élték le életüket, így a különböző tartózkodási helyeiken beszélt nyelvjárástípusok nyomot hagytak nyelvhasználatukban. Az egy szövegen belüli nyelvi ingadozásnak másik oka lehet az író nyelvjárásának és a normatív változatnak a keveredése. Az is elöfordulhat, hogy egy szövegen belül különböző egyének nyelvállapota keveredik, mert a kéziratok gyakran nem eredeti nyelvi szerzőjüktől valók, hanem más egyénektől származó, esetleg többrendbeli másolatok. Ilyenkor minden másoló valamilyen mértékben saját nyelvjárásán szűrte át a szöveget. A nyomtatványok esetén pedig nem szabad megfeledkeznünk a nyomdászok nyelvi szerepéről. A 16-17. században a nyomdászok feladatuknak érezték a szövegek nyelvi „csiszolását". A 18. századtól megváltozik a helyzet, ekkortól a nyomdász már nem nyelvalakító tényező, hanem tipográfiai mesterember.

A végrendeletekkel szemben a tanúvallomási jegyzőkönyvek hitelesebb forrásnak bizonyulnak, ugyanis a tanúvallomásokat rögzítő jegyzőkönyvek követelménye volt, hogy a tanúk vallomását híven, szó szerint rögzítsék (Miklós 2002: 128).

A fenti problémákat figyelembe véve világos, hogy nyelvföldrajzi kutatásokat történeti anyagon csak kellő óvatossággal lehet végezni. Az egyszerűség kedvéért a kicsinyítő képző földrajzi elterjedésének vizsgálatakor mégis az adalék után szögletes zárójelben közölt helymegjelölést fogadom el hitelesnek.

\section{IV.9.2. A SzT. adatainak nyelvjárási megoszlása}

Benkő Loránd kategorizálása szerint a SzT. adatai az újmagyar nyelvjárások (15-16. század fordulójától napjainkig) korából származnak (Benkő 1957: 61).

A 16-18. században a magyar nyelvterület település- és népiségtörténeti viszonyaiban olyan nagy horderejü változások történtek, amelyek a nyelvjárások életét erősen befolyásolták. Ebben hatalmas szerepe volt a 150 éves török hódoltságnak, amely az ország középső és déli részén 
nagymértékben kipusztította a magyar lakosságot. Az elnéptelenedés a mai Magyarország területén kívül Erdély mezőségi részét is érintette. A törökdúlástól csak a nyelvterület peremvidékei szabadultak meg, és ezek a peremnyelvjárások vitték tovább a középkor végi nyelvállapotot területileg változatlan helyzetben, így ezek máig archaikusabbak, mint a többi nyelvjárás (pl. Háromszék vidéke). A 18. században a törökök kiűzése után az elnéptelenedett területeket betelepítették, amelynek következtében új nyelvjárási helyzet alakult ki: a Mezőségre betelepülő románság darabokra szabdalta a korábban egységes mezőségi nyelvjárást, a székelyek viszont továbbra is egy tömbben maradtak.

A 19. századtól viszonylagos állandóság következik, kialakul a nyelvjárások mai képe.

A SzT. adatai a Tisza-Körös-vidéki nyelvjárási régió (ide tartozik Bihar megye, valamint Kalotaszeg), az Északkeleti nyelvjárási régió (észak-szilágyi, nagyjából a Tövishát kistáj területe), a Mezőségi nyelvjárási régió és a székely nyelvjárási régióból származnak. Nyugatról keletre haladva a következő (vár)megyékből vannak adatok: Szilágy (Sz), Kolozs (K), Szolnok-Doboka (SzD), Belső-Szolnok (BSz), Beszterce-Naszód (BN), TordaAranyos (TA), Alsó-Fehér (AF), Hunyad (H), Szeben (Szb), Fogaras, NagyKüküllő (NK), Kis-Küküllő (KK), Maros-Torda (MT), Csík (Cs), Udvarhely (U), Háromszék (Hsz).

\section{IV.9.3. A - $d,-k a /-k e$ és -cska/-cske képzők a nyelvjárásokban}

A nyelvjárási leírások a kicsinyítő és becéző képzők állományának bemutatásával a történeti és leíró nyelvtanokhoz hasonlóan csak érintőlegesen foglalkoznak.

A Magyar dialektológia A nyelvjárási alaktani jelenségek (Kiss 2001: 351361) fejezete a szóképzésnek kis teret szentel, a kicsinyítő képzőkről egy bekezdés szól:

„Gyakorisági különbségként említhetők a köznyelvben is meglevő -kal-ke, -cskal-cske kicsinyítő képzők. Ezek a palócban (...), egyes erdélyi nyelvjárásokban (szépecske 'valóban szép', meredekecske 'igen meredek') igen kedveltek. Szintén gyakoribbak a köznyelvnél más kicsinyítő képzők is ('́gy a -csa/-cse, -ikal-ike). Ezek főként a székely és a csángó nyelvjárásokban, valamint Dél-Dunántúlon, illetőleg Szalvóniában járatosak (fazëkcsa, székcse; sajtika, apika stb.). Mind állományban, mind gyakoriságban kitünik a keleti nyelvjárásoknak, a csángónak és a székelynek a kicsinyítő-becéző származékokban való gazdagsága. Ezzel bizonyára összefügg a gyakorító igeképzők nagyobb gyakorisága és állománybeli gazdagsága. Mind- 
két képzőtípus emotív funkciójú ugyanis, és ez erőteljesebb az archaikus peremnyelvjárásokban. A kicsinyítő-becéző származékok gyakoriságát a csángó nyelvjárásokban erősíti az aktív magyar-román kétnyelvűség abban az értelemben, hogy a moldvai román nyelvjárás ebben a tekintetben szintén nagyon gazdag." (i. m.: 354)

A magyar nyelvjárások területi egységeinek bemutatásakor a kicsinyítő és becéző képzőkről csak a székely és csángó nyelvjárási régió alaktani sajátosságainak elemzésekor esik néhány szó. A székely nyelvjárás jellemzőjeként a -cska/-cske kicsinyítő képzőbokor gazdag jelentését emelik ki:

„A -cskal-cske képző a kicsinyítésen kívül (lovacska, csürkecske 'csirkécs$\left.\mathrm{ke}^{\prime}\right)$ kiemelésre, fokozásra is használatos: szépëcske 'igen szép', ügyesëcske 'határozottan ügyes', hosszacska 'a kelleténél valamivel hosszabb'." (i. m.: 305)

A moldvai nyelvjárási régió alaktani sajátosságainak ismertetésekor azt hangsúlyozzák, hogy a csángó nyelvjárás kicsinyítő és becéző képzőkben igen gazdag, ezek használata gyakoribb a köznyelvinél, amelyet a diminutívumokban ugyancsak gazdag román nyelv hatása is felerősíthet. Mégis csupán ennyi áll a denominális névszóképzők ezen részrendszeréről:

„A névszók alaktanában első helyen a kicsinyítő képzők átlagon felüli gyakorisága emelendő ki. A fontosabb képzők közül néhány: -cska/-cske (facska), -csó (száncsó), -d (könnyüd), -ical-ice (bihalica 'bivalyborjú'), -ikal-ike (apika), -ikó (lányikó), -kal-ke (ökörke), -kól-kó (hosszukó), -ól-ó (ángyó), -ókal-oóke (botóka) stb. A példák azt is mutatják, hogy a köznyelvben is ismert képzőkkel új tájnyelvi származékokat hoznak létre. Ezenkívül a kicsinyítő képzős szavak szöveggyakorisága ugyancsak magasabb a köznyelvinél." (i. m.: 311)

A hosszas idézésre azért volt szükség, hogy világossá váljék: még a nyelvjárásokat monografikus igénnyel bemutató munka is csak nagyon szűk teret biztosít a kicsinyítő és becéző képzők rendszerének ismertetésére. Sok helyen pedig a leírás a laikus tapasztalata szerint is hiányos (pl. a székelyben biztos, hogy nem csak a -cskal-cske képzőt használják a kicsinyítés kifejezésére, hanem a csángó nyelvjárásban gyakori kicsinyítő képzők közül is nagyon sokat).

A kicsinyítő és becéző képzők rendszeréről Szabó T. Attila írt bővebb tanulmányt (1980: 102-165), amelyben megállapítja, hogy a székely és csángó kicsinyítő és becéző képzőrendszer sokkal gazdagabb, mint a köznyelvié. Ennek magyarázata összefügg a két nyelvjárási régió elzártságával, vagyis 
azoknak a gazdasági, földrajzi, társadalmi és művelődési tényezők hatásával, amelyek ezeket a nyelvjárásokat elszigeteltségükben lassúbb ütemben alakították, változtatták. Ez a jelenség megegyezik Bartoli areális normái közül az elszigetelt területek szabályával, amely szerint az archaikusabb formák az elszigeteltebb vidékeken őrződnek meg, hiszen a területi elzártság kedvez a nyelvi konzerválódásnak, valamint a periferikus területek szabályával, amely kimondja, hogy a szavak régiesebb lexikai változatai a központtól távoli területeken maradnak fenn (ez a szabály a nyelv minden szintjére érvényes, nem csupán a lexikaira) (vö. Kiss 2001: 100).

A kicsinyítő-becéző képzők jellemzésében Szabó T. Attila alaktani és jelentéstani sajátosságaikra helyezi a hangsúlyt.

A -cskal-cske a legelevenebb moldvai kicsinyítő-becéző képző, ezt csak a -ka/-ke közelíti meg. Magánhangzós szóvégekhez közvetlenül kapcsolódik (annyicska, bundácska), toldalék nélküli alakjában mássalhangzós alapszó esetén az alapszó és a képző között legtöbbször rövid magánhangzó áll (fejecske, nagyocska). Fokozott melléknevekben a kicsinyítő képző gyakran a középfok jele előtt áll (alacskább, bennecskébb).

A kicsinyítésen kívül (ifjucska 'kissé fiatal', szikrëcska 'piciny, kevés') kedveskedő, becéző jelentése is van (emberecske, lelkecském). Testi vagy lelki tulajdonságokra, valaminek mennyiségére utaló melléknevekben és számnevekben az alapszóban kifejezett tulajdonság kisebb mértékét (aprócska, gyengécske) vagy fokozását jelenti (szépecske 'nagyon szép', ügyesecske 'nagyon ügyes'). Előfordul az is, hogy az alapszó jelentésének valamilyen különleges jegyét emeli ki (illogatócska 'ivóedény', jegyecske 'anyajegy'), vagy tér- és időbeli távolság közelebbi vagy távolabbi voltát fejezi ki (későcske, elégecske, külyëcskébb, tojébbacska).

A -cska/-cske mellett legelevenebb a -kal-ke képző. Jelentésköre a -cska/-cske-nél is bővebb. Kifejezheti valakinek, valaminek a rendesnél kisebb voltát (báránka, csuporka), becézést (asszonyka, kedveske, istenke, ártánka, köntöske). Testi vagy lelki tulajdonságokat jelölő melléknevekkel alakult ilyen kicsinyítő képzős származékokban a -kal-ke az alapszóban kifejezett tulajdonság kiemelését, hangsúlyozását, fokozását jelöli (erőske 'jócskán erős', magoska 'jó magas'). Az alapszó értelmének specializálódását jelenti olyan származékokban, mint pl. felvetke 'gyapjúból kötött kiskabát', hajtóka 'bölcső' stb. Határozószókban a határozó jelentésének kicsinyítése vagy fokozása a funkciója (alatka, hamarkább). Román nyelvi hatást mutatnak azok a származékok, mint pl. cigánka 'cigány asszony' (< r. țigancă), magyarka 'magyar nő', zsidóka 'zsidó asszony'.

A - $d$ a köz- és irodalmi nyelvből, sőt a népnyelvi terület legnagyobb részén is már kihalt. A csángó nyelvjárásban az értett jelentésű, de elavult képzők csoportjába tartozik. Egyetlen - $d$ képzős főnévre van példa: szád. 
Három becenév alakult vele: Józsid, Marid, Rózid. Valamivel gyakoribb mellékneveken: kicsid, könnyüd, terped 'törpe', valamint ezeknek határozóraggal, illetve igeképzővel ellátott alakjaiban: kicsiden, kicsidül stb. Középfokú melléknevekből alakult határozószókban is előfordul: alábbad, inkábbad, továbbad.

A nyelvjárási, nyelvtörténeti és leíró nyelvtanok áttekintése után az a kérdés, hogy a SzT. adatai milyen képet mutatnak: az erdélyi régiségben a -d kicsinyítő képző valóban csak a székely nyelvjárási régióban bukkan-e fel, máshol pedig a - $d$ képzős származékokat -kal-ke, -cskal-cske képzős alakok helyettesítik-e.

\section{IV.9.4. A kicsinyítő képzős származékok földrajzi elterjedése a SzT. adatai alapján}

A SzT. egyik előnye, hogy - ahol csak lehet - az adalékok után szögletes zárójelben feltünteti az idézett nyelvi adat keletkezési helyét, amely lehetővé teszi ezek nyelvföldrajzi vizsgálatát. Ennek alapján következtetéseket lehet levonni nemcsak egyes lexikális elemek földrajzi elterjedtségére vonatkozóan, hanem akár az erdélyi nyelvjárások 16-19. századi állapotára is. A szűkebb értelemben vett Erdélyen kívül - a partiumi részek nélkül - Szatmár és Máramaros megyéből származó levéltári adalékok is bekerültek a SzT.-ba. Olyan változatos forrásokból származnak, hogy átfogó képet kaphatunk különböző nyelvi jelenségek nyelvföldrajzi állapotáról.

A vizsgálat első szakaszában azt néztem meg, hogy a - $d$ kicsinyítő képző, illetve a - $d$-t tartalmazó képzőbokroknak $(-d A d$, $-d e g)$ milyen a földrajzi megoszlása, majd összehasonlítottam ugyanazon alapszavaknak a -cskA és/vagy - $k A$ képzős változatával. Végül pedig a ritkább kicsinyítő képzőkkel létrejött származékok földrajzi szórtságát vizsgáltam meg.

A SzT.-ban mindössze 13 - $d$ képzős, illetve $-d$-t tartalmazó képzőbokros származék van: alábbadka, apród ${ }^{97}$, jobbad, jobbadik, jobbadka, kevesed, kicsid, kicsidded, kicsinyd, kicsinyded, közeldeden, nagyobbadka, nehezedke. A legkorábbi -d képzős adat 1558-ból származik: Az melly Arwakat En Mostan tarthok mynd kyczydeket, mynd, Nagyokat azt Akarom hogy Meeg Eleghechek [JHbK XLIII/21 Mikola Ferencnè Melyk Anna végr.], a legkésőbbi 1852-ből: A béjáro kitsind ajto cserefa kapu féllel fenyő deszkábol [Felfalu MT; DE 4]. Ezeket hasonlítom össze ugyanezen alapszavak -kal-ke, -cskal-cske képzős származékainak földrajzi elterjedésével: alábbacska, aprócska, jobbacska, kevesecske, kevéske, kicsinyecske, kicsinyke, nagyobbacska, nehezecskén. A közeldedennek nincs -ka/-ke vagy -cskal-cske képzős párja. A különböző címszavaknak

\footnotetext{
${ }^{97} \mathrm{Az}$ apródnak természetesen csak a melléknévi ‘aprócska, kicsike’ jelentésnél besorolt adatait vettem figyelembe.
} 
275 adalékát vizsgáltam meg, amelyek közül $164-d$ képzős, 5 -dkal-dke, 8 pedig -dad/-ded képzőbokros, 89 származék -cskal-cske kicsinyítő képzős, 9 pedig -ka/-ke-vel ellátott.

A címszóként szereplő származékok változó számú adatot tartalmaznak, de itt példaként mindegyiknél csak egyet idézek, a legkorábbit. A kiemelt címszó után zárójelben feltüntetem az adott címszó alá beszerkesztett adalékok számát.

alábbacska (11) 1762: azon nevezetŭ hellyben allabbotska [Backamadaras MT; CsS].

alábbadka (2) XVIII. sz. e. fele: Rétetskéje ... van ... Petlendi Puszta Falu helyena az elébbenivel egj sorba alábbatka [AbN].

aprócska (1) 1651: Egy óregh Orosz Leany formara czinalt Gyemantos Függő melyb(en) vagyon nedgy óregh Gemant Aprob gyemant 2. Harom oregh szem Gyengy Negy Aproczkab [Wass 27 Wass Judit kel.].

apród (2) 1778: Marhái és Fakultásaira eset portioja én réám iratott mint el maradott őzvegjére Aprod gjermekeimmel egjütt [Agárd MT; Told. 8].

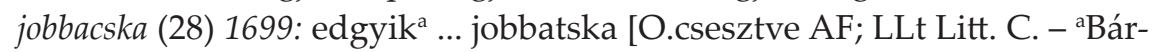
$\mathrm{ka}$.

jobbad (5) 1571: egy jo paripat nem talalunk, lofeweknek sokaknak es keossegnek is kijet kijet jobbadnak hallottak nyayatul el üzettek [SzO II, 326].

jobbadik (1) 1633: Chaualt barani börök jobbadiknak No. 62. Alab ualo chaualt döggel holt barani börok roszak No. 75 [Fog.; UF I, 311].

jobbadka (1) 1694: Majorság-Szőlő ... Ennek két felől fel menő szelei ... igen pusztások, homolittatni kévánok: a közepe(n) jobbadka [Kisenyed AF; BfR néhai ifj. Bálpataki János urb.].

kevesecske (4) 1663: Erdélyben az mi kevesecském ezelőtt volt ... azokhoz való jutásimat is ő nagyságok telyességesen meggátolták [TML II, 570 Teleki Mihály Bánfi Dieneshez].

kevesed (1) 1826: a praetendált jövedelemnek kevesed része az özvegyi kevés Joszágnak az igazi jővedelme [Ne; DobLev. V/1114. 9a].

kevéske (2) 1589 k.: Az Demeter deakott penigh tudom hogj foglalt egj keueskett az attia birodalma vtan Vgian ott az szeken valo feoldben [Szu; UszT].

kicsid (123) 1558: Az melly Arwakat En Mostan tarthok mynd kyczydeket, mynd, Nagyokat azt Akarom hogy Meg Elegechek [JHbK XLIII/21 Mikola Ferencne Melyk Anna végr.].

kicsidded (1) 1585: Talak kicsid(d)ed keozepzerewek vadnak Niolcz, tizenharmadfel font, tt f 2/7 [Kv; KvLt Vegyes I/2-3]. 
kicsind (32) 1731: azon Szoross útb(an) az Agyagas és Iszopos Sárt ă Viz annyéra concumulálni szokta, hogy Marhájok(na)k nem kicsind erőltetésével vontattyák azon ált(al) a terhet [Kv; Pk 7].

kicsinyded (6) 1584: Cathalin Borbely Ianos felesege Vallia ... Lattam esmeg Arany forintokatis Nalla eg kichinded fekete keskeny Sachkoba [Kv; TJk IV/1. 389].

kicsinyecske (1) 1812: ezen Fok nevezetü fiatalos Berek gyermekségemtől fogva őrőkké a' Nagy Laki Eklesiájé volt, e' nevelte ekkorára, mert én tudom mikor a fák kitsinyetskékis voltak [Nagylak AF; DobLev. IV/943. 25b].

kicsinyke (7) 1570: Keth darab teoroth arany es egy kychynke azokkal Egywth [JHb QQ Temeswary János reg.].

közeldeden (1) 1662: szegények a százezer tallért is megígírték vala, úgy, hogy magoknak is valahol mi pénzek, ezüst marhájok volna, összehordván ... akiket főképpen olly értékes urakat, főembereket a szomszédságban közeldeden tudhatnának, illy utolsó nagy szükségekben, a véghelynek megmaraszthatására ... kölcsönpénz-kérés dolgában éjjel-nappal megtaláltatnák, supplicálnák [SKr 575].

nagyobbacska (42) 1658: Kett Eöregh lada Est f 1 d 60 Kett masfel singes lada Est $\mathrm{f} 1$ Egy singes es mas nagiobaczka [Kv; KJ].

nagyobbadka (1) 1644/1648 k.: egy Veres scarlat szüniegh nagiobbatka [Born. XXXVIII. 14].

nehezecskén (2) 1790: A' Szarvas Marhák itt mostis dŏglenek, és tilalom alatt vagyunk ... melly miá az ott valo oeconomia nehezetskén foly [Sztrézakercesora F; TL. Wessényi Dániel gr. Teleki Józsefhez].

nehezedke (1) 1796: Zsuzsi Urnaptol fogva a Gyapot mivelésel bajlodik, de nehezetke a keze, hanem idŏvel tsak meg tanul [IB. Molnár György héderfáji ref. pap lev.].

Bár kevés származék jött létre - $d$ kicsinyítő képzővel, tehát az erdélyi régiségben is már az elavulóban lévő képzők közé tartozik, az adatok mennyisége azt mutatja, hogy bizonyos régiókban még használták/sőt használják mind a mai napig. Jelentésének elhomályosulását példázza az a tény, hogy funkciójának megerősítésére képzőbokor elemévé vált: -dad/-ded (pl. közelded) és -dkal-dke (pl. nagyobbadka, nehezedke). Az Új Magyar Tájszótár (1979) címszavai is azt igazolják, hogy fóként a nyelvterület keleti részén (a székely és csángó nyelvjárásban) a mai napig használják ezeket a kicsinyítő képzős származékokat. Az SzT. idézett címszavai közül a következők találhatók meg az Új Magyar Tájszótárban: 
alábbacska hsz alabbacska (Moldva 1153: 461) I alábbacska (Bibarcfalva 1403: 341, Pürkerec 753: 60, Bukovina-Dtúl 2039: 46) | alábocska (Lészped Dtúl 716: 28, 303) 'alább, lenn, lejjebb' Itt alábbacska vagyon egy mély sánc (népm. 753: 60).

alábbad hsz alábbad (Moldva 1153: 468) 'egy kissé alább, lejjebb' Fogjátok alábbad! (uo.).

aprócska mn aprócska (Moldva 1153: 461), aprócskább (uo.) 'kicsi, apró'.

jobbacska mn jobbacska (H.nánás 2085, Gyimes-v. 360: 41, Moldva 1153: 459, 462) jobbecska (uo. 1398: 62, uo. 1153: 462) 'kissé jobb' (Az úri nótákat) jobbacska zenészektól tanulta.

kevesecske mn kevesecske (Moldva 1153: 463) 'kevés, kevéske'.

kevéske mn keveskét (Moldva 1153: 479), keveskébb (uo.) I kööszke (uo. 1798: 144) I köszkébb (uo. 1153: 479) I köveszke (uo.). Csak perméze (permetezett), ety keveskét ese (esett) (uo.).

kicsid I. Mn 1. kicsid (Tószeg 943a: 121, Halmágy 1272: 221, uo. 1801: 396, Er.vidék 641, Bibarcfalva 1403: 46, Sükő 702: 7, Gyergyó-vid. 1402: 189, Hilib 1406: 237, N.bacon 1163, Se.sztgyörgy 1164: 442, Bukovina - Dtúl 2039: 46, Andrásfalva - Dtúl 1712: 59, Moldva 314: 4, uo. 1153: 462, 463, 468, 469, uo. 1356: 300, uo. 1398: 110, Klézse 505: 292), kicsidek (Moldva 1153: 469), kicsidek (pokolpatak - Dtúl 716: 159, 325), kicsidök (Szé. keresztúr vid. 1228), kicsid (Moldva 1153: 469) 'kicsi'. Kicsid lyányocska (1153: 462). 2. kicsid (Se.magyarós 1164: 83) 'kevés' Nálam a munka kicsid (népm., uo.). II. Fn kicsidem (Somoska 1697: 168), kicsidemet (Gye.alfalu 288: 212) 'kisgyermek, csecsemö'.

kicsidecske mn kicsidecske (N.bacon 1413: 108) I kicsidöcske (Halmágy 1399: 230) 'kicsike'.

kicsidke mn kicsitke (Hidvég 1402: 105) 'kicsike'.

kicsike mn kicike (Bogdánfalva 366: 118) I kicsikke (Moldva 1153: 479) I kisikek (tbsz Jugán 367: 256).

kicsinyded - mn kicsinyded (Tordasztlászló 1466: 184) ‘kisded' Ne féljetek, ím mondok örömet, megszületett a kicsinyded Jézus (népk., uo.).

kicsinyecske - mn kicsinyecske (Moldva 1153: 463) 'kicsike'.

kicsinyka - mn 1. kicsinka (Kéménd 274): 'kicsike'. 2. (-t tárgyragos alakban hsz-szerüen) kicsinkát (Érsekújvár 190) 'rövid ideig, kicsit'.

nagyobbacska - mn nagyabacka (Gálbény 288: 469) I nagyabbacska (Moldva 1153: 463) I nagyobbacska (Gálbény 288: 156) 'nagyobb, nagyobbik' Kissebbecske siltim lábamhoz tegyétek, nagyobbacska siltim fejemhez tegyétek (népb. uo.).

nagyobbka - mn nagyapkább (Moldva 1153: 479) 'kissé nagyobb' A vessző kissebb, a bot nagyapkább (uo.). 
nehezecske mn nehezecske (Moldva 1153: 452) I nehezecske (uo. 1153: 459) 'elég nehéz'.

A legtöbb címszó mindkét helyen megtalálható, vannak azonban eltérések is. A SzT. címszavai közül a következők nincsenek meg az Új Magyar Tájszótárban: alábbadka, apród, jobbad, jobbadik, jobbadka, kevesed, kicsidded, kicsinyke, kicsind, közeldeden, nagyobbadka, nehezedke. Ezek jórészt olyan származékok, amelyekre a SzT.-ban is kevés adalék van, kivéve a kicsind címszót, amelyre 32 adalékot szerkesztettek be a szerzők. Természetesen az Új Magyar Tájszótárban is találhatók olyan származékok, amelyek a SzT.-ban nincsenek meg: alábbad, kicsidecske, kicsidke, kicsike, kicsinyka, nagyobbka.

Táblázatban összefoglalva a SzT. és az Új Magyar Tájszótár - $d$, -cska/cske, -kal-ke és a - $d$-t tartalmazó képzőbokros származékok a következő képet mutatják:

\begin{tabular}{|c|c|c|}
\hline Származék & SzT. & Új Magyar Tájszótár \\
\hline alábbacska & + & + \\
\hline alábbad & - & + \\
\hline alábbadka & + & - \\
\hline aprócska & + & + \\
\hline apród & + & - \\
\hline jobbacska & + & + \\
\hline jobbad & + & - \\
\hline jobbadik & + & - \\
\hline jobbadka & + & - \\
\hline kevesecske & + & + \\
\hline kevéske & + & + \\
\hline kevesed & + & - \\
\hline kicsid & + & + \\
\hline kicsidecske & - & + \\
\hline kicsidded & + & - \\
\hline kicsidke & - & + \\
\hline kicsike & - & + \\
\hline kicsind & + & - \\
\hline kicsinyded & + & + \\
\hline kicsinyecske & + & + \\
\hline kicsinyke & + & - \\
\hline kicsinyka & - & + \\
\hline közeldeden & + & - \\
\hline nagyobbacska & + & + \\
\hline nagyobbadka & + & - \\
\hline nagyobbka & - & + \\
\hline nehezedke & + & - \\
\hline
\end{tabular}


Ha a számszerű adatokat összevetjük, azt látjuk, hogy a SzT.-ból az Új Magyar Tájszótár adataihoz viszonyítva 6 hiányzik, az Új Magyar Tájszótárban a SzT. adataiból nincs meg 12. Ennek alapján azt a következtetést lehet levonni, hogy az erdélyi régiségben (16-19. század) a kicsinyítő képzős származékok állománya gazdagabb volt, mint a mai nyelvjárásokban.

A másik kérdésünk az, hogy mutatkozik-e valamilyen földrajzi megoszlás a különböző kicsinyítő képzők használatában, a SzT. adatai igazolják-e azt a feltevést, hogy a székely nyelvjárásban gyakoribb a - $d$ képző, a többi nyelvjárásban helyét a -cska/-cske, -kal-ke tölti ki. A SzT. azért nagyon fontos forrás ebből a szempontból, mert a szerkesztői elvek közé tartozik, hogy a címszavak alá bekerülő adalékok a nyelvterület minél nagyobb részét lefedjék. Az adalékok nagy többségében könnyü eldönteni, honnan származnak, hiszen ha pontos helymeghatározás (pl.: 1770: Buta Anutza három holnapos Fiatskájával Hesfelán Szimionnal àrvasagra maradott ... neveletlen kitsind Hesfelán Szimion nevŭ Fiatskájaval edgyütt [Nagyernye MT; Ks 67. 48. 31]) nincs is, de a megyejelzés szögletes zárójelben megjelenik (pl.: 1792: a Széna Sátés, drága, és igen kitsidek a Portiok [H; Ks 80. XLVII. 5 vk]). Problémásabb a különböző levéltárak nyelvi anyagait földrajzilag behatárolni, hiszen a levelek keltezési helye legtöbbször nem egyezik meg a levélíró származási helyével. Szintén problémát jelentenek Kolozsvár városa tanácsának jegyzőkönyvei és Kolozsvár városának törvénykezési jegyzőkönyvei, ugyanis a tanúk vallomását, bár hűen lejegyezték, sok esetben a tanú máshonnan érkezett, helymegjelölésként viszont Kolozsvár szerepel. Itt esetleg a helynévi eredetú személynévből lehet következtetni a valló származására, de ezen esetekben sem mindig. A 275 - $d$, -cska/-cske és -ka/-ke képzővel ellátott származékra vonatkozó adat közül kénytelen voltam azokat kihagyni (28), amelyek keltezési helyének megállapítására nincsen semmi fogódzó, mert a kicsinyítő képzők földrajzi elterjedésének vizsgálatában nem relevánsak, és csak azokat vettem figyelembe, amelyeket valamilyen módon lokalizálni lehetett.

A megvizsgált és helyhez köthető 249 adat közül 151 - $d$ képzős, 4 -dad/-ded képzős, 5 -dkal-dke, 80 -cskal-cske és 9 -kal-ke kicsinyítő képzős származék. A (vár)megyék szerinti megoszlás a következő képet mutatja:

1. a - $d$ kicsinyítő képző megyék szerinti megoszlása: Sz: - $(0 \%)$; K: 27 (17,88\%); SzD: 7 (4,63\%); BN: 2 (1,32\%); TA: 2 (1,32\%); AF: 7 (4,63\%); H: 7 (4,63\%); Szb: - (0\%); Fog.: 1 (0,66\%); NK: 2 (1,32\%); KK: 7 (4,36\%); MT: 27 (17,88\%); Cs: 16 (10,59\%); U: 32 (21,19\%); Hsz: 14 (9,27\%); 
2. a -dad/-ded képzőbokor megyék szerinti megoszlása: Sz: -; K: 3; SzD: -; BN: -; TA: -; AF: -; H: -; Szb: -; Fog.: -; NK: -; KK: -; MT: 1; Cs: -; U: -; Hsz: -;

3. a -dkal-dke képzőbokor megyék szerinti megoszlása: Sz: -; K: -; SzD: -; BN: -; TA: 3; AF: 1; H: -; Szb: -; Fog.: -; NK: -; KK: 1; MT: -; Cs: -; U: -; Hsz: -;

4. a -cska/-cske képzőbokor megyék szerinti megoszlása: Sz: 4 (4,49\%); K: 17 (19,1\%); SzD: 3 (3,37\%); BN: - (0\%); TA: 6 (6,74\%); AF: 6 $(6,74 \%) ;$ H: 3 (3,37\%); Szb: 4 (4,49\%); Fog.: - (0\%); NK: - (0\%); KK: 2 (2,24\%); MT: 23 (25,84\%); Cs: 7 (7,86\%); U: 4 (4,49\%); Hsz: 1 $(1,12 \%)$;

5. a -kal-ke képzőbokor megyék szerinti megoszlása: Sz: $-(0 \%)$; K: 2 (2,24\%); SzD: - (0\%); BN: 1 (1,12\%); TA: - (0\%); AF: $-(0 \%)$; H: - (0\%); Szb: - (0\%); Fog.: - (0\%); NK: - (0\%); KK: - (0\%); MT: 2 (2,24\%); Cs: - (0\%); U: 3 (3,37\%); Hsz: 1 (1,12\%).

A számadatok azt mutatják, hogy a -d kicsinyítő képző földrajzilag elsősorban a székely megyékben, valamint Kolozs megyében elterjedt, ezen a viszonylag kompakt tömbön kívül sokkal kisebb arányban jelenik meg. Ha a székely megyéket (Kis-Küküllő, Nagy-Küküllő, Udvarhely, Csík, Háromszék és Maros-Torda megyét is ide tartozónak tekintem) egy tájegységként kezeljük, akkor kiderül, hogy az adatok 64,61\%-a innen származik, további 17,88\% Kolozs megyéből, és csupán 17,51\% Erdély többi részéről. A -cska/-cske, illetve -kal-ke képzőket egy kategóriába sorolom. Az adatok 48,28\%-a koncentrálódik a Székelyföldre, 21,34\% Kolozs megyéből, 30,38\% pedig Erdély többi részéról való.

A százalékos arány alapján tehát az mutatható ki, hogy a - $d$ kicsinyítő képző elsősorban a Székelyföldön volt elterjedt, a nyelvterület többi részén (Kolozs megyét leszámítva) csak szórványosan jelenik meg. Ezzel szemben a -cskal-cske és -ka/-ke kicsinyítő képzők használata földrajzilag jobban megoszlik, mindenhol használják őket.

Ha viszont a számadatokat vesszük figyelembe, akkor a megvizsgált címszavak adalékai inkább arra engednek következtetni, hogy összességében (ugyanazoknak az alapszavaknak) jóval kevesebb (89) -cska/-cske és -ka/-ke képzős származéka van, mint - $d$ kicsinyítő képzős (151), ami azzal magyarázható, hogy az idézett szavak inkább - $d$ képzős alakjukban voltak gyakoribbak, vagyis - annak ellenére, hogy - $d$ képzős címszó a SzT.-ban mindössze 13 van - ezekben a $-d$ még nem engedte át teljesen a helyét a -cskal-cske és -kal-ke kicsinyítő képzőknek. 
A nagyszámú származékot létrehozó -cskal-cske és -kal-ke kicsinyítő képzők Erdély teljes területét lefedik, földrajzi szórtságukban nem fedezhető fel különbség.

Jóval kisebb számú származék keletkezett más kicsinyítő képzőkkel (-ó: agárkutyó, ángyó, cserecsutkó; -cs: kövecs; -csa: gyakorcsa, gyermekcse; -ika: ládika, pálcika; -ikó: darabontházikó, házikó, juhászházikó, ládikó, pálcikó, parasztházikó; -ók: szénafiók; -óka: botóka; -őc: gyerkőc; -ócal-őce: kakóca, gyerkőce; -uka: bátyuka, mamuka; -icska: házicska; -icskó: házicskó; -docska: jobbadocskán), és ezeknek nagy része lexikalizálódott, ami arra utal, hogy a korábbi nyelvtörténeti korokban produktívabb képzők a középmagyarra elvesztették produktivitásukat, egy-egy származékban maradtak fenn. Földrajzi megoszlásukat tekintve elmondható, hogy - bár általában csak egy-egy adalékban fordulnak elő - Erdély minden területén megjelenik egyik vagy másik képző. Az -ó Kolozs, Szilágy, Szolnok-Doboka és Kis-Küküllő megyékben adatolt (1654: praemendatt attam ... Haro(m) Agar kutjonak lib. nro 9 [Egeres K; Ks 70 Szám. 51]; 1766: le menvén Damokos Ferentz a' Battyahoz Damokos Janoshoz monda az Angyának Damokos Janosnénak jol mondotta ked Angyo (: mint hogy az elōtt valo estve ott volt :) hogj ne menyek el hanem hallyak itt mert valami bajom lész Azon beis tellyesedék rajtam [Szilágycseh; BfR 104/2]; 1806: jőjen kend Ángyo szoporán lásson ujjságot [Dés; DLt 250/1808]; 1781: ez oljan Sŭrŭ erdŏ volt nagy Csere tsutkok fák Tŏvis Fŭz rakotya es egyeb tseplesekkel ... rakva volt ... a Nagy Fakat Puska Porral hanyattatta el ... eŏ Nga [Balavásár KK; Ks 19/IV. 8]). A -cs kicsinyítő képző a kövecs lexikalizálódott származékban maradt meg Maros-Torda $\left(9^{98}\right)$, Szolnok-Doboka (7), Udvarhely (5), Háromszék (2), Csík (2), BelsőSzolnok, Hunyad és Kolozs (1-1) megyében (pl.: 1806: (Az a hely) pusztaságban hagyatott, mint viz aradásával kŏvettsel s porondal meg hánt helly, marhák deleltenek azon a hellyen [Erdősztgyörgy MT; WH]; 1737: egj egj szekér porondot és követset vigjen vagj vitessen [Dés; Jk]; 1697: edgi darab ben valo ŏrŏkseg ... vicinussa egi felŏl ... a Fejerniko vize es kŏvetse [Kadács U; Pf]; 1864: földje száraz természetü fekete és agyagos követsel elegyitett [Alfalu Cs; GyHn 19]; 1781: A Kővetsben (sz). Kövecsek lábján (k) [Szárazpatak Hsz; EHA]; 1762: a Nagy Szamos ... ezen hellyet a midön el szakasztotta követtsel porondal és minden ágokkal megrakta [BSz; SLt XXIV. 6]; 1770: Ezen helyet nem de nem a hegyről le folyo eső, és hoviz tőltôtte fel porondal, és kővetsel [H; JHb XXXI/17. 3 vk]; 1758: A Kŏvets hegj alatt (r) [Sztána K; EHA] stb.). A régi grammatikákban is említett -csal-cse (1. Geleji, Komáromi, Pereszlényi grammatikái) a SzT.-ban két származékot hoz létre: gyakorcsa és gyermekcse. Ezek Háromszék, illetve SzolnokDoboka megyékből kerültek elő (1705: ezen Falu határán Apró gyakorcsa

\footnotetext{
${ }^{98}$ A zárójelbe tett szám az illető megyéből előkerült adalékok számát jelzi.
} 
nevü hellyen [Altorja Hsz; Borb. II]; 1688: Egy itt quartelyozo Lutheranus németnek, recens natus, és ige(n) beteg gyermekcsejét ... meg kereszteltem [Bethlen (SzD) kör.; UtI]). Az -u(j)ka képző két származékot hoz létre: bátyuka, mamuka. Az adalékok Udvarhely és Kis-Küküllő megyéből kerültek elő (1598: az en iozago(m)ba hazamba be fogatta(m) vala, magam otalmaert... engemet, elessen es niugosso(n), tiztessegben tarczio(n) mint battiat... de eö nem tekintette az Vristent sem az attiafiwsagot eö engemet tiztessegbe nem tartá rutolt zidot kouetem az kegtek zekit Batiukanak lelek kuruanak es halallalis feniegetet engemet [UszT 13/117]; 1812: a Groffné nagyon indulatba jőtt, és a' Grofot nagyon kissebitetté sőt motskolta, gazolta mondván: Te Samuka, Mamuka, Mamujka, Tőkős [Héderfája KK; IB. Molnár György (58) ref. esp. vall.]). Az -ika, annak ellenére, hogy csak a láda és pálca alapszavakhoz járul, több adalékban is megjelenik, amelyek a következő megyékből származnak: Szolnok-Doboka (4), Kolozs (2), Maros-Torda (1) és Hunyad (1) (pl.: 1846: Egy ládika Klauzal Gabor képével [Dés; Berz. 20]; 1647: latua(n) hogi balta va(gyo)n kezeben ugi mente(m) kj egi palczikaual, hogi jneziem hogi mennien tovab [Kv; TJk VIII/4. 236]; 1629: ez az Andras sokat kesek borertt Uram megh uere egj palczikaval [Mv; MvLt 290. 156a]; 1755: verni kezdék Lázár Jánost, akinékis csak egy kis palczika vala kezében [Ribice H; Ks 112 Vegyes ir.] stb.). Az -ikó az -ika képzőhöz hasonlóan szintén a láda és pálca alapszavakhoz járulhat, illetve a ház és a ház utótaggal létrejött összetett szavakat is kicsinyítheti (darabontházikó, juhászházikó, parasztházikó). A többi - ritkábbnak minősüló - kicsinyítő képzőhöz viszonyítva, -ikót tartalmazó adalék viszonylag sok (27) van a SzT.-ban. Ezek megyék szerinti megoszlása a következő képet mutatja: Maros-Torda (9), Kolozs (5), Szolnok-Doboka (4), Udvarhely (3), Torda-Aranyos (2), Kis-Küküllő (1), Háromszék (1), Csík (1), Fogaras (1) (pl.: 1849: Kis ladiko finom cirkalmakkal 30 Rft [Görgénysztimre MT; Born. G. XXIVd]; 1774: Zŏld Uram aban az Ǔdŏben a Falun kivŭl egy oldalban az Uraság fŏlgyin egy paraszt Hazikot epitetett [Mocs K; Ks Conscr. 31]; 1765: az midŏn Varga Gyŏrgy az emlitett patzikoval hadarászot és hátra felé ment volna, Szabaszlai uram beléje szaladván, akkoron érte azon pálczával az karját egyszer [Szépkenyerúsztmárton SzD; Eszt-Mk Vall. 13]; 1844: kitsin Háziko [Etéd U; NkF]; 1798: Kádár János ö kegyelme Cserében adot Joszágan egy Haziko vagyan ... Tar János ö kegyelme Feleségének Kadár János által, lett Csere Joszágban lévő házikónak amig hasznát lehet venni vegje hasznat [Csegez TA; Borb. I Csegezi Csongvai Pál Hütös assessor kezével]; 1832: Hazikojába [Kissáros KK; DLev. 2. XII. A. 2]; 1840: a' Solyom kŏ alá épittetett volt egy házikot [Bikszád Hsz; MkG]; 1757: Czigánynak egy kűsded Hazikoja [Taploca Cs; Sándor conscr.]; 1640: vagi(on) ennek 
felette 19. muntanis Jőveveniek kiknek valami hazikoiokis vagio(n) szabadosak el menny vagi ot lakni [Szevesztrény F; UC 14/48. 78]; stb.).

A legritkábbnak tekinthető kicsinyítő képzők csak egy-egy származékot hoznak létre, és csak egy-egy adalékban jelennek meg. Ilyen a Kolozs megyei adalékban szereplő -ók (1824: edgy Széna fiok alatt vártuk az esső elmulását [M.légen K; KLev. 9]), a csak helynévi adalékban megmaradt -óca Maros-Torda megyéből (1820: A Kakotza erdő [Udvarfva MT; EHA]), az -icska és -icskó egyaránt Szolnok-Doboka megyéből (1840: bátorságosabban bírhassam azon Hazitskat [Dés; DLt 1420]; 1843: tetzet ... admoneáltatni hogy a Tegla vetŏ helyen fel epittetett Házatskát es egy kis veteményező Kertetskét elrontsam, holott az a Házitsko az egésség fen tartására ... szükséges képpen meg kelletik lenni ... méltoztasson azon Házitskot a maga valoságában meg hagyni [Dés; DLt 1358]), a -docska pedig Alsó-Fejér megyéből (1747: Samuel Ur(am) ... beteges allapottal van, de most Jobbadocskán van [Buzd AF; Ks 96 Mikó Ferenc feleségéhez]). Az -óka - bár egyetlen származékban jelenik meg - több adalékban előfordul, amelyek közül négy Maros-Torda, kettő pedig Alsó-Fejér megyéből származik (pl.: 1636: ezt az fogoly legent ... Nagy Zabo Istvan karon foghta vala, es ugy vonza uala... nyerges Istvanis utanok ballagh uala az botokaual [Mv; MvLt 291. 68a]; 1733: Edgj Varro ladátskáb(an) recze kŏteshez valo botokák [Marossztkirály AF; Told. 2] stb.).

Az -őc és -ő́ce képzők egyaránt a gyerek alapszóhoz járulnak, de ezeket a származékokat nem lehet lokalizálni (1838-1845: járni kezdett a gyerkő́ [MNyTK 107]; 1838-1845: „Purkuj, porunkuj” (: a román „prunk, prunkuc=gyerkőcével egyeredetü" :) [MNyTK 107]).

A SzT. adalékai tehát azt mutatják, hogy a kicsinyítő képzők használata egész Erdély területére jellemző. A legnagyobb földrajzi szórtsága értelemszerüen a legnagyobb produktivitású -cska/-cske képzőnek van, ezt követi a -kal-ke, amely szintén Erdély teljes területéről adatolt. A - $d$ és $-d$-t tartalmazó képzőbokorral létrejött származékok elsősorban a székely nyelvjárási régióból, valamint Kolozs megyéből, a csupán egy-egy származékban megjelenő kicsinyítő képzők pedig általában elszigetelten kerültek elő. 



\section{V. ÖSSZEGZÉS, KITEKINTÉS}

Célom tehát az volt, hogy a SzT. kicsinyítő és becéző képzőit minél alaposabban elemezzem, minél átfogóbb képet nyújtsak róluk. Mivel a képzőrendszer más elemeinek (pl. az igeképzők rendszerének) vizsgálatához kidolgozott szempontok nem alkalmazhatók a kicsinyítő képzőkre, ezért olyan szempontokat alakítottam ki, amelyek segítségével az erdélyi régiségben előforduló diminutív képzőket jellemezni lehet. Fonetikai, morfológiai és szintaktikai tulajdonságaikon túl kitértem egyéb aspektusokra is: milyen szerepet töltenek be a beszédhelyzetben, ki(k)nek a nyelvében fordulnak elő, milyen szövegtípusokra jellemző használatuk, illetve milyen földrajzi szórtságot mutatnak.

A vizsgálat eredményei a 16-19. századi Erdély nyelvére vonatkoztathatók, bizonyos fenntartásokkal, hiszen mindig figyelembe kell vennünk azt a tényt, hogy a SzT. adatai földrajzilag nem oszlanak meg arányosan. Bizonyos helyekről sokkal több adalék került be a SzT.-ba, mint máshonnan. Tehát az eredményeket mindig megfelelő óvatossággal kell kezelnünk.

A SzT. diminutív képzéssel létrejött származékainak vizsgálata a következő eredményekkel járt:

1. A kicsinyítő képzők vizsgálata során az első megoldásra váró probléma terminológiai természetű: kérdés, hogy a kicsinyítő képző melyik toldalékosztályba sorolható, illetve hogy besorolható-e egyértelműen valahova.

A klasszikus képzőmeghatározások a képzőknek általában azt a vonását emelik ki, hogy új szót (új lexéma új jelentéssel) hoznak létre. Az újabb nyelvtanok viszont - annak ellenére, hogy definíciót adnak - problematikusként, illetve nem minden képzőre érvényesként kezelik a meghatározást, ugyanis gyakran nem lehet elkülöníteni eléggé élesen az inflexiós eljárásokat a derivációsoktól. 
Ennek értelmében szükség van olyan kritériumok meghatározására, amelyek kijelölik a tipikusan inflexiós toldalékok tulajdonságait, illetve a tipikus derivációs toldalékokét. Ezt az elkülönítést Dressler végzi el, 20 olyan kritériumot fogalmaz meg, amelyek alapján meghatározhatók a fokozatbeli különbségek inflexió és deriváció között. Ennek értelmében azok a toldalékok, amelyek teljesítik az összes inflexióra vonatkozó kritériumot, prototipikus inflexiós toldalékok, amelyek pedig a derivációra vonatkozó feltételeket teljesítik, prototipikus derivációs toldalékok.

A megadott kritériumok alapján a kicsinyítő képzők bizonyos ragszerű tulajdonságokat mutatnak (jelentésük morfoszemantikai szempontból általában transzparens, produktívak, nem változtatják meg a tő szófaját, általában egy jelenik meg a tövön, nem feltétlenül raktározódik el egységként a mentális lexikonban), tehát nem lehet egyértelmúen a tipikus képzők kategóriájába sorolni, az inflexiós-derivációs skálán az inflexiók felé mozdulnak el.

2. Egy képző akkor tekinthető produktívnak, ha új szó hozható létre vele oly módon, hogy a származék jelentése általában levezethető az alapszó és képző jelentéséből, vagyis kompozicionális. Fontos viszont azt is leszögezni, hogy ha egy képzett szó lexikalizálódik, még nem jelenti, hogy nem produktív képzésmóddal jött létre, hiszen a produktivitásnak nem kizáró kirtériuma az, hogy a származékok nem lexikalizálódhatnak.

A SzT.-ban megjelenő kicsinyítő képzők közül $(-c s k A,-k A,-d$, -óca/öce, -cs, -cs A, -dkA, -dAd, -docska, -deg, -ó, -ö, -ica, -ôce, -óca, -ika, -ikó, -kó, -icska, -ốcske, -icskó, -uka, -uca, -ók, -ő́c) a -cskal-cske mutatja a legnagyobb fokú produktivitást, szinte minden megkötés nélkül kapcsolható bármilyen (névszói) alapszóhoz, még a mai nyelvre érvényes grammatikai tiltó szabályokat sem követi, miszerint nem kapcsolható -ság/-ség képzős elvont főnévhez. Az erdélyi régi nyelvből ilyen példáink vannak: adósságocska, reménységecske stb. Ezt követi a -kal-ke, amely az adott korban és régióban - bár sokkal korlátozottabban, mint a -cska/-cske (hiszen egy adott alapszóhoz csak meghatározott szabályok szerint kapcsolódhat) - szintén produktívnak mondható. A diminutív képzők állományának többi tagja már a 16-19. századi Erdély nyelvében sem termékeny, ezek csupán kevés (pl.: $-d,-i k a,-i k o ́ s t b$.$) , illetve esetenként egy-egy származékban fordulnak elő$ (pl.: -csal-cse, -öc, -őce).

3. A kicsinyítő képzős származékok szemantikai szerkezete általában (per definitionem) az alapszó és diminutívum 'kis, kicsi' jelentésjegyéből áll össze. Vagyis a kicsinyítő képző szerepe a képzési folyamatban nem más, mint az alapszó jelentéséhez hozzáadni a 'kis, kicsi' szemantikai kom- 
ponenst, ezáltal mintegy „lekicsinyítve” azt. Beszédhelyzettől függően viszont előfordulhat, hogy a kicsinyítő képző vagy tisztán pragmatikai jelentést kap, vagy bizonyos pragmatikai jelentésárnyalatot. Ennek értelmében a diminutívumot tartalmazó képzett szavak jelentésének a meghatározásakor nem elég pusztán az alapszó és képző jelentéseit „,összeadni”, hanem egyéb tényezőket is figyelembe kell venni, mert különböző beszédhelyzetekben ugyanannak a származéknak más és más jelentése lehet.

A SzT. adatainak vizsgálata során kiderült, hogy a kicsinyítő képző gyakran nem méretbeli csökkenést eredményez, hanem akár az ellenkezőjét, nagyságot is kifejezhet. Ennek értelmében a SzT. adatai alapján a kicsinyítő képzőnek a következő szemantikai funkcióit különböztethetjük meg: a. méretbeli csökkenést eredményez (pl.: asztalka 'kis asztal'), b. a több alkotóelemből álló dolgok alkotóelemeinek számát csökkenti (pl.: csokrocska 'kevés virágból álló csokor'), c. életkorra vagy időtartamra vonatkozó fönevek esetében nem a fizikai kiterjedést módosítja, hanem az időbeli kiterjedést (pl.: bárányka 'fiatal bárány'), d. a fokozható melléknevekhez járuló kicsinyítő képző intenzitásbeli változást eredményez (pl.: magasacska 'nem túl magas'). Ha egy kicsinyítő képzős származék több jelentéssel szerepel a SzT.-ban, azt jelenti, hogy a diminutívum az alapszónak különböző jelentésjegyeire hat (pl.: kicsid jelentései: 1. 'kicsi, kis'; 2. 'apró, kicsinyke'; 3. 'kis kiterjedésü'; 4. 'kis termetü, alacsony'; 5. 'gyermekre von. kis, kicsike'; 6. 'kis/rövid idö'; 7. 'fiatal'; 8. 'kicsi rész'; 9. 'kicsi baj/betegség'; 10. 'egy kis/rövid ideig'). Az eltérő jelentések megállapítása csak kontextus alapján történhet.

4. A SzT. diminutívummal ellátott származékainak szintaktikai viselkedésének vizsgálatakor egyrészt arra a kérdésre kerestem a választ, hogy a kicsinyítő képző befolyásolja-e az alapszó mondatbeli szerepét, másrészt arra, hogy milyen módon határolja be bővítményeinek körét.

Az erdélyi régi nyelv kicsinyítő képzős származékainak szintaktikai vizsgálata azt mutatta, hogy a diminutív toldalék nem gátolja a származék szabad elhelyezkedését a mondatban. Mondatbeli szerepét tekintve ugyanúgy viselkedik, mint az alapszó: leggyakrabban alany, tárgy vagy minőségjelző, de ettől eltekintve minden olyan szintaktikai szerepet betölthet, amelyet az alapszó szófaja lehetővé tesz számára.

A szintaktikai vizsgálat másik megválaszolásra váró kérdése az volt, hogy befolyásolja-e valamilyen módon a kicsinyítő képző az alapszó bővítményeinek körét. A SzT. adatai szerint a kicsinyítő képzős származék ugyanúgy bővíthető, mint az alaptag: leggyakrabban önmagában, bővítmény nélkül fordul elő, de lehet jelzője, határozója vagy alanya is, azaz bármilyen bővítmény, amelyet az alapszó szófaja lehetővé tesz. Lényegi 
eltérés az alapszavakhoz képest a bővítmények jelentésében mutatkozik, hiszen a kicsinyítő képző blokkoló elemként müködik olyan bővítményekkel szemben, amelyek a 'nagy' jelentésmezejébe tartoznak. A SzT. adatai azt mutatják, hogy a kicsinyítő képzős alaptaggal rendelkező szószerkezetben nem elég a 'kis, kicsi' jelentésű képző, hanem ezt megtoldják egy hasonló jelentésű bővítménnyel is. Ennek eredményeként olyan bővítmények kapcsolódnak a diminutívummal ellátott alaptaghoz, mint: apró, csekély, kevés, kicsi, parányi, törpe stb. Néhány adalékban az figyelhető meg, hogy a szabályostól eltérő, a 'nagy' jelentésmezejébe tartozó bővítmény jelenik meg a szerkezetben: jókora, nagy, sokkal stb. Az ilyen adalékokban a kicsinyítő képző jelentése sem 'kis, kicsi', hanem annak az ellenkezője. A bővítmények körében további sajátos szemantikai kategóriát képeznek a negatív jelentésárnyalatú bővítmények, mint pl.: avatag, gonosz, gyenge, hitvány, kopott, lyukas stb., ami szintén azt jelzi, hogy a kicsinyítő képző sem alapfunkciójában jelenik meg.

5. A kicsinyítő képzők, mint a produktív képzők általában, a nagy lexikai kategóriákhoz (főnév, melléknév, határozószó) járulnak.

A SzT. adatai is ezt igazolják, hiszen az erdélyi régi nyelvben leggyakrabban a fönév diminutivizálható (pl.: bárányka, gyermekcse, legényke stb.), ezt követi a melléknév (pl.: jókorácska, kicsid, nagyocska stb.), majd a melléknévi tulajdonságokkal rendelkező (azaz fokozható) határozószó (pl.: messzebbecske, távolabbacska, távolkábban stb.). Csak egy-két adat van kicsinyített számnévre (egyecske) és névmásra (amicske), de ezek is alkalmi főnevek az idézett szövegrészletekben. A magyar nyelvben kicsinyített ige csak gyermekorientált beszédhelyzetben fordulhat elő, de erre nincs példa a SzT.-ban. Alaki felépítésében kicsinyítő képzőt tartalmazó ige van ugyan a SzT.-ban, de a kicsinyített melléknévhez járul igeképző (kicsidell, kicsidít).

Tehát ha a SzT. adatai alapján hierarchiát állítunk fel a kicsinyíthető/kicsinyítő képzőt tartalmazó szófajokról, akkor a legmagasabb fokon a főnév áll, ezt követi a melléknév, alsóbb szinten a határozószó, majd a névmás és a számnév (ez utóbbi kettőhöz nem produktív módon kapcsolódik), illetve a hierarchia legalján az ige áll, amely a magyar nyelvben csak nagyon korlátozottan, kizárólag gyermekorientált beszédhelyzetben fordulhat elő. A többi szófaji kategória pedig teljességgel hiányzik a hierarchiából.

6. A kicsinyítő képzők alaktani jellegzetességeinek vizsgálatakor két szempont állt a középpontban. Egyrészt az, hogy milyen tőhöz kapcsolódhat: egyalakú vagy többalakú tőhöz, a többalakú tövek esetében pedig melyik tôváltozathoz. Másrészt az, hogy a kicsinyítő képző milyen helyet foglal el 
a szóalakban: milyen morfémák előzhetik meg, illetve milyen morfémák követhetik.

A SzT.-ban megjelenő kicsinyítő képzős származékok töveinek megoszlása azt mutatja, hogy a leggyakoribb az egyalakú tő, ezt követi a tővégi időtartamot váltakoztató tőtípus, majd csökkenő sorrendben: tőbelseji időtartamot váltakoztató, hangzóhiányos, hangszínt és időtartamot váltók, véghangzóhiányos, hangszínt és időtartamot váltakoztató v-s tő, időtartamot váltakoztató v-s tô, változatlan tőhangzós v-s tő, hangzóhiányos változatú v-s tô, valamint van néhány olyan származék, amelyiken felismerhető ugyan a kicsinyítő képző, de a tő önállóan nem él a magyar nyelvben.

A kicsinyítő képző helye a szóalakban a klasszikus képzőmeghatározások szerint vagy közvetlenül a tő után áll, vagy más képző(k) után, követheti jel és rag. Mivel viszont a diminutívum nem tekinthető minden szempontból tipikus képzőnek, ezért a szóalakban sem feltétlenül a tő vagy más képző után áll, hanem előfordulhat az is, hogy például jel (a középfok jele) előzi meg, ahogy azt a SzT. adatai is igazolják. Legtöbb adat a $\mathrm{T}+$ DIM felépítésre van (pl.: aprócska, aranyocska, bárányka stb.). Ugyancsak ide sorolhatók a T + DIM + T alakok, vagyis az olyan összetett szavak, amelyek előtagjához járul a kicsinyítő képző (pl.: borjúcskabőr, inaskaköpönyeg, majorocskahely stb.). Szintén szabályosnak tekinthető a T + DIM + K felépítés, ahol a kicsinyítő jelentéssel bíró formánst általában valamilyen szófajváltó képző követi (pl.: boglyácskányi, kétremekecskéjü, apródonként stb.). Ennek a fordítottjára is van példa, vagyis a szó felépítése: T + K + DIM (pl.: reménységecske, betegesecske, szokatlanocska stb.). A kicsinyítő képző inflexiós jellegének bizonyítéka az a tény, hogy a SzT. középfokú mellékneveinek, illetve határozószóinak morfémái között a diminutívum - egy adalék kivételével (távolkábban) - szabály szerint követi a középfok jelét (pl.: hosszabbacska, jobbacska, szebbecske stb.).

7. A SzT. adalékainak morfopragmatikai szempontból való vizsgálata azt mutatja, hogy a kicsinyítő képzőnek alapfunkcióján túl (ti. az alapszóhoz a 'kis, kicsi' szemantikai jegy hozzáadása) gyakran pragmatikai funkciója is van, bizonyos beszédhelyzetekben használatuk stratégiai fontosságú. A Dressler-Merlini Barbaresi-féle csoportosítást követve a kicsinyítő képzőket pragmatikai funkciójuk szerint négy nagy csoportba lehet sorolni (diminutivum puerile, diminutivum sociale, diminutivum modestum, diminutivum ironicum), bár a SzT. adalékai alapján ezt az osztályozást tovább lehet árnyalni, módosítani. Az első módosítás a négy főcsoportot érinti, hiszen a SzT. adalékai alapján a diminutivum modestum a diminutivum sociale alcsoportját képezi. Ezen a kategórián belül két további alcsoport 
különíthetô el attól függően, hogy a beszélő saját személyét vagy a tulajdonában álló javakat kicsinyíti-e. A diminutivum ironicum kategóriáján belül pedig szintén két alosztály különíthető el: az egyikbe azok a kicsinyítő képzővel ellátott szavak sorolhatók, amelyek becsmérlést, szitkozódást tartalmazó beszédszituációban jelennek meg, a másikba pedig azok a származékok, amelyekben a kicsinyítő képző és a származék jelentése között ellentét (esetenként akár ellentmondás is) van. Tehát a SzT. kicsinyítő képzős származékainak kontextusban való vizsgálata lehetőséget ad arra, hogy ezen formánsok pragmatikai funkcióit pontosan feltérképezzük.

8. A kicsinyítő képzők kapcsolódási szabályainak vizsgálata során (a vizsgálatba csak a -cska/-cske, -ka/-ke formánsok kapcsolódását vontam be, ugyanis a többi, az erdélyi régiségben előforduló kicsinyítő képző már a vizsgált korban sem volt produktív) arra a kérdésre kerestem a választ, hogy milyen fonetikai tényezők befolyásolják egyik vagy másik képző használatát, hiszen jelentésükben nincs különbség, tehát valami egyébnek (pl. a szóvégnek) kell irányítani a kettő közti választást. A vizsgálat eredménye az lett, hogy az erdélyi régiségben a $-k A$ képző előfordulhat egyszótagú szavakkal, de ezek a származékok már lexikalizálódtak, vagy a lexikalizálódás útján állnak (szipka, rabka, szánka, tálka); zárhangra végződő többszótagú szavakhoz is kapcsolódhat $-k A$ az erdélyi régiségben (darabka, árpádka, beszédke, rövidke, csigafalatka, falatka, huncfutka), kivéve, ha az illető zárhang $m, g$ vagy $k$; $a$ és $e$ végú szavak a maihoz hasonlóan az erdélyi régiségben sem kaphattak - $k A$ képzőt. A SzT. adatai azt bizonyítják, hogy az erdélyi régiségben a magánhangzóra végződő szavak többnyire a -csk $A$-t kapták. A mai nyelvben kivételnek az $i$ végüek számítanak, amelyek inkább - $k A$-t vesznek fel. Ezzel szemben a SzT.-ban nyolc olyan -cskA képzős címszót találtam, amelyek alapszava $i$-re végződik, és egy példa sincs arra, hogy $i$ végü szóhoz - $k A$ képző kapcsolódna (amicske, annyicska, holmicska, kocsicska, lájbicska, mántlicska, régicske, stelázsicska).

9. A képzővizsgálat hagyományosnak tekinthető szempontjain (szófajalkotó szerep, jelentés, alaktani jellemzők stb.) túl a SzT. adalékai újabb szempontokat is nyújtottak, mégpedig a történeti szociolingvisztika és a történeti nyelvföldrajz módszereinek alkalmazása is tanulságosnak bizonyult a SzT. kicsinyítő képzős származékainak vizsgálatában.

Hagyományosan a nyelvtörténeti vizsgálatok középpontjában a grammatikai rendszer valamely elemének diakróniai változása áll, teljesen elvonatkoztatva attól a szociokulturális környezettől, amelyben a szöveg mint kommunikációs egység elhangzott/megíródott. Világossá vált azonban, hogy a nyelv nem pusztán szabályokba foglalható grammatikai rendszer, 
hanem leírásakor nem hagyható figyelmen kívül a humán faktor, a beszélőknek a vizsgálata sem.

A SzT. célja, hogy a korabeli erdélyi élő nyelvet mutassa be, vagyis a szerkesztői elvek között központi helyet foglal el az, hogy a címszavakat eredeti kontextusukban, lehetőleg adatközlőjük identitásának (az adalékok után, ahol csak lehet, megjelenik az adatközlő neve, társadalmi státusa, kora) pontos feltárásával közöljék.

Az erdélyi régi nyelv kicsinyítő képzős származékainak szociolingvisztikai vizsgálatakor az a kérdés, hogy létezik-e valamilyen nemi, társadalmi funkcióbeli, illetve életkor szerinti meghatározottság a kicsinyítő képzők használatában.

A SzT. kicsinyítő képzős származékokat tartalmazó adalékainak vizsgálata alapján szociolingvisztikai szempontból három nagy kategória rajzolódott ki. Az elsőbe olyan adalékok tartoznak, amelyekből nem derül ki semmilyen információ a kommunikációban résztvevő felekről. Ezek általában tárgylajstromokból, leltárakból stb. kiragadott részletek. A második kategóriába olyan adalékok sorolhatók, amelyek után ugyan nem jelenik meg információ az adatközlő(k)ről, a szövegből viszont kirajzolódik az a kontextus, amelyben a kommunikáció zajlott. Az ilyen adatok elsősorban pragmatikai szempontból érdekesek. A harmadik (szociolingvisztikai szempontból releváns) kategóriába kerültek azok az adalékok, amelyekből pontosan kiderül az adatközlő identitása.

A beszédaktus résztvevői alapvetően két szövegtípusban azonosíthatók: egyik a levél (levélíró és címzett), a másik az élet legkülönfélébb kérdéseiben felvett vallomási jegyzőkönyvek szövege. Itt elsősorban a beszélő alakja azonosítható, a beszédtársé nem mindig. Ezeknek a vallomási szövegeknek az az előnyük, hogy a beszélt nyelvhez állnak közel, hiszen követelmény volt a valló szövegének hiteles rögzítése, az adatközlőről pedig pontos információkat nyújtanak: nevén kívül a korát, valamint a társadalmi funkcióját is közlik.

Attól függően, hogy az adalék utáni szögletes zárójelből milyen információ derül ki a beszélőre vonatkozóan, több alcsoportba sorolhatók az adalékok: 1. a szögletes zárójel pusztán az adatközlő nevét tartalmazza; 2. az adatkölző kora is megjelenik; 3 . a név mellett a társadalmi funkció vagy foglalkozás is kiderül; 4. a negyedik az előző háromnak a kombinációja, vagyis az adalék utáni szögletes zárójelből információt kapunk az adatközlő nevére, korára és társadalmi funkciójára nézve egyaránt; 5 . az ötödik csoportba írott szövegek, levelek tartoznak, amelyekben a kommunikáció mindkét résztvevőjére, az adóra és vevőre is van információ; 6 . az adalékokból az adatközlő személyén kívül a szöveg funkciója is kiderül. 
A SzT. adalékainak szociolingvisztikai vizsgálata alapján a kicsinyítő képzős származékok használatáról elmondható, hogy elsősorban az alacsonyabb társadalmi kategóriába tartozó középkorú férfiak nyelvében gyakori, a kétrésztvevős kommunikációs szituációban is. Nőktől származó szövegekben sokkal ritkábban fordul elő, ennek viszont az írástudó rétegből való kirekesztettségük lehet a magyarázata.

10. A történeti nyelvföldrajz a nyelvtörténet különböző korszakai nyelvi jelenségeinek földrajzi megoszlását kutatja. Szemben a mai nyelvállapot nyelvföldrajzi vizsgálatával, a történeti anyag esetén különböző nehézségekbe ütközünk, például abba, hogy írott nyelvi anyag áll rendelkezésünkre, amely tükrözi ugyan a beszélt nyelvet, de az írott betú nem adja vissza minden esetben pontosan a hangzó beszédet. Tehát annak ellenére, hogy a SzT. adatai változatos forrásokból származnak, csak kellő óvatossággal kezelhetők.

A SzT. előnye nyelvföldrajzi szempontból, hogy - ahol csak lehet - az adalékok után szögletes zárójelben feltünteti az idézett nyelvi adat keletkezési helyét, amely lehetővé teszi ezek nyelvföldrajzi vizsgálatát.

A SzT. adatai a Tisza-Körös-vidéki nyelvjárási régió (ide tartozik Bihar megye, valamint Kalotaszeg), az Északkeleti nyelvjárási régió (észak-szilágyi, nagyjából a Tövishát kistáj területe), a Mezőségi nyelvjárási régió és a székely nyelvjárási régióból származnak. Nyugatról keletre haladva a következő megyékből vannak adatok: Szilágy (Sz), Kolozs (K), SzolnokDoboka (SzD), Beszterce-Naszód (BN), Torda-Aranyos (TA), Alsó-Fehér $(\mathrm{AF})$, Hunyad (H), Szeben (Szb), Fogaras, Nagy-Küküllő (NK), Kis-Küküllő (KK), Maros-Torda (MT), Csík (Cs), Udvarhely (U), Háromszék (Hsz).

A számadatok azt mutatják, hogy a -d kicsinyítő képző földrajzilag elsősorban a székely megyékben (64,61\%), valamint Kolozs megyében $(17,88 \%)$ elterjedt, ezen a viszonylag kompakt tömbön kívül, Erdély többi részében sokkal kisebb arányban (17,51\%) jelenik meg. A -cska/-cske, illetve -ka/-ke képzők esetében az adatok 48,28\%-a koncentrálódik a Székelyföldre, 21,34\% Kolozs megyéből, 30,38\% pedig Erdély többi részéről való, vagyis használatuknak területi megoszlása sokkal kiegyensúlyozottabb, mint a - $d$ képzőé.

Pontosabb kép kialakítása végett a vizsgálat későbbi szakaszában elemezni kellene a kor egyéb (a SzT.-ban forrásként nem használt) erdélyi dokumentumainak kicsinyítő képzőit, majd pedig ezt a rendszert összevetni magyarországi levéltáraknak ebből a korból származó irataival. További kutatást igényelne a régi és mai nyelv diminutívumainak összehasonlítása. Fontos feladat volna feltérképezni a hasonlóságokat és eltéréseket (gondolok itt olyan jelenségekre, hogy a mai nyelvben egyértelmúen egyre 
nagyobb megterheltséget mutat a diminutív képzésmodell, de míg a régi nyelvben a -cska/-cske, -ka/-ke-féle képzők voltak gyakoribbak, ma a becéző képzők kerülnek inkább előtérbe (pl.: szenya, naci, ubi stb.). 



\section{FORRÁS ÉS BIBLIOGRÁFIA}

\section{Forrás}

Szabó T. Attila (főszerk.) 1975-1984. Erdélyi magyar szótörténeti tár I-IV. Kriterion Könyvkiadó, Bukarest.

Szabó T. Attila (főszerk.) 1993-1995. Erdélyi magyar szótörténeti tár V-VII. Kriterion Könyvkiadó, Bukarest - Akadémiai Könyvkiadó, Budapest.

Vámszer Márta (főszerk.) 1996. Erdélyi magyar szótörténeti tár VIII. Kriterion Könyvkiadó, Bukarest - Akadémiai Könyvkiadó, Budapest.

Vámszer Márta (főszerk.) 1997-2002. Erdélyi magyar szótörténeti tár IXXI. Erdélyi Múzeum-Egyesület, Kolozsvár - Akadémiai Kiadó, Budapest.

Kósa Ferenc (főszerk.) 2005. Erdélyi magyar szótörténeti tár XII. Erdélyi Múzeum-Egyesület, Kolozsvár - Akadémiai Kiadó, Budapest.

\section{Bibliográfia}

*** 1832. Magyar helyesírás és szóragasztás fóbb szabályai. A Magyar Tudós Társaság különös használatára. Pest.

*** 1846. A’ Magyar Nyelv' Rendszere. A Magyar Tudós Társaság, Buda. Antal László 1961. A magyar esetrendszer. Akadémiai Kiadó, Budapest.

Bárczi Géza - Benkő Loránd - Berrár Jolán 1967. A magyar nyelv története. Tankönyvkiadó, Budapest.

D. Bartha Katalin 1958. A magyar szóképzés története. Tankönyvkiadó, Budapest.

Bauer, Laurie 1996. No phonetic iconicity in evaluative morphology. Studia Linguistica. 50. 2., 189-206.

Bauer, Laurie 1997. Evaluative morphology: in search of universals. Studies in Language. 21. 3., 533-575. 
Beard, Robert 1998. Derivation. In: Spencer, Andrew and Zwicky, Arnold M. (eds): The handbook of morphology. Blackwell, Cambridge MA \& Oxford. 44-66.

Beeching Kate 2007. A politeness-theoretic approach to pragmatico-semantic changes. Journal of Historical Pragmatics 8. (1), 69-108.

Bencédy József - Fábián Pál - Rácz Endre et al. (szerk.) 1991. A mai magyar nyelv. Tankönyvkiadó, Budapest. 140-142.

Benedek Mihály - Domokos Lajos - Gál András et al. (szerk.) 1795. Debreceni Grammatika, mellyet készitett Debreczenbenn egy magyar társaság. Bécs.

Benkő Loránd 1957. Magyar nyelvjárástörténet. Tankönyvkiadó, Budapest.

Benkő Loránd (főszerk.) 1970. A magyar nyelv történeti-etimológiai szótára. Akadémiai Kiadó, Budapest.

Benkő Loránd (szerk.) 1991. A magyar nyelv történeti nyelvtana I. A korai ómagyar kor és elözményei. Akadémiai Kiadó, Budapest.

Benkő Loránd (szerk.) 1992. A magyar nyelv történeti nyelvtana II/1. A kései ómagyar kor. Morfematika. Akadémiai Kiadó, Budapest.

Benkő Loránd (szerk.) 1995. A magyar nyelv történeti nyelvtana II/2. A kései ómagyar kor. Mondattan. Szöveggrammatika. Akadémiai Kiadó, Budapest.

Benő Attila 2008. Kontaktológia. A nyelvi kapcsolatok alapfogalmai. Egyetemi Mühely Kiadó, Kolozsvár.

Berrár Jolán 1974. Új szempontok és módszerek a szóképzés vizsgálatában. In: Rácz Endre és Szathmári István (szerk.): Tanulmányok a mai magyar nyelv szófajtana és alaktana köréból. Tankönyvkiadó, Budapest. 99-125.

Berrár Jolán, Keszler Borbála. Rácz Endre 1994. Alaktan. In: Faluvégi Katalin - Keszler Borbála - Laczkó Krisztina (szerk.): Magyar leíró nyelvtani segédkönyv. Nemzeti Tankönyvkiadó, Budapest. 9-41.

Brown, Penelope - Levinson, Stephen 1987. Politeness. $2^{\text {nd }}$ edition. Cambridge University Press, Cambridge.

Dahl, Östen 2006. Diminutives and Augmentatives. In: Brown, Keith (ed.): Enciclopedia of Languages \& Linguistics. Elsevier. 594-595.

Deme László 1959. A XVI. század végi nyelvi norma kérdéséhez. NytudÉrt. 20.

Dressler, Wolfgang U. 1989. Prototypical Differences between Inflection and Derivation. In: Zeitschrift für Phonetik, Sprachwissenschaft und Kommunikationsforschung 42. 3-10. 
Dressler, Wolfgang U. - Merlini Barbaresi, Lavinia 1991. Elements of morphopragmatics. In: Verschueren, Jef (ed.): Levels of Linguistic Adaptation. Selected papers of the International Pragmatics Conference, Antwerp, August 17-22, 1987. Pragmatics \& Beyond. 6:2. 33-53.

Dressler, U. Wolfgang - Merlini Barbaresi, Lavinia 1994. Morphopragmatics. Diminutives and Intensifiers in Italian, German and Other Languages. Mouton de Gruyter, Berlin\&New York.

Dressler, U. Wolfgang - Merlini Barbaresi, Lavinia 1997. Morphopragmatics. In: Jeff Verschueren, Jan-Ola Östman, Jan Blommaert \& Chris Bulcaen (eds.): Handbook of Pragmatics, $A-D$. John Benjamins Publ. Co., Amsterdam-Philadelphia, 1-17.

Dressler, U. Wolfgang - Kiefer Ferenc 1990. Austro-Hungarian Morphopragmatics. In: W. U. Dressler, Hans C. Luschützky, Oskar E. Pfeiffer, John R. Rennison (eds.) Contemporary Morphology. Mouton de Gruyter, Berlin-New York, 69-77.

Ettinger, Stefan 1974. Form und Funktion in der Wortbildung. Narr, Tübingen. Fogarasi János 1843. Mữvelt magyar nyelvtan elemi része. Heckenast, Pest. 64.

Galgóczi Gábor 1848. Magyar nyelvtan. Pest.

Geleji Katona István 1645/1906. Magyar Grammatikácska. Nyelvészeti Füzetek 30.

B. Gergely Piroska 1997. Az Erdélyi magyar szótörténeti tár használhatósága a beszélt nyelv történeti vizsgálatában. MNyj. XXXIX. 65-74.

B. Gergely Piroska 1999. Élő nyelv a nyelvemlékekben. In: V. Raisz Rózsa - H. Varga Gyula (szerk.): Nyelv és kommunikációs kultúra az iskolában. Magyar Nyelvtudományi Társaság, Budapest, 323-31.

B. Gergely Piroska 2000. Szóhasználati párhuzamok Heltai Gáspár fabuláinak és a korabeli Kolozsvárnak beszélt nyelvéből. MNyj. XXXVIII. 41-51.

B. Gergely Piroska 2002. A közéleti és beszélt nyelv viszonya az erdélyi fejedelemségben. In: Hoffmann István, Juhász Dezső, Péntek János (szerk.): Hungarológia és dimenzionális nyelvszemlélet. Előadások az V. Nemzetközi Hungarológiai Kongresszuson (Jyväskylä, 2001. augusztus 6-10.). Debrecen-Jyväskylä,187-199.

B. Gergely Piroska 2008. Az Erdélyi magyar szótörténeti tár felhasználása az újabb magyar nyelvtörténeti kutatásokban. NyIrK. LII. 147156.

Gombocz Zoltán 1951. Alaktan. Jegyzet.

Gràcia, Luïsa and Turon, Lídia 2000. On Appreciative Suffixes. Acta Linguistica Hungarica, 47. (1-4), 231-247. 
Gyarmathy Sámuel 1794. Okoskodva tanító magyar nyelvmester. Kolozsvár. Györke József 1943. Tő, képző, rag. MNy. 39, 2: 111-133, 3: 176-195.

Hegedűs Attila 1986. Történeti szociolingvisztika? MNy. 4. 438-441.

Herman József 2001. A történeti nyelvészettől a nyelvi változások elmélete felé: problémavázlatok. In: Bakró-Nagy Marianne, Bánréti Zoltán, É. Kiss Katalin (szerk.): Újabb tanulmányok a Magyar strukturális nyelvtan és nyelvtörténet köréból. Kiefer Ferenc tiszteletére barátai és tanítványai. Osiris Kiadó, Budapest, 389-407.

Horger Antal 1914, 1926. A nyelvtudomány alapelvei. I-II. Budapest.

Hutterer Miklós 1967. A nyelvi struktúra változásának problémája a nyelvszociológia tükrében. ÁnyT. V. 169-187.

Jackendoff, Ray 1991. Parts and boundaries. In: Levin, B., Pinker, S. (eds.): Lexical and conceptual semantics. Blackwell, Cambridge, 9-45.

Juhász Dezső 2002. Magyar nyelvjárástörténet és történeti szociolingvisztika: tudományos kérdések. In: Hoffmann István, Juhász Dezső, Péntek János (szerk.): Hungarológia és dimenzionális nyelvszemlélet. Előadások az V. Nemzetközi Hungarológiai Kongresszuson (Jyväskylä, 2001. augusztus 6-10.). Debrecen-Jyväskylä, 165-172.

Juraffsky, Daniel 1996. Universal Tendencies in the Semantics of the Diminutive. Language 72. 533-578.

Kádár Edit 2007. Alaktan és szófajtan. Egyetemi Műhely Kiadó, Kolozsvár.

Károly Sándor 1965. A szóképzés grammatikai jellegéről, a szuffixumfajták elkülönítéséről és a képzőproduktivitásról. NyK. 67. 273-289.

Kassai József 1817. Magyar nyelv-tanító könyv. Sárospatak.

Kenesei István 1996. Képző vagy nem képző? In: Terts István (szerk.): Nyelv, nyelvész, társadalom: Emlékkönyv Szépe György 65. születésnapjára barátaitól, kollégáitól, tanítványaitól. II. kötet. Janus Pannonius Tudományegyetem, PSzM Projekt Programiroda, Pécs, 92-95.

Kenesei István 1998. A toldalékmorfémák meghatározásáról. Nyr. 122/1, 67-81.

Keszler Borbála 1997. Képzö-e a -hat, -het? Nyr. 121. 86-90.

Keszler Borbála 2000. A szóképzés. In: Keszler Borbála (szerk.) Magyar grammatika. 307-321.

Kiefer Ferenc 1998. Alaktan. In: É. Kiss Katalin - Kiefer Ferenc - Siptár Péter: Új magyar nyelvtan. Osiris Kiadó, Budapest. 187-289.

Kiefer Ferenc 2000. Strukturális magyar nyelvtan 3. Morfológia. Akadémiai Kiadó, Budapest.

Kiefer Ferenc 2003. Morfopragmatikai jelenségek a magyarban. Általános Nyelvészeti Tanulmányok. XX. 107-128. 
Kiefer Ferenc 2004. Morphopragmatic phenomena in Hungarian. Acta Linguistica Hungarica. 51 (3-4), 325-349.

Kis-Erős Ferenc 1915. A magyar nyelv rendszeres vizsgálata. Kalocsa.

Kiss Jenő 1970. A nyelvtörténet leíró szempontú képzővizsgálatáról. MNy. 210-213.

Kiss Jenő 1972. A strukturális nyelvföldrajzról. MNy. 345-354.

Kiss Jenő (szerk.) 2001. Magyar dialektológia. Osiris Kiadó, Budapest.

Kósa Ferenc 1976. Erdélyi magyar szótörténeti tár. NyIrK. XX. 105-107.

Kugler Nóra - Laczkó Krisztina 2000. A névmások. In: Keszler Borbála (szerk.) Magyar grammatika. 152-175.

Ladányi Mária 2001. Szempontok a morfológiai produktivitás megállapításához. In: Bakró-Nagy Marianne - Bánréti Zoltán - É. Kiss Katalin (szerk.): Újabb tanulmányok a strukturális magyar nyelvtan és a nyelvtörténet köréböl. Kiefer Ferenc tiszteletére barátai és tanítványai. Osiris, Budapest, 232-249.

Ladányi Mária 2004. Szinkrón összefüggések - elméleti, funkcionális és történeti magyarázatok (Megjegyzések a -ka/-ke és -cska/-cske fönévképzőről). In: Ladányi Mária, Dér Csilla, Hattyár Helga (szerk.): "... még onnét is eljutni túlra ..." Nyelvészeti és irodalmi tanulmányok Horváth Katalin tiszteletére. Tinta Könyvkiadó, Budapest, 52-64.

Ladányi Mária 2007. Produktivitás és analógia a szóképzésben: elvek és esetek. Tinta Kiadó, Budapest.

Leech, Geoffrey 1980. Explorations in Semantics and Pragmatics. Benjamins, Amsterdam.

Leech, Geoffrey 1990. Semantics. The study of meaning. Penguin, Ringwood.

B. Lőrinczy Éva (főszerk.) 1979. Új Magyar Tájszótár. Akadémiai Kiadó, Budapest.

Maitz Péter 2000. A nyelvtörténetírás elvi kívánalmairól a német nyelv magyarországi története kapcsán. Nyr. 4. 501-513.

Mártonfi Attila 2004. Az -é birtokjel névmási jellegéről. In: Ladányi Mária, Dér Csilla, Hattyár Helga (szerk.): „„... még onnét is eljutni túlra ...". Nyelvészeti és irodalmi tanulmányok Horváth Katalin tiszteletére. Tinta Kiadó, Budapest, 64-74.

Mendoza, Martha 2005. Polite diminutives in Spanish. A matter of size? In: Robin T. Lakoff - Sachiko Ide (eds.): Broadening the Horizon of Linguistic Politeness. Benjamins, Amsterdam-Philadelphia. 163-173. 
Miklós Gabriella 2002. Nyelvi egységesülés az északkeleti régióban a XVII. század elején. In: Gréczi-Zsoldos Enikő, Kovács Mária (szerk.): Köszöntő kötet B. Gergely Piroska tiszteletére. Bíbor Kiadó, Miskolc, 126-129.

Papp László 1961. Nyelvjárás és nyelvi norma XVI. századi deákjainak gyakorlatában. NytudÉrt. 25.

Pete István 1997. A szóképzés kompozicionális jellegéről. Nyr. 4. 470-475.

Rácz Endre - Takács Etel 1993. Kis magyar nyelvtan. Budapest.

Romaine, Suzanne 1988. Historical Sociolinguistics: Problems and Methodology. In: Mattheier, Klaus J. (ed.): Handbook of Sociolinguistics. Walter de Gruyter, Berlin. 1452-69.

Sárosi Zsófia 2003. Történeti szociopragmatika - magyar nyelvtörténet más megközelítésben. MNy. 4. 434-448.

Stefanescu, Ioana 1992. On diminutive suffixes. Folia Linguistica. 26. 339-356.

Szabó T. Attila 1980. Elavult, halódó és élő kicsinyítő-becéző képzők a moldvai csángó nyelvjárásban. In: Szabó T. Attila: Nép és nyelv. Kriterion Könyvkiadó, Bukarest. 102-165.

Szathmári István 1968. Régi nyelvtanaink és egységesülő irodalmi nyelvünk. Akadémiai Kiadó, Budapest.

Szegfü Mária 1991. A névszóképzés. In: Benkő Loránd (főszerk.): A magyar nyelv történeti nyelvtana. A korai ómagyar kor és elözményei. Akadémiai Kiadó, Budapest. 188-259.

Szenczi Molnár Albert 1610/2004. Novae grammaticae Ungaricae libri duo. Ford.: C. Vladár Zsuzsa. A Magyar Nyelvtudományi Társaság Kiadványa, Budapest.

Szvorényi József 1861, 1864. Magyar nyelvtan tanodai használatra. I-II. Pest.

Temesi Mihály 1963. Szóalaktan. Tanárképző Főiskola, Budapest.

Tompa József (fószerk.) 1961-1962. A mai magyar nyelv rendszere. I-II. Akadémiai Kiadó, Budapest.

Vandenbussche, Wim und Willemyns, Roland 1999. Sprachvariation in Flandern im 19. Jahrhundert: theoretisch-metodische Probleme der historischen, soziolinguistischen Forschung. Sociolinguistica. 13. 141-159.

Verseghy Ferenc 1818. Magyar Grammatika. Buda.

Volek, Bronislava 1987. Emotive signs in language and semantic functioning of derived nouns in Russian. Benjamins, Amsterdam/Philadelphia. 
Zelliger Erzsébet 2002. A történeti szociolingvisztika egyetemi oktatása. In: Hoffmann István, Juhász Dezső, Péntek János (szerk.): Hungarológia és dimenzionális nyelvszemlélet. Előadások az V. Nemzetközi Hungarológiai Kongresszuson (Jyväskylä, 2001. augusztus 6-10.). Debrecen-Jyväskylä, 303-309.

Zsilinszky Éva 2003. Szókészlettörténet. In Kiss Jenő - Pusztai Ferenc (szerk.): Magyar nyelvtörténet. Osiris Kiadó, Budapest, 173-204. 



\section{ADATTÁR}

ablacska 1692: Ló Istálló ... ennek két kis ablacskai (!) ${ }^{\mathrm{a}}$ [Mezőbodon TA; BK 4. $-{ }^{\mathrm{a}}$ nem merő elírás ablakocska h.?].

ablakocska 1636: az kamoraczkan egy ablakoczka. Abbol viszont nylik mas egy fejer fel szer vas sarkos pantos aytó az kamora szekre, azon ket ablakoczka [Siménfva U; JHb Inv.]; 1679: Puszta ablakocskaja nro 2 [Uzdisztpéter K; TL Bajomi János lelt. 26]; 1679: Onban foglalt, kivül vas keresztes, paraszt uveges ablakocskaja [Uzdisztpéter K; TL Bajomi János lelt. 26]; 1694: az felso Hazacskajab(an) nemet lakik, üveg Ablakocska rajta [Kővár; JHb Inv.]; 1744: vagyon kisded 4 szegü kamarátska két ablakocskái [Szentdemeter U; LLt Fasc. 67]; 1759: Egy ablakocska eleibe valo tarka Sellyem superlátot [Nsz; Tsb 7]; 1763: ablakotskái dészkával bé tsinálva vadnak [Hortobágyfva Szb; Born. XXIXa]; 1772: egy négy szegeletü Ablakatska ... Ezen Ajto felett égy szakadozott Ablakatska láttatik [Kv; BKt Mikes conscr.]; 1790: Ezen Kamarának ... vagyon egy kisdég kerek ablakotskája [MNy XXXVIII, 208]; 1827: a' Kert felöl valo ablakotskának két Táblátskái ki vagynak tőrve [Koronka MT; Told. 34]; 1842: van égy kis kamara ... van rajta égy kis fa kereszt rostélyos ablakotska [Oprakercisora F; TSb 51].

ablaktartó vasrudacska, vas ablakrácsozatrudacska 1731: rámában ablak tarto vas rudotska [Gálfva MT; Sár.].

acélláncocska acélláncocska 1668: Egy kis fekete Aczel Lanczoczka [Mk Kapi György lelt.10]. adósságocska kis összegú tartozás 1733: hogy nékem se légyen semmi panaszom, a mint hogy nem sok adósságocskám lévén hátra ... tehát azokat fizesse meg az Vr Battyám vram [TK1 Teleki Sámuel lev.].

ágacska 1. sarjadzás (a fiatal fa hajtása) 1800: ezen erdő hellyen, mit-sem erő apro agotskák vagynak [Csekelaka AF; EHA].

2. átv sarjacska 1667: az meg nevezett édes Urátol maradott egyetlen egy árva Agacska ugy mint Lázár Imreh ur(am) [LLt 70/13].

3. ág (folyóvíz kisebb kiágazása) 1807: ezen ... puszta hely mellett a Szamosnak egy kis ágotskája fojván el egy Pallo vagyon épitve [Apahida K; RLt o. 5].

4. hímzésminta bokorszerűen elágazó alakzata 1803: vékony patyolat nagy keszkenő ... szélein égy égy kissebb ágatskák szkofiummal varrattattak [UnVJk].

5. ágszerü hajék/dísz XVII. sz. m. f.: hajra valo hajlott Agaczka [Klobusitzky lev.].

agárkutyó agárkölyök 1654: praemendatt attam ... Haro(m) Agar kutjonak lib. nro 9 [Egeres K; Ks 70 Szám. 51].

ágasocska kics (fölül) kétágú, (fedéltartó) oszlop/karó 1729: Az Ur erdejeből vagtam ... egj Kapu ally fát, s egj agasocskat [A.karácsonyfva AF; Told. 31]; 1736: négy agosotskára epitett, perellyere fedett az két oldalába ragasztott kis Szekér szin vagy Arnyék [Noszoly SzD; CU]; 1736: volt égy négy agasotskán állo kunnyo [Martonfva NK; CU]. 
agátoskő-pikszisecske agát/achátszelencécske 1714: Porn(a)k való leveles Agathoskó Pixisetke (!) [Nsz/Fog.; REkLt II. Apafi Mihály hagy. 10-1].

ágyacska kicsi ágy 1675: Egy hársbol kőtőt edgyes rosz ágyacska [Dés; Borb. II]; 1736: Gyermeknek valo kŏzŏnséges ágyotska [CU]; 1749: Egy semmire kellő rosz agyácska [Királyhalma KK; Ks 23/XXIIb]; 1763: gyenge fenyo deszkábol valo agyatska [Hortobágyfva Szb; Born. XXIXa/19]; 1791: Más kissebb béllett Ágyatska [Nagyalmás K; JHbK XXIX/32]; 1791: Egy Karikás ezek közzül edgyik alá bé járo Ágyatska [Déva; Ks 108. Vegyes ir.].

ágyneműcske kics ágynemű 1791: Néhai Lukáts Mihálynénak meghalálozásakor maradot ... valami ágynemütskéje [Déva; Ks 79. XXVI. 8].

ágyúcska kics löveg, ágyu, 1714: Mas Gyermek(ne)k valo két Agjutska rezes apparatussal egjütt [Nsz/Fog.; REkLt II. Apafi Mihály hagy. lelt. 26]; 1714: Franczia agjutska duplas Csuvel [Nsz/Fog.; REkLt II. Apafi Mihály hagy. lelt. 48].

ajándékocska 1. 1701: Ezen bizonyos emberitül Kegyelmednek Az mint Szegény ifiu legenysègemtűl telik, egy kis ajándékocskát kủltem [Gyeke K; Ks 96 Kornis István Gyeröfi Borbálának]; 1755: Husvéthi Innep napon szokásunk szer(ént) mulatván Falunkbéli Iffjaink ... Falunkban el járo utasokkal is jádzo modon szoktak bánni, hogy valami kevés ajándékocskát nyerjenek [Balsa H; Gy].

2. kb. sápocska 1765: az Executorok Biráinkat szidták verték ... ha pedig ajjándékocskát adhattak Biráink nékik, s az intertentio dolgabanis kedveskedhettek, akkor tsendesebben viselték magokat [Szeszcsor H; Eszt-Mk Vall. 251]; 1765: néha midőn előre el küldöttük a pénzt ... azis haszontalan volt, ha valami ajándékotskát nem adtunk a Commissariusoknak [Ompolyica AF; Eszt-Mk Vall. 19].

ajtócska 1636: egy lud hizlalo olaczka szalmas, egy aytoczka rajta [Siménfva $\mathrm{U} ; \mathrm{JHb}$ Inv.]; 1636: tyuk oll hoszan ket szakaszban ... ket aytoczka raytok, uas, retezesek [Siménfva U; JHb Inv.]; 1636: Gabonas haz ... az padgyara fel nilo aytoczkaja [Siménfva
U; IHb Inv.]; 1680: vagyon egy paraszt pohar Szék, melynek bé tevŏ ajtaczkája vas Sarkokon pántokon forogh [A.porumbák F; Ált Inv. 5]; 1692: ezen haznak padgyara fel jaro kis vas sarkas, pantos, reteszes, reteszfüs ajtocska vagyon [Görgénysztimre MT; JHb Inv.]; 1692: Tisztarto Háza ... ajtócskája vas sorkokon pántokon járó fūrész Deszkabol valo [Mezőbodon MT; BK Inv. 6-7]; 1692: vagyon ... almarium. ennek két felé nyilo vas sarkokon pantokon járó Aitócskái [Mezőbodon MT; BK Inv. 11]; 1694: (A) kapu edgyik Felin, vastag Tölgj fabol csinalt ki jaro kis Ajtocskajais van [Kővár; JHb Inv.]; 1694: Az Pincze Ajto keozepin egy Praebenda kioszto ablak annakis Ajtocskaja Vas Sarkos pantos [Kővár; JHb Inv.]; 1694: Vagjon ... vas sarkokon pantokon forgó retezes, retez fejes tabla forma Ajtótska [Borberek AF; BfR]; 1695: edgy Vas sarkokon Pántokon forgo Ajtocska [O.csesztve AF; LLt]; 1697: Ezen hazbol vagyon egy kis kamaráb(a) ki nyilo bérlett fenyo Deszkábol állo vas sarkokon fuggó kisded ajtocska [O.brettye $\mathrm{H}$; Born. XXIXa 2]; 1698: egj Tornacz ... ajtocskaval edgjütt [Kóród KK; LLt fasc. 72]; 1699: Ezen külsŏ Udvarrol ... az fas kertben nyilik bé egy kis cserefa ajto melljékű ajtocska [Szentdemeter U; LLt]; 1699: mentünk bé egj alacson ajtócskán [O.csesztve AF; LLt]; 1699: vagyon zōlden festet ajtocskaju almariumocska a falban [Boroskrakkó AF; BfN]; 1714: Egj dió fabul való Iro Ladatska, Ajtotskaja rezes Rosaval ékesitett [Nsz/Fog.; REkLt II. Apafi Mihály hagy. 55]; 1715: vas Sorkakon forgo vas reteszu ajtocska [Pálos NK; LLt Fasc. 140]; 1724: Vagyon a' kívűl füttő kemenczére be jaro kemeny alat egy ajtocska [Koronka MT; Told. 27]; 1732: ezen Palotában találtunk ... egj avatag fenyŏ deszkábol álló zŏld festékü asztalt, melynek ajtocskái nyilnak vas sarkokon [Kv; Ks 40 Varia XXVIIIC]; 1732: a Tabernaculum asztalos munkával aranyozva ... kicsiny vas sarkokon fordulo ajtocskájával [Kóród KK; Ks 12/I]; 1736: (a) Pintzének ... Cserefa fiok Gerendátskáira borogatott Csere fa padlása vagyon, rostéllyos kis ajtotskája [CU]; 1736: egy ... tapasztatlan szalma fedelü pajtátska ... ennekis fenyő deszkábol valo paraszt aj- 
totskája van [Várhegy MT; CU]; 1740: (A pohárszék) rekeszén vagyon vas Sarkocskán forgó, vas reteszes és párkánjozott ajtócska [Gyéressztkirály TA; Ks 89 Inv. 6]; 1750: vak Ablak ... vas Sarkakra egy felé nyilo Ajtocskával [Papolc Hsz; Hr]; 1753: avatag egy felé nyilo kapu, égy Gyalag bé járo fa Sarkakon forgo Bikfa deszkákbol készitetett ajtacskájával együtt [Sajókeresztúr SzD; JHbK XXIX/7]; 1765: Az Udvarb(an) meg kivantato Ajtocskákra tŏb szŭkséges helyekre ... erog(altam) Nro 239 [Nagybarcsa H; Ks 71. 52 Szám.]; 1768: Pohárszék két felé nyiló vas sorkain forgo záros ajtacskáival edgyüt [O.kocsárd KK; Ks 74, 55]; 1772: (A sövény kertnek) fa sorkokon fordulo Ajtotskái vadnak [Szászfenes K; BKt Mikes conscr.]; 1781: ezen Gyümöltses kertben járnak bé a' ... hitvány fenyő deszkábol valo Ajtótskán [Mánya SzD; Hr]; 1781: egy kis Sendelyes fedelŭ fenyŏ deszkábol valo Ajtótska [Petek U; Hr]; 1788: Két kitsin fejér ajtótska [TSb 47]; 1788: Egy almariumra valo kis ajtotska ajto béléssel égyŭtt [Mv; TSb 47]; 1797: vagyon egy ajtocska [Kőrispatak U; Pf]; 1851: tyuk-ól ... ennek négy ajtócskáin van két kis vas sarok [Erdősztgyörgy MT; TSb 34]; 1851: közönséges ló-istálo ... Van egy gané hányásra alkalmazott kis ajtócska [Erdősztgyörgy MT; TSb 34]; 1852: Az Hiuba fel járo ajtotska nints [Dés; DLt 1248].

ajtócskahely elfalazott kis ajtó helye 1741: a padláson fenn ki bontottak egy régi ajtotska hellyet [Meggyesfva MT; Ks 184. LXXXVIII].

ajtótáblácska ajtószárny 1757: fenyō Deszka kisded bé járo Ajto Táblátska [Nagyernye MT; LLt].

akasztó-horgocska ablak-kitámasztó horog 1772: Mind ezen két Ablakoknak festetlen Fenyőfa Dészkábol való két két vas sorkokon forgo külső Táblái vadnak, égy égy akasztó horgotskákkal [Szászfenes K; BKt Mikes conscr.].

akócska kis akó 1761: (Lopott) Papuk Péter ... Szurdukán Juontol egj akócska vagj buria pálinkát [Fazsacel H; Ks 113 Vegyes ir.]; 1761: Papuk Peter ... tőllemis el lopott őtt kupa pálinkát egj kis akócskában [Fazsacel H; Ks 113 Vegyes ir.].

alábbacska lejjebbecske, egy kissé lejjebb 1762: azon nevezetŭ hellyben allabbotska [Backamadaras MT; CsS]; 1767: Mégis ott alábbatska igen jó hellyen ... szánto föld [Kincsi MT; LLt Fasc. 129]; 1767: Ugyan ott alábbatska hasonlo hellyen [Pete MT; LLt Fasc. 129]; 1767: Ugyan abban a Sorban vagyon alábbatska a falunak kōzepe fele [Pocsfva KK; LLt Fasc. 129]; 1776: mingyárt kőztők nagy verekedés támada, de ki miként űtete egymást, mint hogy alábbatska is mentek volt, nem láttom [Katona K; Born. VI/14]; 1779: Alábbatska egy kis Főld [MkG]; 1789: (A föld) alábbatska levŏ szellyessége ... [Kisadorján MT; Sár.]; 1791: A Szűget közepitől fogva ... mindjárt alábbotska [CU Naláczi A. conscr.]; 1791: Alábatska tavally le ésett égy jo Musdalyly fa [MNy XXXVIII, 53]; 1797: a' Tsáni szegbe, az elé jároba, alábbatska [Ajton K; CU]; 1800: Ezen Kedekistirol (!) Malmokon alábbatska levő Sos Forrás penig ma nincs meg [Indal/Mikes TA; JHb].

alábbacskavaló gyengécskébb 1746: minthogy az Urfi ö Nga része alábbatska Való ennek gyengesége expleáltatik a felső To felett lévo szakodasban lévő kis foltotskával [Mezőbodon TA; JHb XI/22. 8].

alábbadka lejjebbecske XVIII. sz. e. fele: Rétetskéje ... van ... Petlendi Puszta Falu helyen $^{\mathrm{a}}$ az elébbenivel egj sorba alábbatka [AbN. - ${ }^{a}$ Túr (TA) határában]; XVIII. sz. e.: fele Szánto fold van alábbatka azon Sorba [AbN.].

alábbvalócska 1 . hitványabbacska, gyengébb fajtácska 1802: Mostoha attyatol 8 jármas okrek volt, melyekbōl ... a aláb valotskakat az Exponensnek adot (így!) [Komjátszeg TA; Komjátszegi lev.];

2. gyatrábbacska, silányabbacska 1801: A kissebbetske és alábbvalotska készületü Hidas [Gernyeszeg MT; TL.].

álacska kics hossz- és területmérték-egység 1693: ada(na)k ... egy fel alaczka földeczket [Sszgy; BLt]; 1698: vagion egi fel áll ... azon heliben egi fel állaczka [Szentimre Cs; Hr 2/39]; 1715: Vagyon a patakra menőbenis egy fel allacska (ti. föld) az Utat által keli [Étfva Hsz; Borb. II.]. 
alakorasztagocska alakorkévékből rakott kis asztag 1723: Zab és Alakor Asztagocska [Holtmaros MT; EMLt].

alkalmasocska kics megfelelő 1745: az vanyolohoz egy vedres üst, 1 vizmelegitő alkalmasotska [EMLt]; 1791: egy boronafábol készittetett és Náddal bé fedetett alkalmasotska Tselédház [T; CU].

alkalmatlanocska kics alkalmatlan 1755: (A) nagy házbol ... két ajto nyilik ... edjiken nyitanak s.v. az Arnyék székre, mellynek ajtoja minthogy nintsen meg duplázva az házban lévő ágyhoz kŏzel esvén; alkalmatlanotska [Ludesd H; BK sub nr. 1020].

alkalmatosabbacska alkalmasabbacska 1768: meltoztassek Ngtok I(ste)nesen meg tekinteni Szegényeket, hogj ok is a szolgálatra is alkalmatosabbatskák lehessenek [Esztény SzD; Told. 5a].

alkalmatosságocska kics kb. kedvezés 1689: N. Boer Thamas, és B. Péter Uraimék Proponálva(n) az eo Ngok Fogarasi Felső Székin Felsŏ Venicei joszagokba(n) sokkeppe(n) valo meg bántodásokot, instaltak mi előttünk kőzőnsegese(n) azo(n): hogy az iránt valo háborgattatásokba(n) ha mi alkalmatossagocskaval mi tőllünk kőzőnsegese(n) lehetne az iránt valo succursusunkot ne denegalnok [Fog.; Szád].

állapotocska kics (vagyoni, társadalmi) helyzet 1656: Az temetés pedigh, tsak az en csiekely allapotoczkamhoz kepest legien, tudgiak ki voltam en [Ádámos KK; Bál. 93 végr.].

állásocska állványocska 1804: egy Kis állasotska egy Darab Deszkával [Borosbenedek AF; SLt].

allódiatúrácska földesúri birtokocska, majorságföldecske XVIII. sz. közepe: az földes Ur mindenkor szabad volt maganak allodiaturatskat excindalni [Kük.; Ks 66. 45. 17h].

almafaágacska XVIII. sz. vége: Minden fele virág mag hamaréb virágzik ha minek elötte el veted, almafa agocskába Szurod, s ugy főldbe teszed [Ks Kerti Oeconomia].

almafácska 1736: ezen le irt metátol edgy Stucz lŏvesnyire edgy alma fácska mellé erigaltatot edgy fŏld halom [K; SLt F. 40]; 1776: (A) bokros helly ... a rét kōzepin lévö kis alma fátskátol kezdve jutot ... Gróff Bethlen Miklósné Aszszony eō Exja részére [Szalonna SzD; JHbK XLII/9]; 1821: van egy nehány almafátska [Uzdisztpéter K; TGsz 18].

almafaoltványocska (oltott) almafacsemetécske 1747: Egj Kis alma fa oltványotska Flor Hung 1 [Déva; Ks 73. IV. 59a].

almafiatalocska almafacsemete 1595: nap niugot feleol eg' arant eg' vegb(en) vagion harom alma fiataloczka [Abrudbánya; Ks 42. B. 22].

almáriumocska 1. (fiókos, üveges) szekrényke, pohárszékecske 1699: vagyon zŏlden festet ajtocskaju almariumocska a falban [Boroskrakkó AF; BfN]; 1714: Egy Almariomotska elephant tsontal [Nsz/Fog.; REkLt II. Apafi Mihály hagy. lelt. 19]; 1714: Kis Almariomotska Tenger szinre festett külsö Tablakkal [Nsz/Fog.; REkLt II. Apafi Mihály hagy. lelt. 55]; 1737: Egj főldőn állo paraszt Almáriumotska [Csákigorbó SzD; JHbK XXVI/13. 6]; 1739: egy festékes almariumacska [Kv; Pk 6]; 1742: deszkából csinált Almariumotska [Pókafva AF; JHb XXV/58]; 1745: Vagyon ezen házb(an) egy fejér keskeny magas Almariumotska [Marossztkirály MT; Told. 18]; 1770: Kitsin Almáriumotska tojokás 1 [Királyhalma KK; 23. XXIIb]; 1788: Egy kitsin festett hat tojokáju almariumotska [Mv; TSb 47]; 1797: Egy almárjomotska őt Tojokaival [Mezőköbölkút K; CU]; 1825: ezen Asztalon lévö fijokok tetejére tsináltatott ... egy két felé nyilo levél tarto belöl apro rekeszü, gyöngy szinre festett Almáriumotskát [Dés; DLt 595].

2. faliszekrényke 1699: egy kő falban levő régi almariumocska [Szentdemeter U; LLt]; 1794: A nagy hăzban a' Falban levŏ almariuomotska Rf. 2 [Deva; Ks 73. IV. 10]; 1797: egy kisded kō falba botsátott fenyŏ deszkábol valo almáriumotska [Kőrispatak U; Pf]; 1797: Egy falba csinált festékes almariumocska [Szu; UszLt XII. 87]; 1802: egy falban lévö almariomotska [Kv; Pk 4].

almásszürkécske foltosan szürkés 1815: mely lovak kŏzŭl, az egyik kicsiny, almás szŭrkétske ... hitvány, paripa [DLt 222 nyomt. kl]. 
általagocska 1. hordócska 1585: Regy zokas zerent az Atalagochkanak feneket ky wagattak volna es a' bort a feoldel emesztettek volna megh [Kv; TanJk. I/1. 7]; 1585: Apro Altalagochkak $5[\mathrm{Kv}$; KvLt Vegyes I/2. 4]; 1589: Iget boris vala egi altalagoczkawal [Dés; DLt 226]; 1664: Keottettűnk égy általagotskát pro $\mathrm{f}-\mathrm{d} 15[\mathrm{Kv}$; SzCLev.]; 1697: Az kőzepső pinczeb(en) ... Bor eczet Kétt altalagaczkab(an) [Borberek AF; Mk Urb. 4]; 1717: hoztanak ... egj kis atalagocska sert [Abosfva KK; Ks 96 Mátis István lev.]; 1719: Almakerékről, vagy negy Általagocskámat ŭrmŏs(ne)k és veres(ne)k el kŭldem [Ebesfva; KJMiss. Rétyi Péter lev.]; 1726: Edgj pálinkának való általagocska [Görgény MT; Born. G. VII. 23]; 1735: egy Mustárnak valo atalagocska [Királyhalma KK; Ks 23. XXIIb] 1740: Öt átalagotska [Ap. 5 Apor Péter lelt.]; 1741: találtunk ... egj őtt vedres átalagotskát teli alma etzettel [Mezőbánd MT; LLt Fasc. 146/B]; 1744: egj kisded általagotskáb(an) etzet ágy [Borsa K; LLt Fasc. 24]; 1746: Bortis kŭldek ket kŭs Altalagotskával [Gagy U; Ks 83 Péterfi Sándor lev.]; 1752: egy négy kupás Átalagotskát ... fel szakasztván ... három kupányit meg ittunk [Algyógy H; BK]; 1754: Groff Teleki Lajos Ur vitetett Bort ... 4,5 Vedres szerü Altalagotskával [Vajdasztiván MT; TGsz 33]; 1763: az utrizált koltsár egy cir(citer) 7 vagy 8 ejteles átalagotskát borral meg tôltvén haza vitte [Betlensztmiklós KK; BK Gazd.]; 1767: Két vedres átalagocska, mellyb(en) Czibere tartatik [Marossztkirály MT; Berz. 5. 38/P. 2]; 1793: az utzán egy borral tellyes általagotskát kapék [Zalán Hsz; Mk]; 1796: egy általagatska palinkás [Nyárádsztbenedek MT; Told. 37]; 1796: kűldőttem egy Átologotskátis [Vaja MT; Ks 101 Balla Imre lev.]; 1798: Egy 7 kupás atalagotska [Vingárd AF; KCsl 5]; 1799: Két Atalagotska mellyek(ne)k égy égy Feneke nintsen [F.zsuk K; SLt Vegyes perir.]; 1805: Egy kis altalagotskát meg tŏltōttem fenyŏ vizzel [Szotyor Hsz; KsMiss. I. Gidófalvi László lev.]; 1812: Egy tiz Kupas általagotska [M.gyerómonostor K; KCsl 11]; 1812: Más hitvány általagotska [M.gyerőmonostor K; KCsl 11]; 1813: Két Általagocska az egyik egy a' másik két akos [Kosesd H; Ks 111 Vegyes ir.]; 1819: Mintegy Őt vedres általagatskába ... régi bor [Baca SzD; TSb 6]; 1820: Egy általagotska ... mint egy circiter 4 vedres [F.gezés NK; Told. 30]; 1847: egy átalagatska sos vizet kaptam [Dés; DLt 891]; 1850: egy darab 1 vedres átalagotska [Algyógy H; Born. F Ii].

2. egy hordócskányi, egy általagocskányi 1685: Zarnóczi hozta Czitromlév két általagocska egísz [UtI]; 1696: láttam ... egj atalagocska mézét [Kv; LLt Fasc. 146]; 1744: vittem ki ... egy Altalagocska bort [Besenyő AF; Told. 3]; 1748: Vagyon egy atalagocska éget bor [Mezősályi TA; Ks 7. XVII. 12]; 1759: az el-múlt őszszel ... egy negy vedres áltologocska bort szürtünk [Marosludas TA; TKl]; 1798: két átologocska Bor [H; Ks 108 Vegyes ir. 58]; 1849: egy átalagocska pálinka [Drassó AF; HG Lázár lev.].

amicske I. fn-i jellegű haszn-ban: amennyicske, amennyikó 1644/1785: az Ur Isten ... az én Szerelmes Attyámfiát Nyagu Borbárát rendelte Házas társul ... Haza Törvénye szerint a micském van nagyobbára vélle együtt szerezvén őtet illetné [BfN Kémeri Huszti Menyhárt erdélyi főharmincados végr.]; $1710 \mathrm{k} .:$ az szebeni nyomoruságos Estendők alatt ki vesztegettem vala kevés Pinzemet, a' mittske meg maradhatott az terhes kŏltésimböl [Cs. Vajda lev.]; 1748: a' mitskéje volt, el takaritatta [Ne; Told. 56]; 1782: Veress Samuel ... házasságának oly éretlen idejiben oka a' volt, hogy arván maradván a' mitskéje, két felé osztva maradott ne pusztulyon el [Torda; KW]; 1791: a' mitske vagyonis a ketskék által el rágatot [Doboka SzD; MkG]; XVIII. sz. v.: a' mitském vagyon, mind a' Szegény Anyám Aszszony Jussán vagyon [AbN]. II. mn-i jell. haszn-ban: ami kevéske XVIII. sz. v.: a'mitske Joszagotskám vagyon mind a' Néhai b.e. Szaniszló Sigmond Uram Joszágibol valo [AbN].

ampolnácska korsócska 1629: Egj ampolnaczika Teriek Egj kis darab czinadoff [Gysz; LLt Fasc. 155]; 1681: adnak ... Két ompolna terjeket azon kivul kicsiny ampolnacskakb(an) terjeket $3[\mathrm{UtI}]$. 
angáriácska negyedévi járandóságocska 1776: Recognoscalom ... Egy Angariatskámat pro Mensibus Majó Junio et Julio A. 1775 kivévén, Aztot mái napon méltoztatott nékem meg-kŭldeni [Moson MT; Bál. 92].

angyalképecske angyal alakú ékszerdíszecske 1716: egy rubintos nyak szoritó 19. remekbül álló egy kis angyal képecske az Fityegője [Wass 11].

ángyelika 1. többszínű könyvkötő-papiros 1750: a Tabellakot mind ujjolag kellett compingáltatnom Angelicába igen szépen [Ap. 3 Rétyi Antos István lev.]; 1832: Fizettem Diariumok készellessire (!) Angyelikara [RLt O. 4 Rettegi Imre költségjegyz.]. 2. ? angyalgyökér/fü; Angelica 1757: Postára orvosságra Angyelikára és egjéb edgyet másra Rfr 02 xr 4 [TL. Teleki Ádám költségnaplója].

ángyó bec rendsz csak megszólításban: ángy 1766: le menvén Damokos Ferentz a' Batytyahoz Damokos Janoshoz monda az Angyának Damokos Janosnénak jol mondotta ked Angyo (: mint hogy az elōtt valo estve ott volt :) hogj ne menyek el hanem hallyak itt mert valami bajom lész Azon beis tellyesedék rajtam [Szilágycseh; BfR 104/2]; 1806: jőjen kend Ángyo szoporán lásson ujjságot [Dés; DLt 250/1808].

annyicska akkorácska 1813: ugy gondolkodtam, hogy kedves Bátyám Uramat meg instáljam arra, mely szerént Kedves Bátyám Uram a' maga Földgyéből keresztül annyitska helyet a'mennyi egy kőzőnséges Fogadonak szükséges ... által adni méltoztassék [Dicsősztmárton; RLt O. 3 Gyárfás Ferenc Weress Sámuelhez].

apparátusocska készülékecske 1732: Mathesishez tartozando apparatusocska egj tokban [Ks Kornis Zsigmond lelt. 20].

aprócska kicsike 1651: Harom oregh szem Gyengy Negy Aproczkab [Wass 27 Wass Judit kel.].

apród I. mn aprócska, kicsike 1778: Marhái és Fakultásaira eset portioja én réám iratott mint el maradott őzvegjére Aprod gjermekeimmel egjütt [Agárd MT; Told. 8];

Hn. 1591: (Egy föld) hatara az falu feleol az Aprod Arok [Náznánfva MT; EHA]. apródonként kevesenként rég, táj kicsidenként I rendre-rendre 1584: az mit hozza kezdeth aprodonkenth Jomodon felúette rezeth es elmenth [Kv; TJk 4/1. 292]; 1599: Az Eoregh Marok Vasnak szama ... 4762, keolt el benne 469 ... aprodonkent attuk kit alab kit fellieb az mit èrt [Kv; Szám. 8/ XI. 27]; 1710 k.: meg akartam fizetni azon Summát aprodonkint [Cs. Vajda lev.]; 1754: Ugy emlékezünk, hogy a' mikor a' Maros eszt a' Szigetet nem aprodonként valo lotsogatása, hanem egész darabban áradásával a' Maros Nemeti Határbol avelláltá mintegy tizenhat Esztendeje Vagyon [Haró H; GyK]; 1755: öt hordobol szu ljukakon ... aprodonként mig észre vettük folt el 10 veder [Kiskend KK; Ks 71 Szám.]; 1755: Berkeszinek is amit egyszer, másszor aprodonként adott meg fizettem Rhflr 2 xr. 33 [TL. Teleki Ádám költségnaplója]; 1756: a Nagy Szakadás alatt lévő Sziget ... nem ... a Szamos vize által el szakasztatott helly legyen, hanem aprodonkent viz mosása és lotsogatása? [BSz; Ks 19/IX. 11 vk]; 1757: Méltoságos Aszszonyunk eŏ Excellja ... kivánta ... In Sequentibus ezekröl parantsolni hogy aprodonkint Dévai Tiszt Uraim effectumba vegjek [Déva; Ks 92. I. 23]; 1772: (Az erdőt) azoltatol fogva Irtogatták a' Bátoniak mitől fogva tőllünk aprodonkint occupálták [Bálványosváralja SzD; Ks 101]; 1778: Ezen Erdőt ... egyszer mászor aprodonkint elhordották [Koronka MT; Told. 79]; 1780: amit ád approdonként végre őszve Summalván azon Summa investiáltassék a Czigányakra [Mv; Bet. 4 Újfalvi János lev.]; 1801/1804: eő kigyelmektől aprodonként feles pénzt vettem [Dés; DLt]; 1804: Ezen Szőllők ... apródonként szereztettek [Somlyó Sz; CU Aspremont vall.]; 1806: Vettem Apradonként egytől is mástol is Fadgyatt 53 lb [Tresztia H; Ks 109 Vegyes ir.]; 1819: fél kupa Sylvoriumot rend szerént aprádonként el költet [Kv; Pk 2]; 1820: a Sz Egyedi kőzőnségis a Borzás es Hársos tetón foglalt el egj darab erdőt s apradanként ki irtatgatván ma mint szantó es Kaszalo helyeket birja [Szék SzD; Wass 4]; 1821: Nuksori Denyille Tógyer ... költsönzött légyen Bárbu Albunak 7 Forintokat, mellyet most Bárbu Alb ugy 
állit hogy egyszer is máttzor is le fizette (!) volna aprádonként [H; JF 36 Prot. 3]; 1823: Ötves Szathmári Györgynek adta el ezt is apprádonként őszve verve és darabolva [Kv; KLev.]; 1826: a materialék szerezgettetnek approdonként [Mv; Told. 7]; 1840: aprádonként az árusok naprol napra kijjebb teddegelték fedeles asztalaikat [Dés; DLt 784]; 1841: a viz tehát aprádonként alább alább mosta a földet [KLev. 11]; 1844: a' Szamos vize hol ide hol amoda veszi folyását, aprádanként magát a' $\mathrm{Fe}$ nesi határhoz és a' Monostori Szölök alá huzván, a' helyt el hagyta [Szászfenes K; KmULev. 1]; 1844: a' Szamos kaszállo helyét aprádanként mosogatta [Szászfenes K; KmULev. 1]

apródonkénti apránkénti, rendre-rendre való 1837: az a felett fekvő meredek hegyek aprodonkénti le le süllyedezések [Dés; DLt 631].

apródutka (három) garasos ércpénz-érmecske 1628/1635: Egj hozzu sakban negj zaz forint arra apro dutka [Bodok Hsz; BLt]; 1674: Egy Tarisznyab(an) ... Kőremczi pénz, floreni huszonnegy. Apro dutka, huszonkilenc ... Egy tallér ... Nyolczvan apro dutka [Szászvárosi ref. egyh. 1t. Halics Mihály lelt.].

apróleányka szolgálóleányocska, szolgálócska, pesztonka 1666: Az Apro leankaknak is hattam ... egy ŭnő tinőt (!) [Abafája MT; Told. 21].

aranyfogacska ? fogazásos arany szegélydísz 1714: Regi Vorös Barsonybul való Asztali Szúnyog (!), Széllen arany fogatska [Nsz/ Fog; REkLt II. Apafi Mihály hagy. lelt. 5].

aranyfonal-gombocska aranyszálból kötött gombocska 1711: Egy fejer Scárlát Dolmán, az allyán fejer Viragokra aranyassan szütt béllésü apro arany fonal Gobotskák rajta [Told. 19]; 1714: Baraczk szin Seljembul Dolmanj ... az uyán ... 16 aranj fonal gombotskakkal [REkLt II. Apafi Mihály hagy. lelt. 7]; 1714: Ferfi gjermek(ne)k valo Vörös Bársony Mente ... 8. par aranj fonal gombotskakkal [REkLt II. Apafi Mihály hagy. lelt. 24].

aranyfőkötőcske aranyszálból varrt, kötött női fejrevaló 1673: Egj aranj fökötőtske egj nehanj boglarral [Marossztkirály AF; IB]. aranyfüggőcske arany mell-ékecske/medálocska 1634: 1 kis Arany fwggeöczyke [Kv; JHbJ XVII/15]; 1668: Vagyon egy kis Arany függŏczke [Mk Kapi György lelt. 10]; 1733/1813: Egy arany függőtske, kinek kőzepében igen igen szép égetett Saphir [Kv; SLt XLII. 6. 26P. Horváth Krisztina hagy. lelt.]; 1786: Egy Arany fügőtske egy nagy rubint benne [Nsz; Ks 74. 56].

aranygombocska 1633: azon Lanczban vannak peszmas arany gomboczkak Negyuen hatt [Ks Vesselini Kata kel.]; 1706: Egy arany gombocska kek es fejer zomancsal (!) [LLt Fasc. 108].

aranygyứrǘcske 1585: Vagion ... Harom Arany gywreochke [Kv; Szám. 3/XIX. 2]; 1585: Nemeth Menyhart Arany Gywreochkeye vagion zalagba [Kv K; Szám. 3/ XIX. 3]; 1586: ada ... ezen keòwl haro(m) apro Arany gyurochykeketh [Told. 27]; 1586: egi kis Arany giurochike [Told. 27]; 1617: (Adott) Egi Aranj njomo Aranj giureoczket [Kv; Pf]; 1622: Egy granatos felkete (!) zamancos aranj gyeoreoczke [Kv; RDL I. 119]; 1634: Ket arany gyüreoczket nem adhattak ele [Kv; RDL I. 119].

arany-homlokelőcske kb. arany-fejék 1637/1639: Egj Arany homlok előcske [Kv; RDL I. 111].

aranykapcsocska 1732: Az Gyémántos Arany kapcsocska ... Kŏzre maradot [Nsz; Ks 73. 55].

aranykarikácska 1774: Egy Kis Arany Karikátska [Nagyida K; Told. 26].

aranykezecske kéz alaku aranyékszer 1709: 1 kis arany kezetske 2 rubit (!) bene [Wass 11 Árva Matskási Erzsébet lelt.].

aranylakatocska 1728: Az Antal Vrffi arany mives Ládájában vadnak ezek ... 1 rajta pedig egy aranny lakatocska [Nsz; Ks. 1. Köv. a fels.].

aranyláncocska 1586: az melly Arany Lanczocska en teolem el wezett [Kgy]; 1637/1639: Egy Arany Lanczocska egy kis függeouel együtt [Kv; RDL I. 111]; 1648: Egy kek Zomalczos Arany lanczoska [Mk Kapi Kata kel. 1]; 1655: Egy Aranj lantzocska egy moneta raita [Kv; RDL I. 29]; 1668: Egy kis gyenge Arany Lanczocska, ŏt Arany benne [Mk Kapi György lelt.]; 
1716: egy kétczeresen faragott arany lánczocska [Wass 11]; 1763: Egy kis Nyakba való Arany Lánczocska [Nsz; TGsz 51].

aranymarhácska aranynemücske 1684: Arany ezűst marhátskám a mi vagyon meg czédulázom, kiki a szerint talállya [Dés; Pat.]; 1710: Anno 1710. Die 5 July Szamlalvan meg keves Szamu arany marhacskamat mellyis kŏvetkezik a Szerint [Wass 11].

aranymarhás ládácska aranyneműs ládikó 1746: Arany Marhás Ládácska [Nsz; Told. 19].

aranymérő-ládácska aranymérő dobozocska 1791: 1 Arany mérŏ Ládácska [Mv; MvLev.].

aranyocska 1 . aranypénzecske 1631: tudom hogi volt az Aniadnak penze, arra azt felelte hogi hagiot edes koma(m) Aszony ... hagjot ennekem szegeny egi nehany araniaczkat [Mv; MvLt 290. 259a].

2. aranydarabocska 1754: Aproság Aranyotskák Flor. hung. 9 [Nsz; Told. 19 Oszt. 16].

aranyóra-kulcsocska aranyóra felhúzásához való kiskulcs 1791: egy arany Ora Koltsotska [DLt nyomt.].

aranyszívecske szívalakú aranyékszerecske 1786: Egy kis Zamántzos Arany Szivetske egy rubint a közepibe [Nsz; Ks 74. 56].

aranyvirágocska virágalakú aranyékszerecske 1758: Egy Rubintos Arany virágotska [Nsz; TSb 21]; 1768: Egy Rubintos Arany virágocska [Nsz; TGsz 51].

araszocska 1750: Egy araszocska Füresz fel kézre [Bezdéd SzD; LLt Litt. B].

árkocska 1572: Byzonnyal Twggia az Kys Arkochka desy hathar [Dés; DLt 184]; 1642: (A telek) viczinussa egy Arkoczka [Nagymeregyó K; JHbK XVIII/20]; 1694: Arx Keôvár ... Az leg also es kűlső kapuja eleiben menvén ki az Varnak ... Ezen belől mindgyart va(gyo)n egy kőből rakot Arkocska [JHb Inv.]; 1724: az Erdö alatt el jaro utt egyik vege utkezik egy Arkocskaban [M.zsombor K; EHA]; 1745: Szakad bé az Erdőről az holt Szamosra egy árkocska [Szurdok SzD; JHbK XXVI/5]; 1746: egj essō Csinálta árkacskán alol lévŏ kis Ormocskán le a fen álo kert Szegeleteig ... volt is valami kis káposztás kertecs- kéje [Monor BN; Ks 7. XX. 19]; 1764: vólt úgyan e nevezett két hellyek között ezen $a^{\prime}$ hellyen ... valami Arkotska [Vajdasztiván MT; JHb IX/46]; 1765: az en értemre mindenkor volt a fele Tocsa és pocsoja ... melyet ... mindenkor ott bocsátott el a falu arkotskán [Bethlen SzD; BK]; 1775: (A föld) vége ... rug egy Arkotskára [Dés; Ks 73. 55]; 1794: a' Szász Káplán Kertyéből lejövö Árkotska [Hosszúaszó KK; EHA]; 1797: az Csorgo vagyis kis árkotska felol falo (!) kert [Kőrispatak U; EHA]; 1798: égy arkotska [Korond U; Pf]; 1800: égy keresztűl tsinált árkatskáig [Dés; DLt]; 1803: egj viz nélkŭlt valo árkotska nyúlik a' Galotzás patakára [Toplica MT; Born. XVC. 1/95]; 1804: szabad volt gyümöltsfáimat égy olljan árkotskával ... az el károsodástol oltalmazni [Kv; Pk 3]; 1814: vulgo Pereu Algyeutzi nevezetü Arkatska [Récekeresztúr SzD; Bet. 3]; 1815: a Petro Grozávi nevū árkotska [Kosztes H; Ks 112 Vegyes ir.]; 1818: el kezdvén ... a Sztrigy follyo Vizére Szatsal felé le szolgálo Sephedékes, és motsáros Árkotskánal [Szentkirály H; Born. Vegyes oszt. 4/43].

árkocskatorok kics ároktorkolat 1572: egy $\mathrm{Ar}$ kochka Thorokban egy hathar kew wolt [Dés; DLt 184].

árkusocska (papír)ívecske 1783: Egy árkusatska Feleletemre K. Bátyám Uram circiter 4. árkos irással felelt [Mv; Told. Fasc. 20].

árpaasztagocska 1760: égy Arpa Asztagotska is volt [TGsz 18].

árpádka magyar kiskabátfajta 1861: egy arpádkanak a készitése 4 f. 20 Sing [Kv; Kócsi lev.].

ártányka herélt kansüldőcske 1681: Artányka nrō 20. [Szúv; UtI]; 1682: Esztendős Artanyka nrō 11 [Szúv; UtI]; 1688: Egj Esztend(ős) Artanjka nrō 45 [Fog.; UtI]; 1695: A' Teli Artanka nro 3 [O.csesztve AF; LLt Litt. C]; 1697: Ez idei Artanyka van no 10 [Radnót KK; UtI]; 1753: Eme Sertés No 2. Eme Sŭldŏ No 1. Artanka [Búza SzD; LLt].

ártánykamalac herélt kanmalacocska 1698: Tavaszi Artánka Malacz volt 27 [O.csesztve AF; LLt]. 
ártányocska herélt kanmalacocska 1684: Téli artanyocskák nro 20 [Ebesfva;UtI]; 1686: akkori Artanyocska tiz [Radnót KK; UtI].

árucska árucikkecske, portékácska 1586: Ieowe hozzam Igiarto Giorgi az kamoracikaban Azhon ennekem Arwcikam vagion [Kv; TJk IV/1. 618-9].

áruló-boltocska üzletecske 1826: a' Szekhaz alatt lévő Kis arulo Boltotskák [UszLt XII. 88].

aszalócska kics gyümölcsaszaló 1743: perelylyén szalmával fedet Sŏvénybŏl valo aszalocska [Boroskrakkó AF; BfN dobozolt anyag VI].

asszonyka asszonyocska 1582: Mikor Menne az Ló és az Azzonyka Gereznaiaban vthanna siethe, Az gereznatole vag miteól vg Jyede meg az ló es ug Ruga fel [Kv; TJk IV/1. 114].

asztagocska 1. 1683: Buza Perceptioja Kalongyába(n) Asztagocskakban rakatott Kal(angya) [Szúv; UtI]; 1700: Az gabona ... asztagocskaban, es Csürbeli odorb(an) vagion [Bál. 71]; 1714: egj kalongya rakás Szalma három ros sup egj asztagocskával egy kalongya Széna [Pálos NK; LLt]; 1742: az Ispotály Csüréb(en) két asztagocskát ... rakunk [Méra K; Aggm. C. 12]; 1748: volt mint egy 40 . vagy 50 . kalongyábol állo asztagotskája [Torda TA; Borb.]; 1754: tanoltunk ... egy asztagocskában egy nehány Kalongya Buzáját [Bukaresd $\mathrm{H}$; Ks 62/4]; 1758: vagyon egy Asztagocska [M.bikal K; Mohai lev.]; 1771: lesz edj kis Asztagotska valami husz kalongjabol valo [Esztény SzD; Told. 52]; 1776: ki ki az magok Számokra egy egy szekér Nádot vittek Asztagocskájoknak meg fedése végett [A.kápolna KK; BK Betlensztmiklós cs.]; 1786: Tavaly két Asztagotskát rakattunk vólt [Egerszeg MT; TL Málnási László ref. pap lev.]; 1789: A Kőlős magam ... egy jo asztagatska lőn igen termet néhéz [Berz. 5. 43 S. 88]; 1792: Az also Tsürhez rakatott egy asztagatska [Kályán K; JF 36 LevK 23]; 1804: két 1802béli Asztagotskában tiszta Tavasz buza [Alsójára TA; BLt 11. II]; 1822: jo Szántott földbe Ió Gabonát a maga Jdejében vessen el ött hat Asztagatska elig vagyon [Mv; IB gr. Korda Anna lev.].
2. Jelzői haszn-ban: egy kis asztagnyi 1706: egy Asztagoczka Buzát Tőtt (!) György Csépeltette (!) el [Szederjes U; KvAKt Mss 261]; 1759: Sz. Gothárdi Ferencz Uram Confiscaltatott Asztagotska buzája el Csépeltetvén ... találtatott Metr Nro 30 véka [Branyicska H; Borv. II]; 1760: égy Arpa Asztagotska is volt [TGsz 18]; 1793: most tsépelik a' Tavallyi kis Asztagotska Árpát [Kv; JF 36 LevK 372 Vég Mihály pref. lev.]; 1813: egy asztagocska Tavasz Buza [Veresegyháza AF; Told. 18]; 1814: egy regi meg avult vén Csŭr ... vegeb(en) egy asztagotska ros [M.sályi TA; RLt].

asztalka asztalocska, kisasztal 1636: egy hitua(n) asztalka [Siménfva U; JHb Inv.]; 1679: Olasz labas hoszszu asztalka czak fejéren nro 1 [Uzdisztpéter K; TL Bajomi János lelt. 18]; 1680: ez kamraban vagjon bakokra szegezve ket szal deszkabol hoszszu asztalka [A.porumbák F; ÁLt Inv. 29]; 1698: edgy kōzep hoszszu asztalka [Kóród KK; LLt Fasc. 72]; 1744: Kisded négy szegü Asztalka [Szentdemeter U; LLt Fasc. 67]; 1756: Negj szegeletü kis Asztalkák [Somkerék SzD; Ks gr. Bethlen Imre lelt.]; 1780: A Tiszti Lako Házban ... Hosszu iro asztal $1 \mathrm{~s}$ kerek fejér asztalka 1 [Bethlen SzD; BK]; 1788: Dio fábol valo kerek talpu égy lábon állo kisded rakott Asztalka [Mv; TSb 47]; 1802: Egy Chinai festesŭ kis asztalka [Mv; TGsz 52].

asztalocska asztalka 1652: Egy kereszt lábon Asztalocska benne [Görgényi vár MT; Törzs Inv. 19]; 1692: vagyon ebben egy fenyő deszkabul csinalt uj asztalocska labostul [Görgénysztimre MT; JHb Inv.]; 1692/1737: Szen Peteren az Imátkozo Erkelykéb(en) ... láttom az Asztalotskáján sok kủlőm külőm arany müveket [Szilágycseh; EMLt]; 1712: vagyon ... edgy kis asztalotska lábastol [Mezőbodon MT; BfN 54/12]; 1761: egy egy kisded negy szegŭ asztalotska [Mezőcsán TA; Ks 15. XXIX. 3]; 1765: Egy nagy kerek és más kissebb asztalacska [Szászsztjakab SzD; Told. 8]; 1786: Ezen Théka mellet egy kis Asztalotska 1 [Nagyalmás K; JHbK XXIX/36]; 1805: Három kisded rakot Asztalotskák [A.jára TA; BLt 9]; 1819: egy régi kisded rakatt asztolatska [Baca SzD; TSb 6]; 1827: Egy 
kisded zöld Asztalotska fiokjával [F.zsuk K; SLt Vegyes perir.].

autoritásocska kics (hivatali) hatalom, tekintély 1678: eö keglmek sok helyeke(n) diffamalnak hogy Tiszt leve(n) ott, authoritasotskammal abutaltam, nyilvan valo kárommal, mint türtem s szenvedtem [Törzs. Osdolai Kun István a fej-hez].

avatagocska avultacska 1784: vagyon égy tizenkét őkőrre való marha pajta, mely avatagatska fábol készült szalmával fedve [Burjánosóbuda K; JHbK LX/18. 8].

bádog-borsolóládácska borstartó pléhládika 1736: Bádog borsolo Ládátska nro 1 [Mikefva KK; CU XIII/1. 159].

bádogpoharacska ónpoharacska 1683 k.: vagyo(n) egy Bádog poharacska [Désháza Sz; SzVJk 136].

bádogtáblácska pléhsütőlap 1801: Iros teszta sŭtŏ két Bádog Táblátska [Vargyas U; CsS].

bagaziácska bagaziadarabocska 1764: Egy Zöld festékes tojokás ládátska, haszantalan aproság fekete bagoziácska mi benne [Kál MT; Berz. 6. Fasc. 54. L. 2].

balánka fehérszőrü tehén 1757: Egj Balánka bogár szarvu, futtosott 3 es(zten)dŏs ${ }^{a}$ [Pusztasztmiklós TA; FRK. - ${ }^{a}$ Tehén].

baltácska 1. fokosszerü csákányocska 1801: Vagyon egy kis Baltátska vj Nyellel fel keszitve [Vargyas U; CsS]; 1807: engemet is egy nálla lévö Baltátskájával Főbe akara ütni [Magyarfenes K; KLev. 84].

2. ? 1824: Szilkrotbol készúlt baltátska [Fugad AF; HB].

barackfácska kajszi-/őszibarackfácska 1694: (A) Gabonás ház megett vagjo(n) egj Vetemenjes kert ... Ebben most semmi vetemény; harom baraczk fátská(n) kivűl [Borberek AF; BfR].

báránybőröcske bárányirhácska 1770: valami fejér apro báránj böretskékre volna szükségem [Ne; Told. 5a]; 1779: Bárány bőrőtskék [Nsz; CsS].

bárányka bárányocska, fiatal juhocska 1750: kŭldőttem bé ... őtt Csirkecskét, két Pipét, két ifju Nyulacskát, és ez oráig Annyát szopo két Kis Báránykát [O.csesztve AF; Ks 83]. bárányocska bárányalakú ötvösmü-részlet 1714: Meg aranyozott ezüst Pohár Krisztus Vrunk Kinszenvedésit reprezentalo harom figurakkal ékesitett, hasonlo fódéllel, melly(ne)k a tetejen Bárányotska vagjon [Szb/Fog.; REkLt II. Apafi Mihály hagy. lelt. 28].

bárdocska 1679: Sindelyezéshez valo régi bárdocska nro 1 [Uzdisztpéter K; TL Bajomi János inv. 72]; 1756: kis bárdocska 1 [Ks 92. I. 32 a dévai kúria lelt.]; 1777: Sendelyező Bárdotska ... Nro 1 [Mezőméhes TA; Wass 2]; 1801: Két kis bárdotska [Mv; MvLev.].

barmocska 1. szarvasmarhácska 1584: Zekel Balint vallia Eleyn barmochkat tartottam, de hogy twzert Ieót oda eze(n) Azzony, senkire $\mathrm{Ne}(\mathrm{m})$ gianithatta hogy barmanak el vezet Teye, hane $(\mathrm{m})$ ez Azzonra [Kv; TJk 4/1. 251]; 1617: (A kaszáló) reszet More Boldisar az battianak oda engedte, igi azert hogi ha mi barmoczkaia loua leend azokot ki teleltesse [Abrudbánya; Törzs.]; 1839: Ŭgyekezetem utánn az Isten vagy két Barmotskát rendelt ... azon Barmotskáimnak olyan alkalmatlan hajlékok vagyon, - hogy teljességgel nem képes abban ki telelnem (így!) [Szentdemeter U; Told. 39].

2. ? disznócska 1802: osztályra vetendő barmotskák s. v. Sertések [Kv; CsS].

barnácska barnás 1804: hosszuko barnátska Abrázatu [DLt nyomt. kl]; 1805: Felvintzi iffiabb Kolosvári Mihálly ... barnátska, kerék Abrázatu [DLt nyomt. kl]; 1846: Forgáts Lázár ... barnácska ábrázatu [DLt nyomt. kl].

barnásocska barnásszerű 1802: Püsokan Juon ... Barnásotska tiszta ábrázatu [DLt nyomt. kl].

bársonymentécske 1710: Egy viseltes baraczkvirág szin bárson mentécske [DanielAd. 88 id. Daniel István lelt.].

bársonyocska-láda bársonyborításos ládikó 1768: Barsonyotska Ládába talaltattak ... Kŏnyvetskék 3 [Marossztgyörgy MT; Ks 23 XXIIb].

bástyácska kastély/vártornyocska 1623: legyen ... az Zegeten Egy zep Bastaczyka mostani forman kiben 25 puskas legeny 
feryen Zw(kse)gnek Jdeyen [Törzs. Bethlen Gábor gazd. ut.].

bátyuka alk. gúny bátya, bácsika, öreg 1598: az en iozago(m)ba hazamba be fogatta(m) vala, magam otalmaert ... engemet, elessen es niugosso(n), tiztessegben tarczio(n) mint battiat ... de eö nem tekintette az Vristent sem az attiafiwsagot eö engemet tiztessegbe nem tartá rutolt zidot kouetem az kegtek zekit Batiukanak lelek kuruanak es halallalis feniegetet engemet [UszT 13/117].

becsületecske kics becsület 1730: az ország tellyes vala az Aszszony ream valo nehezsegevel s engemet kissebittö, s csak nem átokra fokado Szavaival, de én mind azokot hitetlenséggel, és jora valo magyarázáss $\mathrm{s}$ türessel palastoltam, söt ... azonn kész affextiomot tartom fenn az Aszszonyhoz (: kivált ha becsületecskemet tapasztalhatom :) mellyel ennek elötte viseltettem [Fehéregyháza NK; Ap. 2 gr. Haller István br. Apor Péterhez]; 1730: (Az Isten) engemet az igen terhes Hivatallal ${ }^{a}$ nem tsak szeretett, hanem magha Dütsóséghere, édes Városon Tisztességhire, 's magamnakis kicsin Betsületetskémnek nevekedésére, annak végb(e) viteleb(en) jo Lelke által vezérlett [Kv; TJk XV/7. 134. - ${ }^{a}$ A városi notáriusság]; 1793: Ngod parantsolattya ellen kezem alatt lévén $\mathrm{Az}$ Apámnak sem kedveznék, mennyivel inkább ennek a' valoságos Akasztofára valonak, aki betsűletecském Nsgod altal valo nagy Sérelmére okott szolgáltatott mikoron cselekedném [Kályán K; JF 36 LevK Vég Mihály pref. lev.].

békácska kis béka-formára készült ékszer 1719: Egy rubintos békácskát Szent Páli Jstvánnak maga adot el az Feleségem Pénzért [Wass 1 Wass Dániel sk. lelt.].

belsőcske belsőségbeli telkecske 1853: A falu rendjibe egy belsőtskén [Hr; Inv.].

berbécsecske kosocska 1629: Tavalyi berbécsecskék nro. 116 [SzO VI, 102 Szu vára lelt.].

berbencécske bödönöcske 1594: Ratio Acetorum. Restal az warban egi hordoban altalagba(n) es harom Berbenczechkeben Echjet Somliai chjeberrel cub. 8p. 1 [Somlyó; UC 78/7. 7, MNy LXI, 112]. bércecske csúcsocska, hegyes halmocska 1745: a Tó felé nyuló Bércecskén [Nagyida K; EHA]; 1746/1831: az negyedik vágatott gyepüs vőlgyben két gődör kőzt ki nyuló bértzetskének kőzepin [Csöb U; Told. 38]; 1757: a Hegjnek két bérczetskéje [Kissolymos U; Márkos lev.]; 1777: Elsŏ Tábla ... a mint az Aranyos teriről a' vőlgy fel menyen a fenn lévő három águ gödrŏk vagy vŏlgyetskék kŏzt lévŏ három bértzetskék kŏzŭl, a' felsŏ, vagy nap nyugott felŏll valo bértzin fel mindenütt a tetŏre [Magura TA; Ks 89]; 1830: a Malom helyén tul a bértzetskéig énis égy kaszálot 3 Esztendeig birtam árendába [Köszvényesremete MT; Born. G. XXIV. 1]; 1737: a Kapus Bérczecskék mellett [Nagyida K; EHA]; 1745: a Bértzetskén a gŏdrök felett valo kerek domb [Nagyida K; Told. 9].

béresinaska béreslegényke/bojtárocska 1719 : Két béresré szorultam azt is az édjiket csak rontja az hideg az béres inaska pedig még Csomasodot de nem is az udvrab(an) hanem az ökröknél volt [Tövis; Ap. 2 Molnár Márton Apor Péterhez].

béreslegényke béresbojtárka/bojtárocska 1850: jővének az ottan levő tőb béres legénykéket meg támadok [Dés; DLt 1320].

berkecske (vízparti) liget(erdőcske) 1694/1764: A Marus follyó vize szakadékjai kőzőtt valo Berketskék [Abafája MT; Told. 26]; 1694/1764: a Gőrgény vizén tul szakadotott Kis Berketske [Abafája MT; Told. 26]; 1697: a' megböcsűlt Hely felet valo berkecskenek teteje [Dés; Jk]; 1729/1733: attuk volt itten a Görgényi ${ }^{a}$ határban ... egy darab Berketskénket őrőkősőn [Born. G. II. 24. - ${ }^{\mathrm{a}} \mathrm{MT}$ ]; 1733: leven ... azon Berek vicinitassib(an) egj kis berkecskeje [Nyárádtő MT; SLt évr.]; 1762: Ezen hellyen értem egy darab Berketskét, ezen Arak és Maros portya (!) kőzőtt [Körtvélyfája MT; Bál. 87]; 1762: értem egy darab Berketskét ... de hogy a kis berekböl szakadatt volna nem értem [Körtvélyfája MT; Bál. 87]; 1820: A Malom mellett egy Berketske [Körtvélyfája MT; LLt].

beszédke mondóka 1838/1845: A pseudoorvos egy sarlot vagy kést vévén elő, a kelés körül és felett jártatja, mintha éppen 
aratna, mialatt e beszédkét szavalja el ... [MNyTK 107].

betegesecske betegforma 1820: En regtŏl fogva betegesetske allopottol vagyok [Mv; Borb. II. Mátyás Sámuel ügyvéd lev.].

bikácska fiatal bika 1627: tauali kis bikaczka Nro 1 [Mezőrücs MT; BLt]; 1632: Egi taualy bikaczka [Hsz; LLt]; 1632: Bikátska 1 [Nagyercse MT; Told. 70]; 1756: Két esztendős Bikácska 1 [Déva; Ks 92. I. 32].

birodalmacska 1 . országocska, államocska 1678/1638: jllik azert ... magokra igen vigiazniak ... kiket kőzületek ... Ez Erdelj Birodalmocskaban Is(ten) megis tovabra tartvan helheztet, s, helheztetet [Ks Kornis Gáspár kezével].

2. (föld)birtokocska XVIII. sz. v.: Azan kis Birodalmotska mellyet ... Arenda titulus alat bir [Usz; Pf].

birtokocska kicsiny birtok 1806: ezen birtokocskát Sebess Uram birta [Nagymon Sz; Bál. 68].

bivalypajtácska bivalyistállócska 1820 k.: A Csürős kertbe ... tanáltatik égy Tőlgyfa Sasokon állo Bival pajtácska [Dés; RLt].

bivalytehenecske nősténybivalyocska 1775 : Hagyok és testálok Bóér Sofia kedves Ŏtsém Aszonynak egy három esztendos bial tehenetskét [Örményszékes AF; Bet. 6 Özv. Szalántzi Józsefné Boér Borbála végr.]; 1793: Egy ket esztendös Bihal Tehenetske [Bodola Hsz; BLt 2].

bizonyság-írásocska bizonyságlevelecske 1780: vettem 'a Száz harmintz egy M Forintokat melyről adom is ez bizonyság irásotskámot [Szava K; RLt O. 1 egy kis papírszeletkén Sombori László kezével].

bodonka 1. (fedeles) bödönöcske 1637: Harom Bodonka Egresnek valo [Teremi KK; Ks 69, 50, 44]; 1740: hét budonkát ... ki vitette (!) az Asz(o)ny ö Nsga [Ap. 5 Apor Péter lelt.]; 1770: Egy kartya, egy dobonka [Usz; Pf]; 1801: Egy degenyeges dobonka [Koronka MT; Told. 23]; 1840: Két Budunka Záldog fábol Fuszuika tarto xr 50 [Várhegy MT; TLt közig. ir. 1042/840].

2. (laposacska) víztartó hordócskaféle 1730: Egy kártya, egy dobonka [Körispatak U; Pf]; 1744: Dubunko 1 [Branyicska H; JHb 103/151]; 1754: két tarka Erdélyi
Kantso egy kis bodonka [Kincsi KK; JHbK XXVIII/10]; 1761: Mezōre Viz hordo Dobonka [Siménfva U; JHb LXX/2]; 1781: Egy kártya. Két Dobonka [Mocs K; CU].

boglárka boglárdíszecske 1744: ezüst Csatt 12. kis ezüst boglarkák rajtok [Szentdemeter U; LLt Fasc. 67]; 1758: Egy győngyős Párta, 138 őreg győngy, 9. kisded Rosa forma boglárka, egy egy kisded Rubintotska mindenikbe [Nsz; Tsb 21]; 1768: Rubintos apró boglárkák [Nsz; TGsz 51].

boglárlábacska ? 1733: Az T. Kolosvári András Uramnál lévo arany romlott boglár lábotkátis hagyom az nagy oltárhoz forditsanak valamit vélle [Kv; SLt XLII. 6. 32 P. Horvath Krisztina végr.].

boglárocska boglárka, boglárdíszecske 1591: az ezwst keozeot latek egi kis feier boglaroczkat [Kv; TJk V/1. 180]; 1673: harom boglárotska [Marossztkirály AF; IB]; 1681: Egy gyongyős pántlika rosa egy rubintos boglarocska az fütyögöje [Wass 27]; 1681: Két gyongybŏl gomb formára kŏtŏt fŭlbe valo mindenik végiben egy kis boglárocska [Wass 27]; 1703: egy egy kicsin arany boglarotska mindenik boglaron negy negy szem jo fele gyongyoske [LLt Fasc. 115]; 1716: Egy homlok eló Parta 24 gyemantos boglarocskakkal fŭzőtt [Wass 11]; 1720: ket kis boglárocska [Kv; Pk 6]; 1734: Szőr Selyemmel kōtōtt fŏkŏtŏ ezŭst fonallal boglaratskaval rakat [Born. XXXVIII. 3 Kornis Krisztina lelt.]; 1742: holmi dirib darab apro boglárotska [Nsz; Told. 19]; 1742: Ôt kis Arany boglárocska [Nsz; Told. 19]; 1761: holmi aproság boglárotskák jőttenek volt által Nehai ... Bartsai Josefné Károli Ersebet Aszszonyrol ... Bartsai Agnes Aszszonyra [Szentmárton Cs; Berz. 15. XXVII/12]; 1766: Nyak szoritto tizen nyolcz darabbol állo arany boglárotskával [Szárhegy Cs; LLt Fasc. 96]; 1771: Egy kis Boglárotska két jo féle gyöngyőtske benne [Nagyida K; Told. 19]; 1776: Tizenhat kicsid, apró fejér zomántzas boglárotskák [M.köblös SzD; RLt Sombori Klára és Sándor lelt.]; 1786: Három kitsin fekete boglárotska [Nsz; Ks 74/56]; 1801: Három zomántzos Boglárotskák [Kv; Ks]; 1801: Két darabba ŏszsze aggattatott fekete zamántzos tizennégy Boglárotskák [Kv; Ks]. 
boglyácska 1 . széna v. szalmarakásocska 1724: Szénája volt két bugjátskával [Buza SzD; LLt Fasc. 109]; XVIII. sz. köz.: A Kis Simon végiben egj darabocska; mellyen mikor terem; egj kŏzönséges buglyácska lessen [Koronka MT; Told. 18]; 1763: amennyi kivántatott annyi fát vágtunk le s e szerint a' hellyet tisztitottuk, hol egy bogjátskára valo hellyet hol többet [Zágon Hsz; SzetkZs]; 1763: egy két bugjátskára volna [Köpec Hsz; Köpeczi lev.]; 1788: A Jég verte buzát meg kaszáltatván lott rajta ŏt buglátska [Esztény SzD; Told. 6]; 1798: Az erdőn csinyált kalongyacskakot 7 ... 3 buglacskát [H; Ks 108 Vegyes ir. 44-5]; 1823: a Szenafün Kaszalba rakatot 33 bugjatska [Budatelke K; Born. F. Ic]; 1825: vagyon a volt Bironak meg mintegy ket szekeretske bugjátskája [Jedd MT; LLt].

2. Jelzői haszn-ban: vhány kis boglyányi, vhány kis boglyára való 1681: (A kaszáló) csak kicsin edgy küs Buglyácska széna terem rajta [Néma SzD; LLt 16/2]; 1727: az emlitett irottvany ... nem volt nagjob egy buglyacska Szénára valonál [Középfva SzD; SLt 29. I. 26]; 1749: edgj buglyátska Szénát kŭlŏn hagjván [Ohába AF; Told.3]; 1751/1753: hat boglyátska szénát is tsináltanak [Koronka MT; Told.78]; 1761: a' Rét nehol gazosotska lévén irtógattam, és mind a' felsŏ, mind pedig az alsó végiben egy egy Bogjatska szénára valot a' Falu kŏzŏnségesnek tartótt [Illyésfva Sz; BfN 45/9]; 1764: adōtt el mint egy vékásnyi foldet egy mellette lévő kitsiny kaszálotskájával edgyŭtt ... terem rajta egy mezei bugjátska széna [Cserefva MT; Told. 30]; 1771: egj bugjatska Sarju maradot volt [Esztény SzD; Told. 5a]; 1804: egy Bugjatska Széna [Borosbenedek AF; SLev.]; 1822: Hat bugjátska Szalma [Somkerék SzD; HG Mara lev.]; 1841: Egy buglyátska Széna [Kissármás K; KLev.]; 1849: Egy bugjátska széna [Dés; DLt]

Szk: egy ra való 1753: egy két buglyátskára valo kaszáloját ... Olá István birja [Szováta MT; Told. 3a]; 1754: tudok ... egj buglatskára valo kaszálotskát [A.jára TA; CsS]. boglyácskányi egy kis boglyányi, egy kis boglyára való 1732: Egy mezei buglyácskáni ${ }^{a}$ [Göcs MT; Berz. 15. XXX/7. - ${ }^{\text {aTi. a }}$ széna]; 1740: lévén ... a njárád nevü Patakon (így!) egj két kővű Malmocskája ... a végiben egy kis bugjátskáni szénát termő kaszálóval [Nyárádmagyarós MT; Berz. 15. XXXVI/9].

bojérocska kb. (havaselvi v. moldvai) köznemes 1641: niomunkban az Vayda kuldeot ... hogi mindenunet az felso orzagi boierok es boieroczkak el mennienek [Hurm. XV/ II. 1084 Michael Literatus bistriciensis a beszt-i követekhez].

bokálycsészécske ónmázas (díszes, finom) kicsiny cserépcsésze 1752: Gyümölcs ala valo két bokaj tseszetske [Marossztkirály AF; Told. 19].

bokályocska ónmázas (díszes, finom) cserépkorsócska 1733: Zőld bokallyotska 1 [Marossztkirály AF; Told. 2]; 1736: Zöld mázu apro bokállyotskák [CU]; 1748: Zőld bokájocskák edgyik tarkás [Ks 8. XXVIII. 5. Kornis Antal lelt.]; 1748: Úveg bokájocska Nro 1 [Ks 8. XXVIII. 5. Kornis Antal lelt.]; 1748: 12. Zőld bokallyotska [Marossztkirály AF; Told. 2].

bokálytálacska ónmázas (díszes, finom) cseréptálacska 1594: Vagjon Bokali talachkais No 1 [Somlyó Sz; UC 78/7. 34].

bokrétácska csokrocskaszerü ékszer 1768: Egy Zamantzos bokrétátska 7 rosátskával 4 rubint benne és három jo féle győngy [Nsz; Ks 74. 56].

bokrocska cserjécske 1602: wala egi kis arok walamj fwzes bokroskak aba hengeredé be s wgy maradhatek meg hogi le nem waganaka [UszT. - ${ }^{a}$ Ti. az üldöző hajdúk]; 1727: Ha kinek Tiszta Reth avagy Csak igen keves bokrocskákbul állo Tóvisseis adatodott volna [Dés; Jk]; 1756: tsak Bokrotskák s Fák Törsökei Vadnak némely részéb(en) [Veresegyháza $\mathrm{AF}$; Told. 30]; 1774: a' Gyŏrgyedben (e) ... ebben tsak térdig érő bokrotskák vadnak [Gerendkeresztúr TA; EHA]; 1781: $\mathrm{A}^{\prime}$... hellyt ... Néhai Kolumbán János Vr kezdette volt fel fogni és holmi apró Bokrotskáktul meg tisztittattni, írtattattni [Perecsen Sz; IB]. 
boltocska 1. (bolthajtásos) szobácska 1685 e.: az Sido Uczában ... az elsō ház ... Ebbōl az más boltban nyilik ... jo Záros ajto ... Ebbōl az belsōb boltocskára jo vas sarkos pantos ajto nyilik [Gyf; MvRK Urb. 22, 24]; 1716 : adtam Szállásul itt Brassob(an) a Klastrom vczaban lévŏ Házamnak belsŏ Boltoczkaját adhaeralo kis tŭzelŏ Konyhácskaval [BLt]; 1737: Ezen Aszszony Házábol ... egy fél béllett fenyő ajto ... nyilik egy kis kőből valo Boltotskara ... Az meg nevezett Kis Boltotskábol ... bélletlen ... fenyő ajto vagjon [Csákigorbó SzD; JHb XXVI/13. 6]; 1742: (A) rab háznak az Délre nézŏ vegiben vagjon egy kis boltocska [Gyeke K; Ks 4. VII. 1]; 1757: Ki jövén ezen bóltoskábol azon Félsö nagy Házban ... [Tapolca Cs; Sándor conscr.]; 1761: két házbol, s kŏzŏttŏk lévŏ egj pitvarból, és ugjan azon Pitvarbol ki szakasztott Kémény alatt lévŏ Boltotskákbol állo ... udvarház [Spring AF; JHbK LVIII/1. 499]; 1775: menvén ... be omlott menyezetű Boltotskára [Buza SzD; LLt Csáky-per 107. L. 17].

2. (bolthajtásos) kamrácska 1629: Eleol Egy Kalmar Bolt, vtanna Egy kis Boltoczika Hatul Egy io Boltos szobaczika [Kv; RDL I. 132]; 1629: az külsö falbeli egy kis torony felső bolt ... Az boltocskaban harom kis tonna por [Szu; SzO VI. 92 a vár lelt.]; 1652: egy kis boltocska három lövö lyuk rajta [Görgény MT; Törzs.]; 1681/1748: azon Pitvarbol vagjon egj kis hus tarto boltoczka [Balázsfva; KvAKt Mss lat. 236]; 1681/1748: mélly ház héjján vagjon égi Templom forma boltoczka [Balázsfva; KvAKt Mss lat. 236]; 1708: Boer Joseph ur(am) foglalt volt el a' kulcsár ház mellet egy boltocskát [Fog.; KJ Fogarasi János lev.]; 1718: Pestis alkalmatosságával ... Szükség praeservatiora nézve gondot viselni, az imit amót Bóltocskákban, és kunyhókban Sordidé magokat viselö, es Lako Emberekre ... az affele Szemetes lyukak taploi es Fomentuma az afféle nyavalyáknak [Kv; KvLt Fasc. I. 225 gub.]; 1732: ezen hazb(an) be nyilo ajton belöll vagyon a kő kemenyhez ragasztot teglabol ki rakot boltotska [Tancs K; Told. 11/70]; 1752: az also Pallota végibe(n) vagyon a Pincze torkán téglábol épült egy kisdég, de meg repedezett Boltacska [Pókafva AF; JHb XXV/73]; 1756: a secessus ... Bolthajtás alat lévén egj Ablak hellye szolgál a le irt Boltotskábol [Branyicska H; JHb LXX/2. 22]; 1761: Az alsó Contignatioban ... vagyon egj egj németes oldalú egj contiguitásban lévŏ Stukaturás három kisded alkalmatosság, mellyek jollehet Stukaturások, mind az által Boltotskáknak neveztettnek [Szászvessződ NK; JHbK LXVIII/1. 211]; 1807: egy szobában, és egy boltotskában, egy szijjgyárto vagyon szálitva Trandafir által [Kv; WLt Miss.].

3. kb. árulóbódécska 1787: a Fazakasok szinynyek szomszédságában lévő Boltotskájára ... rá menvén ... [Dés; DLt]; 1791: Darlatzon Néhai édes Attyámrol Sztojka Juonrol maradott Boltotskának meg nyerése instantiám által Nagyságodhoz alázatoson follyamodtam vala [Déva; Ks 75. VIII. 159]; 1826: Boltotskais ... vagjon Városunk Piattzán [Dés; DLt 243]; 1826: méltoztassék ... azonn ... boltacskát nékem ... ki adni [Dés; DLt 872]; 1844: détzkábol ... talpra készūlhetō Boltotskákat tsak annyi nagyságuakra tsináltatnok, a' mennyire az eddig elő már ki mutatott árulo hellyūnk mekkorasága vagyon [Dés; DLt 1366].

bónumocska tbsz holmicskák, portékácskák 1732: hazi eszközökből álló Bonumocskák [Kémer Sz; Bölöni L., A Bölöni család tört. 28]; 1750 k./1811: A Csik Sz. Mártoni Janka Miklos Bonumotskái következnek eszerint ... [HG].

borhütőcske borhűtő-edényke 1715: A Réz edényt fel osztván ... jutot Was Laszlo Vram(na)k ... edgy kis virágos réz borhütőcske [Wass 27 Wass-osztozás].

borítócska kis (élelmiszer) borító-harangocska 1737: Egj boritocska [Brassó; Ap. 5 Apor Péter lelt.].

borjúbőröcske nyers v. kikészített borjúirhácska 1755: Ki készitett borju bŏretske 1 [Batiz H; BK sub nro 1020 Naláczi conscr.]; 1755: attam el kis vékonj bornju bőröcskét [Kiskend KK; Ks 71. 52 Szám.].

borjúcska 1681: Az Milványi ${ }^{a}$ megh holt jobbágy(omnak) ... maradott eökre négy két borjacska égyik őkőr másik üsző [RLt 1. - ${ }^{a}$ Milvány K]; 1744 k.: a Menyem Actrix hozot volt házomhoz edgy kis borjucskát 
[Kersec H; Ks LXII/13]; 1752: az borjucskám meg njomorodván meg is Dőglőt [Diósad Sz; WLt]; 1764: találtam itten ... Két Kisded fejős bornyus Tehenet valami bornyutskákkal edgyŭtt [Udvarfva MT; Told. 44/26]; 1793: Egy esztendős metzetlen borjutska igen nyomoru [Bodola Hsz; BLt].

borjúcskabőr borjacskairha 1757: 2 hitván bornyucska kicsin bőr adatot el [Kiskend KK; Ks 71. 52 Szám.].

borjúpajtácska borjúistállócska 1777: egy Bornyu Pajtátska, és a Tehenek aklya [Meggyesfva MT; LLt].

borocska 1 . egy kevéske bor 1579: Igen nagy insegbe, es zwkelkedesbe volt az zegenyseg mostanis mely sok zwksege vagio(n) e kewes borochkara kynek az hire nagiob hogy sem mint Az Summaia [Kv; TanJk V/3. 203b]; 1592: hul huzon eot hul harmincz ket vider borochkam leott ott zeoleomeon [Kv; TJk V/1. 230]; 1605: gonduiseleseert egy Altalagh borochkat Aad [Kv; TJk VI/1. 709]; 1633: Edgy kis Boroczkat tŏltelekre vettvnk [UtI]; 1670: Az mi keves Buzaia ugy mint ket sak buzaia es Boroczikaia ugy mint Tiz veder ... maradot ezeketis hadtuk az relicta kezenel hogy taplallia az szegeny Arvakat [Kv; RDL I. 152]; 1747: had kūldhetnék egy kevés borotskát eo Excell(enti)a(j)a számára [Gagy U; Ks 83 Péterffi Sándor lev.]; 1748: minden esztendŏn szŭrt borotskátis [Torda TA; Borb.]; 1764: itten Jó borotskát alig talál az ember [Szu; LLt Fasc. 160]; 1852: Már erre bizony csak ki üríthetnek vagy egy pohár borocskát magokis [Kv; Pk 7].

2. (egy) hordócska bor 1570: mikor az Byro Rea Bochiatta volna Kalmar Janost hogy Marhayat Beochwltesse megh ... eok swhwl semmy Marhayath Nem Talaltak ky az adossagot megh Erthe volna, Talaltak volt egy Borochkayat, De aztis Mas foglalta volt ely adossagaert [Kv; TJk III/2. 144]; 1585: hoztanak wala Sombory vramnak egy boroczkat witte Somborra Zaz Janos 2 Lowan [Kv; Szám. 3/XVIII. 12]; 1595: az mjnemü 2. boroczka Zilahrol 6. okkres z(ekere)ken hoznak [Kv; Szám. XVIIa/6. 306 ifj. Heltai Gáspár sp kezével]; 1609: Biro V(ram) ö kegyelme veot Fejede- lem aztalara ... egy boroczikat Vgy minth tizen kilenczj vedrest [Kv; Szám. 126/IV. 23]; 1688: egj kis borocskamat arultam ki [Kv; UtI].

boronakertecske dorongfa-kerítésecske 1782: vagyon egy borona kertetske [Kisesküllő K; SL].

boroshordócska 1801: Aprobb Boros Hordotskák [Vargyas U; CsS].

boroskarafinácska borospalackocska 1801: Hat pár régi Fátzánra való boros karafintátskák Dugok nélkŭl [LLt 106/1].

borosocska ittasocska, pityókoska 1772: mi ezt eszre nem vehettük ben a házban külömben is már akor borosatskák voltunk [Sályi TA; Mk V. VII/17].

borzafácska bodzabokrocska 1788: Ezen Curia ... Nap nyugot felől valo vége egy Borza fátskánál keresztúl méretvén, találtatott 36 harmintzhat őlnyinek [Melegföldvár SzD; SLt XLI].

borzbőröcske borzprémecske 1849: Egy ki készitett borz bőrőtske [Somkerék SzD; Ks 73. 55].

botocska 1. 1574: Mond az Kewer Marton, Al hattrab te Azzony ... orrodat Aiakastwl ely Mecchem azt ely higged, egi Botochka volt Nala Meg feniegeteis veleh [Kv; TJk III/3. 365]; 1703: senkit nem bantott ez az Csere István egy botocska volt nálla csak, nem is szitkozodott [Kv; Wass].

2. 1597: most is kewannyak ew kegmek hogi ez mostani vasarbirakis az reghieknek nyomdokat keowessek. Hogi penigh nem chiak ez varossi ember, hanem az kewlseo nepis megh esmerhesse ewket az ew tiszteknek ielet az botochkat az elebi vasarbirak moggia zerint az vasaron mindenkoron kezekben hordozzak [Kv; Tan]k I/1. 295].

botóka 1. botocska 1636: ezt az fogoly legent ... Nagy Zabo Istvan karon foghta vala, es ugy vonza uala ... nyerges Istvanis utanok ballagh uala az botokaual [Mv; MvLt 291. 68a]; 1638: egjeb nem vala egj kis botokanal Uidombakinal [Mv; MvLt 159a]; 1686: az tordai vitézek elrugazkodának, engem elszakasztának az lobonczok ... sokan vagdaltak hozzám, egy botokával hántam ellent [TT 1889. 509 SzZsN]. 
2. csipke- v. receverő pálcika 1733: Edgj ládácskában botokák [Marossztkirály AF; Told. 2]; 1733: Edgj Varro ladátskáb(an) recze kŏteshez valo botokák [Marossztkirály AF; Told. 2]; 1761: őt darab szedett pántlika, mellynek szélin arany és ezüst botokan vert kőtésetske vagyon [Koronka MT; Told. 8]; 1788: Egy tettzin sejemmel ezŭstel botokán kōtōtt fūzzō [Mv; TSb 47].

bödölőcske bödönke, bödönöcske 1812: Egy kis uj Bodőlőtske (!) [M.gyerőmonostor K; KCsl 11].

bödönke bodonka (abroncsos, dongákból készített faedényke) 1679: Vaj tartó Bődőnke nro 1 [Uzdisztpéter K; TL. Bajomi János lelt. 61].

bővebbecskén bőségesebbecskén 1758: csak adgjon Isten bŏvebecskén mint Karkoban ${ }^{\mathrm{a}}$

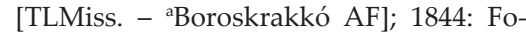
gados Szász Gyuri el mene tölle kaptam bövebbecskén pénzt [Széplak KK; SLt évr. Sipos Miklós P. Horváth Ferenchez].

bővecskén 1. jócskán 1738: itten az vetések igen szépek, essōis bővecskén kezdet lenni ugy az hovasokon hovacskák, melyeknekis gyakor hoharmati vadnak [Szamosfva K; Ks 99 Kornis Antal lev.]; 1772: az Erdöhátságon ... a' Tavaszi Buza, és Zab vetés vagyon nevezetesbb bōvségb(en) ... Mikor pedig bōvetskén terem distrahálni szoktak Zalatnan, és Szászvárosan [Algyógy H; JF 36 Ferentzi Ádám szb kezével Tt]; 1826: Szilva és Alma bővetskén vagyon [Szentháromság MT; Pf].

2. túl bőven 1725: igen bővőcskén elte(ne) k őkglmek Kolosvárat ... innen az magunkébő (!) kellet ki potolni [K; TKl].

bőr-párnazsákocska bőrhuzatos párnácska 1804: Bör Párna Zsákotska nro 1. [Tresztia H; Ks 108].

bőrvánkosocska bőrpárnácska 1675: ket rosz bőr vankosoczka [Dés; Borb. II].

bővebbecske gazdagabbacska 1768: Enyeden bővebbetske szüret volt [TLMiss.].

bundácska 1766: Adtam ... egy Zőld bundácskát [Berz. 9 Fasc. 73]; 1786: Az Udve(zült) Ur ō Exjától maradott egy Házban viselni szokott Bundátskát ... elvittem magamnak [TL]; 1815: Pál Márton .... szŭletésére nézve Udvarhellyszéki Oroszhegyi ... viselt fekete Bárány bŏr kosokat, vagy Bundátskát [DLt 68 nyomt. kl].

butácska maflácska 1841: Lakatos Ferencz ... egy kissé butácska [DLt 697 nyomt.].

butácskán ? kb. maflácskán 1807: (A szökött rab) beszédjét ugy ejti, mint a' vastag nyelvŭek tudniillik butátskán 's keményen, egyeb aránt folytában 's akadozás nélkŭl, bátran beszéllŏ [DLt 674 nyomt. $\mathrm{kl}]$.

butéliácska karcsú-nyakú palackocska 1751: kültem butéliatskákb(an) mind az Specialébol, mustrát mind az másikbol, azaz a második aszszu szōlō borábol [Szentdemeter U; Ks 83 Borbándi Szabó György lev.].

butuja hordócska 1743: kŭldŏttem ... Egy butuja Tejfelt [A.árpás F; EMLt Váradi Zsigmond gr. Teleki Ádámhoz].

búzácska 1. (egy kevés) szembúzácska 1633: My az Malmot ... igy Attuk eo kegmenek. Hogy Epitse megh s legien eoue Birja mint Sajatyat s mi nekunkys legien hol Erőlnünk ne kellessek falukrol falukra budosnunk Buzaczkankal [F.venice F; Szád.]; 1716: szintén most akarnék valami élésettskét, s buzácskát szállitatni vellek Szebenbe [Kiskend KK; Ks 95 Biró Sámuel lev.]; 1748: Tudom hogy volt két lova, szekere, buzátskája, egy Tehene [Torda TA; Borb.].

2. kics learatott, kalangyába v. asztagba rakott búza 1748: láttam egy kis buzátskájátis cir. 30 Kalongyánit [Torda TA; Borb.]. 3. egy kevés szembúza-járandóság 1654: Nd meltoztassek Asztalom tartasara valami keves Buzaczkámatt megh adatnj [Gerend TA; KemLev. 1427]; 1793: ha Nagyságodnak is ugy tettzenek jo volna az oda valo kerülőnek, valami kevés $\mathrm{Bu}$ zátskát fizetni s inkább tartoznék Kötelességinek tartani réá vigyázni [Hadad Sz; JF 36 LevK 232].

bükkfadeszkácska bükkdeszkácska 1772/1812: Bikfa keskeny Deszkatskákbol öszve rakott s fa Sorkokon járo Kapu [Kál MT; HG Conscr. 128]; 1795: ezen Háznak padlása vagyon hat darab Gerendákra ra- 
kott, és helyheztettett Bükfa Deszkátskákbol [Algyógy H; Ks 74/56 Conscr. 9-10].

bükköcske bükkerdőcske 1756: az Alfalvi határba Kerek bűk névű tilalmas Bűköcske [Szárhegy Cs; LLt Fasc. 90].

cápocska bakgidácska/gödölyécske 1639: Cziapoczka ez idey nro 2 [Hsz; LLt]; 1646: Ez idei czapocska nro. 7 [Örményes TA; RákGI 601]; 1684: Ez idej Czapocska nrō 9. [Déva; UtI]; 1699: ezidei czapocska ketŏ [Boroskrakkó AF; BfN dobozolt anyag VI]; 1706: Az idei czapocskak no. 6 [Görgény MT; Born. G. VII. 4]; 1743: Tavalyi Czápocska No 1 [Buza SzD; LLt 221. B]; 1791: In December 13a Kész pénzen vettem Tavaszi Czapocskákot 8 [Ks 108].

cápocskabőr bakgidabőr 1684: Ez idej Czápocska Bōr nro 8. [Déva; UtI].

cédulácska (üzenetes) papírlapocska 1780: külgyen édes Aszszony Anyam egy kis tzédulátskát $\mathrm{s}$ tudam hogy őkegyelme szolgál a kenyérrel [Kp III. 203 Újsófalvi Sámuel anyjához]; 1812: Ezen Czédulátskámot meg ado Reinhard János [K; KLev. 15]; 1846: irja ki néki egy czédulátskára meg-tudakolás véget $[\mathrm{Kv}$; ÖCLev.].

cigánysátorocska 1763: egy kitsin czigány Sátorotska [Udvarfva MT; Told. 44/15].

címerecske heraldikai jelvényecske 1733: $\mathrm{Az}$ ajto felett egj czimerecske felette vadaszoknak képe [Hacecsel H; JHb Jósika Zsigmond udvarházában].

cinadofkeszkenyőcske finom vászonkendőcske 1576: wagion ket wekon czynadoff kezkenyechke [Szamosfva K; JHbK XVIII/7. 5]; 1628/1635: Egi czinadoff uiselt kezkenoczke [Bodok Hsz; BLt 5 Béldi Kelemen hagy.].

cipócska kis cipó 1584: Teremy Peternenek Adot vala ... a' zemet birone eg czipochkat melyben hogy eowek Azoniom mingiarast eyel meg bolondula, Enys harmad napian Eóm vgia(n) azon czipoba, de nem veltem hogy attol bolondult meg Azoniom, es enyis mihelt Eóm benne mingiart ell kezdek fwtny ezem nelkwl volta(m), Mas hozot haza, de $\mathrm{Ne}(\mathrm{m})$ tudom honnat [Kv; TJk 4/1. 246]; 1773: midön ezen oláh Fenesi Udvar épittetett szoktak volt há- rom három Czipotskát adatni Napjáb(an) [O.fenes K; JHb II/3].

cipóka cipócska 1834: A’ kerti Szőllő megszedésekor Anyám teméntelen vendéget hivott ... Az üdő sanyarutska volta mellettís vigan mulattunk, a Tracta állot Czipoka, és lágy kenyérből [Kv; Pk 7 Pákei Krisztina lev.].

cipőcske-forma kiscipő alakú 1846: Egy gombostő tarto cipótska forma [Dés; Berz. lelt.].

compócska kis compo 1735: Apáczára kŭldōttem ... ot vettem 60 darabol alo szép Csuka fiakat egj nehánj Czompocskais vagjon [Barót Hsz; Ap. 4 Cserei Sámuel Apor Péterhez].

cucorka kender-, szösz- v. csepúkoszorúcska 1838-1846: Pucorka, pucurka; cucorka, fonók alkalmatosságával kender-, szösz- v. csepüből készitett koszoru, rakva jelenlevő legény- s lányjegyző tincsekkel, miket fölgyujtván, mikénti égésökből jósolnak s nevetgélnek rajta [MNyTK 107. 32].

csákányka fokosocska 1634: Kerekes Ianos ... ki ragadva(n) cziakankajat monda: Ez az en Atyamfia, megh lattia ki bant [Mv; MvLt 291. 2b].

csapalja-fenyőkádacska csap alá való fenyőfa kis kád 1794: Csap ajja Fenyo kádatskák [Zentelke K; CU].

csapalja-kádacska csap alá való kis kád 1850: egy kis csapoja kádocska [Gyéressztkirály TA; DE 5].

csapógátacska partvédő-vízvető töltés 1803 : (A) Malom árkábol bé follyo viz Árka elött lévŏ Csapo Gátatskája [Náznánfva MT; Berz. 4 31/37].

csat-gyưrücske csatos gyürücske 1710: Egy kis gyémántos csatt gyürücske [Daniel, Ad. 93].

csatocska 1634: attak ... egy cziattocskat szij vegre valot [Kv; RDL I. 105]; 1637/1639: valamj Eöre ualo csatoczjkak [Kv; RDL I. 111]; 1818: Négy Sor nyakba való Gránát, a' végibe égy 4 szegeletü ezűst meg aranyozott csattotska, meger $15 \mathrm{Rf}[\mathrm{Kv}$; Pk 5].

cseberke 1. csebrecske, dézsácska 1756: Egy tsŏjŭ Lombikhoz valo kis Cseberke réz tsŏ egj benne [Somkerék SzD; Ks gr. Bethlen 
Imre lelt.]; 1836: egy Cseberke lépes mézzel [M.péterlaka MT; TGsz 18];

Szk: borhütő 1736: Bor hüttő Cseberke [Várhegy MT; CU].

2. (vhány) dézsácskányi 1595: 5 Jŭly ... vöttem 1 Czöber oh Almat ... d 16 ... 7. Jŭly ... 1. Czöberkeúel p(er) d 8 [Kv; Szám. 6/ XVIIa. 199 ifj. Heltai Gáspár sp kezével]; 1595: 13 Júly Wistai Nagy Istúán hozot. 1. Czeberke raakot ... d 29 [Kv; Szám. 6/ XVIIa. 200 ifj. Heltai Gáspár sp kezével].

csebrecske 1 . dézsácska 1652: egy hosszu szabásu Jégnek valo Csebrecske [Görgény MT; EMLt]; 1694: Va(gyo)n ebb(en) az Pinczeben ... egj Czap ala valo Csebrecske, vagjon mas rendbeli jó viznek valo Cseberis harom [Kővár; JHb]; 1732: találtunk két csebrecskét [Kóród KK; Ks 12. I.]; 1742: Négj Csebretske, öt Désa [Pókafva AF; JHb XXV/58]; 1756: Kisded csebrecske 4 [Déva; $\quad$ Ks 92. I. 32]; 1776: ezen Pinczében vagyon ... két csebrecske Cir. egy egy vedresek [Mezőméhes TA; Wass]; 1804: Csebretske [Hosszútelke AF; Kath.]. Szk: csős 1778: Más-fél vedres Csős Csebrecske [Csapó KK; Berz. 4. C. 18] * kétfülú 1747: ket fŭlŭ Czebrecske [Aranykút K; Ks 73. 55].

2. vhány dézsácskányi/dézsácskára való 1669: Egj czebreczke ablaknak valo ŭvegh Tanjer [Királyfva KK; Ks 67. 46. 24a].

3. vel (vhány) dézsácskányi/dézsácskára való 1747: adatott ... az Béreseknek is ... fél tsebretskével [Borsa K; Told. 3].

csegelyecske ék alakú (szántó) földecske 1724: egy küs cseglecsketöl fogva az Sombari Ur(am) reszin valok be szántottak volna harom őlnyit közönséges ember ölivel [M.zsombor K; Told. 2]; 1724: egy Szánto föld ... vicinussa egy Darabigh az Almás vize mellett egy cseglecske napkeletröl viz folyás Arkocska (a szomszédja) [M.zsombor K; Told. 2]; 1727/1790: hiva minket ... tiszteletes Popa Mihaila ... hogy elmennénk ... Ádámosra ${ }^{a}$ az oláh Templom vagy Czinteremhez tartozando Cseglyetskére vagy Darabotska helyetskére ... evegre hogy ott ... amely Vallokat mü előnkben állitana ... azokat erős hittel meg esketnők [MvLev. - ${ }^{\mathrm{a} K K .}$ ]; 1731: a viz felŏl valo belsŏ darab csegeljecske is ... azo(n) malomhoz szŭkseges volna [Lörincfva MT; Berz. 15. XXXIII. 1]; 1745: A ... vizmosáson és az óldalon fekŭvŏ szántófŏldek alsó barázdája kŏzŏtt maradott keskeny gyep Cseglyecske le felé hasadva ... juta Fŏldvári Ferentz Ur(na)k [Told. 9]; 1747: A Falunak felsŏ végiben ... valo Allodialis Rét, az Vrak Láb fólgje és a Nagj Patak szomszédságiban amenyire Cseglyes és egyenetlen voltához képest intéztethetett ... juta az Vrank a Felsŏ vagj a Malom felŏl valo része peniglen azal a Csegletskével - melyett a Viz az Aposztol Juvon haza melle szakasztott az Asszonynak ... a Teke felŏl valo része azzal a Csegletskével mely vagjon a Nagj árkon tull [Nagyida K ; Told. 9]; 1766: A' Szŏllŏ alatt egj tseglyecske [Szentgerice MT; LLt B. 339]; 1811: a' Patakon innen a' Kakasdra járo Hidnál kezdve a' Bodoni Határ Szélig lévő Csegelyetskék [Mv; MvLev. 2].

csegelyföldecske ék alakú (szántó) földecske 1641: Az Biro ligeten tudok egj kis darab czegely fŏldeczkèt [Sülelmed Sz; GyK X. 30/8]; 1759: Néhai Alb Tyiron ... egy F. Fentősi Menyecskét szeretvén ... egy alkalmatossággal a' Fentősiek rajta kapták bujálkodásokan és azon cselekedeteiért adta vólna a Fentősiek(ne)k ezen csegellj földecskét [F.fentős Szt; TL. Buttyán Petre (66) nb vall.]; 1765: a nagy árok mellett és az erdŏ alatt kis tsegely fŏldetske [Szentháromság MT; EHA].

csegelyhelyecske ék alakú földdarabocska 1773: Küs puszta porongjos, Küs Csegelj heljecske [Nyárádsztlászló MT; Sár.].

csegelyke ék alakú földecske 1793: egy darab bokros tsegelyke ... tsak úgy méretlen maradott [O.palatka K; RLt O. 2].

Szk: föld 1787: Vagyon ... egy Csegelke föld [Désakna; Hr 1/22].

csegelynyilacska (sorshúzás útján osztályrészül jutott) ék alakú földdarabocska 1693: $\mathrm{Az}$ Biro cserejében egy kŭs csegely nyilacska [Dicsősztmárton; EHA].

csegelyrétecske ék alakú rétecske 1750: egy kis tsegelly rétetske [Mezőbánd MT; $\mathrm{Hr}$ 2/4].

csehgyémántocska cseh műgyémántocska 1757: egy ezŭstben cse gyémantotska [Marossztkirály MT; Berz. 3. 1. 11]. 
csekélyecske jelentéktelenecske 1825: Az Egerpataki Bosa Jószág tsekélyetske [DLev. XIV. 5].

cselédecske 1. gyermekecske 1641: Miuel lattuan Pap Janosne Aszoniom hogy Vratol rajta maradot bonomokbol Nullo modo nem hogj magat czjeledeczikejuel eggjut sustentalhattna ... azert ... engede ... Pap Margit Aszonnak es posteritasok(na)k eoreokeoskeppen Negyuen forintert [Uzon Hsz; Kp I/53].

2. szolgácska, emberecske 1742: Király Biro Ur(am) kedre törvenyes napot indicalt, s edgy Jobbágjomot halálra keresik; s ha lehetne Comparealnék annak az Törvényin, mint hogy Cseledetskemet tartozom defendalni [Zalán Hsz; Ap. 2].

cselédházacska szolga-lakocska 1817: A Kapun belől mindgyárt vagyon, egy kis cseléd házatska, mely bornábol vagyon ki rakva, és szalmával fedve [Kövesd NK; $\mathrm{Kp} \mathrm{V/319].}$

csepleszerdőcske bokros, bozótos erdőcske 1797: In Sziliváje ... Erdő helynek valo némely része Szántonak ... egy résziben ... tseplesz Erdőtske [Szentegyed SzD; Wass. Conscr. 179-80].

cserebodonocska tölgyfabödönke 1740: Hét fedeles Tsere buddonotska [Ap. 5 Inv.].

cserécske tölgyfaerdőcske 1589 k.: vagio(n) Zabo Thomasnak tizta feolde annak vegebe volt valami keues cziereczke, tudom hogy azt ki irtotta [Szu; UszT]; 1728: Vagjon ... egj kis darab Cseretske [Aranykút K; 55. 73 Petky Dávid inv.]; 1746: (A határ) fel mégyen égy kerek nyárfás Tserécske alá [Nagyida K; Told. 9]; 1768: azon Cserétskét ... valaki vágta vólna [Csapó KK; Berz. 3. 7/C. 7].

cserecsutka 1747: sokáig keresvén ... ezen erdő(ne)k az Dél felől valo határát, holott egy bongorba ezen borozdán egj régi Csere Csutkacskára vágá(na)k keresztet [Vaja MT; VH].

cserecsutkó tölgyfatönk/csutak 1781: ez oljan Sŭrŭ erdŏ volt nagy Csere tsutkok fák Tŏvis Fŭz rakotya es egyeb tseplesekkel ... rakva volt ... a Nagy Fakat Puska Porral hanyattatta el ... eŏ Nga [Balavásár KK; Ks 19/IV. 8]. csereerdőcske tölgyfaerdőcske 1775: jó veszszős karónakis való Csere erdőtske [Komjátszeg TA; AbN]; 1783: Prészétsi nevezetü hellyben egy Csere Erdőtske [Hosszútelke AF; EHA].

cserefa-fiókgerendácska tölgy-keresztgerendácska 1736: (A) Pintzének ... Cserefa fiok Gerendátskáira borongatott Csere fa padlása vagyon rostellyos kis ajtotskája [CU].

cserefakádacska 1819: egy Szapullo rosz Cserefa Kádatska [Baca SzD; TSb 6].

cserefaládácska tölgyfaládikó 1816: Cserefa fiokos ládátska [Kv; Born. IV. 41].

cserefiatalocska tölgyfa-csemetécske 1783: Csere Erdő mellyben tsak Szöllő Karoknak valo Csere Fiatalotskák találtatnak [Hosszútelke AF; Kath.]; 1821: egy erdő ... ritkás Csere fiatalotskákbol áll [Uzdisztpéter K; TGsz 18].

cseregerendácska tölgyfagerendácska 1742 : hat csere gerendátskakra fenyŏ deszkákkal padlott [Pókafva AF; JHb XXV/58].

cserenyilacska tölgyerdőcske 1798: vagjon ... ŏ nganak ... szep allodialis szallos tsefas (!) Erdeje melynek deli szomszedcságaban nekem is vagjon egy kis apro tsere nyilatskam [Ádámos KK; JHb XIX/58. 25].

cserépfedőcske agyagfedőcske 1798: 3 cserep kitsiny fedőtske [Vingárd AF; KCsl 5].

cserépfüstölgőcske agyagfüstölőcske 1733 : Talatska 2. Cserép fŭstŏlgetske [Marossztkirály AF; Told. 2].

cseréptálacska agyagtálacska 1733: mazos tserép tálatska 5 [Marossztkirály AF; Told. 2]; 1750: két cserép tálatska [Szamosfva K; JHbK LVIII/4.2]; 1772: Cserep talatskák [Tarcsafva U; Pf].

csészécske findzsácska 1710: egj Cseszetske [Told. 19]; 1714: egj Vơrős börrel boritott futrálj, melljb(en) méreg ellen valo furfán Csiszétske vagyon és bőres talatska Indiai figurákkal ékesitett [Fog./Nsz; REkLt II. Apafi Mihály hagy. 18]; 1736: Vintzi bokálly Mazu fŭles Csèszétske [CU]; 1752: Egy ezűst belől aranyos Csészétske [Nsz; CU 2]; 1772: 1 kis Csészetske [Egeres K; Ks]; 1793: egy retzés szélü 2 füli fedeletlen cseszetske [TL Conscr.]; 1801: Egy hármas kis Csészétske [Kv; Ks]. 
csigafalatka (húslevesbe való) csigatésztácska 1838-1845: a reszelt tésztából, ormos henger által egybesodort kis csigafalatkák, miket dara - vagy reszeltbe, mintegy előljárokul tesznek bé [MNyTK 107 rigó fütty al.].

csikóbőröcske 1744: hitván Csiko borecske [Marossztkirály MT; Told. 18].

csikócska kiscsikó, rég vemhecske 1736: Istálotska ... van egy kisded ... Lo Istaló mellynek ajtotskaja Vas Sorkokon forog eltelelhet benne ket kis tsikotska [Mártonfva NK; CU XIII/1. 244]; 1807: egy két esztendŏs, barna Csitkocska [DLt 391 nyomt. kl].

csillagocska 1. csillag alakú mintácska 1811: visel ... égy fejér gyapot gyolts fersinget, égy fejér karton veres csillagostskákkal elŏ ruhat [DLt 508 nyomt. Kl].

2. csillagszerü fehér ló-homlokfoltocska 1843: Fekete szőrü paripa ... a' homlokán egy fejér csillagocska [DLt 1378 ua]; 1843: Piros pej kantza ... a' homlokán egy kis csillagocska látszik [DLt 1378 ua].

csinosacskán szépecskén 1736: Az ... udvarrol ... vagyon ... aditus ... Csinosotskán faragott ... fenyő deszka kapun rajta lévő kis Csekélly két vas Sorkokon forgó vas reteszszel zarlodo gyalog ajtotsával egyetemben [Várhegy MT; CU].

csipkebokrocska csipkerózsa/vadrózsabokrocska 1778: Ezen Erdŏcskénekis a' hegy oldala ... Csipke Bokrocskákból alló [O.sályi KK; Berz. 4. 8. C. 18].

csipkécske 1714: külőmbféle ki varrott Virágokkal ekesitett Keszkenyö, kőrős kőrül arany Csépkétskével fl. Hung. 5 [Nsz/ Fog.; REkLt II. Apafi Mihály lelt. 28].

csirkécske 1760: Azonban ezen Talyigán két Zsák szárnyas majorságnak valo buza rostaalyát kŭldőttem bé, Holnap Napra penig, őtt Csirkécskét, két Pipét, két ifju Nyulacskát és ez oráig Annyát szopo két Kis Báránykát [O.csesztve AF; Ks 83 Szabó István lev.].

csizmácska kiscsizma 1769: Gyermeknek valo viseltes két pár Csizmacska [Nagyercse MT; Told. 19]. csomócska 1. kis csomó 1598: Zeŏch Miklosne Anna azzony ... wallia. Ennekem vetet wala Vgrai Istwanne egi kannat zalogba huzon eot penzbe egi nehany nap múlwa ieowe oda komaromba(n) egi chiomochka penzt hoza mint egi ket forintig s ki walta az kannat teollem s el wiwe [Kv; TJk V/1. 153]; 1740: (Egy) Csomocska Fa haj [Novoly K; LLt Fasc. 47]; 1747: a molnarne ada egy Csomocska Lisztet az ablakon az Leánynak [Déva; Ks 101]; 1754: Egy csomocska Stukaturához kévántato Drot [Roskány H; Ks 76. IX. 3]; 1824: négy Csomotska aprobb-nagyobb gyász gyöngy [Fugad AF; HG]; 1848: 1 csomocskáb(an) fülfŭggo, kís gyŏngy és apróságok [Pk 2]; 1849: Láttam szemeimmel Hogy Csuléj Stefán fia Vaszilia - viszen egy 'sák almát még nékemis adott egy Csomotskát a gyermekeimnek [Héjjasfva NK; CsZ].

2. kötegecske 1744: egj Csomotska viasz Gyertya [Szentdemeter U; LLt Fasc. 67]; 1824: Egy tsomocska égetetlen paszománt [Dés; Újf. Újfalvi Samu hagy. 1]; 1840: Egy tsomotska Lo Szört Zaprán Győrgynéa [Dés; DLt 450. - ${ }^{\mathrm{a} T i}$. vett meg].

3. ? gombolyagocska 1779: Egy csomotska veres Fejtő [CsS]; 1788: Két tsomotska karmasin szín és fekete Bétsi Selyem [Mv; TSb 47]; 1804: Egy tsomotska veres fejtö [DLt nyomt. Kl]; 1817: Égy Csomotska gyapott [Mv; MvLev.].

4. göngyölegecske 1706: Egy Csomocska dirib darab kék posto [LLt Fasc. 146]; 1741: 1 Csomotska kender vaszon [Szentdemeter U; LLt Fasc. 67]; 1748: Kis Csomotska szősz vászon [Nagyida $\mathrm{K}$; Told. 11/95]; 1801: vagyon 2 Csomotska Csepŭ Vászon [Vargyas U; CsS].

5. rakásocska 1750: Egy szegény Ember(ne)k vagjon resziben jutott circiter három kalongjáni buzája egj tsomotskában [Szamosfva K; JHbK LVIII. 4.3]; 1750: Vagjon egj Tsómotska Zab Szalma [Esztény SzD; Told. 25]; 1763: maradatt azon Session a' melyen laktam nékem egy kalongyátska szénám ... Ezen kívül raktam más Csomotskáb(an) két szekerre valott [Záh TA; Mk V. VII/1. 14]; 1794: 1792 béli tsomotska zab szalma [Gyalakuta MT; TSb 17]; 1812: Két Csomotska Sendely 
[Gyerőmonostor K; KCsl 11]; 1840: Egy Csomotska Széna betsűltetett R. for. 6 [Várhegy MT; TLt Közig. ir. 1042]; 1843: Egy csomocska széna 5 Rf [Kövend TA; KLev.]; 1854: égy Csomotska Kő ... égy Csomotska zsendely [Sárd KK; Wass].

6. csomagocska 1780: Kolosvárrol is ... kủldőtt Cserei Uram ide az Öreg Asszony kezibe egy tsomotska portékát bé takarva, s három hellyen le petsételve ... én kezemben vévén a tsomotskát igen Sulyos nehéz portékának érzettem [Bethlen SzD; BK. Juliana Ersekujvári conj. St. Butzi (24) vall.].

7. (mirigy) daganatocska/bogocska 1608: a' fŭle tǒvinél vagyon ismét egy Csomótska mint egy kisded Dió [DLt 638 nyomt. Kl]; 1738: (Marján kocsist) meg nehezedvèn, meg nèzettem az batyaval ha pestisbe vagyonè, de leg kisebb csomocskajais nem volt [Gyeke K; Ks 99 Kornis Antal lev.]; 1852: egy vílágos piros pelyparipa ... hasa közepén ... egy dionyi tsomotska [Dés; DLt 1066].

csontládácska 1674: Vagyon egy kis Csont ládácska melyben vagyon oh pénz és egy Nihány tallér [Beszt.; Wass 72/6].

csontorka kb. tő, gyökér 1584: Domini Senatores ... deliberarunt Miert hogy az eggik vallŏ... sokzor hallotta azt Zabo Catotol, hogy eo rea az Anniarol marat volna halala vta(n) az Bozorkansagh es attol az Bozorkansagot meg tanolta, Mely vallasa tantum facit hogy Bozorkannak mongia magat, Ez vallasahoz penigh hogy eo ollia(n) zemely volna, illiendolgay accedalnak es ereossitik tudomaniarol valo vallasat hogy az fazakasnet meg feniegette hogy chontorkaiabol ky vagattia nyelwet addeg $\mathrm{Ne}(\mathrm{m})$ Niugzik [Kv; TJk IV/1. 222].

csoportosocskán sokacskán, számosacskán 1733: I(ste)n kegyelmébul neveletlen arva gyermekim csoportosocskán vadnak [Ap. 4 Árva Károlyi Klára lev.].

csorbácska csorbás, csorbásocska 1817: kivül ezen kis malmon vagyon még ēgy csorbátska also malom kő, melly nagy Szűkségben adplicalhato lenne [Ördöngösfüzes SzD; OrmMúz. Conscr. 9]; 1817: (A malomból) ki menvēn az udvarra, talāltunk Gerendellynek valo kēt faragatlan Fát és ēgy felső kisded malam kővet mely ēgy felől csarbátska [Ördöngösfüzes SzD; ÖrmMúz. Conscr. 10].

csőcske csövecske 1803: a' ... négy virágzat a' Pohár szárához a' virágokot felyül és aloll égyben foglaló tsőtskéken áll [Nagyteremi KK; UnVJk 203]; 1803: ezŭst Pohár, mely fenekébŏl ki nyúló kŭsded srofjánál fogva egy három ujnyi magosságu és a' talpja' sipjából egy hat szegeletŭ tsŏtskén fel-nyuló szárához foglaltatik [Széplak KK; UnVJk 212].

csukácska 1585: 27 Janua: Jútanak az Warady Birak B. $\operatorname{Vra}(\mathrm{m})$ hagiasabol kulte(m) Nekiek 2 Chukaczkat 9 fontot f-d. 29 [Kv; Szám. 3/XVIII. 19a]; 1597: kwltem Aiandekot ... 2 kicszin Czwkacsykat waroset [Kv; Szám. 7/XIV. 50]; 1685: vettem ... Kővi halakat és egj Csukácskat [UtI]; 1730: Az tegnapi halasztatas Ur(am) En rajtam el nem mult - harom Csukacskat harmincz Karaszt Kilenc vén Rakokat fogtak [Szentpál K; TKl Mihály Deák Teleki Pálhoz].

csúpocska domb/hegycsúcsocska 1747: a Fŏldek ütkŏznek egy csupotskán lévő erdőtskéb(en) [Nagyida K; Told. 9, EHA]; 1747: (egy) Cziheres keskeny erdőtske elé njúlván a ... második Csupotskára [Nagyida K; Told. 9, EHA]; 1747: a Puszta szőlő nevezetű hellyén felljűl lévő második Csupotskára [Nagyida K; Told. 9, EHA].

csuporka 1. bögrécske, csuprocska 1740: $\mathrm{A}^{\prime}$ Kamara hijján egy Láda, mellyben vagyon egy viseltes bőr vánkos. Egy derekaj rajta lévő vereses kőz vászon hajjal együtt. Két Fringysia. Egy kis tsuporka [Hermány U; Ap. 5 Apor Péterné lelt.]; 1782: Aprosag tsuporka [Szentimre Cs; Hr Inv.]; 1787: egy tsiporkába Tejet tőltvén azt meg nádmézelte [Backamadaras MT; CsS]; 1798: (A) Pohár Székben ... egy Patikabeli Fejér tsuporka orvassággal [Vingárd AF; KCsl 5].

2. Jelzői haszn-ban: vhány csuprocskányi/ csuprocskára való 1810: adott égy Csuporka mézet [KLev.].

csuprocska bögrécske 1733: Mazos tsuprotska 2 [Marossztkirály AF; Told. 2]; 1768: Csuprotska 4 [EMLt]; 1785: vett(em) egj tsupratskát orvasságnak [Kv; Pk 7]. 
csürfiacska csűroldalhoz ragasztott fióképületecske 1743: Tsür, oldalába ragadot őtt ágosokra hoszszan lévŏ polyva tartojával vagj csŭr fiacskájával edgyütt [Boroskrakkó AF; BfR dobozolt anyag VI].

csüröcske 1673: Kls Aszonyom az mely helyre hitván majoromot Epitette(m) ig(en) sáros szoros hely leve(n) ninczen hova egy hitvan csŭrüczket czinaltassak [Fog.; Törzs. Cserej János a fejedelemasszonyhoz]; 1718: az mostani Köhazakot T. N. Miko Judit Aszszonnyal Szerelmes Hazas tarsaval épitették, ugy azon Nemes Curian levö egjeb épúleteket is (: egj Kis csűrőcskén kívűl :) [Szentmihály Cs; Borb. II]; 1763: ezen Csürőtske kitsin ugyan de nem régen alittatván fel, semmi ruina nem laczik rajta [Hortobágyfva Szb; Born. XXIXa. 19 Néhai Hortobágyi Gergély György conscr. 16]; 1764: a hól ezen főld vagyon Bődia tsűrecskémet éppen a tájékján tsináltattam lévén nékemis ott a Borzási Határban ... edgy kis lábotskám [Bethlen SzD; Ks 8. XXVIII. 12. - ${ }^{a}$ M.borzás tőszomszédja Bőd SzD]; 1815: Ez a' Csűrŏtske betsültetett ... 90 - kilentzven Rf és 24 - huszon négy xra [Bálványosváralja SzD; Ks 77/19 Conscr. 849]; 1816: vagyon egy székelyesen épittetett Csŭrŏtske [Szentháromság MT; UnVJk 119]; 1827: van egy szalmás fedelü paraszt tsüretske [Somkerék SzD; Ks 73. 33]; 1832: Egy Kis tsürötskét volna Szándékom épittetni [Dés; DLt 854].

csűröskertecske szérüskertecske 1783: Tsürös kertecske fa Tsürivel most ... Veteményesnek coláltatik [Nagyrápolt $\mathrm{H} ; \mathrm{JHb}$ XXXI/28].

dagadtacska dagadtas, duzzadtas 1836: a Gróf Kendefi féle kancza csíkónak hátulsó bal lába hasonló sértődést kapván ezis dagattocska [Zsibó Sz; WLt Nagy Lázár kezével].

darabka darabocska 1589: Enis Irtottam ez peres feoldbe(n) ... egy darabkat [Szentkirály U; UszT].

darabocska I. 1. darabka 1576: wagion keteos (!) nem zynten wy weres taffotara warroth mynth egy wyomny A zele negy darabochka [Szamosfva K; JHbK XVIII/7. 14]; 1679: Cserzet, Tehen bőr, ket darabocska [Uzdisztpéter K; TL. Bajomi János lelt. 12]; 1700: Fejer ezŭstŏs Materia ... két darabotska [Hr 1/20].

2. földdarabocska 1572: Nadasy balynth zamara valo foldetis Egy darabochykath byrnak [Gyerőmonostor K; KP Thamo (?) Mate jb vall.]; 1587: melibe egj darabochjkat Zarka Antal az eo vduarához az dizno olnal el kertelt [Jedd MT; Bál. 1]; 1590: Az tarchahazy feoldreól vegheztenek, hogy az Apahidy Kabos Mihallial Zolnj Akarnak, Az zigetbe egy darabochkat veesznek (!) [Kv; TanJk I/1. 141]; 1607: az falutol vett daraboczka ${ }^{a}$, az az Ingerens kezebe

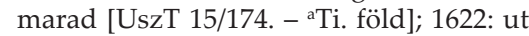
altal valo labian egy Retth ... Moso rihben egi daraboczika [Csicsókeresztúr SzD; SzJk 14]; 1678-1684: Rethek vadnak ... az Bőshazi Patak mellett egy daraboczka [Szilágycseh; SzVJk 126]; 1694: egj jo darabocska Szőlős Kert [Kővár; JHb inv.]; 1695: azon puszta ház heljbŏl egy darabocskát Vass Daniel vr(am) ház helyihez kerteltek [Cege SzD; Wass]; 1710: ugar sém maradott tőb két darabocskánál [Cssz; BCs]; 1714: Szántófŏld egy kŭs darabocska [Koronka MT; Told. 26]; 1728: taxas föld ... vagyon a koncz dombjan ... harom darabocska [Nagyborosnyó Hsz; SVJk]; 1736: (A) Szőlŏt Acs Győrgy Epittetté Erdőből maga háza utān, azutān egy Darabocskát az Bāttyānak ... adot belōlle [Szentegyed SzD; Wass Ács György (60) jb vall.]; 1746: egy darabotska ... most fogatatt - fel pusztábul [Vadasd MT; Told. 42]; 1746: egy darabatska fetske farkulag marad osztatlan a B(áró) Ur(a)k közöt [Mezőbodon TA; JHb XI/22. 10]; 1751: az kerek Tisztássa szélyin valo erdőket, nem kủlőmben az Szálos erdőnek végiben egy darabatskát ... magok részekb(en) el vevék [Ákosfva MT; Told. 8]; 1752: vagyon egy más darabatska ${ }^{a}$ [Pókafva AF; JHb XXV/73. 23.

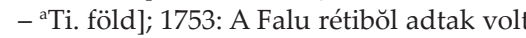
egy darabacskát [Kisapahida AF; Told. 18]; 1753: az fen megh irt Erdŏhez tartazvan megh egj darabacska, az melljetis ... attunk o kegjelmenek ... husz vonas forintakban [Torockó; Bosla]; 1757: a meg nevezet orrŏkségnek ... nagjobb részit a viz mosta el, s a mi a viztŏl meg maradot edgj darabacskát latván az Mgŏs Groff Beth- 
len Dávid Vr eŏ Nga Bohoroj Juon nevŭ jobbágya hogj senki semmi kőzit hozzá nem tartyá a maga őrőkségihez applicalta [F.borgó BN; BK Orbanás Iuon (60) jb vall.]; 1761: A rét végeib(en) valo két kis darabotskákat ugy tudom hogy Falusinak tartatatt, s a' ki leg elsőb(en) kaszálhatta [Illyésfva Sz; IB 45/9 Marosán alias Rekore Aleksza (40) zs vall]; 1762: a midőn Falu kőzőnseges erdeit, osztották fell, elsőbbenn is egy darabocskát az Udvar számára ki osztottak, s azután egymás kőzőtt fell osztották [Bögöz U; IB Andreas Kováts (47) jb és Andras Csiki (35) jb vall.]; 1767: egy darabacskát ki irtatta [Mocs K; HG. Eszterházi lev.]; 1769: ezen ... Hegyes ér Nevezetŭ hely kŏrŏs kornyŭl ... Nyárádtŏ kŏzŏnséges Falu helye volt, de ebŏl ... Horváth Ferentz Ur számára is fogtanak egy darabatskát [Nyárádtő MT; SLt XXVIII. 15]; 1772: A Zab Főldek kőzőtt égy Darabatska [Szászfenes K; BKt Mikescons.]; 1787: a Péterajjaban lévő Darabocskáknak fele [Kisesküllő K; SL]; 1805: égy darabatska ehez tartozo Dioszegi rész föld volt [Dés; DLt az 1825. évi iratok közt]; 1824: Ezen Colonusnak különösen kaszálloja nintsen hanem az Exponens Urasag Allodialis réttyeibŏl szoktanak nékije imit-amot - égy égy darabotskát ki szakasztani [Szásznyíres SzD; Ks 79 Conscr. 125]; 1841: Szerzett meg ezen ... Joszág mellé ... egy darabatskát [Torda; HG]; 1843: akkor pedig a' Deresztés a' Jovábol egy darabotskát magának felszántott, 's ugy használta [Bodola Hsz; BLt 12 Molnár Györgye (60) szolgáló ember vall.]; 1866: én ide Valo Szovátai Kŭs Míklos ... a Sok nyomoruságaim ki potlása véget kételinttettem (!) a belsŏ lako Joszágomnak a kŭlsŏ és also végibŏl egy Darabotskát el adová teni [Msz; Bereczki József lev.].

3. egy val egy kicsivel/kevéssel 1769: az ország uttya ... a' mostani hidon felyúl égy darabocskával ki tért [Apahida K; JHbK XLII/24]; 1843: a pank egy darabotskával bennebb esik a határnál [Körtvélyfája MT; LLt].

4. egy ig a. egy kis ideig 1783: Megnyugodni látszatott égj darabotskáig az eŏ nyughatatlan elméjek [Torockó; Thor.
XX/5. 42]; 1786: a' kőzelebb el-mult télen egy darabotskáig Szappany Utzában Pós Thrésiánál laktam [Kv; KLev.]. b. egy kis darabon, bizonyos távolságig 1789: Len gyólts, kit (!) végén és Szélén is egy darabotskáig fel Totos Csipkével ékesített kendŏ [Bölön Hsz; Palotay 18]; 1802: Az Utza felől ... egy darabotskáig avatag Borona palánk [Türe K; MkG]; c. egy ideig/ egy kis darabon 1774: Számtarto Ur(am) ... a' szekeret ki késérte egy darabotskáig [O.zsákod KK; LLt 196]

5. részecske 1732: Viola szin bibor Materia 3 sing, s, egy darabocska [Kv; Ks Kornis Zsigmond lelt. 6]; 1788: Fejér Fláner 1. sing kék veres és kŭlŏmbŏzŏ szinŭ kartonok darabotskák [Mv; TSb 47]; 1841: Kék kotzkás Sponyolét dorobotska [Dés; DLt 466]; 1844: Balog Mosinak az Szallannája el veszvén meg Matoztotta s nállam egy Kis Kosárba talált egy darabatskát a Matozo Hütesség [Bágyon TA; Klev Nutzuj János (21) vall.].

6. törmelék 1679: masut minden fele romlott ŭveget, akár mi kicsiny darabocskatis, hordora gyujtenek [Uzdisztpéter K; TL Bajomi János lelt. 36]; 1717: Edgy kőnyi Só, appro darabocskákb(an) [Kentelke $\mathrm{SzD}$; JHbK L/3].

II. Jelzői haszn-ban: 1. 1628: Harom daraboczka feier karasya ... Harom daraboczka dirib darab verez Braszlaj [Gyalu/Kv; JHbK XII/44. 10]; 1668: eo Kēge fianak ... advan el penzen egy daraboczka fejer on szomorlast (!) p. 12. finum ezwst gyanant [Kv; ÖJk]; 1696: negy darabocska arany láncz [LLt 102/24]; 1714: Egj darabotska kek Vaszony [Szb/Fog.; REkLt II. Apafi Mihály hagy. 33]; 1724: Három apró darabotska karos fogasok [Koronka MT; Told. 29/12]; 1733: Darabatska aczél 2 [Marossztkirály AF; Told. 2]; 1733: Edgj darabatska folt Csemellyet [Marossztkirály AF; Told. 2]; 1733: Öt darabotska kisded fejér on [Marossztkirály AF; Told. 2]; 1753: Edgj darabatska viasz [Mezőzáh TA; Told. 18]; 1754: Oldalos nro 2 Sodor nro 7., item 12 darabotska hus [Mezőgerebenes TA; BLt 7]; 1788: darabotska vastag vászon [Mv; TSb 47]; 1796: négy darabatska fát le vetett az Ispotály számára vitt szekér fá- 
bol [Kv; Aggm. B. 15]; 1798: 1/2 darabotska on xr 1 [Kv; Pk 6]; 1800: két izben egy egy darabotska hordo bort ki árultatott a' Selléreivel [Msz; DLev. 3]; 1805: Egy darabatska rez [Szamosfva K; BLt 9]; 1805: Ket darabbatska Ujj Kartan [Szamosfva K; BLt 9]; 1810: Kétt darabátska fa [Jedd MT; LLt]; 1817: Egy darabotska Tot Csipke [Mv; MvLev. 8 Simonffi Susánna, elébb Csizmadia Prodán Lászlóné, majd kőmíves Csipkés Sámuelné hagy.]; 1839: Het Darabotska Talp a Dirib Darab Bőrőkkel [Dés; DLt]; 1840: Edgy darabatska fejér harisnya poszto rongyos szélŭ [Dés; DLt 1590].

2. kis darab (föld) 1626: az meli daraboczika zeóleőie uolna Kis Mihalinak ... ada eőreŏkbe Pethki Ersebeth Azoninek (!) [Marossztgyörgy MT; Törzs. Gieorfi Gieörgi Szabedon es Kolosuari Janos Deak Kváron lakó nemes ember biz. lev.]; 1631: az Stomp mellett egy daraboczyka rét [Abrudbánya; EMLt Georg. Egri (54) jur. civ. vall.]; 1648: az Patak mellet egy Daraboczka fü [Berkes TA; Berz. LXIV/11]; 1650: Az Mezőn két daraboczka Buza vetes [Sólyomkő K; SLt GH. 5]; 1650: ket daraboczka főld [Dicsősztmárton KK; Pf]; XVII. sz. köz.: daraboczka fold [Bethlen SzD; BLt]; 1652: adot ... két daraboczka szena füvet [Illyefva Hsz; BLt]; 1653: Vettem ... Egi daraboczka Erdot [Kercsed TA; Borb]; 1658: Az Alvinczi Felső varb(an) vőn egy darabaczka ház helyeczket [Alvinc AF; Berz. 1]; 1670: volt hat daraboczka Erdeje [Tarcsafva U; Pf]; 1671: adott volt Samsond falua holmi daraboczka feòldeczket [Mezősámsond MT; Berz. 14. XVII/8]; 1676: I(ste)n oltalmazzon hogy ollyan darabocska fŏld felett és alkalmatlankodgyam kglddel [Tövis AF; Bál. 1]; 1680: egy darabocska szanto fŏld [A.porumbák F; ÁLt Urb. 50]; 1685: Tudom hogy az Sándor János uramék gondviselője Gaspár Benkő Samuel Uramnak adta vólt hogy megh kaszáltassa azt az Kisseb Vizi Péter joszága kőzőtt való kis daraboczka joszágot [Altorja Hsz; Borb. II]; 1685: egy darabocska lóétetni való hely [Nyárádtő MT; Told. 27]; 1686: egj darabocska Puszta tóhely [Désakna; Hr 5/1];
1687: az Tompos Imre Csüre hata mégget vagyon égy darabocska kővécs [Menaság Cs; EHA]; 1690/XVIII. sz. köz.: ozon Dorna oldalanak nap kelet felől valo Vegeben egy darabotska Volgy és oldalatska marada fen osztatlan [M.fodorháza K; RLt 1]; 1693: ada ... Uzonba(n) egy darabocska Joszagot ... ada egy darabocska kender fodet [Uzon Hsz; BLt]; 1694: lapos csere kŏzŏt hagyatot egy darabocska főld [Mezőméhes K; Wass]; 1695: jutat elsőben egy darabacka őrőgsegh (!) [Ilencfva MT; DM 2. XIII B/b. 4]; 1696: vagjon ... ègj darabocska kaszálo [Cege SzD; Wass]; 1697: azt az Daraboczka helyet Diosi Ur(amna)k zalogb(an) nem atta [M.köblös SzD; RLt 1]; 1699: ezen joszaghoz szakasztanak ... egy daraboczka joszagot [Kilyén Hsz; BLt]; 1700/XVIII. sz.: egy darabotska szénafü [M.felek U; Hr 5/4]; 1702: az a Darabacska lopally az Kin ... Fejer vari Sandor Sigmond Vram kapdas [Fejér m.; Kath.]; 1702: egy daraboczka veteményezni valo fŏldet, mindenkor éltéig ád, és enged [Kv; Pk 7]; 1703: Egj kis darabaczka szőlő́czke [Ádámos KK; Pk 7]; 1711: egy darabocska Joszag [A.csernáton Hsz; BLev.]; 1711: égj Darabacska majorság Szőllő [Mv; RK Bethleni András kezével]; 1712: az Bárdosi hataron levŏ egj darabocska erdŏ [Mv; Wass]; 1714: (A) Ház helly avagj darabacska csegely vagjon ... azon Balastelkj Lutheraba Ecclesia Papság Házának háta megett [Balázstelke KK; JHb XX/3]; 1716: vagyon két darabocska erdŏ [Csekelaka AF; KCsl 16]; 1717: vagyon egy darabocska kaszálo [Dés; DLt 504]; 1719: egj Darabocska hasáb szőlő [Ecsellő AF; Kath.]; 1722: Vagjon Egy dorábacskā szanto fŏld [Szőkefva KK; Kp III. 112]; 1722: edgy darabocska föld [Kissolymos U; Márkos lev.]; 1722/1814: egy Darabotska Fetske farku Circiter három kőblős Szánto Főldetske [Kisjenő SzD; Bet. 1]; 1723: azon ház helyecskéböl régentén el Szakadott vagy quo quo modo el foglaltatott volna azon darabocska Czikelly [Dob.; RLt vk]; 1726: lévén egy darabotska széna füvetskeje a Falunak keskenyen az Ur fŏlde mellet [Koronka MT; Told. 19/1]; 1728: Vagjon ... egj darabocska kaposzta fŏld [Málnás Hsz; SVJk]; 
1731: egy darabocska egres (!) fagbol (!) allo Szabados erdőcske [M.nemegye BN; Berz. 7. XVIII. 68/1]; 1732: A Szŏlŏ Hegy felett a Kellési patakra nyulik le edgj darabotska tilalmas makk termŏ Csere Erdŏ [Szászsztjakab SzD; TSb 51]; 1733: két kis darabatska szánto fŏld [Gálfva MT; Sár.]; 1733: Vagjon ott fennyeb az Er mellett égj darabocska egy Bugjára valo Retetske [Vaja MT; Sár.]; 1733: ada harom fordulo határban harom darabocska főldeket, es az felső tanorok nevü heljben az porongjnal egj darabocsa (!) szena füvet Zalagban [Jánosfva U; Borb. II]; 1735: két darabatzka Pusztás Szŏlŏ [Pókafva AF; Kath.]; 1735: Janosi István Uram ... Urszan Gabortul kérte azan darabacska kender földet [Szentegyed SzD; Wass Fazakas Peter (20) zs vall.]; 1736: a' Cséhnél van egy darabotska Tziheres [Búzásbesenyő KK; EHA]; 1736: egy darabotska Lo tzőveklő helly [Noszoly SzD; CU]; 1736: Vagyon egy darabotska tŏvisses berek az Nyárosba [Földvár TA; CU XIII/1. 295]; 1740: A János Cseréjében edgj darabocska bokros helly (k) [Egrespatak Sz; EHA]; 1742: A kŏrpényesen egj darabotska vágot Erdŏ [Marokháza K; Ks 4. VII. 1]; 1744: A Nyár fánál egj darabocska irtott rét [Marossztkirály AF; EHA]; 1744: egj darabotska majd haszontalan helj a Falu Borju Tanorokja mellet [Backamadaras MT; EHA]; 1744: egi darabotska puszta sessio [Désakna; Hr 1/31]; 1746: Popa Adám ... Exponállya hogy itten ... idősb Gyurgya Juontól egy darabotska őrőkséget vettem 20 márjásokkal [H; Ks 62/10]; 1746: adott Daroczi Samuel Ur(am) két darabotska főldet [Szőkefva KK; Ks 91]; 1747: a' Falu adott vólt az elmult Tavaszkor nékem egj darabotska hellyet [Kismuncsel H; Ks LXII/20]; 1748: lá Pojána áluj Petru nevü helyben leven egy darabotska irtása néhai Száva Andrásnak [Brettyélin H; Ks 62/16]; 1748: vólt egy darabotska széna fŭve [Torda; Borb.]; 1750: a Só székig egy darabotska Rétet és óldalt praetendálnak a' Szabad Rendek Falu kőzőnséges Réttyinek lenni [Koronka MT; EHA]; 1751: In Gura Péreul (!) a pruszi lévén edgy darabotska helyem ... ellébbi obligatioja ellen az I nem aquiescalt a métákot ki vetetté s mostan is hábor- gatotom általá azon darabatska földőmben [H; Ks 62/5]; 1751: A Bene Revinel egy darabotska Ecclesia füve [Egerpatak Hsz; DLEv. 5. XIV. 1]; 1753: igirtŭnk ŏ kegyelmenek az magunk hatarunkan egy darabacska erdŏt [Torockó/Gyertyános TA; Bosla]; 1753: egy kis darabacska föld [Kv; Aggm. 64]; 1754: (Ezen) felyúl (!) vagyon égy darabotska tővisses erdő [Hosszúmacskás K; BHn 142]; 1754: Az Vágás Utra jár véggel egy darabatska szanto Föld [Kisillye MT; EHA]; 1755/1805: most Sz. György napjára akarnék váltani ki egy darabatska Joszágot [F.zsuk K; SLt XLVI. 7 Suki János Ferentzi Györgyhöz]; 1756: égj darabotska szánto fŏlde [Petek U; Hr 3/15]; 1758: edes Fianak ... ada itt a' Meszkŏi hataron egy darabatska rétet $a^{\prime}$ Köz pad nevŭ helyben [Asz; Borb. I]; 1758: Ada ... Vadadnak also resziben Telkén egy Dorobotska ben valo örokségit [Vadad MT; EHA]; 1758: az Fügŏ tetőn tudak egy darabatska Főldet [Feketelak SzD; LLt 64/1767]; 1761: egy darabotska puszta Csere [Fejérd K; HG]; 1762: két darabotska fŏld [Kide K; Bíró János lev.]; 1762: a ... berekböl szakasztatta ki ezt az darabatska berket a víz [Körtvélyfája MT; Bál. 87]; 1762: egy darabotska Rét [Rigmány MT; LLt 86/2]; 1762: az melly darabotska Házhellyétsket [Túr TA; AbN]; 1763: egy darabocska kaszálocska [Szabéd MT; Berz. 5. 44. 5. 30]; 1763: egj daraboczka két ől szélességü ... pusztás szolejek [Torda; KW]; 1764: a szőlők mellet ... a mely darobatska szánto Főld vagjon ... ki birta ...? [Fejér m.; JHb XXVI. 22]; 1765: más hasonlo egj darabotska puszta hellyetske [Csávás KK; LLt]; 1765: egy darabatska szánto földem [Szentháromság MT; Sár.]; 1765: maradatt egj darabatska szŏlŏje itt az Bágjonia határan [Told. 3a. - ${ }^{\mathrm{a} T A}$ ]; 1766: Vagyon két felől égy égy Darabocska kaszállo [M.köblös SzD; RLt]; 1766: Pap Stefán ... egy kis darabotska Irottvánt kezdet volt [Szentegyed SzD; Wass Molduván Kratsun (80) zs vall.]; 1767: vane egy darabocska Lábocskánk [Dob.; MkG]; 1767: egy darabatska nyil [Pete K; LLt Fasc. 129]; 1767: egy darabatska hellyt fenyő deszkákbol valo padlásai vadnak [Nagyernye MT; LLt Fasc. 129]; 1769: lévén ... egy darabotska 
Szánto földje [Backamadaras MT; CsS]; 1769: Nyocz vékán vetett kétt darabacska buzája Kétt darabacska Tőrőkbuza Vetesse [Marossztgyörgy MT; Ks 67. 48. 31]; 1773: egy darabatska fŏld [Vingárd AF; LLt 53/17]; 1773: egy darabatska Puszta hely [Mezőerked K; LLt]; 1774: a Kapunál egy darabotska Cziheres bokros puszta szöllö föld [Vaja MT; EHA]; 1774: adott volt más darabotska szilvást tserébe [Kettősmező SzD; JHbK LIV/3. 5]; 1776: egy daraboczka kaszálo Rét [Backamadaras MT; Hr 1/15]; 1776: egy darabadtska Akol hellj [Keresztúr MT; MvLev. Nemes lev. 9]; 1777: egy darabocska Szena fü hellyem [Szentkirály Cs; Hr 8/27]; 1777: Tudom bizonyoson hogy a' meg nevezett Jobbágyok esztendőnként egy egy darabotska Földeket adtanak ki barázdára [Sajóudvarhely SzD; KS Steph Veress (46) jb vall.]; 1779: kérvén egy darabotska Rétetskét [Kv; HG]; 1779: egy darabotska Szánto Főld [Szövérd MT; Told. 25]; 1780: Kétt véka kendere valo darabatska Főld [Bukuresd H; Ks 113 Vegyes ir.]; 1780: egy darabatska ... Erdeje [Backamadaras MT; CsS]; 1780: (Adnak) Ugyan azon Hegyen két kis darabocska Szŏlŏt [Zilah Sz; Borb. II]; 1780: egj darabatska heljet vettem a Nemes Várostol [Torda; KW]; 1781: egy darabotska irtás [Királyfva KK; LLt 24/25]; 1781: Controversias heljnek edgy darabotska részit az belső széllin az mesde háton szántotta [Bibarcfva U; Hr 1/22]; 1784: Vagyon ... két darabatska erdeje [Diós K; JHbK LX/19. 63]; 1786: Vagjon az Rakosi Labban az Körtövefánál egj darabotska szanto föld [Asz; Borb. I]; 1786: Mindgyárt a' Gáton fellyül a' To Marton vagyon egy darabotska Szegelet az Ut és a' Tó kŏzŏtt [Mezőbánd MT; TSb 51]; 1787: Vettem ... egy Darabatska kaszálott [RLt Mich. Szarvadi kezével]; 1789: égy darabatska gyep [Mezőköplény MT; Hr 6/55]; 1791: volt Csipkés Borkának egy darabotska őrőksége [Várfva TA; Borb. II Nic. Székely (59) nb vall.]; 1791: Telek pataka mellet lévŏ egy darabotska kaszálo [Firtosmartonos U; EHA]; 1792: Vagjon Rákoson a Falu derekáb(an) ... egj darabotska Joszág [Aranyosrákos TA; Borb. I]; 1793: a Comunitás erdejéből egy darabotska mintegy egy szekér szénára valo rétetskét mi irtottunk az Atyámmal [Kalotasztkirály K; KHn 54]; 1793: edgy kis darabatska Erdeje [Kakasd MT; DM 2. XIII. B/b. 16]; 1793: a' Kis Buruzlo nevü helyb(en) lévő kétt darabatska íratvány [M.köblös SzD; RLt]; 1794: semmi bizonyost vallani nem tudok ... azon darabotska hellyetskéről [Somlyócsehi Sz; BfR dobozolt anyag X]; 1796: Az Ŏrdŏg vára alatt, egy darabatska kaszállo [Pujon SzD; Wass]; 1797: vagyon egy jo darabotska Erdö [Szentegyed SzD; Wass Conscr. 177]; 1799: Tit: Dosa Gergely ur három szegü forma darabotska Joszága [Kakasd MT; DM 1. I. 7]; 1799: valami darabotska Comune terrenum [Dés; Hr 5/46]; XVIII. sz. v: ezen darabatska Szalatruk nevezetü Teritoriumatskánktol is meg fosztatnánk [Szelistye H; Ks 75. VIII. 97]; 1801: Vagyon égy darabotska kaszálloja a Levitanak [Mocs K; SzConscr. külön mell.]; 1802: ujj Fogások kőzőtt lévő azon Darabotska szöllő helly [Dombó KK; EHA]; 1802: egy darabotska valamenyib(en) fel Serdŭlt Cziheres erdeje [Lőrinczfva MT; SLt 12. V. 18]; 1803: vagjon ... egy darabatska erdeje [A.jára TA; CsS]; 1803: adott egj darabotska kaszálotskát [A.jára TA; CsS]; 1803: adott volt egy kis Joszágotskát, és egy darabotska Főldet [Szenterzsébet U; Borb. II]; 1804: egy darabatska helly a Gátan innen a be keritett Törŏkbuzás kertnek felső széliben [Km; KmULev. 3 Zágani Szabó András kezével]; 1805: Mitu Kodrán ... kér magá(na)k egy darabotska hellyet az hová házat épithessen [Volkány NK; JF 36]; 1805: lévén a Kakasdi határb(an) egy darabatska hasonlo fel Serdŭlt Cziheres erdeje [Lőrincfva MT; SLt 12. V. 21 Kis Görgényi Jánosi Antal hit. ass. vall.]; 1806: 4. darabatska allodialis szölő [M.sáros KK; DLev. 4. XXXVIII]; 1806: az Árok szomszédtságiban kis darabotska kerek bük erdejek [Bede MT; EHA]; 1807: Kőblős felőll vallo Fordulojában az ugy nevezet Gombásné Gődre fenekében égy darabatska Bokros iratvanyak [Páncélcseh SzD; EHA]; 1808: egy darabotska kaszálo [Szárazpatak Hsz; Hr 19]; 1812: leven Kis Illyében ket darabatska kaszalom [Mv; LLt]; 1813: Ugy látom, hogy ezen darabocska fŏld ... a kŏrŭl szomszédolt, és Ha- 
tárbeli jegyekkel kŏrŭl vétetett Mlgos Exponens Groffné Aszszony eŏ Nga fogásának, mintegy egy kŏbŏl férŭségét tészi [F.berekszó Szl; BfR III. 12/9]; 1814: Az Udvarház háta meget vagyon égy darabotska Palánt Szőllŏ [Septér K; Bet. 3]; 1814: Három darabatska Erdejek [Szászmóric SzD; CU]; 1815: edgy darabotska Erdő [Kissáros KK; DM 2. XI. A. 14]; 1815: édgy Darabotska Szegelet Szőlöm [Backamadaras MT; Hr 1/9]; 1817: a zsendelly alatt lévő Párkány egy darabatska hellyt Repara(ti)ot kiván [Ördöngösfüzes SzD; ÖrmMúz. 1]; 1818: a' Juon Morus praedecessora irtott az Dán Morus helje oldalaban egy Darabotska oldalt mint egy 6 ploszka széna termŏ heljet [Petrilla H; JF 36 Prot. 25]; 1818: egy darabatska Szöllö [Kelementelke MT; BkF]; 1820: két darabatska Erdök [Nagyadorján MT; NkF]; 1820: egy kis Darabatska szánto Földök [Etéd U; NkF]; 1822: Egj kis darabotska szŏlotske [Kv; Pk 7]; 1822: egy kaszállotska égy más Darabotska Szőllő [Jára MT; KelM]; 1823: egy darabotska maleval be vetett föld [Dés; DLt]; 1823: egy darabatska szegelet erdő [Dés; DLt]; 1825: a' ... Botzokban lévő darabatska erdŏ [Majos MT; Told. 48]; 1828: égy darabatska Szŏlŏ helly [Cege SzD; Wass]; 1829: léven egy Darabocska erdeje az Erdő Farka nevezetű heljen [Csekelaka AF; KCsl 16]; 1830: Szurdok Tsorgojánal ... azon darabotska Föld eddig is az Eklésiájé volt [Magyarókereke K; EHA]; 1830: Hét darabotska Szánto Földekkel [Nagyadorján MT; NkF] 1838: egy darabatska most le vágott Erdö hely [Mezőnagycsán TA; TGsz 35]; 1840: két darabocska kaszáló [Bikszád Hsz; MkG Urb.]; 1841: Percipialtam ... Felsŏ sz Mi(haly)falvan a a Két Darabotska Puszta telekért 15 Rft [Bosla. - ${ }^{\mathrm{a}} \mathrm{TA}$ ]; 1842: Vagyon egy darabotska bokros erdő a' Büdes oldalon [Felfalu MT; EHA]; 1842: Vas Mihálly ... által adá egy darabotska fölgyit [Bözöd U; Borb. II]; 1848: égy darabatska Fűzessel bé nőt Szegeletecske, főld [Dés; DLt]; 1863: lévén ... egy Darabotska haszony vehetetlen parlagjak [Szováta MT; Bereczki József lev.]; 1871: égy Darabotska pusztás hely [Bere MT; EHA].
3. gombolyagocska 1664: Egy daraboczka Fonal [Dés; Hr 2 Fasc. 23]; 1677: két daraboczka gyapott [Kv; RDL I. 155b].

4. hordócska 1748: most ŏt darabotska borát vitette Lŏtsei vramhoz [Torda; Borb.].

5. szakaszocska, rövid szakasz 1636: az haz vegibe(n) vagyon egy daraboczka keŏ kerités [Siménfva U; JHb Inv.]; 1851: van egy darabotska sövény kert meg lehetős állásu [Erdősztgyörgy MT; TSb 34].

6. részecske 1626: egj küs daraboczka faual ugj oltalmazza uala magat [Szentgyörgy Cs; BLt]; 1633: oda ada neki azt az kis darabocska hustis [MvLt 290. 139b]; 1638: Hallottam hogy montak az emberek hogy az Ura(m) Szabadossa egy Daraboczka kővet vit volna el az kőz kőből [Torockó; Thor. XVI/1 Joh. Bartha (35) jb vall.]; 1694: az harmadik penig vak Ablak; melljb(en) keresztül áll egj darabotska deszka hol mit le tenni és tartani valo [Borberek AF; BfR Néhai ifj. Bálpataki János kúria-leírása]; 1726: az városon pedig senki csak egy darabocska kenyeret sem adott [Ne; Ks 90]; 1751: Láttam Fazakas Ferencz Uramnit egy darabocska Cserefát [Szárhegy Cs; LLt Fasc. 151]; 1776: egy darabotskát ā pereczből M. Annikó Kis Aszszony bé fala [Msz; LLt Christina Kováts cons. Stephani Miklos (55) vall.]; 1781: az ... Élés házban sints most egyéb számba vehetőbb portéka egy darabotska Szalonnánál [Pálos NK; $\mathrm{Hr}$; 1829/1830: egy kitsiny darabotska miveletlen arany [Zabola/M.régen Hsz/MT; TLt Közig. ir. ad 196/830].

Szk: egy ideig 1846: le mentem boltunkba s ott voltam egy darabotska ideig [Dés; 530/1847] * egy idó alatt 1814: a' maga hellyén árulván egy darabotska idő alatt [Dés; DLt 203] * egy idő múlva 1765: És midőn egy Darabotska űdő mulva viszszá jőttem volná a Falub(a), találám [Kóród KK; Ks 18/LXXXVIII. 11] * egy időtól fogva 1765: edgj darabocska idötöl fogva [Tarcsafva U; Pf]; 1808: egy darabotska időtől fogva oly privatum Just kivánt formálni [Mezőpanit MT; Berz. 5. 43. S. 113] * egy-egy ideig 1840: ollykor ollykor mint Kereskedǒ Emberek szoktak még hol égy égy tsikot, hol más Marhátskákatis égy égy darabotska ideig tartogatni, 's ismét el 
adni [Balásháza Sz; RLt] * jó idő múlva 1823: jo darabotska idő mulva haza felé indulván [Dés; DLt].

darabontházacska hajdúlakocska 1647: Az porkolab haza rendiben harom Drabant hazaczkak, fabol eppittetek, ajtajok mindeniknek jó ketteiben sővinj kemencze Egjikben Szekelj Janos az Drabant rakatott volt kemenczet. Hejazattjok semmire nem jo [Marosillye H; VLt 55/5415]; 1694: va(gyo)n egy Darabont Hazacska kinekis egy kis rosz Kas kemenczejé padlasa penig semmire kellő [Kövár; JHb Inv.]; 1694: va(gyo)n egy Darabont hazacska, ennek ajtaja bellet, de az esső el rothasztotta [Kővár; JHb Inv.]; 1699: va(gy)on jo szarvazás régi sendelyezés alat ... darabant házacska [Szentdemeter U; LLt].

darabontházikó hajdúházacska 1744: boronafábol rakott kis ded Darabont háziko Sendelj fedél alatt [LLt Fasc. 67].

daruszürkécske hamuszürkés 1757: Egy par kiketz (!): egyik kesej hasu, a masik daru szúrkétske, 5 esztendŏsŏk ${ }^{a}$ [Pusztasztmik-

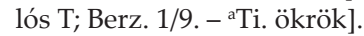

defektusocska hibácska 1757: kitsiny defectusotska intervenialt ... harmadik Esztendejének ki nem tőltésében [Kv; Aggm. C. 24].

delnicácska (föld) nyilacska 1773: Azon Kertin kivŭl valo Delnitzátskájában megterem esztend(őnként) 1 [Szárhegy Cs; LLt].

demonstrációcska elszámolásocska 1774: Ezen occludált Demonstratiotskat Curiosusabbatskan comportaltam volna az egész Confusioba voltam [Sáros KK; SLt XL Kŏrmŏtzi Joseff Suki Jánoshoz].

Szk: t tesz 1733: nékem egy kis demonstratiocskát tégyen [TKl Teleki Sámuel kezével].

derékaljacska 1615: Egj kws derekaljochka [Kv; RDL I. 97]; 1627: egi fel Derekaliochka [Kv; RDL I. 131].

derékaljhajacska 1625: egy kekes derekaly hajaczka viselt toldozott [Kv; RDL I. 126].

derékaljka derékaljacska 1736: Az Úr Házáb(an) ... Fejér hajas avatag derekalylyka 1 [Várhegy MT; CU XIII/1. 103]. deszkaajtócska 1744: Epittetett ... Gabonást ezen Gabonásnak az hijjara fel jaro deszka ajtocska bőr sarkakon forgo [Ádámos KK; JHbK XXVIII/10]; 1753: vagyon egy Sáfár házatska melyben nyilik egy Vas Sorkokon és pantokon forgo deszka ajtotska [Marossztkirály AF; Told. 18]; 1793: Az Szabo András Háza ... Pitvara is Bűkfa Deszkával meg van padolva, ezen van az hijjában járo két fenyŏ fa Deszka ajtotska retesszel a' Sarkai vas kávákkal az melylyen forog az Sarok [Szér Sz; JF 36 LevK 170].

deszkácska 1582: zekerche fokkal valo wthesys vagion az Ayto mellet valo dezkachkan [Kv; TJk IV/1. 9]; 1723: Egy deszkátskára tekert Sárga szŏr selyem [Koronka MT; Told. 29/2]; 1772/1812: Bikfa keskeny Deszkatskákbol oszve rakott s fa Sorkokon járo Kapu [Kál MT; HG Conscr. 128]; 1780 k.: Tsináltam két deszkátskát a léptsőre [Szászváros; BK]; 1796: No 37 szál, vagy darab deszkátskákért ... szála 18 4/8 [Déva; Ks 95]; 1797: a Gerendához Szegezett kétt jukas deszkátskákba egy fenyŏ rud [Körispatak U; Pf].

deszkakapucska 1742: deszka kaputska [Pókafva AF; JHb XXV/58].

deszkaszékecske 1679: Közönseges apro deszka szekeczke nro 2 [Uzdisztpéter K; TL. Bajomi János inv. 10]; 1761: Kis Deszka széketske 1 [Szentmargita SzD; Ks CII. 16].

deszkaszínecske 1848: égy détzka fedellel fedett detzka szinetske [Somkerék SzD; Ks 73/55].

deszkatokocska kb. (üvegrekeszes) deszkaládácska 1756: Egj kitsiny két ŭveg Palaczkot tarto Deszka tokotska nros 7 [Somkerék SzD; Ks gr Bethlen Imre lelt.].

deszkatornyocska deszka-haranglábacska 1729: Vagyon ezen N(o)b(ilita)ris Curiahoz tartozandǒ... egy szép hegy tetejin pasintos helye(n) epittetett kö templomocska .... sendellyel fedve és harang(na)k való deszka Tornyocskája, plével boritott kereszt kettŏ a' tetejin Czinterme lészás tamoszos kertel bé véve [Buza $\mathrm{SzD}$; JHb $\mathrm{V} / 2]$. 
dézmácska tizedecske 1582: semmikeppen milto nem volna az eó faluia dezmaczkaiatol azokkal ${ }^{a}$ egi arant walo arendat fizetni [Gyf; ETA V/1. 17. - ${ }^{a}$ Ti. Kérővel és Ormánnyal (SzD)]; 1583: Kun Caspar Rosaly ... ielenti hogy az eó faluianak Monostorzegnek $^{a}$ dezmaiatol zinte anny Arendat kel eo neki fizetní minth az Ormany $^{\mathrm{b}}$ auagy kerŏy ${ }^{\mathrm{c}}$ dezmatol fizetnek. Miert peniglen hogi az eó faluianak azokhoz kepest igen kichid hatara wagion ez zeleo hegieis ninchyen, semmikeppe(n) mílto nem volná az eo faluia dezmaczkaiatol ... anny arendat fizetni [Wass. fej. - ${ }^{\text {a- }}$ 'Monostorszeg, Ormány és Kérő (SzD)].

dézsácska 1. csebrecske 1594: Az Varbeli hazakban ualo Inuentarium ... egi desachkaban valami appro jskatulak [Somlyó Sz; UC 78/7. 22, 33-4]; 1679: Sós tej ala valo désacska nro 12 [Uzdisztpéter K; TL. Bajomi János inv. 116]; 1699: az nyári ház alatt lévŏ Pinczében ... Pisztrang(na)k valo désácska nro. 1 [O.csesztve AF; LLt Gyulafi László inv.]; 1735: Sóós halnak való kis Désacska 1 [Királyhalma KK; Ks 23. XXIIb]; 1748: Vaj, és méz tarto Desátska [Koronka MT; Told. 11/95]; 1770: Egy vedres Désátska [Esztény SzD; Told. 29]; 1773: viszek Nyolcz darabbol állo desáczkába vajat [Szárhegy Cs; LLt Fasc. 149]; 1788: Egy Désátska félig Tök maggal [Mv; TSb 47]; 1813: Kis Désácska 1 [Veresegyháza AF; Told. 18]; 1849: Egy nagy turos dézsa és égy dezsátska [Somkerék SzD; Ks 73/55].

2. Jelzői haszn-ban: vhány dézsácskányi 1692: Ket desácska Vaj [Szárhegy Cs; LLt]; 1717: küldöttenek két desácska vajat [Abosfva KK; Ks 96 Mátis István lev.]; 1788: ő általa kŭldettem konyhára valot ... egy désatska Téjfelt [Bencenc H; BK Bara Ferenc lev.].

diófaasztalka 1790: Ketske Labu Diofa Asztalka 1 [Sv; Ks]; 1790: Diofa Asztalka kanape eleibe valo 1 [Sv]; 1797: egy diofa rakat asztalka láb nélkŭlt [Koronka MT; Told. 34].

diófaasztalocska 1790: Diofa 3 Labu Asztalotska 1 [Sv; Ks]. diribdarabocska 1. (több) kis darabka 1576: walamy dyryb darabochkak [Szamosfva K; JHbK XVIII/7. 15]; 1825: egy úgyes jo nagyobb Marhatarto Istállo ... felső Deszka padlózattja dirib darabotskábol [Dés; DLt 595].

2. Jelzői haszn-ban: kis darabocskákban levő 1749: találván az Kebeliben Dirib Dorobotska Hájat [Marossztkirály AF; Told. 25].

diszkréciócska lekenyerező ajándékocska 1738: ennek akare ur(am) ktek valami discretiocskával lennj [Fog.; KJ Fogarasi János lev.].

disznócska sertésecske 1587: Tizedben jutott eot diznochka, es egy Meh [Kv; Szám. 3/ XXXII. 6]; 1842: közelebb mult öszön egj Disznotskát hizni fel vetettünk pajtára [Bözödújfalu U; Pf].

disznóólacska sertéspajtácska 1692: egy sŏvenybol font Disznó olacska [Mezőbodon TA; BK Inv. 16]; 1702: vagyon ... az kérthez ragasztva, egy Sŏvenybŏl font, Szalmával fedett Disznó olacska is [O.brettye H; Born. XXIX. 4. 9]; 1748: meg rongyollot Szalma fedél alat épŭlt hizo Diszno ollocska is Vagyon egy [Nyárádsztbenedek MT; Told. 79]; 1773: egy Diszno olotskát gyujtott fel [Burjánosóbuda K; KLev.].

disznópajtácska sertésólacska 1699: A Kŭ= kŭllŏ parton vagyon edgy edgy hitva(n) fakbol rakott romladozott félb(en) álló rossz fedelŭ diszno pajtácska, kib(en) edgy rosz valuis vagyon [O.csesztve AF; LLt Gyulafi László inv.].

disznósüldőcske növendék/süldődisznócska 1587: az harom faluban iutott dezmaban Swldeo diznochka 16 ... Ezekben az Dizno Swldeochkekben attunk el 8 fl. d. 62 [Kv; Szám. 3/XXXII. 7].

dolgocska (apró-cseprő) tennivaló 1710: magam dolgocskám [Cssz; BCs]; 1722: én Ncsagas Uram csak dolgacskaimat végézhessem fél mégyék runkra [Kéménd $\mathrm{H} ; \mathrm{JHb}$ XIII/39 Váradi András br. Jósika Imréhez]; 1762: szorgos dolgotskáim léven Erdő Csinádra haza mentem [Told. 43/88]; 1769: Ottan kilentz vagy tiz napok alatt dolgotskáimat végezvén, Excellentia- 
dtoknak tiszteletekré sietek [TSb gr. Teleki Sámuel kezével].

Szk: jához lát munkácskájához fog 1738 : En az Innep elött egy hettel ujjobban le betegedvén csak tegnap $\mathrm{s}$ tegnapelőtt kőnnyebbettem annyira, hogy dolgotskaimhoz csak gyengén is lathattam volna [Kudu SzD; Ks 99 Pongrácz György lev.].

dolmányka dolmányocska 1748: volt egy Dolmánkája [Torda; Borb.].

dombocska 1. 1589: Thudom mikor en Zondj István zolgaia valek mikor ez feoldet Irtani kezdeok akkor egieb Azalt fa oott (!) nem volt hane(m) egy Domboczjkan van valami kewes [Szentkirály U; UszT];

1599: My azon az zekeren eölteonk ... egy dombochka mellet megh zorul az vt ott az Nemes ember kochya megh zorita az lowakat [Kv; TJk VI/1. 379]; 1603: az ember kie a' tehe(n) volt ... ky futamek egy dombochikara, kezde tolwai kialtani [Kv; TJk VI/1. 695]; 1724: egy küs kaszaloja ... nap nyugott felé megyen altal egy küs kerek Dombocskán [M.zsombor K; Told. 2]; 1739: (A föld) vege a falu félől tovab nem ment hanem csak ezen halas To erányáb(an) lévő elecskeig vagy dómbócskáig [Mocs K; JHbK XLVII/24]; 1744: lévén ... a két híd kőzőtt egy dombocska ... Posta Mester Ur(am) a' Domb tetején lévén futattya a Posta Sipot [Szentandrás $\mathrm{H}$; Ks 101]; 1745: (Egy föld) mégyen az ellenb(en) lévő Sovány Dombotskára [Nagyida K; Told. 9]; 1754: A Piatzon fejül valo Dombotskán vagyon a' Rft Nagy Kö Templom [Dés; Dési ref. e. m. lt Conscr. II]; 1756: mikor az utrizált Széna Rétet ki járák és határát ki mutatak ... meg nem egyezhetének rajta ... hogy hova ásattassék a' kő, mint hogy Tompos János Uram a' Rétnek also végire és szegeletire akará tétetni, Andrási János Uram pedig azon fejűl egj dombocskára [Balavásár KK; Ks 17/LXXXI. 20]; 1774: Láttám, hogy ... az Arkon tul a Dombocskán ott is Sereglenek feles emberek [Nádorvallya H; Ks Serbán Juon (40) jb vall.]; 1796: ki menvén ... Felső és Also Szovátok ${ }^{a}$ kőze az Ns Unitaria Sz(e)nt edj haz Czinteremjenek Dél felől valo Szeliben ... levő Dombotskára [SLt XLII. 2. $\left.-{ }^{a} \mathrm{~K}\right]$; 1830: a' Fürész mellett lévő dombotskán én kaszáltam mindég [Köszvényes-Remete MT; Born. G. XXIV. 1]; 1835: ugy nevezett Falu kerittés nevü helyben lévő kis dombotskára el mentünk [Magyaró MT; EHA].

2. csúcsocska 1792: az hegynek hármason ki állo dombotskájának kŏzepin [Magura TA; Ks 89].

3. halmocska 1817: a Levelés Ládát ... férébb egy dombotskára le vetvén [Torda; KvAKt Mss 363].

döbörke bödön 1838-1845: putina: (a putonból) kis döbörke, dézsácska [MNyTK 107. 32 putina al.].

dőlőföldecske kis dülőföld 1694: Az also határban gát farkon egy dŏlŏ főldeczke [Kilyén Hsz; LLt].

drágácskán drágábbacska áron 1756: Fyat falván ${ }^{a}$ levő kis portziotskájának nékem engedését az Aszszonynak, noha drágatskán, de meg is Szivemnek telyes háládatosságával kőszőnőm ... egész igyekezettel rajta vagyok, hogy hová hamarább meg Szerezhessem [Bonyha KK; JHbK XXIV/10. - ' Fiátfva U].

durvábbacska 1821: Egy kisség durvábbatska ujj Kender Lepedők [Backamadaras MT; CsS]; 1844: 14. Keszkenyő az durvábbatskábol is hasonlo képpen azan szerint van [Kv; IB Konetzni Ignátz takácsmester kezével].

durvácska egy kissé goromba 1802: Déák Mihály, szármozásra Kolosvári ... durvátska beszédü [DLt nyomt. kl].

ebecske ?kutyácska, kutyakölyök 1597: B. V. kwlde Zekel Martont Vi Varban Egy kis Ebechikeert [Kv; Szám. 7/XII. 56 Filstich Lőrinc sp kezével].

edényecske 1 . edényke 1760: kinek Légejje, kinek penig egyéb edényetskéje volt [Szászörményes KK; Ks 92].

2. hordócska 1754: Vetetett egy edény Muskotály Bort ... Még más két edényetske is volt jocska [Sárpatak MT; TGsz]; 1797: ki adott hét edényecske Bornak árát ... incassaltam [Lunka H; Ks 108 Vegyes ir.]. 
edényke edényecske 1738: két mázos edényke herbatének való [M.bikal K; Mohai lev.]; 1759/1779: Pálinka 3 Edénykébe [Zaránd $\mathrm{m}$.; $\mathrm{CU}]$.

egyecske kicsinyke 1721: alazatoson még szolgalom az Mlgos Urnak ha nekém is ég sértesecskét küld ézen meszét le vivő talyigan tavaj nem busitotam az Mlgos Urat mivel vot de most égyecsket őletem vot mind aprolikja mind szalonaja mind egy falatig el fogot (!) [Szentpál K; TKl Mihály Deák Teleki Pálhoz].

egyetmásocska 1. holmicska 1711: Edes Anynyátol jutot egyetmasotskájábol ... mi vagyon oda [Kv; Pk 6]; 1723: kértem Olosz Ferenczné Aszszonyomott vegye el tŏllem bár csak Esztendeig, probállya micsodás az a Leányka, ugy vitte el eŏ kglme tŏllem egjetmásocskajával edgjüt $[\mathrm{Kv} ; \mathrm{KvRLt}$ VII. 18 Miszti Eötves Pál végr.]; 1733: Még ha valami kevés edgyet másocskáim vólnának, azokatis reignálni az vr Battyam vram ne terheltessék [TK1 Teleki Sámuel kezével]; 1748: Bizonyoson nem tudom hogy mit adtanak a Joszagert, de halottam hogy egyetmásotskát ... ŏkrŏt is adtanak érette [Uzon Hsz; Kp I „Eva Kispál Martini Dánér relicta vidua" (70) vall.]; 1754: oldal Deszka kamarabéli egjetmásotskáit kik és kik által Arestaltattak? [Gernyeszeg MT; TGsz 33 vk]; 1766: (A szolgáló) holmi ringj rongj egjetmasatskáinal egjebet az Udvarbol szekeremen nem vitt [O.kocsárd KK; Ks 8. XXV. 18].

2. fejérnemû fehérneműcske 1715/1761: Kevés ezŭst marhám, kŏntŏsŏm, Fejérnemŭ égjetmásotskám a' mi meg maradot vólt Havasalfoldébenn, azokat is hagyom ... édes Feleségemnek [Nsz; Berz. 17a].

együgyúcske ügyefogyott 1761: Bongardos Bálint és Iános Testvérek léven, publice notum, hogy ezen két Atyafí kivált Bálint együgyütske vólt, 's meg sem vóltak egymás kőzött osztozva, hanem mint ollyan együgyü Atyafiak ... mindeneket el adogatták [Kv; PolgK 45].

eklézsiácska kis egyházközség 1693: En Iffiabbik Czegei Vas György ... Vitettem el egy Harangot Csaszari kicsid Ecclesiacskamb(a) [RLt 1]; 1722 k.: Ennek az Ekklésiátskának égy darab szŏlŏje van [Unoka MT; GörgJk 161]; 1755: Romlásban vagyon egészben e kis eklézsiácskában a templom [Unoka MT; ETF 107. 24].

ekonomiácska kis gazdaság 1802: kevés oeconomiátskám folytatására ... keresetem ... meg tsökkent [Dés; DLt].

elébbecske 1. egy kissé elébb, arrábbacska 1767: Ugyon ott elébbecske oldalas Sovány hellyen ... széna fü [Kincsi KK; LLt Fasc. 129]; 1784: Ottan találtam elébbecske az ecsellei ... cigányomat [Vízakna AF; Halmágyi NIr. 671 Bogáthy János lev.]; 1809: Mindgyart elébetske a' gyumolcsos kert felé menve találtatik egy ... kisded ház [Algyógy H; Ks 75. 14].

2. valamivel korábban, korábbacskán 1740: felŏ hogy az vetes is el ne romlott legyen az Nagy fagy miatt. kŏzŏnsegesen vekony remenseggel biztattyuk magunkot, mivel elebbecske jo idŏk leven az buza ki fokadozott vala [Ikafva Hsz; Ap.4 Dombi János Apor Péterhez].

élecske kis él/gerinc 1673/1682: az Bothaziak ellenzették az Also Szovátiakot hogy az melly életske az Gyermek erdŏnek Kiraly erdeje felŏl való végire megye(n) azo(n) innet Botháza felŏl ne birják [Keszü K; SLt Q. 12 Mike Mihály (60) jb vall.]; 1681/1748: égj darab kaszálo Réti ... szomszédgja a’ Völgj felől, az ország uttya mellett valo élecske [Tür AF; KvAKt Mss lat. 236]; 1732: la Poenicze nevŭ ēletskén a Hoszszu Erdő kőzepin ki a nagy élre [Szászsztjakab SzD; TSb 51]; 1739: (A föld) vege a falu félől tovabb nem ment hanem csak ezen halas To erányáb(an) lévő elecskeig vagy dómbócskáig [Mocs K; JHbK XLVII/24]; 1746: a Recsibát farka felé egy ormos Eletskén belŏl [Nagyida K; EHA]; 1746: Azon életskén tul lévő eszkatskát fel méretvén ... hoszszuságra ... huszonhárom kötel [Mezőbodon TA; JHb XI/22. 6]; 1747: a méta ... az utrol viszont meg tér és egy életskén mégyen [Nagyida K; EHA]; 1751: A' Tsűr helly nevezetű gődrős helly mind két felől mellette lévő erdös két Óldalotskákkal együtt, azon két eletskéknek közepéig hoszszára gondoltatván, keresztül két egyenlő részekre szakadott [Koronka MT; Told. 31/4]; 1769/1802: a Goronyis 
nevü hely élletskéjén ... egy Nyárfában a régi határ keresztet még mostis meg kaphatni [Torda; TJk III. 35]; 1777: mindenŭtt egy kis életskén mennyen fel a Határ szél a Hegy tetőig [Resztolc (később: Hosszúmező) SzD; JHbK LVIII/28]; 1821: az Abodi Gergely lapossán belöll elö járo életskénél [Szováta MT; Told.].

eledelecske egy kevéske/kevesecske élelem 1785: magamnak eledelecskéért vagj italatskáért ... fizettem [Kv; Pk 7].

elegyesecske elegy-belegy é.n.: Az itt valo Pék fortelyoskodik mivel jó elegjetske a' Buzánk ne(m) igen akarja bé venni [Fog.; KJ Rétyi Péter lev.].

élésecske egy kevés eleség 1716: szintén most akarnék valami élésettskét, s buzácskát szállittatni vellek Szebenbe, az mostani Conjuncturához képest; engemetis pedig Senki ā félekben ne(m) Segitt [Kiskend KK; Ks 95 Biró Sámuel lev.].

élésházacska éléskamrácska 1769: Az Istállo mellett lévő Lábos ól Hflor. 2 Dr. 4 ... Ezen Lábos ol mellett lévő Élés házacska Hflor 6 Dr. 12 [Felőr SzD; Bet. 7 özv. Szalánczi Józsefné Boér Borbála lelt.].

elnyílásocska kismérvü elhajlás 1793: az Uttza felől lévő Falnak a' Bót-hajtás végétől lett elnyílásatskáját tapasztalok $[\mathrm{Kv} ; \mathrm{Pk}$ 2].

előkötőcske-fő kötényrész 1576: En Mellytth Anna hattam Baranyay Annok Zeoksegere ... Egy eleo keteo feochket wonth aranyat wysseltet Mas eleoketeochke feot Arays (!) wyseltet [Szamosfva K; JHbK XVIII/7. 13]; 1576: Wagion wyselth eleo keteochke feo feyr Selyemwel Aranyal waroth [Szamosfva K; JHbK XVIII/7. 14].

előruhácska kötényke 1576: Egy eleo Rwhachkaro walo zederies Aranyas zel mynth egy Syng [Szamosfva K; JHbK XVIII/7. 13a]; 1627: Egy veres fonallal szwtt Eleo ruhaczika tt. f. - d. 20. [Kv; RDL I. 132].

emberecske 1. emberke 1827: Szegény sokgyermekü, nyomoru Emberetske [K; KLev.].
2. kb. emberke-alakú dísztárgy 1746: (Földböl) Niderlandban csinált 9 emberecskék; bécsiek. Hat ahoz való kis ón tángyér [Vargyas U; DanielAd. 255].

emécske kocamalacocska, táj emse 1681: Artany nro 18. Eme nro. 53. Kan nro 3. A(nno) 1680: Kann nro 2 Artányka nro. 20. Emecske nro 30. [Szúv; UtI]; 1684: Téli emecskék nro 33. [Ebesfva; UtI]; 1684: Az idei emécskék no 38. [Ebesfva; UtI].

énekecske 1808: Igen nagyon emelné betsületét nyelvünk(ne)k az is, ha ahoz értő emberek szednék Nemzeti nyelvünkben lévő szebb szebb Eneketskéket [Kemény, Coll. Manuscr. Tom. XXX. Varia XII].

eperfácska 1694: vagjon ... Nagj Majorság Szőlö ... Vannak benn gjümőlts fak is, ugj mint ... Baraczk fák nro 3. Eperj fátska nro. 1 [Borberek AF; BfR néhai ifj. Bálpataki Jánosk kúria-leír.].

építésecske kisebb építkezés 1778: Mosonban ${ }^{a}$ folyó Epítésetskéinek Nagy hátramaradásával kelletvén ide fáradni [Msz; Told 3a. - aSzékelymoson MT].

épületecske kis épület 1699: Ezen eppületecskék vadnak külŏmb kŭlŏmb féle fakbol fel rova [Vécke U; LLt]; 1748: ház hellje rajta lévŏ epuletetskevel edjŭtt [Msz; Told. 43/47]; 1782: Vagyon ... égy Nobilitaris Fundussa (: az holott most ugyan tsekély Kertek és Epŭletetskék vagynak :) [Mv; Told. 45]; 1842: égy két ajtoju árnyék szék ... ezen épületetske csak a' folyo év Junius honapjátol kezdve épűlt [F.árpás F; TSb 51].

erdőcske 1575: Zegenieknek az Zent lelek Espotalyaba zakaztasson Byro vram egy darab Erdeoczket otth hwl Az varos hazahoz vagnak [Kv; TanJk V/3. 110b]; 1604: zagion egj Darab Erdeoczjkeje az falunak [UszT 18/63]; 1646: a halas tok felet valo ket darab Erdőcske [Bethlensztmiklós KK; EHA]; 1668: czak az égh kis erdŏczké vala kŏztŭnk [A.hagymás SzD; Ks 9. XXXIII. 4]; 1676: egy Kerek Erdőcske [Mezőharasztos K; Told. 8]; 1676: Az Tsonker oldalban egy Erdocske ... alol Falu Erdeje Vicinussa [Szentgerice MT; EHA]; 1685: egy darab erdŏtske [Sepsisztkirály Hsz; BLt]; 1700: egy darab Erdŏtske mellyis Erdŏ fark(na) k neveztetik [Csekelaka AF; EHA]; 1727: 
Vagyon ... tőbbire tővis, és csere törsőkőkből állo jo darab, de apro erdőcske [Mezőcsán TA; Ks 15. XLIX. 5]; 1747: a Fŏldek ütkŏznek egy csupotskán lévő erdőtskéb(en) [Nagyida K; EHA]; 1753: A' Margita ${ }^{a}$ felől való Plágán vagyon egy erdő ... minthogy igen el vágták gyarló erdőcske, mogyoró és gyertyán veszsző is terem rajta [M.décse SzD; EHA. - ' ${ }^{\text {A }}$ tőszomszédos Szentmargita SzD]; 1761: Vagjon ... bokros gyortyán fábol allo Erdŏtskeis a nyiren kivŭl [Ülke U; JHbK LXVIII/1. 152]; 1766: Ezen Sessiotska utann valo Erdőtske vagyon a Bodoni ${ }^{a}$ Felsŏ fordulo Határ-

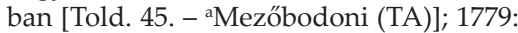
Groff Bethlenia Gergely Ur ő Nagycsága, a nyáron azon Jobbágyomnak irtásában nevekedett erdőcskéjét hatalommal le vágotta [H; Bk ad nr. 305. - ${ }^{a}$ Tollvétség lehet Bethleni Bethlen h.]; 1798: ezen miveletlen Szöllő ... a mellette lévő kis erdőtskével ... légyen Sáráé [Dés; DLt 12/1806]; 1803: a Magyaro gyakorban erdǒtskék vagynak [Bere MT; Bet. 5 Sig. Vajda (70) lib. vall.]; 1831: az magam Nemesi Erdőtském meg visgálására menvén ki egyszer csak hallok valami őkrőket hajtani [Hosszúfalu Szt; TKhf Drágos Dumitru (72) ns vall.].

Szk: bokros 1718: Az nyar szegb(en) egj kis bokros Cseres erdŏczke [Sárd MT; EHA] * ciheres 1747: (Egy) Cziheres keskenj erdőtske elé njúlvún a ... második Csupotskára [Nagyida K; Told. 9] * cserés 1718: Az nyar szegb(en) egj kis bokros Cseres erdŏczke [Sárd MT; EHA]; 1765: igen szép Szalas Cserés Erdőtske volt [Náznánfva MT; Berz. 13. V. 12] * függố . '?' 1764: A két kerek erdő ... a kís széna fün lévő tos bűk nevü függő erdőtskékkel adatott ... részekre [M.köblös SzD; RLt] * makktermő 1744: a Gyertyánosba mak termő tilalmos erdőtske [Szentdemeter U; LLt Fasc. 67] * puszta 1766: a Brányistyán tul ... indivise maradott puszta Erdőtskét [Doboka; DHn 13] * szabados 1731/XVIII. sz.: egy darabocska egres (!) fagbol (!) allo Szabados erdőcske [M.nemegye BN; Berz. 7. 68. 1] * szálas 1750: A' Reformata Eklesia Szálas Erdőtskéjének Bos felől való Széllyin lévő Erdőtske [Koronka MT; Told.]. erdőnyilacska nyílvonásos erdőpászmácska/ pásztácska XIX. sz. eleje: Nyirágos Erdŏ nyilatska [Pk. 7]; 1821: Köszönöm baráttságos fáradozását mellyet tett a' Kakasdi erdö nyilatskák fáinak el adásában [Ne; DLev. 3. XXVIII A]; 1827: Négy Erdőbéli Nyilait, ugy mint Felső Nagy Bükket, Also Bükket, Tormást, és Kerek Bűkk Kapuját ... Erdő Nyilatskáknak Fáit meg vásárolta légyen [Bede MT; EHA].

erdőrészecske 1863: A Faludi nevű Erdőben fekvő, erdő reszetském [Csekelaka AF; EHA].

erecske 1. csermelyecske 1640: A szena rett hazul felül egy ereczkere jeö labbal [Ne; DobLev. I. 10]; 1685: Az Markos Molna Meget egj darabotska főld az Eretske mellett, vicinussa az Eretske [Kilyén Hsz; LLt]; 1728: Szena fŭ ... egj erecske tartja az hatarat [Sszgy; SVJk]; 1754: az Arokba szakadnak az Sáros Fakadékos eretskék olyan helyt pedig belŏll az árok partyán pástos-forrott hellyekenn jár az ember [Szárhegy Cs; LLt Fasc. 152].

2. vérerecske 1759: az Gyermeknek az Bal kezecskéje keze fején alol tsudálatos mozgásban van, minden inai erecskéiben olylyan rángotás formalag mozog ugyan tsak az kezecskeit az Gyermek nem fájlolta, kivált az hüvelykecskeivel, s mutato ujjával az Gyermek kolcsokatis meg fogott, s tartottis [M.csesztve AF; Ks Mike Antal lev.].

ereszecske 1. kis ereszalja 1773: ezen Házból bal kézre nyilik más Ajto egy Sővénnyel bé kerittetett ereszetskére [Szászpéntek K; Mk].

2. kis esőfogó fedél/tető 1699: egy kis hat kötesekre csinalt kő falba meg gerendázot csere fa deszkaval meg deszkazot ereszecské alat mennek bé ... ajton az gabonas hazba [Szentdemeter U; LLt Inv. 22]. 3. fedélszínecske, rég árnyékocska 1754: egy sütő kementze a falu közönséges helljen egy kis Ereszetske alatt [Hsz]]; 1774: egy Sendelly fedél alatt lévő ereszetske [T; Conscr.].

4. tornácocska 1737: a Nobilitaris Curia ... Frontispiciuma előtt ... tornacz vagjon. Ezen Tornáczbol ... nyilik egy fenyő deszkábol valo tziffra vas sorkokon forgo béllett, de zár nélkűl levő ajto egy 
Kis ereszetskére [Csákigorbó SzD; JHbK XXVI/13. 5].

5. kics szakállszárasztó 1632: Komanai Uduarház ... Az Ucza feleől nilik be az Uduarra egy eőregh dezkas kapu, az fele Sindeliezett. Mellette zagion egy kis felszer parazt Aytǒ Az kis aiton kiuwl egy Sindeliezett ereszeczke [Komána F; UC 14/38. 118]; 1772: Vagyon ezen bé járo kapu mellett égy sendelly fedél alatt lévŏ Ereszetske, melly alatt égy Cserefa ŭlŏ Pad találtatik [Szászfenes K; BethlenKt Mikes conscr.]; 1821: a Kapu előtt kivűlről mind két felől vagyon két kisded ereszetske avatag sendely fedél alatt ezen ereszeknek alyai és mindenek oldalai bé vagynak deszkázva mind a kettőben végig vagyon egy szakáll száraszto karos deszka pad [Koronka MT; Told.].

ergécske 1. ? kb. holt meder 1762: mikor én ide szármoztam akkor a szamos egészen innét Magosmart felöl fojt ... s tul Közepfalva felöl a hol most az Exp(onens) urfi malma vagyon semmi árka vagy nyoma nem volt egyéb egy kis viz nélkül valo Ergétskénél ... lévén ottan az elöttis valamely kitsin száraz viz nélkült valo Ergétske s abbol kapott osztég a viz oda [Virágosberek SzD; SLt XXIV. 5].

2. ? 1592/1593: en azt az zigetett soha tilalmasban nem túdom ... innet egy kis ergeczke volt rajtha [Désakna; Ks. - A dési és a szentbenedeki határ vitás részére von. vall.].

erkécske? kis erkély 1742: Ezen Házból ... az Udvar fele egj kis Stukaturás és padimentomos Erkétske ${ }^{a}$ protentálodik [Gyeke K; Ks 4. VII. 1. - ${ }^{a}$ Tollvétség is lehet Erkélyetske h.].

erkélyecske bódé 1666: Az Vár előtt vagjon egi Sancz az Arkon kivúl ... egi Strasallo deszkabol czinalt erkeljecske [Gyalu K; GyU 162].

erkélyke csukott/zárt kis erkély 1692/1737: Szen Peteren az Imátkozo Erkelykéb(en) ... láttom az Asztalotskáján sok kủlőm külőm arany múveket [Szilágycseh; EMLt].

erősségecske 1 . kis erődítmény 1653: Ilyen nagy vigyázással kellett a sok félelmes nép között oltalmaznunk magunkat a kicsiny parányi erősségecskében ${ }^{a}$ [ETA I, 77 NSz.
- ${ }^{a} \mathrm{Mv}$ nagytemploma körüli erődítményben, a Kastélyban]; 1677: Az Oláh Országi határok felől valo szély helyekben épittetet Erŏsségetskékre a' Székelység ugy provideallyon, hogy ne ruinaltassanak sŏt inkáb job móddal conservaltassanak [AC 156].

2. 1661: Az odabocsátott német kapitánnal egyértelemből, ha tetszenék neki is, az istáló körűl kellene valami jó erősségecskét csinálni, árokkal is bekeriteni, úgy hogy az várból is lehetne defensioja [SzO VI, 235 a fej. Fog. főtiszteihez].

esővíz-árkocska esőmosta/vájta árkocska 1746: ezen essŏ Viz Arkocskán fejül [Kissajó BN; Ks 7. XX. 19].

északocska kics északi fekvésű föld 1746: Azon életskén tul lévő eszakotskát fel méretvén ... hoszszusága ... huszonhárom kötel [Mezőbodon TA; JHb XI/22. 6].

ételecske 1791: 4szer ételetskeje légyen ${ }^{a}$ gyénge savanyuságu korpa Cibre, vagy megyből kēszitett Levesetzke [Dés; DLt. aTi. a beteg gyermeknek]; 1840: házamnál a sints aki keves eteletseinket meg keszitvenn gedelgesse őreg voltam tisztálassal és egyéb házi szűkséges dolgokkal [Dés; DLt 948];

étkecske ételecske 1751: a' Tisztartok ... mig eŏ Excell(enti)aio Erdeyben volt ... a konyhărol fogtak egj ket Tal étketsket [Gagy Z; Ks 83 Péterffi Sándor lev.]; 1759: az nap kezdett gyengén észre venni az Gyermeknek nyelvecskéin szájánis hasanlo mozgást, ugyan tsak ezek mellett az gyenge étkecskéit meg ette, mulatott, jádzott [M.csesztve AF; Ks Mikes Antal lev.].

extraktusocska kics kb. (rövid) elszámolás 1672: Ebesfalvi Kastélyban eddig bé iöt Majorság, dézma, és egyéb gyülevész borokrol valo rövid Extraktusocska [UtI]; 1672: Almakereki Majorság, dezma, Kilenczed es egyéb gyülevész borokrol valo Extractusocska [UtI].

ezüstboglárka 1744: ezüst Csatt 12. kis ezüst boglárkák rajtok [Szentdemeter U; LLt Fasc. 67]. 
ezüstboglárocska 1734: Szőr Selyemmel kötött fŏkŏtŏ ezŭst fonallal boglarotskaval rakat [Born. XXXVIII. 3 Kornis Krisztina lev.].

ezüstcsatocska 1768: Ezŭst tsattotska 1 [Mezősztgyörgy K; Ks 23. XXIIb]; 1818: Négy Sor nyakba való Gránát, a' végibe égy 4 szegeletű ezüst meg aranyozott Csattocska, megér 25 Rf [Kv; Pk 5].

ezüstcsészécske 1740: Egj Liktárium alá valo hollyagos virágu ezűst Csészétske [Ne; Told. 19].

ezüstgombocska 1. 1591: Kűn Palné Cathalin vallia ... Lattam Susannanal apro ezwst gomboczkakat [Kv; TJk V/1. 181]; 1662: Egy Failandis Veres szokniat, az mellien apro Ezüst gombocsikak [Kv; RDL I. 146]; 1682/1687: Attam Egi Uy Angliai Ueres Mentett, Ez is uolt megh premezue egi rend feier ezűst galonnal. Tizen Niolcz feier ezűst gombocskak raita [Fog.; Borb. II Rákosi Anna kel.]; 1720: Vagyon Egy Csomoban füzve egy pár Palastra valo kapocz es ket ezűst gombocska, 4 ezüst karikácska, valami kapcsocskák Nro 8 ket kis boglárocska [Kv; Pk 6].

2. ezüstgömböcske 1682/1687: Attam Egi Ezüst aranias egi bokor kesnek ualo hiueliett, kinek az uegin egi kis ezüst gombocska volt [Fog.; Borb. II Rákosi Anna kel.]; 1714: Atzéljos Pantzér, melljn(e)k nyakra valója meg aranjozott ezüst gombotskákkal ékesitett s hasonló kesztyökkel [Nsz/ Fog.; REkLt II. Apafi Mihály hagy. 51-2]; 1788: Fekete Selyem sinor őv ezŭst gombotskákkal gombozva [Mv; TSb 47].

ezüst-gyóntatópoharacska ezüst úrasztali/ vacsorai pohárka 1728: Vagjon egj ezŭst gyontato poharoczka [Sepsisztkirál Hsz; SVJk].

ezüstgyürücske 1629: uette(m) vala egjszer ket ezüst gjürüczkét teöle [Mv; MvLt 290. 181a].

ezüsthordócska 1692: Egy ezűst hordocska aranyas abroncsokkal belöl aranyas [Bilak $\mathrm{BN}$; JHbK 2. 36].

ezüstkalánka 1733: Edgj ezŭst kalánka [Marossztkirály AF; Told. 18]; 1752: Egy Ezüst Nadmeztarto Iskatuja hat ezüst kalánkajaval [Marossztkirály AF; Told. 19]. ezüstkalánocska ezüst kiskanál 1693: Jankonak egy ... ezust Kalanocska [Ne; DobLev. I/38. 9]; 1744: Gömböljeg nyelü régi ezűst kalánotska [Szentdemeter U; LLt Fasc. 67].

ezüstkannácska 1598: hattam az Gazda Azzonnak, egj eoregh Serleget, kin az en magam neuem es Czimere(m) rajta vagion egj rottiaz (!) ezwst Kannaczykat, es egj eozue Jaro Aranyas kupaczykat [Gerend TA; Törzs. Gerendj Pál végr.].

ezüstkarikácska 1615: Egy kezkenŏre ualo Geongiòs gomb, ezüst karikaczkak raita [Kv; RDL I. 96b]; 1720: ket ezüst gombocska, 4 ezűst karikácska, valami kapocskák Nro 8. [Kv; Pk 6]; 1764: Egy Kis ezŭst Karikátska [Pókafva AF; Kath.].

ezüstkehelyecske 1728: Vagjon egj ezŭst kehelyecske (!) arannyas kareju [Szacsva Hsz; SVJk].

ezüstkötésecske ezüst csipkécske 1761: őt darab szedett pántlika, mellynek szélin arany és ezüst botokan vert kőtésetske vagyon [Koronka MT; Told. 8].

ezüstkulcsocska 1772: 1 Iro Lada ... zárjához valo ezűst koltsoskájával együtt [Egeres $\mathrm{K} ; \mathrm{Ks}]$.

ezüstládácska ezüstládikó 1604: Egy kis ezwst ladachka negy szegw, ormozatos fedelw, partozasa aranias labas, vagion benne m. 2 p. 39 [Kv; RDL I. 77]; 1629: egy ezüst ladaczkaban vagyon szaz aranya [Kv; TJk 5].

ezüstláncocska 1820: Egy ezüst lántzotska ... a' Léánka nyakába [Mv; MvLev.].

ezüstmarhácska ezüstholmicska/nemúcske 1598: Az mi keuez ezwst marhaczkam volt, azokbol hattam az Gazda Azzonnak, egj eoregh Serleget, kin az en magam neuem es Czimere(m) rajta vagion egj rottiaz (!) ezwst Kannaczykat, es egj eozue Jaro Aranyas kupoczykat, kit megh regen Vy Eztendeoben attam volt nekie [Gerend TA; Törzs. Gerendj Pál végr.]; 1637/1821: (Ha) Feleségeknek, Gyermekeknek párta-övöket, kösöntyüjöket, s egyéb ezüst marhátskájokat öszve kell olvasztaniok is, még is praestállyák a még lehet Nagyságodnak valo Igéreteket, hogy tŏllünk megszabadúljanak [Torockó; TLev. 8/1]; 
1658: Az My keves Ezust Marhaczka vagion Tudgyak az gyermekim hol vagyo(n). Azokbol hagyok az felesegemnek egy Ezust poharat egi giras pohart [Mv; Nagy Szabó Ferenc végr.]; 1679: kevés ezüst marhácskám vagyo(n) [Marossztkirály AF; Told. 18]; 1683: Edgy aranyamis marat volt ezust marhaczka ket arany gyuru [Kv; Sár.]; 1684: Arany ezüst marhátskám a mi vagyon, meg czédulázom, kiki a szerint talállya [Dés; Pat.].

ezüst-mosdókorsócska 1732: Egy ezŭst kis mosdo korsocska [Kv; Ks. Kornis Zsigmond lelt. 11].

ezüstoszlopocska 1714: Mas Asztali óra külömbféle meg aranjozott réz figurákkal, és 4. ezüst oszlopotskaval ékesitett mind(en) felöl órákot mutatván ... a' tetején ezüst Cupido [Nsz/Fog.; REkLt II. Apafi Mihály hagy.].

ezüstöcske 1. ezüsttárgyacska 1595: küldtem Dyák Mihálytól 3 ezüst karikát, két darab lapos ezüstöcskét ... 1 aranyat, 2 tallért [SzO V, 159 Fejes Mihály alsócsernátoni ember lev. feleségéhez a havaselvi hadakozásból].

2. ezüstholmicska/nemücske 1776: Kevés Ezűstőtskéjeketis bé vinni tartozzanak [M.köblös SzD; RLt Sombori Klára és Sándor lelt.].

ezüstpalackocska 1802: A' környül metéllö Instrumentum hozzá tartozo ezüst palatzkotskákkal [DLt nyomt. zsidó vagyontárgy-jegyzék].

ezüst-pártaövecske kics ezüst-övfajta 1633: vagion Juditnak egj kis szakat Ezwst parta Eoveczke f. 7. d. 40 [Kv; RDL I. 103].

ezüstpohárocska 1598: Gerendj Istuannak hattam egj Ejteles ezwst poharoczkat [Gerend TA; Törzs. Gerendj Pal végr.]; 1746: Lévén az Ekkl(ézsi)anak egy harom lotos és két köntinges ezüst pohárotskája, in superabundanti, ezt el adta Megye bira (!) Nagy Fernecz Ur(am) Brassai ötves(ne) k per flr. 3,50 [Kökös Hsz; SVJk]; 1771: az idvezült Teleki Ádám Ur ... az irt M. Nagy Aszszony(na)k adott volt által négy ezüst fertalyos pohárotskát [Kendilóna SzD; TL. Teleki Pál hagy.]; 1803: égy Ezüst Pohárotska circiter égy fertáljos, Arany Virágos [Bethlensztmiklós KK; UnVJk 33];
1824: Fejérnép vetkezŏhez tartozo Kigyo lábokon állo két ezŭst poharatska B. B. R. betükkel jegyezve [Fugad AF; IB].

Szk: capás 1755: Egj Küsded gjermek italra valo ezüst Czapás poharocskát [Petek U; TGsz 51].

ezüst-srófocska ezüstcsavarocska 1732: 3 kis ezŭst srofocska [Kv; Kornis Zsigmond lelt. 21].

ezüstszegecske ezüst-díszszegecske 1714: Ezüst szegetskékkel ékesitett külsö Tüker fl. Hung. 2 [RekLt II. Apafi Mihály hagy. 12].

ezüsttálacska 1637/1639: Egj Ezüst Talatska mereo aranjos, m. 1. p. - f. 16d. - [Kv; RDL I. 111]; 1817: Három Dultsátzának való Tekenŏsbéka formáju ezŭst Tálatska [DLt 105. gub. nyomt., ugyanez BesztLt 354 al. is].

ezüsttányérocska 1816: Egy ezŭst Tángyérotska [Nyárádsztlászló MT; UnVJk 66].

ezüsttokocska 1732: Egy Szagló két felé nyilo kis ezŭst tokocska [Kv; Ks. Kornis Zsigmond lelt. 21].

ezüsttollacska ? 1673: Egj kis ezüst tollatska [Marossztkirály AF; IB. I. Bethlen Domokos hagy. I. Bethlen István lelt.].

ezüstvillácska 1629: Egy Ezwst villaczika [Kv; RDL I. 132].

ezüstvirágocska ezüstvirágdíszecske 1736: Meltosagos Groffi Vri Aszszony Bethlen Kata Aszszony Nehai Teleki Ioseph Groff Vr házas társa buzgo indulatbol I(ste)n dicsősegere conferalt egy ezüstbe foglaltatott arany füstel üttetett flajtz viragokkal ekesittetett es gyöngyőkkel is czifrazott Kristály pohárt, melynek fedele tiszta ezüstből állo arany füstös ezüst viragocskákkal tornyozott [Lisznyó Hsz; SVJk].

fabotikó botocska 1792: Abran Marton ... tsuszo mászo nyomorék ember volt ... az alfelin tsusztatván két kis fa botikokot fogott a kezibe meljekkel maga erotlenségit segithesse [Kőrispatak U; Pf].

fácska 1. fiatal fa 1756: lattuk fát vágni ... sőtt enis Pap Gáspár egykor vágtam valami fátskákat az Vr Malmában vivén ŏrleni [Bácsi H; KB Casp. Pap (60) ns vall.]. 
2. fadarabocska 1585: Halasz Gergelne Orsolia vallia, Latam Hozzw lukachot es kichini feyer fachka vala kezebe [Kv; TJk IV/1. 421]; 1597: tekintek be az szükseg helyre, tehat egy gyermek szabasu fekszik ot, egy faczkaval fel vona(m), tehat holt gyermek [Kv; TJk V/1. 133]; 1650: Beczki vramis ugy üté egy vekony faczkával hozza de hogy az a' ütes halálos képpen leőtt volna, nem volt [Becski]; 1742: Fájok penig sokszor nem volt eröss Télnek idején, magam sokszor hántam a' ház héjárul, hogy holmi dorab ... facskákbul tüzet tsinálhattanak magoknak [Kv; Aggm. C. 12]; 1797: Szávu Markut az al peres rab egy fátskával meg hajtotta [Déva; Ks 115 Vegyes ir.]; 1800: égy kis fátskát fel kapott [Dés; DLt]; 1838/1845: Cigle, ciglésdi, azon játéknem, két végén hegyezett fácskávala ${ }^{a}$, mit másutt cigére, pi, pige névvel hívnak [K; MNyTK 107. 15. - ${ }^{a}$ Tollban maradt: játsszák].

3. lécecske 1676: Ezen Udvarház kapuja ... mellett jobb kéz felől nyilik bé ajtaja ... az szemöldökfáján felyül hat darab szegeletes fácskákbol csináltatott rostélyka [Galac BN; ETF 108. 8].

4. 1700: facskat mitt be szallitvan vele pinzt kap(na)k [Dob.; OL Gub. Közig. öszszeírások Doboka Sup.].

faedényecske 1742: egy fa edényetskéb(en), hat darab fūlbe valo gombok és egy ezűst gyưrü [Kisborszó SzD; TL. Kifor fam. lelt. 42].

fafarkacska ? 1831: Al Csernatoni Provid Thodor vagy Vantsa Győrgy 24 esztendős ... vall ... tsak ugyan két fa farkatskát kötellel kötve hoztunk [A.csernáton Hsz; HSzjP].

fagrádicsocska falépcsőcske 1630: Gabonas haz ... karfas nagyon kiczid fa gradiczoczka [Siménfva U; JHb Inv.]; 1743: egj keskeny karfás fa gradisocskán juthatni egj folyosocskában [Boroskrakkó AF; BfN Dobozolt anyag VI].

faházacska 1694: va(gyo)n egy faragot Tőlgy fabol csinalt eoszve eresztet es bardolt Golyobis Tarto fa Hazacska [Kővár; JHb Inv.]; 1695: Találtuk az nagj hámort, az nagj hámor végiben két kő bótot és egy kiss fa házacskát, azon felett két kiss házacskát es egj kamarát, padok, asztalok lé- vén mindenik házakban [CsVh 116]; 1703: $\mathrm{Az}$ hámor ház végében találtunk ... egy kisded kementzétlen fa házacskát fa sorkas es fa kelencses ajtajával együtt [CsVh 118]; 1754: edgy kŏzŏnseges Fa Hazacska [Dés; Hr 5/27]; 1783: egymás mellett lévő két Livágya vagy Füves kert, melyekben vannak feles szilva fák, és égj fa Házotska melyben Zsellér lakik [Kéménd $\mathrm{H} ; \mathrm{JHb}$ XXXI/28]; 1784: a' Csűr Birŏ... égy kis Szalmával fedett fa házatskája [Burjánosóbuda (később: Bodonkút) K; JHbK LX/18. 11].

fahidacska 1594: monostor vczay kű Hidon tull Egi fa Hidattckatt [Kv; Szám. 5/XXIV. 20]; 1838: A So Ut felöl a Mészárszékhez menve vagyon egy fa hidatska [Km; KmULev. 2].

fa-iskatulyácska fadobozka 1717: Egy körökös (!) Kapszátskáb(an) foglaltatnak ... 3. Fekete Futraljkáb(an), két Perspectivam ... 4. Egj kis fa Iskatulatska [Nsz/Fog.; REkLt II. Apafi Mihály hagy.].

fakápolnácska fatemplomocska 1842: A magyarok telepedésekor Isten segitsen 1774ben, Hadikfalván 1784ben, Andrásfalván 1785-ben épült fakápolnácskák, mind elromlottak, most árendált házokban tartatik az istentisztelet, Fogadj Istenben még állnak a kápolnácskák [WLt Egyház és iskola csomó. Bíró Mózes andrásfalvi ref. lelkész jel. Kelemen Benjáminhoz, br. Wesselényi Miklós jószágigazgatójához].

fakosárka vesszőkosaracska 1724: Két kis fa kosárka [Koronka MT; Told. 29/12].

fakultásocska tbsz vkinek anyagi javacskái 1765: Kornis Gábor Uram ... valami atyafiságot praetendalván ahoz az aszszonyhoz azon atyafiság Jussán el vette magához szegénynek facultásotskáit ... engemet küldött volt azon szegény aszszony Kornis Uramhoz ... admonitiora, hogy az el vett Javait $s$ pénziből pedig bár tsak 100 forintott adgyon ki [Alvinc AF; Eszt-Mk Vall. 153].

faládikó faládácska 1805: Egy Györtya tarto Ladiko Teli Buzaval ... találtunk Egy Fa Ladikot Aszszu Almaval [Szamosfva K; BLt 9]. 
falatka falásnyi, darabocska 1838/1845: Tokán ... akárminemü, apró falatkákban rántott s borssal (: borsos tokán :) ... vegyitett hús [MNyTK 107].

falucska 1579: V neky vagio(n) chak keozel eordeongeosheoz eg faluckaia Bozed [Néma MT; Told. 31/1]; 1618: Ngos Boczkoj Miklos vrünk(na)k az mjnemö faluczkaia itt ben Erdeljben most vagjon ... hatta es engette vsq(ue) bene placitüm (!) [Kv; Törzs.]; 1630: Nagodnak müis Agnes nevü kis Hugocskánkal edgyütt, mint Keglmes Urunk(na)k ko kŏnyŏrgŭnk ... méltoztassék azon Negy Falucskainkrol Nova Donatiot Conferalni [JHbK LVII. 31. - ${ }^{\mathrm{a} T i . ~ a ~ f e j-n e k] ; ~}$ 1630: tób Jozagot ne(m) vetett szalogb(an) az tot faluczkanal [Gálfva MT; Told. Huszár lev. 17a]; 1632: Ez kis faluczkabol ${ }^{\mathrm{a}}$ az el mult két esztendeő alatt, az mint hitek szerent mongiak az gabonanak szwk uolta miat heten futottanak el, kik mostis oda vadnak [CU 14/38. 143. - " "Lupsa integra possessio" mindössze hat jobbágy-családfővel szerepel az összeírásban]; 1659: kénálá ... égy Lonkafalua ${ }^{a}$ ne'ueŏ ... faluczkáúal ... hogy zalagosul venne kezehez egy ideigh, bizonyos sum(m)a penzigh, meddigh az Ur redimalhatna [Dés;

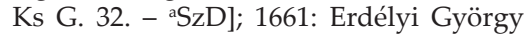
... egj Szent Jakab nevü Falucskát birna [Gyf; Told. 1 a fej.]; 1663: oly falucskáimra vetettenek az passák számára minden hétre tizenöt-öt szán szénát s öt szán fát az mely falucskámból egyikből-egyikből két ekénél vagy szánnál több ki nem jöhet [Szentdemeter U; SzO VI, 282 özv. Gyulaffi Lászlóné Balássi Erzsébet Bornemissza Anna fejedelemasszonyhoz]; 1663: hitván falucskáim emberim nélkül, pusztán maradnak [Szentdemeter U; SzO VI, 282 özv. Gyulaffi Lászlóné Balássi Erzsébet Bornemissza Anna fejedelemasszonyhoz]; 1669: conferalt volt Barcsai Akos Fejedelem Kŭvár videken egj kis Bozonta nevŭ Falucskát, mely csak ednehány hitvan Emberekbŏl ál [Ks 101 Kornis Gáspár a fej-hez]; 1670: Barátfalva Olah Falucskám [ETA V/2. 3]; 1694: Bodos ${ }^{\mathrm{a}}$. Ez szabad rendből álló kis falucska [SzO IV, 331. - ${ }^{\mathrm{a} H s z]}$; 1708: Póka ${ }^{a}$ nevŭ Falúcskáb(an) [SLt AU. 23. - ${ }^{\mathrm{a} M T}$ ]; 1712: Gyergyoban leuen egy
Uaslabu neuw Falutskaja [Görgénysztimre MT; LLt Fasc. 160 fej. okl.]; 1723: Majos $^{\text {a }}$ nevŭ egész Falucskam [Koronka MT;

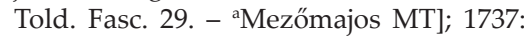
Bánffi Ferencné asszonyom Décse ${ }^{\mathrm{a}}$ nevü falucskájokban épiteni kezdett ... kőtemplomocska [ETF 107. 30. - ${ }^{a}$ M.décse SzD]; 1741: azak a kis Falucskák azan Dominiumbeli több Falukhoz lévén applicaltattva a proportio(n)e supportáltak mindeneket [Kéménd H; Ks 99 Zejk István lev.]; 1779: még régi Eleink által el idegenitett, és sok esztendoktől fogva Per alatt, s idegen kéznél sinlődő Sütmegi, Magyaros-ági, és Kék-bűkki Praediumbéli Anyai Rész két Falutskáinkat és Fél Praediumunkat ... Czegei Groff Vass Samuel Urnak által adjjuk [Kv; JHb XIV/46]; 1792: Tormás ${ }^{a}$ nevü Falutskának az Fiscusra kelletik dévodálodni [Kv; TSb 10. - $\left.{ }^{\mathrm{a}} \mathrm{H}\right]$; 1841: 6a May Kereszteltem egy a' Kolosvári hataron a buza között általam talált gyermeket, Kardosfalván, az a falutska lévén kőzelebb [Méra K; RAk 26].

Szk: puszta 1663: több egy heténél éjjelnappal rakva törökkel itt való puszta falucskám [Szentdemeter U; SzO VI. 282].

fa-oratóriumocska fa-imaház 1754: A puszta templom mellett egy kis faoratoriumocska és egj fábol valo haranglábon égy harang is vagyon [Dengeleg SzD; ETF 107. 28].

faragottkő-lábacska 1736: tüzelő kementze alatt lévő faragott kő lábotskákon álló ugyan faragott Tüzhelly kővek vadnak [CU].

farkacska 1. farkinca 1838-1845: farkinca: kicsid farkacskája az állatkáknak. Székely kicsinyített szó [MNyTK 107].

2. farokszerü nyúlványocska/részecske 1745: az erdŏ kŏzi bé nyuló farkacskának a kŏzepin [Nagyida K; Told. 9]; XVIII. sz. e. f.: az ŏ Ngă erdejébŭl rug azon patakba két farkotska azon hegjbül [Petlend TA; $\mathrm{AbN}]$.

3. becsm. 1567: vxor Valentini dorotheam Dorkochka farkochka apellaset [Kv; TJk III/1. 9].

farkaskölyköcske farkasfióka 1763: adott néki ... egy eleven farkas kőlykőtskét [Mv; Told. 33/26]. 
farkerdőcske ? erdőnyúlványocska 1747: a ... Toldalagi Mihályné Aszszonj Lo Tilalmassán felljül és az Ilje Pojánnján alól ki nyúló farok erdőtske [Nagyida K; EHA].

farudacska ? 1789: Haj por Tok(na)k valo 4. fa rudatskák Rf. - xr 4 [Mv; ConscrAp. 39].

fasajtócska faprésecske/sajtolócska 1835: A' Sütő Házban ... Egy sŭtŏ Lapát - egy szakaszto Asztal ... Egy czudar fa sajtótska [Zsuk K; SLt Vegyes perir.].

fátácska (román) leányka 1715: hallottam ... it egy faluban két olha (!) fataczkat [Bethlen SzD; BK].

fatálacska 1627: Egy fa tailaczika Eöt talnierral [Kv; RDL I. 132].

fatekenőcske fateknőcske 1681: Kulcsár Haza ... Vagyo(n) ezen házban ... Kicsiny fa Tekenöczke No 1 [Vh; VhU 527]; 1699: Ezen pinczében ... Csepegés ala valo fa tekenŏcskék nro 3 [O.csesztve AF; LLt Gyulafi László inv.].

fatemplomocska 1737: Fenn létemben adtam volt méltóságos erdélyi cancellárius uramnak egy felséges urunknak szoló alázatos memorialist itt nemes Belső Szolnok vármegyében feleségem és Bánffi Ferenczné asszonyom Décse nevû falucskájokban építeni kezdett, de a méltoságos főispán úr által megtiltatott kő-templomocska felszabaditása iránt, kit is ennekelőtte a szentek alamizsnájából kezdvén építeni egy kő-templomocskát, minthogy a seculis fennálló fa-templomocskájok szintén nyakokba szakadoztak volt ${ }^{\mathrm{a}}$ [ETF 107. 30. - ${ }^{a} G r$. Bethlen József br. Szilágyi Sámuelhez írt lev-ben az építés folytatására engedélyt kér]; 1750: Vagyon ennek a kicsiny eklézsiának a Verőfényben, a falu közepe táján egy kisded fatemplomocskája és annak napnyugat felől való oldala mellett egy kis tornyocska [Unoka MT; ETF 24].

fatokocska 1791: atzél Petsét nyomó Fa tokotskájával [DLt hiv. nyomt.].

fatornyocska 1. fa-huszártornyocska/(fa) fedéltornyocska 1745: A' Palotákra mennek bé faragott kŏ gráditsos, és faragott kŏ padimentomos Folyóson ... mindenik felŏl ... sendély fedél alatt, mely Sendelyezésnek-is a' kŏzepe táján vagyon egy kis sendelyes fa-tornyotskája [Marossztkirály MT; Told.].

2. (fa) harangláb 1750: Vagyon ... a falunak dél felől való oldalába a Görgény partján egy tisztességes fatemplom és mellette napnyugot felől egy kis fatornyocska és abban két harangocska [Radnótfája MT; ETF 107. 23]; 1750: Vagyon a falu közepében egy kőtemplom, egy tisztességes fatornyocska, abban egy harang [Sáromberke MT; ETF 107. 23].

favályúcska Szk: sótörő 1688: Egy so tŏrŏ fa valyucska [Kozmás Cs; Eszt. Inv. 3].

fazekacska 1. 1696: Volt ennekem ... egy egy keves penzem fazekacskaban [Dés; Jk]; 1700: Zóld mazu fazekacska [Szászerked K; LLt]; 1738: egy küs Tálatska ... egy Fazékotska [M.bikal K; MLev.]; 1760: a' Tehén Pásztorné ... hoz vala egj Fazekacskában Tejet az szokmánya alat dugva [Kóród KK; Ks 17. XXXI]; 1772: és jol esik neki, ha adok vagy egy fazakacskát, vagy egy takarodzot [HSzj takaró al.].

Sz. 1774: Keszeg Pált jol üsmertük s tudgyuk hogy minden vagyonyait anyiban el vesztegette sőt adosságokkalis magát annyira meg terhelte s végtére ... a kreditorok ... kevés házi portékátskájára reájőttek ... az Fiara Keszeg Györgyre csak egy Fazekatska sem jutot [Gálfva KK; Ks 66. 45. $17 \mathrm{c}]$.

2. Jelzői haszn-ban: vhány fazekacskányi/ fazekacskára való 1760: Az Apám is ada kezembén egy fazakatska Mézet [Bethlen SzD; BK. Kodo Kosztán (22) jb vall.].

fedelecske tetőcske 1742: (Egy épület) külön Fedéletske alatt vagjon [Pókafva AF; JHb XXV/58]; 1768: rez kászro fedeletske egy [Szárhegy Cs; LLt Fasc. 116].

fedőcske 1733: Uj Fedŏtske 5 mazos tserép tálatska 5 [Marossztkirály AF; Told. 2]; 1798: 3 cserep kitsiny fedötske egy Patikabeli Fejér csuporka orvossággal [Vingárd AF; KCsl 5].

fegyverecske 1782: Egy kis Spanyol fegyveretske $[\mathrm{Mv} ; \mathrm{NkF}]$.

fejecske Szk: keze je 1759: (A gyermeknek) tsak az kezefejecskéib(en) láttzottak az inak, és ezek nem annyira reszketés, mind 
rángatolog mozgani [M.csesztve $\mathrm{AF}$; Ks. Mikes Antal lev.].

fejérecske I. 1812: Misztrai Álexa ... fejéretske, kerek abrázatú [DLt 506 nyomt kl]; 1836: Muresan Péter ... fejérecske 's kerek ábrázatu [DLt 510 nyomt. kl].

II. fn-i haszn-ban 1722: Barna Szŏrŭ Ló 3 esztendŏs, az Lapoczkáján hátul Egy kŭs fejérecskéje vagyon [Kv; TJk XV/3. 85].

fejszécske 1812: Egy Fejszétske ... égy jobbatska fejsze [M.gyerőmonostor K; KCsL $11]$.

felesebbecskén többecskén 1725: ugy történhetik, hogy ha az alatt felesebbecskén jüne penz kezem közi, egészlen is meg maradhatna [Darlac KK; Ap. 2 gr. Haller János Apor Péterhez].

felesecskén sokacskán, számosacskán 1739: az mièink ... eruptiot csinálván hat ágyujokot elnyerték ${ }^{\mathrm{a}}$, s felesecskénis vestek az elenségek közül [Nalác H; Ks 98a. - ${ }^{\mathrm{a} T i}$. a töröknek Kornis Antal lev.]; 1744: mikor az Adózó Rend egyben gyŭlt Kŏpeczre azon Adozo Rend Gyŭlésekben vetettek Pénzt fel felesetskén [Középajta Hsz; INyR Vall. 9]; 1749: Gabona felesecskén vólna [Gagy U; Ks Péterfi Sándor lev.]; 1779: Itt a' Czitrom fákot igen meddŏn találtam, valami Narantsok vad(na)k felesetskin érŏ felben [Kercisora F; TL. Málnási László ref. főkonz. pap gr. Teleki Józsefhez].

feleske felesecske 1754: Idvezult edes Anjátol feleske Edjetmásokkal Vitéz Ersébethnek adatott Ládák [Gernyeszeg MT; TGsz 33].

felházacska felső szobácska 1656: Kapu felet ualo fa oszlopokon allo fel hazacska [Doboka; Mk Inv. 5].

feljebbecske 1. fennebbecske, fentebbecske XVII. sz. köz.: (A földnek) vicin(usa) ... kívül a Gáton felyül mindjárt az Uraság Diszno Dinnyének fogott főldje felyebbetske a' kerülőjében ... a réája rugo Főldek vége [Mezőbánd MT; Wass]; 1732/1793: a' Szász ut mellett egy hold ... felyebetske egy fél ál [Albis Hsz; BartosLev.]; 1754: Koszta Mihally is feljebbetske rajtak irtoni kezdett vólt [Erdőalja KK; Ks 39/XI. 11]; 1754: az Utrumb(an) Specificalt Sz. fŏldet Vládék ... fogtak volt fel tŏvisbŏl es gyepbŏl Koszta Mihally is rajtak feljebbetske belé szurta volt magát [Erdőalja KK; Ks 39/XI. 11]; 1796: Ismét ottan fellyebbetske rosz föld [Balázsháza SzD; Wass]; 1824: Ugyan ott fejebbetske a Petzér réten [Szásznyíres SzD; Ks 79 Conscr. 98]; 1841: a kŏ rakástol fejjebbetske ésmet le rogyot a tsiko és az edgyik hid alol valo posvány végébe beleesett az iszapba [Dés; DLt 1541. 8a].

2. kissé magasabban 1770: ha a Király falvi Malmat jol Le eresztik, s magos gátot nem kötnek néki az Adamositis felyebbecske vennék, mind a kettő foroghatna [Sövényfva KK; JHb LXVII. 111].

3. egy kissé előbb/fennebb 1807: azon szántás mellyrŏl fellyebbetske emlékezetet tettem, az én ŭdŏmbe is Contraversia alatt volt [KmLev. Georgius Bakos (77) mákói (K) ns vall.].

felserdültecske serdülő-formácska 1752: Boldur Mariska, mikoron ide jőtt ... ezen Josziv akkor alig lehetet kétt esztendős, a másik penig Márk felserdültecske lévén Josika Ur főldes Ura maga birtokab(an) vette [Vermága H; BK ad nr. 1134 Krisán Máris (66) jb vall.].

fenekecske kb. boglyaaljnyi 1810: egy feneketske széna [K; KLev.].

fenékgátacska kb. csapógátacska (vízterelő gátacska) 1681: Veteményes kert ... az egregi ${ }^{a}$ vizinek sokszori ki áradása ighen el vesztegette es a földét is ighen le szaggatta; ... eszt eddighis kőnnyü lőt volna megh orvosolni, ha ellenező fenék gátaczkát bár csak ket helyen vetettek volna [Vh; VhU

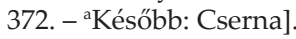

fennebbecske feljebbecske, fentebbecske, vmicskével feljebb 1714: Váltó szántok ... Ugyantsak ot fennebbetske [Borberek AF/ Mv; RLt O. 3]; 1775: ezen Joszágokban lakó, már fennebbetskeis meg nevezett Jobbágyok [EMLt].

fenyőajtócska fenyőfa ajtócska 1742: mentünk fel ... törpe fenyŏ Ajtotskán [Pókafva $\mathrm{AF} ; \mathrm{JHb}$ XXV/58].

fenyőasztalocska fenyőfa asztalka 1737: Két Varro parkanyos keskeny fenyő asztalotskák [Csákigorbó SzD; JHbK XXVI/13. 6]. 
fenyőcsebrecske fenyőfa csebrecske 1681: Felső Pincze ... Vagyon itt ... Bor töltéshez valo Fa Liu Nro 1. Kisded fenyő ŏ csebricske Nro 1 [Vh; VhU 530].

fenyődeszka-ajtócska 1842: egy simpla fenyö deszka ajtocska [Oprakercisóra F; TSb 51].

fenyődeszka-asztalocska 1817: Vagyon ezen Házban ēgy 4 Szegeletü viseltes fenyő Dészka asztalatska, fenyő dészka lában ... mozog, és ingadoz az asztal [Ördöngösfüzes SzD; Örm-Múz. 3].

fenyődeszka-ládácska 1735 : Ezen Kamarában, Vagjon egj oh fenyő deszka ládacska [Mezősztjakab TA; JHb XI/9. 7].

fenyődeszka-padocska fenyődeszka lócácska 1750: az házba egj hoszucska Asztal lábastol: két fenyŏ Deszka padotska [Szamosfva K; JHbK LVIII/4].

fenyődeszka-táblácska fenyődeszka ablaktáblácska 1756: a Kitsid Bolt Ablakainak vadnak kulsō részeiben két felé nyilo két két vas Sorkokon fordulo fenyŏ Deszka Táblátskái [Branyicska H; JHb LXX/2. 24].

fenyődeszka-tolóka ?fenyődeszkafiók 1756: Ures fenyu Deszka Tojoka [Nagyrápolt H; $\mathrm{JHb}$ XXXV/35. 23].

fenyőfa-ajtócska 1815: ket otska kapufél Fa, kapu nélkül a mellette lévő Fenyő fa Ajtotskával [Kosztesd H; Ks 111 Vegyes ir.].

fenyőfa-csebrecske 1819: egy Cserefa avaték hordoban három véka tŏk mag, egy vedres fenyŏ fa csebretske [Baca SzD; TSb 6].

fenyőfadeszka-ajtócska 1793: Az Pitvara is Bükfa Deszkával meg van padolva, ezen van az hijjában járo két fenyŏ fa Deszka ajtotska retesszel [Szér Sz; JF 36 LevK 170].

fenyőfa-székecske 1797: egy láb alá valo alatson fenyő fa széketske [Náznánfva MT; Berz. 4 Fasc. 22 Lit. No 22]; 1814: egy kis fenyö fa festetlen láb alá valo Széketske [Forró AF; KCsl 5].

fenyőfa-tolóka ?fenyőfa fiók 1824: Egy kisded fenyő fa Tojókába talált két hitván pugilláris [Fugad AF; HG. Mara lev.].

fenyőkádacska fenyőfa kádacska 1675: Eőregh Kad három, és kiczin fenyő Kadaczka [Dés; Borb. II]. fenyőládácska fenyőfa ládikó 1594: Az Varbeli hazakban ualo Inuentarium ... Az Musicusok hazaban ... Fekethe fenieó ladachka vagjon No 1 [Somlyó Sz; UC 78/7. 22. 9].

fenyő-padocska fenyőfa padocska 1801: Egy fenyö padotska [Koronka MT; Told. 23].

fenyőrámácska fenyőfa keretecske 1742: Fenyŏ Ramátskákan tsinált 14. Sybillak [Pókafva AF; JHb XXV/58].

fenyőszékecske 1833: Láb alá valo fejér fenyő Széketske egy [Katona K; Ks 73/55].

fenyőtáblácska fenyő nyújtódeszka, táj fenyőfalapító 1794: Konyhára Valo Vágo kis Fenyŏ Táblátska [Tasnád Sz; CU].

feredőházacska fürdőszobácska 1629: iutot ... Egy Boltos konyha feredeo hazaczikaual Egiwtt [Kv; RDL I. 132].

feredőkádacska fürdőkádacska 1658: 1 Feredeő kadaczka Est f - d 40 [Kv; KJ].

ferslagocska 1. ládácska 1759: im küldom tojocskaban v. ferslogocskaban a Specimeneket [Komlód K; WLt Árva Daniel Polixéna lev.]; 1768: Egy kis Freslogotska (!) [Mezősztgyörgy K; Ks 23. XXIlb].

2. vhány ládácskányi 1826: Egy Ferslagotska Fuszujka [Dés; DLt 8/1827].

fertályórácska negyedórácska 1760: Barcsai Gergelyné Naláczi Sára úriasszony ... ebéd előtt egy fertályórácskával csak azt mondá: „Jaj, be meghevülék." S azonnal lankadozni kezdvén, míg a mellrevalóját róla lekapcsolták, meg is hala [RettE 11-2].

fésücske 1729: Az árvák számára valo küs fésücskékért d 6 [Szentbenedek SzD; Ks 26. XIV. 1].

fiacska 1. rendsz birt. szr-os alakban: vkinek a kisfia 1573: Anna nehay Nagy dienesne Azt vallia hogi az Nagy Lwkachne haza eleot Latta az ferenchy Istwan fiachkaiat mely Nap az Maiorok meg egtek [Kv; TJk III/3. 190]; 1584: Dorottea Kerekes Ianosne vallia Giakorta panazolkodot enneke(m) Zabo Casparné hogy eotet Keodme(n) Ianosne fattias kwrwanak zidta ... egy fiachkaia vagyon ... Azis az eo vratol Kowach Ianostol valo volna [Kv; TJk IV/1. 367]; 1593: marad az czywr Balintnak egy kis fiaczykaia Aruaié ky megh polkas (!) volt, 
es nemis wl vala [UszT]; 1644: Vagio(n) ket vagj haro(m) Ezust Calano(m) ha holta tertenik ketteit az fiaczkaianak hadgia [Mv; MvLt 291. 437a]; 1666/1799: ha Isten annyi esztendőssé neveli fiatskáját hogy az dologról vallást tudhat tenni, tehát fiatskájávalis Confirmaltattya az alkuvast [Torockó; TLev. 5/16 Transm. 287]; 1681: azon ben ualo őrokseghnek ... az Beres pataka felŏll ualo belsò reszeczkeje, marada Marko Borbara fiaczkaianak Istoknak [Homoródsztmárton U; Borb. II]; 1706: Szasz Gergely fiacskaia Miklos lehet nyolcz esztendŏs [M.bölkény MT; Born. G. VII/4]; 1726: egy kővel ... ártatlan Fiacskáját főven hajtotta és vérit botsátotta [Dés; Jk 15b]; 1730: az én Jnaskám Tőrők, s - az Fiacskám haza jővé(n)ek s - mondák hogy Szakács Máttyás áskált azon Jószágon [Altorja Hsz; Borb. Donát Jánosné Aszsz(ony)m Ilona (46) ns vall.]; 1749: Angjom Aszszony(na)k irtam volt egy Invitatoriat a 9um $\mathrm{p}$ (rae)sentis meg akarván kereszteltetni az Fiatskánkat [Zsibó Sz; WLt Wesselényi István Wesselényi Ferenchez]; 1771: Az egyik Cigán(na)k egy Fijatskája is vagyon maga mellett [Mv; DLev. 3. XXXIII. 10]; 1783: Megholt Varga Janos Fiatskaja [Inaktelke K; RAk 3]; 1795: Lorinczi Joseff Uram ... a Fiatskajat ki edgygyetlen edgy meg vérte [M.köblös SzD; RLt Ládár Dávidné Vanna (30) vall.]; 1853: Kováts András fiatskája [Bács K; RKAk 89-90].

Szk: árva 1725: néhai Déési János Arva Fiacskáját Pap Gyŏrgytől el vévén ... eo kgle vegye kezéhez és Scholaztatván tanittassa [Dés; Jk 376b]; 1790: Eresztevényi Elek testvér Etsémnek árva fiatskáját ... segitetvén [Eresztevény Hsz; HSzjP] * csecsemő 1708: Commendans u(ramna)k ŏ $\mathrm{Ng}($ na)k penig csecsemŏ fiacskaja meg halva(n) ma Temettek el [Fog.; KJ. Fogarasi János lev.]; 1758: Márk Prekupis ... elszőkék házos Koraba egy csecsemő Fiacskaja volt ... ezis ā Szilágyba ment [Szelnice SzD; TSb IV. 7] * csecsszopó 1680: Radul Serbanne ... ez egy csesszopo (!) fiacskajaval együt A. Porumbákon1 lakik [Szkorei F; ÁLt Conscr. 67]; 1832: égy Csecs Szopo Fiatskáját ... tartsam és neveljem [Dés; DLt
186] * felserdülendő 1831: Abba vagjok ennyi felszegsegemben szerentsés, hogy egj felserdülendö Fiatskam bele kapott mestersegembe, ki az én mutogatásom mellett faritskál [Dés; DLt 828] * kicsiny 1719: Baroti Mihály ur(am) ... Relictája ... egj kicsiny Fiacskája meg halván, annak el takarittatására ... adta volt Zálogba ${ }^{\mathrm{a}}[\mathrm{Ne}$; DobLev. I/97. - ${ }^{a}$ Ti. két földjét]; 1750: egy régi füstős házban valami Karasznai Mester Győrgy nevü Tisztartóját tartotta ... holála után maradott két kicsin Fiacskait ... az Attyafiai ki vitték Karasznára ${ }^{a}$ [Bor-

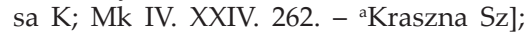
1752: Illianak egy kicsin Fiatskája is vala [Mojgrád Sz; Ks 36. 4. 18] * kis 1576/1577: Egy kys fiaczkayays Maradot Az Azzonnak Thorozkay Christophtol [Torda/Kv; TA/K Thor. VI/4. Gr. Zabo de Dengelegh ns vall.]; 1585: Teomeoswary Balintne vallia laktam Zentkiraly Andrasne hazanal ... Egy kis fiachkayais vala [Kv; TJk IV/1. 429]; 1598: kyldettem vala egy kis fiaczkamat vizre [UszT 13/27]; 1613: Keresztesi Pal Uram ... igen beteges allapottal leue(n) azonkeppen hazanepeis, seot egy kis fiaczkaiais most holt megh [Törzs. A fej. Fr. Balassi senior de Veczke usz-i kapitányhoz]; 1660: Baczy Katha asz(ony) ugy mint Tutrix Iffiabik Baczy István kis Fiaczkajanak Petinek Sos Martont vallia Procuratoranak Buday Mihaly ellen [Kv; TJk VII/3. 309]; 1665: Primipilus Petrus Zoltani de Zoltan (60) fatet(ur) ... el jöve velünk az Czerjek Pal Uram földiröl Zoltanbol egy küs fiacskajaval Thamassal edgyüt [Zoltán Hsz; HSzjP]; 1705: édes kis Fiacskaja Osvat Janko [Kv; Pk 6]; 1739: az kis Miska fiacskam, meg himlözött veres himlöben, de már jobban vagyon [Ks 99 Kornis Antal lev.]; 1763: én egy kis Fiatskámat le kŭldém négy ŏkrŏs szekeremmel Várhegyre [Udvarfva MT; Told. 44/15]; 1780: Egy Bukur János nevŭ Feleseges gyermekes ŏs Jobbagyom ... hon nem letemben hirem s akaratom ellen Gagyban Miklosi Mihaly Uramhoz szégŏdŏt esztendeig beresnek ... kŭs fiatskajaval edgyŭt a kiis szabad ember [Bözödújfalu U; Pf]; 1856: halt meg Tót István fazakos Tot Istvan kis fiacskája 10 hetüs korában [Dés; RHAk 78] * kisded/kisdeg 1662: kis ded fiacz- 
kajat fel Enyedi Janos Deak maradekjat Istokot [Bszt.; Hr 6/10]; 1722: Feleség(em) I(sten)nek hála, békével meg érkezék, de kisded Fiacskánk változob Statusvan vagyon, mint mikor el ment volt [Fog.; KJ. Rétyi Péter lev.]; 1759: Martinnak is vagjnak három kisded Fiatskái [Girbó AF; JHb Valászie Muntyán (99) zs vall.]; 1776: Dán Iuvonnak a Felesége és Kisded fiatskája mit miveltenek ezen Verekedésben? [K; Born. VI. 14 vk]; 1816: vagyon egy kisdeg fijatskája [Torda; KvAkLt Mss 363]; 1831: Vaszi meg halálozván egy küsdeg fiatskája maradott árván [Szentdemeter U; Told. 39] * mászó 1756: egy mászò Fiatskajais volt [Sszgy; LLt] * nevedékeny 1743: Popa Jion ... egy nevedékeny fiatskával $[\mathrm{BfN}]$ * neveletlen 1644: ügjekezzenek ... az kiczin neueletlen fiaczkamot az edes kis Mihokomot menteŏl beczŭlletesben neuelni es scholaban iartatni [Nyárádtő MT; Sár.]; 1768: Nehai Ajtai alias Kardas István Uram megh hagjatott Eőzvegje Tot Maria Aszszony mind maga s mind penig maga neveletlen Fiatskainak Győrgjnek és Istvannak képekben jővenek én hozzám [F.sinfva $\mathrm{TA} ; \mathrm{AbN}]$ * neveletlen, árval árva, neveletlen 1651: szegjnj neveletlen arva fjaczkam [Körtvélyfája MT; Bál. 1]; 1681: Zarandvarmegyeben Bethlenŏsŏn ${ }^{a}$ lako szegeny emberek ... Bethlen Domokos vrunknak egy darab idŏk alatt mint ŏs ŏrŏkŏs iobbagyi adot fizettenek, de Bizonyos idŏktol fogva nem adozvan, mostan meg irt vrnak neveletlen arva Ficskaianak Tekt Nemzetes Iktari Betlen Istvan vrunknak Tutora Tekintetes Nemzetes Véér Kristina Aszszony eo kge ... szofogadatlansagokert katonak altal hozatvan fel azon Betleniŏs nevŭ falubol ket nŏtelen legenyeket [IB. Thuroczi András közbíró Désfalván lakó vall -alpusztult település Arad és Hunyad m. határvidékén.].

2. Fiúgyermekre von. megszólításként birt. szr-os alakban 1771: hallottam a Száva Marján Szájábol ezeket beszélleni ... hogj az Utrizáns Bágjuléknak attját Bágj (!) Juont az ŏ édes attja hozta, vagj szőktette ell Vintzről, ide Csákljára, ekképpen hitegetvén őtet, gjere ell édes fiatskám én velem mert én meg ruházlak, s felnevel- nevellek ('́gy!), s gondodat viselem [Girbó AF; JHb Nikoje Patru (70) jb vall.].

3. kisfiú 1574: hagiom w kgnek tartanj az fyaczykath es az leankath [Gyf; JHbK XXI/12]; 1725: Az Fijacskát első napján az Innepnek a Jesuvitakhoz küldétték misére [Darlac KK; Ap. 2 gr Haller János apósához]; 1758: Aztán vigasztalt meg Isten, ismét egy fiacskát adván [RettE 68]; 1837: égy Nasztászia nevu oláh leány szolgálo és égy mintégy tizenégy esztendŏs Latzi nevu fiatska beszélték ${ }^{\mathrm{a}}$ [Doboka; Bet. 1. ${ }^{a}$ Köv. a nyil.].

fiatalocska I. fn csemetécske 1742: Sok féle virágok s fiatalotskak [Pókafva $\mathrm{AF} ; \mathrm{JHb}$ XXV/58].

II. mn 1797: Hargos magu Szilva fák Nro 203 ezek kŏzŭl némelyik fiatalotskákis találtatnak de nagyobbára régi meg vénhedettek [Kőrispatak U; Pf].

fickócska serdülő fiúcska 1753: hat szemelylyek voltak ... az hatodik penig egy Kis Fitzkotska volt [Nyárádsztbenedek MT; Told. 28].

fickó-szolgácska serdülő fiú-szolgácska 1778: Volt egy kis Budai ${ }^{a}$ Fitzko szolgátskaja [K; KLev. - 'Burjánosóbudáról, azaz Bodonkútról (K) való].

ficsőlik-földecske ?szakadék-földecske (szomszédos földből kiszakadt földdarabocska) 1766: az hol a kérdésb(en) forgó Főld vagyon nekemis vagjon harom darab Főldem, mellyek azon Dőllŏ Földnek a bútüire mennek a melyből az utrizált Fitsőlik Főldecske ki szakadott volt ... ezen két főldből szakadott és a tőbb Főldnek végibőllis, amellyek azon Dőllő Főldre mennek [Kökös Hsz; Kp I. 234 Füzi sen. (60) miles ped. vall.].

filegóriácska 1. faházacska/házikó 1723: Az udvarház szerént vagjon, Egj tisztesseges fabol épitett filegoriacska Deszkával [Holtmaros MT; Told. 29/7]; 1736: Ezen Filegoriátskának tsak kitsin Szarvazatotskája van [CU]; 1775: az alatta lévő Kő pintze Gátorja felett, egy kis Sendely fedél alatt lévő, mind fedelire mind oldal Deszkaira nézve meg rongyollot és el pusztult filegoriátska [Buza SzD; LLt Csáki-per 107. L. 14]; 1778: Ezen pincze Torok(na)k felette vagyon egy kis filegoriacska oldalai fenyü 
Deszkábol bélettek [Csapó KK; Berz. 4. 8. C. 18].

2. kertiházacska 1699: a palankhoz vagyon ragasztva kőtéses, deszkás, karfás Filagoriacska [Boroskrakkó AF; BfR VI]; 1736: Ezen Gyümölcsös közepiben van egy hulladozott, régi ... Nyári Gyümöltstartó fóld szinbe épittetett pintzére fellyúl az padlásán épittetett volt égy kis Filegoriatska [Sárpatak MT; XIII/1. 71].

3. kb. huszártorony 1756: A Templon felett edgy Félegoriátska mellyben vagyon mint égy Öt ejteles harangotska [MREmLt Conscr.].

4. ? 1699: fel menvén két rendbeli Sendejezes alatt lévŏ Gradicsokon, Cserefabol valo kŏtésekre csinált vesszőkből meg font jo készületü tapaszos Sindelyes Hazban melly Gradicsoknak a kŏzepin, edgy filegoriacska van, két oldalán penig ezen háznak kŏrŭl kŏtésekre Csinált félb(en) meg deszkázott fojosoja [O.csesztve AF; LLt]; 1723/1799: égy Tŏlgyfa lábokon állo tornatz, avagy Filegoriátska [Vámosgálfva KK; CU]; 1736: az ... Filegoriátskábol hoszszu Gráditson hag fel az ember az Palota kettős Tornátzába [CU].

fillérecske kics 1792: magam tulajdon Sok faratságom s hellyes ŭgyekezetem által szereztetett vagyonotskaimbol, az Én Istenem Ladajaban el rendeltem egy Filleretskét vetni; Az az Hagjok és Testalok a' ... KolosVári Unitarium Collegium Szŭkségire ŏrŏkŏsŏn ... Hung fr. 10000, az az Tiz Ezer Magyar forintokot [Héjjasfva NK; SLt XLIII. 17 Felső Dobofalvi Marothi István kezével].

findzsatálacska csészealj, kistányér 1759: szállittasson el ... Két kŏzŏnséges Finsia Tálatskát [Sárd AF; TSb 51].

fióka 1. fiúcska 1661: De talám azért nem jutott eszedben, gondolád, nem fiókád, hanem fátád leszen [TML II, 176 Teleki Mihály feleségéhez, Veér Judithoz]; 1723: Luka Vaszilyi ... kétt hetu (!) gyermek ágyban lēvŏ feleségét āgyābol fel verte, erŏssen megh kŏtvén māsuvā vitte, ott lānczon nyomorgatta kis fiŏkajaval a hideg hāzban [Hodák MT; VGy. Prekup Gligore (34) jb vall.].
2. fiókocska 1817: Felső Pintzébe Három Ferslag Egy Gyertyás Fióka [Told. 58].

3. fiókocska, rekeszecske 1674: Egy festett kissebb ládáb(an): Tizen-őtt Tőrók keszkenő ... Két elő ruha, az eggyik reczés ... Egy kendő az fiokáb(an) [Szászvárosi ref. 1t. Halics Mihály hagy.].

4. csürfia (mellék/oldalcsür) 1752: a Csŭrŏs kertben is vagyon ... szalma fedel alatt lévő Csür, mellyben tsépelhet egyszersmind tiz ember, az Fiokáib(an) pedig belé fer két száz kalangya [Pókafva AF; $\mathrm{JHb}$ XXV/73. 15].

fiókgerendácska keresztgerendácska 1736: (A) Pintzének ... Cserefa fiok Gerendátskáira borongatott Csere fa padlása vagyon, rostéllyos kis ajtotskája [CU].

fiókocska 1. 1714: Körtvely fabul valo s feketere festett Kis almariom hal tsontall kivüll kirakott 9 fiokotskakkal fl. Hung. 5 [Nsz/Fog.; REkLt II. Apafi Mihály hagy. lelt. 54]; 1714: Kis Almariomotska Tenger szinre festett külsö Tablakkal, kőrős körül külömbféle irott képekkel ékesitett, 7, fiokocskákkal fl. Hung. 12 [Nsz/Fog.; REkLt II. Apafi Mihály hagy. lelt. 55]; 1778: kisded Tábori Asztalocska fenyü Deszkából fiokocskájával, a' Lába Cserefábol csinált [Csapó KK; Berz. 4. 8. C. 18]; 1797: Egy Fiokotskaban Mentére való Arany készŭlet [Koronka MT; Told. 34]; 1807: Egy fijokotskába tsatora (!) a forma darab tsontok [Körtvélyfája MT; LLt. - ${ }^{a}$ Elírás csutora h.?].

Szk: záros 1737: ezen Pohár szek(ne)k három egj más rendiben lévő párkányos, fenyő deszábol tsinált, ki huzogato Záros fiokotskai vadnak [Csákigorbó SzD; JHbK XXVI/13.].

2. Jelzői haszn-ban: boglyácskányi/boglyácskára való 1823: az edgyik fiokatska szenat elis vitte [Dés; DLt].

fityegőcske (ékszer) csüngő/függő része 1681: egy pantlika rosa formara csinált fütyögöcske egy rubint benne meg az vigibe egy orientalis gyöngy [Wass]; 1758: Egy Arany Rubintos, és győngyős Fityegőtske ... az 3. fityegője, mint egy Mezei borsó [Nsz; TSb 21]. 
fiúcska 1. kisfiú 1748: voltanak gyermekei ... egy Fiucska s egy Leányotska [Aranyosrákos TA; LLt]; 1826: Az egész Ser háznál égy örmény fiutskán kivül senki sem lakik [Dés; DLt 251]; 1846: Dosáné asz(sz) ont magánál kapta - kit is a' fiutska hivutt haza [Kakasd MT; DE 2]; 1848: Nagy kár, szép, derék fiútska volt [Kv; Pk 7]; 1849: szoljon a nő igazat, hogy azon fiucska ... kitől valo légyen? [Kv; Végr. Vall. 27].

Szk: t kap 1849: (Krizsán Máriskó) magától Kelemen Bénitől kapott egy fiucskát [Kv; Végr. Vall. 27] * kis 1814: égy kis Fiutska Kerekes Inas [Dés; DLt 222].

2. birt. szr-os alakban 1803: tekintse meg ezen két fiutskáinkat, kikért tőrekedűnk [Ebesfva; Pk 4]; 1849: Kelemen Béni tőllem a fiacskáját elvéve további dajkálás s nevelés végett átadta ... Holczer Ignácznak [Kv; Végr. Vall. 22].

fizetésecske 1. csekély (munka)bér 1742: ă két szolgálo kevés fizetésetskéje esztendeig 17 forint [Kv; Aggm. C. 12]; 1752: Fizetésetském irántis igen alázatosan, de tellyes bizalommal instálok, ha kegyes szivére nem vészi a' Mlgs Ur igen bajosan Subsistalhatok [Szentdemeter U; Ks 83]; 1764: szoktam vala ... nemelykor enis Praefectust tartani ... fizetésetskéjek. s. Joszagotskaiis a kezek alatt alkalmasin (!) volt annyi, mint a Kovátsnak [Középlak $\mathrm{K} ; \mathrm{BfR}]$.

2. papi csekélyecske/csekélyke papibér 1795: M Vásárhellyi Papi Fizetésetské(ne) k jobbittására tzélzott Pium Legatuma [Mv; Told. 50].

flintácska rövid flinta 1782: Egy kopot damaskos szegeletes Csőủ ezŭstel munderozott kőnnyebbszerŭ flintácska [Mv; NkF]; XVIII. sz. v.: Esmet hozat az jáger ... egy kis flintátskat melnek egy által járo szeget csinaltam [Kv; BK. Gyarmathi Sámuel lakatos kezével].

Szk: rezes 1788: Rezes régi Flínta égy. Más régi rezes Flínta égy. Egy kisded Rezes Flíntátskă [Mv; TSb 47].

fogacska hímzésminta 1714: Elökettő szélylyén 3. rendbéli fogatskákkal ki varrott fl. Hung. 3 [Kv; REkLt II. Apafi Mihály hagy. 31]. fogadócska kis kocsma 1799: a' Kéreia Hágo innenső allyáb(an) valo Fogadon innétvalo Fogadotskával szemben bé érték [Dés; DLt. - aA Kérő (SzD) határában levő].

fogaska fogasocska 1798: egy darabotska Deszkabol egy kis potzoska ... Egy Pipa tarto Fogaska [Vingárd AF; KCsl 5].

fogasocska 1694: Az emlitett Zőld Palotabol nyilik mas Ajto mas Hazacskara ... Ebbŏl a Hazacskabol nyilik mas hasonlo Ajto mas hazacskara ... keorös kŏrnyŭl zőlden festet sima Fogasocskák vad(na)k benne az oldalan ... egy rejtek Kamaracskaja va(gyo) n ennek az haznak [Kővár; JHb Inv.]; 1699: (A szoba) minden benne levő appertinentiákkal, kemenczekkel, fogassal, kivévén egy fogasocskát és az Tál tartot [HSzj fogas al.]; 1735: egy kis fejér fogasocska [Királyhalma NK; Ks 23/XXIIb]; 1748: appro fogasotskák az oldalána [Koronka MT;

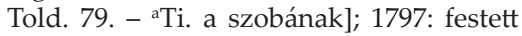
8 fogakbol állo fogasotska két vas rudatskákkal le van szegezve [Kőrispatak U; Pf]; 1799: A' Fal Oldalán vagyon Egy hét Srofos Vass Szegekkel készúlt kőntőst aggato Fogasotska [F.zsuk K; SLt Vegyes perir.]; 1807: Tanaltatik a hazban egy fogasotska mint egy harmad fel singni [Dés; Bet. 6 Gy. Uj Falvi Nagy Ferencz kezével].

fogócska 1748: Vas Fogocska Nro 1 [Mezősályi TA; Ks 7. XVII. 12].

fogvájótartó-tokocska fogvájótokocska 1782 : Egy Másfél Iznyi hosszuságu fogvájo Tarto Ezűst Tokocska ${ }^{a}$ [M.fodorháza K; RLt.

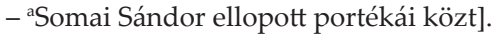

fogvájó-tokocska fogvájótartó tokocska 1743: Egy fog vájo ezŭst Tokotska [O.fenes (később: M.fenes) K; JHbK XXIX/28].

foltocska 1. 1814: Egy ŏtt Esztendős, sŏtét pej ... ki herélt Paripa Ló mellynek bal szeme fejér, és az Homlokán-is, és (!) ${ }^{a}$ kis foltotska vagyon [DLt 769 nyomt. kl. - ${ }^{a}$ Nyilvánvaló elírás égy h.]; 1823: Egy ... pej Kantza ... Hátán négy fejér fototska [DLt nyomt.]. 2. darabocska 1746: minthogy az Urfi ö Nga része alábbatska Való ennek gyengesége explealtatik a felsö To felett lévo szakodasban lévő foltatskával [Mezőbodon $\mathrm{TA}$; JHb XI/22. 8]; 1746: A Szŏlŏ végéb(en) lévó verö fény ... fel méretvén, hoszszassága huszonkét kötel es tizen harom ŏl ... 
legalol egy foltotska jutott Mlgs. B Josika Mojzes Ur ŏ $\mathrm{Ng}(\mathrm{na}) \mathrm{k}$ [Mezőbodon TA; $\mathrm{JHb}$ XI/29. 4].

3. Jelzői haszn-ban: darabocska, nyilacska 1773: egy foltotska kaszállo [Vingárt AF; LLt 53/17]; 1814: imitt amott a' határon vagyon égy égy Foltotska közre birato Cseples erdős hellyek [Benedekfva Sz; Bet. 3]; 1817: egy Fototska Erdő [Bádok K; BHn 28].

foltocskányi darabocskányi 1808: az Szekely Győrgytöl acquirált kitsin fotostskanyi (!) Joszag 11 Forintal acquiraltatot es ... az 11 Forintal vasarlot Joszagotska az Szekely Boldisar kezére ment [Harasztos TA; Borb. II].

folyamatocska patakocska 1764: Valaki a' Tohban menő vagy szolgálo vizi folyamatotskákat maga hasznára ki szakasztya, el vészi, nevezetesen a Verespataki nagy Toban folyo Rotundul patakat ... az ollyan 12 forint birságban inkurállyan [Abrudbánya; Born. XXXVIII. 8 Abrudbányai bányászok törv.]; 1768: a' Berek nevŭ Erdŏ alatt Le menŏ folyamatatskan innet a Szánto Földek felŏl egy kis oldalos helynek a tetején vagyon ... egy nyilas Szánto fölgye [Cege SzD; Wass].

folyamocska patakocska 1860/1861: a Kétárok nevü folyamocska [Mezömadaras MT; Benkő, MszIsm. 321].

folyóka patakocska 1757: Gonorás folyóka mellett a hoszszu ág fojókája [BfN Bánffi László conscr.].

folyosócska tornácocska 1699: vagyon nyolcz cserifa köteses oszlopokon allo foljosocska karfa nélkült [Szentdemeter U; LLt]; 1699: vagyon egi ajto ki az meg emlitet fojosocskára [Szentdemeter U; LLt]; 1742: a' fejjebb emlitett gjümöltses kert felé egj Folyasotskaban mennek [Pókafva AF; JHb XXV/58]; 1745: vagyon egj tŏlgy fa talpakra, Sas-fákra kŏtésesen épitett deszka Padimentumú ujj Tornátzotska ujj Sendelyezés alatt ... errŏl a' kŭlsŏ Recessusra szolgál egy kis Folyosótska hasonló épŭletŭ ... Melly kis Folyasotskárol a' keritésre szolgál le egj kis paraszt ujj fa-grádits [Marossztkirály AF; Told. 18]. fordítócska kicsi fordító, (ablak)kallantyúcska 1732: edgj ... kŏbŏl epittetett rend épúlet ... béllelt párkányos ajtaja ... elŏtte penig edgj vas Sarkokon két felé forduló fenjŏ deszkábol csinált levél ajtó vagjon ... négy ónba foglalt, vas Sárkotskákon nyiló Cserefa rámás ablakjai ... vonodnak vas forditotskákkal [Kv; Ks 40 Varia XXVIIIc]; 1736: vadnak csinos ablak rámátskájok (így!) és rájok szegezett apro vas Sorkotskákkal egyetemben, Nem maradván hátra a' bé záro vas forditotskák és fogantyu kis karikák [EMLt].

forintocska 1. kics forint 1644: eöt forintoczkam volt az szatior czuczaba(n) [Mv; MvLt 291. 399b]; 1788: Ha az Ur I(ste)n Békeséget parantsol, reménlyhettyŭk az Aszszu-szŏlŏ Borának arrábol a' Nyereséget; ha az 1000. s' valamivel többetske vederb(e) Ngd béverte vagy 200. Forintotskáját, de ide hátrébb azt lehetne legalább 6000-forintokon distrahalni, a' Nyereség ... szépetske lenne [Kercsesora H; TL. Málnási László ref. konz. pap gr Teleki Józsefhez].

2. Jelzői haszn-ban: vhány forintnyi értékü 1807: most nem régiben váltám ki a Csáni portiomot, ebbölis 300. forintocska árendát kapok [Kv; Incz. XII. 3a br. Josinczi József lev.].

formácska kb. minta 1788: Holmi díríb darab rongy, ezzel édgyŭtt valami hulladék gáz végek. Holmi díríb darab formátskák és példák [Mv; TSb 47].

forradásocska hegecske, sebhelyecske 1805: a' bal Pofáján egy Seb forradásotska [DLt nyomt. kl].

forrásocska 1620/1754: Az Iszka uttya mellett vagyon egy forrásotska [Ompolyica/Metesd AF; Told. 22 Fejérvári káptalanok]; 1744: melly vŏlgyb(en) egy kŭs forrásotska van [Torockó; Bosla]; 1775/1802: amint mentünk fel az oldalan ... azon forrásatska felé, a mely ... az eszakban egy meredek oldal alatt vagyon [BSz; JHb LXVII/3. 83].

fosztánocska fosztánkelméből készült, ujjatlan kabátocska 1614: Feieruari Giorgj hoz ... 6 Apro foztanoczkat ... d 4 1/2 [Kv; Szám. 23/XIIIa. 41]. 
főemberecske gúny főnemesecske/uracska, inci-finci főnemes 1736u.: Ó mostani felfordult világ! egy nyomorult fö emberecske nem hogy más ember jobbágyaszszonyát de magát is jó nemesembert vagy annak gyermekeit szégyenlené atyafiának mondani, nemhogy valamivel succurálni olyan megszűkűlt még közelről lévő atyafiának is [MetTrCs 481].

főkötőcske 1673: Egj aranj fökötőtske, egj nehanj boglarral [Marossztkirály AF; IB]; 1823: fejében égy kis főkőtétskét (láttam) [Dés; DLt].

földdombocska-métázás határhalmocskahatárolás 1782: Az Also Sukiak a' Tavasz félt valami fŏld dombotska métázást tsináltok [F.zsuk K; XLII. 5. 28 Udvarhellyi János (33) zs vall.].

földecske szántóföldecske 1582: adek ... egy feŏldechket Kouach Balynti mellett [Uzon Hsz; Kp 1]; 1582: en az en felesegemteöl el valaso(m)ba Marthatol ... es az el valasbely lewelnek valtsagaba ... adek Lazlo papnak ... egy feöldechket [Uzon Hsz; Kp 1]; 1589 k.: Tudgia az Zabo Thamas feoldett az Zeken hogy darab feoldeczjkett foglalt es rea ment az varas [Szu; UszT]; 1619: ada ... egy kws foldecziket [Petek U; Hr 1/2]; 1671: adott volt Samsond falua holmi daraboczka feoldeczket [Sámsond MT; Berz. 14. XVII/8]; 1676: Vagyo(n) egy Feldeczke [Szentgerice MT; Told. 8]; 1693: Az Sulymos tonál negi hold fŏldetske [Ne; DobLev. I/37]; 1695/1717: edgy kis fŏldetske [Tarcsafva U; Pf]; 1717: ada ... egy kŏblŏs fŏldecskéjét [Pálos NK; Hr 1/42]; 1717: a kŭs fŏldecske [Pálos NK; Hr 1/42]; 1728: főldecskét bir a Tőke szerb(en) [Dés; Jk]; 1737: Földeske (!) van Völcsŏk felŭl valo Forduloban is A: Bölcsŏs uton [Szamosújlak Sz; Végr.]; 1741: tavally egy Ház hellyetskének minemő részecskéit szerzették meg ... és egy bizonyos főldecskét ... adtak volna [Nyárádsztbenedek MT; Told. 22]; 1750: Volt egj kűs főldecskéje [Kál MT; Berz. 2. 40/64]; 1755: es Tudok egy kűs Főldecsket [Szentimre Cs; Hr 3]; 1757: küsded Joszágotskához tartozo kétt Földetske [Vacsárcsi Cs; Sándor conscr.]; 1766: Kispál Bálint Ur(am) igy felel hogy, ezen Főldetske ebből a Dŏllő Főldből sza- kadott ki [Kökös Hsz; Kp I/234]; 1772: édgy darab földetske [M.nagyzsombor K; Somb.]; 1773: Hevederfenyőb(en) vagyon egy szilak földecske [Szentsimon Cs; Hr]; 1798: Ád holmi diribb darabb főldetskétis [Dés; DLt]; 1805: Rátz Éva Aszszony adá (!) Cserében a' Falu végén ... egy Földetskét [Kőd Sz; Végr.]; 1806: Matskási rész Fŏldŏtske [M.palatka R; RLt O. 2]; 1809: Monostori Utra járo Főldetske (sz) [Nyárszó K; KHn 123]; 1825: Igen jo kis fŏldetske [Szárazpatak Hsz; SzentkZs Conscr. 337]; 1853: visszá Botsássák azon kítsin fŏldetskét neki [Héjjasfva NK; Pf Nagy Károly lev.].

földhalmocska határhalmocska/dombocska 1782: Groff Székely Adám Vr ... Praefektussa ... az Also Suki Lakosokkal, a' Nemes Suki és Also Suki Határok kŏzé ki menvén ... bizonyos fŏld halmotskákat Vagyis métazásokat tsinalt az emlitett két Faluk hataraik kőzőtt [F.zsuk K; SLt XLII. 5. 15 Moldován alias Marosán Alexa (36) zs vall.]; 1782: a' Kesej Torkátol, vagyis patakátol fogva ... elkezdvén az Szamos folyamattyáig le mindenŭtt fŏld halmocskák hányattattak, mellyeket ... azon kijártatás alkalmatosságával tsináltatott, vagy hányattatott volt [F.zsuk K; SLt XLII. 5. 10 Juráth Ignath $\mathrm{jb}$ vall.].

földörökségecske földbirtokbeli örökségecske 1748: fŏld őrőkségetskéimet ... őrőkősön birhassák [Komjátszeg $\mathrm{TA} ; \mathrm{AbN}$ ]; 1748: méltozatott auctiot adni Harmintz őt magyar forintot ... föld őrőkségetskéimre [Komjátszeg TA; $\mathrm{AbN}$ ].

földpincécske földbe vájt pincécske 1722: Az Tőrők buzás kertben vagjon egj főld pintzétske Kortsoma háznak valo [Algyógy $\mathrm{H}$; Born. XXIXa/8 Bornemisza János conscr. 2]; 1763: A ... Kortsoma Ház(na) k kamarája alá, egy Főld Pintzétskeis vagyon ásva ... Melynek száda felett hitván régi drániczával fedet, és fenyŏ fábol valo deszkakkal két felől bé tsinált árnyék van [Hortobágyfva Szb; Born. XXXIXa/9 Néh. Hortobágyi Gergély György conscr. 28].

földtálacska cseréptálacska 1787: Két tsorba kantsó négy kis főld tálotska [Mv; MvLev. 8 Tolvaj alias Varga Mihály és fel. Varga Kata hagy.]. 
fruktusocska hasznocska 1733: Ami pedig az Joszágnak az administratioját illeti, a való, hogy tudva lévő egy néhany Esztendők(ne)k el folyása alatt, mivel rám sokat nem kőtődtek (!), még csak praétendalhatnék valami Fructusocskat; de én azok(na)k békét hagyok [TK1 Teleki Sámuel lev.].

fundamentumocska szerény létalap 1692: minden szántot főldeim redeáltak ki annál nagjob kár, s eletem fundamentomocskájának ebben az hazáb(an) meg szakadása [Monostorszeg SzD; Ks 9. XXXVIII Buday Sigmond lev.].

funduska fundusocska, telkecske 1743: Nagyságodis remenséget adott a Kantai kis funduská(na)k restitutioja és megeresztése arrant [Kvh; Ap. Szotyori István Apor Péterhez].

fundusocska telkecske, házhelyecske 1671: Bál Pataki János kőnyőrőg ... Kgls Aszszonyom ... Házammal altal ellenben Borberekben ${ }^{\mathrm{a}}$ vettem vólt egj szegenj nemes Aszszontol egy kis paraszt Fundust ... az én kezemmel ket kőből buza alá valo földetskevel több utánna nintsen ... meltoztassek Nagd azt az egy Fundusotskat cum appertinent(iis) nekem, felesegem(ne)k es ket agon lévő maradványaim(na)k őrőkőssen adni, meg-is nemessitteni [Törzs. - ${ }^{\mathrm{a} A F]}$; 1684: nehai Lipcsei Gyŏrgj Ur(am) itt Kisfaludon ezeket az ház hellyeket birta életében ... Az patak mellet egj kis fundusocskát [Kisfalud AF; Incz. V/57a]; 1701: azon Falu vegin valo fundusotskát ... bőcsüllenek, és bőcsüllenk tőbb esküttekkel tiz magjar forintokra [Szárhegy Cs; LLt Fasc. 151]; 1730: lévén egj kis darabocska Fundusoskája ... ezen Kis darabotska fundusoskáját által adja ŏrŏkŏssŏn Berzenczei István ur(a)m(na)k [Mezősámsod MT; Berz. 5. 42. 5. 48]; 1747: azon két kisded fundusotskán a' Nemes var(me) gye Postalis Commoditasokot epithessen, és birhassa pacifice [Déva; Ks 73. III. 18 1/2]; 1747: Curiám alatt lévŏ kitsin Fundusotska [Vaja MT; Sár.]; 1777: leváltam ujra őtt Magyar forintokot 8 Den az Ns Küküllő vármegyei Erdő allyai fundusotskára [Kük.; Ks 66. 45. 17d].
Szk: belsô 1726: adott vólt egy kiss belsŏ Fundusoczkát Gyergyó Sz. Miklóson [Szárhegy Cs; LLt Fasc. 68]; 1747: egy Váradi nevü Tisztartoja ... egj belső fundusocskát két felé szakasztott, felit ... Porcsiren (!) Juon nevü Sellérinek atta ... meg halván ... az emlitett Sellér az emlitett Sesziocskátis, vagyis inkáb huruba helyecskét az ... M. B. Kemén Samuel Ur részire szakasztatott hellyhez foglalták el [Mezősályi TA; Ks 7. XV. 20 Moldovan Jefftin (50) jb vall.]; 1833: tŏbbszeri ajánlásokra accedálván, adá tserében ... egy belső fundusotskáért a kŏvetkezendŏ kaszálo és szánto helyeket [Csekelaka AF; KCsl 16] * bennvaló 1690: szamos künes ben valo fundusoczka [Csíksztmárton (később: Nyárádsztmárton) MT; Berz. 1. 20/15] * kolonikális jobbágytelek 1760: Brinze Dumitrunak ... volt és vagyonis egy fel antiqua Sessioja ... egy fertalynyi puszta colonicalis fundusotska [Runk TA; Ks 89] * nemes 1722: Vagjon ... égy ugyan Nemes Fundusatska [Zágon Hsz; SzentkZs] * puszta 1717: Attam Cserében ... Egj Ép szőlót ... Egj kis puszta fundusotskaért [Boroskrakkó AF; BfN dobozolt anyag VI]; 1740/1761: requiráltatván az Harai R: Filialis Ecclesiatol egy ugyan ott Haroban lévő puszta Fundusatskám iránt ... hogy épitenén(e)k réája egy kis Isteni Tiszteletre valo Hajlékotskát ... adom és conferálom azon mentionált Fundusatskát Istenünk dítsőségére [Kéménd $\mathrm{H}$; JHb XXXIII/37]; 1768: Lévén itt(en) Gy(ergy)ó Allfaluban edgy kis puszta Fundusotska [LLt 1. A]; 1815: Egy darab puszta fundusotska [Mv; MvLev.].

furfan-csészécske ? 1714: egj Vőrős börrel boritott futrálj, melljb(en) méreg ellen valo furfan Csiszetske vagjon és bőres talatska Indiai figurákkal ékesített [Nsz/ Fog.; REkLt II. Apafi Mihály hagy. 18].

fúrócska 1740: Ōt átalagotska. Hét fedeles Tsere buddonotska ... Harom furutska [Ap. 5 Apor Péter lelt.]; 1757: Kis furucska 2 [Kiskend KK; Ks 71. 52. szám]; 1798: beretva kés xr 2. Kisded sututska xr. 6. Kis furutska xr. 1 [Kv; Pk 6 Pázmány Sámuel hagy.]; 1801: Két kiss bárdotska ... két 
kiss furutska [Mv; MvLev. Tóbiás Antal hagy.].

furulyka ?furulyácska 1811: egy ko (?) patkolo vas Kalapáts ... egy furulyka ... két Abrosz [Jedd MT; LLt].

fuszulykakarócska paszulykarócska $1810 \mathrm{k}$.: (A) Tanú ... egy Malatzot, a' kezében vólt fuszulyka karótskával Maga is a' vizből ki emelt [Dés; DLt 82].

futrályocska tokocska 1714: Elseö Pintzetok foglal magáb(an) Egj Cseh Orszagi Koncha formara valo Üvegett futraljotskab(an) Harom gombotskan alló ugjan Cseh Országi fedeles Pohár futraljotskab(an) a' tobbi öszve zuzott fl. Hung. 3. - [Nsz/ Fog.; REkLt II. Apafi Mihály hagy. 56].

fúvócska fújtatócska 1679: Tűz gerjeszteni valo fuvocska nro. 1 [Uzdisztpéter K; TL. Bajomi János inv. 27]; 1685 e.: az Sido Uczában ... az elso ház ... az más boltban ... vadnak ... Iskatulyas ladacska ... Nro 1 ... Kicsin fuvocska Nro 1 [Gyf; MvRK Urb. 22. 24]; 1788: Nádméz fŏzŏ két fŭlŭ réz medentze és ehez valo kítsín Fuvocska [Mv; TSb 47].

függőcske 1. kis nyakék 1590: Chaki Gabor chinaltatot velem egy arany eoweth ... tudom hogy egy Arany lanczotis chjnaltam es egy fwggeochket melyben a' mint emlekezem ket keo vala [Kv; TJk V/1. 19 Mich. Igyartho Judex Coloswarien(sis) vall.]; 1648: Egy Pellica(n) forma kis fügőcske [Mk Kapi Katalin kel. 1]; 1681: Egy Rubintos Smaragdos kis fügöcske Cupido képe van belé csinálva [WassLt]; 1716: Egy kerék rubintos hat szem gyöngyű fŭggő́cske [WassLt]; 1749: Egy gyemántos fŭggŏtske, ŏt gyemánt benne, jó féle gyŏngy fityegője [Koronka MT; Told. 12/4]; 1786: Egy mászli formára tsinált függőtske 6 kő héjjával [Nsz; Ks 74/56].

2. ? (ékszer) csüngő/fityegő 1697: Egy homlok párta ... fuggŏcskéjen apro Rubint nro 9 [KGy]; 1697: Egy kis arany boglár, egy kis fŭggŏcske rajta [KGy].

fülbevalócska kis fülbevaló/fülönfüggő 1710 : Egy pár filbevalócska, 8 szem gyöngy benne [DanielAd. 92]; 1758: Egy más gyémántos, és Rubintos Arany Fülbe valotska, két nagy Rubint, és 5. 5. Gyémánt mindenikbe [Nsz; TSb 21]; 1768: Két régi
Rubintos Fülbe valocska ... Egy más Gyémántos, és Rubintos Arany fúlbe valocska [Nsz; TGsz 51].

fülecske ?horgocska 1780: Az béres szekérre ... tiz kis pántotskát xr. 06. az vas matskákra tsináltam három lábat tizen egy fületskét nolts font vasbol tsinaltam Rf. 1 xr. 17 [Szászváros; BK].

fülemilécske kics 1811: a' kis Filemile ... Ekként hangitsálta az első Énekét ... Prognébol változott a' gyors szárnyú Fetske, Én pedig lettem a' kis Filemilécske [ÁrÉn. 106].

fürészecske 1802: Olto Fürészetske [Türe K; MkG].

fürjészecske fürjecske 1728: az Aszszony sajtal s Fürjeszecskével valo kedveskedését alázatoson vettem [Darlac KK; Ap. gr. Haller János gr. Kálnoki Borbálához].

fürtöcske 1. hajtincs 1811: a' haja mostani módi szerint el-vagyon vágva, és elŏl egy kis fŭrtetske a' homlokára le-nyulik [DLt 151 nyomt. kl].

2. szőlőfürtöcske 1639: latom az egyik(ne) $\mathrm{k}$ az kezeben vala egi kis firtecz(ke) ... s ragais megh az szemeben [Mv; MvLt 291. 180b].

füstházacska ? kis füstölő helyiség 1753: Ezen ... Pitvarban vagyon egy fŭst házotska melyre nyilik egy sövény ajto [Maroszsztkirály AF; Told. 18].

füstölgőcske füstölőcske 1733: Uj Fedŏtske 5 mazos tserép tálatska 5 ... Talatska 2. Cserép fŭstŏlgetske 1 [Marossztkirály AF; Told. 2].

füvecske 1. valamennyicske fü 1592/1593: az mely porond vetis felet perleódik Serieny Miklos Vra(m) Cristoph Vrammal az soha zent Benedeky ${ }^{\mathrm{a}}$ marhatul ne(m) volt tilalmas ... az mikor fwuechyke volt rajtha zabadon elthe minden barom [Szilágytő SzD; Ks 35. V. 12. - ${ }^{\mathrm{a}} \mathrm{A}$ tőszomszédos Szentbenedek SzD]; 1722: aszt az terribilis őreg Gerendákat 8 ŏkrŭ szekeren kel vinni, és barom kostot ne $(\mathrm{m})$ lesz hová tenni, Tavaszszal lehet affélét vecturázni vgy mikor fŭvecske vagyon [Fog.; KJ. Rétyi Péter lev.]; 1760: mig fŭvetske volt benne azok étették meg az kiknek részek volt benne [Kilyén Hsz; LLt]; 1800: A város 
számára hagyott fŭvetskenek kaszállásáért fizettŭnk -/60 [Torockó; TLev. 5]; 1813: az Gabonainkat és szélin lévő füvetskéinket erőszakkal meg ne étessék [Déva; Ks 117 Vegyes ir.].

2. kaszálócska, rég táj szénafüvecske XVIII. sz. eleje: vagyon edgy kis darab füvetske [Tordátfva U; Pf].

füveskertecske szénáskertecske 1849: Az Udvar ház előtt ... egy Tőlgy sas fákba rakott fenyő fa gerendákkal kőrül kerített füves kertetske [Somkerék SzD; Ks 73/55].

füzfácska XVIII. sz. e. f.: két fiatal Fűz fátska mintegy gyalog karo vastagságuak [Petlend ${ }^{\mathrm{a}}$; AbN. - a A Tordától Kv felé vezető út mellett egykor önálló település, ma kisebb házcsoport].

gabonácska 1. (egy kevéske/kevesecske) szemgabona 1722: Ha megis árra volna az Marhá(na)k, s Gabonácská(na)k mind szerezgetnék keveset kevesett [Fog.; KJ. Rétyi Péter lev.]; 1736: Bongárdon ${ }^{\mathrm{a}} \mathrm{a}^{\prime}$ pénz keresetre egyéb ut mod nintsen, hanem a' kinek márhátskája, gabonátskája van abbol a mit szerezhet még azokbol is nehezen [CU. - ${ }^{\text {aSzb] }}$; 1737: két rend bili Sertesek beritis kérik Erőssen tőllem ... En nekem nincs miből meg fizetnem ha Gabanacskabol meg nem fizetek ez utan [Somlyó Cs; Ap. 2 Léstyán János Apor Péternéhez]; 1754: Ezen fen Specificált Jobbágyoknak ezen Sepcificált Taxához accedálnak ezek: ugy mint két Héti kaszálás, Gabonátskából való Dézma adás [M.gyerőmonostor K; Told. 12/40]; 1808: a' Désen lévő kévés gabonátskám [Kackó SzD; DLt 622].

2. (egy kevéske/kevesecske) gabonatermés 1756: az Báts midőn maga p(re)mendajat kérte ... meg verte Balog Uram azután ... Az Lábát butukban tétette három hétig raboskottatta ... hogy az Gabonája Maléja kün ne veszen az Felesége adot Ba$\log \operatorname{Ur}(\mathrm{am})$ (így!) 6 Marjásokat de ugyan tsak Gabonátskaja s: Maléja kün veszet [Butyásza (Később: Bucsonfva) Szt; TK1 5 r. jb vall.]; 1840: vagynak más rendbéli Haramiáskodó Katonaságok bé hordott Csŭrŏm kŏrŭl lévŏ kevés Gabonátskámat 's Csüröm fŏldjét ujra készek fel tapodni [Dés; DLt 935].
3. csépeletlen, szalmás gabona 1776: Midőn az őszszel kevés Gabonátskámot Csamoba ractam (!) volna ... Valami Sitvei szászok ... otton Nád Zsupot Csinálván ... azoknak nyomakon fel vakargatván az hulladékjaikat, azzal jőttem haza, és ugy ráztam meg Gabonácskamnak Csamoba rakatt tetejét [A.kápolna KK; BK].

gabonáska magtárocska, táj gabonásocska 1825: egj kis Deszkabol Csinosonn keszult gjalut (!) deszka oldalu és fedelŭ kis Gábonáska (!) [Szárazpatak Hsz; SzentkZs Conscr. 365].

gabonásocska magtáracska, rég. táj gabonáska 1747: egy kis gabonásotskát épített [Dés; DLt Liber Inventationis]; 1763: vagyon jó berena Háza pitvaral ... és egy kis gabonasatskával [Felőr SzD; Torma]; 1778: egy egy Marha Pajtátskát vagy egy kis Gabonásotskát tsináltak [Pósa Sz; s 34. VI. 1]; 1802: vagyon ... épület, a melly Három lakhato Házakat ... és konyhát, nem külŏmben egy Deszka padlásu gabonásotskát ... foglal magába [Kv; Pk 4]; 1811: Ágosokra Dészkábol épült édgy Gabonásotska [Mezőőr K; MkG]; 1842: a' pincze felett van égy rongyos szalma fedelü gabonásotska [F.árpás F; TSb 51]; 1773: Egy kis Gabonásatska [Récekeresztúr SzD; Becski].

galambbúgocska 1. galambdúcocska 1750: (A Csicsókeresztúri Torma-kúria) Kapuja ... fenyőszarufákkal szarvazott, fenyőlécekkel lécezett, sendellyel fedett, egy kis galamb bugocska a teteibe [Papolc Hsz; $\mathrm{Hr}$.

2. galambházikó 1750: a tetejen ${ }^{\mathrm{a}}$ fenyö deszkabul csinált kis Galamb bugacska [Papolc Hsz; Hr. - ${ }^{a}$ A gabonásnak].

gallérocska 1576: Egy kamoka hímel waroth kys galerochka [Szamosfva K; JHbK XVIII/7. 15].

garasocska (fél poltura értékű) pénzérmécske 1723: Az apró garasocskáknak bár különböző formája legyen is: a krajczároktól különbözik és kettő teszen egy polturát [SzO VII. 313 gub.].

gátacska kis gát 1751: János Pap úr Gáttya nevezetü Gátotska [Koronka MT; Told. 31/4]; 1764: a' Marosnak két ágai közt lévő porondos és berkes hellyhez nem igen régen 
ragasztatott az utrizált gátatska [Vajdasztiván MT; JHb IX/46]; 1784: Tŏrvénytelen, és Calumniosa a' Querulansok(na)k procedurajok, mert elsobben Malmunk(na)k gatatskaját potentiose el vagták, tollalták s annak utánna kivánnyák a' differentiát Sopiáltottni [Szováta MT; Jeremiás György és Lơrinc folyamodványa (Mt)]; 1805: Kádár Iuon ... kére minket az iránt, hogy ... mennénk el occulatiojára azon Gátotskának, melyet ő ... kőttetett a Cserefalvi határon ... adnánk arrol hiteles bizonyság Levelet, hogy azon Gátotska okozott é valami kárt ... Embereinek Főlgyeikre, vagy nem [Rusor H; Ks 92].

gazdácska kics 1. jó jazda 1763: az én Dobai Györgyöm ... amig ide haza az én kezem alat lakot, olly virtuosus Gazdátska volt, hogy nem tsak a Rettegi hanem mind a kŏrül valo Nemesseg tsudalkozot az io szorgalmatosságan [Retteg SzD; TL. Árva Bágyi Susanna lev.].

2. birtokos 1790: tŏbb Mezŏségi Gazdátskákkal édgyŭtt égy kevés ŏsz buzámnál egyéb Semmim sints [Sztrézakercsesora F; TL. Wessényi Dániel jószágig. gr. Teleki Józsefhez]

gazdagabbacska módosabbacska, tehetősebbecske 1760: Szánto-Főldekre, és Széna retekre nézve mellyik részre jutott jobban nem tudjuk. De Marhásabb és gazdagabbatskák, és jobb Gazdák mentenk (!) Mlgos Groff Bethlen Győrgy Vr ö Nagys(á)g(ána)k [Somkútpataka/Kővár Szt; KS r. tanú vall.].

gazdaságocska kics gazdaság 1793: azon alázatossan instálok Nsgodnak gazdaságotskájok fojtathatásában Méltoztassék hozzájok grátiát Mutatni [Kályán K; JF 36 LevK].

gazocska bozótos helyecske 1728: körülötte vagyon azon halmoknak egy darab gazocska [Maladé Sz; BfN].

gazosocska kissé bozótos 1761: a' Rét nehol gazosotska lévén irtógattam ... egy Bogjatska szénára valot [Illyésfva Sz; BfN 45/9 Brállya Maftyéj (48) zs vall.].

gerebenecske kics gereben 1836: edgy pár Ujj modi Drot fogu gerebenetske [MNy XXXVIII,132]. gerendácska 1589: Egi kwfeoldi (!) emberteol veotte $(\mathrm{m})$ egi gerendaczkat d. $8[\mathrm{Kv}$; Szám. 4/X. 58-9]; 1594: vőttünk ... vgian Ezen Hidaczkakra Egi ttollgi (!) ... d 15 gerendackanak [Kv; Szám. 5/XXVI. 22]; 1732: Az udvar felŏll valo kŏz kert mellett vagyon edgy hoszszu, szalmával fedett tőrŏk buza kas, mely hat fŏldb(en) ásott ágasokra, nyujtott gerendátskakra veszszŏvel font [Erdőszengyel/Szentjakab MT/SzD; TSb 51]; 1754: az Hazocska alá Nagy Gyorgy ... gerendaczkakat vonagatot pitvarat maga tsinalta Tapogatassal s fedellel [Dés; Hr 5/27].

gerendafácska kics 1595: vöttem Ezen Brett fü kis higiahoz nigy gerenda faczkatt [Kv; Szám. 6/XV. 64].

gereznadarabocska szőrmedarabocska 1576: Egy giolch Sachkoba walamy gywlwez walamy postho zel igen Roz walamy gerezna darabochkak es walamy Nest fark es egy nehan orso [Szamosfva $\mathrm{K}$; JHbK XVIII/7. 9].

gírácska átv talentumocska (szerény tehetség) 1636: igyekezetem az vólt mindenkoron, hogy én-is az én Istentol kezemben bizatott Giratskával vagy kereskedhessem, vagy jó szólgának találtassam [ÖGr 3 I. Rákóczi György sk aláírásával zárt előszóban tett nyil.].

golyóbiska puskagolyócska 1666: Syskáka és szakalloshoz váló vár golyobisok ... Golyóbiskák [MNy XXXVIII, 133. - 'A közlésben sajtóhibával].

gombocska 1. 1588: Vagyon tizenhat Apro gheombelegh Gombochkak kopot Araniasok (így!) [Kv; KvLt Inv. I/2. 13]; 1776: Hét Lot Ezűstből állo Gombotskák [M.köblös SzD; RLt O. 1. 34]; 1785: kis gombotskaert - 30 [WLt Cserei Heléna jk 10a. - ${ }^{a}$ Értsd: dénár]; 1807: lájblira valo gombotskák [Körtvélyfája MT; LLt].

Szk: aranyfonal 1711: Egy fejer Scárlát Dolmán, az allyán fejer Viragokra aranyassan szütt béllésü apro arany fonal Gomboskák rajta [Told. 19]; 1714: Baraczk szin Seljembul valo Dolmanj az uyan ... 16 aranj fonal gombotskakkal, es annyi követskékkel ékesitett fl. Hung. 24 [Nsz/Fog. $\mathrm{AH}]{ }^{*}$ ezüstskófium 1759: Égy szederjes sima bársony Aszszonyi mentét ... ezüst 
szkofium gombocskákkal meg gombozva [Nsz; TSb 7] * fejérezüst 1682/1687: Attam Egi Uy Angliai Ueres Mentett, Ez is uolt megh premezue egi rend feier ezüst galonnal, Tizen Niolcz feier ezüst gombocskak raita [Fog.; Borb. II Rákosi Anna kel.]. 2. gömböcske 1596: Vagion Negy nyoszolya kettey himes az eggyknek gombochkak raytha aranyasok, az masik rakot az feyetewl [Kv; RDL I. 65]; 1714: Korbatsotska het szegletes Kristaljomos nyelével, mind a' ket végén arannjal boritott $s$ alab valo Türkesz követskekkel ki rakott, ostorocska penig arany s ezüst skofiummal boritott s aranj Scofium, apro gjöngjekkel ki rakot gombotskaval ekesitett fl. Hung. 30 [Nsz/Fog.; AH 36].

3. kivonó ablakgomb 1764: Egy ablak rámákra szegeletes Sorkokért, által foglalo vesszőkért, kivono gombocskákkal és bezáró forditokkal 1 Rfl. 8. xr. [HSzj által-foglaló-vesszô al.].

gombolyácska gomolyácska 1748: Gyapot fonal egj Gomboljátska [Nagyida K; Told. 11/95].

gombolyagocska vhány gombolyácskányi 1746: Egy kis gyomboliegocska ${ }^{a}$ czérna [Vargyas U; DanielAd. 255. - 'Így az eredetiben, de nyilvánvaló tollvétség g-s szókezdet h.]; 1840: Egy gombolyagotska fonalat Eperjesi Mihalya [Dés; DLt 456. aTi. vett meg].

göcsöcske 1. göböcske, csomócska 1852: a' hol a kőnyőke van hátul egy kitsin götsöske vagyon [Dés; DLt 1066].

2. kb. dudorocska 1827: Ezüst kapocs, mellynek karimája négy ezüst götsötskékkel ki van tzifrázva [Kv; DLt 1156].

gödröcske 1. vápácska 1742: Vagyon egy Gödrőtskeis ... egy szekér széna termő [Kincsi KK; SLt 8. K. 15]; 1745: az ŏsvény kŏzŏtt való gŏdrŏtskén [Nagyida K; Told. 9]; 1817: egy gazos bokros gödrötskébe találla [Dés; DLt 18].

2. (ásott) üreg 1779: (A) Széna Fŭnek szomszédgya ... Marton Ferencz ... Széna Fŭvecskéje, s, vagyon az Szélyiben egy ostormény Fa Bokorhoz csak két Lépésnyire egy Gŏdrŏcske [A.szovát (Késóbb: M.szovát (K) egyik része) K; JHbK VI/17];
1800: El foglaltunk egy Czihert ... Az Erdő farka nevü hellyen ... határozván ezen tzihert ... mind a' két felől gyakor - ásott godrötskék is [Csekelaka AF; KCsl]; 1842: égy gödrötskét ás [Dés; DLt 85. 10].

3. állon lévő mélyedés 1812: Liebenberger Antalnak ... az állán égy kis gŏdrŏtske láttatik [DLt 254 nyomt. kl]; 1815: Chilipp nevezetŭ Gonosztévŏnek ... fejér veressel elegyitett ábrázatú, hegyes állú, mellynek kŏzepén egy kis gŏdrŏtske vagyon [DLt 96 nyomt. kl].

gömbölyegvas-rudacska 1699: a Sütő hazb(an) ... paraszt kalyhakbol valo tüzelŏ kemencze az allyab(an) edgj gŏmbőlyegh vas rudacska van fel alva [O.csesztve AF; LLt. Gyulafi László inv.].

görbécske egy kissé görbe 1815: két hátulso lábai gŏrbétskék [DLt 481 nyomt. kl]; 1820: Básta János ... Silesiai 38 esztendŏs ... hegyes görbetske orru [DLt nyomt. kl].

görcsöske bibircsó, bibircsók 1830: az orra eggyik felén eggy gőrtsőske láttatott [Kv; KLev. 8].

grádicska lépcsőcske 1681: Vajda Hunyad Vára ... Templom fölött levó Kö Ház; a. fellyeb irt deszkas folyosorul ezen haz ajtajara jaro garadiczka fabul eppettetett [Vh; VhU 502, 551].

grádicsocska 1. lépcsőcske 1699: fel menénk ed (!) fenyō fakbol valo gradicsocskán ezen Pitvarnak és házaknak hijjára edgy kis Vas sarkokon pantokon forgo reteszes es retesz fejes ajtotskán [O.csesztve AF; LLt]; 1736: Tornátzos Gabonás Ház, mellyre hágnak fel Tserefábol készŭlt graditsotskán [CU]; 1743: egy tiz foku vagy lépcsőjŭ csere fábol valo karfás gráditsotska [Boroskrakkó AF; BfN dobozolt anyag VI]; 1772: Ezen Epületnek égy Ajtaja nyilik nap keletről, mely Ajto előtt négy fogu fenyőfa Dészkábol valo Garaditsatska vagyon [Szászfenes K; BethlenKt Mikes conscr.]; 1816: Az palotanak ajtaja megett fenyŏ deszkákbol készült garádicsocskán ... bé mehetni az Nappali Szobába [Jobbágyfva MT; Bál. 67]; 1842: Ezen gabonás elein van, minden oszlopok nélkül égy tornáczotska ... ezen tornáczra égy három léptsőből állo gradicsotskán van a feljárás a' gabonásba [Oprakercesóra F; TSb 51]. 
2. lépcsős feljáró 1680: (A pince) gator(na) k ket felŏl valo oldalán megjen fel egy gabonas hazra ket karfás garadicsocskák (!) [A.porumbák F; ÁLt Inv. 30. - ${ }^{\mathrm{a} M e g k i ́-~}$ sérelték a végső $\mathrm{k}$ törlésével egyes számú alakra javítani]; 1852: az udvarra feljáro gradisatska mely fábol fa leptsŏkbŏl volt készitve elromlott [Dés; DLt 1248].

Szk: feljáró 1744: (A gabonásnak) Vagyon tágos tornáczocskája deszkával meg berelve, három foku fel járo gradicocskája [Ádámos KK; JHbK XXVIII/10]; 1772: Az Tornátzban sendely fedél alatt égy fel járo garádicsocska vagyon, mellynek két oldalai bé vadnak felignyire szegezve [Szászfenes K; BethlenKt Mikes conscr.].

gránátszoknyácska posztószoknyácska 1576: Wagion kesken granath zoknyachka Alyara walo [Szamosfva K; JHbK XVIII/7. 15].

granumocska szemcse 1757: Kérdés támad ez iránt is: Ha az az vizek folyamatiban talalhato Arany ott termetté, vagy Mineralis Hegyekből devolvalodat oda? ... az illyen Arany többire korpa forma lapasotska, mert az hoszszas kövek közt valo devolutio es attritio által, az eredetekor gőmbőlyeg granumotska hogy meglaposadik opinione mea ac aliorum mélto a' hitelre [Zalatna AF; JHb. Borsai lev.].

gúnyácska ruhafélécske 1727: az én halalos betegsegemb(en) mellettem forgolodo $s$ hiven serenkedő Cseledim(ne)k legjek szabados Testalni Tiz Tizenkét farintokat, vagj egjeb Gunyácskát [Gyf; JHb XVI/1]; 1829: kéntelen voltam a mi kevés gunyátskám volt el adni hogy elhessek [Dés; DLt 246]; 1845: a' mi gunyátskát ... szerezhetett [Dés; DLt 591].

guttácska enyhe/gyenge szélütés Szk: meglegyinti a 1851: Sala Farkas is tegnap eret vágatott magán ... mint ha nyelvét valami kis guttátska legyintette volna meg, alig tudott hebegni [Kv; Pk 7].

gyakorcsa ?sürücske 1705: ezen Falu határán Apró gyakorcsa nevü hellyen [Altorja Hsz; Borb. II].

gyalmocska kerítóhálócska 1717: most ujjolag el kủldőttem edgy gyalmoczkámot Méhesre $^{a}$ ha valamit tehetnének vélle, hogy Sogorkáimnak is succurrálhatnék a bőjtre, itt pedig éppen Szűkösök vagyunk friss hal dolgabol [Darlac KK; Ap. 2. Haller János Apor Péterhez - ${ }^{a}$ Mezőméhesre (TA)].

gyalogajtócska 1736: Az ... udvarrol ... vagyon aditus ... Csinosatskán faragott ... fenyő deszka kapun rajta lévó kis Csekélly két vas Sorkokon forgo vas reteszszel zarlodo gyalog ajtotskaval egyetemben [Várhegy MT; CU]; 1742: Azon ... Curiának Vass sorkokon forgo két felé nyiló regi fenyŏ deszkábol epŭlt kapuját találtuk, mely kapunak is a bal kézre nyilo felin ki jaró gjalog ajtocska is vagjon [Gyeke K; Ks 4. VII. 1]; 1753: vagyon a Curialis Sessiora be nyilo kétt Cserefa kapu fél fák kőzőtt Sővényből fontt avatag egy felé nyilo kapu, égy Gyalag bé járo fa Sarkakan forgo Bikfa deszákbol készitetett ajtacskájával együtt [Sajókeresztúr SzD; JHbK XXIX/7]; 1791: vagyon bémenetel az irt nobilitaris curiara égy toldott cserefa kapufelekre alkotott, avadag fenyődeszkából való, zsendellyel fedett galambbúgos, égyes nyílású kapun, melynek nyílásánál vagyon égy törpe gyalogajtocska [Ludvég K; ETF 208. 13].

gyalogfogasocska falifogasocska 1761/1818: két hoszszab és egy kisded gyalog fogasotskák [Marossztkirály AF; CU].

gyalogkapucska kisajtócska 1669: Ezen haz szegeletiteŏl fogva az derek hazok alat valo kapuczka melynek ajtaja Vas sorkon forgŏ fa kilincz rajta [Királyhalma NK; Ks 67. 46. 24a]; 1716: Vagyan ezen fen Specificalt Grid nevü Falunák oldalában egy ... Nobilitaris Curia melyre nyilik nap nyugotrol egy felszeres Gyalag Kapucska tőlgy fa mellyekivel és fedetlen Gerendával [Grid F; BfN 92/4]; 1732: az Uczára járo kapŭ... Sendelj fedél alatt cserefa ajtó melljékeken állo két gyalog kapucskákkal [Kóród KK; Ks 12. 1]; 1763: Ezen udvarba ... két felé nyló nagy kapu mellett lévő gyalog Kaputskátol tsak három Lépésnire' ... adgya elő magát egy kőből kirakott Kut ... a Veteményes(ne)k ... dél felöl valŏ szélyin ... palánk vagyon; melynek falai kŏszt egy kis gyalog kaputska is van [Hortobágyfva Szb; Born. XXIX/19. 16 néhai Hortobágyi Gergély György összeír.]. 
gyalogkertecske kb. alacsony kerítés 1721: egj hitván darab gjalog kertecske vagjon egj végben [M.gyerőmonostor K; KCsl 5]; 1730: Elebb menuen iobb kezre van egj kis gjalog kertecske ragasztva a hazhoz [Szemerja Hsz; HszjP].

gyalog-kőhidacska 1593: Az ouarosban vallo folliamra ... Egi giallag ku Hidaczkatt czinallttatta(m) [Kv; Szám. 5/XXIV. 5-6].

gyalogösvényke ösvényecske 1753: helyben hagyom és approbálom ... azon gyalog osvénykének békerteltetésit [Koronka MT; Told. 19. 9].

gyalogpadocska kicsi pad 1729: Egj keskenj Agj elŏtt valo gjalog padacska [Marossztgyörgy MT; Ks 23. XXIIb].

gyalogsajtócska kis szőlőprésfajta 1744: a Kapu tornáczában találtunk egj Gyalog Sajtotskát cum suis appartinentiis [LLt Fasc. 67].

gyalogszánka kéziszánkó 1772: a Gyertyánosbol ... hoztanak fát haza Maftye fia Vonul gyalog szánkával Rátz Pistát is ... láttam [Dés; DLt 321. 82b]; 1783: ketten ... két Gyalog Szánkát meg raktanak fával s el hozák [Kissáros KK; JHb XX/8. 20]; 1783: Kiket látott ... hogj ... Szekérrel, szannal, hatakon vagj gjallog Szánkákkal Tüzi fát ... hordottak volna? [Kük.; JHb XX/8. 3 vk]; 1836: Egy gyalog Szánka [Dés; DLt 905].

gyalogszánocska kéziszánkó 1756: Tudom bizonyosan hogy meg nevezet Makkolo Erdŏbŏl Beretzk András és Kováts Joseffel edgyŭtt ... sŏtt egykor énis ... oda menven egy kis gyalog Szánotskával onnet hoztam, réám találván Beretzk András azon Erdŏben gyalog Szánatskámmal fat hozni [Bácsi H; KB Joanes Onadi de eadem (53) $\mathrm{nb}$ vall.].

gyalogszékecske kisszékecske 1770: Gyalog Széketske Nro 2 [M.királyfva KK; Ks 23. XXIIb].

gyalogszekerecske kéziszekerecske 1732: Bihalos taliga 1. fa hordo gyalog Szekerecske 1 [Szentbenedek SzD; 40. XXVIIIc].

gyalogtékácska (fali)szekrényke 1737: négy darab paraszt gyalog fogasok vagy(na)k oldalaira vas szegekkel fel szegezve, egy paraszt gyalog Tékátskával edjütt [Szép- lak KK; CU Petrichevich-Horváth Boldizsár Conscr.].

gyalogutacska ösvényecske 1794: a Csontás, vagy gyalag utatska [Búzásbocsárd $\mathrm{AF}$; EHA].

gyapotasztalkeszkenőcske 1789: gyapot Asztal keszkenőtske [Abásfva U; EMLt].

gyarlócska kb. ostobácska 1764: Maradtanak gyermekei is ${ }^{a}$, de gyarlócska lévén az aszszony, amint láttam neveléseket, nem hiszem egyik is apja fia legyen [RettE 178.

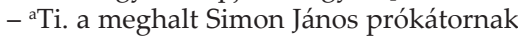
és Ponori Krisztinának].

gyémántocska 1. gyémántszemecske 1652: Egy Kis veress skatulyacskab(an), ket arany gyŭrŭk egyikb(en) ket gyemántocskák [Nsz; IB X. 2 Bethlen István lelt.]; 1685: Ket Arany gyürü, edgykb(en) 3 gyémántoczka [Berz. 2. 27/29]; 1757: Egy kis Gyémántocska [Jobbágyfva MT; BálLt 71]; 1766: 'a boglárokban két Gyemántotska [Szárhegy Cs; LLt Fasc. 96]; 1786: Egy Medajotska 24 rubint benne és 4 gyémántotska [Nsz; Ks 74. 56]; 1786: Egy reszketö tő hét gyémántotska benne 8 rubinottska kőzepibe egy nagyotska rubint két felőll, a függője egyik rubint, a másik gyémánt. Más reszkető tő 14 gyémánottska benne a kőzepin egy nagy Smaragd a függője is egy Smaragdotska [Nsz; Ks 74. 56]; 1798: Más Keresztes fejü Zamántzos aranj giürü, ă kőzepibe egj négj szegü gjémántatska, kőrülette négj felől rubint $[\mathrm{Kv} ; \mathrm{Pk} 6$ Rázmány Hedviga hagy.].

2. Jelzői haszn-ban; gyémánt kövecskékkel ékesített/rakott 1716: Vagyon azon ladacskab(an) öt aranyban foglalt gyemántocska tô aprolekos fŭggókbül hulladozott rubintocskakkal egyŭt [WassLt].

gyengécske 1. kissé gyenge 1806: delelöt gyengétske voltam delutannis, egyszer víszsza adták a Letzkémet [Dés; Ks 87 KMN 198].

2. rosszacska, hitványocska 1832: Az Ajtoja ${ }^{a}$ egy felé nyílo - gyengetske [Sárom-

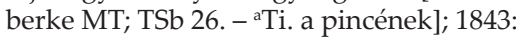
látván hogy a Bakkan Kupfer van ... fel bontattuk, gyengetske Lakatját ő a kezivel le fotsarván, kŏvetkezőleg a ... talált portékákat ki vettŭk [Bágyon TA; KLev. Török István (26) vall.]. 
3. gyatrácska 1765: ă Termes pedig gyengebbetske [Náznánfva MT; Berz. 13. V. 12].

gyengécskén 1. kissé legyengülten 1822: Vére el folyása miat Gyengétskén talaltam [KLev. 15].

2. van gyengélkedik 1724: Laczika csak fajtattya az Lepit bizony gyengecskén vagyon [Nyújtód Hsz; ApLt 2 Apor Péter feleségéhez].

3. egy kevéssé egy kissé gyengén 1759: Hatházi Czilika ... hogy a' rudat ezen földre le ne fektethesse, egy kevéssé gyengécskénn mellybe megtaszitotta ... Marusán Gavrila [Árpástó SzD; BK].

gyepcseglyecske ék alakú parlagföldecske 1745: A ... vizmosáson és az óldalon fekŭvŏ szántó fŏldek alsó barázdája kŏzŏtt maradott keskeny gyep cseglyecske le felé hasadva ... juta Fŏldvári Ferentz Ur(na)k [Told. 9].

gyepecske gyepes földterületecske 1669: azon lekencze mellet keskeny ala jaro gyepeczke [Mezősámsond MT; Berz. 5. 41. S. 10]; 1690/XVIII. sz. köz.: Ez földek vegeben ... ket gyepetske [M.fodorháza K; RLt].

gyérecske ritkácska 1803: Ezen szőllő csutkos gyeretske, nem igen jól mivelt [Koronka MT; Told. 23]; 1823: a' Rosunk gyéretske, de ha az Isten szemmel meg áldaná alkalmosint gyűlne gabonánk [Veresegyháza AF; Told. 7].

gyérecskén ritkásan 1813: egy Csűr vagy szekér szin, az oldalai sővénnyel gyéretskén bè fonva [Koronka MT; Told. 18].

gyerekecske gyermekecske 1800: azonn gyereketskének fürt haja ... kezébenn maradatté? [Dés; DLt].

gyerkőc gyermekecske 1838-1845: járni kezdett a gyerkőc [MNyTK 107].

gyerkőce gyermekecske 1838-1845: Purkuj, porunkuj" (: a román „prunk, prunkuc = gyerkőcével egyeredetü" :) [MNyTK 107].

gyermecske gyermekecske 1570: Bak Matthias ... vallya, hogy egy nap Regwel haza Ment volt, es egy gyermechke eo zolgaya Mongia Neky ${ }^{\mathrm{a}}[\mathrm{Kv}$; TJk III/2. 18. 130c. ${ }^{a}$ Köv. a nyil.]; 1585: Repas Mihaly Nem tuggya minemeo Allapatbely volt Zent Kiralj Andras ... Az felesege sokaigh az Vra holta Vta(n) ige(n) zegenyul éle egy giermechkeyewel [Kv; TJk IV/1. 428]; 1603: Zabo Miklos ... vallia ... Nyreo Mathenak az eo tercialitassaba adiudicaltak volt az Arbiterek f 15 d. 66. Ezenkeowl ezen azzontul valo Nyreo Mathenak germechikeienek portioiat [Kv; TJk VI/1. 645]; 1732: János nevü gjermecskejeis ott lévén ugj meg ijedett hogy talan Ember Soha nem lészen belőlle [Dés; Jk].

gyermekcse gyermekecske 1688: Egy itt quartelyozo Lutheranus németnek, recens natus, és ige(n) beteg gyermekcsejét ... meg kereszteltem [Bethlen (SzD) kör.; UtI].

gyermekecske kisgyermek 1681: Udvarhelyszéki Uarosfalui Cziki Balas es Cziki Janos Lofŭ szemelyek ... szollanak òkis Biro Istuan Urunknak, hogy ... adna megh eo Kegyelme anny penzt, az menyuel edgy borius tehenet uehetnenek azon Marko Borbaratol aruasaghra hagyatott kiczin gyermekeczke tartasara [Borb. II]; 1722: ā Gyermekecskénk igen el fogjotkozott [Fog.; KJ Rétyi Péter lev.]; 1759: én magam cir(citer) Tiz vagy Tizen egy esztendŏs voltam, a' tŏbbi Testvéreim pedig apro futkoso Gyermeketskék [Girbó AF; JHb Szász alias Bágyu Dumitru (70) vall.]; 1764: kezében lévŏ kis gyermeketskéjét le teszi [Nagyida K; Told. 78]; 1791: a' gyermekecskét magamhoz hivtam [Bács K; RKA].

Szk: csecsemő/szopó 1724: Rusz alias Hafrik Mihállynak az Anya ... bé jŏ az Atyám házáb(a) egj kis csecsszopo Gyermekecskével a karján, es kérdi az Anyam ... hol vetted menyecske ezen kis Gyermeket [Nagykájon SzD; BK Kiskájoni lev. Czermure Iuon (46) jb vall.]; 1749: az Ik ... romladozott házok meg gjuladván ... edgj ártatlan tsetsemŏ gjermeketske is szomorán meg holt [Torda; TJkT III. 265].

gyermekleányka serdülő leányka, bakfis 1759: ezek(ne)k jobb resze az árva Gyermek Leanykáje [Marossztgyörgy MT; Ks 67. 48. 81].

gyermeklovacska egy-hétéves hímcsikó 1653 u.: Gyrokonak, ha ki akarja tôlteni az Inas esztendeit tartozzanak katonaságra felkésziteni: ha pedig nem, egy gyermek lovaczkat adgjanak nekj [JHbK XLII/3 
Kovacsóczy Zsuzsánna végr.]; 1736: T. Biro Ur(am) kezére ment fel fogott marhát modo legitimo adván Mlgos Bánffi Dénes Vrffi Tisztartaja egy seregély szürke szŏrŭ harmad fŭre meno Gyermeklovacskát, s azon Gyermek lovat T. Biro ur(am) az Város Menessére kŭldvén és ottan megtalálván Marton Birtalan Civisŭnk ... mind hárman ... fateallyák hogy a praedeclaralt Gyermeklo tulajdon Márton Birtalan igaz marhája [Kv; TJk XV/12. 40]; 1741: egy harmadfü Sárga szőrü gyérmek lovacska [Mocs K; JHbK XLIX/25]; XVIII. sz. köz.: Nehaj Czutak Janos is adot vala egi giermek louaczkát [Impérfva Cs; BCs]; 1754: Tavay őszszel jőttem égy alkalmatosságal Szasz Janossal ... égy Pej Gyermek Lovatskát vezet vala magával [Káptalan $\mathrm{AF}$; TL Béres Petru (26) jb vall.].

gyermekpásztorocska bojtárocska 1767: minden ide valo Lakosak valakinek tulkoi, és arra valo Gyermek pásztoratskájok volt ... az kérdésben fargo őkőr Tilalomba választás nélkül Jártották [Burjánosóbuda K; JHbK LVI/5. 21].

gyertyatartócska Szk: ón 1732: Két ón magos Gyertya tartocska koppantoval vassal [Kv; Ks Kornis Zsigmond let. 31].

gyolcskeszkenőcske gyolcskendőcske 1576: Wagion egy galos gyolch kezkenyechke Selyemmel waroth [Szamosfva K; JHbK XVIII/7. 7]; 1847: egy győlts (!) csipkés keszkenőtske [UnVJk 11].

gyolcsocska gyolcsdarabocska 1659: Ket darab Angliay poszto Angliay Teorők mente ennek maradekia ualamy darab gioczoczka [Cssz; LLt 118 Litt. C].

gyóntatópoharacska ref úrasztali/vacsorai poharacska 1728: Vagjon egj ezŭst gjontato poharoczka [Sepsisztkirály Hsz; SVJk].

gyöngyöcske XVII. sz. m. f.: hajra valo hajlott Agaczka, melyben vagyon kilencz Rubint és harom szem győngyőcske [Klobusitzky lev.]; 1714: Egj Par Sveciai Kesztjŏ arany Szkofiummal ki varrott s apro gjöngjötskekkel ki rakott fl. Hung. 3. [Nsz/Fog.; REkLt II. Apafi Mihály hagy. 23, 37].

Szk: jóféle drága/igazgyöngyöcske, keleti gyöngyöcske 1703: egy egy kicsin arany boglárotska, mindenik boglaron negy negy szem jo fele gyongyoske [LLt Fasc.
115]; 1771: Egy kis Boglárotska két jo féle gyöngyőtske benne [Nagyida K; Told. 19].

gyúrótekenőcske 1758: három gyuro tekenőtske [HSzj gyúró-tekenyő al.].

gyümölcsfácska 1694: Vannak itt hol mi Gyumőlts fatskak is, melljeket tsak az ott lakos sellérek usual(na)k [Borberek AF; BfR. Néhai ifj. Bálpataki János hagy.]; 1756: Libertinus Regeni Kis Győrgy Uram ... Titt. Vásárhellyi Kata Aszszonynak adá zalogban a Nagy Enyedi Határon ... levö ugyan puszta szölö földjét rajta levö nehány gyümölts fatskáival egygyütt [Ne; DobLev. I/271. 1a].

gyümölcskertecske 1654: Apaczy Janos ... Gyümŏcses kertecskeje [Szásznádas KK; Ks Bánffy Anna urb.]; 1758: A Kőzép oldalon egy gyümőltsős kertetske [Bh; EHA]; 1777/1780: vagyon ... egy őss Curia ... egy Contiguitásban lévŏ Gyŭmŏltsŏs Kertetskéivel edgyŭt [Alparét SzD; JHbK LII/4]; 1781: egy kitsiny Gyümöltses Kertetske [Mákó K; Hr]; 1783: Vagjon gyümöltsüs Szilvás, és veteményes kertecske [Nagyrápolt H; JHb XXXI/28]; 1820: Az Also Gyŭmŏltsos Kertetskében vagyon egy Lábnyi Vastagságu ép olaj Fa [Páncélcseh SzD; Becski].

gyümölcstálacska gyümölcsös tálacska 1651: Apro festet Gyúmőlcz Talaczka Nedgy. [WassLt Wass Judit kel.].

gyürücske 1582: Giulay Eothweós Jstwan ... vallia ... Egczer Baba Istwannehoz chak be menek boros valek az Azzonys ${ }^{\mathrm{a}}$ hat ot vagion es vgy Adek eg Gywreóchket chak Io akaratomba Neki [Kv; TJk IV/1. 68. aTi. Thwri Pálné]; 1628: egy gyureocyke p. f. 3/50 [Kv; RDL I. 123]; 1651: Egy kŭs Czipkes forma gyŭrŭ... Mas edgy gyúrüczke, edgy túrkeseczke vagyon benne ... Edgy Sas kóróm formara czinalt gyúrúczke edgy vekoni Tabla Gyemant benne [WassLt 72/2 Wass Judit kel.]; 1669: nyoltzad fel nehezek ezwstit ... eleven az Ceh ladajab(a) teotte az Inasnak ket gywrwczkejevel egyŭt [Kv; ÖCJk]; 1700: Egy láncz forma gyenge gyŭrutske egy szem gyóngy a tetejib(e)n [Hr 1/20]. 
Szk: gamahós 1637/1639: Egj Gamahos más gjúrücsjke nyo(m) Aran(yat) 2. ort(ot) 1. f. 4 [Kv; RDL I. 111].

hadacska kis hadsereg 1619: (Szkender pasa) azmely hadacskával az ozi varra csináltatni ment vala is, az is eloszlott régen, maga Szilisztrán vagyon [BTNª 374].

hágócska meredek oldalacska/meredek utacska 1763: a' Pétris nevű hágotskán alol [LLt 302. B].

hajacska huzatocska 1625: egy kekes derekaly hajaczka viselt toldozott f. ./. $20[\mathrm{Kv}$; RDL I. 126]; 1734: Egy Sahos Abrosz. uj, két kis fekete selyemmel varrott vánkos hajacskák [Kv; Pk 6].

hájacska 1685: Szalonnát láttam ... kettőt egy hajjacskát [A.szilvás H; Kath.].

hajdúvároska 1662: Az olah vajdák ... Váradnak délről Szentmárton ${ }^{\mathrm{a}}$ nevü hajdúvároska alatt s határában olly helyre szállottak vala, hogy csak az álgyúgolyóbis a várbul reájok ne érhetne [SKr 447. - ${ }^{a} \mathrm{~A}$ Váradtól délre fekvő Pusztasztmárton].

hajóshidasocska ?kompocska 1806: Az altal járo Pallo hellyett készittetett Hajos Hidasotska akkora ... hogy abban ket ŏkŏr Szekérrel bele férhetne [Oroszfalu MT; Born. XVI Páskuj (48) vall.]; 1806: Valakik a' fennebb emlitett Helységekbŏl a Szász Regeni Hajos Hidasotskán szoktanak járni ... a' Vizek miatt kerulnenek inkabb a Vetsi Hidon [Szászrégen; Born. XVI. 91 Kádár János (63) vall.].

halastócska haltartó (tavacska) 1681: Vizi Malom ... eze(n) malom mēllett, mindgiart a malom haz felső végenel ighen szep halas tóczka lehetne; melyben ā vizet csatornán vehetnék ... ebb(en) mindenkor friss halat tarthatna(na)k [Brettye $\mathrm{H}$; VhU 593-4]; 1699: a Sütő István kertiben szalma es tővis fődel alat sǒvenyből font kertel bé keritve égy kis hal nélkűlt valo bŭk fábol fel rot halas toczka hal nelkűlt, mellybe mennek bé kis bűkfa ajton [Szentdemeter U; LLt Fasc. 35]; XVII. sz. e. f.: ásott 18 1/2 öllnyi keskeny halas Totskának felsŏ véginél [Petlend ${ }^{\mathrm{a}} \mathrm{TA} ; \mathrm{AbN}$. - ${ }^{\mathrm{a}} \mathrm{Ma}$ csak kisebb házcsoport]; 1739: eŏ Nga Lab főldinek az vége az falu felől tovab nem ment ezen élecskénel az hol móst allunk ezen Halas Tocska arányaban [Mocs K; JHbK
XLVII/24]; 1753: a Maros Parton Vagyon tölgy fa Sass fákb(an) boronákkal fel rott halas tocska Sorvadozolag lévő lészás kertel körül véve [Marossztkirály AF; Told. 18]; 1783: Vagjon kőzel az Udvarhoz a Maros mellett jo kertben véve halas Tocska, vagj inkább hal tarto Nro 1 [Branyicska $\mathrm{H}$; $\mathrm{JHb}$ XXXI/28]; 1790: Látom most, itt ezenn két Halastócskákat [Báld K; BLt].

halmocska határdombocska 1592/1633: (A földnek) egy feleol hatara az hegjen fen egy kis halmoczka [Gyeke K; Ks 90]; 1674: jutot az falu helynel ... az Aszszonyok(na) k egy szelben harmincz egesz rud: melylyet az ott hanyot apro halmoczkakkal hataroztanak el az Daczo Uramek reszetŏl [Gyalu K; SLt AK 4]; 1728: ott vagyon két halmacska egymás mellett [Maladé Sz; BfN]; 1746/1831: ezen két ut a' hol két felé kezd ágozni, ottan ... hányattunk egj Halmocskát [Szentdemeter U; EHA]; 1755: az uton kivűl tsak közél egy máshoz ismét tsinálának két halmotskát [Nagygyeke K; Ks K. 80]; 1791: a Fogadonál lévő Felső lábat ... keresztúl méretvén ... két végin, ugy kózepin is kisded halmatskákkal mindenik részt meg kủlőmbőztettűk [Szászsztlászló TA; JHbK XXVI/10].

hálócska 1679: Lisztes Ház ... Szakadozott, rosz haloczka nro 1 [Uzdisztpéter K; TL. Bajomi János inv. 61].

halomdombocska határdombocska 1727: egj halam dombocska [Vajdasztiván MT; JHb IX/7].

hálóövecske 1687: Egy kis igen el viselt Zŏld selyem halo ővecskét [Déva; Szer.].

haltartócska 1616: Egy hal tartoczka is vagion az haz alat, kinek vize egy beŏ forrasbul jeő ki, czak mellóle [Náznánfva MT; Berz. 13. II/2]; 1640: Maros Szekben Szent Laszlo nevű falu hataran az hal laknak (!) dugatot fel egy kis haltartoczkat [Sár.]; 1746/1831: a' Falu között való Hal tartócska [Szentdemeter U; Told. 38].

hambárocska 1763: 1 Hambarotska [Kv; TJk XVII/1. 17]; 1780: Vagjon az boltban egj 3 rekeszŭ Hambárotska [Kv; Pk 6]; 1849: vagyon egy avas Hambarotska ... Fedele alól Nád felöl pedig vinyike [Nagypacal Sz; Berz. 8 Fasc. 72]. 
haranglábacska 1. 1727: Az Udvar kőzepiben ... egj simplex tôlgj fabol valo puszta fedél nélkűl valo Haranglabatska vagjon [Csákigorbó SzD; JHbK XXVI/13. 12]; 1752: a reformata religion lévő emberek égy haranglábocskát emeltenek [Szentlászló MT; EHA]; 1784: a nemes unitária religion lévő becsületes atyánkfiai megavult és elrongyollott, régi, kicsin haranglábacskájok helyibe újat és nagyobbat is kívánnak épitteni [Kőrispatak U; ETF 107. 34. - A teljesebb szöv. a harangláb-hely al.]; 1789: Egy nagyobb Harang ... vagyon a ... Haranglábocskában [Abásfva U; EMLt]; 1844: A csonka fatorony a kŏzelebbi szelek alkalmával erőssen megrongáltatván, kötelességévé tétetik az egyház előljáróinak, hogy ... ha a harangok többé veszedelem nélkül abban fenn nem állhatnak, levétessék s égy haranglábocskára emeljék fel [Válaszút K; ETF 107. 19].

2. huszártorony 1750: Vagyon az falu derekában fábol csinált templom, az haranglábocska a templom fedeléból nyúlik ki, melyben vagyon két harangocska [Jára MT; ETF 21].

harangocska 1. 1643/1687 k.: vagyon ă makfalvi Ecclab(an) ... ă Templom hijjánís ... égy kis harangocska [Makfva MT; MMatr. 187]; 1714: 20. fontott nyomo Harangotska fabul való apparatussal egjütt, körös körül irva vagjon: Ditsösség Istennek az magassagb(an) fl Hung. 20 [Nsz/Fog.; $\mathrm{AH}$ ]; 1730: Egy kis harangocska [Körispatak U; Pf]; 1750: Vagyon itt ... a felső falu végin egy tisztességes alkalmas magasságú fatorony és abban két jókorácska harangocska [M.fülpös MT; ETF. 107. 21]; 1756: A Templom felett edgy Félegoriátska mellyben vagyon mint égy Öt ejteles harangotska [MRConscr.]; 1778: Cserefa agasokon ... vagyon mintegy 20. 25. fontos harangocska [Csapó KK; Berz. 4. 8. C. 18]; 1793: Felolvastatott a' Görtsönia ${ }^{a}$ Ref. Eklesia ... mostani Levelében az emlitett Harangotskának által adattatása iránt valo kérését meg ujitja [Kv; SRE 288. ${ }^{a}$ Sz]; 1797: Van egy harangotska ... Van egy Onn kannatska [Nyárádsztlászló MT; MMatr. 146]; 1803: vagyon ... a parochiális funduson égy cserefa agason szalma fedél alatt égy szép kis harangocska, mint egy 45 vagy 46 fontos [O.asszonynépe AF; EHA].

2. csengettyü 1585: Ket Bokor Harangochka [Kv; Szám. 3/XIX. 5 a Szent Mihály templom inv.]; 1591: Az Zegeniek hazaba ... Ket harangochka [Kv; Aggm. A. 53]; 1714: Gömbölö harangotskák No 98 fl. Hung. 5 [Nsz/Fog.; AH]; 1736: a' Tornatz Gerendái kőzőtt fekszik vas Csapos és Vas Kantákkal szoritott Tengellyetskéjeken álnak, és Ingadoznak kis Harangotskak ... (a) kissebb mondhatik tsak Inkánb (!) Tsengettyűnek mind Harangnak [Várhegy MT; CU]; 1757: Égy Rettegi Prodán nevü harangöntőtŏl Magam Bélyegére valo három kisded Harangotskakat es ket Csengettyút vévén, fizettem erette Rh f 25 xr. 30 [TL. Teleki Ádám költségnaplója 113b].

Szk: csengettyü 1742: egj ebedre csengetŏ Jókora csengetyü harangotska [Pókafva AF; JHb XXV/58. - Tomai László kijegyzése].

3. kolomp, csengő 1807: meg Szollitottam Tyimost ... hogy nem vette volnaé le az őkrőm nyakáról a harangotskát [Szászfenes $\mathrm{K}$; KLev.].

Szk: csengető 1783: egy Tehénről egy Tsengető Harangotskát el lopott volna [O.hidegkút U; Told. 9a] * hámori 1815: egy kis Hámori Harangotska van kŏtel darabbol (!) a' nyakába kŏtve ${ }^{\mathrm{a}}$ [DLt 862 nyomt. kl. - ${ }^{\mathrm{a}}$ Ti. a tehénnek].

hársládácska hársfaládácska 1604: Vagion egy vy hars ladachka Vasas egy singes ket Zarral, kiben eggyetmas tartatik [Kv; RDL I. 77].

hártyika átv is hártyácska 1792: Törvényeink Sebeink bégyogyult fris Hártyikáit ollyanok által újra Sértettettni és fell bontattni láttyuk, kik magokis ... a' Sérelmek iránt Siránkozván, azoknak orvosságát, ohajtva várták [Déva; Ks 73. 73. VII. 98]; 1806: láttam a Morhának a Ganéját s afélé morha bél hártyikákat [KLev. 10].

hasábjószágocska kb. osztályos birtokocska/ jószágocska 1758: (A) hasáb joszágotskának vici(nu)ssa ... Bede Tamás [Papolc Hsz; Hr]. 
hasábocska (föld)táblácska/darabka 1764: Künn a' Mezőbenn Cserélt ... egynehány hasábocska földet [Csüdőtelke KK; Told. 8]; 1778: két hasabocska puszta szŏlŏ vagyon [M.köblös SzD; Becski]; 1785: ezenn Bodon kutra rugo égygyik hasábotska Foldnek jobb része vizenyős lévén meg nem Szanthattuk [Kv; Aggm. B. 26]; 1796: Őzvegy Groza Vasziliáné Marina, és két fiai ... égy hasábotska szöllejeket Zállogképpen alkuvák és adák el Titt. Bartok Sándor Vrnak, és Posteritassinak [M.igen AF; DobLev. IV/757. 1a]; 1809: A kőből kut nevü hellyb(en) volt egy hasábotska Szőllöis [Udvarfva MT; Told. 44a].

hasacska kics hasikó 1799: Németi Samuel ... nem tudom trefábolé a vagy valojában mit kért mit nem Györfi Máristol mondván: adgyon ked égy kitsit hasatskán ... az után azon szora a Leány azt mondotta a Legénynek, mennyen ké a Legény viszszá azt felelte igen de ked nem jő [Dés; DLt].

hasznocska jövedelmecske 1625: My Varostol ualaztotot Djrectorok Teolczeres Nagy Tamas es Hannes Eppel szamado Regestumunkat be aduan, ezen eztendöben valo keues haznoczkaual, mely az Varosra zallot Maradot kezunknel f $19[\mathrm{Kv}$; Szám. XXXIII/16. 25]; 1674: Nehai boldog emlekezetü Arkosi Benedekne Orelt Anna Asz(szo)ny ... az Nadas teriben ... feőldet ... masok(na)k adva(n) hasznoczkajaval eldegelt [Kv; TJk VIII/11. 321]; 1781: élelményekre eddig elé ki Szakasztott Portiojokbol még ez esztendőben jövendő hasznotskájokban Részt a Leány Testvérek is ne kiványanak [Told. 27]; 1827: talám tsak nem egyeztethetö dolog lenne, hogy azon tsekély hasznotskáért Házomnak Nemessi jussát és Jussomatis valakinek által adjam [H; Ks 121 Vegyes ir.].

Szk: ját látja vminek 1757: (A) Bányais ... négy esztendőkig (: beléhagyatván:) pusztánn állótt, akkor a' Mgos Gróff Exp(one) ns Vr kezdette ujra dolgoztatni, és ... igen vékony hasznotskáját latni [Nagyalmás $\mathrm{H}$; BK ad nro 144] * t talál vmiben 1775/1781: annak elŏtte a jovát a Bányának mind meg dolgozták vólt, 's el is vették vólt a hasznot belŏlle, s mi tsak imitt amott találunk benne egy egy kis hasznotskát [Nagyal- más $\mathrm{H}$; JHb LXXI/8. 421] * t vehet 1672 : enis most vehetnek mind hasznocskat $\mathrm{s}$ mind (penigh) elelemre valot [Kantafva (Szu-be olvadt bele); Bál. 1]; 1756: én ${ }^{a}$ látván hogj nagyobb hasznacskát vehetnék azon helységről ${ }^{\mathrm{b}}$, magam két részemre Malmot építettem [Ribicsóra H; Ks LXII/7. - ${ }^{a}$ Kles György ${ }^{b} T i$. a Gura Brazilor nevü helyről].

határdombocska határhalmocska 1572: eg' Ther helyen Talalank ugy mint egy ryghy fel hant hathar dombochkat [Dés; DLt 184]; 1780: (A) hegynek is Napnyugatrol valo nyakán, hol más esketés alkalmatosságavalis mútatták, egy éget Bikfa a' regi út helly, ugy is Határ dombotska tsomófőld vagyon a Sunkai Ribitsori, Ribitzei, és Vákai Határokot conterminálodni tartyúk [Zsunk H; TL]; 1542/XVII. sz. v.: A Giróti Tó nevû́ Végibe a kenderes fŏld borozdája iránt ... felyŭl egy határ halmocskát hagyván ekképpen kezdettek el osztását [Gyeke K; Ks].

határhalmocska határdombocska 1681/1748: a régi barazdanak ket végihez alkalmaztatott ā kőzepeis, és határhalmocskákkal meghatároztatott [KvAKt Mss lat. 236]; 1760: holott bizonyos kő rakások, és határhalmotskákis vagynak [Báld K; BLt].

határhompocska határdombocska/halmocska XVIII. sz. v.: A' Berczen levŏ ezen határ hompotskátol fogva ... a' belsŏ hatar hompotskaig [Told. 25].

határka ? 1614 e.: Határka pataka [Mezőbánd MT; EM XLVII, 313]; 1639: az határkában [Mezőbánd MT; EM XLVII, 313]; 1767: A Határka pataknál [Mezőbánd MT; Hr 1/49]; 1807: Az Határka Patakra jár ki véggel fetske farkulag égy 38 vékás láb [Mezőbánd MT; Hr 3/25].

határkövecske 1788: Ezen Curia ... egy Borzafátskánál keresztűl méretvén, találtatott 36 - harmintzhat őlnyinek ... a' Borostyán aránnyában tétetett Határkővetskénél 32 őlnyinek és 4 lábnyinak jutott [Melegföldvár SzD; SLt XLI].

határocska 1. kics 1580: Immar Annyera Iutottanak hogy Aminemeo hatarochka volt a' harom faluhoz ${ }^{a}$ Azis gondwiseletlenseg Miat el foglaltatot [Kv; TanJk I/1. 43-4. - 
${ }^{a} \mathrm{Kv}$ három jb-falujához: A. és F.füléhez, vmint Asszonyfvához TA].

2. határrészecske 1777: Praedium Hosdóa. Vagyon egy darab Hosdó nevŭ határotska kiis tsak egy vŏlgybŏl ál [JHb XXXI/29. $\left.{ }^{\mathrm{a}} \mathrm{H}\right]$.

hátrábbacska hátrácskább, egy kissé/vmivel hátrább 1813: Hátrébbotska az Erdö ... bütüjibe foglalt Keresztesi István is mint egy 16 vékásnyi helyet [Koronka MT; Told. 22].

havacska 1738: itten az vetések igen szépen, essöis bövecskén kezdet lenni ugy az hovasokon hovacskák, melyeknekis gyakor hoharmati vadnak [Szamosfva K; Ks 99 Kornis Antal lev.].

havasocska 1756: Virtope nevezetü havasocskáért p(rae)stalnak Rf 8 × 20 [Bulzest H; Ks 101].

hazácska játszi kics haza 1798: a mi Édes Hazátskánkat az emberek nem igen méltoztatnak esmerni [MNy XLVI, 154 Gyarmathi Sámuel Aranka Györgyhöz Göttingából].

házacska 1. 1560: zezerman vagion haz Item seller eozvegy azzony hazachkaia kiknek sem fewldeok sem kertek ninchen [Szeszárma SzD; Makkai, SzDPuszt. 51]; 1570: Trombitasne azt Monta hogy ... egy hazachkat veotte $(\mathrm{m})$ megh kely az arrat adnom [Kv; TJk III/2. 160 Kwthy Antal, es Anna az felesege vall.]; 1591: most Georgy Gereb biria az helyet. Kochis Peteris lakek raita az Gerebek szamara egy kis hazachkaba [UszT]; 1599: Hogi plebanos Vram az kút mellet walo kis hazochkat meg chinaltatta, keoltet ... fl 17 d 89 [Kv; Szám. 8/XVI. 22]; 1619: az kws Hazaczjkat Georgj Antalne Czjnaltatta uala oda az eöreöksegre fiaynal egjwtt [Tusnád Cs; BLt]; 1644/1759: Az hátulso két Bolt házacskák ... az Udvaron ellenekben lévŏ kis házatskával és kamarácskával ... a' Tasnádi István Árváinak jutot [Ne; DobLev. III/651. 7a]; 1676: regenten egy Kis hazaska volt rajta [Backamadaras MT; Told. 8]; 1694: Ezzel által ellenb(en) vagjon ... egj kis hazatska kertetskejevel egjgyütt [Borberek AF; BfR Néhai ifj. Bálpataki János kúrialeír.]; 1729: Vagyon egy szép proportioju rakó fabol epült házocska mellette lévő oldal ka- marácskájával edgyütt [Buza SzD; JHbK V/2]; 1735: ezek a Sellérek ... az Udvar Ház hellyre csináltak Házacskakott, azokban laknak [Gyéres TA; JHb XI/9. 50]; 1735: levén egj igen kitsiny ben valo fundussa mellyen tsak egj Házotska vagyon [Kissolymos U; Márkos-lev.]; 1739: más Hurubácskát 's darabocska földet excindálván nékie, azon Házacskára ... reá ment [Dés; Jk]; 1757: Szakara Szimont énis ismertem, s emlekezem arais hogj ezen Utrumban specificalt örőksegen lakot edgj kis házocskában [F.borgó BN; BK. Orbanás Juon (60) jb vall.]; 1765: égy kisded Házotska Szalma Fedél alatt égy Istálotskával edgyütt [M.peterd TA; CsS]; 1768: Az Utrizált Veres részen vagy öt Házotskák mint mezóségen Jobbatskák de a többi ollyak hogy tsak egy vagy két esztendŏ mulvais másokat kel hellyekben tsináltattni [Kissármás K; RLt 4. Hét r. tanú vall.]; 1803: Van még egy házocska az udvar kapuja előtt [Ispánlaka AF; MkG]; 1837: vagyon egy más Agosokon epült sövény kertelésü Hazotska meg lehetös allapatba [Szentbenedek SzD; Ks 73. 55].

Szk: kalibaforma 1705: (Az) eőrőkseg igen kiczin fundus s most egy kis kalyiba forma hazaczka raita [Szárhegy Cs; LLt Fasc. 151].

2. szobácska 1573: Megen hozza az hazachkaba hwl feksik volt, odya fely az Sebet hogi be keosse [Kv; TJk III/2. 55]; 1593: Az templúmbeli kis hazochkanak Lantornat vettŭnk ... d 11 [Kv; Szám. 5/ XX. 122]; 1603: En is akkor abbany Az hazachykabany voltam, Az Echyetes Altalaghy mellett wleok vala [Kv; TJk VI/1. 666 Varga Caspar leania Sophika (7) vall.]; 1632: Kocziolatai ${ }^{a}$ Udvar ház ... Masodik ház. Inne(n) nilik egj kis hazaczkara egj fejer bellett vas pantos sarkas aito ... Az negiedik kis hazachkara nilik ... parazt Zaras aito forditoiaual be vonoiaual edgiwth [UC 14/38. 34-5. - ${ }^{\mathrm{a}} \mathrm{F}$ ]; 1654: Roska Demeter ... kis hazacskaja pituarocskaja [Liget MT; Ks Bánffy A. urb.]; 1681: Ezen malom házban vagyo(n) a Mólnárnak es (!) ki hazaczkaja [Vh; VhU 575]; 1692: Nyilik ezen tornaczocskábol bal kezre fen megh-irt kis kamara felett lévŏ kis hazacskára ... fŭrész 
deszkából való parkanyos aitó [Mezőbodon TA; BK Inv. 11]; 1723: Egy nagy kő lábokon állo házotskára járo le omlásra hajlando Tornácz [Boldogfva $\mathrm{H}$; Born. Vegyes I. 16. F.]; 1756: ezen Serfőzőben tanáltatik egy kis óldal házatska Ezen házacska alatt vagyon egy szalad öntő helly [Déva; Ks 92. I. 32]; 1796: a Néhai Groff Ur Eŏ Nagysaga ... épittetett egy jo Fogadot ... azon hellyre egy fedél alat egy kőz pitvarbol egy másba nyillo két házatskát, az édjik ház vége alá egy kis fábol epŭlt Pintzétsket [Szentgothárd SzD; WassLt].

Szk: belső 1692: Ezen háztol el-rekesztetett ugyan az ur ŏ kglme Belsŏ Erkelyes Hazacskája az ur ŏ kglme nagy Házátol az nap kelet felŏl-valo része fenyŏ deszkából csinált rostellyal vagyon el-rekesztve [Mezőbodon TA; BK Inv. 9] * hátulsó 1694: ennek az haz(na)k pitvarkaja es hatulso Hazacskajais van, kibenis egy sing Rud vason, es Vas Labocskan allo paraszt Kemenczecske van [Kővár Szt; JHb Inv.] * tanuló 1803: égy Classis(na)k való kisded Kamarátska vagy Házatska égy kis Tanuló Házatska vagy Kamarátska [Désfva KK; UnVJk 183] * tüzeló 1681: vagyon az béresek számára csináltatott, új szél deszkával fedett, négy szegü tüzelő házzacska [CsVh 96] * tüzes 1703: találtunk ... Azon hámor felet két tüzes házacskát és egy kis kamrácskát vas sorkas ajtókkal együt [CsVh 118].

házhelyecske házastelkecske 1620: Kis Pal Balintnak ... conferaltam ... haro(m) buidosso vratlan Jobbagyokat ... es hazhelyeczket ... engedgye bekessegesen birnyi [Kp 1. I. 27 Bethlen István ad. lev.]; 1658: Az Alvinczi Felső varb(an) vőn egy darabaczka ház helyeczket [Alvinc AF; Berz. 1]; 1698: adtuk azon haz hellyetskéjét három forinton [Dés; Jk]; 1716: az Nagy Ercsei $^{\text {a }}$ portionakis egész hasonfele eo kglmét concernállya de meghis Filstich Péter ... egy rosz Ház helyecskével szurta ki a szemét [Kozmatelke K; Told. 52. - ${ }^{\mathrm{a} M T}$ ]; 1736: Tòrok István Isntantiájara engedtetik ... egy haz hellyetske eletéig eā conditione hogy semmi nemŭ szin és praetextus alatt az epuletet nem abalienallya [Torda; TJkT I. 16]; 1767: adá ezen Szilágyi Ferentzet
... ki szakosztot kitsin ház helyecskével [Bethlenfva U; Hr]; 1802: (egy) ház helylyetske ... vagyon [Csekelaka AF; KCsl 6]. Szk: nemes 1673/1873: A' Patak hellyben vett volt egy Nemes házhelyetskét [Tövis AF; Kath.] * puszta 1658: attunk eŏ kglmenek az Uy keresztienek felŏl valo Kapu előtt, egy puszta haz helieczket, ki merő kőszikla volt [Alvinc AF; DLev. 3. XXXI. A. 9].

házicska házacska 1840: bátorságosabban bírhassam azon Hazitskat [Dés; DLt 1420].

házicskó házikó 1843: tetzet ... admoneáltatni hogy a Tegla vetŏ helyen fel epittetett Házatskát es egy kis veteményező Kertetskét elrontsam, holott az a Házitsko az egésség fen tartására ... szükséges képpen meg kelletik lenni ... méltoztasson azon Házitskot a maga valoságában meg hagyni [Dés; DLt 1358].

házikó 1. házacska 1640: vagi(on) ennek felette 19. muntanis Jőveveniek kiknek valami hazikoiokis vagio(n) szabadosak el menny vagi ot lakni [Szevesztrény F; UC 14/48. 78]; 1748: Házikót magok épittetnek [Ákosfva MT; Told. 8]; 1757: Czigánynak egy kűsded Hazikoja [Taploca Cs; Sándor conscr.]; 1798: Kádár János ö kegyelme Cserében adot Joszágan egy Haziko vagyan ... Tar János ö kegyelme Feleségének Kadár János által, lett Csere Joszágban lévő házikónak amig hasznát lehet venni vegje hasznat [Csegez TA; Borb. I Csegezi Csongvai Pál Hütös assessor kezével]; 1826: 14. öl Hosszuságu hellyet ... égy hazikonak fel lehet adni [Dés; DLt 930]; 1840: a' Solyom kŏ alá épittetett volt egy házikot [Bikszád Hsz; MkG].

2. kunyhócska 1841: egy rongyos Házikó [Torda; HG].

Ha. 1761: háziko [Jedd MT; Told. 45/3]; 1765: haziko [Szászbanyica K; BfR Fasc. A. Nr. XXI.]; 1765: egy kűss Házikoban [Msz; Pf]; 1786: egy kis háziko [Mezősámsond MT; Berz. 15. XX/18]; 1797: házikoban [Náznánfva MT; Berz. 3. Fasc. 3. N. No 21]; 1815: Házikot [Orsova MT; Born. G. XV. 13 Szegedi László (58) ns vall.]; 1825: háziko [M.légen K; KCsl 4]; 1831: házikot [Dés; DLt 163]; 1832: Hazikojába [Kissáros KK; DLev. 2. XII. A. 2]; 1835: Kis Háziko 
[Etéd U; NkF]; 1844: kitsin Háziko [Etéd $\mathrm{U} ; \mathrm{NkF}$.

házülés-helyecske telkecske 1725: leven marosszekben Vajaban három Ház űlés helylyecskeje [VH].

hegedüske csak hn-ként bizonytalan jel-sel 1761: Hegedüske [Kiskászon Hsz; SzNM Eml. 61].

hegyecske 1694/1764: az hegyetske tetejéig [Királyfa K; Told. 26]; 1738: azon hegyetskében az Szalai Rész szŏlŏn fellyúl [Balavásár KK; Ks 13. XV]; 1848: A’ Kápolna félre egy hegyetskén vagyon építve

[Born. F. VIIC Csiki Sámuel lev.].

hegyesecske Szk: orrú 1821: Monka (!) János ... hegyesetske orru [DLt 631 nyomt. kl]; 1825: Romoselyi Nyikuláje Szimulyészk ... hegyesetske orru [DLt 767 nyomt. kl].

hegyeske hegyesecske 1835: A Hegyeskékben (sz) [Nyén Hsz; EHA].

héjacska huzatocska 1629: Egj varrot vankos heaczjka [Gysz; LLt Fasc. 155].

helyecske 1763: Lévén szüksége ... egy helljetskére aholis ketskéket nyuzogathatna [Szárhegy Cs; LLt Fasc. 149]; 1767: Nehai Ladányi legált 1000 For. Interessét, approbállya 'a Supr Consistorium hogy fordittassék Bibliotecha augmentatiojára, sőt hogy azon Testans emlékezetire 'a Bibliotecháb(a) kŭlŏn helyetskére tétessenek azok a kőnyvek mellyek ezzel vásároltatnak [Nsz; BK A kv-i ref. koll. csomója].

Szk: bejáró 1726: Busittatom Becsűletes Perceptor Uraméktol, az mostani magyar utzai házam végiben levő kapu béjáro helyecském iránt [Kv; Pk 6] * fatartó 1694: az Kemenczebe fat szoktak be hanni, kinekis vagot fa tarto helyecskejeis va(gyo)n [Kővár Szt; JHb Inv.].

2. földecske, határrészecske 1600: En mindenkor Fekete Balaseeknak tuttam azt a helechket ... eók kazaltak [UszT 15/87 Iswanffy Isthwan, Kaidichfalui, Zabad Zekely vall.]; 1636: Ez negyedik resze az kertnek cziak magaba(n) valo szep fuues baraniok hizlalasara valo kies helieczke [Siménfva U; JHb Inv.]; 1667: Vagion két küs hellyeczike ... azt szancziuk ki az patakig [Imecsfva Hsz; LLt]; 1733: Toth
János szabad szemellj heljecskéje [Backamadaras MT; LLt Litt. B]; 1751: neha palánt magot vetettek belé az hol száraz hellyetske találtatott [Kóródsztmárton KK; Ks 17/LXXXI. 18]; 1766: ezen kis helylyetske mindétig Falu Fŏldének tartatott [Szentegyed SzD; WassLt Pap Togyer (40) zs vall.]; 1825: Ezen hellyetske igen jo helly [Szárazpatak Hsz; SzentkZs Conscr. 337]; 1784: a' Mlgŏs Groff ur ŏ Nagysága ... kaszáltatott mintégy két szekér szénára valo hellyetskét [M.gorbó SzD; JHbK LIX/4.28].

Szk: árkos 1762: az utrumban ... Specificalt Árkos Hellyetske ... égy darab idŏtŏl fogva senki nem curálván ... abalienalodott [Cege SzD; WassLt] * bokros 1690: van $\mathrm{Ngd(na)k} \mathrm{egj} \mathrm{kis} \mathrm{hellyetskéje,} \mathrm{mely}$ ... semmire kellŏ iszapos Olt most a porond ... magab(an) haszontala(n) bokros hellyetske [Fog.; Szád. Recsei Bojer Péter lev.]; 1807: egy fenekes bokros keskeny helyjetske ... most pusztáb(an) hever [Nyárádsztbenedek MT; Told. 37] * erdôs 1774: négy őlnyi Szélességű Erdős hellyetske [T; CU] * gyümölcsös 1798: égy Gyümőtsős helyetske és Pusztácska ... tőrőkbuzás és káposztás főldetske [Kv; Pk 6] * pityókás 1825: a Falu also végibenn vagyon egj kis pityokás hellyetske [Papolc Hsz; SzentkZs Conscr. 191] * puszta 1672: Bodis Peti puszta darab hellyekeje (!) [Alvinc AF; Incz. VI]; 1765: egj darabotska puszta hellyetske [Csávás KK; LLt] * seppedékes 1799: Azon seppedekes hellyetske ... a Kender fŏldekbǒl szakadott é el? [T; Ks 89 $\mathrm{vk}]^{*}$ szabad 1752: szabad kis hellyetske [Msz; LLt 80/9] * tisztás 1761: a kérdésben fel tőtt Vad almafák, ezen tisztás helylyetskével vagy kaszalotskával égyjütt ... eo Nga földéhez tartoznak [Koronka MT; Told. 26] * vizes 1764-1766: vagyon égy kitsin motsaros vagy vizes hellyetske ... mellyet mikor meg lehetne kaszálni a viz es ingovány miatt Lenne rajta két merekje széna [Nyárádkarácsonfva MT; Told. 76]. 3. (ház) telkecske 1681: Az holott valami oly alkalmatos helyeczke volna, melylyen is Groff Vrama eŏ Nga Cziganyinak kellene lakniok; az ollyan helyek el van-

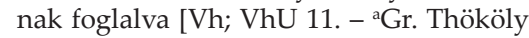


Imre]; 1770: azon kis hellyetskén ... egy Kurucz Tivodor nevezetü szabad ember épített leg elébb házat [Burjánosóbuda K; JHbK LVI/1]; 1795: a' Szánto Sándorné Jármi Ágnes Asszony fél Puszta Sessioja ... a' Turi Kristina Aszszony Kis Hellyetskéje pedig ... Szánto Sándorné Aszony(na) k ... az Turi Kristina Aszszontol adatot Hellyetske kissebb volt [Veresegyháza AF; DobLev. IV/756. 1a]; 1806: Getse Klára aszszony azonn Teleket mely az nehai Őregeke volt jol réám tudta Sütni advánn érette Négyszaz tiz 410 vforintokat mely ennekem bizony amint ki ki lathatja eleg drágábann áll azonn kicsid helyetske [Dés; DLt 17/1809].

Szk: belső 1784: itt bedetsben ${ }^{a}$ vettünk egy Küs Belső helyetsket [Szentimre Cs; EHA. - ${ }^{a}$ 1567-ben Bedechy (SzO II, 220), 1601-ben Bedecsfalva (EHA) néven még önálló település, később - de mikor, nincs rá adatunk - Szentimrébe olvadt bele] * bennvaló 1741: a' fellyebb le írt ben való helyetskét meg vásárlották [Koronka MT; Told. 22]; 1759: Vagyon itten ā Faluban egy benn valo helyeske ... egy huruba vgyan el térne rajta [Tusnád Cs; BLt 9]; 1760: egy benn valo hejetske [A.volál Hsz; LLt] ${ }^{*} k u$ riális udvarházhelyecske 1781: égy Curialis hellyetske [Berend $\mathrm{K} ; \mathrm{CU}]$.

4. helyiségecske 1776/1787: egy Bóltnak valo heljetske [Dés; DLt].

Szk: kovácsszéntartó 1694: Kovacs mihely ... az Garadics alat va(gyo)n egy meg romladozot ritkason megis Deszkasztatot Kovacs Szentarto helyecskeis [Kővár Szt; $\mathrm{JHb}$ Inv.] * vaskőtartó 1681: vagyon ... szén tartó csür, melynek jobbik oldalában vagyon fenyő boronákkal el rekesztetett vas keő tarto hellyecske [Vh 89].

Ha. 1658: helieczket [Alvinc AF; DLev. 3. XXXI. A. 9]; 1673: helyecske [Fog.; Törzs.]; 1727/1790: helyetskére [Ádámos KK; MvLev.]; 1737: hellyecske [Tancs K; Told. 11/73]; 1749: Hejecskének [Dés; Jk 535a]; 1766: hellyetskéjin [Szentegyed SzD; WassLt Öreg Pop Iuon (76) zs vall.]; 1770: helyetskère [H; JHb XXXI/17. 3]; 1815: Hellyetske [Msz; LLt 88/13]. helységecske földecske, határrészecske 1744: A Lunka Kinyipa helységetskét ... Gánya Petru birta ... s háza volt ott [Nagyalmás H; BK sub nro 181 Szidera Filip (58) jb vall.].

hetecske (vhány) röpke hét 1758: Barcsai Jánosnál laktomban mentem volt ki az asszonnyal Váradra az feredőre ... Négy hétig laktunk ott, de elmondhatom, hogy sohasem éltem olyan jól, mint ott azt a négy hetecskét [RettE 65].

hevederecske keresztpántocska 1699: az aiton egj fa rostély, vas hevederecskeken Sarkokon forgo [Boroskrakkó AF; BfR dobozolt anyag VI]; 1736: vas kávátskaban alol vas Tsapon forgó ugyan Cserefa Sorkokba vésett, két hevederetskére fa szegekkel szegezett Gyalog kapu [CU].

hiányosocska meglehetősen hiányos 1798/1812: egy ujj, de héjánosotska Conscriptio [Msz; HG Conscr. 222].

hibácska kis hiba 1772: ezen Malomnak, a' mint láttam, némely apro hibátskái vadnak [Ádámos KK; JHb LXVII/2. 313]; 1826: Ifjab Ajtai Moses ... némely aprolékos hibátskákért büntettetett tsak három ezüst forintokig [Kv; ÖCJk].

hibásacska 1785k.: Kata ugyan mégis nem oly hibásacska: Dolgaiban serény, sokkal is jobbacska, Alattomban ő is akaratosocska [EM XX, 503 Balás-kódex].

hidacska 1. kis híd/palló 1585: (Az ölfa) Egy Rezet az kezep kapún belol walo hidachkara Raktak. Hogy ez hidachkat megh Chinalta az Korcholiasz Negied Magaúal fizettem ... d. 25 [Kv; Szám. 3/XVIII. 26a]; 1594: vőtünk ... vgian Ezen Hidaczkakra Egi ttolgi gerendackanak (így!) d 15 [Kv; Szám. 5/XXIV. 22]; 1679: Felső Tó ... Ez mint hogi ighen csékely, gáttyais nem ighen derekas Zugoja ninczen, hanem az folyásan egy hidacska [Uzdisztpéter K; TL. Bajomi János inv.]; 1727: ezen Vendég fogadonál vámot az úton jároktol vesznek ez szerint ... Ezt penig abban az uttban találtato egj nihány Hidatskáktol vészik [Csákigorbó SzD; JHbK XXVI/13. 25]; 1758: tőnek ... az Korodi pallon avagy hidatskán valo által járásokért illyen meg égyezést [Kóród KK; Ks 17/LXXXII. 14]; 1758: van edgy Cserefa Gerendákon állo boronákkal meg padol- 
tatott Hidatska [M.kiskapus K; Mk]; 1806: a' Pallo Hellyett azon kis Hidatskát keszitették ā melly hellyenis a' Viz szelessegere nezve a' mint hozza vethetek vagyon mint egy 100 ŏlnyi (így!) [Szászrégen; Born. XVI/76 Kiss György (50) vall.].

Hn. 1728: A hidacskánál Pataki hagob(an) (sz) [Aldoboly Hsz; EHA]; 1750: A hidotskanal (sz) [Körös Hsz; EHA].

Szk: karfás 1694: ezen az Var árkán altal vagjon egy keskeny hitván regi Karfas Hidacska, az kŏzepin ennek erős Pallo va(gyo)n [Kővár Szt; JHb Inv.].

2. Szk: felvonó 1632: Fogaras vára ... uagion egy fel uono hidaczka keötelesteöl, kin uagion egy hat szemw lánczbol czinalt retez [UF I, 130]; 1694: az ŏreg Kapunak ... kőzepe irant egy keskeny Pallo formara fel vono Hídacskajais van [Kővár Szt; JHb Inv.].

3. gyalogos kompocska 1806: jol tudom hol vagyon egy kis által járo Hidatskája ... Azon a hellyen a hol tudni illik az emlitett hidasotska vagyon [Szászrégen; Born. XVI/85 Sepres Mihálly (80) vall.].

hidasocska gyalogos kompocska 1770: a' Szasz Regenieknek azon altal járo Kis Hidasotskája a Mellyet ... a' viz által gyakorta el rontatott pallo helyibe tsináltattanak [Szászrégen; Born. XVI/79-80 Kiss Márton (98) vall.]; 1806: Azon által járo pallo hellyett keszittetett Hidasotska jol lehet akkora legyenis, hogy azzal ket lovat a' Vizen altal lehessen vinni ... csupán a' gyalog valo járás engedtetik meg [Radnótfája MT; Born. XVI. Csavasi Mihály (34) ns vall.].

hidegecske meglehetős hideg 1836: a hó le esett ... az óta el lepve a fŏldet áll - most hideecske (!) van, de nincs nagy fagyás [Zsibó Sz; WLt Nagy Lázár lev.]; 1847: Az nap is ... több izben esett hidegecske eső [KCsl 13].

hímecske hímzés 1576: Wagion egy weres tereok Ingh taffota kereol A galyran igen zep gyngye (!) Aranyos hymechke [Szamosfva K; JHbK XVIII/7. 4].

himlőhelyesecske egy kissé himlőhelyes/ ragyás 1822: Kibédi Samuel ... hoszszuko himlŏhelyesetske ábrázatu [DLt 70 nyomt. kl]; 1822: Pipa Antal ... szŭrkétske himlŏhelyesetske ábrázatu [DLt 73 nyomt. $\mathrm{kl}$ ].

himocska ? 1692/XVIII. sz. köz.: Nyulasra $^{a}$ menŏ utt mellett egj darab himocska

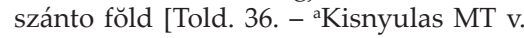
Nagynyulas K?].

hintócska 1.kis hintó 1687: az mely 18 lovat masodszor Szigetre hoztak vala, penzen el ne(m) attam 8 bénne, hanem kit az Generalne hintocskajaert, kit tŏrŏk aszanyokert, gyermekert [ApLt 6 Kálnoki Sámuel feleségéhez Nagybányáról].

Szk: német 1687: Ha elombe ki jŏvel, az szep nimet hintocska szinten ma fog altal jŏni az maramarosi havason, s azon édgjüt mehetnénk haza [ApLt 6 Kálnoki Sámuel feleségéhez Nagybányáról].

2. játékhintó 1816: Egy Sárga festékü gyermeki kitsi Hintotska [Bányabükk TA; MkG].

históriácska 1. történetecske 1736: Gondolod talám, ez az utolsó két-három históriácska nevetésre való; de bizony nem nevetésre, hanem nagy oktatásodra vagyon, kedves olvasóm, ha jól meggondolod [MetTr 420-1].

2. szent $\sim$ bibliai történetecske 1823-1830: Trencséni Sámuel nevű pap ... holtáig Marosvásárhelyt lakott egyes-egyedül egy kis házikójában ... A városon felkereste a gyermekes házakat, ott tanította őket vallásra, szent históriácskára, azután küldözgettek neki egy-egy kenyeret s egyebet [FogE 94].

hitványka satnyácska, véznácska 1749: Tavallyi ... okŏr bornyu 2 Az edgyik hitvánka [Marossztgyörgy MT; Ks 23. XXIIb].

hitványocska 1 . csenevész, satnyácska 1750: egy tavalyi ŭnŏ borju vagyon de maga hitvánocska [Marossztgyörgy MT; Ks 23. XXIIb].

2. silányocska 1781: A nagy Palota ... ajtaja ... zöld festékŭ, és Sárga párkányu fenyŏ deszkábol való de hitvanyotska [Petek U; Hr]; 1792: széna 8 Szekérnyi Tavalyi pedig hitványotska 4 Szekernyi [Szentkirály Cs; TL]. 
3. rosszacska 1752: a' most kŏzelebb elfólyt ősszel a' kert hitványocska volt [Abosfva KK; Ks 8. XXIX. 29]; 1812: Egy négyfelé hányo Drotos Hitványotska Rosta [Körtvélyfája MT; $L L t]$.

4. rozoga 1847/1851: Az uttza kapu mellet egy hitványocska ház [A.szovát K; Pk 3].

hivatalocska állásocska 1765: eő kegyelme ... ezen Fassiomért ujrais meg neheztelhet és ... mint potens ember ... hitvány hivatalocskámban meg ronthat [Borbánd $\mathrm{AF}$; Eszt-Mk Vall. 316]; 1853: szabadulva hivatalocskám bajaitol, igyekeztem ... dolgaiban el járni [Balástelke KK; DE 3].

hívesecske I. mn hűvösöcske, meglehetősen hűvös 1723: most esmét ... harmadnaptol fogva esmét szep üdök kezdének fordulni, de az etczakák hüvesecskék, s kivált az el mult etczaka ugyan hüves vala [Darlac KK; ApLt 1 gr. Haller János anyósához]. II. fn meglehetősen hűvös idő 1848: estve felé vólt, s hivesetske [Kv; Pk 7].

hívesecskén hủtöttecskén 1778: (Hasszorulás ellen) itassanak vele hivesetskén sok szöke Savót, fött Szilva Levet magára [MvÁLt Mátyus, ConsSan. gub.].

hízódisznó-ólacska hízó-ólacska 1748: meg rongyollot Szalma fedél alat épŭlt hizo Diszno ollocska is Vagyon egy [Nyárádsztbenedek MT; Told. 79].

holdacska ${ }^{1}$ csak lóra von.; fejér (homlok) foltocska 1629: latam akkor azt az Czikotis ot ... kerdemis teöle, hogj ha vagjone jegj rajta, s monda hogj vagjon egj kis holdoczkaja, enis szinte ugj lata(m) hogj vagjon egj kis fejer holdoczkaja az homloka(n) [Mv; MvLt 290. 165a]; 1703: Gyeröffi Borbára Nénem Aszony eő kglme egy Pej lovat (: kinekis az homlokan levén egy kis holdocska :) hozám kűldöt [Kv; Ks 38. VIII. 4]; 1807: Egy setét pej, az homlokán egy fejér hódotskája vagyon [DLt 391 nyomt. kl]; 1837: barna pej kisded paripa Ló ... jobb felől való szügyének egy kis szűrkés holdotskája láttatott [DLt 391 nyomt. kl]; 1837: Vagyon egy barna kisded vén paripa Ló ... az első lábánál levő lapotzkáján egy xrosnyi mekkoraságu szürke hódotska találtatott [DLt 391 nyomt. kl]. holdacska ${ }^{2} \quad 1$. mértékegység 1678/1684: Wagyo(n) Tihocz alattis egy holdacska ${ }^{a}$ [Szilágycseh Sz; SzVJk 126. - 'aSzántó]; 1685: A' Tórvény fa alatt egy hóldacska cir 1. vekas [Nyárádtő MT; Told. 27]; 1693: Szănto fŏldek ... Az Bŭdŏs kutnál négy holdatska [Ne; DobLev. I/37]; 1783: Ezen mellettem lévő egy holdacskának szomszédgya fellyul 2. Kötél Borbereki Vramé [Újfalu AF; DobLev. III/573].

2. Jelzői haszn-ban; vhány holdacskányi 1635: az mely apro holdaczka Zanto feőldeket Kun Janos uram be kerteltetet [Kál MT; Berz. 2. 40/82]; 1719: lévén ... két holdacska szántŏ földgye az Nagy retes Nevŭ szŏlŏ Málra fel jaro lábban [Ne; DobLev. I/97]; 1767: vagyon a hegy és szŏllŏ alatt áz árkon fel rugo egy holdatska szánto fŏld Cub 1 1/2 [Ne; DobLev. II/380. 3a]; 1845: A Vervolgybe 2 Holdatska földért 7 Rf [F.szentmihályfva TA; Bosla].

holmicska 1737: amibe lehetet a kartol igjekeztem oltalmazni az holmicskeje volt Ngodnak kezem alatt [Noszoly SzD; ApLt. 4 Hatházi Kristóf Apor Péternéhez]; 1749: az Ablakon bé meg nézém, s láttam holmicskét, máskint igen keveset [Hosszúaszó KK; EMLt Georg. Kádár (45) jb vall.]; 1765: az Commissariusok ha látak modot benne erovelis vettek holmitskéket [Ompoica AF; Eszt-MK Vall. 18]; 1790: Fekete uram is kŭldett holmicskét, azokatis az eŏ klme levelével egygyŭtt bé kŭldettem [Bencenc H; BK Bara Ferenc lev.].

holocska ? 1778: a Vajatis küldöm Holotskával még ha, lehet fogatok s magam bé viszem $\mathrm{Na}$ (go)dnak [Nagyida K; Told. 6].

homlításocska bújtatás (bújtatott szőlőveszsző) 1667: maga Monostori Uram egy homlitásotskát megh fogván fel huza [Kv; RDL I. 148e Stephanus Fekete alias Szeots jur. centum vir Colosvariensis (67) vall.].

hordóbélyegző vasacska hordóhitelesítő vas 1654: Egy hordo Bilegzö vasaczka [Szásznádas KK; Ks Bánffy Anna urb.].

hordócska 1. 1645: egj kis hordoczkais uala [Szárhegy Cs; LLt Fasc. 120]; 1669: Ezen pinczeben vagyon ... Egy cziknak valo ŭres hordoczka [Királyhalma NK; Ks. 67. 46. 24a]; 1679: hal hordáshoz valo hordocska nro 1 [Uzdisztpéter K; TL Ba- 
jomi János inv. 136]; 1699: Hitván űress hordócska Nro 1 ... Ser Szürő kosarocska Nro 1 [O.csesztve AF; LLt Gyulafi László inv.]; 1706: Egy hordocskaban Malom por vagyon cub 1,3 [Görgény MT; Born. G. VII. 4]; 1789: Egy 12. Vedres Hordotskába valami két vedernyi meg veszett Bor [Mv; ConscrAp. 7]; 1797: ött száz Hordótskáknak készittéséhez meg kévántató dongákot, és fenekeket Lipovára egyenesen ... le szállittatok [Déva; s 78. 20/20]; 1846: Az Udvar ház ... hijjba tanáltattak - egy hoszszu egy fenekü hordotska [Szászerked K; LLt].

Szk: boros 1801: Aprobb Boros Hordotskák [Vargyas U; CsS] * ecetes 1693: edgy eczetes hordoczka den. 30 [Tarcsafva U; Pf] * 1741: egj etzetes hordotskában bor etzet [Mezőbánd MT; LLt 146. B]; 1744: egj kis eczetes hordotska [Szentdemeter U; LLt Fasc. 67] * gabonatartó 1801: Egy Gabona tarto Hordotska [BLt II/11] * öreg $\sim$ nagy hordócska 1720: egy vak ablakban egy ŏreg hordotska [Köröspatak Hsz; HSzjP] * vízhordó 1784: viz hordo kis hordotska [Rücs MT; Ks 21. XV. 22].

2. vhány hordócskányi mennyiség 1823 kortsomárolni valo Borunk nints, hanem veszűnk egy-egy Hordotskával [Alpestes H; Told. 7].

3. Jelzői haszn-ban; vhány hordócskányi 1736: egy Cir(citer) tiz vedres Hordotska bor [CU]; 1738: S: Miklosi korcomaros korcomalot el harom hordocka bort [Gysz; LLt]; 1741: Egj hòrdotska éczét ... 1 [M.nádas K; RLt Csekelaki Varsányi Benedekné Beszprémi Orsollya lelt.]; 1749: lesz egy Hordocska boro(m) [Buzd AF; Ks 96 Mikó Ferenc feleségéhez]; 1766: oly szoros ez a' két Ház között valo Vdvar, hogj ha ez két felé szakasztatnék is, és kerteltetnék, tsak egj Hordotska Borátis egijk Gazda maga Pintzéjéb(e) nem vihetné szekérrel [Torda; TJkT V. 327]; 1848: egy hordotska sos káposztát el éltek [Dés; DLt].

horgocska kampócska 1699: az Ablak tablai vas pantocskakon s horgocskakon forgok [Boroskrakkó AF; BfN VI].

hornyocska ? 1729: Marhák lábához valo hornyotska [Tarcsafva U; Pf]. hosszabbacska 1748: mely le irt helység ha valamivel hoszszabatska lenneis az más rész atyafiak Erdejeknél, de sokkal keskenyeb, alá való és pusztáb [Kál MT; Berz. 2. 41/127]; 1803: (A ház) fedelire kének (!) még fel őlni hoszszuságunál hoszszabbatska bükfa Dranitza 50 szál [Kőrisbánya H; Ks 108 Vegyes ir.]; 1822: Girotán János ... az ŭstŏke nyirott, hátul hoszszabbatska haju [DLt 67 nyomt. kl]; 1839: két darab hoszszabatska folyo gerendák [Dés; DLt 700].

hosszabbacskán 1700: Takarodot estve avval ${ }^{a}$ harangozzanak hoszszabbacska(n) mint eddig [Dés; Jk 311a. - 'AA Dési Diószegi István adományozta kis haranggal].

hosszacska hosszúkó 1698: edgy hoszszacska asztal [Kóród KK; LLt 72] I egy hoszszacska folyoso [Buza SzD; LLt Fasc. 208 B]; 1720: nem kaphatak az ki négy hitvány Lovamat el hajcsa, kettǒvel ménuén pedig nem lehet az utnak alkalmatlan s hoszszacska voltara nezve [Balázstelke KK; Ks 96 Simon Pál lev.]; 1721: az harmadik haszacska mustranak singe 48 pénz [Ks 96 Bornemisza Imre lev. Nsz-ből]; 1754: Festetlen keskeny hoszszatska fogasok vannak ezenn Házban [Uzdisztpéter K; CU]; 1766: egy hoszszatska régi fogass a' falon Szegezve [Hosszútelke AF; Kath.]; 1802: Anniska ... közép kartsu termetü, hoszszatska száraz ábrázatu [DLt nyomt. kl]; 1808: hoszszatska szakálla bajuszsza [DLt 101 nyomt. kl]; 1832: megkaptuk a kaptzáját a mely szŏr volt és égy krajtzárt, továbbatskát égy hoszszatska pipa szárt [Kv; KLev.].

hosszacskán 1. vminek a hossza mentén 1739: a miolta én értem minden esztendőben használtak a Sz: Benedeki Révészek égy darabotska rétet a Révre menő uton alol hoszszatskán és keskenyen a Viz le mentére [Dés; Ks 28. V].

2. hosszacska ideig tartó 1765/1783: Hogyha ... a $a^{\prime}$ Venditorok ... azon Csekelaki Portiot valamely praegnans impedimentum miatt által nem adhatnák, és által adása hoszszatskán terjedne ... tehát azontul egész az által adásig legalis Interessé az o Nsgok fel adott penzek(ne)k currályon [Kv; DobLev. III/574]. 
hosszúcska hosszúkó 1710 k.: Az alsó állam éle hosszucska volt [BÖn. 492]; 1726: Vagyon Sővénnyel font perje fákra szalma fedél alatt készitett hosszutska disznó ól [Nagyfalu Sz; BfN Nagyfalusi csomó]; 1732: ezen kamorában ... találtunk ... egj rendbeli kovacsnak való miv szert, ugjmint egj nagj vas pŏrŏljt, egj hoszszucska szinkáló vasat [Kóród KK; Ks 12. I]; 1749: Mas hoszszutska pintze tokb(an) Srofos Üvek [Marossztkirály AF; Told. 19]; 1788: Ûvegnek valo kitsin tojokás Ferslog ... Egy hoszszutska fejér Tojoka [Mv; TSb 47]; 1845: Egy hosszucska fenyőfa asztal [Doboka; Mk]

hosszúka hosszacska, hosszúkó 1693: Tizenhat aranyas hoszszuka Dolmanra valo gombok Szives formak pikkel [Ne; DobLev. I/38. 8b]; 1710 k.: Termetem sem hosszú, sem kurta ... ábrázatom hosszúka, barnaszeg, piros [BÖn. 491]; 1838: Kadár János ... égy kevéssé hosszuka halavány ábrázatu [DLt 264 ua.].

Hn. 1637/1778: Hoszszuka mezŏ (sz) [Erdősztgyörgy MT; EHA]; 1774: a Hoszszuka Mező Pataka [Erdősztgyörgy MT; EHA].

hosszúdad 1864: Várhegy, melly is egy felemelkedett hosszudad hegj [Nagyalmás K; KHn 316].

horgocska kampócska 1699: Ket Ablaknak az Ramain vagyon paraszt vas plehecske tizenhat horgocskával [Boroskrakkó AF; BfN VI].

húgocska 1. testvérhúgocska 1599: ha zerelmes hugoczkamnak az Isten zerenczet paranczol [BálLt 51 Kowachoczy János nyil.]; 1598: azonkippen az kis hugocskamrais legen io gongia kegdnek hogj ne apagjon dolga hanem araggjon [BálLt 51 Kowachoczy János nyil.]; 1630: Nagodnak műis Agnes nevü kis Hugocskánkal edgyütt, mint Keglmes Urunk(na)k kŏnyŏrgŭnk ... méltoztassék azon Négy Falucskainkrol Nova Donatiot Conferalni [JHbK LVII/31]; 1784: Minden Fejér gunyabéli részemet ... hagyom az kis Hugatskámnak Fodor Hedvigának [Aranyosrákos TA; Borb.].
2. unokahúgocska 1631: Agoston Falvanak $^{a}$ hason felit ... hagyom ... az kis neveletlen hugoczkam(na)k Petki Katának ... el ne vegyék tŏlle az eŏ rész jószágottskájaval edgjüt [Nagyteremi KK; Ks L. 5 Sükősd György végr. - ${ }^{\mathrm{N} N K]}$.

huncfutka 1817: Márton Juon Hajdú mintegy 24. esztendŏs ... fekete hajú barna ábrázatú szemŏldŏkŭ ... hoszszu huntzfutkája van, nyirt haju [DLt 444. nyomt. kl].

hurubácska viskócska 1739: más Hurubácskát 's darabocska földet excindálván nékie; azon Házacskára ... reá ment [Dés; Jk]; 1772: Ezen Akollyba vagyon egy rosz Hurubátska [Szászfenes K; BethK Mikes conscr.]; 1793/1794: Vagyn(a)k még ben a' Faluban kőz helyre épúlt egy néhány házatskák, vagy is Hurubátskák, mellyek ... hagyatnak a' Falu pásztorainak [M.bagó AF; DobLev. IV/739. 21b]; 1836: egy kis hurubátska [Dés; DLt 556]; 1810: Hurubátskája [Nagyesküllő K; Lészai lev.].

huruba-helyecske $\mathrm{kb}$. hurubás telkecske 1747: egj Váradi nevü Tisztartója ... egj belső fundusocskát két felé szakasztott felit ... Porcsiren (!) Juon nevü Sellérinek atta ... meg halván ... az emlitett ... Sellér az emlitett Sessiócskátis, vagyis inkáb huruba helyecskét az ... M.B. Kemén Samuel Ur részire szakasztott hellyhez foglalták el [Mezősályi TA; Ks 7. XV. 20 Molduvan Iefftin (50) jb. vall.]

húzóka fiókhúzó (fogantyú) 1849: két almárium ... 9.9. tojokáikkal, - mellyeknek kŏzepén vasbol huzokájok van [Szentbenedek SzD; Ks 73/55].

hüvelyecske kb. tokocska 1625: Ezűst es arany marhak szama ... Egy ezűsteos hiuelyeczkeis [Kv; RDL I. 126].

hüvelykecske hüvelykujjacska 1759: az Gyermeknek az Bal kezecskeje keze fején alol tsudalatos mozgásban van, minden inai erecskéiben ollyan rángotás formalag mozog ugyan tsak az kezecskeit az gyermek nem fájolta, kivált az hüvelykecskeivel, s mutato ujjával az gyermek koltsokatis meg fogott, s tartottis [Csesztve AF; Ks Mike Antal lev.].

időcske 1767: Kis Vaszij és Telegucza Juvonis ... bellyeb nem jővének hanem egy időcske mulva el menének onnon [Betlensztmik- 
lós KK; BK. Demeter Ersok Forkos András Felesége (32) vall.]; 1769: jó időcskét edgjŭtt beszelgetvén [Oltszem Hsz; Mk]; 1791: ez kitsiny idŏcske alatt hozzánk érkezének [Szucság K; RKA]; 1791: én is, egy idŏcske mulva bé menék a' házba [Méra K; RKA].

idősecske öregecske a. emberre von. 1757: egy Geréb nevŭ Csapodar N(eme)s ember vagyon kŏztŏk, idŏsotske, ez hol egyinél hol másiknál élödik ŏ az tanátsosok ${ }^{a}$ [Retteg/Kendilóna SzD; TKl Perlaki András gr. Teleki Ádámhoz. - ${ }^{a}$ Ti. a rettegieknek]; 1800: Salat Ur már üdősötske ember [TLev. 5/17 Köpetzi Nagy Iosef Nsz-ből]; 1823-1830: Ez az asszony Görög Mária volt ... Mikor Bakcsi elvette, idősecske leánynak kellett lenni, mikor gyermekei kezem alá jöttek már nagyon csorba volt [FogE 99]; 1823-1830: A kutyfalvi pap volt Daroczi György, idősecske, de jó beszédes ember [FogE 117]; b. állatra von. 1805: Egy kisded barna pej Kantza minden jegy nélkŭlt, idŏsetske [DLt nyomt. kl]; 1823: mokány-fejü mint egy 11 Markos már idŏsetske-Lo [DLt 68/1806 nyomt. kl].

időtöltöttöcske idősebbecske, idősöcske 1758: időtöltöttöcske volt ugyan, de jóforma dáma lévén, csak elvettem volna [RettE 73-4].

ifjacska I. $m n$ fiatalka, fiatalocska 1753/1781: néhai idŏsb osdolai Kun Miklós Ur(na)k ŏzvegyét kiis sok pénzŭ és nagy Joszágu volt, noha ŏreg is vólt, B. Jósika Imre pedig igen iffiatska lévén, nem is igen gazdag vólt maga el vette, a kitŏl nagy gazdagságot nyére, erősen meg gazdagula [Nagyrápolt H; JHb LXXI/3. 332-3 Komán Togyer (50) jb vall.]; 1763: Küsded, barna, iffjacska Leány volt [Nyárádsztlászló MT; Sár.].

Szk: korában 1736 u.: ott voltamª igen ifjacska koromban apámmal, mikor Székely László lakodalma volt [MetTrCs 465. - ${ }^{a}$ Cserei Mihály] * goromba 1710: Felnevelkedvén azalatt Lászlóa, királyságra beállítatik, de goromba ifjacska lévén ... Hunyadi Lászlót és Mátyást, a Hunyadi János fiait, hite ellen megfogatja [CsH 62. - ${ }^{\mathrm{a} V}$. László 1444-ben, majd 1453-1457 közt magyar király].
II. fn kb. legényke 1614/1615: egizer egi iffiaczka Ieóue hozzá az Christoph deakne Azzonio(m) zolgay keozwl [Györgyfva K; Ks 14. 20a]; 1629: en attam oda az müre az iffiaczikat en tanittattam [Kv; TJk VII/3. 110]; 1702: edes Atyamnak üdvezült Banjai Istvan Uramnak ... keves Bonumi ... én holtom után adattatnának az T. Unitaria Ecclesiaban, az vegre, hogy az Scholaban tanulo szegenj Iffiacskak ... azokbol segiltessenek [Kv; Jakab, Kvtört. Okl. II, 458 Sárdi Mihály végr.]; 1724: mikor én ezeket hallottam ... Circiter 16, 17 Esztendős Iffiacska voltam [Backamadaras MT; Ks 12/III Michael (80) jb vall.]; 1732: Kováts al(ia)s Budai Szimeon ... ennek egj fia Nikulaj jo Ifiatska [Szentbenedek SzD; Ks 40. XXXVIIIC]; 1740: en akkor iffiacska voltam [Kobátfva U; Pf]; 1748: láttam azon alkalmatossaggal a' kètt iker Fiaitis és már jol fel-serdŭlt Iffiacskák valának akkor [Aranyosrákos TA; LLt]; 1799: Vagyon véllek még egy 16. Eztendŏs forma Nagy Elek nevŭ Nemes Iffiatska-is [DLt nyomt. kl].

ifjacskán fiatalocskán 1629/1676: Nagj Erdéllyi Miklos is megh halvá(n), igen Ifiacská(n) maradott Bátyá(m) [Somkerék SzD/Sv; WassLt St. Erdelly vall.].

ikerfiúcska 1748: Nézze kgld az én kétt iker Fiacskáim micsoda nagyott nőtek már [Aranyosrákos TA; LLt]; 1748: két iker Fiacskáival ... innen elsőbb(en) a' Szilágyságba mentenek [Aranyosrákos TA; LLt].

imádságoskönyvecske imakönyvecske 1596: In 16. Imatsagos keonywechke Nemetewl [Kv; RDL I. 65].

inacska 1763: Jobban vagyon kis Jankó Urffi Lábais, meg rándúlt volt valami inatskája [Ks Baló Antal lev. Nsz-ből].

inaska 1. legényke 1600: Én Gyeörgyffi Martont, mindenkor Gyeörgyffi Balint fianak tuttam ... a mikor el wetekezek hazulis az Marton io kora inaska wala, nekem hagyá $\mathrm{s}$ az apiawal eggiott mi tartuk oztan [Zetelaka U; UszT 15/38 Gyeörgyffi Thamas Ersebet lib. vall.]; 1760: Hallottam valami inaskáktol ... hogy ... etczakának idején iffiu Boda Juvonnét egy kertben látták egj Férfival [Kóród KK; Ks 17. XXXI]; 1764: Az hideg kuton alol ... volt ... egy darab 
Réttyek ... mikor az Inoskák sástépni oda mentenek, Miklós Déák Uram megkergette őket [Ne; EM XXXVIII, 228]; 1767: (Ezen földnek) egy vad tseresznyefa volt a belső barázdájában, arrúl sokszor meg is kergette Boldisár Győrgy termésének idején az reája menő Inaskákat [Göcs MT; VH].

2. fiúgyermek 1800: az Alperes kis Leánya és Inaskája szilvát vittek [Dés; DLt].

3. tanonc, ek apród 1683: Az Szakacs, es az Janos nevü inaska dolgat az mi illeti, mivel Uram magame s Atyam Uramis magam szamara tanittatta az szakacsot; az inast pedigle(n) magam tartottam örokbe; mint jo Uramat kerem alazatosan kegyelmedet, ha tovab nem, bar csak harom vagy negy esztendeig, mig edgyet tanitana engedgye ide, mivel kegyelmednek szakacsokat eleget adott [Diód AF; Incz. V. 20]; 1695: Bánfi Mihály Uram(na)k egy idegen arva Inaskábúl alló (így!) Szakács Inassa Tekei Tivadar tőbb lator Complices társaival egyűtt az eo klgmek ... Sz: Királyi pinczejét egy néhány izbe(n) fel vervén, nem kevés karokat tôtt [Marossztkirály AF; WassLt Sz:Győrgyi Mihally sch(ola) mester vall.]; 1771: Tavaj Ugarláskor ugy esik, hogy Kis Istvánnál lévő akkori Tímár Inaskát Enyedi Marczit el kérvén Timár Istvántol hogy ott az Ekét hajtaná ki addig a Béla hegy alá és ott étesse a marháját ... a Gyermek Inas fel ment a Béla Hegy tetőre ... ott étette az Ŏkrŏkket Imbrefi Ferentz is hogy ki jŏve azt mondá az Inaskának hat te mért butál el előlem hogy idejöjj Lantzas Diszno Ordog Menkŏ Kutya Teremtette? [Dés; DLt 321. 39b-40a].

4. szolgalegényke 1580: Az my penigh Illety az varassy feo zemelyeket es tyztesseges lakasba eleoket vegeztek eo kegmek hogy ha az Iambor hazas Emberek ollya(n) tyztesseges lakasba vannak es leendnek, azoknak zabad legie(n) hog Inaskaya zablayat vtana vigie $[\mathrm{Kv}$; Tan]k V/3. 231b]; 1696: vőt két par csiszmát két Inaskának [Kv; LLt Fasc. 146]; 1730: az én Jnaskám Tőrők, s-az Fiacskám haza jővé(nek) s-mondák hogy Szakács Máttyás áskált azon jószágon [Altorja Hsz; Borb. I Donát Jánosné Aszsz(onyo)m Ilona (46) ns vall.]; 1742: Moldován Győrgyőt Flora
Vonyát egy kis Magyar inaskájával hogy Vágta és hordotta az szilva fát láttam [Kincsi KK; JHbK XXVIII/6]; 1779: oda futamodek égy Iosi nevŭ Inaskája az mostani Tisztŭnk(ne)k az ki (!) égy bottal ugy meg ŭtött hogy mingyárt egybe gŏrbett [Záh TA; Mk V. VII/12].

5. bojtárlegényke, béresfiú 1596: oda menek tahagh zynte be fogiak az eŏkreket megh úaro(m) be fogok, ozton el veóm az Inaskaktol [UszT 11/33]; 1701: edes Anyam Aszszony ... ha az ökröt el adgya kegjelmed fizessem meg kegjelmed az kinek ados ha penig tartani akarja fogadgjon egj inaskat hogy gondot tudgyan viselni az ökörre [Ne; BLt 9 Toth István a koll-ból édesanyjához Angyalosra (Hsz)]; 1751: mongja az Juhaim mellett lévŏ Inaskám [Torda; CsS]; 1771: Szengyorgyi Czako Josef Uram házánál béreskedo Repa Jancsi nevŭ Inaskáját tudom hogy az Ŏkrŏk Nyakakrol a harangokat be lopogatta [Dés; DLt 321. 5b-6a].

inaskaköpönyeg $\mathrm{kb}$. béresfiú-köpenyeg 1798: Vitt magával ell a' Kotsis egy Inaska köpenyeget és ugyan azon Inaskának holmi fejérnémüit [DLt nyomt. kl].

inasocska szolgalegényke 1771: egy kobor inasocska ... maga beszéllette hogy ö ... valami Lovokot által a' Markodi patakon [Berekeresztúr MT; BetLt 7 Fr. Katso (30) ns vall.].

ingecske 1576: Weres zel Selyem zel (így!) Mynth egy wynyira walo zeles, tyzon egy Syngh, kyth Rwhajara kyth Ingechkeyere chynalok [Szamosfva K; JHbK XVIII/7. 13]; 1752: ott hagytam az hálo egyet mását, 2. Ingetskéjét [Beszt.; Told. 37. 44].

ingvállacska (rövid) női ingecske 1629: Egy hitua(n) Jng vál ... d. 50 Más, Egi hitua(n) Ingh vállaczika ... d. 10 [Kv; RDL I. 132].

instanciácska kérvényecske 1819: egy egy Instantiatskát irogattam [Fog.; Konstantinus lev.].

interesecske kamatocska 1779: a husz pénznek ... interesse egy pénznél valamivel tŏbbecske, viszontag ajállom a Tekintetes Aszszonynak, hogy azon interesetskét méltosztassék ez alkolmatossaggal meg fizetni [Bő MT; Sár.]. 
íráska 1. írásocska 1678/1683: In nomine D(omi)ni Anno 1678 kezte(m) ez iraskamhoz [Ks Kornis Gáspár kezével].

2. levelecske 1664: Énnekem is Kegyelmed ez kis íráskámról meg bocsásson és ne tartson idegennek [TML III, 328 Teleki János atyjafiához, Teleki Mihályhoz].

írásocska 1. 1632: noha k(ne)k ualazt irattam mind az altal ket harom szoual magamis ez reouid irasochkammal akaram kdet biztatni keöztunk ualo bekeseges alkalom es eggiesegh feleöl [Kv; Ks 41. D. 20 Lud. Bornemisza lev.]; 1795: Kérem jó $\operatorname{Vr}(\mathrm{am})$ Kgldet, szives köszöntésem mellett, ne terheltessék ezen irásotskámot közolni azon Jó Vraimmal [TL. Málnási László ref. főkonz. pap Debreceni István tt-hoz]; 1817: fel vévén egyszer akkora irásotskát, mint az edgyik tenyerem, vagy valamivel nagyobbatskát [Torda; KvAkKt 363].

2. iratocska 1663: Kérem azért, jó és csendes alkalmatossággal, igen szépen, rendesen instáljon az én kegyelmes vram ő nagysága előtt, méltóztassék ez iránt valo kegyelmes igéretiről egy kis írásocskát adni ... donationak kellett rúla lenni [TML II, 476 Teleki Mihály Gilány Gergelyhez]; XVIII. sz. eleje: Pálosi dólgokatt illetö irásotskák [Ks 1593-beli okl. reg.]; 1752: egj negyedrész papirosra irt irásotskát láttam Tótfalusi subscriptioja alatt [Bálványosváralja SzD; Ks 43].

íróasztalocska íróasztalka 1767: hamu szinre festett négy fijokós iró Asztalocska záros [Marossztkirály MT; Berz. 5. 38. P. 2].

íróházacska dolgozószobácska 1679: Úr Haza ... Ezen házban levő Erkély vagi iróhazacska [Uzdisztpéter K; TL Bajomi János inv. 19-20]; 1735: bojt hajtásos iró házacska [MNy XXXVIII. 55].

íróládácska írószeres ládika/ládikó 1714: Egj dió fabul való Iro Ladatska, Ajtotskaja rezes Rosaval ékesitett, 8. tsiga formala (!) tsinalt labain áll. külombfele fiokokat foglalván magáb(an) fl. Hung. 15 [AH 55].

írótáblácska 1714: Iro Tablatskanak valo futrálj, meg aranjozott ezüst bagjoggal ezüst viragokkal ekesitett fl. Hung. 6. Egy par Iró Tablatskaknak való futraly Tekenjös békaval ki rakott fl. Hung. 20 [AH 12]. irotványka irtványocska 1703: Somos odal felett egj kis Irotvánjka és az Borbelyok Irotvánja [F.tők SzD; RLt]; 1739: az Tŏvisses hellyben edgj darabocskát hagjanak az irotvankához [Szentmargita SzD; Kgy]; 1763: vagyon egy szekerre valo irotvanka [Ispánmező SzD; Torma].

Hn. 1739: az ... Irotványka közt levŏ tŏvisses [Szentmargita SzD; Kgy]; 1773: Trombitás Janos irotványkája [Bálványosváralja SzD; EHA].

irotványocska irtásocska 1744: Lévén ... egy edes szúleiről rea deveniált irotványnya és a mellett ... eŏ kglmétől aquiralt zalogos irtovanyocskaja [Dob.; WassLt]; 1754: Tudom bizonyossan hogy ezen kérdésben forgo irtoványotskat erdőből Husziai Nehai Temes On, és Fia Temes Togyer irtogatták [Goroszló Sz; WLt Román János (38) jb vall.]; 1766: Pap Stéfán ... egy kis darabatska Irottvánt kezdett volt ... de Szabó Pál Uram nagy darab Irotvánt tsinált belolle ... a' ... Fundeturában lévő kis Irotványotskával egyut négy Véka Tŏrŏkbuzát és két Német forintokat adott érette Szabo Pál Uram [Szentegyed SzD; WassLt Molduván Kratsun (80) zs vall.]; 1777: Kŏdmŏnŏsrŏl egyszersmind őt Szarvas Marhát egj ejtzaka el lopván a' Tolvajok ... akkoron éppen ide Nyomoztuk felyŭl rajtunk egj kis keres Irtoványotskába, a hol meg kőtve tartották a Tolvajok a lopott Marhákat [Resztolcs SzD; JHbK LVIII/28]; 1739: Kozma Janos irotvanyocskája [Szentmargita SzD; Kgy]; 1761: iratványocska [BSz; BfR 38/18]; 1766: Irotványocskák [M.köblös; RLt].

irtásocska irtványocska 1643: Uagion egi iritasoczjka [Szentsimon Cs; BLt]; 1800: A tőllem kérdett két Irtasotskakat mind az Kŏdi emberek birják [Benedekfva Sz; BfR II. 58/21 Fodor Vaszali (!) (67) col. vall. Várvölgyi Bányai János kézírásában]; 1800: Kelentze és Kŏd nevezetŭ Faluk kŏzŏtt ... két darab irtásotskákon kivŭl, hogy az ŏszve rugó Határok felett valami versengés lŏtt volná tudja é, hallottaé értette é a' Tanŭ...? [KSz; BfR IV. 58/21 vk]; 1824: Vagyon égy kis Irtásotskája az Aknás dombjába [Szásznyíres SzD; EHA]. 
iskatulyácska, skatulyácska dobozocska, ládikó 1685: Egy skatulyácskáb(an) Szebeni Patikában vött Ket Kis Csuporbeli Mel Rosar. [UtI]; 1697: Egy kis Scatulácska apro oh Pénz [KGy]; 1716: Bal felőll valo iskatulyacskáb(an) egy győngyős fekete Csipke hát alyával együtt [WassLt]; 1737 k.: Edgy fejer Skotuja, más Véres Skotojacska [Brassó; ApLt Apor Péter lelt.]; 1744: 8 Iskatuljatskak [Szentdemeter U; LLt Fasc. 67]; 1752: egy Iskotolácska aprosaggal [Eszt. Gr. Petkiné lelt.]; 1764: Egy Veres kerek Skatujácskában égy szép jó féle Győngy párta [Kál MT; Berz. 6. 54. L. 2]; 1773: Egy uti gömbölyü borsolo Pléh Iskatulya, benne lévő hat kerek Iskatulyácskákkal [Lele Sz; Marinai Pap lev.]; 1798: égy Szalmábol kötött kitsi iskatulyátska [Dés; DLt]; 1807: Kitsiny iskatulyatskák ... Egy rosz Iskotulyában krispány virág [Körtvélyfája MT; LLt]; 1807: Kitsiny iskotulyátskák, mellyekb(en) orvosság formák vagyn(a)k 5 ... Egy Scatulyába fejer gálitzko [Körtvélyfája MT; LLt]; 1810: Egy tojás kerekségü ezüst Skatulyátska [DLt 368 nyomt. kl]; 1816: Négy Iskatulyátska [Varsolc Sz; Born. IV. 41 Bornemisza Krisztina conscr.].

iskatulyaforma-ládácska ládikó 1767: drága győngyős és Kőves Reszkető Tőket, és Boglárokat is láttam azon kisded Iskatulylya forma Ládátskában [Egrestő KK; Ks 21. XVIII. 78].

iskatulyaládácska ?fiókos ládikó ?rekeszes ládikó 1767: (A) kitsi Záros Iskatullya Ládátskában tudom hogy volt Kézre es Nyakra valo két rendbéli jo féle, és Orientalis Gyöngy [Egrestő KK; Ks 21. XVIII. 78].

istállócska 1699: Vagyon Tisztarto lova Istállócskája mellyis fŭz vesszŏbŏl támasz nelkűl Sással meg fedetve épettetett [O.csesztve AF; LLt Gyulafi László inv.]; 1736: Istálotska van egy kisded négy Csere ágosokon állo Tapaszos oldalu Szalmával supozott Lo Istaló mellynek ajtotskaja Vas Sarkokon forog [Martonfva NK; CU XIII/1. 144]; 1740: Vagyon ... edgy négy Lónak valo jó istállócska ... fedele szalma, és igen meg avúltt, hidlás is vagyon benne [Szentkirály TA; Ks 89 Inv. 8]; 1757: még két Istálocskát kivántatván végsŏ igazitásba vétetni el ne mulassák [Déva; Ks 92. I. 23]; 1762: Mlgos Groff Bethlen Lajos Ur eŏ Ngă Boros nevezetŭ Vas mives Cziganya(na)k ... volt egy Kis Istállocskaja [Bethlen SzD; BK. Szabó Marton (56) jb vall.]; 1797: (A) Házacska ... vegiben ... vagyon ragasztva Közönséges Csere ágasokra veszövel font, és meg tapasztott négy Márhákra valo istállocska [Hosszúaszó KK; JHb XX/35]; 1825: egy kis Tölgy és Bikkfa Boronákbol épittett Istállotska ujj csinos zsupfedéllel megfedve [Szárazpatak Hsz; SzentkZs Conscr. 386]; 1830: égy szinetske ... vagyon az udvar napkeleti oldalába, melynek oldala, és fedele avaték Dészka, egy ehez hasonlo dészka fedelŭ, és oldalu Istállotska [Kv; Somb. II].

istenke kics átv vki vkinek mindene 1832: ugy láttzik, hogy ez a' Fia az Istenkéje [JHb Br. Jósika Jánosné gr. Csáky Rozália fiához, Samuhoz].

italocska kevés ital 1785: magamnak eledeletskéért vagj italatskáért ... fizettem [Kv; Pk 7].

ittasacska kapatosforma 1762: Tudom azt világoson hogy az Utrizált Házhoz Kassai János jőve és ott kűskődőtt ... ezen kívűl mit tselekedett egyebet nem jut eszembe, mivel ittasatska voltam [Geges MT; IB. Fr. Csok (35) ppix vall.]; 1774: mindjajan többire itasatskák voltunk [Bábahalom KK; Ks 19. VII]; 1794: magam által mentem itasotska is lévén Zakariához [Déva; Ks 79. XXVI. 10]; 1820: Gán Silip ... mikor ittasotska azt szokta mondani, hát nekem egy semmi parantsollyon Demén Máriskó [Várfva TA; JHb Bontz Mária Szakmári Samuelné (37) vall.]; 1843: elsŏ szavaibol észre vettem hogy ittasacska [Dés; DLt 65].

Ha. 1838: ittasotska [Nagyadorján MT; TSb 15]; 1842: ittasotska [Dés; DLt 916].

ittasacskán kapatosan 1778: mint egy ittasotskán mondotta ezeket alattomba sugva [K; KLev.].

ivókancsócska ivóvizes kannácska 1748: Apro ivó kantsotskák [Nagyida K; Told. 11/95]. 
ivókutacska 1766: ezen Rétnek az Also Vége jő égy ingoványos és égy kis forásos ivo kutacskára [M.köblös SzD; RLt].

járóka járni kezdő kisgyermek; járószék/ szekér (kisgyermeket járásra szoktató alkalmatosság) 1823-1843: járóka 1. járni kezdett gyerkőc; 2. kereken járó gépkosár (így!) melybe ide-tova mozgatással tanol a gyermek járni [MNyTK 107. 23].

javacska 1 . kb. vagyontárgy 1614: az negy vtolzorj Arúaknak penigh iouachkait Sopia Azzonnak vgj mint Edes Anioknak gonduisellesébe(n) biztúk [Kv; RDL I. 96a Andreas Júnck kezével]; 1640: Ez megh irt jouaczkakat penigh az giermekekkel, edgieőt, az Atiafiak akarattiabol, hagiok ... Vigh Laszlonal, vgi mint edes Apiok kezenel [Kv; RDL I. 123]; 1655: (Feleségem) Nem regen hon nem letemben titkon ... hazamtul el ment, hazamot jovaczkaimot praedára hagyván [SzJk 74]; 1670: oly iavaczikaia maradot melliet szükseghtöl kenszeritetven el kellet az relictanak adni [Kv; RDL I. 152]; 1710: akarja ... Isten kegelmebŏl gongyat viselni mind maganak, mind kicsin jovacskainak [Vadad MT, VK]; 1738: Váradi Mihály Atyánkfian(a) k ... minden Javacskája 's Haza elégett [Dés; Jk]; 1774: Ha ollyas Jobbágy hólt meg, kinek gyermeke Nem maradott, bé hoszták 'a mi jovatskája vólt az Udvarban [Szentdemeter U; LLt Vall. 104]; 1817: Az Eccla régi Jovatskáiról való Conscriptiok [Csókfva MT; UnVJk 381]; 1844: a' mi kevés jovatsáink vagjan azokra mŭis gondat tudunk viselni [Várfva TA; Borb.].

2. vagyonka 1623: Az giermeketis kiczin Jouaczkaiaual eggiut adtuk es biztuk az éo kegme Tutelaja Ala [Kv; RDL I. 121]; 1627: (Öreg Kanta Mihályné) vgj viselhessen gondot Jouaczkaiokra, hogj Jstenteol Aldast es az Emberektol Jo hirt n(eue)t vehessen [Kv; RDL I. 134]; 1629: (Az árváknak) Az Anyai harmadot Excidalnok, Es Jnuentariumba(n) Czinalnok, hogy ieöendeoben eokis tudnak az eo keues Jouaczkaiokat mi volna [Kv; RDL I 146]; 1687: Telegdi Beniamin Sogor vr(am) ... árvaságra maradó kedves házas társomnak, s édes gyermeki(m)nek ... javacskajuk takargatásaban, s gyermekim neveltetésekben ... szeretetit és igaz affectiojat meg bizonyitytya [Alpestes H; Incz. VI. 19a]; 1727: kevés jovacskájábol rájok nézendő portiojokot ki akarván mutattatni ... [Kv; Pk 6]; 1758: nékik, hozzájok illendŏképpen mint Gazda embereknek vagyon keves javotskájok [Bethlensztmiklós KK; BK].

3. vminek jobbik/jobbacska fele/része 1752: az Szarvas marhák kőzűl a jovatskáját, kit Tiz forint, kit kilentz forintokra [Torda; CsS]; 1792: Makfalvána felettébb sok rosz fóldek vagynak a' jovatskáit mind rontya a' Kükúllő vize [Mv; DLev. 2. XXA. - ${ }^{\mathrm{a} M T}$ ]; 1843: a' Dereszte körül, a' Deresztés számára, a' Helynek Jovatskája felszántatott, 's a' Deresztésnek ... termett az Árok körül a' Jovatskáján egy egy kevés szénájais [Bodola Hsz; BLt 12].

Ha. 1662: javacskáimot [Mv; SzO VI, 266]; 1664: jovaczkajnak [Kv; RLt 1 Diosi János kezével].

jegyecske 1. ismertető jelecske 1747: Pap Mihály ... falumbéli ismérem, ábrázattyában fejérszeg, Szőke Sárga bajusza vagyon ... az állán pedig egyik felől forradás forma jegyecske vagyon [Csicsópoján SzD; Ks 27. XVII].

2. (tulajdon) jelecske 1803: (Az abrosz) égyik szélyin veres fejtövel varrott jegyetske láttzik, égyik szinéről égy küs keresztetskét, az ellenben valo $\mathrm{p}(\mathrm{e}) \mathrm{d}(\mathrm{ig}) \mathrm{O}$ forma Betŭt mutató [Désfva KK; UnVJk]. 3. foltocska XVIII. sz. v.: egy Nyári pej tsikotskával melynek a homlokán kis jegyetske [PfM IV].

jegyzőkönyvecske 1735: Ez jegyzőkönyvecskét ecclesia számára, Két nyujto padokat halottak számára, Templom pitvarában mindnyájunk hasznára, Kovásznai András az oskola rectora ... Csinálta mind ingyen januariusban [Martonfva Hsz; HSzjP].

jobbacska 1. 1699: edgyik ${ }^{a}$.. jobbatska [O.csesztve AF; LLt Litt. C. - ${ }^{a}$ Bárka]; 1722: a kapu mellett vagyon jobbotska lèszáju kert [Algyógy H; Born. XXIXa. 8 Bornemisza János conscr. 1]; 1733: Jobbatska abrosz három, edgyik igen kisded [Marossztkirály AF; Told. 2]; 1735: ŏrŏmmel értettem az Excellentiad jobbatska appetitussát, reménlem hogj az erejitis lassan 
lassan recuperalhattya Excellentiád [Ks Borosnyai N. Márton lev. Nsz-ből]; 1741: lehetne pedig jobbacska reménség ... de igen vékony reménség [Told. 74]; 1813: Három tekenŏ jotska ... Egy Tekenyőtske ... Kis Asztal egy jobbatska, más haszon vehetetlen [M.sályi TA; RLt Szikszai Szikszai Elek kezével]; 1817: Égy jobbatska, és égy roszszabb Cserge pokrotz $[\mathrm{Mv}$; MvLev. 2]; 1836: a tolvaj Pujkás János volt ... ha v(ár)megye kezébe adjuk be fogják zárni s ezis elég rŏvidseget okoz, mert elŏl hátul most csak ő jobbacska lovaglo [Zsibó Sz; WLt Kemény Benjámin lev.].

Szk: állapotú 1844: Egy kö Istállo ... a' Kas felŏl valo bütüje bé van fogva veszszövel ... - a' más oldala jobbatska állapotu [Abafája MT; TSb 11].

2. jobbfajtácska/félécske 1698: Csereböl Erdöböl al az hatarunk tobbire es Tövis bokorboll ... az mi benne jobbocska asztis az Possessorok ö kglmek birják [Told. 24]; 1716: az széna fŭ majd egyenlŏ, noha ottis jobbacskának láttzik valamivel az Flistich rész [Jára MT; Told. 52]; 1789: azon Fŏldeket ... a melyek jobbatskák Tŏrŏk Buzának szokták hagyni [Szkr; UszLt XIII. 77]; 1796: a Szaraz Malomtol hoztanak 160 véka szilvát mivel ott volt jobbatska termes egyebütt most szedetjük [Szilágycseh Sz; IB Fogarasi István lev.]; 1846: 40 véka ros egy része jobotska egy része gyenge [Csán TA; Born. F. Id].

3. egy kicsivel/vmivel jobb 1798: egj Fekete Fodor Fátyol félviseltesnél jobbatska 3//6 [Kv; Pk 6 Pázmány Hedviga hagy.]; 1811: Rako fákbol épúlt három Majorság olak mellyeknek kettejé avatag az harmadika jobbacska [M.bogáta SzD; BetLt 5]; 1806: dél elött nem a leg jobb voltam, délután jobbatska [Dés; KMN 207]; 1836: (A búza) már reményleni lehet ez is jobbacska árron el kél [TSb 20].

Szk: magaviseletü 1795: jobbatska magaviseletü Embert formálhatnék belőlle [Mv; Told. 47] * egy szikrával 1807: dél előt egy szíkrával jobbatska voltam mínt ez előt [Dés; KMN 368] * sokkal 1785 k.: Kata ugyan mégis nem oly hibásacska: Dolgaiban serény, sokkal is jobbacska. Alattomban ő is akaratosocska, Titkon lappang, mint az alá néző macska [EM XX, 503 Balás-kódex] * valami kicsinnyel 1807: egész délig majd semmit sem tanultam rosz voltam, délután valami kitsinyel jobbatska voltam [Dés; KMN 351]; 1807: dél előtt igen rosz voltam kivált magam viseletemb(en), a Letzkeis sovány volt, dél után valamivel jobbatska voltam [Dés; KMN 216].

4. jóval jobb/kedvesebb 1824: Reád haraghatnánk, édes Máriskó a feredőn még jobbacska voltál, de Branyitskan", Illjén ${ }^{\mathrm{b}}$ felénk sem jöttél [Kv; EM XVII, 173 Csáki Rozália Lázár Benedekné Bethlen Máriához. $-{ }^{\mathrm{a}} \mathrm{H}$. ${ }^{\mathrm{b}}$ Marosillyén (H)].

5. nagyobbacska 1831: azon adosságnak jobbatska részit tsipegve tsupogva per partes 170 száz hetven Rforintokban s 20 Xrokban, kezemhez vettem [Hagymásbodon MT; Pf Pogány Sándor lev.].

6. kissé jobb/kedvezőbb/kissé szebbecske 1683: Jobbacska üdő volt Istennek hálá [Torda; SzZs 254]; 1684: Augusztus 12. Ez három nap mind esett az eső. 13. Jobbacska üdő volt Istennek hála [Torda; SzZs 254].

Szk. tehetségü tehetősebbecske 18231830: Vagynak ezen ispotályokban ${ }^{\mathrm{a}}$ betegre ügyelő cselédek (Krankenwärter), a férfiaknak férfi, a fejérnépeknek asszony. Ide még a jobbacska tehetségű városi betegek is bevitetik magokat [FogE 261. - ${ }^{\mathrm{a}} \mathrm{A}$ bécsiekben].

Ha. 1744: jobbacska [Marossztkirály MT; Told. 18]; 1750: jobbacskă Főldecske ház hellyetske, Malmotska, Szőlőtske [Vecsérd NK; Berz. 11. 88/5.]; 1764: jobbatska [Polyána H; JHb XXXII/37]; 1782: jobbatska [Bukuresd H; Ks 113 Vegyes ir.]; 1799: jobbatska [Albis Hsz; BLev.]; 1805: jobbatska [Hodák MT; Born. G. XVI/14].

jobbacskán 1. vmivel jobban 1771: Minthogj néha jobbatskán, néha pedig igen roszszul viselnek a' Bethlen Miklósné Asszonj eö Excellentiaja Adámosi Malmára gondot kéttség kivúl az az oka roszszul forgásának [JHb LXVII/173-4]; 1807: dél előt ... semmi Letzkét nem mondottam, akkor bé küldőtt a Rector egy tzedulával Nagy Papához, ot jol le motskolt pirongatott Nagy Papa, sírtam, ki jövén elmondottam 
a Letzkémet, irtam exponáltam, jobbatskán mint ez előt [Dés; KMN 353].

Szk: érzi magát 1742: Az Orvosság vétel után jobacskán érzi magát [BálLt 1 Gyulaffi László lev. Bécsből]; 1780: En be vitettem volt magamat Kolosvárra curaltatni, ā hunnétis tegnap délben érkeztem meg, már most Istennek hála jobbatskán érzem magamat, tsak erőm nintsen [Korpád K; SLt XL Henter János Suki Jánoshoz]; 1851: a' lelkem Anyám ... jobbatskán érzi magát $[\mathrm{Kv} ; \mathrm{Pk} 7]^{*} \sim$ van/lesz 1672: Asszonyunk Istennek hála most jobbacskán vagyon [TML VI, 48 Naláczy István Teleki Mihályhoz]; 1717: I(ste)n(ne)k hála az Gyermekeim jobbacskán vadnak, ... igazán meg vallom hogj féjtem őköt [ApLt 2 Kálnoki Borbála férjéhez, Apor Péterhez Szu-ről]; 1722: Gyermekecskénk ugjan jobbacskán vagjon, de ig(en) el fogjott gyenge [KJ. Rétyi Péter lev. Fog.-ból]; 1722: Ha szinte Felesége $(\mathrm{m})$ el mehetneis és jobbacskán lenne gyermeke, de én nem mehetek [KJ. Rétyi Péter lev. Fog-ból]; 1747: már kevéssé jobbatskánn van [LLt 135 Litt. C Cserei Farkas lev. Nsz-ből]; 1852: a' Lelkem Anyám egy nap jobbatskán van másnap fekszik [Kv; Pk 6 Pákei Krisztina férjéhez].

2. vmivel jobb állapotban 1731: Sok és nagj kőlcséget tétetvén az Nemes Város az Jég, és Szertelen Arviz miatt meg romlott s el szakasztott Gátunkon Ugyannyira hogy már szinte érőleg érnők, ha el esett Marhai kőzőtt jobbacskán maradott Marhait kiki hárman, négyen őszve fogván szalmát főldet hordana az öszve foglalt Gátnak le nyomtatására [Dés;DLt 415a]; 1777: az oláhok Szőleje maradót jobbacskán [Szászcsanád AF; BfR II. - ${ }^{a} A$ jégverés után].

3. bővebbecskén 1722: Ugy itilem ha más Regentia ne(m) supervenial a sok boros Gazdák miatt kevés lucrum lesz az korcsmákrol, de ha szorosb Statusban vétetŏdik a Proventusis jobbacskán lenne s gyŭlne [KJ. Rétyi Péter lev. Fog-ból]; 1751: Az Madarasi szőlő ... néha jobbacskán néha pedig szűkebb(en) termett [Backamadaras MT; Told. 29/51].
4. kb. mentől előnyösebben 1792: biztam vala a' Feleségem képében Testvér Bátyámra Dévai Istvánra azt hogy M Bándi kevés minket illető portiotskánkat ki vévén onnan az hol eddig volt és jobbatskán el adván a' mit abbol kaphatunk, tehát ... follyo Caussáinknak ki őrlésére forditanok [Kük.; MbK XI/84].

jobbad jobbacska 1571: egy jo paripat keoztunk nem talalunk, lofeweknek sokaknak es keossegnek is kijet kijet jobbadnak hallottak nyayatul el üzettek [SzO II, 326]; 1627: Egy vekoni len szál lepedeő $t t \mathrm{f} 1 \mathrm{~d}$. Más Duruáb lepedeő tt f. - d. 65. Jtem, Annal iobbad lepedeo tt f. - d 85 [Kv; RDL I. 132]; 1627: Egy viselt Kender szál lepedeö aestimaltuk f 1 ... más Egy iobbad Kender szál lepedeő ... f 1 d. 25 ... Egy szeősz lepedeő alábvalŏ.. d. 32 [Kv; RDL I. 133]; 1637: az Gal Mihaly szŏleie iobbad lott volna az Sarosi vramenal [Szentlászló MT; Sár.]

jobbadik jobbacska 1633: Chaualt barani börök jobbadiknak No. 62. Alab ualo chaualt döggel holt barani börok roszak No. 75 [Fog.; UF I, 311].

jobbadka jobbacska 1694: Majorság-Szőlő ... Ennek két felől fel menő szelei ... igen pusztások, homolittatni kévánok: a közepe(n) jobbadka [Kisenyed AF; BfR néhai ifj. Bálpataki János urb.].

jobbadocskán jobbacskán 1747: Samuel Ur(am) ... beteges allapottal van, de most Jobbadocskán van [Buzd AF; Ks 96 Mikó Ferenc feleségéhez].

jobbadon 1. jobbacskán 1586: Eo kegmek varosul, egy bizonios es reowid napra halaztottak, az Instructionak iobbadon valo megh igazitasat vgy hogy mind az malom bírak vraim s mind az Molnar Mesterek megh maradhassanak mellette [Kv; TanJk I/1. 28]; 1589/XVII. sz. eleje: az Legeny rend ez Varosbol el mehet iobbadon valo tanulasnak okaert idegen mesterekhez, orszagokat iarhat az tudomany kedueert [Kv; KőmCArt. 7-8]; 1590: ebben a' gondvisselesben ha eo kgmek az peres tanachbely vraim kesedelmet ereznek, $\mathrm{Ne}$ a' Io Akaratnak meg vonasanak, hane $(\mathrm{m})$ az Igyekezetnek iobbado(n) valo vegheoz vitelenek tulaydonicchak [Kv; TanJk I/1. 138]. 
Szk: vagyon (vele) 1651: az Labaim kezdettenek vala faini, most I(ste)nnek hala ismet jobbado(n) vagiok vele [Fog.; BK. Kemény Jánosné Kállai Susánna lev.]; 1749: ha meg holt is szegény kis Fiam, ha eletb(en) vagyon, ha jobbadon is had tudgyam, mivel meg nem csendesithetem magamot [Buzd AF; Ks 96 Mikó Ferenc feleségéhez].

2. alaposabban 1587: Valaztottanak ket feó vraimat ... Eotweos Andrast, Benchel Andrast $\mathrm{Hog}^{\prime}$... az Istennek tíztesseget ... eorizek otalmazak, ha mely zemelyheóz Bizonios Sorok (!) erteteodnek, az bwnnek megh chelekedeseben (így!), Azokat citalliak, seot iobbadon ertekezwen az bwnreól meghis fogtathassak [Kv; TanJk I/1. 48]; 1588: Jobbadon Akarnak Cancellar(ius) vrammal a' Paticar(ius) feleol zollany veghezny es tudokozny [Kv; TanJk I/1. 76].

3. bővebbecskén 1595: Bogathj W. fö szolgaiis ... panazolkodanak hogy fel nem erttek volna az elessel: Adatot Biro W. Jobbadon [Kv; Szám. 6/XVIIa. 182 ifj. Heltai Gáspár sp kezével]; 1621: Biro Vram hagia hogi az keözeönseges Postaknak iobbadon Gazdalkodgia(na)k [Kv; Szám. 15b/ IX. 17]; 1722 k.: Proventus Pastoris ... A Nemesektŏl a kik(ne)k jobbadon vagyon vetesek Buza Gel. 10 [Msz; GörgJk 125].

Szk: bírja magát 1589: tudom azt hogy az ado dolgabol vgy vegezenek hogy az ki Jobbadon biria magat tehat az teobbet adgion [Szu; UszT]

4. inkább 1621: Annakokajert hogj Biro vram eő kglme mindenfele iobbadon el erkezhessek ... es az reank imponalt subsidionalis penztis zallithassak, vettetek eó kglmek adot egj vonasra f. $1[\mathrm{Kv}$; TanJk II/1. 333].

jobbágyházacska 1729: egj kis Jobbágj házatskab(an) njomorog [Sövényfva KK; TSb 51]; 1760: Mósa László Uram ... épitett ... egy kőzőnséges Jobbágy házatskát, és Sendelly alá, egy kapú fél fát [Árpástó SzD; BK].

jobbágylegényke 1764: Jármas őkrők az irt Jobbágy Legenkéknek vagyon nro 2 [Pókafva AF; Kath.]. jobbágyocska 1657: Bojér Simon nevű bortöltő szolgája mellett instálék, hogy Fogarasföldén Kopacselen valahány jobbágyocskát adna nekia; kire felele, van azonféle jószág Gitás nevű faluban, azt neked adom. Ekképpen ada szegény kéretlen azt az joszagocskat [KemÖn. 97. 'Bethlen Gábor]; 1662: Kun Gergelj vram Algiogon ${ }^{a}$ és ott kőzel léuö két három falukban levŏ husz ház iobbagiocskámot Ngodtol ... megh kérte volt uolna, melj portiocskát ... conferalt volt $\left[\mathrm{KJ} .-{ }^{\mathrm{a}} \mathrm{H}\right]$; 1715: keözöttünk lako némely egyházi rendeknek lévén nemes vármegyében ... két vagy harom jobbágyocskája ... mégis velünk együtt contribuálni nem akarnak [SzO VII, 207 a székely nemzet kivánalmai a gub-hoz]; 1756: (Az attestatoriából) ki tetczik hogy tized magamal kell a házamnál a' Sot ennem, s azon kivűl kéves Jobbágyatskaimat $\mathrm{s}$ pénzes dolgassaimat etellel kell tartanom [Feldoboly Hsz; DobLev. I/279. 2b].

jobbágyocska-zsellér zsellérecske 1747: az Falu nem mind eŏ Ngaje mert az Szabad emberekbŏl állo derékos Falu, hanem tsak udvarháza van eŏ Nganak abban az Faluban tiz tizenkét Jobbágjotska Sellérekkel édgyŭt hozzá [Gagy U; Ks 83 Péterffi Sándor lev.].

jócska I. mn 1. meglehetős jó állapotban levő 1710: jotska viseltes ŏreg gombok [Told. 19]; 1750: Egy Jocska lo keffe [Bezdéd SzD; LLt Litt. B]; 1761: Avadag jocska altalag ... 3 [Branyicska H; JHb XXXV/39. 22]; 1794: Kapa 19 melyek közül kilentz jotska Rosz haszon vehetetlen kapa Nro 7 [Gyalakuta MT; TSb 17]; 1806: Kotyetz roszszatska, Kerittés pedig a Telek körül jotska [Nagymon Sz; BálLt 68]; 1829: Egy jotska abrosz [Mv; MvLev. 1e]; 1849: E' Szoba ajtaja veress festékü jotska [Somkerék SzD; Ks 73/55].

2. elég jó (minőségű); A. Földre von. 1732: egy láb főld ... mellyet falu fŏldiből fogtanak fel jotska főld [Nagyida K; Told. 11/70]; 1739: A' Felső Vágásban ... ez jótska Erdő [Erdőcsinád MT; TSb 51]; 1803: szánto főlgyeitis tudom ... de azok kőzzüll kevesett mondhatok csak jótskánakis, nagyobb része el soványodott majd a ha- 
szonvehetetlenségig [Márkod MT; BetLt 5 Emericus Kováts (53) ns vall.]; 1843: a' ki borozdolt Helyrŏl, a' hol jotska volt, hordottuk a' hompot a' Dereszte Árka töltésire [Bodok Hsz; BLt 9]. B. Termésre, terményre, termékre, takarmányra von. 1724: Koronkaj fel hegy szőlő sajtolt Bora jocska Ur 29 [Koronka MT; Told. 27]; 1752: az határunk(na)k mi voltához képest Jotska Gabonáink termettek és teremnek [Ludvég K; Told. 30/30]; 1753: Penna pénzt a Dézmasnak minden Ember ordinarie 4 ejtel mustot szokott adni ha jotska szüret van többetsketis [Cikmántor KK; KCsl 5]; 1780: Sarju is jotska volt rajta [Csehétfva U; Pf]; 1796 k.: A Dedradi es Batosi born(a)k vedret ako jotska három Márjás alol nem adják, az Tekei dragabb [Banyica K; IB. Gombos István lev.]. C. Állatra von. 1757: Egy pár Csonka kesej a más bingyo jotskák 6. es(ten)dŏsŏk [Mezőpagocsa TA; Berz. 3. I/9]; 1820: egy sárga jocska kantza [Born. F. Ig]. D. Időjárásra von. 1807: Délig mindig esett az éső keményen ... délután nem esett jotska idő volt [Dés; KMN 269]. E. átv képességre/magaviseletre von. 1807: délelőt meg lehetős Repetiot mondottam, delután is jotska voltam [Dés; KMN 353].

3. jobbacska, derekabbacska 1734: Ujsagul írhatom Ngod(na)k hogy Brassóbol a Nemetek kemenjen szŏknek altal a Tŏrŏk Pártra Molduvába, ínnét a mi jótska régj katonak voltak ki vittek egjnéhány nyomoru ujjakat hoztak helyibe [BK. Bethlen Ferenc anyjához, özv. gr. Bethlen Lászlóné Folthi Máriához].

4. jókorácska, kiadósacska 1758: nem ugj vagjon a termés mint másszor, ugyan csak itt többecskét ád Isten Ngának, jócska lészen [Boroskrakkó AF; TL]; 1781: Tegnap elött az Isten jocska essöt adott [Mv; TSb 13 Bethlen Zsuzsánna lev.]; 1807: reggel vgyan jotska ho volt de délután olvadni kezdett [Dés; KMN 356]; 1807: Ma $^{a}$ reggelre jotska hoharmat volt [Dés; KMN 363. aMáj. 5.]; 1841: mi előtt haza érkeztünk, 's azóta is jócska essők voltak, 's éppen mostis esdegel [Kv; Pk 7].

5. módosacska, tehetősecske 1774: jotska Gazda [Gerend TA; CU].
II. fn 1. holmicska, javacska 1798: Már ekkor még meg Nem holt volt az Aszszony, s a' mi Jotskája volt, el takarittatta Kováts István Uram Miko Urfival ... minden jo felkelhetőit Csernátonba magához [Szentkatolna Hsz; Mk IX/109. 4].

2. val alább jóval alábbacska 1739: szomoru és véletlen actusok volt az Nagy Táboron lèvöknek, vgy mint Mascherozván Orsova fele alá Landorfejerváron jocskaval alab ... az exploratorokot az fak melöl harmincz ezerig valo jancsár puska szokal excipialtak [Ks 99 Kornis Antal lev.].

jócskán 1. 1715: némellyek nékem jocskán adossok [BSz; JHb I/23]; 1720: jocskān ōszve vesznek [H; UtI]; 1736: Az uraknak, első főrendeknek az pompára való mentéjek hosszú volt, annak nagy hosszú szèlyes galléra, hogy majd a háta közepit érte, az karjának felit, elől is az mellye felől jócskán leért [MetTr 350]; 1740: Puskaporos és seretes Zácsko mindenik jocskan Teli [Novoj K; LLt 47/1216]; 1761: Kantza Csitkok ... egy sárga szőrüa a Homloka jotskan hodoss [Branyicska H; JHb XXXV/39. 16. aCsikó]; 1794: foj vala a' vére a' fejiből jotskán [BfN Dobozolt anyag X]; 1809: Már jottskánn zajosok lévénn durvábbul tréfáltak Váradi Mártonnéval szobolis [Dés; DLt 145]; 1843: akkori gazdám vagy két poffot adott Nékie, s' (me)g lehet jotskán találta [Dés; DLt 586. 19-20].

2. derekasan, derekasacskán 1784: Ludesdenis meg fordultam ... ottis jotskán trágyáztak [Bencenc H; Bk. Bara Ferenc lev.]. 3. jó bővecskén 1718: Proventust Husvét után kŭldhetnék jocskán, csak tudhassam hová [KJ. Rétyi Péter lev. Fog-ból]; 1742: Török buza ... három esztendŏkben jotskán volt [Méra K; AggmLt C. 12]; 1771: most is vagjon jótskán mind Buza mind Málé, de nem mérem fel mig tőbetske nem gyül [Eszteny SzD; Told. 5a]; 1774: (Az erdőből) hordott jotskán Gyertján ágat [Csóka MT; Ks 31. XXIXb]; 1791: ottan ${ }^{\text {a }}$ derék Tél ${ }^{b}$ vagyon ... és a' Ménes alig gyŏzi szalmával, de szénája is jotskán lévén bizik hogy takarékosan bánva ki éri a' Kostal [Sztrézakercsesora F; TL. - ${ }^{a}$ A.szőcsön (SzD). bFebr. 18-án Wessenyei Dániel jószágig. gr. Teleki Józsefhez]; 1847: dinnyénk csak 
teremget ... zsendűlt szőlőt az enyimből már ettünk, téli gyümőltsis jótskán lesz [Kv; Pk 7].

Szk: csak is 1752: itt ritkán szokott csak jotskán is ereszteni a Gabona [Ludvég K; Told. Fasc. 30].

4. elég jól 1772: A szegény Salánki Mózes ... Jó gazda is volt, tudta hogy ő életre való, jócskán is tanult, tehetôs is [RettE 285]; 1804: Dél elött jotskán tudtam a Letzkét ... a G. Antiquitásbol is meg lehetösön tanultam [Dés; KMN 14].

5. elég/jó sokkal 1753: jotskán bellyeb szántottak az igaz határánal [Nyárádsztbenedek MT; Told. 28].

jókorácskajócskánnagy 1724: egj Gyŭmŏltsŏs jokorátska [Mezőmadaras MT; Berz. 13. II/36]; 1749: vagyon ezen cinteremben egy fabul épített harangláb, melyben vagyon egy jókorácska harang [Nagyercse MT; ETF 107. 22]; 1750: Vagyon ... egy alkalmas magasságú fatorony és abban két jókorácska harangocska [M.fülöp MT; ETF 107. 21]; 1803: égy jó korátska nagyságu szép Harang [Nagyteremi MT; VJk 204].

jószágocska 1. birtokocska $1592 \mathrm{k} .:$ az Jsten az en Atiamott ell veotte az mi kicsi(n) eoreoksege es Jozagoczykaia s marhai volt minket Jlletett volna az en Atiamnak ket fiawal Peterrel es Mihállal [U; UszT]; 1595: az louas legeni Caspar Deak mellettek ${ }^{a}$ legien, es miert hogi annak az Jozagocskanak gongia viseleseben alkalmas ertelme vagion [Kv; TanJk I/1. 253. - ${ }^{\mathrm{a}} \mathrm{Az}$ ispánok mellett]; 1621: azon Thorda es Colosz (!) warmegieben leueo kiczin Jozagoczkayat birhassak [Gyf; LLt Fasc. 155]; 1681: Joszágocskáim alapottyărol ualo jedzések. 1681. Balintith Sigmond mapr. szŭksegesnek itiltem ... hogy a mi keues Joszagocskaim uadnak ... azoknak allapottyokrol ualami tanusagot hadgyak nekik Feier Varmegyebeli Joszagocskaimrol ... Vduezült edes Atyámrol ... két féle Joszagocskám maradot [BálLt 1]; 1714: Méltóságos Elsö Appaffi Mihály, akkori Erdéllyi Legitim(us) Fejedelem Kegjelmes Urunktól Conferáltatott kegjelmesen azon Csatáni Jószágocskája szegény Városunkn(a)k [Dés; Jk 547a]; 1757: küsded Joszágotskához tartozo kétt Főldetskei [Vacsárcsi H; Sándor conscr.]; 1782: édes Annyárol maradott Joszágotskája, s vagjonkája ne pusztuljon el [Torda; KW]; 1838: Nékem itten Ns Hunyad Vármegyében egy Szép kis joszágotskám jött kezemben N. Rápoltan Gr: Haller Jánosné Néném Testamentumánál fogva [Nagyrápolt H; Bosla br. Miske Ferenc lev.].

Szk: fiskális 1712 k.: most azon Fiscalis jozágocskanak birodalmában vagiok [EsztMk Cserei Cserei Mihály kezeírása] * külső 1785: itt Thorotzkon, tsak nem minden Gazdának mint (!) Fundussa rajta lévö Epületével, mind belsö és külsö Joszágatskája, partim örökös, partim Zallag titulus alatt pénzében áll, mert ... vagy tulajdan maga, vagy Elei acquirálták, s vásarlatták ... a' mellyböl igaz az, hogy nem Meltoságos Patronus Uraink adamánnyábol vagyon Joszágunk [Torockó; TLev. 6/1. Transm. 19a] * zálogos 1792: azon kis Zállogos joszágotska ... minekutánna ki váltatatt, azon szerzemény-joszág árrát el osztották három felé [Borb. II Agillis Andreás Kedei ez M. Sákod ${ }^{\mathrm{a}}(97)$ vall. - $\left.{ }^{\mathrm{a}} \mathrm{U}\right]$.

2. földecske 1652/XVIII. sz. v.: Fel Dobolyb(an) a az Erdö Szélyb(en) vagyon egy darab Joszágotska vicinussa ab una Szabo János, és Sándor Joszága, melj Joszágotska ugyan a feljül meg irt Joszágnak egyik szelib(en) mégyen [DobLev. I/17. - $\left.{ }^{\mathrm{a} H s z}\right]$; 1685: Tudom hogy ... Gáspár azt az kérdésben megh irt darab joszágoczkának az füvit nekem adta vala, hogy az kőrűl vgyan tegyek edgy darab kertet, én kertelék edgy darabot érette [Altorja Hsz; Borb. II Andreas Biro (42) pp kezével]; 1791: Lévén ... egy Kis Joszagotskája nevezet heljetskék égy fél Szekér Szenát termŏ Retetske [Vaja MT; VH]; 1801: Lévén ... Szilágyi Borbárának valami Joszágocskája ... Szükŏ felé forduloban Rokalik nevezetü helyben Szilágyi parlagának nevezik [Malomfva U; EHA].

3. telkecske 1696: ada ... Bikfalvan all tizben egy kis joszagoczkat ... az templo(m) hidgya elŏt [Bikfva Hsz; EHA]; 1721: kelletett maga Joszágocskáját egy ház vlését áruban bocsátani [Koronka MT; Told. 26]; 1779: ezenn Joszágotskának a Patak felŏll valo vége [Szövérd MT; Told. 25]; 1803: azt 
hallottam Szabo Andrástol, hogy a Nagy Anyának Nagy Moses János mint Léányának adott volt egy kis Joszágotskát, és egy darabotska fóldet [Szenterzsébet U; Borb. II Agilis Máté Mihály (78) vall.]; 1805: Bartos Sara Asszony itt az Albisi rész joszagotskáját el adá őrőkősőn ... ôtse Uranak ... 100 száz Magyar forintokert, mely joszágotska vagyon itt Albisban ${ }^{\text {a Felszegb(en) }}$ [BLev. - ${ }^{\mathrm{a} H s z]}$.

Szk: belső 1728: A' Leány Testvéreknek ismét Commoditassakban intéztŭnk el egy darab Belsŏ Kertŭnket ... ezen belsŏ Joszágatskám is egy kis Gazda meg férhet ha házat kivannanak reája épitteni [Marossztgyörgy MT; Pf]; 1806: felső falu Szeriben égy puszta belsŏ Joszágotskája [Szabéd MT; EHA]; 1829: egy belsö Joszágotska [Sóvárad MT; NkF] * bennvaló 1763: adott ... egj 4 ŏlni benn való Joszágotskát [Udvarfva MT; Told. 44.14]; 1794: lévén ... M.Járában egy darab ben valo Joszágatskája [LLt 2/7] * ôs örökös 1802: lévén ... benn a Faluban egy kis benn Valo ŏs ŏrŏkŏs eleirŏl maradott Joszágotskája [Lőrincfva MT; SLt 12. V. 18] * partikula 1770: Bodó Páll el árvásodván nem volt modgya, hogy ... Testvér huga szegotséget a Melgos Udvarnak meg fizethesse kéntelenittetett azon ... pártikula jószágotskát orokos fundusábol kiszakasztani [Madéfva Cs; Ks 65. 44. 13] * puszta 1632: kicziny puszta Jozagoczikaiat kezehez kelletet volna venni [LLt 100/9]; 1840: Lévén ... egy puszta Joszágotskájok, melly Joszágot Kitsinsége és közös volta miat ... használni nem tudhatván által adák örök Tserébe Tkts Kispál Károlly Urnak [Uzon Hsz; Kp V. 369].

jószágocskabeli vmely birtokocskához/jószágocskához tartozó 1581: wagion az Sohoz tartozo hawas allat egy nagy kazalo mezzeó ... az En Jozagochkambeli zegeny Jobbagimis onnat Eltenek minden fele mwhebe (!) walo fakkal .... barmokotis ott tarthatta [Gyf; Törzs Szentpáli Kornis Mihály a fej-hez].

jövedelmecske 1 . bevételecske 1621: Zam veweőket zoktanak valaztanj, kik az varosnak kewes Jeöwedelmeczkejenek exitusarol, es mindenfele erogatiokrol az Tiztviseleő vrainktol zamot zoktanak vennj [Kv; TanJk II/1. 335]; 1649: akkori kiczid iovedelmeczkeból Postakra Orszagh szolgálattiában forgolodo rendekre ... az mire érkezhettünk abbol kőltőttünk [Dés; DLt 424]; 1657: az honnan mi kevés jüvedelmecském jü vala, én azt az hadakra, kémekre és uram dolgai mellett költöm vala [KemÖn. 237]; 1709: Az Ecclésiákban sok helyeken az Ecclesiák jŏvedelmecskéjét, ugjmint, borát, búzáját és egyszer s másszor gyŭlt pénz kŏlcségét rész szerént egymás kózt régen ki osztottanák, és mostan is osztogattyák az Ecclesiák kárara [REkLt Cons. jk I. 30]; 1726: egy kevés cameraticai jövedelmecskének okáért szabados lévén [Cssz; SzO VII, 328]; 1764: a' két féle jŏvedelmetskébol inkább élhetne [Szőkefva KK; BálLt 1]; 1840: nem tartozik osztozni azon ... kitsiny Jővedelmetskéből [Dés; DLt].

2. hozamocska 1605: minden ember joszágának jövedelmecskéjéből táplálta magát [SzO VI, 14]; 1622: annak ${ }^{a}$ jeővedelmeczkejeben semmit ide nem szolgaltattanak [Dés; KGy. - ${ }^{a}$ A révnek]; 1643: Mivel ... azon ioszagoczkamnak jeovedelmebeol egyebüttis az decimat ki szoktam vetetni ... Azert az mi kiczin az ott valo ieovedelmeczkeből jut annak mind exigalasabol s mind erogatiojabol ehez tarcza magat [ETA V/2. 75 I. Bethlen István ut. a bethlenősi dézma felhasználása felől].

3. járandóságocska 1683 k.: az Pástor jővedelmecskejenek része ... Fa hordas es marhacskaianak táplálására valo szena adás [Szilágycseh Sz; SzVJk 123]; 1739: mivel a' Feleki Taxát a' Quartas szokta percipiálni ... a' melly Jővedelmetske az emlitett Falu(na)k Proventusaiból szokott eddig járni a' Curatorok(na)k az ennekutánna légyen és cedáljon a Quartas(na)k [Kv; SRE 173]; 1794: nintsen hatalmokban jővedelmetskéinkben minket megszorittani s abban minket meg károsittani [Mv; Berz. 7. 71/7].

jövésecske sarjacska, sarjadzásocska 1821: Doboka vármegyében Ŏs nevŭ Falu Határán La Saleo nevŭ hellyen egy erdŏtske ... haszontalan apro jŏvésetskék láttzanak tsak [TSb 18]. 
juhászházikó juhászkunyhó 1777: egy főldetskének a vegire tsinált volt Nehai Pap Gábor eŏ klme egy Juhász Házikot azután a maga Nemes Curiáját ugj vitte azon földek végeiben valo nyilatskara [Marossztgyörgy MT; MkG 36. 5/5 Bojtos Todor (63) zs vall.].

juhocska 1599: Iffiú koromba(n)is volt Juhoczkank es ott a' taiban tartottak neha [UszT Antonius Thorniay de Zataloka (!) (60) pp vall.]; 1614/1777: Iván István ... valami kevés Johatskája es vagyon [Zágon Hsz; Szentk]; 1633: Tudom hogy Nagy Thamas Vram Ide jöue Komanara Mindenfele marhayatt ide hoza, Juhat, disznajat, Tehenet, Eőkrit Menesit, es itt is adogattak az emberek Jŭhaczikakat [A.venice F; Szád. Radul Juonie (70) vall.]; 1659: ez fekete juhoczkanak meghalt az barania [HSzj fekete al.]; 1711: egy nehany Juhotskamis talam aztis nem veszi el tollem [Ks 96 Árva Kemény Kata leányához, Gyerőfi Borbárához]; 1729: az Atjám adot neki két tulkot edgj fojato tinot és egj nehanj juhocskát [A.oroszfalu SzD; BK A.oroszfalusi jb-ügyek. Pap Jonásk (40) vall.]; 1742: a Fatens, kevés Juhocskaja Lévén kőzikb(en) sem egyelitette magát [Kovácskápolna Szt; TKhf Dancs Adám (30) vall.]; 1814: Ezeknek felette hallom, hogy Kevés Juhacskája Tulkocskái lennenek Barabás Uramnak [Banyica K; BfR 117/1 Ladislaus Dorgo (49) ns vall.].

jussocska 1. birtokocska 1791: Jussotskájoknak terjesztéséb(en) tőrőkődvén itt valo kicsiny s majd haszon vehetetlen Jussatskajokot ... által adák [Ádámos KK; JHb XIX/33]; 1815: Mü, ide alább subscribált nemes Szárhegy falvának hütös birái és esküttjei ... sárhegyi Czimbalmos Albert gyalog katonának ... Szárhegy Alszeg tíziben ... adó(n)k egy kicsin particula jószágot, vagyis belső lakhelyet ... vitzinusa ... napnyugatról az Páll András gyalog katona moston kapott jussocskája örökire [RSzF 110. 1.Cs]; 1845: Berei István Uram ... által adá ... minden Köz hellyekböl jutando jussát örökösön $7 \mathrm{az}$ az hét magyar forintokért ... evictziot is vállala Berei István Uram magára hogy azon Vas János Uramnak által adot kis Jussotskában Vas
János Uramot meg tartsa és oltalmozza minden háborgatok ellen 3 válto magyar forint vin Culom (!) terhe alat [Bözöd U; Borb. II].

2. örökrészecske, örökségecske 1751: Tts Basa Istvan ura(m)n(a)k Sepsi Székben Egerpatakon holmi Jussotskája volt és vagyon most ... a Ttes Basa Istvan Uram Relictaja ki keresésére Basa Ferentz uram is mint igaz Attyafi nem denégalja, hogy az ŏ klme Eg(er)patakon levŏ jussaban része nintsen [DLev. 5. XIV. 1]; 1774: leven ... egy harmad részni Jussotskaja [Bölön Hsz; Berecz lev.]; 1847: Mivel már mind a férjem mind pedig az atyámfiai háborgattak, hogy a szüléimtől maradt jussocskámat eljátszottam ... azonba válást is inditottam [VKp 153 Varga Katalin kezével].

Szk: anyai 1817: Reám jővén által ezen kőtelesség hogy ... Sárdi Nemes Szilágyi Ádám, és Felesége Váradi Kata jussán bíro kevés Anyai jussotskájok iránt a Tit Urhoz tudosittást tegyek [M.igen AF; KmULev. 3 Benkő Sámuel lev.] * jószágbeli 1791: Lévén ... Néhai édes Annyok, és nagy Annyok ... Jussán ... Adamoson, bizonyos rész Joszágbeli portiotskájok ... mely Joszágbeli Jussotskajoknak sok felé szakadozások de effelett távol lakások mián telyességgel semmi hasznát is nem vehetvén ... által adák ... eŏ Excelentiajanak [Ádámos KK; JHb XIX/33]; 1791: Jussatskájoknak terjesztéséb(en) tőrőkődvén itt valo kicsiny s majd haszon vehetetlen Jussatskajokot ... által adák [Ádámos KK; $\mathrm{JHb}$ XIX/33].

kacolácska kancácska 1620: Az két elól jaro eőkrókót hagjom Balas fiamnak az veres kaczolácskát is neki hagyom [HSzj kacola al.].

kádacska 1. 1594: Az Somlioy maior hazban ... Soos viznek walo kadachka vagjon No 1 [Somlyó Sz; UC 78/7. 16-7]; 1621: Veǒttwnk egy kadachkat sos viznek p(ro) d 28 [Kv; Szám. 15b/VII. 25]; 1632: Komanai Uduarház ... Pincze ... Egy kis kadaczka N 1 [Komána F; UC 14/38. 129]; 1647: Kisded Kádatska [Borsa K; Told. 49]; 1683: (A káposztát) egy uy kicsin kadacskában szep tisztán bē sozattam fedél s lakatt alatt tartom [UtI]; 1743: fenyŏ fábol csinalt ka- 
dacskák [Boroskrakkó AF; BfR VI]; 1754: Két Kádatska, és egy őszve omlott Cseber öszve rakásáért egy Ernyei Embernek adott in denar 60 [Mezőgerebenes TA; BLt 7]; 1761: Lenmag ... egy Kádacskáb(an) Metr 2 [Branyicska H; JHb XXXV/39. 12]; 1781: égy kádotska [Szentdemeter U; Hr]. Szk: faabroncsos 1849: Csap alá valo fa abrontsos kádatska egy [Somkerék SzD; Ks 73/55] * kerek 1790: Csap alá valo Kerek Kádatskák 4 [Déva; Ks 76. IX. 24] * szapuló 1770: Szapullo kádatska [Esztény SzD; Told. 29] * szürő 1793: Nyomo kádok és aprobb Szürö kádotskák No 5 [Kettősmező Sz; JHb XLVI/8] * víztartó 1694: Egy viztarto Kadacska [Kővár Szt; JHb/Inv.].

2. vhány kádacskányi 1708: A (commendans) holmi discrecziokat kevanna latom, egy szeker szenat bar csak egy kŏbŏl szep buzat, edgj kadoczka kaposztat keves kerti vetement és egj kőből kasatis emleget [Fog.; KJ. Fogarasi János lev.].

kádacskaforma kádacskaszerű 1820: Egy talpon állo Czirádás szélü, és viragos fedelü Nád méz tarto ... égy kádacska forma fedeles és ovalis figuraju más Nád méz tartó mind a kettő F. T. betükkel jegyezve [Felör SzD; BetLt 5 Fráter Theresia kel.].

kádárló-házacska bodnár/pintérműhelyecske 1744: Kádárló kis Házacska, padlásozatlan [Marossztkirály AF; Told. 18].

kakaska kakasocska, kiskakas, táj kakóca. Szn. 1759: Susanna Kakaska [Dés; RkAk 37].

kakóca ?kiskakas. Hn. 1820: A Kakotza erdő [Udvarfva MT; EHA]; 1840: A Kakotzánál (sz) [Udvarfva MT; EHA].

kalamáris-ládácska írószeres és irattartó ládikó 1773: Kalamáris Ládácska holmi aprólékokkal Nro 1 [Jobbágyfva MT; BálLt 71]; 1775: egy viseltes vasas kis Pintzetok forma Kalamáris ládátskát ... fel nyitottunk [Szászerked K; LLt FAsc. 110].

Szk: ezüstös 1673: Egy ezŭstŏs két felé nyiló fekete kalamáris ládácska [Fog.; UtI]; 1679: hozzon ... egy francia ezüstös kalamáris ládácskát [TML VIII, 449 Teleki Mihály lev.] * lakkírozott 1746: Az asszon író asztalán lévő lakirozott kalamáris ládácskában ... Vargyasi jószághoz tarto- zó levelek ... Néhai idvezült méltóságos asszon bécsi útjáról való maga diariuma [Vargyas U; DanielO 256].

kalangyácska 1. gabonakeresztecske 1808: Hát arra emlékeziké a Tanu, hogy azon Hetven kalangyátskákat is ... nem a maga csürihez, hanem az erszény Lupujéhoz rakatta? [Erked K; LLt vk].

2. szénaboglyácska 1791: Csinyáltattam ... szénát ... az Erdőkőn kalongyácskákot 4 [H; Ks 108 Vegyes ir.]; 1798: Az erdőn Csinyált kalongyacskakot 7 ... 3 buglacskát [H; Ks 44-5].

3. vmiből vhány kalangyácskányi 1742 : égy kalangyácskát tiz vonás forintokon

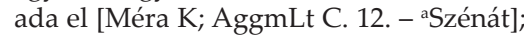
1750: vagjon tavallyi szalma egj kalongyátska [Szamosfva K; JHbK LVIII/4. 3]; 1750: kaszáltatott két kis kalongyátskát [Kárásztelek Sz; Told. 3]; 1823: Az alsoreti Széna egy kalongyatska [Budatelke K; Born. F. Ic]; 1840: Még széna van három kalongyácska 's egy fenék [A.ilosva SzD; KfMiss.].

4. Jelzői haszn-ban; vmiből vhány kalangyácskányi 1761: Sárpataki Lászlo Ur(am) egy kalangyátska szénát tsináltatott az ide valo Lipitorokkal [Szeszárma SzD; BK. Popa Alexa (30) jb vall.]; 1765: Margai Ferentz Vram(na)k ... Vagyon a Csüres kertben egy kalongyátska szenaja és egy kazlatska szálmája [Ispánlaka AF; JHb XXVIII/49. 9]; 1781: edj kalongjatska széna vagjon [Esztény SzD; Told. 6]; 1794: az idén nevezetesen elég avar gyujtogatás volt mindenfelé s nekemis ... volt egy kalangyatska szénám, s ha ki nem mentem volna oltalmára ott égett volna [Nagykristolc SzD; JHb]; 1803: Egy Kalangyátska Széna Hfr. 18 Dr. 36 [O.asszonynépe AF; DobLev. IV/862. 28b].

kalánka kiskanál, kávéskanál 1654: kwldeottem ... kŭlen egy Jwegh palaczk vizet, melybeŏlis harmadnaponként igyek égy egy kalankaual regellenken (!) [Gyf; BesztLt]; 1744: Lapos nyelü ezüst régi vásott kalánkak 2 [Szentdemeter U; LLt Fasc. 67].

Szk: tojásevő 1772: 1 Fő szerszám reszelő egy tojás évő kalánkával [Egeres K; Ks]. 
kalánocska kiskanál, kávéskanál 1700: Harom fejer kis kalánocska [Hr 1/20]; 1763: hat aprob kalanotska [Hsz; Ks 23. XXIIb].

kalapocska 1. 1787: (A) Leg kissebb árvának, Mihállynak 2. Pendejes Ingre, egy fonalas Materia Kantusra, égy kalapatskára ... égy téli flánel Kantusra [Mv; MvLev. Csiszár György hagy. 14].

2. egy kalapocskányi, egy kis kalapnyi 1806: instáltam, hogy ne terheltessek én nékem édgy kalapotska szilvát adni [Dés; DLt 82/1810].

kalaptokforma-ládácska kerek ládácska 1780: Cserei Uram beszéllette nekem dicsekedve ... hogy nékem adták az Gróf Urak eo Nagyságok a kalap tok forma ládátskában lévő jo féle győngyőket is, mellyeket Ked is láthatott [BK. Beniamin Orosz de Sárd (20) ns vall.].

kalendáriumocska naptárocska Szk: asztali 1847: Maga számára tett le vagyis küld általam az angyal néhány darab csekélységet válogatott dalmüvekben, és égy asztali kalendáriomocskát [Kv; Pk 7].

kalibácska (cigány) putricska 1681: Mint hogi a' Cziganyok(na)k, valami bizonyos jó rendb(en) valo hazok nincze(n), hanem csak imit amot, ā ki hol csinalhat maganak kalyibacskat, az Úr földen, ugi lak(na)k, azert bizonyos Sessiojok nem is irattathatot [Vh; ÁLt Urb. 41]; 1829: Az Ujj hegyrŏl le jővő, út mellett a Város végénn, az agyag gődröknél vagyon egy szegeletetske, melyenn egy földbe ásott kalibátska meg férne [Dés; DLt 729].

kalmárboltocska áruló-bódé 1744: Curialis Fundus vagyon edgy Allvintzen az Piatz soron romlodozot puszta kőfallal, mellynek edgyik végéb(en) épitet fábol egy kicsiny kalmár Boltotska [Alvinc AF; Ks 23. XXIIb].

kályhafütőcske csempe/cseréptüzhelyecske 1813: van az Házban egy hitvány és dőlő félben lévő gogány Kementze egy avatag kájha füttőtskéivel [Udvarfva MT; Told. 42].

kályhakemencécske csempekemencécske 1743: fŏd tŭz helyre rakot rakonni kezdet zŏd de regen épitet kályha kemenczécske
[Boroskrakkó AF; BfN dobozolt anyag $\mathrm{VI}]$.

kamarácska 1. szobácska 1636: Azon hazbol nilik egy kamaraczkara egy hasonlo festett bellett vas sarkos pantos forditos kiliczies ayto vas be vonojaual eggŭt [Siménfva U; JHb Inv.]; 1636: Vagyon eggik szegeletib(en) dezkaval altal rekeztue(n) egy kis kamoracska [Siménfva U; JHb Inv. - ${ }^{a}$ A serfőzőháznak]; 1803: égy Classis(na) k való kisded Kamarátska vagy Házatska égy kis Tanulo Házatska vagy Kamarátska [Désfva KK; UnVJk 183].

2. (élés)kamrácska 1637: Korczyoma haz ... sendelyes haz ... az pituarrol nylik bal kez fele egy hazra vagy vas sarkas pantos ayto ... Azon hazbol nylik egy kamaraczykara egy uas sarkos, pantos, reteszes ayto [Fog.; UF I, 424]; 1701: az regi Majorhaz Sơvenybűl való kis szobájávál es kamoracskajaval [Páncélcseh K; Hr 1/4]; 1752: (A) Specificált Házak kőzőtt vagyon egy kisdég Pitvaracska ... Nem kủlónben ... egy kisdek Kamarácska be nyilo ajtajával együtt [Pókafva AF; JHb XXV/73]; 1754: nyilik egy bérletlen vas sarkon járo ajto ... egy kis Kamarátskában [Uzdisztpéter K; CU]; 1797: tanáltatik egy Szalma fedél alat valo parasztosan készített épület, melynek a Kapun felől valo résziben vagyon fenyő deszkákkal Csere gerendákra padolt Házacska ... Kicsin pitvarával és hozzá ragasztott Kamarácskájával [Hoszszúaszó $\mathrm{KK}$; JHb XX/35]; 1825: egy régitske fenyő Boronából épült Ház ... ezenn fedél alatt vagyon egy kis kamarátska is ugyantsak Boronából rakva [Csomakőrös Hsz; SzentkZs Conscr. 3/7].

Szk: cipótartó 1748: egy nagy Hinto Szin ... Gabonás felől valo Szegeletib(en) vagyon Czipò tartò égy nyári Kamarácska [Kocsárd KK; Ks 8. XXVI. 5] * szalonnatartó $\sim$ 1774: Szalonna tarto Kamaratska [Pókafva AF; Kath].

3. kb. áruló-bódécska 1586: ki leowe hozzam Igiarto Gieorgi az kamaracikaban Azhon ennekem Arwcikam vagio(n) [Kv; TJk IV/1. 618-9]; 1621: Az Eóregh keo Boltok Jövedelme az kenyr Zer feleol ... Zigiarto Ambrusne Bottia is puztaba allot, 
Eo magais Buday Tamasne kamaraczkajaba keolteozeot [Kv; Szám. 15b/IV. 2].

4. raktárhelyiség/szobácska/szerszámkamrácska 1632: Az kapu keözeöt uagion eöt kamoraczka mellien uagion egj egj felszer parazt aito [Fog.; UF I, 131]; 1656: Az Istallo faraban egy kis gabonas haz forma kamaraczkaban, ket buzanak valo veszszőkből font kas tapaszos, haro(m) üres hordo [Doboka; Mk Inv. 7]; 1732: ezen major háznak is van az óldalában egy kamarácska ... találtunk benne egy régi fŭstŏs pohár széket [Kóród KK; Ks 12. I]; 1795 : Találtatott egy Szalmaval fedett sorvatt fedelü Sövény oldalu Ház ... pitvarával a hátul lévö kis kamarátskájával Hfr 15 - E mellet találtatott egj más Sövény oldalu ház meljnek fedele hasonlolag el van sorvadva ugyan Szalmaval fedett ez is Pitvarával hátulso kamaratskajával ... Hfr 15 [Ne; DobLev. IV/750. 1a]; 1797: Ezen ház oldalában tsinálva vannak kétt kitsid kamarátskák [Kőrispatak U; Pf]; 1807: édgy Szena tartó és édgy Nyereg Szer szám tarto Kamorácskam [Szentmargita SzD; Ks 76/56 Conscr. 7].

5. bódécska, rekesztékecske 1632: (A) hazban uagion egi dezkabol rekesztett kamoraczka, mellien vagion egj paraszt félszer uas sarkos pantos retezes aito [Fog.; UF I, 137]; 1711/1761: A tornácz végiben sövényből font kis kamarácska, dészka ajtaja, vassarkokon járo fazárja [Szászveszsződ KK; ETF 108. 10].

kamukamentécske damasztatillácska 1763: 1. Egy szin kék kamuka mentetske béletlen arany varrással [Nsz; Szer. özv. Harsányi Sámuelné Tisza Ágnes lelt.].

kanavászzubbonyka 1662: Ebéd után ... szekerében nagy nehéz álom jött vala reáa, mellybül felserkenvén, hát nagyon megizzadott, csizmáját ... Levonta dolmányát is aszerint és csak a kanavász zubbonkában ... egész Vécsig ${ }^{\mathrm{b}}$ mind aludt [SKr 290. - ${ }^{\mathrm{a}} \mathrm{II}$. Rákóczi Györgyre. ' $\mathrm{MT}]$.

kancacsikócska nőstény csikócska XVIII. sz. v.: egy fekete esztendős kancza tsikotska [Pf].

kancácska nőstény lovacska 1627: Tauali luoaczka Nro. 4. Tauali kanczaczkais Nro 4 [Bodola Hsz; BLt1];1639: KetSurke(!) Kan- cziaczika Egi Veres holdos Kancziaczika [Hsz; LLt]; 1725: Nekem jŏve ... egj Seregély Szŏrŭ forma negjed fŭ Kanczacska [Usz; Pf]; 1778: egy Kantzátskát 8 forintón ... tserélt [K; KLev.]; 1798: béfizették ... Egy vén, s kisded kanczácskának az árát $21 \mathrm{Rf}$ 15 xr [H; Ks 108 Vegyes ir. 57]; 1812: Egy egér szinŭ 4. esztendŏs Kantzátska [DLt 383 nyomt. gub-i kl].

kancalovacska kancácska 1640: egi rosz kancza Louaczka [Kv; RDL I. 123]; 1698: Kancza lovaczka nro. 1. Tanulatlan [Oroszfalu MT; LLt Fasc. 138].

kancsócska 1698: edgj zŏld kancsocska [Kóród KK; LLt Fasc. 72]; 1749: Husz darab Üveg Cre(de)ntia Nro 20 Hozza valo Nagyobb és kissebb pohárkáji és kantsotskaji Nro 32 [Told. 19]; 1791: Két portzellán fertállyos Kantsotskák [Mv; MvLev.].

Szk: szopó 1678: Dje 18 July Eperjesi által vasaroltatván az Uj Keresztenyektül vinczi edényeket ez szerent ... Bokaly kancsot őtőt Tizenőt őt pénzen egyet egyet teszen f - // 175 ... Szopo kansocska hét három penzen egyet egyet facit - // 21 [UtI].

kandérocska fazekacska 1714: Harom par harom szegletes Konderotskák 8 kb. 3.84 [AH 49]; 1729: Egy káposztás Uti réz Kandérotska [CsS].

kannácska 1560: En thorouk (!) Marton Nagylaky feyer warmegey Jspan kyralnak w felsegynēk dyrectora adom Emlekezetre Myndeneknek, hogy ... weotem kezzemhez ... Zewch Lenartwl bezterczey polgartul ... Egy kys azywsth (!) Kanaskath [Beszt.; BesztLt 27]; 1596: Egy nagy sima kanna harom eyteles ... Esmet harom dretteles kannachkak [Kv; RDL I. 65]; 1612: ket kis fertalyos kannaczkak [Kv; PLPr I/3. 1612-1615]; 1623: ket kis vy kannaczka es egj Talaczka niomnak Lib. 8 [Kv; RDL I. 121]; 1728: Egy plebol valo kannácska [Árkos Hsz; SVJk].

Szk: bécsi 1596: Ket eggyaranyw Bechy kannachkak drettelesek [Kv; RDL I. 65] * keresztelö 1633/1687 k.: Vagyon ā Paniti Ecclában ... egy keresztelö fertalyos kannátska [Panit MT; MMatr. 341]; 1722/1770 k.: a' Keresztelő Kannátskát pro tempore engedte $^{a} a^{\prime}$ Batzai Ecl(esi)a usussara, de úgy hogy el-ne veszszen [SzConscr. 227. - 
aCsicsómihályfalvi (SzD) ref. ekl.] * sima 1615/1628: Egy sima meszelyes kannaczika [Kv; RDL I. 96c] * törpe 1615/1628: Egy kis teorpe kannaczika [Kv; RDL I. 96c]; 1629: Egy kis teorpe Kannaczika mely nyom Ket Girat harom nehezeket aestimaltuk tt f $41 \mathrm{~d}$ [Kv; RDL I. 132].

kanocska kandisznócska 1682: Esztendős Kanocska nro 2 Esztendős Artanyka nro 11 [Szúv; UtI]; 1798: A Nagy kanok egy kanocskának bélit kiontván megőlettem a Cselédek(ne)k [H; Ks 108 Vegyes ir. 51]; 1826: én Istálnék Ngodtol egy Tavallyi Kanotskát [Mv; Told. 7].

kantusocska köntösöcske 1775: midőn ottan az irt Kis gyermeket kantusocskájába fel akartuk volna öltöztetni, monda az Aszony Annya ne vigyék, mert mezitláb vagjon [A.volál Hsz; HSzjP Sigismundus Illés (40) vall.].

kapácska 1791: Egy kerti két águ kiss kapácska [Déva; Ks 108 Vegyes ir. Grék Mihucz kereskedő hagy.]; 1817: Egy viseltes Ásó és Négj Kapa, Két Kapatska [Mv; MvLev.].

kapcsocska 1585: Ersebet Sarlay Ambrusne vallia ... Agya es leple haz ezkeoze vala Az Azzonnak es keosseontuye, kapchochkaia, es egy Eowechkeyeis [Kv; TJk IV/1. 428]; 1615: Mas ket Bokor kapczioczka szokniara való nem igen viselt niom G. p 11 [Kv; RDL I. 96b]; 1635: adatot volt... egy bokor kapczioczikat [Kv; RDL I. 105]; 1720: Vagyon Egy Csomoban füzue egy pár Palastra valo kapocz es ket ezúst gombocska, 4 ezúst karikácska, valami kapcsocskák Nro 8 ... Valami elegy belegy pénzecskék [Kv; Pk 6].

Szk: aprólék/apróság 1611: Ezwst teö tarto valamj aprolek kapsochkaual ... f. 1 [Kv; RDL I. 88]; 1763: Három Lántz végire valo Kapots Uagy holmi aprosag kaptsotskák nro 24 [Nsz; Szer. özv. Harsányi Sámuelné Tisza Ágnes lelt.] * virágos 1637/1639: Egj kis szokniara valo viragos kapcsocsjka njo(m) p. 9 . f. 3 d. 50 [Kv; RDL I. 111].

kapitálocska tőkécske, tőkepénzecske 1792: valameddig az Sz. Ur Isten hatra lévŏ rŏvid eletemnek fog kedvezni, mind addig azon Capitalotskaim, és azoknak Interesse hatalmom és birodalmom alat lé- gjenek [Héjjasfva NK; SLt XLIII. 17 Felső Dobofalvi Marothi István nyil.].

kapocska 1. (ékszerü) ruhakapocs 1637/1639: 1. Szoknyara ualo viragos kapocska - p. 9 - f. 4 [Kv; RDL I. 111]; 1720: ket ezüst gombocska, 4 ezűst karikácska, valami kapocskák Nro 8. ket kis boglárocska [Kv; Pk 6].

2. ácskapocs 1640: Tatrosi Nagj Ja(nos) ... panczel Cheben malom Hazara ment eyne(k) ideien ... molnarinak zekerczeiet furuiat, kapoczkaiat el(vitt)e [Dob. Ks 90]; 1696: Kapoczka Atsnak valo no 1 [Bethlen SzD; BK]; 1726: Egj szekertse (!) ... Egj Uy kapoczka ... Három furu [Kv; Pk 6]; 1816: Egy nagy Kapotska ... Egy kupás, és egy tollas véső [Varsolc Sz; Born. IV. 41 Bornemisza Krisztina conscr.].

kápolnácska 1662: Báthori István azon harcon ${ }^{a}$ lovával és súlyos sebekben való elesésének emlékezetére építtetett cseréphéjjazat alatt levő kápolnácska ma is fennvagyon [SKr 517. - ${ }^{\mathrm{a}} \mathrm{A}$ kenyérmezei csatában 1479. okt. 13-án]; 1724: Bosi Miklos vr(am) Ô Kglme maga ... fateala hogj $a^{\prime}$ Bosi $^{a}$ Kapolnacska főldéért a megye Közŏnséges buzajabol adtanak buzat metr nro 6 [MMatr. 301. - ${ }^{a} \mathrm{MT}$ ]; 1742: egj kis bólt hajtásos, ugjan tsak padimentumos kápolnácskára ... kŭlŏn kŭlŏn ajtok nyilnak [Gyeke K; Ks 4. VII]; 1767: Egy Kápolnátska is ... vagyon [Csapó KK; Berz. 3. F. 7. C. 6]; 1781: ezen Kápolnátska bólthajtás alatt vagyon [Pálos NK; Hr].

káposztácska káposztavetésecske 1768: Hagjma semmi sem lett ... a kaposztatska mutattya magát, talán lesz valami belőlle [Esztény SzD; Told. 5a].

káposztáskertecske 1746: eŏ Nagjga Nehai Csincsa Mihály nevŭ Jobbágjának volt egj kicsiny kápasztás kertecskéje [Monor BN; Ks 7. XX. 19]; 1766: holmi káposztás kertetskéket procurálnak az uton alol tŏbbire minden emberek [Szentegyed SzD; WassLt Barnosz Precup (54) zs vall.].

kapszácska ládácska/szekrényke 1714: Egy ... Kapszátskáb(an) foglaltatnak 1. Réz Pixisb(en) Tengeri Compasz. 2 Microscopium födelestül. 3. Fekete Futraljkáb(an), két perspectiva(m) egjik zöld másik fejér. 4. Egj kis fa Iskatulatska [AH 35]. 
kapucska 1. 1637: Az varbol kj menven az jstallokfelé nylik be az jstallokra egy nagy eöregh deszkas kapu s mas egy kws kapocsykaia, mellyeknek kapu baluany czifrasok [Fog.; UF I, 411]; 1676: (A) kapucskan tul az Majorhaz elleneben vagyan sások kőzze boronában fel rokott ... tapaszos jstallo [Fog.; UF II, 74]; 1717: vagyon egy kitsid kapucska [Körispatak U; Pf]; 1736: Azon fedél alatt van a' Hinto Szin ... fa szegekkel Csekelly Hevederre szegezett kaputskája két felé nyilik [Várhegy MT; CU XIII/1. 111-2]; 1842: Egy rongyos kaputska és hasonlo ajto nyilik égy őszve hánt kerittésen belől a' szilvásba [F.árpás F; TSb 51].

Szk: egyes 1842: A' Csürös kert, melybe a' major kertből égy rongyos édgyes kaputska nyilik [Oprakercisóra F; TSb 51] * félszeres 1681: Innen elébb menvén, vagyon az vas hámor gáttyára nyíló, fenyő fábul csinált mellyékủ vastag deszkákbul álló, ugyan afféle deszkákkal meg fedett, fa kilincsetlen fél szeres kapucska [CsVh 90] * fenyődeszka 1715: az nagy Tanorokra nyilik égy sendelyzés alat valo Kapu fél fák kŏzzŏt fa Sorkokon forgo Fenyŏ deszka Kapucska, melynekis Fa Zára Fenyŏ Deszkábol csináltatot [O.brettye H; Born. XXIXa. 2 néhai Bodoni Balázs conscr.].

2. kiskapu 1656: Tudom hogy Damokos Thamasnit szolghaltam es Beczeŏ Miklosne kapuczkat tartot ot ki az Beczŏ Peter hazanal ki az templom fele [Ikafva Hsz; HSzjP Koczis Ferenczne (70) vall.]; 1680: nyilik ... az hazok meget valo kertre fa Sarkon egj gerezdes kolcsos kapucska [A.porumbák F; Ált Inv. 22]; 1732: ezen Csŭrŏs kertbŏl ... a gjŭmŏlcsŏs kertbe njilik egj ... kapucska [Kóród KK; Ks 12. I]; 1742: Nyilik egj kis fenyŏ deszkából csinált kaputska a' Major haz udvarára [Pókafva AF; JHb XXV/58]; 1742: reteszfejes kaputska a' Gyümoltsos kertbe [Pókafva AF; JHb XXV/58].

Szk: bejáró (kis) 1698: Mely udvarházon Északrol nyilik tölgyfábol faragott bálványu állo vas kávás két fele nyilo deszka kapu bejáro kis kapucskával vas be tolyo zárjával edgyütt [HSzj faragott-bálvány al.]; 1758: vagyon edgy bé járo kaputska
[Kiskapus K; Mk] * kis/kisded (benyíló) 1680: az harmadik vetemenyes kertb(e) ... nyilik ... fa sarkon fa kógerezdes, kolcsos egy kisded kapucska [A.porumbák F; ÁLt Inv. 28]; 1697: ezen udvarházhoz ez ut felól vagyon egy Fenyő Deszkábol álló viseltes kapu vas sorkakon fŭggő mellyhez vagyon applicálva egy küsded kaputska ugyan Fenyŏ Deszkábol csinaltatot ... egy kisded bé nyilo kapucska vas sorkon álló ugyan Fenyŏ fábol valo [O.brettye H; Born. XXIXa. 2 néhai Bodoni Balázs conscr.]; 1758: (A) Két rend galambbugos kapu ${ }^{a}$... aspectusa napnyugotra néz mellette lévö kis kapucskájával együtt [Kiskapus K; Mk. - ${ }^{a}$ Néhai Gyerőffi Kata udvarházának telkén]; 1775: vagyon ezen emlitett Nagy Kapu mellett egy Kis Kaputska [Mihálcfva AF; LLt Csáky-per 106. L. 13].

3. kisajtó Szk: leveles 1680: Az Sŭto haznak pitvarábol nyilik az kemeny alylyara fa Sarkakon egy leveles kapucska [A.porumbák F; ÁLt Inv. 7].

4. felvonó felvonóhidacska 1694: Az Garadicson fellyül az leg felsőb varnak fel vono Kapucskaján kivűl va(gyo)n egy boltozatos Szugalyat [Kővár Szt; JHb Inv.]; 1754: A’ kő folyósóról mennek bé a Palotákra egy reteszes, reteszfós vas kaptsos fel vonó kaputskán, melly(ne)k két mellyékin vannak vas kaptsos Táblák [Marossztkirály AF; Told. 18].

kaputocska ${ }^{1}$ kabátka Szk: anginét 1813: Belmán György Bavariai ... anginét Kaputotskát visel [DLt 229 nyomt. kl].

kaputocska² fejezetecske 1806: dél előt egy Caputotskát el mondottam Repetitioba [Dés; KMN 197].

kardikó kardocska 1738: Az úrfi Kardikoját ki hozattam Bányárul [Nagysomkút Szt; TLMiss.].

kardocska 1700: Egy kis Zŏld aranyos Gyermek(ne)k valo kardocska [Hr I/20]; 1714: Kissebb szablja Zőld barsonnjal boritott, markolattja hasonloképpen meg aranjozott ezüstel s selyem Szijal fl. Hung. 24 ... Kardotska hasonlokeppen ékesitett, Vơrös barsonnjal boritott futraljb(an) fl. Hung. 16 [AH 7]; 1737 k.: Edgy kis kardocska [Brassó; ApLt Apor Péter Inv.]; 1763: egy fekete kardotska fekete sellyem 
maitz kŏteivel ... Egy kitsiny veres barsonyos kardotska Gyermek(ne)k valo [Hsz; Ks 23. XXIIb].

Szk: aranyos 1688: Egy Gyermek(ne) k valo Portaj Arányas kárdocska véres barsonnyal boritot szyval fel kőtve boglarosson szablya tasalys (!) rajta [Beszt.; Ks S. Misc. 27] * ezüstös 1823-1830: csak a consiliariusokat láttam gyermekkoromba kicsiny ezüstös horgos kardocskával járni későbbre a Királyi Tábla assessorait [FogE 64].

karikácska 1. 1742: onba rakott vas Sarkotskákkal, vesszőtskékkel, es karikátskákkal [Pókafva AF; JHb XXV/58]; 1797: az ajto egy tojogalo fiok vas kis karikátskával [Körispatak U; Pf].

Szk: kivonó 1669: (Az ablakon) ki vono karikacska hat [Krakkó AF; BfN dobozolt anyag VI].

2. ?ablakkarikácska (ablakszemkeret) 1676: Ezen házon most vagyon két ablak ... onban foglalt üvegekkel csinálva kiknek vas sarkai, pantyai, forditoi, és karikaczkai megh vannak [Fog.; UF II, 721].

karniol-gyürücske karneolköves gyűrücske 1791: egy Garas nagyságu Carniol Gyŭrŭtske [DLt hiv. nyomt.].

karócska 1. 1768: Nyikita egy szekér kast akart csinálni, mely(ne)k karotskait az földben fel szurdolván, már kertelni akarta, de Nemes Toth Gábor Fia Juvon kezib(en) levo bottyával az karotskakat el ütötte [Káján SzD; BK]; 1849: A' Színtől a marhák pajtájáig vagyon égy hegyes karotskákkal el látott Csinos kert [Somkerék SzD; Ks 73/55]; 1849: Rostéllyos kertnek valo hegyes karotskák [Somkerék SzD; Ks 73/55].

2. szénakarócska/boglyácska 1819: 1818ban termett Szederjesi Széna Egy karotskába [Baca SzD; TSb 6].

3. vhány karócskányi/boglyácskányi 1736: Egy Karotska Tavaji Széna cur. 2. [Martonfva NK; CU XIII/1. 249]; 1788: Egy Karotska sátés Széna [Mv; TSb 47]; 1791: égy Karotska szénáját elsŏben én alkuttam volt meg [Gálfva MT; Sár.]; 1810: Egy karotska Szénája [Nyárádsztbenedek MT; Told. 37]; 1816: a' Balás János Méhészinél vagyon égy karotska Szénája [Mezőmadaras MT; Born. XVb Puro Juvon (50) méhész vall.].

karosszékecske karszékecske 1585: chinaltatúnk Aztalos Benedekel az Scholaban az Mester hazaban egy Aztalt es egy karos Zekechket, es egy fenywfabol chinalt padzeket, attunk az chinalassatol f. 1. d. 20 [Kv; Szám. 3/XIX. 29]; 1594: Az Eczetes hazban ... Karos zekechke No. 1 [Somlyó Sz; UC 78/7. 25]; 1638: vagion az szamtarto haz ... Egy kis pitvarkajara nilik eggj kis paraszt aitoczka. Vagion benne eggj eggjes karos szekecske [Fog.; UF I, 661]; 1685 e.: Rŏvid karos szekecske Nro 1 [Borberek AF; MvR-KLev. Urb. 7].

kárpitocska 1647: Vagjon két reghi karpitoczka, ember kep rajta [Marosillye $\mathrm{H}$; VLt 55/5415]; 1656: vagyon az szamtarto hazban ... az falhoz szegezve 2 labas fogas egyik alat vagyon ramara szegezett karpitocska [Fog.; UF I, 111-2].

karszékecske karosszékecske 1632: Komanai Uduarhaz ... az Szakacz hazra nilik egy parazt felszer Ayto ebben vagio(n) ... Kèt parazt pad szék N 2 ... Egy kis kar szekeczke N 1 [Komána F; UC 14/38. 120].

kártácska kb. hirdetményecske, falragasz 1698: Az pápista atyafiak novemberben indítának olyan hírt, hogy nekik akadémiájok leszen, és ugyan egy nyomtatott kártácskát is ragasztának az óvári, immár 3 esztendők előtt az unitáriusoktól elvött schola ajtajára [Kv; KvE $271 \mathrm{SzF}]$.

kártékonyosocska kártevőcske 1776: Popa Györgyrŏl mondhatom azt hogy eleitöl fogva kártekonyosotska Ember(ne)k tapasztaltam lenni [Tyéj H; Ks 113 Vegyes ir.].

kártocska fakannácska, táj kártusocska, kártyácska 1679: Kicsiny fedeles kártocska nro 1 [Uzdisztpéter K; TL. Bajomi János inv. 28]; 1688: Luczai Sándor administrált ... Kártocskát, nro 6 [Porumbák F; UtI].

kártyácska, kártyáska fakannácska, táj kártyusocska 1748: Kis kartyátska nro 1 [Nagyida K; Told. 11/95]; 1822: Kretsun Nutzuj egy Kis Kartyába egy Kupa Bort vett magához, ezen Kártyáska borral Nagy tüzzel Nagy Indulattal, felém jött [KLev.]. 
kasocska 1. kosaracska 1717: (A pitvarban) két kis kasottska, edgyikben ... Csicsiri borso metr 3 [Abafája MT; JHbK XXXIV/20. 2]; 1748: Kissebb, s nagyobb kasocskák, melljekb(en) gyümőlcsőt Tojást, és egyebb $\mathrm{e}^{\mathrm{e}}$ félét Szoktak tartani, és hordani Nro 9 [Ks XXVIII. 8. 5]; 1770: Az Hijjuban Két vékas Kasotska [Esztény SzD; Told. 29].

2. kukoricagórécska 1738: el Csepeltettem kezem ala ingredialt kasocska Torok buzat ingredialt belöle mett 130 [Szentbenedek SzD; Ks 70 Szám. 51].

Szk: gabonatartó 1742: Gabona tarto kis Kasotska [Bh; Told. 25].

3. vhány górécskányi 1818: Még van ... egy kasatska Majorság Mále. Csépeletlen [Galac BN; WLt Kováts Mihály gondv. lev.]; 1850: egy kasatska Tórőgbuzámnak felét ... verettem el ... az Császári Dragonyos Lovakkal étették meg [Nagylak AF; DovLev. V/1282].

kastélyka kastélyocska 1650: az Castelyka eő magaba(n) keo keriteseuel eggiut alkalmas ... az benne valo lakasra [Folt H; BK sub 117].

kastélyocska templomváracska 1653: Immár kastélyocskánknak tiz holnapja vala hogy csinálni kezdettük vala, és a czinteremet is két kicsiny bástyácskával erőssitteni kezdettük vala [ETA I, 81, $88 \mathrm{NSz}$ ].

kaszáló-csegelyecske ék alakú kaszálócska 1751: a Tó gáton alól és a' Nagy Árkon túl lévő kaszáló Tsegelyetske [Koronka MT; Told. 31/4].

kaszálócska 1714: To kert nevŭ helyb(en) egy darab kaszálocska [Lengyelfva U; Orb.]; 1724: az Sásba egy kaszalocska [Középlak K; JHb VI/3]; 1762: az Néhai Orbán Győrgytöl zállagasitatt kaszállotskát birta [Körtvélyfája MT; BálLt 87]; 1822: egy kaszállotska ... égy más Darabotska Szőllő ... égy kitsiny Nova Sessiotska [Jára MT; KelM].

Szk: allodiális 1798: allodialis kaszálotskát bir a Fogados mely a fogado után kaszáltatik [Mezőbodon TA; IB] * dirib-darab 1797: Falu osztatlan kőzőnséges helylyei vagynak imitt amott egy egy csegely diríb darab kaszállotskát [CU IX. 2. 115] * kerülő 1785: a Két víz kőzőtt lévő Major- ság szánto főld végénél ... két kerŭllŏ kaszállotska [Varsolc Sz; Born. XXIX. 20/378 Kornis Krisztina conscr.] * zálogos 1762: volt ... az Falu kőzönséges Berkes hellyén tul egy kevés Zállagas kazállotskája [Körtvélyfája MT; BálLt 87].

kaszálódarabocska 1821: Fodor Irimia ... kénteleníttetett ... bizonyos Kaszállo darabotskát ... Zállogjára vetni [Szőkefva KK; Kp II. 117].

kaszálófüvecske kaszálórétecske 1639: egj darab kaszalo füvecske [M.köblös SzD; KmKonv. C. Doboka D. 43]. 1690: ada egy kis kaszáló fuvecskét [Aldoboly Hsz; BLt].

kaszálóhelyecske kaszálórétecske 1699: Ezen haz hely utánn Van két kaszallo heljecske [Vécke U; LLt]; 1728: az Ivanka patakánál égy darabotska föld ... a labja kaszalo helylyetske [Mogyorós Hsz; SVJk]; 1762: még az el mult Holnapba ki idéztetvén a' meg írt Czegei Eskŭttek és ŏrŏgŏk, ègy darab kaszállo Hellyetskének el igazittása végett [Cege SzD; WassLt]; 1770: Vagyon ... egy darabotska kaszálo helyetskéje ... mint egj szekeretske szenat termő hellye [Berekeresztúr MT; BetLt 7]; 1786: azon darabotska hellyért adtam Cserébe az én részemen Gyulai nevezet alatt lévő kaszállo helylyetskémet [O.borosbocsárd KK; DobLev. IV/762. 1a].

kaszálónyilacska sorshúzással vki részébe jutott kaszálócska 1701: egy Kaszálo nyilacska [Nagykend KK; Told. 28/5]; 1788: a Bornyu kert nevezetü helyben egy fertály kaszálo nyilatska [Mezőbodon MT; MMatr. 317]; 1821: Fodor Irimia ... kéntelenittetett ... Zállogjára vetni ... egy kis kaszállo nyilatskáját [Szőkefva KK; Kp II. 117].

kaszálóparlagocska parlagon hagyott kaszálócska 1801: égy kis kaszalo pallagotska [Székes MT; MvLev. Msz-i anyag 8].

kaszáló-pojánocska kaszálórétecske 1747: a Zaharia kalibájánál lévŏ, három apro szánto és kaszáló Pojánátskák(na)k tetejétŏl fogva ... a Bértz felé [Nagyida K; Told. 27]; 1747: apro szánto és kaszálo Pojánotskák [Nagyida K; Told. 27]. 
kaszálórétecske 1641: Kozla Gergelj ... bir eggiuttis másuttis egj égj kis kaszálo reteczkéket [Kisgoroszló Sz; GyK X. 30/8]; 1721: adtak volt ... két kaszálo retecskét [M.gyerőmonostor K; KCsl 5]; 1762: lévén egy darabotska kaszalo retetskem [Szentrontás MT; Sár.]; 1830: Hét darabotska Szánto Fŏldekkel és egy kaszállo rétetskével [Nagyadorján MT; NkF].

kásztrofedelecske lábosfedőcske 1768: rez kászo fedeletske egy [Szárhegy Cs; LLt Fasc. 116].

katlanocska Szk: égettbor-fóző 1722: A Sütö házban ... éget bor főző katlanocska [HSzj sütókemence al.].

katonatisztecske 1778: a Gyulai Kolozsvárt quardizonban lévő katonatisztecskéi mind odavesztenek volna [RettE 384].

kávékalánka kávéskanalacska 1748: Egy káffé kannácska 36 1/2 loth ... 6 cáffé kalánka 5 1/2 loth [Brassó; DanielAd. 261 Georg Ötves Ollesher testimoniuma néhai Vargyasi Daniel Ferenc ezüstnemúiről]].

kávékannácska 1748: Egy kaffé kannácska 36 1/2 loth [Brassó; DanielAd. 261].

kávéskalánka kávéskanalacska 1772: Ezüst ... 9 kávés kalánka [Egeres K; Ks]; 1800: Nyóltz kaves kalánka ezüst [LLt]; 1803: Nyoltz egy forma kávés kalánkák [Ne; DobLev. IV/858. 1b-2a].

kávéskalánocska kávéskanálka 1748: Néhai Kordai Sigmond Ur eo Nga Özvegye Nemes Iulia Asz(szon)y, dolgoztatott vélem ... holmi kávés kalánotskákot és egy Néhány kés Nyeleket [Kv; Szentk. Sam. Jónás (42) vall.]; 1748: Én Frajja voltam Néhány esztendőkig az Aszszonynak Korda Sigmondné Aszonyomnak ... vittünk volt ezüst portékákot oda e-szerint: egy ezűst ibriket 12. kis kávés kalánotskaival edgyütt [Bögöz U; Szentk. Julia Szabo (22) vall.].

kávézó-asztalocska 1787 k.: Katzkoia udvarban talalhato Fa Eszkozŏk ... Keskeny kavezo fél viseltes asztalocska [RLt. - $\left.{ }^{\mathrm{a}} \mathrm{SzD}\right]$.

kazalocska kis kazal 1650: Egy kazalacska s Eőtteódfel kalangya szena [Sólyomkő K; SLt GH. 5]; 1735: Csak edgy kalongya széna van az is el fogy ... hanem van meg az katonai ${ }^{a}$ határon két kazalocska [Gyeke
K; Ks 99 Bíró János lev. - $\left.{ }^{\mathrm{a}} \mathrm{K}\right]$; 1765: Margai Ferentz Vram(na)k ... Vagyon a Csüres kertben egy kalongyátska szenaja és egy kazalatska szálmája [Ispánlaka AF; JHb XXVIII/49. 9]; 1804: 3. Kazalatzka Szalma [Hosszútelke AF; Kath.].

kecsécske szőnyegecske 1643/1770 k.: Vagyon a' Prédikálló széken egy darab zőld posztó, mellynek egyik vége rojtos. Vagyon a' Prédikátor székin egy tarka Keczeczke [Bethlen SzD; SzConscr.].

kehelyecske kelyhecske 1728: Egj on kehelyetske Brassai Kis Gjŏrgjne Collatuma [Gidófva Hsz; SVJk].

kemencécske 1694: Arx Keővár ... Ezen Kapu kőzőtt az also reszin vān egy kis Darabont Ház ... Mely Darabont Hazon fellyül van mas egy Kis Hazacska ... egy rosz tapaszos font Kemenczetske benne [Kővár Szt; JHb Inv.]; 1742: egj Sütŏ Kementzétske ... égetett téglából rakott kementzetske, és két kis Lantorna ablakotskáji vad(na)k [Pókafva AF; JHb XXV/58. - Tomai László kijegyzése]; 1774: Tészta néműek sűtésére keszittetett kis kerek kementzetske [T; CU]; 1798/1821: van még égy Vas pleből valo viseltes avatag Kementzéstske is [Kv; Pk 5].

keményebbecskén kissé erélyesebben 1732: csag (!) eppen aszt láttam vona leg szükségesebbnek lenni, hogy az M: Ur ot létiben ö Nganak kemenyebbecskén szollat vona, és tanácsával is éltette vona a M: Ur, ŏ Ngát [Kóród KK; Ks 99 Kornis Ferenc Kornis Istvánhoz].

keményecske 1. 1778: Jo az igen bádgyatt és álmosságba, hagymázba merült betegnek a' két szárok ikrájára ... Kovásszal és meg tört mustár maggal s' kevés etzettel tsinált keményetske tésztát kötni egy gallérni nagyságra, hogy verességet, vagy hojjagot szivjon [MvÁLt, Mátyus, ConsSan. gub. L. Színi Karola kijegyzése].

2. szigorúcska, jócskán szigorú 1807: hálá légyen a Jo Istennek esmét egy esztendŏt bé végzettünk, mellynek tele keményetske vala [Dés; KMN 271].

kéményecske 1736: a konyha ... sŏvénybŏl font tapaszos Kéményetskéje [CU]. 
keményke Szk-ban: szó esik köztük XVIII. sz. köz.: ha szintén magok kőzt kemenyke szo eset vagy eshetettis [Nsz; Told. 2].

keménykén keményecskén, egy kissé keményen 1736: Tőmlecz Tartoi kŏtelességheis kénszeritette, hogj keménykén visellye magát, az elegy belegy személlyekbŏl allo Rabokhoz [Kv; TJk XV/12. 5].

kenderecske egy kevés kender 1751: Soha felit sem adta ki fizetésb(en) igért Gabonájakat, Eledeleket, s Kenderetskéjeket [Marossztkirály MT; Told. 29].

kenderföldecske 1696: Kender kertb(en) van egy Kŭs Kenderföldecske [Szemerja Hsz; LLt]; 1702: Két Kender fóldetskét minden Esztendőnként tartoznak égyszer meg szántani [M.valkó Sz; SzVJk 44]; 1710: egy kŭs kender fŏldetske [Backamadaras MT; CsS]; 1737: a patak mellett lévő Kender főldecskével edgyütt [Nagyida K; EHA]; 1760: Harom Populosa Sessio vagyon a Bartoké mind jobb mind nagyobb, a más kettőt lehetne potolni egy egy vékás kender főldetskével [Feltorja Hsz; LLt]; 1788: a Tit. Felszegi és Kakutsi Rész Kender Főldetskéje [Melegföldvár SzD; SLt XLI]; 1807 k.: az Nyilas Kender Földen kivŭl egy Kis Kender földetsket a Reformata Ecclesia Szomszedgyab(an) melly Burkus Gyuritol kerűlt odá miképpen ki Szerzemennye altal nem tudom [Sinfva TA; Borb. II Pető Ferentz (67) szabad személy vall.].

Szk: csegelyes 1678/1741: A Somodiban a Magjar Szilásban ... egy Csegelyes Kender földetske [Nagylak AF; DobLev. I/27a].

kendőcske ?terítőcske 1694: kétt kis viselő kis kendőcske Zőld selyemmel varot [Homoródsztpál U; BálLt 71]; 1742: Két kis kendőtske [Kisborszó SzD; TL 42 Kifor család lt]; 1763: 1 Kendőtske - 29 [Kv; TJk XVII/1 Polykter István hagy. 13-4].

kenyerecske 1800: Vettŭnk egy kenyeretsket [Torockó; TLev. 5].

képecske 1. 1710 k.: Corderius Colloquiumit és valami képecskékkel nyomtatott kis evangéliumot exponáltam kicsiny koromban [BÖn. 535]; 1733: két rámában valo kisseb képecske [Hacacsel H; JHb Jósika Zsigmond udvarházában]; 1756: harmadik almárium, melly asztal Almáriumnakis neveztetik, mellybe bé járó Ládács- kák járnak ... edgyikben űvegben foglalt őt apró képecske reperiáltatik [Déva; Ks 92. I. 32]; 1757: Egy Ezűstben foglalt képecske [Jobbágyfva MT; BálLt 71]; 1807: valami képetskét vettünk kis Mámátol [Dés; KMN 277].

Szk: üveges 1782: űveges Képetske [Nalác H; CsS].

2. 1770 k.: Nemes és Vitezlő Szász Mihály $\operatorname{Vr}(\mathrm{am})$ Istenéhez valo szent buzgóságából conferalt az Arpastói Ekla(na)k egy ezűst pohárt ... a szárán három füle vagyon ... a fedelé(ne)k a gombján egy képetske vagyon [Árpástó SzD; SzConscr. 221].

Szk: oltári 1805: játzodtunk ... onbol őntőtt oltári képetskékkel gyértya tartokkal [Dés; KMN 113].

kérdésecske kics (leckeként) feladott kérdés 1804: Dél elött a tegnap elött hagyott Letzkéböl tanultam két kérdésetskét [Dés; KMN 39].

kerekecske 1756: negyedik asztal ... kicsin kerekecske [Déva; Ks 92. I. 32].

kereskedőcske kiskereskedő 1826-1829: Nemes Torda Városa Piaczán Azaknak az Arusoknak s Kereskedőtskéknek Nevei, a' kik ... tartoznak fizetni ${ }^{a}$ [Torda; TVLt sztlan. - ${ }^{\mathrm{a} K o ̈ v}$. a nevek fels.].

keresztecske 1. 1816: a kapu teteinek két szélyin cserefábol keszitett két keresztecske tiszteltetik [Jobbágyfva MT; BálLt 67].

2. keresztalakú jelecske 1803: (Az abrosz) égyik szélyin veres fejtövel varrott jegyetske láttzik, égyik szinéről égy küs keresztetskét, az ellenben valo $\mathrm{p}(\mathrm{e}) \mathrm{d}(\mathrm{ig}) \mathrm{O}$ forma Betŭt mutató [Désfva KK; UnVJk].

3. kalangyácska 1819: egy keresztetske Buzát találtunk itten [Dés; DLt 91].

kertecske 1. kis kert 1586: Zok peter vallia, megh ertem hogy Arullia lakatos Tamasne az eo kertechkeyet, velle egie(te)mbe ky Menek latny, kerdem mint hatta volna, Azt monda hogy husz frton Aggya [Kv; TJk IV/1. 578]; 1595: az haz ... eg' darab kerteczkeuel [Abrudbánya; Ks 42. B. 22]; 1623: Ez ... kerteczjkét ... ada órókósón fiurol fiura Alvinczi Andras deaknak [Dés; KGy]; 1681: Udvar ház ablaka alatt lévő kis kertecske sŏvennyel kerétett; fedele ighen bomladozott [Hátszeg; VhU 603]; 
1694: vagjon ... egj kis hazatska kertetskejevel egjgyútt [Borberek AF; BfR]; 1718: lévén ... az Piacz szerben egy puszta romladozott kő háza nemes Curiacskájával és kertecskéjével edgyütt [Torda; JHb XV/17]; 1772: Ezen kis kertetskébe nyilik égj Ajto [Szászfenes K; BethK Mikes conscr.]; 1777: (A) nem Unitus Pap is Nehai Also Janos Uramnak esztendönként egy egy Baranyt adott ... az ott lévö Pajtatol es kertetskétöl [Mezőpagocsa MT; BK. Vermesán Thoma (35) zs vall.].

Szk: allodiális 1825: Egy ... alodialis kertecske vagyon a Falu also végiben [Körös Hsz; SzentkZs Conscr. 323] * gyümölcsfás 1802: Egy Gyümöltsfás kertetske, melyben vagyon termő és terméketlen 55 fa [Mezőrücs TA; SLev. 1 Somlyai János udvarháza] * méhes 1738: Ezen Vetemenyes kertnek az Felső résziben ... egy szegletben van egy Méhes Kertecske kerekdeden kerített jo Támaszos Sátoros kertel bé keritve [Szászvessződ NK; Born. XX/12] * szegelet 1775: szegelet Kertecske [Dés; Pat.] * veteményes 1726: egjébutt a veteményes kertecske kŏrŭl, találtatott valami rossz, Tŭzre valo porgolát kert [DobLev. I/124]; 1783: Vagjon gyümöltsös Szilvás, és veteményes kertecske [Nagyrápolt $\mathrm{H} ; \mathrm{JHb}$ XXXI/28] * veteményező 1783: A Major Ház megett va(gy)on Veteményező kertetske tsellédek számára valo [Branyicska $\mathrm{H}$; JHb XXXI/28]; 1843: tettzet ... admoneáltatni hogy a Tegla vetǒ helyen fel epittetett Házatskát és egy kis veteményezó Kertetskét elrontsam [Dés; DLt 1358] * virágos 1679: Belső, virágos kis kertecske Ez az Aszszonj eo Kglme haza mellet, es az Leany Aszszonyok hazai ablaki alatt vagyon [Uzdisztpéter K; TL. Bajomi János inv. 57]; 1842: égy virágos kis kertetske [O.kercsisóra F; TSb 51].

2. kerítésecske 1584: Ekkert Mihaly vallia, Zememmel láttam hogy ez varganę Annianak Aminemeo hitwa(n) kertechkeie vagyon ot vala es egy tamaz mellet $\mathrm{Al}$ vala, le haylot vala ... es vgy keny vala 'a Tamazt [Kv; TJk IV/1. 285]; 1721: a' Nagj Enyedi Vartzogás uttza végin lévö gjümölcsösek ... eddig indivisé volt ... 's a két fél közőtt sem(m)i circulus vagj kertecs- ke kőrŭllette nem épittetett, hogj belŏlle hasznot vehette(ne)k vólna [DE 2]; 1750: (A) templom és harangláb környül van véve az helységnek vékony tehetségéhez képpest valami kertecskével, néhol támaszos is [Unoka MT; ETF 107. 24].

Szk: rekesz 1710 k.: Egy kis rekesz kertecske az ablak alatt, mely miatt az ember az ablakhoz nem mehetett [BÖn. 562] * törpe 1804: a fenn irt kerteknek epitesire ugy keszüllyenek az emberek, hogy a Pünkősd Napja elŏt esendo Heten egyszeribe fel tetetodgyon és be is fedődgyek, támaszul meg rakattasék az ut hoszan a kert vedelmére valo tőrpe kertetske meg csinaltassek [Zágon Hsz; Szentk.].

3. juhfejő kosaracska, karámocska 1781: az elott igaz hogy tsináltatott vólt ... azon hellyre egy kis Juh fejo kertet, és egy fél kajiba formát ... de azon hitván kertetske azonnal mindjart azon esztendobe el pusztult, és nem emlékezem hogy tsak egyszer is fejték volna benne a' Juhokat [Perecsen Sz; IB. Valentina Máthé (60) jb vall.].

kertszőlőcske kerítéssel körülkerített szölőcske 1684: egj kert szŏlőcske az falu végin [Borosbocsárd AF; Incz. V. 52].

késecske 1668: Egy kis Zomanczos keseczke mely tart ket szem orientalis gyŏngyŏt, Zomanczban van be foglalva, egy kis függŏ gyŏngyis rajta [MkG 10 Kapi György inv.]; 1714: Egj kisetske elephant csont nyelével [AH 12]; 1714: Kisetske ezűst Nyelével fl. Hung. // 80 [AH 23]; 1714: Gyermeknek valo 4 ezust lábon allo Ladatska ... fedelének belsö részén vagjon egj Tüker, Ladatskab(an) penig kisetske [AH 32]; 1723: Vagyon egy pár ezŭst nyelŭ gyŏngyházas késetske hŭvelyével [Koronka MT; Told. 29/2]; 1798: egy Arany élü Késetske [DLt kv-i nyomt.]; 1801: Tizenkét Pár vékony ezŭst nyelŭ Confecthez valo kiss Késetskék három ágú Vass évŏ Villákkal [BfR 106. 1].

keskenyecske keskenyke 1744: Zazor vőlgyin valami keskenjecske hellyen [Vécke U; LLt Fasc. 67]. 
keskenyke keskenyecske 1576: Wagion egy nehan Syngh tyzta Selyem weres zyl zeeold zyl walami keskenke partha zabasw [Szamosfva K; JHbK XVIII/7. 3].

későbbecske egy kissé később 1844: későbbetske vissza hozták Szŏllősi Jozsit is [Torda; KLev.].

későbbecskén egy kissé később 1670: jobb későbbecskén lenni az dolognak jól, hogy sem futva rosszabbul [TML V, 264 Teleki Mihály Bethlen Jánoshoz]; 1753: késŏbbetskén ocupalta ${ }^{a}$ [Marosbogát TA; MkG. - ${ }^{a} A$ földet]; 1785: Lunda késébbetskén jött bé mint sem a tőbbi [Torda; KLev.]; 1801: ha késŏbbetskén is, de tsak ugyan ha élek, bizonyoson eleget teszek igéretem(ne)k [Kv; SLt 17 P. Horváth Miklós öccséhez]; 1816: én késöbbetskén a Piatzon jártam [Déva; Ks 116 Vegyes ir.].

későcskén (egy kissé) későre 1718: enjim let volna a kŏtelesség hogj a Groffnak eléb inserviállyak, de késŏcskén érkezvén kevés Szŭretemen vagjok occupatus [Postelke KK; Ks 96 Székely Ádám lev.]; 1740: $\mathrm{Az}$ doktortol késöcskén kaptam választ [M.csesztve AF; Ks 99 Kornis Antal lev.]; 1763: a' mi pénzetskét gyüjtegethettem a Joszag proventussábol, ha késécskénis, el indultam, és ide Szökefalvára le hoztam [Szőkefva KK; BálLt 1]; 1797: estve későtskén a' Falus Birot holmi szükséges (!) dolgoknak ki-Szolgáltatások végett elő Nem Vehettem [Kolozs K; Told. 42/24]; 1809: most késöttskén vagyan (: s A Pappiros Malmunk késŏre lett le készíttése miatt :) a kivánt két kötés Pappirassat előre küldem, oly alázatos kérelem mellett, hogy a Rongyok által kŭldésében nem késni méltoztassék [Bogát NK; UszT 1600]; 1843: Levelet vettem (: jol lehet kesétskén a' Datumra nézve :) [Zentelke K; BetLt 4 Török Zsigmond lev.].

későcskére egy kissé későre 1748: Mikor az Ura Enyedról meg szabadult, akkor is életb(en) volt, s fenn járt Tasnádiné, 's még azután későtskére eset le a' lábáról [Marossztkirály MT; Told. 56]; 1803: most pedig későtskére érkezvén meg a' Szebeni Computusrol, magam mentem Kétszer Házomba [Kv; MészCLev.]. keszkenőcske 1. kendőcske 1570: Anna Semy (!) Jakabne ... vallya, hogy ... Ment volt Zabo Janos hazahoz es chak ketthen eznek volt Zabo Janosne az Trombitassal ... Az wtan az Azzon vyth volt egy kezkeneochket hogy gombot Rea (így!) kerdy kinek chinaltatya azt Mongya hogi az Trombitasnak [Kv; TJk III/2. 32]; 1576: Wagion egy Jgen zep wekon czynadoffon varoth kezkenyechke kamoka hymel [Szamosfva K; JHbK XVII/7. 5]; 1584: Golchey Sigmond vallia, Latam hogy Zabo Georgnek megh Ada cheob Georgy az tizen egy forintot es meghis olwassa egy kezkeneochkebe thewe [Kv; TJk IV/1. 211]; 1770 k.: Veres fonallal szőtt veres elegyes Keszkenőtske [Bálványosváralja SzD; SzConscr. 210]; 1726: Emleget ellene(m) egy hitván keszkeőtskét [Dés; Jk].

Szk: árnicsos 1692: Ket arniczos keszkenőczke den. 12 [Zabola Hsz; HSzjP].

2. templomi terítőcske 1732: ezen oltáron vagjon két kŏnyv alá valo kicsinj párnácska, edgj oltár takaró csipkés gyólcs, egy abrasz ... egj keszkejŏtske, egy antipendium [Kóród KK; Ks 12. I].

keszőcske ? 1714: Egy fa Palcza ... meg aranyozott keszötskekkel fa futralban, melln(e)k a' gombja Cseh országi Szegeletes Adamas köbül valo fl. Hung. 8 [AH 6].

kesztyücske 1651: Vagyon harom Kesztyücske, edgik Szederjes Barsony, az Masik Med szin Barson, az Harmadik Zóld Aranyas Terczinilla Mi(n)d az harom Arany Czipkes [WassLt Was Judit kel.].

kétremekecskéjü két darabocskából álló 1719: Egy huszan òtt remekbŏl allo nyak szorito rubintos. Egy husz remekből allò huszan négj smaragdos nyak szorito két remekecskeu [WassLt Wass Dániel saját kézzel írt inv.].

kettecskén kettesben 1831: kettetskén által mentünk Ábelhez a Fogadóshoz, és egy fertály Páinkát nálla meg ittunk [Dés; DLt 332. 4].

kevesebbecske vmivel kevesebb 1730: az Portiot nem fizetők legyenek az elsőbb Classisb(an) mind egy iránt, Az masodik Classisbeliekre kevesebbecske Az 3dik 
Classisbeliekre a legszegényebbekre annális kevesebb [Dés; Jk 401b].

kevesecske kevéske 1663: Erdélyben az mi kevesecském ezelőtt volt ... azokhoz való jutásimat is ő nagyságok tellyességesen meggátolták [TML II, 570 Teleki Mihály Bánfi Dieneshez]; 1710 k.: Bort kevesecskét mindenkor, sert eleget ittunk [BÖn. 575]; 1725: az uton belŏl egj kevesetske ${ }^{a}$ el szakad a' meg irt Tŏkés Mihály nevŭ Felében lakó szabad ember részire [Ménes MT; BK. - ${ }^{\text {aFöld] } ; ~} 1736$ k.: az hol mi kevesecskét vetettek volt is, semmi termése nem volt [Cssz; SzO VII, 380].

kevesed kevesecske 1826: a praetendált jövedelemnek kevesed része az özvegyi kevés Joszágnak az igazi jővedelme [Ne; DobLev. V/1114. 9a].

kevéske kevesecske 1589 k.: Az Demeter deakott penigh tudom hogj foglalt egj keueskett az attia birodalma vtan Vgian ott az szeken valo feoldben [Szu; UszT]; 1879: Megpróbálom értékesíteni azt a kevéskét, amim van [PLev. 38 Petelei István Jakab Ödönhöz].

kezecske 1759: az Gyermek ... azon reszketö kezecskéit Feleségem Kánforos Spiritussal mosogatván tegnap semmi ollyas felettébb valo nagy változása nem volt az Gyermeknek [M.csesztve AF; Ks].

kézfürészecske kézifürészecske 1775: $1 \mathrm{kez}$ fŏrézetske x 3 [Déva; Ks 76. IX. 18/4].

kézikönyvecske tankönyv 1845: az alsobb Classisták kŏzött, némi kézi könyvecskék szereztessenek, és osztassanak jutalomul [Mv/Gerend TA; DE 2].

kézmalmocska kézi daráló (kásatörő/sóörlő) malmocska 1838-1845: rezsnyice: „Resnyice (daráló) kása- és sóőrlő kézmalmocska.” Román „eredetű szó Erdélyben” [MNyTK 107].

kézvonócska kézvonolócska, vonókésecske/ vonószékecske 1683: Mihoknak Egy jŏ ŏreg furu Egy kis kez vonocska [Ne; DobLev. I/38. 9].

kicsid I. $m n$ 1. kicsi, kis 1633: egi kiczid darabbal teòbnek talalkozek az huss annal az menire Kornis Istua(n)ne megh fizetet uala, de Meszaros Georgi akkoris ugia(n) oda ada neki azt az kis darabocska hust is
[Mv; MvLt 290. 139b]; 1636: egy fa keretes Ablaka, kiczid [Siménfva U; JHb Inv.]; 1710 k.: Külömben is dicsérék azt a hajót, hogy az kicsid ... csak úgy jár a vizen, mint egy tök vagy réce [BÖn. 589]; 1745: (A) Ház(na)k vad(na)k ónba foglalt ŭveg táblás három ablakai, egy tábla hijján, és egy kitsid csorbával [Marossztkirály MT; Told. 18].

Szk: ajtó 1797: az kertbe ki járo kitsid ajto [Kőrispataka U; Pf] * asztal 1744: Kicsid négj szegŭ Asztal lábástol [Marossztkirály MT; Told. 18] * bokor 1589: (A földet) ekeiwel fel zantotta ahol akarta ahol valamy kiczid bokra volt aztis teorette [Szentkirály U; UszT] * bolt 1765: a Kitsid Bolt Ablakainak vadnak kulsŏ részeiben két két felé nyilo két két vas Sorkokon fordulo fenyŏ Deszka Táblátskái [Branyicska H; JHb LXX/2] * eklézsiácska 1693: En Iffiabbik Czegei Vas György ... Vitettem el egy Harangot Csaszari kicsid Ecclesiacskamb(a) [RLt 1] * fagrádicsocska 1636: az Istalo mellett vagyon fa labakon allo fŭreszen meczet Gabonas haz, Jo syndelies ereszes tornaczios es karfas, uagyon kiczid fa gradiczioczka rea [Siménfva U; JHb Inv.] * kamara 1786: adam altal ... is Petri Curialisomat égy kitsid komorával ... s ... két kis Sövén Házatskákkal [Kispetri K; RLt O. 4] * kapucska 1797: vagyon egy kitsid kaputska [Kőrispatak U; Pf] * láda 1711: Egy kalmár láda, egy Nagy láda, egy kitsid láda $[\mathrm{Kv} ; \mathrm{Pk} 6]^{*} \sim$ palota 1797: Az kicsid Fó Tiszti Palotán ... Egy tráncsérozo festékes negy szegeletü Asztal [Szu; UszLt XII. 87] * vésó 1749: Az Korodi kádárnál Merk Juonnál lévő Kádár miv Szerszámok ... Küs Gyalŭ.. nü 2 ... 1 Kicsid fületlen vēső [Kóród KK; Ks 18/XCII. 20] * viasz 1733: Az Pinczében taltaltatott egj Sakban nagj és kicsid viasz nro 6 [Hacecsel H; JHb Jósika Zsigmond udvarházában].

2. apró, kicsinyke 1776: Tizenhat kitsid, apró fejér zomántzos boglárotskák [M.köblös SzD; RLt Sombori Klára és Sándor lelt.]. 
3. rövid 1632: az parta óuet latta(m), egi kiczid uala [Mv; MvLt 290. 105b]; 1765: adott el ... egy pej szőrü kitsid Serényü Lovat [Fintoág H; Ks 113 Vegyes ir.].

4. ideig kis/rövid ideig 1590: Amy Nezy a faydalmas zywew vraim kewansagokat, halaztiak eo kgmek varosul $\mathrm{Ne}(\mathrm{m})$ az eo kgmek hozzusagara, hane(m) az Zas vraimnak tawol voltokert egy kichid Jdeigh [Kv; TanJk I/1. 140].

5. átv alacsony 1786: Itten e mi földünken eddig elé a gabonának az időhŏz képest igen kitsid ára vagyon, ugy haljuk hogy Enyed s Torda kőrúl jo árra indult [Bencenc H; BK. Bara Ferenc lev.].

6. ? kis termetü, alacsony 1606: Kychyd Thamas. Az Kiczjd Lukacz Leania marta [UszT 20/9, 20/107]; 1614: Kiczid Istwan lib. [Csomortán Hsz; UszLt VI/56, 3/8]; 1665: Kiczid Andras [Olosztelek U; UszLt X. 79]; 1748: Kitsid Mihaly [Egerpatak Hsz; Kp I. 166].

7. kis kiterjedésű 1583: Kun Caspar Rosaly ... ielenti hogy az eó faluianak ${ }^{\mathrm{a}}$ azokhoz $^{\mathrm{b}}$ kepest igen kichid hatara wagion [Gyf; WassLt, ETA V/2. 17 fej. - ${ }^{a}$ Monostorszeg SzD. ' Ormány és Kérő SzD]; 1679: Kesz To vagon. Nro 2 pokol üdö malmaval. Puszta To hely egy kiczid [Vajdakamarás K; Thor. 21/33]; 1751: Kováts János ... azt mondá hogy Moros székb(en) magánakis valami kitsid portiotskája vólna [Borbánd AF; Ks 83 Borbándi Szabó György lev.]; 1808: nyil után jutot kitsid kaszálo [Szárazpatak Hsz; Hr].

Hn. 1707: A Kiczid erdő felet [Pálfva U]; 1732: A Kicsid nyirnek hivjak csere es nyir fak vadnak benne [Oltszem Hsz]; 1781: Kitsid Erdő megett (sz) [Bencéd U]; 1801: A kitsid orotásba (sz) [Bibarcfva U]; 1821: A Kitsid Avas felett vagy Balás orotásán (sz) [Bodok Hsz].

8. keskeny 1630: aszt $^{\mathrm{a}}$ pedig kiczid ut nélkŭl nem lehet az hun az őrlő el Jarjon [Fehéregyháza NK; TGsz 51. - ${ }^{\text {aTi. az }}$ egyezséget megkötni].

Hn. 1773: az Alfalura menŏ kitsid ut mellett (sz) [Szárhegy Cs]; 1781: Kitsid ut alatt (sz) [Bencéd U]; 1804: Kicsid ut [Alfalu Cs].
9. sekély 1632: kózbe(n) ki jöue Mihali mester az Malo(m) hazbol es mo(n)da Timar Janosnenak ne kósd ide, ugia(n) ne keosd ide az beoroket mert most kicsid az Viz es el fogia az beor az malo(m) kereke alol az Viznek szebesseget [Mv; MvLt 290. 108a]; 1742: A Zsilipje most sem jo ă Malomnak, és ha kitsid ă viz, majd mind alatta foly el [Kv; AggmLt C. 12].

10. gyermekre von.? kis, kicsike 1558: Az melly Arwakat En Mostan tarthok mynd kyczydeket, mynd, Nagyokat azt Akarom hogy Meg Elegechek [JHbK XLIII/21 Mikola Ferencne Melyk Anna végr.]; 1627: Keőmives Jakab fia kiczid [Bibarcfva U; UszLt IV/50, 135]; 1794: akkor mi kitsidek lévén arra nem annyira ügyeltünk [Déva; Ks].

Szk: gyermek 1592: mikor Tot Janos és (!) Eorbe lakot, Ez is az Tot Mihál akkor vette volt es kichid gyermek volt [Dés; DLt 235] * leány 1618: Köpelli Oglinak ... vén anyja vagyon és egy kicsid leánya $\left[\mathrm{BTN}^{2} 166\right]$ * unoka 1784: 1784dik esztendőben Juliusnak 16-dik Napján adta Isten e világra Máté Klára kitsid unokámot [Kp 16 özv. Újfalvi Samuelne Sombori Borbára nyil.]. 11. fiatal 1589/XVII. sz. eleje: az kiknek Zálogiokat el adgiák es belŏlle az Ceh Igassagat ki vészik, effele birsagolt szemeliek, se kiczid, se nagy, ez dologert az Ceh mesterekkel semminemw wdeöben ... ne perelhessenek [Kv; KömCArt. 26-7]; 1653: a kastély ${ }^{a}$ falait az ácsokkal bérleni kezdik nagy cserefákkal belöll, és tölteni földel. Minden ember: bíróné, polgárné, papné, pap, bíró s polgár, nagy és kicsid, a ki életét szerette minden ember a míglen megkészüle, csak hozzája nyult akkor [ETA I, 97-8 NSz. - aA mv-i templomváréit].

12. állatra von. 1744: Kicsid Artány Malacz 5 Kicsid Eme Malacz 9 [Told. 18].

13. kevéske, kicsinyke 1592: Az mely Idon valamy kyczyd makkoczyka hazon volt az felj Byk erdoben, az fanczyaliak diznoiokatt onnatt az orozhegy hatarbol az Nyulad tartomanyabol Ide az Varhoz be hozattak Myndenha Az mykor akartak az Itt valo tiztartok [UszT]; 1656: ha hol mi kiczid prouentuso(n) fogh lenni, aztis igazan akaro(m) fel iratni [Âdámos K; UszT]; 
1792: a Széna Sátés, drága, és igen kitsidek a Portiok [H; Ks 80. XLVII. 5 vk].

Szk: hija 1592/1593: Meegh az Rew hely, az húl altal jarunk valaa igen kichid hija, hogy az keet Malmot reyta nem chinaltak [Décse SzD; Ks. - ${ }^{a}$ Dés és Szentbenedek határán a Kis-Szamoson].

14. csekély, csekélyke 1573: Amint ktek Jria az feiedelmet Nem kellene illyen kichid dologgal bantanj ug' wagyon de az kichid dologbul zoktak esmet nagy dolgot Jndjtanj [Szúv; BsztLt 37. 50]; 1661: A kicsid böcsületem nem engedi urunk mellől való távozásomat [TML II, 127 Teleki Mihály feleségéhez, Veér Judithoz]; 1787: kitsid dolog volna elottem azért Halált is szenvednem [Kackó SzD; Kp II Újfalvi Sámuel Máthéné Újfalvi Krisztinához].

15. szerény 1644/1785: az én kitsid állapatom és rendem szerint ... illyen utolso vallást, rendelést es Testamuntumat Tészek [BfN Kémeri Huszti Menyhárt erdélyi főharmincados végr.].

II. fn 1. egy kicsi rész 1592: Thwdom hogy fen a teteon egy kiczydet foglalt vala Domokos Mihaly be kertelte vala [UszT]; 1658: az kicsidis az mi közel kedvesebb [Bszt.; Ks 90 Cseffey László nyil.]; 1762: ada a ... joszagnak ... Del felől valo szegeletiből is egy egy kitsidet [Káposztászsztmiklós MT; Told. 76].

2. kevesecske 1589: egez eleteonkben az mi kichidet keresteonk vala es giwteottwnk vala, vgy mint fl 32 es tiz singh hean zaz singh vaznat [Máréfva U; UszT]; 1667/1778: bizony senkinek semmimet nem kőtőttem, hanem a mi kitsidem vagyon, tiéd édes uram [Told. Transs. 229]; 1831: az ŏreg Pákeiné is meg holt ... a Szelesek Plénipotentiáriusa elé állott már most Szolga birák által iragattyák a' mi kicsidje volt [Pk 6 Pákei Krisztina férjéhez].

Sz: megszaporithatja Isten a et, elfogyaszthatja a sokat 1738: Meg szaporithatja Isten az kicsidet, s el fogyaszthattya az Sokat [Ks 14. XLIIIa Kornis István végr. fog.] * szánja a et, veszti a nagyot $1710 \mathrm{k.:}(\mathrm{Az}$ országon át Bécs alá vonuló) tatár khám ... a fejedelemmel, ki Fogarasban volt, kívánt szemben lenni .... Szánánk kicsidet, veszténk nagyot ... A fejedelem Fogaras- ból, ugymint a khám marsusából méne Ebesfalvára ... mind menésében, szállásában, megbecsülhetetlen károkat tett [BÖn. 733-4].

3. kicsi baj/betegség 1584: Roma Janos vallia ... eg' delkort Aluzom vala, Megh erzem hogy a' Labom fayny kezde ... Masodnap igen meg Dagada ... kwldem felesegemet ez Catalin Azonyert ... Ezt monda Bizony zegien hogy eoregh ember lewe(n) oly kichiddel fekzik [Kv; TJk IV/1. 275].

4. (egy) del egy kevéssé/kissé, egy kevéssel/kicsivel 1653: (Az) 1651-k esztendőben is ... nagy drágaság vagyon mint a tavalyi esztendőben; hanem újbúzán meg szálla az ára igen kicsiddel [ETA I, 53 NSz]; 1716: ēgy kicsidel soványob az övéa [WassLt. Lako Kis jános (60) jb vall. - ${ }^{a} \mathrm{~A}$ földje Hesdáton].

5. egy ig egy kis/rövid ideig 1672: Viszszatérvén az rácz, utánna kiált Bethlen Domokos: Várd még, úgy mond, egy kicsidig, hadd beszéljek veled [TML VI, 8 Naláczy István Teleki Mihályhoz].

6. Szk: csak , hogy 1701: az házában lövődöztek, csak kicsid, hogy a háza is fel nem gyuladott miatta [Rákos Cs; SzO VII 76] * egy del többet teszen 1710 k.: Hasonlítja tovább Salamon ... a nagy gazdagságokhoz, aranyhoz, ezüsthöz, és azoknál is feljebb becsüli a jó hírnevet, melyet is ha rászabunk, a hírnév magasztalására vagy ócsárlására egy kicsiddel tészen csak többet, mint a drága kenet [BÖn. 424] * egy/ igen en múlik 1618: Bizony csak egy kicsiden múlék, hogy Alexander nem kapá el az moldovai vajdaságot [BTN ${ }^{a}$ 217] * egy/vmi del több vminél 1611: zeöleö ... Bretfeöbe(n) uagyon Egy holdnal teöb ualamj kichidel [Kv; RDL I. 88].

kicsidded kicsiny 1585: Talak kicsid(d)ed keozepzerewek vadnak Niolcz, tizenharmadfel font, tt f 2/7 [Kv; KvLt Vegyes I/2-3].

kicsiddég 1. egy kicsit/kissé 1638: latam az ladat hogi egi kiczidegh fel uala szakadva az sarka [Mv; MvLt 291. 123b]; 1639: kerdem, hogi nem turose kicziddegh az lo s monda Marton, de bizonj az egj kicziddegh Turos [Mv; MvLt 291. 191b]; 1779: ezen helyről még kisidek (!) beljebb 
a Szent Egyedi Határ felé el vétetvén égy Üres Szekerem a Széki Lakasok által máig is oda veszett [Szentegyed SzD; WassLt Mich. Kozma (50) ns vall.]; 1826: (A csikó) a' mult kedden el esvén jártatás kőzben, térdecskéit meg puffintotta, 's égy kicsiddég meg dagadott [Kv; Pk 7]; 1830: Beretzki Borbárának ... egy kitsiddég láttzato csomo a nyakán [DLt 233 nyomt. kl].

2. kevés/rövid ideig/időre 1734: hogj egj kicsidég meg fordultam volt fel vettem magamot ismet a nyavalyaban estem [Meggyesfva MT; Ks 99 Árva Bálintith Susánna lev.]; 1742: hallom hogy nyolcz polturán jo bort adnak vásárhellyt és ha ugy vagyon had haladgyon még egy kicsidég [ApLt 4 Apor Péter más kézzel feleségéhez Nsz-ből]; 1744: én mondam a társomnak hogy egy kicsiddeg maradgyunk meg had menyenek el ezek az rèszeg emberek [Gyeke K; Ks]; 1780: Kovács István Ur azt felelé, most egy kicsidek ki nem nyithatom [Páva Hsz; HSzjP Mich. Gáspár (56) vall.]; 1840: onnét haza jöttem kitsedég [Dés; DLt 1073].

kicsidell kicsinek tart 1763: ha a ket Sézás Lo nagjab let volna ugjan ada Sütném mast Tudi (!) Sigmand Urnak, de kitsidelli [Kóród KK; Ks CII. 18 Szarka József tt lev.]; 1776: azon Bikát az Falu tellyesseggel nem szerette azert hogy kicsidelt es maskentis disztelen, nem szep faju Bika [Szentháromság MT; Sár.].

kicsidít kisebbít 1690: Ha az károkat kicsiditene ... mondgja azt reá, hogy ... ha vala holott valamit fizetnekis tsak semmi, ötőd, hatod, meg tized reszet sem adgyak [Ebesfva; Törzs. Bethlen Sámuel fej-i instrja].

kicsidség 1. gyermekség (gyermekkor) 1795: Ferentz eő kegyelmét tudom kicsidségétől fogva, hogy szolgált [Ozsdola Hsz; HSzjP Ito Mihály (70) gy. kat. vall.].

2. csekélység 1801: Negy ezer embera Erdélynek kitsidség, de gyalázat a nemes embernek erre is patvarkodás [Berve AF;

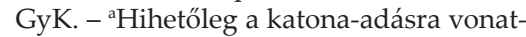
kozik gr. Gyulai Sámuel lev.].

kicsind 1. kicsinyke, kis Hn. 1773: A Kicsind uton terŏben (sz). a Falu mellett Kicsind ut Hoszszában [Alfalu Cs; GyHn 60]; 1773:
A Kitsind Hidnál (sz) [Vasláb Cs; EHA]; 1780: Az kitsind Hídnál (sz) [Kissolymos U; EHA].

Szk: ajtó 1852: A béjáro kitsind ajto cserefa kapu féllel fenyő deszkábol [Felfalu MT; DE 4] * batizi levesestál 1824: Egy kitsind batizi leveses tál fedelestől [Fugad AF; HG Mara lev.] * kamara 1760: ezen Session találtatik egy ház kŏzŏnséges fŭst házával, és kitsind Kamarájával együtt [A.volál Hsz; LLt] * rézüst 1744: másfél ejteles kicsind réz üst [Szentdemeter U; LLt Fasc. 67].

2. alacsony/kis termetü 1796: Providus Kitsind István 23 Esztendős [Albis Hsz; BLev. Vall. 5].

3. apró 1749: Midŏn ki tiloltak szakadozvan az Viragos Kendert, a mely fejek kicsindek vóltak kettŏtis egyben tettetvén, apadott el belölle 2 [Kiskend NK; Ks 70 Szám. 51].

4. kis kiterjedésü 1760: Az Száraz Pataki Kantai Kitsind portiotskák még inventálatlan vadnak [Feltorja Hsz; LLt]; 1760: égy kitsind szanto ... égy kitsind kaszálotska [Körtvélyfája MT; LLt]; 1772: egy kitsind veteményes kertetske vagyon ... az kŏzkert mellett [Kv; BethKt Mikes conscr.]; 1774: a Nyulasi kitsind Portziotska [Sár.]; 1818: ugy meg fizettem egy, két vékás kitsind fŏldeiket, hogy pénzzel tŏbb Esztendokre is el zállogosithattam vólna [Vályebrád H; Ks 111 vegyes ir. Gentsi Aloysius krájnik nyil.].

Hn. 1773: a Kitsind vész n. h.-ben (sz) [Remete Cs; GyHn 48].

5. sekély 1743: az olta miolta a' Sővenjfalvi Malom epittetet mikor kitsind a' viz még akkor is holt vízben járnak a' kerekek, melljet Studio meg is néztem mikor kitsind volt a' Kükŏllŏ [Ádámos KK; JHbK XXXVIII/9]; 1766/1770: Vagyon midŏn a' Viz kitsind ... az harisnyámat iffjukoromban fell türvén kőnyen egy lábbal által mente(m) a' Kükúllő Vizén [Széplak KK; SLt évr. Transm. 262]; 1768: a vizis kitsind lévén, annál kevesebb viz ment a kerekekre [Told. Huszár lev.].

6. Szk: fiacska 1770: Buta Anutza három holnapos Fiatskájával Hesfelán Szimionnal árvaságra maradott, gyámoltalanul, 
akarván tehát édes Attya ... Buta Juon Atyai gondviselése alá venni, neveletlen kitsind Hesfelán Szimion nevŭ Fiatskájával edgyütt ... azon kitsind neveletlen szermek ... Jobbágya volna az [Nagyernye MT; Ks 67. 48. 31] * gyermek 1744: Mikaran engem elvőn Felesegŭl Nehai Grúz Todor akar ezen Grúz Petre igen kitsind gyermek Vala Még esztendős sem Vala [Uraly MT; SLt Nehai Gruz Todor Meg hagjatatt ǒzvegye Oltyán Ráda (58) vall.]; 1770: azon kitsind neveletlen gyermek ... Jobbágya volna az ... Sz Győrgyi Udvarhoz [Nagyernye MT; Ks 67. 48. 31].

7. állatra von. Szk: borjú 1760: tinoját a' Kicsind Borjukkal jártotta [Vadad MT; VK] * csitkós kanca 1763: és az kitsind Csitkos kanczákat nem hágattam meg [Kóród KK; Ks CII. 18 Szarka József tt lev.] * korában 1755: (A bivalyok) mind őszve szagatták a kőteleket, mivel kicsind korakb(an) nem szoktatták volt kőtélre őket [Szentmargita SzD; Ks CII. 18 Kosa Sigmond tt lev.] * malacka 1760: Vagyon két tehenecske ... négy kitsind malaczkaja [A.volál Hsz; LLt].

8. kevesecske 1699: enis in meo privato nem kicsind kart vallok a' kgyld ide nem jŏvese miatt [MvRKLev. 6 Bethlen Miklós lev.]; 1760: a mi kitsind vagjonotskam lészen néki hagyom [Msz; VK]; 1796: ide jöttem vala egy Kitsind nyirfáért [Albis Hsz; BLev. Vall. 3 Tot András (29) jb vall.].

9. csekély 1731: azon Szoross útb(an) az Agyagas és Iszopos Sárt ă Viz annyéra concumulálni szokta, hogy Marhájok(na) $\mathrm{k}$ nem kicsind erőltetésével vontattyák azon ált(al) a terhet [Kv; Pk 7]; 1755: Ngad magais bőlcsen meg itílheti hogy nem kicsind dolog mikor az igaz Nemes Embert maga Nemesi szabacságáb(an) meg akarják rontani [Szentmargita SzD; Ks 18. CII Kosa Sigmond tt lev.].

kicsinyded I. $m n$ 1. kicsi, kis 1584: Cathalin Borbely Ianos felesege Vallia ... Lattam esmeg Arany forintokatis Nalla eg kichinded fekete keskeny Sachkoba [Kv; TJk IV/1. 389].

2. kevéske 1633: megh merte az husst es egi kicsnded (!) hussal teob leon ... azert leon teob, az egi kiczid hussal, hogi az eleot ketczer merte volt fel Georgi Vra(m) [Mv; MvLt 290. 39a].

3. kisded 1594: Amy nezy Az Algiuk, tarazkok es ahoz valoknak el vontatasat, mely tereh visselesben ha az Zwksegh hozná kewantatnek. Ne tala(m) Az zaz vraim lowainak Barmainak oda Adása, az eo kgmek kichinded reghi zabadsagok ellen. Vegheztenek eó kgmek hogy Biro vram aggion mindent ... eo kmeknek eleibe [Kv; TanJk I/1. 237].

II. fn kb. kisded 1661: Légy vígan, könyörögj Istennek ... az ö kegyelmes oltalmában ajánllak mind az édes kicsindeddel együtt [TML II, 181, 185 Teleki Mihály feleségéhez, Veér Judithoz].

III. hsz-szerüen: kissé 1710 k.: Orrom nem a felette való nagy orrokféle volt ugyan, de nagyocska, horgas ... gyermeki csintalanság miatt való esés egy kicsinydéd a hegyét meglaposította volt [BÖn. 492].

kicsinydég kis/rövid ideig 1763: hármon voltunk egy kitsindég az malomb(an) ... akkor énis ki fordultam volt egy kisség az Malomházbol [Záh TA; Mk. V. VII/19 Ginga Pásk (54) vall.].

kicsinyecske kicsinyke 1812: ezen Fok nevezetü fiatalos Berek gyermekségemtől fogva őrőkké a' Nagy Laki Eklesiájé volt, $\mathrm{e}^{\prime}$ nevelte ekkorára, mert én tudom mikor a fák kitsinyetskékis voltak [Nagylak AF; DobLev. IV/943. 25b].

kicsinyke 1. kicsike, picike 1560: Keth darab teoroth arany es egy kychynke azokkal Egywth [JHb QQ Temeswary János reg.]; 1688: 3 eóregh ezűst tál negyedik egy kicsinke [Beszt.; Ks S. Misc. 27]; 1740: Negy őreg vankos 's egy kitsinke [Hermány U; ApLt 5 Apor Péterné Kálnoki Borbála lelt.].

2. kicsike, kis kiterjedésü 1589 k.: Tudom hogy Demeter deak egj kiczinke feoldett mint egy borozda foglala be kertiben [Szu; UszT]; 1666: Azon taybannis egi kitsinke ${ }^{\text {a }}$ vagion [Illyefva Hsz; BLt. - ${ }^{\text {aFöld]; }}$ 1732: az Samsondi territoriumon ... egj kis kender főld orotványbol valo ... Ezen felyül más orotvány ... megis e mellet más kicsinke orotvany [Mezősámsond MT; Berz. 5. 42. S. 59]. 
3. (korra von.) kicsike 1807: két gyermekek lévén azok csak kitsinykék voltanak [Makfva MT; DLev. 4. XL A].

kijjebbecske egy kissé messzebbre/távolabbra 1790: Rutkai $\operatorname{Vr}(\mathrm{am})$, látom magais igen szereti Tŏvisset, s nem örőmest válna meg tölle, de kéntelen, mert szegény; Hunyad Vármegyéb(en) szándékozik meg fészkelödni, s ha módja lenne benne, ott valamivel a' Tŏvissi Részinek árrával kŭllyebetske terjeszkedni, mert nem capax szegény feje ideis tovais figyelmezni [Celna AF; TL. Málnási László ref. főkonz. pap gr. Teleki Józsefhez].

kilimecske 1733: Az Asztalon egj kilimecske [Hacecsel H; JHb Jósika Zsigmond udvarházában].

kisasszonyka főrendú leányka 1661: Az kisasszonyka ${ }^{a}$ felől nem tudósítál édes szívem [TML II, 138. - 'Születendő gyermekét érti Teleki Mihály feleségéhez, Veér Judithoz]; 1661: az kisasszonykának keresztelésében kívánok gazda lenni [TML II, 221 Bánfi Dienes Teleki Mihályhoz]; 1744: ā Kis Aszszonykát ex acquisitio kŏnnyŭ leszen Ngsd(na)k ... a Mákai ${ }^{a}$, és Szép K. Sz. Martoni ${ }^{b}$ Szőlők iránt contentalni [Kv; Ks 40. XXVIIIC. - ${ }^{a}$ Mákón (K) levő. ' 'Szépkenyerüsztmártonban (SzD) levő.]; 1793: a Grófné ... a' Nagyobbik kis Aszszonykával sokkal keményebben bánt, mint a' más kettővel [Koronka MT; Told.].

kisasztalka kicsi asztalka 1756: Négj szegeletŭ kis Asztalkák [Somkerék SzD; Ks gr. Bethlen Imre lelt.]; 1792: Négy Szegeletü kis Asztalka [TL Conscr.].

kisded, kisdeg I. mn 1. kicsi, kis A. 1584: Anna Jllyes Kowachne vallia, Kadas Miklosnenak vala eg giermeke Az laban egy kisded fokadek león [Kv; TJk IV/1. 255]; 1587: Egy Eoregh Serpenyeo d 32 Mas kisded d 8 [Kv; KvLt Inv. II/2. 4]; 1647: Teomleo Turo kisdedek No 1 1/2 [Drassó AF; BK 48/16]; 1696: Arany Gyűrűk jutottanak: A negyven forintos Gyemantós gyürü. Mas egy zomanczos gyűrű. Harmadik egy kisded [Mv; MbK 80. 7]; 1714: Hat öszsze kötött bál Dohány, ketteje küsded [HSzj bál al.]; 1756: A Seccessus kisded lévén nem méretetett fel [Branyicska $\mathrm{H}$; JHb LXX/2.
23]; 1795: Két Ibrik egyik fedeletlen, más fedeles kisdedek [Mv; MvLev. Szabó Moses hagy. 3]; 1803: Két tajték pipák kisdedek [Ne; DobLev. IV/858. 2a]; 1830: az elöl ment 24 deákok vittek kezekben egy zászlót, kisdedet [FogE 243]. B. 1653: Vet magahoz ... Egi Cziatlo lanczot kisdeget [Ilencfva MT; DLev. 1/II. B]; 1758: Egy pár kengyel vas kisdeg [Brassó; ApLt 5 Apor Péter lelt.]; 1760: Cseber Küsdeg [Parajd U; LLt Fasc. 139]; 1766: akkora mint egy kisdeg fél dio [Szárhegy Cs; LLt Fasc. 96]; 1774: a' Fia vágatt le egj küsdég Jáhor fát hogy kalánjokat csináltasson belőlle [Csóka MT; Ks 31. XXIXb]; 1798: Csergék kisdégek viseltesek [Kovászna Hsz; HSzjP]; 1808: Másfél kisdég Szalonna [HSzj szalonna al.].

Szk: ablak 1694: Ket Kisded Ablak va(gyo)n rajta [Kővár Szt; JHb Inv.] * ablakocska 1790: Ezen Kamarának ... vagyon égy kisdég kerek ablakotskája [MNy XXXVIII, 208] * ágyú 1705: Ma jó reggel az hadak kitakarodván ... hat kisded ágyúkat is vivén ki és ahhoz kívántató municiókat [WIN I, 607] * ajtó 1656: Egy vas panthos vas kisded ayto [UF II 113]; 1732: Nagy jo kapu, melette valo kisded ajtajával s rajtok lévő kapu levelekkel [LLt 224. B]; 1761: jobb kézre egj kŭsded Ajtajával a mezŏre járo még kevés ideig meg szolgálhato Galambbugos Kapu [Spring $\mathrm{AF} ; \mathrm{JHb} \mathrm{LXVIII/1]}$ * ajtócska 1697: Ezen hazbol vagyon egy kis kamaráb(a) ki nyilo bérlet fenyŏ Deszkábol állo vas sorkakon fúggó kisded ajtotska [O.brettye $\mathrm{H}_{\text {; }}$ Born. XXIXa/2 néhai Bodoni Balázs conscr.] * almafa 1769: métat csinálván a Küs Maros felől valo kűsdég Alma Fátol fogva [Egerszeg MT; LLt 63/6] * almárium 1752: (A) Tornácznak a kőzepe tállyan vagyon ... Nyari Fillegoria ... abban falban csinált kisdég almarium [Pókafva AF; JHb XXV/73] * almáriumocska 1797: egy kisded kŏ falba botsáttott fenyŏ deszkábol valo almáriumotska [Kőrispatak U; Pf] * általagocska 1747: egj kisded általagotskáb(an) etzet ágy [Borsa K; Told. $24]^{*} \sim$ aranygyürücske 1752: adott Kezemben nékem egy Kisdéd arany gyűrűcskét [Szászerked K; LLt Fasc. 143] * aranylánc 
1562: Egy kysded Arany lancz Negwen hat arany forynth $[\mathrm{KP}]{ }^{*}$ aranyvirág 1770/1773: hagyok ... Edes Leanyomnak ... mas kesdeg Arany viragot, ennek tetején vagyon egy Tŏrkés nevŭ kŏvecske [Szárhegy Cs; LLt] * árnyék 1744: a kert lesza alatt kŭsded arnyék alatt vadnak az ekék nro 3. Borona nro 6 [LLt 67] * asztag 1640: Van egy kisded asztag búza [Marosillye H; Hunyad megyei Tört. és Rég. Társ. Évk. X (1899), 133] * asztal 1615: Egi kisded Asztaltt [HSzj asztal al.]; 1698: edgj kŭsded Asztal ... ket kisdet (!) ablak ŭvegestol [Kóród KK; EMLt]; 1819: egy kisdeg régi rakatt asztal [Baca SzD; TSb 6] * asztalka 1744: Kisded négy szegű Asztalka [Szentdemeter U; LLt Fasc. 67] * asztalocska 1761: egy kisded negy szegŭ asztalotska [Mezőcsán TA; Ks 15. LXXIX. 3]; 1819: egy régi kisdeg rakatt asztalatska [Baca SzD; TSb 6] * bárd 1849: Egy Hus vágo kisded bárd [Somkerék SzD; Ks 73/55] * bejárókapu 1756: (A) kisded bé járo kapu ... Nagy fejŭ Fa szegekkel foglaltatik a' Nagy kapu Zabejához [Branyicska H; JHb LXX/2. 10] * berbence 1802: Egy kisded Berbentze otska cir. tiz vedres ... Más kisded Berbentze otska cir. 6 ved(res) [Dés; DLt 4] * bokály 1773: Kisded tarka bokaly [LLt Fasc. 149] * bolt 1688: edgy kŭsded bolt [Kv; BLt] * boltocska 1752: az also Pallotta végib(en) vagyon a Pincze torkán téglábol epúlt egy kisdég, de meg repedezett Boltacska [Pókafva AF; JHb XXV/73] * boronafa-pajta 1814: ezenn Curialis Telken Találtattak ... Égy kisded meg lehetŏs Boronafa Pajta [Kecskeháta SzD; BetLt 3] * boronaház 1680: vagyon ... egy kisded borona ház [A.porumbák F; ÁLt Inv. 10] * cseber 1586: Csinaltatot ... harom eoreg Cziebret kiert atta(m) -/65 egi kisded Cziepret (!) attam -/6 [Kv; Szám. 3/XXIV. 25] * csebrecske 1756: Kisded csebrecske 4 [Déva; Ks 92. I. 32] * cserge 1842: egy kisdeg csergét bé adnak, hogy özvegy Szabo Ferencznénél kapták [Bereck Hsz; HSzjP] * csésze 1733: Edgj Tokban harom fintsia, edgyik porczenella kisded cseszejevel [Marossztkirály AF; Told. 2] * csizma 1672: Asz(szony)embernek való Kisded Czizmak [UtI] ${ }^{*} \sim$ csuka 1597: 3 kwsded Czwkat waroset [Kv; Szám. 7/XIV. 61 Th.
Masass sp kezével] * csür 1697: Az Var alatt is vagjon edgj kisded szalmaval fedet csür [Alvinc AF; Mk Alvinczi Péter lelt.] * deberke 1728: vagyon egy ŭres, ŏreg deberke más kisded ŭres deberke [Aranykút K; Ks 55/73 gr. Petki Dávid lelt.] * derékalj 1673: A Némanak hagia egi küsded Derekalt [KJ]; 1753: Takas Derekaj Nro 3. Takatlan kisded Derekaj Nro 1 [Szentmargita SzD; Ks 18. CII]; 1819: egy kisdeg keskeny kék tsiku derekaly $[\mathrm{Kv} \text {; } \mathrm{Pk} 3]^{*}$ dézsa 1594: Kis ded (!) desa Nŏ 3 [Somlyó Sz; UC 78/7. 23-4] * ecetes általag 1741: Egj kisdéd étzetes átalag 1 ... Egy igen kitsin tekénŏ ... 1 [M.nádas K; RLt Csekelaki Varsányi Benedekné Beszprényi Orsolya lelt.] * eklézsia 1740: Tiszts és Tks Ballo Judit Aszszony adott egy ejteles ón Kannát ezen kisded Ekkle(si)anak [Hb-Ek] * ereszecske 1821: a Kapu előtt kivülről mind két felől vagyon két kisded ereszetske avatag sendelj fedél alatt [Koronka MT; Told.] * ezüstibrik 1774: Egy kisded Kávés Ezüst Ibrik [Nagyida K; Told. 26 néhai gr. Nemes Judit ingóságainak lelt.] * ezüstpohár 1614: Egy közep szerü kisded szereczendiú Ezŭst Pohar czer Leúelủ az laba [Kv; PLPr 1612-15. 115] * fakalamáris 1789: 10 Nagy Fa Kalamaris ... Rf 6. Xr ... Egy kisded Fa Kalamáris ... Rf - Xr 5 [Mv; ConsrcAp. 33] * faköpéce 1787: egy kisded fa kópétze Dr. 6 [Mv; MvLev. Csiszár Gyula hagy. 8] * faliu 1832: Egy kisdég fa Liu [LLt] ${ }^{*} \sim$ faputina 1837: Egy kisded fa Putina [Dés; DLt 526/1838]* fa-tekerólevél 1820: Egy kisded fa Tekerő Levél [Mv; Told. 19] * fejsze 1837: két Küsdék Fejszi [HSzj fejsze al.] * fenyöcsebrecske 1681: Felső Pincze ... Vagyon itt ... Kisded fenyő ŏ csebricske Nro 1 [Vh; VhU 530] ${ }^{*} \sim f e-$ nyödeszka-asztal 1789: A hátulso Házokban Szálláskodo Boérnál 2. fa Szék és egy kisded fenyŏ Deszka Asztal Rf 1 [Mv; ConscrAp. 16] * fenyőfakád 1765: Két kisded fenyőfa kád [Ilencfva MT; DLev. 2/IX. 13] * ferslóg 1728: Egy kisded avatég Ferslog [Mv; TSb 47] * fogas 1677: Paraszt fogosak karjaival edgyütt és egy küsded fegyvernek valo fogas [Mezőmadaras MT; Borb. II]; 1797: Két Kisdeg fogas a fal oldalán [Szu; UszLt XII. 87] * fogasocska XIX. sz. e. f.: egy kisded fogasotska $[\mathrm{Pk} 5]^{*} \sim$ 
fúró 1656: Egy kisded Furu [Doboka; Mk Inv. 4]; 1714: kúsded furu, egy nagyob [Kászonfelsőfalu; LLt Fasc. 85] * fürész 1750: Nagy és kisdeg Fürész Nr 4 [Gyeke K; Ks 83]; 1777: Rámás kisdég Fűrész Nro 1 [Mezőméhes TA; WassLt] * harang 1700: Teken(tetes) Nemz. Déési Dioszegi Jstva(n) Uram Istenfelő Hazastarsaval ... conferált egy kisded harangot a' Déési Toronyban [Dés; Jk 311a]; 1822: pléh keresztes 'Sendely fedél alatt lévő kisdég Harang [Mocs K; HG Conscr. 17] * harangocska 1757: Egy Rettegi Prodán nevü Harang öntőtŏl Magam Bélyegére valo három kisded Harangotskakat és két Csengettyút vévén, fizettem erette Rh f 25 xr 30 [TL. Teleki Ádám költségnaplója] * ház 1744: a Pater kisded háza ... benne egj asztal [LLt Fasc. 67]; 1636: Ugyan ezen hazbol nylik mas egy kisded hazra egy bellett ... ayto [Siménfva U; JHb]; 1788: Egy Nobilitaris Curia ... Egy barna szalmával fedett nagy Ház ... E mellett egy kisded konyha forma Haz 1 [Feldoboly Hsz; HG]; 1799: kettŏs kisdég ház egy fedél alatt ... fába rakot két kisdég Uveg ablak [Nyújtód Hsz; HG] * házacska 1637: Az masodik contignatiojara az malom haznak, nylik egy ... vas sarkas pantos ayto ... Azon ismet fellyeb egy kwsded rekeszes hazacsykara egy ayto [UF I, 420]; 1752: Vagyon ... Sendely de régi fedel alatt egy kisdek Hazatska, Pitvarával [Pókafva AF; JHb XXXV/73. 13] * házikó 1757: Czigánynak egy kủsded Hazikoja [Taploca Cs; Sándor conscr.] $^{*} \sim$ híd 1850: a mészárszék kapuja, és ajtoja eleibe kívántato négy ŏlŏs hoszuságu kísded hid [Km; KmULev. 3] * hintóderék 1735: egj hinto allya ... Egy kisded hinto Derék avagy kass nem egészszen el készülve [Kv; Ks 40 Varia XXVIIIc] ${ }^{*} \sim$ hordó 1720: találtattak edgy kisded hordoban elegy belegy kŏnyvek nro 62 [Köröspatak Hsz; HSzjP] * hordócska 1789: Egy kisded Hordotskába Cerussa Veneta edényestŏl 55 font Rf 17 xr [Mv; ConscrAp. 8] * húsborító 1715: jutot ... Katona Míhályné Asz(ony)nak edgy hủtő őreg rez palaczk, edgy kisded hus borito [WassLt] ${ }^{*} \sim$ iskatulya 1780: (A) Bethleni Boltban volt egy kisded Záros iskatulya, és ebben állottanak az ŏ Nga drága győngyei, és kőves marhái
[Kv; BK. Sig. Kun (20) lib. vall.] * istálló 1760: egy hitván kisdég istálo [A.volál Hsz; LLt] * kád 1744: edgy küsded kádb(an) fél vékáné köles kása [Szentdemeter U; LLt Fasc. 67] * kádacska 1746: Kisded Kádatska [Borsa K; Told. 49] * kalán 1789: (Az egyik) Fijokban 10 Sárga réz kettŏs kisded kalányok [Mv; ConscrAp. 43] * kamara 1835: A velnitze pitvarába égy jo Sóvény tserénis jol meg tapasztva ... ezen pitvarbol job kéz felől égy kisded kamara ajto nélkűl [Várhegy MT; TGsz 8] * kamarácska 1726: vagyon egy kisded kamarátska vas retez és retezfŏ rajta [Görgény MT; Born. G. VII. 23] * kanta 1777: egy kisded kanta félig mézzel [A.detrehem TA; DobLev. III/503. 3a Haderán Alexa szökött jb javai között] * kapu 1716: levelekből állo kisded kapu [HSzj levél al.] * kapucska 1680: fordulván az harmadik vetemenyes kertb(en) ... nyilik arra fa gerezdes, kolczos egy kisded kapucska [A.porumbák F; ÁLt Inv. 28]; 1697: ezen udvarházhoz az ut felól vagyon egy Fenyő Deszkábol állo viseltes kapŭ... mellyhez vagyon applicálva egy küsded kaputska ... Vagyon egy kisded bé nyilo kaputska vas sorkakon állo [O.brettye $\mathrm{H}$; Born. XXIXa 2 néhai Bodoni Balázs conscr.] * karafin 1761: Három Simma Kisded, karafin [Kémend $\mathrm{H} ; \mathrm{JHb}$ XXXV/39. 28] * kártya 1760: Kisdeg, Kártya, fedeles 1 [Szentdemeter U; LLt] ${ }^{*} \sim$ kas 1755: Csŏs tŏrŏk buza ... két nagy, és két kisdeg kas [M.orbó AF; TGsz 35] * kaszten 1837: Egy Tŭkŏr alá valo kisded két fioku kasztén [Gombás AF; TSb 20] * kásztró 1816: Réz edények ... Fedeles kisded kásztro 2 Rft ... Kisded fedeles uti Kásztro 4 Rft 20 Xr [Kv; Born. IV. 41] ${ }^{*} \sim$ katrinca 1777: tétettŭnk ... azon Párna hajakb(a) ... négy fejér nép Inget, egy Rokoját, egy rongyos abroszt, és egy kisded katrínczát [A.detrehem TA; DobLev. II/503. 3b] * kemence 1697: Ezen konyhabol vagyon ki fúggŏ kisded kemencze egy [O.brettye H; Born. XXIXa. 2 néhai Bodoni Balázs conscr.] * kép 1698: Három kŭsdegh farra valo kép [Köröspatak Hsz; HSzjP]; 1744: üveg tekaba valo fris kisded kép, apácza munka [Szentdemeter U; LLt Fasc. 67] * keszkenő 1803: Egy küsded vastagotska Keszkenő [Ha- 
rangláb KK; UnVJk 168] * kijáró-ajtó 1732: (Az udvari kapu) Tŏlgj fa deszkábol egj felé nyilo csipkés kapu, melette lévő kisded kijáro ajtoval [LLt 224/B] * ${ }^{*}$ kocsi 1647: Egy festekes kisded, kasos, de boer sarhanioju koczy [M.királyfva KK; BK 48/16] * kordovány 1726: nagy veress kordovány nro 25. kisded veress kordovány nr 18 [Görgény MT; Born. G. VII. 23] * kosár 1729: Két kezben hordozo kisded kosár [Usz; Pf] * kötőfejsze 1792: Kisded kőtő fejsze [F.oroszfalu MT; Told. 17] * kristálypohár 1770: Viz ivo Nagy Kristaly poharok 2 Bor ivo Kisdék Kristály Pohár 1 [Rücs MT; Ks 21. XV. 24] * kuffer 1823: Két kisded rongyos kuffer [Nsz; DobLev. V/1080. 3a]* láda 1699: Vagyon más edgj kisded fekete Ládais [Kv; WassLt]; 1728: Egj kŭsded ladaja az Ecclesiának [Illyefva Hsz; SVJk]; 1803: Egy kisdég vasas ládába találtattak: Patyolat Elő kötő 1 [Kvh; HSzjP] * ládácska 1698: selye formán csinált két küsdeg ládácska tele üvegel [HSzj parasztkályha al.]; 1752: Vagyon egy Fejér kŭsdég ládacska a' mellyben tanáltatot Egy begyín szarv puskapor tartó [Brassó; ApLt Apor Péter inv.]; 1767: drága győngyős és Kőves Reszkető Tőket és Boglárokat is láttam azon kisded Iskatullya forma Ládátskába [Egrestő KK; Ks 21. XVIII. 78] * lakat 1813: egy kisded srofos koltsu Lakat [Koronka MT; Told. 18] * lánc a. szekérlánc 1750: Egy bialos szekerhez valo Kisded Láncz [Gyeke K; Ks 83]. b. ékszerlánc 1659: küldtem Kegyelmednek egy gyürüt csak ajándékon ... Bizony lánczot is küldenék, de bizony nincsen olyan kisded lánczom [TML I, 363 Árva Bornemisza Kata Teleki Mihályhoz] * legyező 1679: Festet vászonbul, keregdeden czinált kisded legyező [Uzdisztpéter K; TL. Bajomi János inv.] * malmocska 1772: eö Excellentiaja Malma fogjatkozásának nem az én kisded két kővű Malmocskám, hanem az eő Excellentiaja Tisztei gondviseletlenségek okai [Kük.; JHb LXVII/238] * malom 1772: vagyon Épittve kisded Malom [Tusnád Cs; BethKt Mikes conscr.] ${ }^{*}$ mángorló 1832: Egy kísdég mangurlo [LLt] * motolla 1797: Két Kisded Matolla [Náznánfva MT; Berz. 4/22. N. 22] * nyoszolya 1692: (az) erkelyben vagyon egy kisded nyoszolya, es egy kisded labos asztal [Görgénysztimre MT; JHb Inv.] * óntál 1810: Egy kisded fŭles on Tal ... Rf 7 Xr 43 [Mv; MvLev. Trincseni Mihály hagy. 20] * pajtácska 1825: A' Serház Udvarának végében lévén egy kisded Pajtátska [Dés; DLt 595] * pálinkás általag 1813: Kisdek Pálinkás átalag [Veresegyháza AF; Told. 18] * pálinkás hordó 1830: Négy küsdeg pálinkás Hordó [Msz; Told. 19] * parasztláda 1632: Vagyon egy kisded paraz (!) ladaban Viasz Lib: 68 [UC 14/38 Kománai Urb. 124] * párna 1698: Egj kŭsdegh kék párna [Köröspatak Hsz; HSzjP]; 1798: Egy kisded haj nélkül valo Párna [Mv; MvLev. Cimbalmos Fernecné hagy. 3] * pártaövecske 1588: Wagion egy kisded partha eowechke fekete viselt Mayczos ... 16 boglar rayta [Kv; KvLt Vegyes I/2. 23] * pince 1636: Ezen ŏregh pinczeból nilik ... mas kisded pinczere egy fejer uy felszer vas sarkos pantos, retezes ayto [Siménfva U; $\mathrm{JHb}$ Inv.] * pincécske 1748: Vagyon Szalma fedél alat egy kisded Pintzétske [Nyárádsztbenedek MT; Told. 7] * pitvarocska 1752: (A) Specificált Háza kőzőtt vagyon egy kisdék Pitvaracska [Pókafva AF; JHb XXV/73] * pohár 1696: Egy kisded aranyas Czapas pohár [Mv; MbK]; 1792: Két kűsded keregded egyenlő nehézségü poharak [Kv; SLt 17] * poharacska 1801: Hét Rosolisos kisded virágos pohárotskák [LLt] * rézmozsár 1848: Réz Edények ... Egy Kisdeg rēz mozsár ütöjivel. 1 [Szászerked K; LLt Kovats Mihály gub-i írnok kezével] * rézüst 1687: Egy tőredezett kisded rez üstet [Déva; Szer.] * satucska 1798: Kisded sututska xr 6. Kis furutska xr. 1 ... nagyobb sutu xr. 34 [Kv; Pk 6 Pázmány Sámuel hagy.] * selyemkeszkenö 1847: Egy szivárvány szinŭ, virágokkal s kŏzepén fekete csillaggal ekesitett kisded selyem keszkenŏ [Kál MT; UnVJk 130] * serpenyö 1760: Kisdég Serpenyö N 1 Kisdég Sita (!) ... Cseber Küsdég [Parajd MT; LLt Fasc. 139] * sróf 1803: ezŭst Pohár, mely fenekébŏl ki nyúló kŭsded srofjánál fogva ... egy ... tsŏtskén fel-nyulo szárához foglaltatik [Széplak KK; UnVJk 2/2] * statua 1789: A' Stellasok tetején ... kisded fejér Statua, egy antic fŏ aranyos Rft 4 xr 30 [Mv; ConscrAp. 44] * statuácska 1760: a' 
Frontiscipium Tetein lèszen Gombok helyett három kisded Statuátska [Kv; Told. 26] * sütókemence 1849: Egy kisded Sütő kementze vas pánt a száján [Somkerék SzD; Ks 73/55] * szegletalmárium 1848: A nagy palotán ... Egy kisded szeglet almárjom [Görgénysztimre MT; Born. G. XXIVd] * szék 1753: Kisdeg Tekenyő ... Kisdeg Szék [Buza SzD; LLt]; 1813: küsded székek Koporso alá szolgálók [Betlensztmiklós KK; UnVJk] * székely szekér 1777: kisded szekely szekér [Majos MT; Told. 26/21] * szekér 1774: Máttyás nevŭ Jobbagynak Csak égy kisded Szekere maradat volt [Paptelke/Mocs SzD/K; Ks Conscr.] * szénakonzervatórium 1789: Egy kisded Széna Conservatorium [Mv; ConscrAp. 18] * szepet 1628: Harom wres Teóreók szepet approk egik labas. Egy kisded szepet, Torok szappannal teli [Gyalu/Kv; JHbK XII/44. 8] * szönyeg 1620: Egy kisded szeöniegtul f-/12 ... Egy eöregh es io fele szeőniegtúl es Paplantul arra szerent uegiek [Kv; KvLt II/69 VectTr 15]; 1688: Egy küsded szönyegtöl f -// 24 [BfN Vect.] * szuszék 1632: Az Swteö ház megett ... egy hozzu Suppal keőteőtt fedel alatt uagio(n) egy nagy eőregh ket szakasztasu szuszek No 1 ... Ugian ezen fedel alatt más eőregh szuszek N 1 ... Ezen szuszek mellett mas egy kisded szuszek N 1. meliben vagion keőleős Cub N 11 ... Ugyan itt egj kisded szuszek meliben vagion szemen szedett tizta buza Cub No 10 [A.porumbák F; UC 14/38. 175] * szuszékocska 1741: A Vár mellett ... egy kővü Lisztelő Malom ... Vám tartó kisded szúszékotska Nro 1 [Nagyalmás K; JHbK XXIX/37] * tál 1587: veottem 1 Kisded Talat p(ro) d. 2 [Kv; Szám. 3/XXVI. 66] * tálas 1798: Egy Kisded Tálos -// 30 [Kv; Pk 6 Rázmány Hedviga hagy.] * tányér 1788 : 5. tsipkés Hollitsi kisded fejér Tángyér [Mv; TSb 47 néhai gr. Rhédei Zsigmondné br. Wesselényi Kata hagy.]; 1839: Egy kisdég tángyér [Kv; Pk 3] * tarack 1637: a' mellett vadnak negy vasas kereken egy agyon kett kisdegh tarackok [UF I, 397] * targonca 1839: Vagyon négy kisded Targontzája [Dés; DLt 87/1840] * tekenő 1681: Sütő Ház ... Sütő, szarvas őregh tekenő Nro 2. Kisded tekenő Nro 1 [Vh; VhU
519-20]; 1753: Kisdeg Tekenyő ... Kisdeg Szék [Buza SzD; LLt] * tekenőcske 1682: edgy kovász tartó kisded iszkabas hasatt tekenocske [MNy XXXVIII, 206] * templom 1736: Az templom ... az kiben az catholicusok jártanak ${ }^{\mathrm{a}}$, kívül az városon az hostátban volt; kisded setétes templom vala [MetTr 436. - a Gyf-ott] * tojókácska 1761: Kisded Iro asztal ... melynek a négy oldalán kisded Tojocskája [Branyicska H; $\mathrm{JHb}$ XXXV/39. 7] * tonna 1745: A' Malomban vagjon két kisded Tonna, edgyik vám buzával, a' másik tŏrŏk buzával tele [Marossztkirály MT; Told. 18] * tonnácska 1814: Egy kisded Tonnátska [Mv; MvLev.] * tornác 1760: Ezen Udvaron tanáltatatt egy Négj Szegeletü ... Ház elol valo kisded kerek formáju Tornattzal [Kissáros KK; SLt PQ. 10] * tükör 1791: Két kisded aranyos Czirádáju Tŭker [Mv; MvLev.] * udvarházacska 1775: Ezen ... kisdég udvar házatskának a végínél [Mihálcfva AF; LLt Csáky-per 106. L. 13] * üllő 1820: Edgy nagy és két kisded ülü [Mv; MvLev.] * ülőszékecske 1656: 2 kisded üleö szekeczke [UF II, 124] * üst 1588: Egy kisded fel fwggeo wst [Kv; KvLt Vegyes I/2. 19]; 1719: Egy kŭsded ŭst [TSb] * vagdaló tábla 1697: (A) konyhá(na)k ... vagyon egy le eresztó kisdéd vagdalo Tablája [O.brettye H; Born. XXIXa. 2] * varróládácska 1774: Láttam ... egy kisded Varró Ládátskát [Szentdemeter U; LLt Vall. 93] * vasfütố 1802: Három lábakon állo kisded Vas füttö kéménnyével együtt [Ne; DobLev. IV/858. 8b] * vaskalán 1812: Egy kisded hitván vas kalán [Mv; MvLev. Szabadi József hagy.] * vashorog 1681: Kinzó Bástya ... Vagyo(n) itt ... Kisded szerü vas Macska Nro 1 Kisded vas horog, fa nyelestöl Nro 1 [Vh; VhU 511-2] * vasküsü 1820: Két sima reszelö, és edgy négy kisded vas küsü [Mv; MvLev. lak.] * verő 1681: Edgy kisded szerü vas vágó nro 1 . Kisded verő, egy nro 1 [CsVh 92-3] * véső 1729: egj küsded füles véső egy nagj Fúles véső [Tarcsafva U; Pf] * viaszsajtó 1749: Egy kisdég Lábakra tsinált Viaszsz Sajto [F. zsuk K; SLt Vegyes perir.] * zsák 1740: Vagyon ... egy Láda, mellyben vagyon két kisdég Sakban toll [Hermány U; ApLt 5 Apor Péterné inv.] * zsindelyező szekerce 
1744: Kisded Zsindelyező Szekertze edgy, hornyolgó (!) edgy [Szentdemeter U; LLt Fasc. 67].

2. rövid Szk: karabély 1827: Egy kisded hitván Karabéj két forintba [F.zsuk K; SLt Vegyes perir.] * mente 1756: kisded Jappon forma Seprŏ szin Posztobol tsinált vagy készitett bèleletlen Menték [Burjánosóbuda K; TSb 21] * pisztoly 1714: Egj Par kisded Pisztolj elephant tsontal ki rakott [AH 14] * stucc 1714: Egj par kisded stucz Szilva fa agja elephant tsont viragokkal ékesitve [AH 25-6] * szarvasszarv 1789: Egy fél Dámvad szarv kisded, item egy pár Dámvad Nagy Szarv Rf 4 [Mv; ConscrAp. 13].

3. ideiglen rövid ideig 1590: Az Zam weweo vraim ... eg' kisded ideighlen Walo Warakodast veottenek eleó [Kv; TanJk I/1. 128-9].

4. apró Szk: aranyszemecske 1757: Két Kisded arany szemetske [Szentkirály MT; Berz. 3. 1/11]* boglár 1757: aranybol való. 5. kisdeg boglárok ... aranybol való kapots formára tsinált 6 . boglárotskák [Szentkirály MT; Berz. 3. 1/11] * boglárka 1768: Rubintos apro Boglárkák, nyakra valonak valók 23 ... Egy győngyős párta 138 őreg győngy, kilencz kisded Rosa forma Boglárka, egy egy kisded Rubintocska mindenikbe [Nsz; TGsz 51] * mogyoró 1716: akkara juk volt az csŏjin, hogj egj egj kŭsded magjaro be tért volna rajta [Nagyida K; Told. 22] * sümölcsöcske 1801: az állán egy kisded sŭmŏltsŏtskéje [DLt nyomt. kl].

5. alacsony/kis termetű A. 1710: Fejérvárra ... érkezék ... gróf Seeau, csúfos kisded, görbe hátú, szeles ember [CsH 321]; 1750: Szökött el innet K. Lonárula Ötves Bancsi ... kisded jo vállas, csontos, fekete kondor haju [TK1. - ${ }^{a}$ Kendilóna SzD]; 1757: Hajdu Márton ... kisded és nem igen magos kerek kőpczős ... ember volt [Szováta MT; IB]; 1762: Dobai Joseph ... egy kisdéd, nagy hasú ember volt [Doba/Perecsen Sz; IB IV. 76 Joan. Béres (90) jb vall.]. B. 1745: hallam hogy egy hoszú Sárga bajuszu kisdég katona ŏszve Szidá Feŏ Biro Urat kŏ teremtettének [Mocs K; Ks 5. X. 6]; 1829: egy társa érkezett egy kisdég ember bundába [K; KLev.].
Szn. 1614: Kisded Mathe puer ppix [Bölön Hsz; BethU 194].

Szk: termetü 1772: A szegény Salánki Mózes kisded termetü, de jól tanult, friss ember volt [RettE 285]; 1843: Kovács Ferentz ... kisded zömög termetü [DLt 380 nyomt. kl].

6. Állatra von.: kicsi növésű 1772: Két Gyermek lovat el-adattam ă mult Hunyadi sokadalomban ... az edjik Gyermek Lovat 30 Mfor. 58 pénzen az mást mely-ís kisdég volt - 28 Mfor 50 pénzén [Öraljaboldogfva H; JF Baranyai János lev.]; 1813: Egy Tehén kisded [DLt 788 nyomt. kl]; 1850: Székely szármozásu Bara Joseff ... két lovait tudják ... edgyik veres pejkantza kisded, a' más hasanlo szörü paripa a' másnál magasabb [Mv; DobLev. V/1303 Soos György Tanátsi Biztos kezével].

Szk: borjú 1823: Egy barna kisded esztendős metzetlen mokány bornyu [DLt nyomt. kl] * gyermekló 1801: hodos homloku, fél szemivel tsokás ... kisded, metzetlen gyermek lo [DLt nyomt. kl] * kanca 1801: egy igen setét pej kisded Kantza, turos hátu [DLt nyomt. kl] * kancacsikó 1808: Egy világos pej szörü ... hitvány, és kisded kantza-tsiko [DLt 578 nyomt. kl] * kancácska 1798: bé fizették ... Egy vèn, $\mathrm{s}$ kisded kanczácskának az árát $21 \mathrm{Rf} 15$ xr [H; Ks 108 Vegyes ir. 57] * kancaló 1805: kisded fekete orŭ... Kantza Ló [DLt nyomt. kl] * ló 1619: (A követ) Egy küsded füstös szabású fejér lovon ül vala [BTNa 280]; 1729: Bányabukòn lakó Roszuan Gábor, Fiscus sellérének egj Vértse Deres Szŏrü küsded Lova, el tévejedvén 13. Maji fogatott fel [Kv; TJk XV/7. 40]; 1840: adatt még egy kisdég veres lovat ... Sombori Ferentz urnak [Kisesküllő K; Somb. II] * ökör 1754: Egy kék ŏkŏr 8//16. Más egy kisded Veressetske ŏkŏr 4//68 [Kecset/ Kajla környéke SzD/BN; WassLt] ${ }^{*} \sim$ paripa 1599: az Papnak egy nagy kek lowat adot wolt, az Pap esmegh egy kisded porozka zabasu paripát [UszT 15/190. Nobilis Agilis Joannes Miklossy, Primipilus Jenlakiensis ${ }^{a}$ vall. - ${ }^{\mathrm{a} E ́}$ Elaka U] * paripaló 1837: barna pej kisded paripa Ló [DLt mv-i nyomt.] * tehén 1687: Az Vendég Lovagoknak fizetésekbe is lábán Szŏrin adatat 
ki kamara Ispán Uram ŏ kglme ... Egy vén ősztevér kisded ... Tehenet [Máramarossziget; Törzs] * tehenecske 1768: Béres Gyurkának Conventioja szerént való fizetésében adtam égy kisded Tehenetskét [K; DobLev. II/390. 11a] * tinócska 1575: Két megdőglőtt kisded tinócskák(na)k bőre 2 [Kiskend KK; Ks 71. 52 Szám.].

7. kicsi kiterjedésű A. 1699: menénk bé második kŏzŏnséges Cserefa deszkábol való gerezdes záru ajtócskánn ... edgy kisded vetemenjes kertb(e) mely hat táblábol álván ketteib(en) az ajton belŏll menten veres hagjma van [O.csesztve AF; LLt Gyulafi László lelt.]; 1716: (Az udvarház) hata meget egy kisded méhes kert lészás [Doboka; JHb III668]; 1757: küsded Joszágotskához tartozo kétt Földetske [Vacsárcsi Cs; Sándor conscr.]; 1760: az Szent Iványi ... határhoz szakasztott Kisded rét [Vajdasztiván MT; EHA]; 1761: Dési rész kŭsded Sessio [Pagocsa K; JHbK LXVIII/1. 29]; 1782: kisded kaszáloja két Merekjéni [Magyaros MT; Told. 76]; 1803: advan nehai nagy Moyses János Szabo Miháljnénak egy kitsid ben valot, meljet mostanis Szabo András uram bir egy kitsid kŭn valoval egyŭt ... azon kisded (ben)valo pedig ... Tordai jus volt [Szenterzsébet U; Borb. II]; 1805: a' nagy Szamos follyamattya mellett ... vagyon ... háram szegü Formában adott kűsded Kőves Részecske [Kv; Pk 3]; 1835: A Veteményes kisded kert [Várhegy MT; TGsz 8]. B. 1823: kisdeg veteményes kert [Csekelaka AF; KCsl 16].

Hn. 1810: Kisdég nyilba (sz) [Bibarcfva U; EHA].

8. csecsemő v. gyermekkorban levő 1708 : Parancsolt uolt Asz(sz)onyom ŏ kglme hogy egy tizenkét esztendős leankát szerezzek ... Gergely Mihaly(na)k vagjo(n) egy küsded, talám valnék valamire [Kozmás Cs; ApLt 5 Molnár István Apor Péterhez]; 1710: Csak kisded lévén, olyan meszünnen gyalog úgy jártam, az urakot supplicáltam [CsH 151].

Szk: állapot 1755: Groff Lázár János Ur eŏ Nga akkor kisded nevedékeny állapotában volt [Havadtő MT; LLt 72/6] * árvácska 1764: szoptattam az akkor szŭletett Kisded Arvátskát [Pókafva AF; Kath.] * csecsemó 1779: Lula Josi kisded Tsetsemŏ Josefjét ${ }^{a}$ [Gyalu K; RAk 129. - ${ }^{\text {aTemettem }}$ el] * fiú 1745: Hajdoni szúle Atyánk ... meg halálozván, szule Anyánkat ... édgy kisded Togyer Nevű fiával, ŏzvegységben és árvaságb(an) hagyta [Kápolna SzD; ÁLt Com. Szolnok Interior 2/1795] * fiúcska 1722: kisded Fiacskánk változob Statusban vagyon [KJ. Rétyi Péter lev. Fog-ból]; 1831: Vaszi meg halálozván égy küsdeg fiatskája maradott árván [Szentdemeter U; Told. 39] * gyermek 1592: Az Maylad eleot valo futaskor kisded giermek valek [UszT]; 1724: ezen Jánosnak it vagyon két árva küsdéd gyermeke [Gelence Hsz; BetLt 6 Földi Gergej (56) jb vall.] * leány 1796: égy kisded fiatal Leányt tartott szolgálonak [Bács K; RKA] * leányka 1743: melj Legénkéket adá ... küsded Leánkájok(na)k Groff Lazár Susi Kis Aszszonykának [Szentdemeter U; LLt 25. C]; 1775: a magam kertemben valami magos kendérrel bajlodván égy kŭsdég leánykámmal égyütt [Tarcsafva U; Pf].

9. Állatra von. Szk: kanca 1752: Egj Vén Fejér Kantza ... Egj Tiszta Fekete Kisded Kantza [Dob.; TL 42].

10. csekély 1585: Jlona Damakos Mathiasne vallia, Nallam lakik vala az Ersebet mint egy tizenket eztendeos leanka vala, hat vagy huzon eot penzt gywteogetet volt az Zonzed Azzonyhoz, kenyeret fatis Adot volt oda ... ez kisded vetket tudom hozza [Kv; TJk IV/1. 506]; 1592: Az Biro es tanachis ... keotelesek legienek, az egy eleobe rendelt kisded bwntetest Minde(n) renden meg Vennj [Kv; TanJk I/1. 175].

II. fn csecsemő 1573: Feyerdy Kato azt vallia Twgia hogi haza volt Teremy ferench mellet az Ilona Attyanak, ky azkor kisded volt mykor az attya meg holt $[\mathrm{Kv}$; TJk III/3. 186]; 1766: (Temettem el) Ifju Kadar István kisdedét ki nem régen született vala [Gyalu K; RAk 125]; 1778: Vagyon egy fábol ki mettzett Apálcza (!) kép egy kisdeddel [Csapó KK; Berz. 4. 8. C. 18]; 1785: a' Hostátban gyakran éjjel is vagy terhes betegeknek meg látogatásokra, vagy pedig az ollyan Kisdedeknek meg keresztelésekre, a' kik halo félben vagynak ... meg kivántatnék, hogy ezen negyedik Papnak 
a' külsö Templomnál lenne lakása [Kv; SRE 241]; 1850: a papok teendői közzé tartozik ... össze irni azon Kisdedeknek neveket, kikbe ... a himlő bé nem oltatott [Nagykapus K; RAk 4 esp. kl].

Szk: korában 1710: II. Rákóczi Ferenc ... kisded korában maradván árvaságra, a jesuiták tutélája alatt nevekedik [CsH 328]; 1791: Tudom bizonyason hogy néhai Székely Lászlónak ... voltanak itten Rákoson négy Léányi egyik még kisded korában meg halálozvan a' nagyabbik Judith ment volt férjhez Péterfi Pál Uramhoz [Várfva TA; Borb. II St. Pető (68) ns vall.] * korától fogvalóta 1714: Colosvárj Mihokot boldogtalann kŭsded korátol fogva Orb(an) Elek $\mathrm{Ur}(\mathrm{am})$ tartotta fel, es most Olá falub(an) lakik [Orb.]; 1839: Néhány esztendőkig tartám őrőkképpen kisded korátol olta, most már hajadon Rosaliát [Dés; DLt 1230].

kisdedecske kisgyermekecske 1672: Isten Kegyelmeteket továbbra is oltalmazza, az asszonyt penig gyógyítsa. Szegény kisdedecske teste csak azt kívánta: ő jó helyen van [TML VI, 163 Bánfi Dienes Teleki Mihályhoz].

kisebbecske 1. kicsike, kisebbke 1733: Egj borona kissebbecske [Kv; Pk 6]; 1750: tartozom ... negy Boltot, ketteje Nagyob ketteje kissebbetskék ... Epittetni [Déva; Ks 73. III]; 1793: Tepsi, melyek közül edgyik késsebbetske [TL Conscr.]; 1795: tudok ... két ezust nagy Gazdalkodo kalányokat, melylyek kŏzŭl egy nagy, a masik kissebbetske volt, tudom ... égy ezŭst poharát is egy fertállyosnal kissebbetske lehetett [Folyfva MT; Told. 23]; 1801: A kisebbetske és alábbvalotska készületü Hidas [Gernyeszeg MT; TL]; 1824: Egy nagyobbotska, egy kissebbetske Skatuly (!) [Figad AF; HG Mara lev.].

2. apróbbacska 1786: Egy Arany függőtske egy nagy rubint benne, és 19 kissebbetske [Nsz; Ks 74/56]; 1791: Négy rend gránát kissebbetske [Mv; Told.]; 1800: adott által ... 10 Egy Nagyobatska jo féle győngyöt egy jo hoszu rendes 20 Kisebetske jo féle gyŏngyőt felfuzve 3. kis darabot [O.fenes $\mathrm{K}$; JHb LXXXVI/46].
3. kisebb területű 1779: ezen két darabb Erdŏk kűssebbetskek [Szeredasztanna MT; LLt 90/25]; 1820: Ezen Helység Határan vagyon két fordulo - Also és Felsö az also Kissebbetske [Bogártelke K; KmULev. 2].

kiskalánocska kiskanalacska 1700: Harom fejer kis kalanocska [Hr 1/20].

kiskertecske virágos kertecske 1650: Az harmadik riszt ... also hazak ablaki alat leuő kis kerteczkeuel ... marada ... Folti Farkas vr(am) szamara [Folt H; BK sub nro 117]; 1679: Belső, viragos kis kertecske Ez az Asszonj eo Kglme haza mellet, es az Leany Aszszonyok hazai ablaki alatt vagyon. Ezen kertecskében, majoranna, szekfü, rosa ... tablak vannak [Uzdisztpéter K; TL. Bajomi János inv. 57]; 1814: a' Malomhoz tartozo kis Kertecske [Borberek AF; RLt O. 3]; 1842: égy virágos vagy kis kertecske [Oprakercisora F; TSb 51].

kisleányka 1. leányocska 1583: Vaida Andras vallia hallomassal ... hallotta ezt(is) Biro Mihalnak es Mostany felesegeteol hogy kialtotta az vchan Biro Mihal feleól hogy Az kis leankan kapta volna az vrat [Kv; TJk IV/1. 140]; 1603: Dobaj gergely otalma alat wala az Kis leanka ö kölcziegen Tartota ... ö wiselte az kis leany giermeknekis gongiat [UszT 17/21 Timar Andras Benczier Gergelj hazaban lako gagj vall.]; 1679: Anno domini 1679 die 13 Aprilis. Adott az Úristen egy küsleánykát kedves házastársamtól ... kinek neve Borica [Kv; $\mathrm{KvE} 217 \mathrm{BP}]$.

2. birt. szr-os alakban 1591: Mindeneket hagiok ... kis leankamnak Frusinnanak [Gyf; BálLt 93]; 1639: az mikor fejemet veszikis ez elomben tartota az kús liankamot, hogy annakis ussek el az fejet [Mv; MvLt 291. 198b]; 1701: Estve született küs leánykám Kata [SzZs 309]; 1760: Csetsemǒs kis Leánykaja Rebeka negyed fél holnapos [Feltorja Hsz; LLt]; 1856: Halt meg Fodor János Ur kis leanykaja Ilka 1. éves korában; tüdő hurutba [Dés; RHAk 80].

klárisocska korallszemecske 1824: egy Szem Klarisotska [Fugad AF; HG]. 
kocsicska 1710 k.: Ratisbonában mü egy kocsicskát fogadánk ketten, Norimbergáig, alkudtuk két tallérban [BÖn. 571-2].

Szk: ernyős 1619: (Szölfikár agának ${ }^{a}$ ) nagy kévánsága vagyon arra, hogy ő Felségedtől egy-két lóval ernyős kocsicskát impetrálhatna $\left[\mathrm{BTN}^{2}\right.$ 326. $-{ }^{\mathrm{a}} \mathrm{C}$ saknem egy félszázadig a Portán az erdélyi követek diplomáciai tolmácsa].

kolészácska, kolyészácska kocsicska, kicsi kocsi 1681: Két Ló utan valo Lengyel Kolyiszaczka noha ighen viseltes, de még a' vasai jók Nro 1 [Vh; VhU 505].

komponácska kis karosmérleg 1676: az kủlső safar hazban ... az asztal felett egy komponaczka tiz fontos golyobissal [Fog.; UF II, 712].

Szk: húsmérő 1680: Vadnak ket kisebb szerŭ hus es Turo merŏ kumponacskak is no. 2 [A.porumbák AF; ÁLt] * túrómérő 1680: Turo merŏ komponacska [A.porumbák AF; ÁLt].

kondorocska göndöröcske, göndörke 1811: Togya Lapŭ ... fejér kondorotska hoszszu vágatlan haju [DLt 495 nyomt. kl].

kontroverziácska kics perpatvarkodás, villongás 1764: Hoszszu Gligorás ... azon ... Széna-füvet ... eddig birta békességben, hanem ennekelőtte két Esztendővel volt valami controversiátska iránta, de aztis magok kőzőtt Sopiálták [Buza SzD; JHb IV/13].

konvenciócska kb. (holmi) járandóság 1793: az Asszony eŏ Nga felöl nem felelek ... hogy szokott kegyességétöl viseltetve conventiotskátis nem adott nékie, de ebben bizonyos nem vagyok [Kémer Sz; TKhf St. Dombi (60) zs vall.]; 1793: nem mondom, hogy az Asszony eŏ Nga mint kegyes Asszony talám valami Conventiotskátis nem adott nékie [Kerestelke Sz; TKhf Roska Togyer (80) zs vall.].

konzervatórium-házacska kb. raktárkamrácska 1820 k.: A nagyobbik szoba ajto nyillásán kivül Jobra, van egy jobatska mely a Posta Expeditura Háza volt ... Balra: egy Conservatorium Házacska ... tanáltatnak még ezen Conservatoriumba ... égy poltzos Nagy Almárium [Dés; RLt]. konzervatórium-pincécske pincekamrácska 1820 k.: ezen Epület alatt van égy Fa Graditsos Boros Pintze ... Amellett a kapu felöl egy kisded Conservatorium-Pintzétske [Dés; RLt].

konyhácska 1. kis konyha, nyári konyha 1750: elébb menvén egy kisség jobb kéz felé találtatott egj alkalmas konyhátska régi sendellyezéssel ujj foldozással, sőt még az fala is egj felől rosszatska [Szamosfva K; JHbK LVIII/4]; 1772: Ezen belől egy Konyhátska, vagyis Pitvar vagyon [Szászfenes K; BethKt Mikes conscr.].

Szk: fóző 1638: Az kut mellett vagjon egi sütö, fözö konyhaczka, deszkabol sasokban fel rott, deszka az fedeleis [A.porumbák AF; UF I, 661].

2. tüzelő tüzhely 1694: eze(n) pitvarba(n) egy Kemeny alat túzelő Konyhacskaja, mely mellett, egj Egetborfőző Katla(n) [Kővár SzT; JHb Inv.]; 1716: adtam Szállásul itt Brassob(an) a Klastrom vczaban lévŏ Házamnak belsŏ Boltoczkáját ad haerealo kis tŭzelŏ Konyhácskaval magamnál tartván ezen emlitet Konyhácska(na)k kulcsát [BLt].

3. ját tarthatja ételre valóját megszerezheti 1722: Tŏrvényes Székem nincse(n), hogy abbol bár csak fŭ szerszámra valot, és konjhácskámat tarthatnám [KJ. Rétyi Péter lev. Fog-ból]].

kopottacska kissé kopott 1803: Egy Sőtét zőld festékű kopottatska rostélyos scriptorium szegeletes négy Lábakon [Ne; DobLev. IV/858. 1a].

korbácsocska kis korbács 1714: Korbatsotska het szegletes Kristaljomos nyelével, mind $a^{\prime}$ ket végen arannjal boritott alab valo Türkesz követskekkel ki rakott, ostorocska penig arany s ezüst skofiummal boritott s arany Skofium, apro gjöngjekkel ki rakot gombotskaval ekesitett fl. Hung. 30 [AH 36].

korlátocska palánkocska 1797: vagyon egy fél ŏlni ... labakra keszitett kollátotska [Körispatak U; Pf].

koronácska szószékkoronácska 1803: deszkából készittetett kŭsded festett koronátska ... Ezen korona alatt vagyon három 
gráditsu, kŏbŏl rakott Prédikálló szék [Betlensztmiklós KK; UnVJk 30].

korsócska kis korsó 1652: az Udvarhaz felől valo kis veres bastya ... Tüzős szerszám ötven öt veres korsocskákba(n) benne [Görgény MT; Törzs.]; 1700: kett kis korsocska [Szászerked K; LLt]; 1772: Cserep talatskák ... Ket Korsotska [Tarcsafva U; Pf]; 1829: a' kis korsotskámat kŭldem ha méltoztatik a Tekintetes Sogor Ur egy kis palinkat kŭldeni [Asszonynépe AF; DobLev. V/1154 Zabolai Pál Kŏkösi Dobolyi Sigmondhoz].

Szk: fedeles 1699: Két ezűst ampona es egy kis fedeles ezüst korsoczka [Szárhegy Cs; LLt Fasc. 150] * mustáros 1772: Ezüst ... Egy mustáros korsocska kalanyával [Egeres K; Ks] * rostás 1679: Fejér bokaly, rostas vizes korsocska nro 1 [Uzdisztpéter K; TL Bajomi János inv. 29] * veres 1652: Tüzős szerszám őtven öt veres korsócskákba(n) [Görgény MT; Törzs.].

kosaracska 1. kicsi kosár 1773: egy kűs kosárotskába belé tette [Szárhegy Cs; LLt Fasc. 69].

Szk: sörszürő 1699: Ser Szürő kosarocska Nro 1 Ser merŏ Sajtár Nro 1 [O.csesztve AF; LLt Gyulafi László inv.].

2. Jelzői haszn-ban: vhány kosaracskányi 1836: kűldünk ... egy kosaracska Szőllőt ha erőssen őszsze nem mocskolodnék [Ádámos KK; Pk 7].

3. porcelánkosárka 1714: Ezüstes virágokkal ékesitett kosarotska két hasonlo füleivel 4//50 [AH 43]; 1743: Kafés Csésze gyenge 6. Kosarotska [O.fenes $\mathrm{K}$; JHbK XXIX/28].

Szk: gyümölcsös 1804: Két gyümŏltsös kosaratska [Borosbenedek AF; SLev.].

kosárka kosaracska 1724: Egy kosárkában ... holmi rosdás el vetett kultsok [Koronka MT; Told. 29/12]; 1736: Hal tsont veszszőből font tál forma kosárka 1 [Várhegy MT; CU XIII/1. 101]; 1744: feles kosárkák [Szentdemeter U; LLt Fasc. 67]; 1811: egj Kis kosárka [Jedd MT; LLt].

Szk: kézbe való 1699: Kezbe valo Kosárkák [O.csesztve AF; LLt Litt C].

koshólyagocska 1806: Egy Kos hojagotskáért 12 x [Tresztia H; Ks 109 Vegyes ir.]. koszorúcska 1. ékszerfüzérecske Szk: gyöngyös 1768: Egy Győngyős Koszorucska, mellybe vagyon őt ... boglár Magyarországi forma, apro győngyős virágokkal őszve kőtve [Nsz; TGsz 51].

2. (hagyma) füzérecske 1799: három rudakan 124 koszoru veress Hagyma. Vagyan két koszorutska Fok hagyma is, meljen vagyon Fő 46 [F.zsuk K; SLt Vegyes perir.].

3. Jelzői haszn-ban: vhány koszorúcskányi/koszorúcskára való 1775: 6 koszorutska veres, és 7 fokhagyma x 48 [Déva; Ks 76. IX. 181/4].

kőbástyácska 1650: az Gradicz alat leuő bolt tőmleczel, es napniugat felol leuő reytek Teŏmleczel ... napniugat felol leuo kis keo Bastiáczkaual mind az ket contignatiot ... valaszta maganak ... Folti Ferentz vram [Folt H; BK sub nro 117].

köblöcske vhány kicsinyke köbölnyi 1730: bízom Ngod gratiajában ís vagy egy kőblőtske szalad iránt ... Felesegem fözŏn sert s kerjen fa hozo kalákát [Somlyó Cs; ApLt 4 So János deák Apor Péternéhez].

kőházacska kőházikó 1742: egj kŏzŏnséges fellyŭl padlásos kő házocska [Gyeke K; Ks 4. VII. 1].

kőhidacska kő-gyaloghidacska 1593: Az ouarsorban vallo folliamra vallo kollczig ... Egi giallog ku Hidaczkatt czinallttatta(m) [Kv; Szám. 5/XXIV. 5-6].

kőkamrácska kő-éléskamrácska 1735: ezen Tornácznak bal kéz felöl valo vegiben, vagjon egj el romlott Kö Kamaracska [ÓTorda TA; JHb XI/9. 54-5].

Szk: tejtartó 1636: uagyon egy Teytarto Ablaktalan keŏ Kamoraczkara nylo ayto ... vagyon benne furesz deszkabol czenalt teytarti polcz ... egy hus tarto fogas [Siménfva U; JHb Inv.].

kőkéményecske 1774: az padlásra ki nyúló kő kéményetske [Pókafva AF; Kath.].

kőkéményke 1676: Le jöven az szalonnás házrol, vagyon jobra egy kis darabant ház, ajtaja vas sarkas, vagyon egy kö kemenykéje [Fog.; UF II, 702].

kőkutacska kővel bélelt kutacska 1729: a' mehes kerten fellyül a' föld szinin egy kőzŏnséges kő kutacska, vize mind(en) 
kor lévén szükség(ne)k idején a' vetemeny ŏntŏzésre [Buza SzD; JHbK V/2].

kőlábacska kő-kemencelábacska 1736: tűzelő kementze alatt lévő faragott kő lábotskákon álló ugyan faragott Tüzhelly kővek vadnak [CU].

költségecske 1. kb. (kész)pénzecske 1675: Batjam vram; ha mi kŏlcsegecskeje volna kglmednek valakinel mondana mg kgld [Szotyor Hsz; BLt]; 1684: Nehai Desfalvi Miklosnak kónyveit s kőntősit atta el s abbol allott kŏltsegecskéje [Torockósztgyörgy; Pk 7]; 1712: Bőer (!) Samuel Uram és Feleséghe Nzts Bároczi Christina Aszszony ... jelenté, hogj az mostani közelebb el múlt haborusághos ŭdőkb(en) min(en) marhájokbol nagjobbára ki pusztultak vólna, ugj hogj ... akarnák el adni ... Nagylakon lévŏ portiojoknak egj részét és abból kevés kŏlcségecskét abbéli szŭkségekre szerzeni [Hari AF; DobLev. I/75].

2. kics hideg ételnemúcske (ázalék, sajt, szalonna, túró) 1775: lattam aztis hogy innen Peselnekról honalja alatt egy kevés lisztet ... költségestkét vitt [HszjP Conjunx Ladislai Opra Clara (40) vall.]; 1869: Következik a harmadik pásztor, ki igy hallatja magát: „Én is hoztam egy báránybőröcskét, Örömestebb adnék juhot avagy kecskét, De mivelhogy tartok feles cselédecskét, Eladtam a juhot s vettem egy kis költségecskét ${ }^{a}$ [Orbán, SzfLeír. II, 154 Betl.

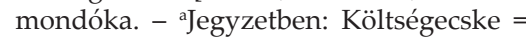
túró s egyéb ennivaló].

köntösöcske 1. gyermekruhácska 1755: Kis Susi Unokam(na)k kőntősŏtskére Rhf. 4 xr. 10 [TL. Teleki Ádám költségnaplója 2b]; 1757: Adám édes Unocskám (!) Kŏntŏsőcskéjére ... R. fl. 3 xr. 48 [TL. Teleki Ádám költségnaplója 140a].

2. kb. szerény öltözet 1665: az ott maradt éhel holt németeknek lenne provisiojok ... kilencz hetét hópénzek kiadásoknak mondják, és azolta a kinek köntösöcskéje s egyebe volt, azt adták el [TML III, 478-9 Béldi Pál Teleki Mihályhoz]; 1823-1830: A prokurátorok is, aki valamire való volt, tartott scribákat. Ezeknek fizetések nem volt a királytól, hanem párjálásból a peres emberektől lehetett a szorgalmas írónak annyit kapni, hogy egy kis köntösöcskét csináltathatott magának [FogE 90].

könyöklő-párnácska könyöklővánkoska 1849: negy kőnyőklő párnátska [Somkerék SzD; Ks 73/55].

könyörgő-levelecske kérelmecske 1658: im egy kŏnyŏrgŏ levelecsket kŭŭldŏttem kegyelmedhez cselekegyek kegyelmed anyi irgalmassagot en vellem olvassa el kegyelmed ezt a kŏnyŏrgŏ levelet [Beszt.; Ks 90 Cseffey László kezével].

könyvecske 1. 1560: Az minemv dolgok ez konyvechkeben vadnak arrol valo Tabla [Kv; ÖCArt.]; 1573: $\mathrm{Ne}(\mathrm{m})$ alkhattak volt meg egymassal, Mond Thamas deak meg Bizonytom haza fut es hoz egy kőnnywechket oda [Kv; TJk III/3. 144b]; 1664: kérvén Kegyelmed én számomra ő kegyelmétől egy nehány könyvecskét [TML III, 59 Kászonyi Márton Teleki Mihályhoz]; 1710: Legvégen az asztalnál ül vala egy szegény katona ... kétségkívül tanúlt ember volt ... a tarsolyában volt egy zsíros könyvecske [CsH 102]; 1768: Barsonyotska Ládába talaltattak ... Könyvetskék 3 [Mezősztgyörgy K; Ks 23].

Szk: vigasztaló 1591: Az Udvarhaznal az Espotalyban a' keŏnyvek ... Egi Magiar Cantualis ... Vigaztalo keŏniwechke [Kv; AggmLt A. 53] * zsoltáros 1801: Egy kis Soltáros kŏnyvetske [Vargyas U; CsS]; 1802: Egy soltáros könyvetske [Dés; DLt].

2. kb. írott mü 1583: Az varost illendeó theorweniekreol ... vgy vegezzenek ... Annak vthanna mikor ezekben $\mathrm{Az}$ valasztot feo vraim eleo Mennek, es az Zep es hasznos múnkat el vegezik, tehagy (!) Az varos eleot referalliak vegezetre mindenek iol meg Ruminaltatwa(n) A menybe(n) a theorwenyreol Irt keonywechke meg tiztul es helyen hagiattatik, Vrunkal eo Ngawal az varossy keosseg keozeot, eoreokbe valo maradasara meg Confirmaltassek [Kv; TanJk V/3. 277a]; 1621: veotte(m) Zabo Thamastol az Azzoniunk eo Flge keonyuenek ki nyomtatasara Papyrossat keotest Nro 9 1/2 ... Vgian ahoz az keoniueczkehez veottem Nyreö Ferenczteol papyrossat Nö 15 [Kv; Szám. 15b/XI. 301]. 
3. (ezüstfüst)-ívecske 1789: 7 Kŏnyv Ezüst, és tiz Kŏnyvetske Rf 5 xr. $24[\mathrm{Mv}$; ConscrAp. 25].

kőpadocska 1799: Alkalmas kő padotska [Bányabükk TA; MkG Conscr.].

kőpalackocska ? 1752: egy kő Palaczkocska [Eszt. Gr. Petkiné lelt.].

kőpincécske 1694: van egy Kő Pinczecskere eppittetett kivŭl belŏl tapaszos jo Sindelyezes alat levő Hazacska, Korcsoma Hazis szokot lenni [Kővár Szt; JHb Inv.]; 1748: Sővényből főnt (!) egy ház mellette lévő kémény aljával kő pintzétskéjével sőveny kerteivel, és gyümőltsőseseivel edgyüt aestimaltatott ad H. fl. 84 [Déva; Ks 73. IV. 59f]; 1777/1780: Ezen Házon fellyŭl vagyon edj romladozott Státusban lévŏ kŏ Pintzéstskeis [Vád SzD; JHbK LII/3. 279].

kösöntyűcske mellboglárocska (női ékszer) 1589: Ket O keosseonthiwchke, egy fekete Mayczw parta Eeowechke [Kv; KvLt Vegyes I/2. 33].

kőtemplomocska 1729: Vagyon ... egy szép hegy tetejin pasintos hellye(n) epittetett kő templomocska, festett, de már hulladozni kezdett mennyezettel [Buza SzD; $\mathrm{JHb} \mathrm{V/2]}$; 1737: adtam ... egy felséges urunknak szóló alázatos memorialist ... feleségem és Bánffi Ferencné asszonyom Décse nevü falucskájokban építeni kezdett, de a méltóságos főispán úr által megtiltatott kő-templomocska felszabadítása iránt [M.décse SzD; ETF 107. 30].

kötésecske1. kötegecske 1746: Egy kŏtésecske vasdrót [Vargyas U; DanielAd. 258]; 1776: En ... el mentem ... Dikuj Toma nevü Jobbágyával ... az Uram eő Nagysága Nagy Erdeje széllyibe ... mind az ketten egy egy kőtésecske Sütni valo aszszu ágbogat kihozván hátainkon fel vetettűk a szekérre [A.kápolna KK; BK. Dikuj Pável (24) jb vall.]; 1804: négy kötésecske Selyem [Borosbenedek AF; SLev.].

2. kötetecskényi 1714: Egj Kötésetke (!) Geographiai jadzo mappat magab(a) foglalván [AH 11].

3. kötött/hurkolt szegélydíszecske 1761: Öt darab szedett pántlika, mellynek szélin arany és ezüst botokan vert kőtésetske vagyon [Koronka MT; Told. 8]. kötéske kötésecske (kötött/hurkolt ruhadíszecske) 1676: Egy Csomo recze, egy csomo fejér kőtes. Egy darab kőteske [Gyf; $\mathrm{JHb}$ XXXI/2].

kőválúcska ? 1797: vagyon fa lábakon kivŭl és belŏl ki rakott kŏ valutskan fel emelve tŭzelŏ kementze [Kőrispatak U; Pf].

kövecs 1. kavics 1737: egj egj szekér porondot és követset vigjen vagj vitessen [Dés; Jk]; 1762: a Nagy Szamos ... ezen hellyet a midön el szakasztotta követtsel porondal és minden ágokkal megrakta [BSz; SLt XXIV. 6]; 1770: Ezen helyet nem de nem a hegyről le folyo eső, és hoviz tőltőtte fel porondal, és kővetsel [H; JHb XXXI/17. $3 \mathrm{vk]}$; 1806: (Az a hely) pusztaságban hagyatott, mint viz aradásával kŏvettsel s porondal meg hánt helly, marhák deleltenek azon a hellyen [Erdősztgyörgy MT; WH]; 1815: a Nagy oldalokrol Zápor Esök ídején áradó és nagy sebességgel rohano viz ... alattább való hellyeinket el iszapollya, követtsel megrakja [Szóváros SzD; HG Gr. Haller lev.]; 1834: a' viz ... a' felŏllem valo partot ... kemény kŏvettsel boritotta bé [Dés; DLt 566/1837]; 1864: földje száraz természetü fekete és agyagos követsel elegyitett [Alfalu Cs; GyHn 19].

Szn. 1627: Keőveczj ${ }^{\text {a }}$ Boldisar, Keőveczi Thamas [Agyagfva U; UszLt IV/50. 37. aA forrás hangjelölésében az olvasat: Kövecs].

2. kavicsos rész/terület 1597: lata(m) hogy az víz mellett az keóueche(n) megh harcholottak, Ferench Keleme(n) el futamodek [UszT 12/78 St. Bondez (!) de Kis falúd jb vall.]; 1687: az Tompos Imre Csüre hata mégget vagyon égy darabocska kővécs [Menaság Cs; EHA]; 1697: edgi darab ben valo ŏrŏkseg ... vicinussa egi felŏl ... a Fejerniko vize es kŏvetse [Kadács U; Pf]; 1775: ugj lépet az hid padlása végere az el törvén ugy eset le az Követsre [Udvarfva MT; Told. 44/50].

Hn. 1590: melj heliet Keoweczj newu heljnek hittunk [Máréfva U; EHA]; 1680/1825: $\mathrm{Az}$ Kővets hagoban (sz) [Vajdasztiván MT; EHA]; 1694/1764: a Kővets hágó alatt [Abafája MT; EHA]; 1698: Kövecs ajban ... egj hod föld [Páncélcseh SzD; RLt O. 5 Solymosi Mihály (38) jb vall.]; 1754: A' 
Kővets hágófőn (sz) [Gernyeszeg MT; EHA]; 1758: A Kŏvets hegj alatt (r) [Sztána K; EHA]; 1770: Kővecs Ajjban Dersei határ-szélben (sz) [Páncélcseh SzD; EHA]; 1797: a' Kŏvets [Etéd U; EHA]; 1781: A Kővetsben (sz). Kövecsek lábján (k) [Szárazpatak Hsz; EHA]; 1784: A Kŏvetsáj torkába (sz) [M.derzse SzD; DHn 40]; 1807: A Kővetsáj torkába (sz) [Páncélcseh SzD; EHA]; 1807: A Kŏvetsen (k) [Mikháza MT; EHA]; 1808: Követsen a' Miklosvári Határon (sz) [Köpec Hsz; EHA]; 1812: a kis Követs Uttzában [Torda; EHA]; 1820/1851: Kővets dombnál (sz) [Makfva MT; EHA]; 1861: Kővets kut rétjin (sz) [Sáromberke MT; EHA].

kövecske 1. ékkövecske 1714: Baraczk szin Seljembol valo Dolmanj, nagjob részrül kek Atlas Materiaval béllett, a' mellyén 15, $\mathrm{s}$ az uyan penig 16 aranj fonal gombotskakkal, és annyi követskékkel ékesitett fl. Hung. 24 [AH 51-2]; 1730: ă ... kereszt el vezett .... hallottam hogy tizenkilencz kŏvek vóltak benne Gyémánt és egyéb apró kŏvecskék [Torda; MvRKLev.]; 1770/1773: Arany virág ... tetején vagyon egy Tŏrkés nevŭ Kövecske [Szárhegy Cs; LLt].

2. húgykő 1773: Balás János ... meg vallotta hogj meg rekett az ökre nem vizelhetik, és hogj meg dőglöttis moga beszellette hogj edgj dorabotska követsskét talált a Madarába(n) vagyis Hojagjában [Aszszonyfva TA; JHb II/3].

3. kő-öntőformácska 1679: Boglár őntéshez való kőveczke [Uzdisztpéter K; TL. Bajomi János inv. 60].

kövérke kis, kövér vad 1704: Ma voltam ki gyalog sétálni a mezőre az úrfiakkal, azonban Haller György és Lázár György uramékkal, amikor is Dienes úrfinak legelső puskásságának gyümölcse volt egy kis kövérke, melyet legelsőbben lött flintával [WIN I, 256].

középnagyobbacska közepes méretü 1729: Egy kőzép nagyobbatska jukas üst [Tarcsafva U; Pf].

középnagyocska közepes 1829: Schütz Márton ... közép nagyotska termetü [DLt 977 nyomt. kl]. közföldecske vmely település köztulajdonú földecskéje 1768: Az also Sziget s Kőz Főldetske a Csorda Pásztorok(na)k hagyatik [Ákosfva MT; EHA].

közkoronácska kb. (drágakövek nélküli) diadém 1628/1635: Az Zegeny Azzonja eolteozeti ... Koronák: Egj gjongjos korona, tizen niolcz, boglar rajta. Mas egj kys aranj boglaros korona uege rubjnt es egj Samaragd benne. Kett gyongj nelkwl valo kóz koronaczka [Bodola Hsz; BLt 5 néhai Béldi Kelemen lelt. - ${ }^{a}$ Néhai Uzoni Béldi Kelemenné Bánfi Mária].

közrétecske részleges földközösségben élt/ használt rétecske 1750: mentünk a' Nagy Berek kőzőtt lévő Falu kőz Rétetskéire, melynek hoszsza 37. ől, Széllye 7. ől [Koronka MT; EHA].

kristályhordócska 1736: Cir(ci)ter Másfél fertállyos Kristálly hordotska 1 [Mikefva KK; CU XIII/1. 157].

kristálykancsócska 1754: Kristálly kantsotskák mustár(na)k 2 [Told. 51].

kristályocska kristályüvegecske 1733: Rosolisnak valo Kristallyotska [Marossztkirály AF; Told. 2].

kristálypalackocska kristályflaskócska 1738 : egy Kristálly Palatzkocskában valami Tsinált viz [M.bikal K; MLev.].

kristálypoharacska 1733: edgj kristally pohárocska [Marossztkirály AF; Told. 2].

kristályserpenyőcske 1679: Fejer kristály labos serpenyőcske nro 3 [Uzdisztpéter K; TL. Bajomi János inv. 24].

kulcsocska 1807: sok apro koltsotskák [Körtvélyfája MT; LLt].

kupácska serlegecske Szk: apró 1597: Kwpas Janostwl wedtem Melybwl az Olahok idtanak 13 Apro kwpaczkat es poharokat ... - 36 [Kv; Szám. 7/XIV. 42 Th. Masass sp kezével] * aranyos 1560: Egy aranios Kupachka fedelestól. Masyk fedeletlen az ys aranias kuppa [JHb QQ Temeswary János reg.]; 1642: egy aranyas kupaczka ad fl. 30 [Koronka MT; Told. 1a II] * aranyos ezüst 1739: egy virágos és ember személyekel rajzolt szép Aranjas ezüst kupácska cir fel ejteles [Szászerked K; LLt Fasc. 96] * fedeles 1628: Egy kis fedeles Uiragos kupaczka [Gyalu K; JHbK XII/44. 4] * félaranyos 
1596: Egy fel Aranyas kúpachka m 0 p 38 [Kv; RDL I. 65] * német 1638/1663: Két óh Nimet Kupáczkám vagion [Bethlen SzD; BLt] * összejáró 1598: hattam az Gazda Azzonnak ... egj eozue jaro Aranyas kupaczykat [Gerend TA; Törzs].

kupás-vésőcske 1656: Ezen saffar hazban vagyon ... Kupas kis veseöczke nro 1 [Fog.; UF II, 114].

kúriácska udvarháztelkecske 1638: Az eöregh Curia mellett oldalul vagion meghint egj Curiaczka [A.porumbák F; UF I, 662].

Szk: nemes 1718: lévén ... az Piacz szerben egy puszta romladozott kő háza nemes Curiacskájával és kertecskéjével edgyütt [Torda; JHb XV/17] * nobilitáris 1755: Nobilitaris fél Curiatska [Mv; Told. 47/52]; 1804/1816: Patak falvána egymás mellett két kis valóságos nobilitaris $\mathrm{Cu}$ riatskája a Falu derekába [Jobbágyfva MT; EHA. - ${ }^{a} U$ ]; 1846: Lévén ... Jobbágy Falván ... két kis valoságos nobilitaris Curiatskája [BálLt 92].

kurvácska ringyócska 1570: Mond volt zabo Janosne Meny ky kwrwachka Mert Beled verem az kest [Kv; TJk III/2. 28].

kurvanőcske szajhácska, ringyócska 1568: Anna consors Stephani Nagy ... fassa e(st), Ezt hallotta(m), hogy ... az leant ... Jgy zida, kurúa nochke, veryelek, de egzer se(m) wtte [Kv; TJk III/1. 185].

kutacska 1751: Bos patakán innen lévő ... Láb főldének alsó borozdáján valo kutatskáig rug [Koronka MT; EHA]; 1768: Vagyon egy kutacska, rosz kut gárgyával [Sarmaság Sz; TGsz 23]; 1781: én meg szonyazván le mentem inya egy Kutacskára [Mezőszopor K; MkG 36. 3/2 Petrásk Atyim (50) jb vall.].

kutyácska kutyus 1704: Pekriné asszonyomtól valamely kicsi kutyácska adattatott volna az asszonynak [WIN I, 269]; 1721: egy kīcsi kutyacskát kŭldet Ngdnak [Nsz; Ks 96 Bornemisza Imre lev.]; 1736: Sok óra volt a házábana: az többi kőzőtt egy az asztalán állott, mint egy bojtos kicsin kutyácska, mikor ütni kellett, megmozdult az asztalon valahány óra volt, annyiszor az száját feltátotta s annyit ugatott, mintha valóságos kutya lett volna [MetTr 337.

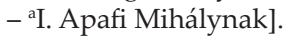

kuttyocska ? 1629: Egy Ezwstbeol czinalt Kuttioczka aestim: tt. f. 15 d. 33 ... Egy Ezustbeol czinalt Bika [Kv; RDL I. 132].

lábacska 1. talpacska 1772: Ezűst ... Egy Asztal kezepére valo Tábla négy lābatskájával [Egeres K; Ks].

2. hintórészecske 1780 k.: az hamu szín hintora ... atsígának (!) egj srof házat meg vágtam hátul az bakan xr. 6. az két kis lábatskáját ki tottam az magam vasambol xr. 6 [Szászváros; BK].

3. földtáblácska 1737: Az Szorosban lévő Lábocska [Nagyida K; Told. 11/73]; 1747: Méltoságos Aszszonj Toldalagi Mihályné Asszony Nyilljátol fogva elé menvén az emlitett Méltoságos Aszszony eŏ Ngā Csegljes Lábotskája (: melj Csegljes Foldetske fekszik a Méltoságos Ur Földvári Ferencz Ur Láb fŏldgyei között :) [Told. 9]; 1756: A Csolti Hidnál valo Lábacskát ... fel szántván ... bé vetette [Szakatura SzD; TKL Pap Gábor (28) jb vall.]; 1764: a hól ezen főld vagyon Bődi tsűrecskémet éppen a tájékján tsináltattam lévén nékemis ott a Borzási Határban ... edgy kis lábotskám [Bethlen SzD; Ks 8. XXXIII. 12]; 1767: Bab főld nevezetü Lábotska a' Bértzen [Mezőbodon TA; Torma]; 1772: A Két Fűznél két Lábocska egymás mellett [Kozmás Cs; EHA]; 1772: A Gorbó vŏlgyiben égy labotska [Szászfenes K; BethKt Mikes conscr.]; 1772: Ezen fellyül égy Lábatska [Szászfenes K; BethKt Mikes conscr.]; 1776: A Felhágó nevezetŭ Hellyben lévŏ Lábatska [Szövérd MT; Hr]; 1776/1823: A' Kurta Láb nevezetű helyben lévő Lábotska [Gerebenes MT; KelM]; 1788: Ez a' Lábotska hoszszára meg meretvén találtatott ... ket száz őlnyinek [Melegföldvár SzD; SLt XLI]; 1832/XIX. sz. köz.: A' Csetelkéböl ki jövö uton fellyül valo lábotska [Novaj K; HG Thorotzkay lev.].

4. Jelzői haszn-ban; vhány táblácskányi (szántóföld) 1756: A' Tavalji esztendőb(en) a' Dézma buzának a' szépit el tsepeltetvén Molduán Vonya kűlőn magának belőlle egy Lábotska főldet bé vetett [Galac BN; WLt Lukáts Onul (60) jb vall.]. 
lábacska-föld lábföldecske, földtáblácska 1788: Vagyon a' Kőblős Lászlo ur udvara felett valo Hegyen kivül fetske farku Lábatska Főld [Melegföldvár SzD; SLt XLI].

lábföldecske földtáblácska 1737: A Ton túl valo Láb Fŏldecske [Nagyida K; EHA]; 1741: A Kőbánya nevü hellyben a Forrásoknál vagyon egy kis kurta Lább főldetske [M.fráta K; EHA]; 1745: Kapusnál lévŏ Láb fŏldetskének also barázdáján [Nagyida K; EHA]; 1747: A két Kapus kŏzŏtt az Eszakban fekűvő Láb fŏldetske [Nagyida K; EHA]; 1756: (A) kis Láb földetskén alol levŏ Tanorokjáb(an) [Koronka MT; EHA].

lábosocska kis lábosnyi (étel) 1823-1830: talán ha élt volnaa, mikor fiat taníttattam, egy-egy lábosocska ételt adott volna annak fel a kollégyomba, mert igen jószívü volt [FogE 280. - a Az emlékíró húga].

ládácska 1. ládikó 1647: Egj hitvan Ladaczka holmi dib dab egyetmasnak valo [Marosillye H; VLt 55/5415]; 1660: Egy kis ladaczka [Lázárfva Cs; LLt Fasc. 117]; 1697: ezeken felyül aprobb ládák s ládácskák nro 5 [Alvinc AF; Mk Alvinczi Péter lelt. 8]; 1720: Más ládátskában Hámokra valo öregh czifra csattok nro 20 [Köröspatak Hsz; HSzjP]; 1733: Edgj kis ládátskában ... vadnak apro ŭvegetskék [Marossztkirály AF; Told. 2]; 1736: Fél singes rosz ŭres Ládátska [Várhegy MT; CU]; 1744: Edgy hitván régi Ládátska s edgy parányi bé zárt régi Pintze Tokotska [Szentdemeter U; LLt Fasc. 67]; 1798: egj kis lādatska [Bodola Hsz; BLt]; 1816: Egy mérő Kampanához valo jo két Ládatska [Bányabükk TA; MkG]; 1828: Két Ládatska festékekel [DLt 118/1829 nyomt. kl].

Szk: bort hordozó 1736: Vasas pintze tok, vagy bort hordozo Ládátska [CU] * fatartó 1849: Egy fa tarto győngy szinre festett ládátska [Somkerék SzD; Ks 73/55] * gyertyás 1793: Egy gyertyás ladatska tanaltattak Reamuri portzellan aranyas viragu edenyek [CU] * gyüszü tartó 1792: Gyüszü s' ollo tarto Ládátska [TL Conscr.] * liktárium 1788: Száraz Lictárium tarto kitsin reteszes Ládátska [Mv; TSb 47] * paramentum hordozó 1690: Egy paramentom hordozó kis ládácska [Tusnád Cs; SzO VI, 426] * pártás 1688: Partas Ladacs- ka [Beszt.; Ks S Misc. 27] * szalmás 1788: Egy Szalmás kis Ládátska [Mv; TSb 47] * tojókás 1683: Tolyokás ladácskáb(an) Székfŭ olaj. Gyik olaj. Lilium olaj [UtI] * üveges 1688: Hintora valo Üveges Ladacska [Beszt.; Ks S Misc. 27] * üvegpoharas 1688: Üveg poharos Ladacska [Beszt.; Ks S Misc. 27] * varró 1788: Más kissebb viseltes varro Ládátska [Mv; TSb 47].

2. (vasazott) záros ládikó 1570: Nagy Janos ... vallya, hogy ... vyt volt az Trombitas egy ladachkat az eo hazahoz fely Nytotta, Es otth latot varrot Jngeket kys kezkeneot gathyat varrotat [Kv; TJk III/2. 24]; 1595/1603: En Zarkadi Anna ... veottem keszemhez egy kezozepszerw lapos ladachykat Az en Bizodalmas Vramtúl Keresztúrj Christoph vramtwl ... Mely ladat veottem oly gonduiselesemben, hogy ha Az vristen, Az en keues Marhamat Megh tarttya, Azúal eggyút gongyat viselem [Hadad Sz; Ks P. 16]; 1627: Egj ladaczkaban Tizenket gjemant giureo [BLt]; 1647: leanya(na)k ladaczikajat fel nytva(n) negy gwrwjet uette volna el [Kv; TJk VIII/4. 232]; 1657: Egy Paczel formara csinalt vastagh arany Lancz egj küs ladaczkaba(n) [Mihályfva NK; JHb XXII/42]; 1726: edgy gŏmbŏlyég fedelŭ kisded új ládátska zár és sarkok nélkŭl [Görgény MT; Born. G. VII. 23]; 1744: Kisded Ladátska tojokás fedelü [Szentdemeter U; LLt Fasc. 67]; 1762: ma ugj el takaritottak onnan a' Mesteri Háztol mindent ... hogy egj Ládátskánál, egy Derekajnál, kétt párnánál, egy Festekésnél egyebb nintsen az Háznál [Oltszem Hsz; Mk RN. IX/109]; 1793: egy Schmuk(na)k valo kis lapos ladatska ueresen s zöldön festve [TL Conscr.].

Szk: bársonyos XVI. sz. m. f.: Volt egy kiss Bársonyos Ladácskában egy Eőregh gyemantos függő [EMLt Klobositzky lev.]; 1757: Egy Bársanyos Főkőtős kis ládácskában ... vagjon ... az Arany portékám [BálLt] * bársony tetejü 1788: Egy Bársony tetejŭ viseltes kis Ládátska [Mv; TSb 47] * borsoló 1744: Borsolo ijos fijas 7. rekeszü Ládátska, záros [Szentdemeter U; LLt Fasc. 67] * fejér 1628: Az kwlseő tár hazban Egy feier szeles Alachon wres ladaczka [Gyalu/ Kv; JHbK XII/44. 8]; 1752: Vagyon egy Fe- 
jér kŭsdég ládacska, a' mellyben tanáltatot Egy begyin szarv puskapor tartó [Brassó; ApLt 5 Apor Péter inv.] ${ }^{*}$ fekete 1681: Vagyon itt Petöne Aszszonyo(m) arany mühőz valo fekete Ladaczkaja Nro 1 aranyas vas fogantoja Nro 2 ... ez most Üres [Vh; VhU 554] * félkéz 1761: Egy Festett vass sorkokon forgó avadag féll kéz Ládácska ... a' Tisztarto Házban [Branyicska $\mathrm{H}$; JHb XXXV/39. 6] * füszerszámos 1774: egy Fű Szerszámos Ládátska [Hosszútelke AF; Kath.] * iskatulyaforma 1767: drága győngyős és Kőves Reszkető Tőket, és Boglárokat is láttam azon kisded Iskatulylya forma Ládátskába [Egrestő KK; Ks 21. XVIII. 78] * koporsóforma 1744: kisded koporso forma zöld festékú zaros ládatska [Szentdemeter U; LLt Fasc. 67] * perselyes 1789: Vagyon egy fél singes kotzkás Zöld festékes jo vas Sorkas, záros persellyes Ladátska, benne egy kis tojoka Iskotulja [Abásfva U; EMLt] * pincetokforma 1748: Pincze tok forma kicsin Ládácska bé zárva [Ks 8. XXVIII. 5]; 1770: Pincze tok forma Ládátska nro 2 [Királyhalma NK; Ks 23. XXIIb] * tojogatós/tojókás 1728: egj Lakattal járó zőld tojokás Ládatska ... $20 \mathrm{Dr}[\mathrm{Kv}$; Pk 6 Rázmány Hedviga hagy.]; 1764: Egy Zöld festékes tojokás ládátska, haszantalan aproság fekete bogoziácska mi benne [Kál MT; Berz. 6. 54. L. 2]; 1768: Tojogatos kis Ládatska [Mezősztgyörgy K; Ks 23] * tubáktartó 1821: egy kis Börös rezes szegeletü egy tubák tarto ládátska [Veresegyháza AF; Told. 19] * vasas 1569: Annak wthana nem sok Nap mwlwa Latyk Egy kys wassas Ladáczkat a Azzonyom Labanal az Agy Alat [Kv; KvLt II/19. - Kiss András kijegyzése] ${ }^{*}$ veres posztós 1733: Edgi kis Veres posztos Ládátskában vagjon holmi elegj belegj recze kŏtŏ eszkŏzek [Marossztkirály AF; Told. 2] * vetkezö 1768: Vetkezŏ Ládátska [Mezősztgyörgy K; Ks 23] * záros 1643: Templom eszközei ... égy záros ládátska [Sóvárad MT; MMatr. 207]; 1700: egy Kiss Záros ladacska [Csicsó Cs; BálLt 71]; 1803: égy fél singes, vas sorkos, Záras Ládatska [Szőkefva KK; UnVJk].
3. pénzesládikó 1637: ada negj avagj eöt szaz forintot ... s en felis veöm en magam hoztam hazais ... egj ladaczkaba(n) [Mv; MvLt 291. 85b]; 1757: Mennyi Summából álló pénze vólt azon Ládácskában $[\mathrm{Kv}$; Mk IX Vall. 209]; 1757: hadgyak 600 M. Farintakat ... egy kis Ládátskában lésznek bé zárva [Torockósztgyörgy TA; Berz. 3. $1 / 4]$.

Szk: rezes 1802: Egy rezes négy szegeletű Ládátskában ... Banko Tzédulákban öt szaz négy m for(to)k [Ne; DobLev. IV/858. $8 b]$.

4. levelesládikó 1740: Egy kis ládátska haszontalan Levelekkel [Hermány Br; ApLt 5 Apor Péterné lelt.]; 1755: A Bándi joszágrol valo levelek mind külőn valának egy kis ládacskában teve [Csomafva Cs; LLt Fasc. 109]; 1854: A Joszágaimat és más egyéb targyakat érdeklö Leveleim kŏzŭl azokat, a melyek ... schatuljában, s egy más ládátskában tanáltatnak ... kedves és jó feleségem tartsa meg [Kv; Végr.].

Szk: leveles/levéltartó 1802: Egy kék festékes Levél tarto Ládátska [Türe K; MkG]; 1805: kezűnk alá vévén azon Leveles Ládácskát mellyet ... Báro Jo'sika János Ur Nehai b. e. Edes Attyának ... által adott volt Néhai L. Báronissa Bálintith Susánna Kis Aszszony [Mv; LLt Reg.] * rezes 1782: egy kis rezes Leveles Sima fábol valo Ládátska [Mv; NkF] * záros 1744: Fejer s zöld Festékü kitsin záros ládátska, misilis régi levelek benne [Szentdemeter U; LLt Fasc. 67].

5. céhládácska 1662: Vagyon az B. Cehnek égy feier ladáczykáia, melyben az B. Céhnek privilegimumj (!) Articulussj, és hasznos levelej vadnak [Kv; SzCLev.].

6. ruhás és holmis ládácska 1629: Az mikor ... ezt az Szantaj Janosnet Susanna Aszont el vette valo Borbely Ferencz, en nem latta(m) semmit hogy oda hozta volna egi kis vankosnal egjebett, s egj kis ladaczkatt [Mv; MvLt 290. 158a]; 1710: Mi elmenénk, ő azalatt a szállásomra menvén, a gazdaasszonyom előtt ládácskámot felnyitja, s ott találván a sok képeket, olvasókat, könyvecskéket, magával elviszi [CsH 140]. 
7. faragásos, festett v. virágozott díszládácska 1714: Gyermeknek valo 4 ezist lábōn allo Ladatska ... fedelének belsö részén vagjon egj Tüker, Ladatskab(an) penig kisetske Vidlatska gyüszŭ, két Pixis, harom fedeles Palack mind ezüstes s meg aranjozott fl. Hung. 30 [AH 32]; 1714: Vőrős Kordovan Börrel boritott Ladatska mind(en) felöl Vasas Pléhell meg erősitett, belöl vaszonnjal boritott fl. Hung. 2 [AH 55]; 1760: Egy Cziprus Fa Filegránt munkával Ezűst virágokkal készíttetett Ládátska [Mv; TGsz].

Szk: aranyos 1735: Egy teczin Aranyas Ládácska [Sv; Hr] * bécsi 1733: Edgj kis aranyos Bétsi ladatskab(an) [Marossztkirály AF; Told. 2] * ezüstös 1796: kérem ... Néhai kedves Bátyám ő Nga kítsíny Veres Bőrős ezűstes Ládátskájat is bé küldeni ne sajnálja [Vajdasztiván MT; DE 4] * fekete (festékü) 1759: Egy fekete s veres záros Ládátska [Alvinc AF; Berz. 20]; 1759: Egy Kis fenyő fa Záros fekete festékű Ládátska [Náznánfva MT; Berz. 4. 22. N. 22] * festett 1808: egy avatég deszka ágyán, egy festett Ládátskáján, egy Jo fejŏ Tejes vedrén, és egy Sajtárján kivül ... egyéb Házi Eszközeit az exponens ur el nem vette [Szászerked K; LLt Bretfelyán Gavril (35) vall.] * halhajas 1673: Egy fejér ládab(an) vagyo(n) egy ueresse(n) festet hal hajas ládácska [Fog.; UtI] * kék 1812: Egy kék Ládácska [M.gyerőmonostor K; KCsl] * rakott 1792: Kitsin rakot Ládátska [TL Conscr.] * török 1714: Festett fabul tsinalt hosszas Török Ladatska Pornak és Tintan(a)k valo 1//50 [AH 34] * veres 1759: Egy kis veres Ládátskáb(an) feles Timsot [Sárd AF; TSb 51] * zöld festékes/festékü 1722: Fél singes zŏld festékes Ládácska [Nagyercse MT; Told. 36]; 1744: kisded koporso forma zöld festékű zaros ládatska [Szentdemeter U; LLt Fasc. 67]; 1748: Zŏld festékes Ládátska volt [Olasztelek U; CsS].

8. hintóládácska 1736: Az ablakban ${ }^{a}$ levő egyik ládácska ... volt az kocsisoké, abban hordozták az patkolózacskót, lóvakarót s törlő szürt s affélét [MetTr 369. - 'A A hintónak így nevezett része].
9. 1847: a' 2ik viz keréknek kalátsai-bérlései, és ládátskái oly roszszak, hogy a' miatt ezen keréknek hasznátis alig vehetni [Kv; KmULev. 2 László János mérnök kezével].

10. ládafia, fiók 1669: Ket kisded szerŭ asztal, egyiknek ladaczkaja vagjon [Királyhalma NK; Ks 67. 46. 24a].

Szk: bejáró 1756: Dévai Curia ... a' két ablak kŏzŏtt vagyon harmadik almárium, melly asztal Almáriumnakis neveztetik, mellybe bé járó Ládácskák járnak őtt számból állok [Déva; Ks 92. I. 32].

11. ékszertok 1748: ada Nékem ... Korda Sigmondné Asz(sz)onyom ... egy Nagy arany Lánczot, s két szép drága kőves Medállyokat egy kis Ládátskában bé tsinálva [Szentk. Sig. Pálffi eccl. ref. Kányádiensis pástor nyil.].

12. aranyzúzó malom ládikója 1757: minek utánna ki hordatik néholt a' Bányábol ki jővő, néholt pedig Tokbol a' Bánya, szájáhaz csatornákan dirigált vizre harom atasz szélességü és négy arasz hoszszuságu ládátskát tsinálúnk, a' fedelét sürün meg furdallyuk [Zalatna AF; JHb Borsai István kezével].

13. Jelzői haszn-ban; vmiből vhány ládácskányi 1732: Haller Ferencz Ur(am) ... el vitt egj ladacska penzt, lattamis a' parna sakba be takarva [Szászvesszős KK; Szentk. Catherina Fogarasi providi quondam Thomae Blényesi (60) jb ancilla vall.].

ládika ládácska, ládikó 1846: Egy ládika Klauzal Gabor képével [Dés; Berz. 20]; 1846: Egy papir lemez ládika [Dés; Berz. 20].

ládikó ládácska 1849: Kis ladiko finom cirkalmakkal 30 Rft [Görgénysztimre MT; Born. G. XXIVd].

Szk: gyertyatartó 1805: Egy Gyertya tarto Ladiko Teli Buzaval [Szamosfva K; BLt].

lágyacska 1. ? könnyű (bor) 1715: lágyacska, de jo italu bor [Ebesfva; UtI]; 1715: Kedves italu finum bor ... Vad izŭ bor ... lágy izŭ de jo bor ... lágyacska, de kŭlŏmb(en) jo bor [Ebesfva; UtI].

2. gyenge kezú, erélytelen 1817 k.: az uj Birorol Nagyságos Groff Ur annyít írhatok, hogy lágyotska, de talám meg szokik, 
mert külőmben eléggé űgyel a parantsolatra [Héderfája KK; IB].

lágyica a malom őrlőszerkezetének ládácskája 1755: malom kŏ kŏrúl valo kéreg régi 1 ... Lágyicza No 3. szál deszkából láb nélkül [Déva; Ks 76. IX. 4].

lájbicska mellényke 1779: Egy Veres, egy Kék, s egy hammu szin láblitskák [Nsz; $\mathrm{NkF}$.

lajstromocska számadásocska 1678: Esztendŏre valo laistromacska $[\mathrm{Mv}$; MvRLt].

lajtorjácska létrácska 1741: találtunk ... egj lajtorjártskát [Mezőbánd MT; LLt 146. B].

lakatkulcsocska 1648: Negy ayto kults zarnelkwl ... 4 apro lakat kutsuczka [Porumbák F; UF I, 887].

lakatocska 1637: az keőfolyoso alatt uadnak eöt rekeszes boltocsykak, azokon mind vas sarkas pantos reteszes aytocsykak ... Az kettein ket lakatoczyka [UF I, 399]; 1676: az ... bastya ház fólőtt valo felső renden lévo másik bastya hazra vas sarkon panton vas retezes retezfos vas fogantyos lapos fejü vas szegekkel megh vert bontákozot bellesű aytó egy ujj lakatoczka rajta [Fog.; UF II, 734]; 1706: Az más szuszekban vagyon circiter korpa cub 28 ... egy lakatocska vagyon rajta [Görgény MT; Born. G. VII. 4]; 1736: Boros pintzén állo nagy Bétsi lakat 1. Aprobb Lakatotskák 4 [Mikefva KK; CU XIII/1. 171]; 1736: (Az) ajto ... retesz fŏbe fŭggŏ lakatotskával zárlodo [CU]; 1750: Három rosz kiss Lakatocskák kolcs nélkűltt [Bezdéd SzD; LLt].

lakhelyecske telkecske 1757: volt egj negyed rèsz puszta lák hellyetskéje [Rákos Cs; Sándor conscr.].

lakír-topánka lakkcipőcske XIX. sz. köz.: egy pár lagir topánka [Berz. 17b].

lakóházacska 1782: sokuknak Lakŏ házatskájoknál egyéb semmijek nints [Torockó; Thor. XX/5].

lakótelkecske házas telkecske 1819: két lako Telketskeinket rajtak fekvö minden épületeinkel [Kóródsztmárton KK; Pf].

lámpásocska lámpácska 1714: Rezes Lámpásotska, hal Csont Ablakotskakkal, futraljb(an) fl. Hung. 1. Más két Lámpásotska egjik rezes, masik feketére festet, mind kettö penig kerekes fel emelt üvegekkel 1//50 [AH 36].

láncocska 1. 1667: Ez Várban mennek bé nap kelet felöl három öregh kapun, kiknek a' külsö kapujan vagyon a' kapu oszlopjában szegezve egy kis lánczocska, mellyel az nagy kaput, és kis ajtot öszve foglalván zárhatni be [UF II, 334]; 1694: Nyilik ott azon Pincze-torokra avagy Gátorra, vas sarkako(n), pántokon forgó őtt szem lánczotskából álló retezes, retezfejes, fa-rosteljos Ajto [Borberek AF; BfR]; 1711/1755: Egj dirib darab Lantzotska [Kál MT; Berz. 1]; 1714: Nád Paltza, ezűst gomball, és hasonló Lantzoskaval fl. Hung. 8 [AH 7]; 1797: Egy darab lántzotska Dr. 10 [DobLev. IV/775]; 1820 k.: Vagyon egy kőből rakatott 8. Lora valo Istállo ... az Udvarra nyillo ajton Retesz hellyett vagyon egy kisded Lántzotska [Dés; RLt]; 1849: Egy Szekérhez valo Sarogja két lántzotskával [Somkerék SzD; Ks 73/55].

Szk: címervas-tartó 1846: két eke gerendélly mind kettőn folytok és Czimer vas tarto lántzotskák [Szászerked K; LLt].

2. ékszerláncocska 1682/1687: Attam Meli füzö uegiben ualo Ezűst Tött, kinek az uegib(en) uolt mint egi Uyomni hoszszu apro szemű Lancsocska [Fog.; Borb. II Rákosi Annak kel.]; 1714: Sziv formára futralyb(an) találtatnak: Kisetske Vidlatska, szivetske, gyüszü, Lantzotska, mind ezustbül [AH 32].

Szk: színarany 1697: Tiz szin arany Lanczottska [Kv; LLt 17/18].

lángocska 1710 k.: A tűz ... megszámlálhatatlan szikráknak, lángocskáknak és a világosságnak véghetetlen, megfoghatatlan sok apró részecskéinek a napban öszvefoglaltatott golyóbisa [BÖn. 448].

lantorna-ablakocska bendőhártyás ablakocska 1742: (A háznak) két kis Lantorna ablakatskáji vad(na)k [Pókafva AF; JHb XXV/58]; 1761: három Lantorna ablakotska az Házban [Kövesd NK; HG].

lapocska vékony deszkalap 1823-1830: hogy pedig elébb-elébb mászhassanak, a bal vállakra és csípőjekre egy-egy falapocskát kötnek szijuval, mi is ilyen lapocskákat kötöttünk magunkra, s úgy mászkáltunk előbb-előbb [FogE 207]. 
laposacska I. mn 1. 1757: a' Míneralis Hegyekben vagyon az illyen ${ }^{a}$ Arany(na)k is eredete ... az illyen Arany tőbbire korpa forma lapasotska, mert az hoszszas kövek kőzt valo devolutio és attritio által, az az eredetekor gőmbőlyég grammotska ... meglaposadik [Zalatna AF; JHb. Borsai István kezével - ${ }^{a} \mathrm{~A}$ folyóvízbeli];

2. orrú tompa/tömpe orrú 1828: Bako Mihály ... laposotska orru [DLt 279 nyomt. kl].

II. $f n$ sík helyecske 1746/1831: mentünk fellyebb égy Lapasatskában [Szentdemeter U; Told. 38].

leánygyermekecske kicsi leánygyermek 1657: egykorban az kapitány Zoltán Jósa ... egy leánygyermekecskének pártjába csinálván levelet külde ki [KemÖn. 198].

leányka 1. kislány 1570: Latthya hogy egy leankat az leorinch deak leaniat ky tollyak az Ayton mynd az kyssebyk gyermekel egetembe [Kv; TJk III/2. 28]; 1582: Kis Tamás ... vallia ... Mastol hallotta hog bele eset Az leanka Az vízbe [Kv; TJk IV/1. 82]; 1600: hozot egi szegen leiankat [Kv; Szám. 9/XIII. 19 Damakos Máté sp kezével]; 1635: $\operatorname{kerdeze}(\mathrm{m})$ de el tágádá az Leanyka [Mv; MvLt 291. 42a]; 1750: szŭletésétŭl fogvást tudom hogy egézségtelen volt ā Léánka [Bulzest H; Ks 113 Vegyes ir.]; 1762: Hallottam Marika alias Molduván Peter Leankájátol beszelleni egy hozzá hasonlo Léánykámnak mondván ${ }^{\mathrm{a}}$ [Gyeke K; Ks. 4. VII/12. - ${ }^{a}$ Köv. a részl. Stefania cons. jobbagionis Todorán Kosztán (34) vall.]; 1818: egy leán, félszeg vagyon ... Ezen félszeg leánykának ... egy tehénye vagyon [Jenőfva Cs; RSzF 244].

2. leánygyermek 1574: hagiom w kgnek tartanj az fiaczykath es az leankath [Gyf; JHbK XXI/12]; 1582: Ilona Domakos Mathiasne vallia ... Rab fabian ... eg kis leankaiat kwlde ${ }^{a}$ vthanna kezde Indulnj az Zekel Mihal Leankaiais [Kv; TJk IV/1. 83. - ${ }^{a}$ Vízért]; 1584: leyankaymnak felseged wthan az mjth nekjk kerestem ha mind bele kel fjzetne(m) ys ydegen kezben ymmar nem hagyhatho(m) [Komlód K; WLt Petrichevich Kozma foly. a fej-hez]; 1599: oda iúta az en leankam, mondá Anja ieoj hasza [UszT 14/27 Catherina Consors
Nobilis Nocolaj Fúlo In Ders vall.]; 1603 : Budaky Georgy Vramnakis Ke(gyelme)d, mondia Zolgalatomat es az mely Leankatt ennekem Commendalt uala itt az en gyermekim keozeott io Egessegbe vagion ... Him warraastis az en lyankammal egywtt tanulnak [Dés; BesztLt 65 Th. Szabo dési városbíró G. Frank beszt-i esküdt polgárhoz]; 1697: neveletlen leanykamat Sarkadi Ersokott meg fogta lanczra vetette [Dés; Jk]; 1719: Száva Mihályné Aszszonyom ... az szegény nehai Antos vr(am) ... Léánkáját maga Tutelaja ala vítette erŏszakoson [Széplak KK; Ks 95 Horváth Boldizsár lev.]; 1724 : kérdettem a Leánkát An(n)ya előtt, ki leánykája vagy [Náznánfva MT ; BK. Roska Nyisztor (45) jb vall.]; 1852: Moldován János lánykája Róza ... Holyagos himlöben halt el [Dés; RkHAk 138].

Szk: árva 1691/XVIII. sz. eleje: Domokos Janos ... Felesegevel Dobos Kisannával ... ha mellettek lévö arva leanykat ... eletekben ki nem hazasithatnak ... holtok utan az Eclesia ${ }^{a}$ tartozzék ki hazasitani [MMatr. 450. - a A szentgericei (MT) ref. eklézsia] * csecsszopó 1647: vadnak szegeny ember marhai is ... mellieket restantiaert hajtottak el ... Az eokreok Oppra Bazarae voltanak. Az pestisben maga fia leany meg holtanak, egy czecz szopo leanyka volna hozza ... 22 forintban betswltek boraraban [Fog.; UF I, 846]; 1800: Lengyel István csecs szopó Leanykája [Gyalu K; RAk 190] * hajadon 1690: Néhai Nemzet(es) Kolosvári Mislei Péter Hajadon Léánykájának Annisnak ... házoknál ... szidalmazta az Ac(tort) [Kv; TJk XIII/1. 444].

3. szolgálóleányka 1584: Luch Gergelne vallia, Tartok egy leankat ... Mondok a leankanak hogy Melliezze(n) eg Ludat holnapra [Kv; TJk IV/1. 246-7]; 1597: Simon Janos wallia ... hiwa egizer eleombe Sardine az leankat, monda neki hallode te leany mond megh az gazda eleot mit chelekedet az vrad veled [Kv; TJk VI/1. 95]; 1633: az eo keglme szolgaloja az kit el boczatot vala en hozza(m) St Leorincz elŏt ... jeot uala, es en ugi szegŏtte(m) uala megh uelle ... keőz igler szokniat igirtek uala az leankanak [Mv; MvLt 290. 132a]; 1708: Parancsolt uolt Asz(sz)onyo(m) ŏ 
kglme hogy egy tizenkét esztendős leankát szerezzek, nem ige(n) talalok az kit hasznos(na)k üsmerhetnék Kgtek szolgalattiára [Kozmás Cs; ApLt 5 Molnár István Apor Péterhez]; 1851: lenne oly jó és szerezne égy el nem romlott jo léánykát előre ... kŏtelességét tanulná bé karácsonig [Kv; Pk 7].

4. leányunoka 1662: Rudnai Anna Aszszony, monda: Myuel engemet Unoka Leankam(m)al Baczi Kis Annaval edgyut ez haborusagos ideőben ellensegh elött ualo futasba(n) ez varosba ualo szorulasban, penzeuel tartot, s taplalt, Papay Imreh vra(m) ... adom, vallom, es kótóm megh neuezet Leankammal edgyut ... Pin-

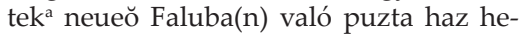
lyeimet [Dés/Beszt.; RLt O. S. - 'O.péntek, Déssel tôszomszédos település].

leánykabárány nősténybarika 1740: fejér nŏstény Bárany ... Tavallyi Leányka Bárány [Vingárd AF; BMúz.].

leánykagyermek 1595: Az Adam Janos Swteo hazaban egi Arva leanka gyermeknek vettunk egi Czondorat f -/ $32[\mathrm{Kv}$; Szám. 6/XIII. 34].

leánykaszolgáló szolgálóleányka 1720: Kiraly Davidne Zajzon Cxtina aszszony az Leanyka szolgalojival az ... specificalt Rétiben bele hajtatta marhait [Koronka MT; Told. 26].

leánykaszőlő 1847: A Cikmántoriak a Madárszőlőt Lyánykaszőlőnek híjják [KCsl 13. - ${ }^{a}$ Cikmántor (KK) lakosai].

leánykaszőlőszem 1847: A Cikmántoriak az Madárszőlőt Lyánykaszőlőnek híjják; ámbár igen tévesen, mert a Lyánjka szőlő szemek sürübbek, sárgásabbak, és sokkal vékonyabb héjuak [KCsl 13].

leányocska 1. leánygyermekecske 1612: ket leanoczkaia es egy ferfiu gyermeke és egy balgatag felesege maradot ithon [Kv; PLPr I/3]; 1630: az szomszed ... Azzoni ... hiuata engemet az Leanioczkaiaual altal hozzaia az paitaba [Mv; MvLt 290. 187b]; 1661: talala meg minket ... Csomai Balintné Aszszonjom, mivel az Ur I(ste)n egy kis lianjotskajat ez vilagbol ki szollitotta [SzJk 174]; 1730: Leven ket leanyocskája is az Aszszony ember(ne)k kiket edgjütt meg vett volt Bartos Marton Ur(am) azo- kot nem manumittálá ö klme, hanem kezit tartya rajtok [Albis Hsz; BLev.]; 1757: Mathe Thodor feleli az praetendensnek sertésit egy Leanocskám találta egy nagy Sárba dögölve [Újbárest H; Ks 62/3]; 1768: egy alkalmatossággal hozzám jött vala Illyefalvi Kovácz Pall betsületes Legeny egy Leanyocskámnak Látogatasa veget [Uzon Hsz; Kp IV Sám. Kováts (64) pp vall]; 1853: Márton Anna ... Márton Mihály leányocskája [Bács K; RHAk 89-90].

2. kisleányka 1783: Még vagyon egy leányocska, testvér Bíró Józseffel. Ennek tartására és ruházatjára adjanak az közönséges gabonából 4 köblöt [Jenőfva Cs; RSzF 235].

léckapucska rácsoskapucska 1772: A Házat Pitvarastol edgyütt aestimaltuk ... Egy létz kapucskát ad // 50 [Nagylak AF; DobLev. II/441. 1a].

leckécske 1806: egy Letzkétskét tanultam a diák Aríthmetikából [Dés; KMN]; 1807: magam egy sovány Letskétskét mondottam [Dés; KMN 360].

léckertecske léckerítésecske 1797: Mentŭnk az ... kis lécz kerteskéhez [Kőrispatak U; Pf].

leeresztő-hidacska kis felvonó/billenőhíd 1681: Nebojsza Bástya ... a le eresztő kis hidaczka mellet ket felöl deszkas volna Ugyan, de eszak felöl valo oldalarol a deszka ighen le hullott [Vh; VhU 557].

légelyke hordócska, csobolyócska 1638: Vagjon eggj hal hordozo legelyke [A.porumbák F; UF I, 658].

legényecske legényke 1736: Egy Bergenyei Legényetskét bé vitetett szekerestŏl az Megye Erdejibŏl [Udvarfva MT; Told. 44/15]; 1736: Imre Minya nevŭ Legényetske [Udvarfva MT; Told. 44/18].

Szk: gyenge 1763: minthogy gyenge legényetskék vóltunk, el szaladozánk széllyel [Udvarfva MT; Told. 44/15] * ifjú 1630: fel haniua(n) az szenat Istua(n) Deak lata(m) hogi ez az Leani egy Inassal fekszik vala, kiket fel pirongatua(n) az Inasnak monda(m), jai iō fiam illien Iffiu Legenieczke leuen bezzeg nagj korpa hwuelihez fogtal volt [Mv; MvLt 290. 197b]. 
legényke 1. legényecske 1585: Marta Vekony Jstuanne vallia, Ez ersebet leany Vala, es Az Gazdaya hon Nem vala, Egykor keseon estwe hat valamy leghenkek vadnak Az leannal ... es hat viragh eneket Mondank, de semmy gonozsagot $\mathrm{Ne}(\mathrm{m})$ latta(m) hozza [Kv; TJk IV/1. 506]; 1743: melj Legénkéket adá és conferálá ... Groff Szárhegji Lázár ur és Felesége Kun Klára Aszsontol eő Nagatol Szŭletett kűsded Leánkájok(na)k Groff Lazár Susi Kis Aszszonkának [Szentdemeter U; LLt 25. C]; 1757: Flora Demeter ... árván maradván Néhai Groff Kornis Istvan Ur az Udvarban bé vétette volt Fellejtár(na)k feketeszeg Legényke volt [Gyeke K; Ks 4. VI. 7]; 1765: némely ide való szász Legénykékis valának ottan, Isván s tánczolvan [Zágor KK; Ks 18/LXXXVIII. 8]; 1783: az legénke Tanko Andris is oda futot [Lengyelfva U; EMLt].

Szk: ifjú 1696: Vagion edgy iffiu Legenyke Mirsa Jonnuts 16 annor(um) [Szentbenedek MT; LLt Fasc. 75]; 1718: Fogatatt meg az megirt Urfi ŏ kglme maga két Czigánj Jobbágyat iffiu legénykeket [M.bece AF; Told. 2]; 1747: Juhaikat örző Iffiu legénykék haza futattak [LLt 47/2]; 1769: Dragán Csilip Csak Iffiu Legenke [Szentgothárd SzD; WassLt Szeletsán Molduván Nyikuláj (40) zs vall.] * nőtelen 1797: Szilagy Sandar mint nőtelen Legenke maga Josagait nem curalhattya annal is inkab maga eddig tanult hivatalját follytatni akarja [Kercsed TA; WassLt].

2. jelentéktelen emberke 1879: Csekélyebb legényke a kis Kálmán, semhogy számot tegyen nekem az, mit ő felőlem elmond [PLev. 43 Petelei István Jakab Ödönhöz].

3. szk-ban; korában 1775/1802: Buda Jonucz ... referalja, ő mintegy 15 vagy 16 Esztendős Legenyke korában ... a Bezdédhez tartozando Erdőben Sertéseket pásztorolt [BSz; JHb LXVII/3] * testvér 1807: hivta segittségül ... Legénke Testvérét Ferkőt [M.fenes K; KLev.].

legyezőcske 1657: (A fejedelmet) én ... legyezvén kis legyezőcskével [KemÖn. 98]; 1657: inas jüvén bé, az legyezőcskét annak adván az írást megolvasám [KemÖn. 98].
Szk: nyári 1717: Egj viseltes njári Legjezŏttske [Nsz; WassLt Wass Zsuzsanna lelt.].

lejjebbecske lennebbecske 1796: Antiqua Populosa Sessio ... a Falu Derekánál lejjebbetske [Cikud TA; WassLt].

lejtőcske kis ereszkedő 1572: Talalank Ismet egy ryggy fel hant hathar domboth az mint nekewnk tecczek Job kez feleol egy Leyteochkeben [Dés; DLt 184].

lelkecske 1661: jobb ez mostani időre nézve annak az ártatlan lelkecskének is az ő Istenéhez, honnan jütt volt, megtérése ${ }^{a}$ [TML II, 55. Bánfi Dienes Teleki Mihályhoz á́jszülött gyermek halálára von.].

lenecske egy kevéske len 1686: En is hoztam kendért ... Lenetskét is affele hitvánt [Madaras Cs; BK].

lepedőcske terítőcske 1738: Egy elegyes sellyemmel varrott lepedŏtske [DobLev. I/171].

Szk: gyapotgyolcs 1706: Két készittetlen uj gyapot gyolcs lepedőcske [LLt Fasc. 146].

levecske kevéske lé 1632: az az Annok ... hoza egj kis labasba(n) egj kis sarga leueczket az piaczra s azt ugia(n) sokan eueök ot megh [Mv; MvLt 290. 94b].

levélajtócska deszka/lécajtócska 1730: Elebb menuen iobb kezre van egj kis gyalog kertecske ragasztva a házhoz, meljen talaltatik egj bele nyilo ajto level ajtocska cserefabol valo az sorka es eleje [Szemerja Hsz; HSzjP].

levelecske 1. iratocska (kisebb jelentőségü vagy rövidebb irat) 1763: Meghala a szegény Ujhelyi András Némában ... Ez ... olyan ember volt, hogy az apja kimenvén Magyarországra ottan megtelepedett s meg is házasodott, vévén el ennek az anyját, medio tempore megholt $\mathrm{s}$ maradtak valami levelecskéi. Ez minthogy jól tanult volt, azon leveleket kezéhez vette s Erdélybe jött s cancelláriára állott s hívatta magát Körmendinek [RettE 156]; 1765: néhai Veres Daniel Ur(am) és mi voltunk a Divisorok, nekűnk ... valami Leveletskéket mutogattak, de mikről valók vóltanak már meg fejtettűk [Kökös Hsz; Kp I. 225 Sam. Sigmond sen. (46) gy. kat. vall.]; 
1832: Kontzeiana Szerzesrŏl szollo két leveletskek de A(nn)o 1740 [Mv; RLt].

2. rövid, kis terjedelmű magánlevél (miszszilis) 1573: Kadas Mathias Azt vallia hogi ... veszen fely gergel deak hazanal az ablakrol egi lewechhet (!) meg olwassa es fely kely az hazbol ky Megen ... Mond otth kywn gergel deak Ihol mychodat Ir ez Neke(m) Nem Igen teccyk, ely olwassa eleotte [Kv; TJk III/3. 155-6]; 1667: Édes Komám uram, asszonyunknak ír Nemes János uram egy kis levelecskét; öt-hat szóból állott [TML IV, 248 Naláczi István Teleki Mihályhoz]; 1670: Ivanoczkiª egy kis levelecskét írt énnekem ... Im, Kegyelmednek azon levelecskét is beküldöttem, abból jobban is megláthatja Kegyelmed [TML V, 334. - 'aengyel nemes, aki Máramaros közelében lakott Katona Mihály Teleki Mihályhoz]; 1729: hoszszasobban most az Asz(szonyo)m(na)k nem udvarolhatok, hanem kivánom ez levelecském találhassa az Asz(szo)nt örvendetes friss jo egességbe [ApLt I gr. Haller János gr. Kálnoki Borbárához Nsz-bőll]; 1797: A Salmzmana tanitásárol, módjáról, elömenetelességiről; s. a. t. ekkora leveletskébe irni bajos volna ... ki ditseri, ki gyalázza [MNy XXV, 262. - ${ }^{a}$ Korabeli híres pedagógus].

Szk: t vesz 1749: vettem az őkeme Levelecskeit [Buzd AF; Ks 96 Mikó Ferenc feleségéhez]; 1791: Az Ur(na)k leveletskéit vettem [Nagyteremi KK; SLt évr. Csatth Lajos lev.].

3. udv magasabb méltósághoz intézett levél 1741: mostan biztam ezen csekelj Levelecském olj kézre, melj vér szerént valo kedves Öcsém Uram által fog menni méltóságos Groff Uramnak kezéhez [TL. Onadi B. Josef alumnus gr. Teleki Josefhez Francofourti ad Oderamból]; 1756: Ezen Alázatos Leveletském elvégzése után enis indulék Tiszt Urammal Merab(a) [M.szentpál K; TK1 Perlaki András Teleki Ádámhoz]; 1776: Onnan ira ... ŏ Ngă egy Leveletskét a' Mlgs Praepost Urnak, mellyben ... nagyon kérte, hogy meg ne eskettené Mlgs B. Henterrel a' Kis Aszszony ŏ Ngát [Kóród KK; GyL. Geor. Vizi (30) rk kántor vall.].
Szk: köszöntő 1668: akarám Fölségedhez valo teljes indúlatomat ez köszöntő levelecskémnek küldésével is megmutatnom [SzO VI, 320].

leveles-kapucska rácsos ajtócska 1648: Az uy hazak alatt valo pinczenek az torkolatytya ... bolt hajtasos felywl sendelyes, küül egy leueles kaputskaja fa sarkon jaro feliul egy vas pantal az gerendara foglalua [Porumbák F; UF I, 890]; 1680: Az Sŭto haznak pitvarábol nyilik az kemeny allyara fa Sarkakon, egy leveles kapucska [A. Porumbák F; ÁLt Inv. 7].

levelesládácska kis levelesláda 1688: Leveles Lada ... Regi leveles kis Lada ... Leveles Ladacska [Beszt.; Ks. S. Misc. 27]; 1750: egj leveles ládácskát vesztet volna el valaki [Pókafva AF; Told. 3a]; 1805: kezúnk alá vévén azon Leveles Ládácskát, mellyet ... Báro Jo'sika János Ur Nehai b. e. Edes Attyának Meltoságos L. Báro Jósika Antal Urnak ... Atyafiságosonn által adott volt Néhai L. Báronissa Bálintith 'Susánna Kis Aszszony [Mv; LLt Regestr.].

Szk: rezes 1782: egy kis rezes Leveles Sima fábol valo Ládátska [Mv; NkF].

levélkapucska kis levélkapu 1730: E mellett ${ }^{a}$ az Csürkertbe benyilo ujj kis level kapucska mely jár cserefa sarkokon, ennek talaltatnak ket kis csere tamaszai ... az istalo feloll talaltatik egj kinyilo Level kapucskaja [Szemerja Hsz; HSzjP. - ${ }^{a}$ A kút mellett].

levélke kis levél alakú hajdísz 1758: Drótra hajba tsinált győngyős levélkék, egyikben 27 győny ('́gy!) [Nsz; TSb 21].

levesecske leveske 1791: 4szer ételetskeje ${ }^{a}$ légyen gyénge savanyuságu korpa Cibre, vagy megyből készitett Levesetske [Dés; DLt. - aBeteg gyermeknek].

libegőcske ? rég reszkető tûcske 1718: 1 Gyongyos libegőczke Gyeongios libegő öreg Gyongiokel [Maksa Hsz; HSzjP].

liktárium-tartó ládácska gyümölcsíz-tartó ládácska 1788: Száraz Lictárium tarto kítsin reteszes Ládátska [Mv; TJb 47].

lineácska 1. sorocska 1737: Mar most ezen atiafisaghos lineacskaim által kivānok Excellentiadnak Istentŭl, minde(n) lelki es 
testi iokat [O.fenes K; Ks 99 Mikola László lev.].

2. vonalzócska 1817: a' kis pad széket két liniátskat a Diariummal edgyütt vettem [Hidalmás K; TSb 11].

lisztecske kevéske liszt 1740: Juhos Anna, lisztecskétt szallonnácskát, Czipot adogatott másoknak [Kük.; Mk IX Vall.]; 1747: láttam hogy ettzer mászszor hozott haza a Molnar Janosne Leanya egy egy Csomo Lisztecskét [Déva; Ks 101]; 1775: Borsai Nagy István Uram ... felesége ... a Jobbágy Aszszonyoknak is szŏ és fon lisztetskéért [Peselnek Hsz; HSzjP].

lisztelő-malmocska lisztőrlő malmocska 1756: Roskánya … Két Lisztelő Malmocskátol, és egj ványolotól Rf 6 xf. 32 Déva [Ks 94. 24. 3. $\left.-{ }^{\mathrm{a}} \mathrm{H}\right]$; 1756: a Falu más két lisztelő Malmocskáért Rf 4 xr. 32 [Vályebrád H; Ks 101]; 1794: lisztelő Malmotska [Papolc Hsz; Hr Torma-osztálylevél].

Szk: kétkövü 1825: egy fellyŭl Csapo ket kővű Lisztelŏ Malmotska [Papolc Hsz; SzentkZs Conscr. 189].

liucska kis liu, fatölcsérecske 1638: Azon aszkon vagjon egj ürös altalagh, rajta egj liuczka [A.porumbák F; UF I, 657]; 1724: Egy Lív ... Egy Liutska [Koronka MT; Told. 29/12].

livádácska ? gyümölcsöskertecske 1828: Egy Livádátska kerteletlen régen Ház volt rajta [Füzkút K; LLt Csáky-per 490. L. 10].

lóistállócska 1762: Boros nevŭ Czigany(na) $\mathrm{k}$... egy lo Istállotskaja volt rajta [Bethlen SzD; BK. Olyégyéla Iuon (40) zs vall.]; 1822: égy ágosokra épült gazzal béllet Lo Jstállotska [M.köblös SzD; RLt Pataki József hagy.].

lombocska leveles ágacska 1771: égykor égy hajnalb(an) meg indulok Engi Uram felé és ... látok valami lombocskát az ablak alatt [Dés; DLt 321. 33b St. Gyŏngyŏsi (43) ns vall.].

lópajtácska lóistállócska 1762: Mlgos Groff Bethlen Lajos Ur eŏ Nga Boros nevü Czigányának az kérdésben emlitet ház mellett egy lo pajtácskája volt [Bethlen SzD; $\mathrm{BK}]$. lovacska 1. csikó, fiatal ló, kistermetű ló 1631: Eŏt louaczka [Hsz; LLt]; 1670: had lenne bárcsak egy tisztességes lovacskám; úgy adom meg az árát, valamint Kegyelmed kivánja [TML V, 11 Ispán Ferenc Teleki Mihályhoz]; 1705: Ugyan ma jött volna a kurucoktól egy trombitás és egy kisgyermek párducbőrösön, kinek hozzávaló kis lovacskája volt és aranyos forgója, kik is délután jüvén ki, estére ismét kimentenek [WIN I, 501]; 1748: Tudom hogy két Lovatskája volt [Torda TA; Borb.]; 1825: a Murhárimbolis ugj annyira kipusztultam, hogj egj Lovatskámnál egjebem nints [TLt Közig. ir. 1470 Vutka Ilia Styopu kérv. a tisztséghez].

Szk: A. almáskék 1640: lattam az teŏbbi keŏzeŏt egy kis vastagh almas kek lovaczjkat, bekoban vala [Mv; MvLt 291. 223a] * barna 1635: ez az Nanasi Gyurkŏ. az vizen egy nyerges barna lovaczkan altal mene [Mv; MvLt 291. 40a]; 1636: egy uekóny bárná lováczyká [Mv; MvLt 291. 71a] * barna pej 1852: egy kis barna pej lovatskát ... vásárolt [Dés; DLt 1066] * fakó 1731: nem is volt edgy kis fako Lovatskájánál tobb de aztis el vitte mikor él ment [Kendilóna SzD; TKl St. Szakáts (40) lib., aulicus et conventionatus coquus vall.]. B. harmadfü 1590: wolt egy harmad fw lowachka [UszT]; 1633: Harmad fw louaczjka [Hsz; LLt] * metszetlen 1788: Kitsi pej szőrü metzetlen lovatska, serénye, farka fekete [HSzj pej al.] * tavalyi 1686: 3dfü s Tavalji Lovacskak ... Az ideje (!) Csitkok [Radnót KK; UtI].

2. csődörcsikó 1700: Egy deczeg Kancza harmad magaval, az Idej Csitkaja lovaczka, az Tavalyi Kancza [Csicsó Cs; BálLt 71].

Szk: pej 1637: Esztendeős kanczacsikok nro 11 Esztendeös csyedeőreök nro 14 Vagyon pey louacsyka ket esztendeös nro 1 mely az menes keözeött maradott volt [Fog.; UF I, 415]; 1798: Egy pejj Lovacskát, és az Nemes kancza két esztendős kancza csikaját ... el adtam [H; Ks 108 Vegyes ir. 47] * tavalyi 1627: Tauali louaczka Nro 4 Tauali kanczaczkais Nro 4 [Bodola Hsz; BLt]; 1633: Taualj louaczjka 2 Taualj kanca 3 [Hsz; LLt]. 
lovacska-csikó csődörcsikó; Szk: tavalyi 1634: Taualj louaczka czitko 3 egjk kek zar egjk fekete 3madik fekete barna [Hsz; LLt]; 1637: Tavaly Louaczka czikok Nro 3. Tavaly kancza Cziko Harmadfw kancza Cziko Nro [Teremi KK; Ks 69. 50. 44].

lövőbástyácska 1664: az csonka bástya végében csináltatott egy kis lövő bástyácskát $^{a}$ [TML III, 95. Katona Mihály Teleki Mihályhoz - ${ }^{\mathrm{a} K o ̋ v a ́ r o n] . ~}$

lunkuca rétecske 1765: ezen Lunkutzát nem emlekezűnk reá hogy mikor és ki irtotta légyen ki [Hosszútelek AF; JHb XXVII. 25. 5].

lyukacska 1. 1783: egyenesen a Papnak mentünk, akkor láttam a meg holt Papnak a fejin hogy egy kis Jukacska volt, s ugy Itéltük hogy a mint a vas villáknak a Nyelin égy vas szeg szokot lenni az érte volna a fejit $\mathrm{s}$ a Jukasztatta volna meg [F.répa MT; KLev. Bondra Todor (34) jb vall.].

2. lejáró pincelejáró nyílás 1727: Vendég fogado ... vagyon egy tôlgy fábol rakott kőzőnséges nagjságu jó főld, torkos Pincze ... mellyre az Ház ereszszèből le járo jukatska is vagjon [Csákigorbó SzD; JHbK XXVI. 13. 25].

madárka 1710 k.: Nevetjük annak a phrygiai embernek együgyüségét, aki filemilét sohasem látott volt és az énekléséről azt gondolta, hogy valami szép nagy madár ... és mikor meglátta, hogy olyan kicsiny s nem is igen szép, öszvecsapja a két tenyerét $\mathrm{s}$ azt mondja: Ez a madárka merő csak szó semmi sem egyéb [BÖn. 422].

madzagocska spárgácska, kötőcske 1584: Angalit Razman Palne vallia, Ez hus hagiatba ez Minapiba meg betegeswlek, hiwan hozzam Zabo Catot, es megh kené vegre fel keonniebedem, Es mikor hazamat seprenem, Az kemencze Alat talalek egy darab sot, es harom Mazagal vala Altal keoteozve rajta, ige(n) Zep feier So vala, es az harom mazagochkan harmincz keotes és chomo vala [Kv; TJk IV/1. 217].

magasabbacska 1. nagyobbacska 1747: ezen katonáknak egyike ... kőpczős és nem igen magos ... az másiknak ... borzos verés kalpagja ... nem éppen olyan erős Compactióju mint az más de anál magasabacska termetŭ [A.hagymás SzD; Ks 27/XVIIb].
2. kiemelkedettebbecske 1819: Szolga Biro Buda Simon Ur állott fel egy magosabbatska hellyre [Sárosmagyarberkesz Szt; Ks 67. 47. 28].

magasacska 1. elég magas 1853: A hegy meredek és magasotska [Kv; KmULev. 4].

2. nem nagyon magasra készített 1766: a Szegeletben Magosotska ... régi Kementze [Hosszútelke AF; Kath.]; 1806/1818: 1 Fiokos tükör magassotska [Mv; Told.]; 1823-1830: Az első ülés vagyon benn a kocsi fenekében, a második középben az ajtónál, s ezek mind eléfelé fordulva, az harmadik ülés vagyon a középsővel szemben, ezeken kívül az első bakon volt még egy magasocska ülés [FogE 253-4]; 1833: Magossatska Túz helj [Nyárádsztanna MT; MvLev. 8].

3. kissé magasra formált 1807: Báts Vonuly ... oláhos magossatska kivŭl szŏretlen bŏr zsiros sŭvegbe ... járt [DLt 494 nyomt. kl]; 1811: Senker Mihálly ... visel ... egy viseltes magosotska fejŭ Kalapot [DLt 148 nyomt. k].

magasacskán elég magasan 1700: ha pedig magossacskán kőtődik az gát ugy híszszűk hogy nem lészen kára nélkúl Vas Daniel Ur(amn)ak [Dob.; WassLt]; 1831: lako Házomnak jo ép Nádos Fedele lévén, noha a Fedeleis Főldtől magossatskán esett [DLt 951 nyomt. kl].

magyarka magyaros férfikabát 1823: Mártonfi Simon ... Jár világos vadgalamb szin mellértes Magyarkában [DLt nyomt. kl]; 1838: Egy fekete uj Magyarka, seprő-szin merino bélléssel; hozzávaló gömbkötő munkáju láljbli (!) [RLt O. 1 Mike Sándor ellopott tárgyai közt]; 1842: Egy magyarka ujra bérelve Rf xr 15 [Kv; Ujf. 1]; 1850: Egy fekete magyarka virágos selyem bérléssel [Mv; DE 2]; 1862: Magyarka kék kőzőnséges posztóbol [M.szilvás TA; HG]; 1870 k./1914: 1834-ben a főkonsistorium leirata szerint a hosszu magyar dolmány, a magyarka ismertetik el törvényes deák

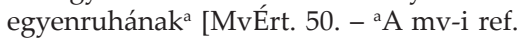
koll-ban].

Szk: nyári 1866: nyári fekete magyarka rongyos bèlléssel [Megyesfva MT; LLt]. 
majc-kantárocska 1732: egy Zŏld majcz kantárocska kis Zabola rajta [Ks Kornis Zsigmond lelt.].

majorházacska kis majorgazda-lakás 1675 : Egy jo Czŭr, mellette vagyo(n) barom tarto okol major hazaczka jó Egy Diszno pajta [Dés; Borb. II]; 1687: Méhes kert ... mellette egy Major Házatska [Nagynyulas TA; BLt]; 1706: egy hitvány major hazocska kŏrŭl kert [Görgény MT; Born. G. VII. 4].

majorocskahely 1776: egy kitsiny Majorotska hellye [Mv; Told. 21].

majorságocska kis gazdaság 1669: mihelt az kevés majorságocskámnak takarítását ... hacsak valami részében is végezhetem, az jószág árának felvételéért bemegyek Kegyelmedhez [TML IV, 505 Ispán Ferenc Teleki Mihályhoz].

makkocska-haszon makkoltatásból származó kicsiny haszon 1592: az mely jdoben valamy kyczid makkoczyka hazon volt az felj byk erdöben, az fanczyaliak diznaiokatt onnatt az orozhegy hatarbol, az Nyulad tartomanyabol jde az Varhoz be hozzattuk [UszT].

malacka 1591: jeowe oda az Peresnek egy keues apro malaczykaiok hire(m) nelkwl [Szu; UszT]; 1730: negy el veszemedet hitvány malaczkák, kik is nem íletre valok [Szentlászló TA; JHbK XLIX/4]; 1760: vagyon két tehenecske ... két kitsind malaczkaja [A.volál Hsz; LLt]; 1781: Aki a faluban belől lakik, vagy egy malackája vagy vetése az határon vagyon: tartozik kertet tenni [Oroszfalu Hsz; RSzF 146]; 1785: Az elszŏkŏt Szem Mártoni Jobbagynak Vintze Jánosnak el maradván egy Malatzkája el adtam [TSb 6].

malacocska malacka 1743: Kis malaczocska eme [Tekerőpatak Cs; LLt Fasc. 158]; 1775: Desŏ János Vramat újra fogadtam Karátsomban, kinekis vólt 12. véka tiszta búzája, ezt kŏltsen el vettem, két malatzotskájával egyŭtt [Örményszékes AF; BetLt 6. özv. Szalántzi Jóssefné Boér Borbára végr.]; 1786: aki egy egy Disznot vagy malatzacskat vehet vegjen [Torockó; TLev. 4/13. 14]. málécska kukoricácska 1714: a felettèb való tavalyi esözés miatt, mind pedig a gabona kevés vólta miatt, felette keveset vethettünk ... a $\mathrm{a}^{\prime}$ vetetlen maratt szántó földek, hijában ne heverjenek, és avagy csak Málécskája lehessen a' szegénységnek, Concludáltuk firmiter, hogj a' buza földekbe is, a kik buzával bé nem vethetik málét vethetnek [Dés; Jk 549b]; 1743: Adott vala Isten ő felsége ... annyi gabonácskát, mely csinosan költve s málécskával elegyitve ... talán elegendő lett volna [HalmágyiNIr. 450].

malmocska 1. 1736: épithet ... azon Patakon egy Malmotskát [CU]; 1750: edj Malmotskais vagyon ezenn Also fordulo határb(an) [Vecsérd NK; Berz. 11. 88/5]; 1770: ezen Kis Nyárad Nevezetü patak vizén ... Vass Ferentz ur(am) Malmotskája [Berekeresztúr MT; BetLt 7]; 1783: La borkutye Si lá Sipot nevezetü hellyeken lehet Malmotskákot állitani [Kéménd $\mathrm{H} ; \mathrm{JHb}$ XXXI/28]; 1801: egy szeglét részetskéjét a Falu kőzőnséges Helljéből fogta bé ... egyenesen elé egeszen a verőfényen ... végibe ragasztott és épitett Malmotskájával [Nagynyulas K; DLev. 5].

Szk: csutora 1756: Onokuszk Thomának ... lévén egy Lisztelo csutora Malmocskája taxáját ad(mini)stralni tartozik Rf. 2 xr. 16 [A.lapugy H; Ks 101] * egykövü 1750: Az Ton fejül egy, egy kővü kis Malmocska [Papolc Hsz; Hr] * felülcsapó 1662: vagio(n) az Babolnay patako(n) ... ket kis fellyúl czapo malmoczka [Bábolna SzD; UtI]; 1722: Vagjon ezen Rápolti patakon egj fellyül Csapo malmotska [Rápolt $\mathrm{H}$; Born. XXIXa. 8 Bornemisza János conscr. 13] * kétkövü 1740: lévén ... a njárád nevü Patakon egy két kővű Malmocskája ... a végiben egy kis bugjácskáni szénát termő kaszáloval [Nyárádmagyaros MT; Berz. 15 XXVI/9]; 1772: eö Excellentiaja Malma fogjatkozásának nem az én kisded két kővü Malmocskám, hanem az eő Excellentiaja Tisztei gondviseletlenségek okai, kik ... szánt szándékkal nem igazittattak [Kük.; JHb LXVII/238].

2. sóörlő sóörlő kézimalom/rezsnyice 1835: A' Hinto Szinben ... Egi so örlő Malmocska [F.zsuk K; SLt Vegyes perir.]. 
malomházacska 1599: Az malom hazaczikanak az Tapaztasatol es mazlasatol attam d 80 [Kv; Szám. 8/XII. 3 J. Chanadj mb kezével]; 1637: Az uduarhazon fellyel uagyon egy malom hazacsyka ... uagyon egy malom benne keö podgyaual ... garattyaual, lizteleö valuyaual, egy keöjuel [Breaza F; UF I, 428]; 1656: Az malom hazrajs nilik egy felszer vassarkos panthos retezes retezfejes aytŏ Ezen malom hazaczka előtt vagyon ... egy kis kert [Fog.; UF II, 103].

mamuka, mamujka csúf $\mathrm{kb}$. ügyefogyott 1812: a Groffné nagyon indulatba jőtt, és a' Grofot nagyon kissebitetté sőt motskolta, gazolta mondván: Te Samuka, Mamuka, Mamujka, Tőkős [Héderfája KK; IB. Molnár György (58) ref. esp. vall.].

mángorló-színecske mángorlás végzéséhez szolgáló színecske 1842: ezen kis kertbe a' cseléd és sűtö ház mellé ragasztva égy avaték sendely fedelü mungorlo szinetske [O.kercisóra F; TSb 51].

mántlicska (gyolcs) köpenyke 1788: Galléros gyolts mántlitska égy és gallératlan négy [Mv; TSb 47].

mányika (bélelt) kesztyű 1699: Egy veress boitos barsony aszony embernek valo kesztyú vagy manyika tetszin pantlikak raita, az pantlikak vegein mind io féle győngy [Szárhegy Cs; LLt Fasc. 150]; 1732: Egy béllet nust kestyü vagy manika [Kv; Ks Kornis Zsigmond lelt. 15]; 1821: Vagyon egy Manyika 3. Rfl [Kvh; HSzjP]; 1829: Vagyon két mányika, 3 ujjas lájbi 30 flo. [Kvh; HSzjP].

marhabél-hártyika marhabélhártyácska 1806: láttam a Morhának a Ganéját s afélé morha bél hártyikákat [KLev.].

marhácska 1. vagyonka 1564: mostan ... ha estwe el iw reggel mingiarast roia az zeginy nipet, es ilien modon roia hogy az mely zeginy ember meg holt, az vagy az mely meg nem adhatna mingiarast az zeginsig miat annak öröksigyt es marhachikaiat el foglalia, es maganak nemesyty es földön lakot hoz reaia [Cssz; SzO II, 178 a cssz-i közszékelység panasza a fej-hez a tisztviselők és fóemberek törvénytelenségei ügyében]; 1588: Ertyk eo kegmek az paticariusne feleol valo panazt hogy Egy Zabo legennyel eggywt Laknak Az
Anya Zent egyhaznak Rendy es Moggya kyweól hwtnélkwl, es a' zegeny Arwanak Marhachykayat tekozollyak [Kv; TanJk I/1. 80]; 1631: annakutanna hogi eözue kelenek Munkaczi Janossal, tudom hogi mind volt Marhaczkaja Munkaczi Janosnak Az mikor penigh munkaczi Janos el ueue azt az Boncz borbarat tudom hogi vala mind Marhaczkaja, $s$ mind penze Munkaczi Janosnak [Mv; MvLt 290. 251a]; 1722: Az én Nervusom ebből áll; ejjel nappal azon igjekezem hogy Marhácskaimat maga(m) hotarát szaporgathassam per curiosam oeconomia(m) [KJ. Rétyi Péter lev. Fog-ból]; 1729: zolgalattjaval szerezte az Marhacskáját [A.oroszfalu SzD; BK. Pap Jonásh (40) vall.]; 1729: Vagyon szép Kenyerü Sz: Martonb(an) ${ }^{a}$... két kőzel való attyaffi iffiu Legény ... ide való Centei ŏrŏkŏs jobbágyok, most szolgálattyokkal marhácskát szereznek magok(na)k [JHbK $\mathrm{V} / 2$. - $\left.{ }^{\mathrm{a}} \mathrm{SzD}\right]$.

2. értéktárgyacska 1570: Angalyt Emryh Kasneren eozwege, Azt vallya hogy My kor gereb Balas megh holt Maradot volt ket germeke, Es az my Marhaczkaya Maradot volt azzal Egetembe hoz Bartosne hordott hazahoz, Es aztis twgia hogy hoz Bartosne Megh Beochwltette volt, Es azt Mongia volt hogy Mykor az germekeknek kellethyk eo Jobbat ad erthe [Kv; TJk III/2. 98]; 1592: Bachmegiey Miklos ... vallia: Mikoron Nagi Balasne Ersebet Azzoni el nehezedet volna, hiuata engemet tiz orakor ejel hozzaia, es mikor eggiet mas marhaczkaiat ele rakatta volna, kere hogi el vigiem velem: kerdem houa kel tenni, ha holta teortennek [Kv; TJk V/1. 284]; 1768: hivanak mint egj Regiusnak hogj közöttök holmi aproság házi portékát és egj nehanj marhàtskát meg oszszak [Kissolymos U; Márkos Lev.].

Szk: belső 1620/XVIII. sz. eleje: Elŏszszŏr az mi belsŏ marhatskám vagjon, vgjmint Arany Ezŭst marhám, pénzem és egjéb drágáb marhám ... az két Fiam Miklos és Gjörgj osztozzanak vélle [SLt AJ. 11. P. Horváth János végr.].

3. holmicska, egyetmás 1582: Műler Potentiana Rlcta qu(on)d(am) Pauli Bwser ... fassa est Kinchies Kalmanne Ieowe en 
hozzam hog Keodmen Janosnetol Az Angalit Neweo leannak vendelyet es marhachkayat megh kernem ... Elys ment es kerte a Leany vendelet es marhayat ... de Azt montha hog Neste kwrwa legien ha Aggia [Kv; TJk IV/1. 3]; 1599: Makay Dekan Mathiasne Ersebet azzony ... vallja ... latta zoknyaiat es egyet marhachkajatis [Kv; TJk VI/1. 281].

4. jószágocska, kevéske lábasjószág 1588: Illyes Nyomorwsagonkis vagyon hogy ith zinte az falw zelen vagyon egy kis Erdeo ... soha ... a falwtwl ell nem zakaztottak sem meg nem tiltottak hanem marhaczykank zabadon rea iarth, mostan Sombori Lazlo vram azth meg fogta nekeonk semmi marhainknak nem zabad rea menny [Zsákfva Sz; WLt Mich. Talas jb vall.]; 1731: Baraika Mikola nevü Jobbagya meg halván, tölle el maradott Onuly nevü Fiacskáyanak marhácskayat, ugy mint 4 ökrit, Circiter 18 Juhát vagy 8 sertesit ... praedalta el hordatta el Zambo Mihally nevü ... Jobbágya [O.bikal K; DobLev. I/143 Ginczke Szimeon (50) jb vall.]; 1815: Hersány Iuvonnak, tudom két nevendék Fijai maradtanak ... Marhátskájok is vagyon ... édes Annyakkal lak(na)k [Orsova MT; Born. G. XV. 13 Szőts Daniela (72) vall.]; 1822: őregségéhez képpest meg gyengülvén a veje kezébe adta marhátskáit [K; KLev.].

5. szarvasmarhácska 1683 k.: az Pástor jővedelmecskejenek része ... a Fa hordas es marhacskajanak táplálására valo szena adas [Szilágycseh; SzVJk 123]; 1757: Csak negy Esztendeje, hogy ide az havasra kezdettem járni marhátskáimmal [Gyszm; DE 3 Juon Rádully (40) jb vall.]; 1774: ezen Legény hogy szántó vető Ember vólt, Magának Marhátskátis szerzett vólt azon végre [O.zsákod KK; LLt Vall. 198]; 1814: Honnan jőtt Bányitzára a tisztelt Tisztelendő Ur nem tudom, valamint azt sem, hogy mije? és mennyije van, hallottam ugyan, hogy vagynak Marhátskái, Juhai, de ezek is, hogy mostan mennyi szammal vagynak nem tudom [Banyica K; BfR 117/1 Andr. Csatt (58) ns vall.]; 1846: a Gujába volt marhátskáim a Gujás által hiba nélkült számba adattatván [Dés; DLt 1248].
Szk: csordabeli 1768: Mikor a falu csordájának tavasszal ideje leszen kimenni, azaz kihajtani: futkosó szérben minden ember tartozik őriznie, akinek vagy egy csordabeli marhácskája vagyon, amíg elkerül egyszer a falun [Oroszfalu Hsz; RSzF 187].

marhapajtácska szarvasmarha-istállócska 1778: egy egy Marha Pajtátskát vagy egy kis Gabonásotskát tsináltak [Pósa Sz; Ks 34. VI. 1].

markocska kis marok 1661: A lovaknak, ha drágácskán is, de ha lehet, szénát, abrakocskát is szereztess; ha egyébb nem lehet, búzát két-két markocskát adass, de vigyázás legyen reá, meg ne zabáljanak [TML II, 137 Teleki Mihály Veér Judithoz]; 1738: egy Mázos Szűrő regi Aszalt Megygyel egy fel Markocskával [M.bikal K; MLev.].

martocska partocska 1765/1770: azon az martocskán is tul ... az a darab hellyis mind Simén rész, az marton aloll pedig mind az viz mosta oda, mert regenten ott volt az viznek jobb, és derekasabb Follyása [Széplak KK; SLt évr. Transm. 350]; 1772: Szántó Főld ... vicinussa Délrŏl az kŏzŏnséges Martocska [Szászfenes K; BethK Mikes conscr.]; 1803: Egy küs szakadozott Martotska [Csíkfva MT; UnVJk].

medálocska 1668: Egy kis Medaloczka Zomanczos smaragd benne [Mk 10 Kapi György lelt.]; 1786: Egy Medajotska 24 rubint benne es 4 gyémántotska [Nsz; Ks 74/56]; 1814: Egy kerek Medalotska, vagyon benne három zamántzos engem ne Felejts [Kv; Born. IV. 14]; 1816: Egy kerek Médályotska, benne vagyon három Engem ne felejts Zamantsos [Kv; Born. IV. 14].

medencécske tálacska 1611: Fa tanyr vagio(n) tizen ketteö es ket hitua(n) medencechke [Kv; RDL I. 88]; 1793: egy kís mosdo csipkés szelü medentzetske [TL Conscr.].

medvebőröcske medvebocsbőr 1732: Sigo Urfi kis Német nyerge $\mathrm{cu}(\mathrm{m})$ apparatu és két kis medve bórŏczke [Kv; Ks 15 Kornis Zsigmond lelt.]. 
meggyeske ? Hn 1722: $\mathrm{A}^{\prime}$ Medjeskeb(en) [Papolc Hsz; EHA]; 1750: A' Medgyeskébe (sz) [Papolc Hsz; EHA]; 1825: A Meggyeske nevü hellyen (sz) [Papolc Hsz; EHA].

méhecske 1. 1662: A méhecskéknek kaptárjokban egy bizonyos anyjok és mintegy királyuk vagyon ... ki mind teste állapotjával, s mind az ö tornyos friss hajlékával a lép között közönséges méhektől megkülönböztetik [SKr].

2. méhcsaládocska 1729: le akarván véllek hozatni ... nállok lévŏ kevés mehetskéimetis annak ideiben [Gyf; Ks 83 Erdei József lev.].

méheskertecske méheske 1736: ezen Méhes kertetskének ajtaja tsak Sŏvénybŏl valo [CU]; 1738: Ezen Veteményes kertnek az Felsô résziben ... a szegletben van egy Méhes Kertecske kerekdeden keritett jo Támaszos Sátoros kertel bé keritve [Szászvessződ NK; Born. XX. 12]; 1799: a' Méhes kertetske [Mártonfva NK; Told. 30].

méhészházacska 1767: tapaszos Sövény padlásu Pitvaros Méhész Házatska [Mezőbodon TA; Torma].

méhtartó-kertecske méhkertecske 1638: Eggj mehtarto kerteczkeis vagion benne ${ }^{a}$ rekesztve, reghi leszas, azonnis hasonlo aitó fa zarja mindeniknek [A.porumbák AF; UF I, 663. - ${ }^{\mathrm{a} A}$ veteményes kertben].

méhszínecske méheske 1822: egy jó állapotu séndelezett fedelŭ Méh Szinetske [Szentdemeter U; Told. 18]; 1827: Az Udvarház nyugoti szegelete mellett találtatik egy meg lehetös állapotba lévö kitsi méh szinetske [Somkerék SzD; Ks 73/55].

melegecskén langyosan 1778: A' kiknek a' Torkok, oldalok, vagy mejjek fáj, azok mindent melegetskén igyanak [MvÁLt Mátyus, ConsSan. gub.]; 1843: a füszereket mustba meg főzve, melegecskénn be önteni a hordóba [KCsl 13].

mellrevalócska mellényke, lájbika 1791: 1 Gyermeknek valo Mejre valotska $[\mathrm{Mv}$; MvLev].

mélyecskén kissé mélyen 1864: a' porondköves hegy méjjecskén be van vágva [Váralmás K; KHn 316]. mentécske (prémezett) felsőkabátocska Szk: csonkaujjú 1616: egj ... csonka vjŭ Mentechke [Kv; RDL 1. 101 Andreas Junck kezével] * kis 1622: Egj kws menteczke f. - d. 50 [Kv; RDL 1. 119]; 1637: Egj kis mentetske barack viragh szin angliai mallal bellet [Marossztkirály AF; IB. Bethlen Domokos hagy-ból Bethlen István lelt.] * rókás 1741: Josef Beszterczére ment volt vassal kereskedni egy kis Szép Fiacskája is vala Rokás mentécskéb(en) [Hévíz $\mathrm{NK} ; \mathrm{JHbT}^{*}{ }^{*}$ szorító 1657: Vala pedig ily rendtartás is: hogy néhány föemberek $\mathrm{s}$ urak gyermekeiből álló inasit maga lovain merő páncéloson, azon feljül páncélszorító veres virágos bársony zubbon avagy szorító mentécske ... nusztal prémezett bársony süvegesen jártatta [KemÖn. 41].

mérföldecske közel egy mérföld 1571: M Vásárhelly Szabad Kiralyi varossa ... Káltól menyi földnire vagyon, nevezetesen hogy ha nem kevesebbé egy Mej földecskénél [Nsz; Berz. 2. 40/80].

mérgesecske kissé mérges természetű 1846: Annyi igaz hogy Ifj: Imre Mihály mérgesetske ember [Kakasd MT; DE 2].

merinó-magyarka merinó-posztó magyaros kabátka XIX. sz. eleje: Egy zöld Nyári mérino magyarka [EMLt].

mérő serpenyőcske mérlegtányérocska 1640: Egi kis méreő serpenieőczkebeől f. - d. 17 [Kv; RDL I. 123].

mesécske rövid mese 1805: a Rector historiát, és mesétskéket mondott nèkünk [Dés; KMN 49]; 1805: mig eljött a Vatsora ideje apro mesétskéket mondott a Rector [Dés; KMN 126].

messzebbecske kissé messzebbre 1782: (A föld) meszebecske vagyon [Kászonújfalu Cs; MvLev. Vegyes anyag 8].

messzecske 1. meglehetős távolságban 1747: a kaljániak Marhákat legeltettek ottan, de meszszetske lévén tőllők egyet sem ismértem kőzüllök [Báré K; Székely lev. Supl. 28-39 Marosán Gligor (38) zs vall.]; 1761: Szolgalattya ezen két Jobbágyoknak, mint hogy Veszszŏdtŏl meszszetske vadnak, az hogy mikor oda mennek dologra egj jo darabig oda tartattnak s az után itthonis jo darabig dolgozhattnak magok számokra [A.gezés NK; JHbK LXVIII/1. 457]; 1792: 
meszszetske lévén hozzája az fárol le szŏkŏtt [Nyárádsztlászló MT; Sár.]; 1796: Meszszetske voltak tőllünk [Kv; AggmLt B. 15]; 1800/1802: az Exponens Ur Lak hellyétől meszetske vagyon [Mv; DLev. 6 Transs. 533]; 1817: lévén ... joval alább a vad Gyümöltsfák kőzőtt meszszetske ... észre nem vehettem [Bos MT; Berz. 9. 73]. 2. ről meglehetősen távolról 1759: láttam meszszetskéről, hogy az emberek ezen hellyre gyülnek, és kiáltoznak [Hosszútelke AF; Kath].

3. meglehetősen sokára 1710 k.: az én második fiamnak ... nagy keresztelőt akarék csinálni, híván komáknak a többi felett Telekit ... Rhédeit, Tophaeus püspököt, de az olyan nagyrendü emberek sok dolgok miatt nehezen érkezhetvén, messzecske rendelé Teleki a keresztelés napját [BÖn. 716].

4. átv meglehetősen messzire 1823-1830: Messzecske távoztam nemzetségem leírásától, de akarom, hogy a régi dolgokból is vegyetek valami kevés esméretet [FogE 69].

mezőcske 1. kis mező 1714: az melly darab mezöcsket fuz fakal ... tegnap ültetet be ... arolis tiltatom eő Kegelmet [Abafája MT; Born. V. 36].

2. legelőcske 1616: egy darab szabad mezeoczke vagion, alat valo lapalios hellyen szinten az Maros Parthon [Náznánfva MT; Berz. 13. II. 2].

3. kaszálócska 1599: ott a' taiba az hul valami kis mezeoczkek uadnak czak ne(m) rege(n) kezdek kazaiokkal birni [UszT 14/13 Petrus Istua(n) de Jlke (40) ppix vall.]; 1781: ā Kŏszŏrŭ pataka fele vagyon egy mezŏcske [Gyszm; DE 3].

4. irtásocska, kis (erdei) tisztás 1572: tugygya azth hogy az gardan, nagy erdew volth Kemeny Peter Kabos Jacabal egy korban oda mene Egy kys darab mezochykeys voth oth azth Kemeny peter haggya kabos Jacabnak [Gyerőmonostor K; KP]; 1639/1727: fellyebmenvén ${ }^{a}$ egy kis mezeockyben Eotődik föld halmot erigaltattunk [Ks. - 'áágor és Kisszőlős között (KK)]; 1757: (Ezen a) hellyen akkor csak egy bugja Szénára való mezzőtske vólt, a többi derék bŭkkŏs Erdőből állott [Gyszm;
DE 3]; 1771: a' Mezőtskében ... meg olyan fü nem volt, hogy a marha ügyeiben ehetett volna [Vadad MT; VK]; 1777: Popa Juon ... egyedúl maga kŏltségén kezdett irtogatni ... eleintén hivta Testvéreit, de ... nem jötte(ne)k hanem most ... láttyák ezen mezőtskét őkis ŏrŏmest részesülni kívánnának [Dupapiátra $\mathrm{H} ; \mathrm{GyK}$ ].

5. kis sima felület 1803: égy Nagyobbatska sima On Tángyér, mely(ne)k feneke kŏzepére kivưlről égymás mellett lévő két küs Mezőtskében az öntönek Czímerei bütűs, a más sima [Harangláb KK; UnVJk 167].

mezővárosocska kis mezőváros 1642: Oda fel Ersek Uy Var mellet Egy Udvard nevŏ mezŏ varosoczka vagio(n) [Fog.; Told.]; 1657: Elfogván azért iránzásképpen egy úton, vőn egy mezővárasocskára, holott bémenvén, az utcában láték egy kovácsműhelt és abban mívelő kovácsot [KemÖn. 55].

mindenecske kevéske vagyon 1663: Ha idegeny uraim mellett nem szántam sok izben mindenecskémet elhagynom, bizony készebb leszek Nagyságtok mellett ... mindent elszenyvednem [TML II, $474 \mathrm{Te}-$ leki Mihály Bornemisza Annához].

minutácska kisebb feljegyzés, iratocska 1676: Arkosi István Ur(am), minutaczkajat producallya, melyb(en) azt irja, hogy az 51 forintokat Fejér vári Mihály(na)k atta $[\mathrm{Kv}$; RDL I. 155a].

mocsárka kicsiny mocsár 1799: a Motsárka mevezetŭ hellyen (k) [Kézdialmás Hsz; EHA].

molnárházacska 1688: az malomb(a) menvén vagyon job kéz felŏl egy molnár házacska [Csicsógyörgyfva SzD; BK]; 1722: Az Udvarház kertén kivül vagyon malom ... Az ut felöll valo oldaláb(an) molnár házotska alkalmatos [Algyógy H; Born. XXIXa. 8 Bornemisza János conscr. 3]; 1759: Vagyon az udvarház arányáb(an) ... Molnár házacska [Lázárfva Cs; BLt 9].

mordályocska (gránátvető) pisztolyocska 1754: Egy pár rezes kápáju kisded kis Mordajotska [Nsz; Told. 19]. 
morécska cigánygyermek 1589: Hallottam bizonnial ki zemiuel latta egi Moreczka ki vgia(n) en zolgam volt [Dés; DLt 226]; 1592: meegh egyczer mikor ez vallo Iuhaz volt akkoron az Juhtul haza menth es hagiot egy Morechikat az Juhual [Dés; DLt 235].

mosdócska kis mosdó 1615: Egj Teörreödeözeöt Sarga mosdochka f - d. $12[\mathrm{Kv}$; RDL I. 97 Junck András kezével]; XVIII. sz. eleje: Egy Szŏllŏ Gerezdes forma leueliuel ezŭstbŏl formalt Mosdocska [Berz. 17. XII].

mosdó-korsócska kis mosdókorsó 1732: Egy ezŭst kis mosdo korsocska [Ks 11 Kornis Zsigmond lelt.].

mosdómedencécske 1793: egy kis mosdo csipkés szelü medentzetske [TL Conscr.].

mozsárágyúcska kis mozsárágyú 1737: Korodon $^{a}$... egy mosár ágjúcska [Ks 40 Varia XXVIIIc. $-{ }^{\mathrm{a} K K]}$.

mozsárocska kis mozsár 1714: 3. fontbul allo Mosarotska törövel egütt $\mathrm{s}$ egj fúlével 1//80 [AH 48].

mugil-poharacska 1655: Egy Mugyil poharotska ... M - p. 25 [Kv; RDL I. 29].

mundér pisztolyocska kis katonai pisztoly 1782: Egy kis aranyozott Munder ezűstős Virágokkal ékesitett Csőjű Dámának valo par Psitolyotska [Mv; CsS].

munkácska 1. kevéske munka 1777: láttunk itt Észag (!) felől valo oldalában ezen hegynek az akkori nagy Erdőnek kőzepőtte tájékán valami munkátskát, mellyet mondottak, hogy az Exponens nagy Apja vit volna véghez ... nem jártunk [Dupapiatra H; GyK. Kretson Szimion (56) jb vall.].

2. rövid jelentés/beadvány 1791: ezen Comissiora bizattatik az is, hogy egy particulare Domest. Consistorium organizatiojárol, hogy ez kikbŏl és hány személyekböl álljon, és mind ennek mind a' plenum Consistoriumnak objectumarol egy munkatskát készitvén a' Consistorium eleiben terjeszsze a megvisgáltatás véget $[\mathrm{Kv}$; SRE 214]; 1794: Eleget mesterkedtem benne hogy Ngōd parantsolattya szerént de otiori Juris cursu valo Munkátskát bé küldhessem, de sohol sem lelem [Hosszúfalu
Szt; TKhf Jakab Gábor gr. Teleki Imréhez]; 1798: Nagyon őrvendek ha jo szivel irt Munkátskám a betsúlletes Communitás ${ }^{a}$ előtt is kedvet nyert légyen, s kivánom is szívemből hogy őrőmmel tellyes ki menetele lehessen, s az idő ugy hozza magával hogy a' reá tejendö feleletre még valami Reflexiot kellene tenni munkámat $\mathrm{s}$ fáradtságomat kedves Jo Vraimtol ... nem fogom sajnallani [Torockó; TLev. 5/14. 1a. - ${ }^{\mathrm{a} A}$ torockói verős kovácsi társaság].

mustocska kevés must 1604: Myerthogy az Zwret instal az zegenseghnek Arra vagion kiwaltkeppen gongya, onnet varhat keolchyegetis maganak ... az Zwret eleot ne $(m)$ vehetnek adot, hogy igy felzegh arran az Zegenisegh kewes mustotskajat arra valo tekintetben el ne veztegesse $[\mathrm{Kv}$; TanJk I/1. 484].

muzsikácska hangszerecske 1681: Tŏrŏk sip uj Nro 2 ... Virgina ... Orosz Musikaczka, ighen kiczin, fa Tokostol Nro 1 [Vh; VhU 539].

nádaska kis nádas 1731: Nádaskában (sz) [Kászonimpérfva Cs; EHA]; 1774: Nadaska hidgjanál (sz) [Kászonfeltíz Cs; EHA]; 1807: Nádaskába felmenő (sz). Nádaska pataka Melet (sz) [Kászonaltíz Cs; EHA].

nagykorácska nagyocska 1750: A cinteremben vagyon egy tisztességes fábol épült fatorony, melyben vagyon két nagykorácska harang [Marosvécs MT; ETF 107. 22].

nagyobbacska I. $m n$ 1. nagyocska A. bútorzatra, berendezési tárgyakra von. 1658: Kett Eőregh lada Est f 1 d 60 Kett masfel singes lada Est $\mathrm{f} 1$ Egy singes es mas nagiobaczka [Kv; KJ]; 1736: nagyobbatska fenyö deszkábol valo paraszt fogas [A.idecs MT; CU]; 1745: egy kitsiny paraszt 's két nagyobbatska karos avatég fogasok vannak benne [Marossztkirály AF; Told. 18]; 1791: egy nagyabbotska viseltes ord Tŭker [Mv; MvLev.]; 1795: Három nagyobb 's egy kis karikás Ágy viseltesek, és egy más nagyobbatska [Mv; MvLev. Szabó Moses hagy. 5].

B. edénynemûre, (házi) használati tárgyakra von. 1648: Harom kiczin fejer Czapa Pohar ... Es egy nagyubbaczka [Born. XXXVIII. 14]; 1719 k.: ket ezust pohár 
nagyobbatskak [LLt Fasc. 115]; 1744: Két ust edgy edgy vedresnél nagyobbatskák [Szentdemeter U; LLt Fasc. 67]; 1768: Vagyon négy tseber edgyik nagyobbatska [Szárhegy Cs; LLt Fasc. 116]; 1816: Négy Désa egy nagyobbatska [Varsolc Sz; Born. IV. 41 Bornemisza Krisztina conscr.].

Szk: óntányér 1803: égy Nagyobbatska sima On Tángyér [Harangláb KK ; UnVJk 167] * rézüst 1817: Égy rosz nagyobbatska réz üst [Mv; MvLev. 2] * skatulya 1824: Egy nagyobbotska, egy kissebbetske Skatuly [Fugad AF; HG Mara lev.] * (vas) serpenyő 1817: Egy nagyobbatska vas serpenyö [Mv; MvLev. 2]; 1832: Egy nagyobbatska Serpenyő [LLt].

C. ékszerre von. 1672: Az gyémántnak az aprója nyolcz, ez tizenkét tallér árra, nagyobbacska kettő, ez tiz tallér árra [TML VI, 44 Nemes János Teleki Mihályhoz]; 1758: Rubintos arany fityegő, melyben vagyon egy nagyobbatska, és 41 apróbb Rubint [Nsz; TSb 21]; 1766: három rubint kettő kissebb egyik Nagyobbatska [Szárhegy Cs; LLt Fasc. 96]; 1781: Apro Győngynél nagyobbatska őszve füzőtt Győngy tizen nyolcz Arany nyomo [Nsz; Told. 3].

Szk: aranyboglár 1786: Három nagyobbatska arany boglár egy egy rubint a közepibe [Nsz; Ks 74/56] * gyöngy 1706: egj nagjobbacska győngy [LLt Fasc. 108]; 1800: adott által ... 1 Nagyobatska jo féle győngyőt [O.fenes K; JHb LXVI/46].

D. állati bőrre von. 1767: nagyobbacska fekete Bárány Bőr [Marossztkirály MT; Berz. 5. 38. P. 2].

2. nagyocska befogadóképességü/ürtartalmú (vmennyi élelmiszer/ital tárolására/szállítására való) 1737: Etzettel tellyes általagok nro 5 - ött, melly(ne)k négje nagjobbatska, edgjík pedig kisded [Csákigorbó SzD; JHbK XXVI/13. 10];1801: Vagyon 3rom Romladozot Gabona tarto Szuszékok, Vagyon két Nagyobbatska regibb [Vargyas U; CsS].

Szk: boroshordó 1787: Egy nagyobbatska üres Boros hordo [Mv; MvLev.] * csobolyó 1738: Harom nagobatska Cobolyo nomero 3 [Gysz; LLt].
3. nagyobb kiterjedésű 1742: az Urffi reszire valo fŏld valamivel nagjobbatska [Koronka MT; Told. 26]; 1768/1771: a' ... Dsugya ... azért repartialta és desumalta is ā ... Pénzt, hogy midőn az Ōrökségeket rudalta ... nagyobbatskaknak találtattak valamivel mint ā több őrőkségek [Bukuresd H; Ks 112 Vegyes ir.]; 1774: az Bencze Kata Aszony ŏroksége valamivel nagyobbatska [Aranyosrákos TA; Borb.]; 1781: el tserélt szŏllŏje nagyobbotska ugyan, de mostani állapottyában igen pusztás [Koronka MT; Told. 10]; 1820: Ezen Hellységnek két Forduloja vagyon, meljek közül az Also nagyobbatska, és jobbatska is a felsőnél [Jegenye K; KmULev. 2]; 1820: Lŏrintzi Péter adta föld tŏbbetske vagy is nagyobbotska a' tisztelt Ur adta fŏldinél [Kőrispatak U; Pf].

Szk: nyíl 1782/1798: Az Elekes felőll valo nagyobbatska nyilakban az harmadik osztásban [Szentbenedek AF; EHA].

4. aránylag nagyocskára/magasabbacskára nőtt 1795: Egy Krumplit, ha nagyobbatska négyfelé, sŏt hat felé-is lehet ... el-darabolni [DLt nyomt. kl]; 1844: meg betsűlték ... az nagyobbatska fákat [Náznánfva MT; LLt].

5. nagyobb (növésû) 1682: Barna Pej nagjubbacska [Görgény MT; UtI]; 1755: 3 eszt(endŏs) nagyobbattska testŭ és szarvu Tulok 1 [Batiz H; BK sub nr. 1020 Naláczi conscr.].

6. vminél idősebbecske 1759/1779: Más fél Esztendösnél nagyobbatska Sŭldŏk [Szilágycseh; CU].

7. serdülő 1770: az Szimion nagyobbacska fiát is Peteléb(e) vitték [Nagyercse MT; Told. 3a].

II. fn 1. nagyobb/felsőbb osztályba járó tanuló 1797: Az gyermekek oskolába járjanak ... Az oskolamester ... szorgalmatosan tanitsa olvasásra, írásra, arithmetikára, szent historiára, a keresztyén vallásnak ágazataira, geografiára, erkölcsi tudományra, éneklésre, s a nagyobbacskákat a deáki tudománynak kezdeteire [Hsz; Csetrí Kőrösi Csoma 43 esp. rend.]. 
2. ja egynemű dolgok közül a nagyobbak 1705: Vagyon elegjes jo féle győngj az nagjobbacskaja 68. az az aprobb 220 [Kv; Pk 6].

nagyobbadka nagyocska 1644/1648 k.: egy Veres scarlat szűniegh nagiobbatka [Born. XXXVIII. 14]; 1692: Apro Tekenŏ no. 4 nagyobbatka. no. 2 [Mezőbodon TA; BK Inv. 13].

nagyocska I. $m n$ 1. nagyobbacska; A. bútorzatra, berendezési tárgyakra von. 1733: (A) Bástyában vagyon edgy nagyoczka fejér láda [Marossztkirály AF; Told. 25]; 1737: Egy rosz regi negy szegú nagyotska lada [Told. 19]; 1763: Egy nagyotska Tükör in fl. $6[\mathrm{Kv}$; TJk XVII/1. 13 Polykter István hagy.]; 1789: Egy Nagyatska sima Tŭkŏr, fekete arannyas rámába foglalva $[\mathrm{Mv}$; ConscrAp. 5]; 1816: Egy viseltes avatég Fenyŏ Fa Nagyotska Láda [Mv; MvLev.]; 1817: Egy Fenyöfa nagyotska Asztal [Mv; MvLev.].

B. edénynemüre, (házi) használati tárgyakra von. 1730: egy nagyocska So tarto [Kv; Ks 15. LVIII. 6]; 1742: Egj nagjotska réz Mosár [Pókafva AF; JHb XXV/58]; 1781: egy nagyotska tsengetyü [Szentdemeter U; Told. 18]; 1789: Bor innya valo arannyas talpos Kristálly nagyotska poharok [Mv; ConscrAp. 4]; 1798: szilva iz főző Nagjotska üst [Kv; Pk 6 Rázmány Hedviga hagy.]; 1801: Két jó nagyotska Kávé pergelŏ Serpenyŏk [LLt 106/1]; 1808: letévén Mátl József mester és Fekete Farkas mester a magok kövedző márjásaikat a békövedzésre ... csináljanak egy lábost, jó nagyocskát fedővel [DFaz. 34]; $1850 \mathrm{k}$.: 1 talpas mettzett pohár nagyocska $[\mathrm{Kv}$; Pk 2].

Szk: dézsa 1732: Találtunk ... hát nagjocska désát [Kv; Ks 40. XXVIIIc]; 1822: egy nagyotska Desa [CsS] * fakompona 1817: Egy Dohány mérö nagyotska fa Kompona [Mv; MvLev. 2] * fatányér 1817: Égy nagyotska Fa Tángyér [Mv; MvLev. 2] * serpenyő XIX. sz. eleje: Egy nagyatska serpenyö [Öraljaboldogfva H; KCsl 5] * tál 1765: Nagyotska tál 6 Aprobb Tál 5 [Ispánlaka AF; JHb XXVIII/8] * üst 1817: Egy Nagyotska lábas üst 12 Rf 40 xr [Varsolc Sz; Born. IV. 41].
C. ékszerre, díszítésre von. 1813: (A) keszkenő ... négy szegeletin négy jukatos nagyotska virágok [Asszonynépe AF; UnVJk]; 1817: Égy nagyotska ezüst, Füles pikkely Gomb [Mv; MvLev. 2]; 1823: Két sor, nagyotska szemekböl állo kláris [LLt Csáky-per 601. L. 1]; 1827: Egy nagyatska arany csiga [DLt kv-i nyomt. kl].

Szk: jóféle gyöngy 1713: Egy elő párta aranybol, 29 szem nagyocska jo féle gyongy rajta [WassLt id. Wass Györgyne Nemes Mária hagy.]; 1733: egy szem jo fele nagyocska győny (!) [Cssz; Borb. I] * rubint 1750: Vagyon egy öreg boglar, az mellyben vagyon egy nagjotska Rubint [WassLt Wass Danielné ékszerei közt]; 1758: Egy Gyémántos, Rubintos, és győngyős Medály, melyben vagyon ... nagyotska Rubint 8 [Nsz; TSb 21]; 1786: Egy reszkető tő két gyémántotska benne ... kőzepibe egy nagyotska rubint [Nsz; Ks $74 / 56]$.

D. szerszámra von. 1840: két fŭrész nagyatskák [Dés; DLt 1039].

2. meglehetősen nagy 1766/1770: a' Küküllőn lévő revünken Széplakra Bonyha felől menet, hatsak valamenyére nagyotska gabonáinkal meg terheltetett szekereinkel nem járhatunk [Széplak KK; SLt évr. Transm. 258]; 1784: kicsin haranglábocskájok helyibe újat és nagyobbat is kivánnak épitteni ... (minthogy harangot is egyet ugyan szépet és nagyocskát vettenek) [Kőrispatak U; ETF 107. 34].

3. kissé hosszú 1801: A' Páltzát vettem Sombori által - nagyotska, de ha lehet elébb adok rajta, mert ŏtsém Uram(na)k még inkább nem való minthogy nem éppen modi az illyen nagy páltza [Kv; SLt 17 P. Horváth Miklós öccséhez].

4. meglehetősen kiterjedt 1789: (A) Szénafüvek Sumájába nagyotskának láttzik [Majos MT; Told. 26/33]; 1823: két vagy három Szekérnyi termésü hellyet foglal magában azon Rét, mert nagyotska darabb Föld [Bh; HG Eszterházi-perek].

5. magasocska 1766/1770: a' viz ellenében ... minthogj az alja kővetses volt, és a' Bonyha felől valo nagjotska Martrol a' gyengébb vagy kissebb vizben kőnyebben ki kaphatott a' Szekér [Széplak KK; SLt 
évr. Transm. 366]; 1807: egy jo nagyatska Barázdának felső és also széllyein [M.fenes K; KLev.].

6. meglehetősen bővizü 1770: a mikor oculáltatott ezen Királyfalvi ... malom a Küküllő nem szállott volt ugy meg mint most, hanem a Küküllő még nagyacska volt, ugy hogy cir(citer) Lehetett fél árjában [Királyfva KK; JHb LXVII/96]; 1772: kitsin Vizben az irt két also kerekek alig alig vánszargattanak is, de nagjocska vizben tellyességgel edgjet sem fordultak [Ádámos KK; JHb LXVII/2. 338]; 1773: a császár ... a Szamoson általcsapatott, de nagyocska lévén a Szamos, megmerült a szekere, melyért nagyon indignálódott [RettE 302]; 1810: Egy nagyotska patak, vagyis follyo Viz keresztúl megyen a' Falunn és határonn [Doboka; Ks 76 Conscr. 197].

Szk: árjában van 1806: mikor a' Vizek Nagyotska árjokban vagynak ... veszedelem nélkŭlt el nem mehetven meg gatoltatnak [Radnótfája MT; Born. XVI Tordai György (34) lib vall.].

7. megelehetősen széles; Szk: karimájú 1703: az ki penig az kalapot veszi, nagyotska karimajut vegyen [Ks 96 Kornis István feleségéhez].

8. kissé túl hosszúra növesztett 1704: Pekri uram hajszín köntösben volt, fekete süveg a fejében, és a szakálla is nagyocska [WIN I, 125].

9. kissé (túl) nagy 1774: Nemes Judit ... szép termetü, kisded, hanem a két felső fogai elöl nagyocskák voltak [RettE 326]; 1823-1830: (A leány) nem is volt dísztelen személy, csak egy kisség nagyocska orra volt [FogE 285]; 1827: Hosa István ... feje nagyotska [DLt 37 nyomt. kl]; 1843: seregély szürke paripa csitkó-feje nagyocska [Dés; DLt 85].

Szk: orrú 1813: Gros Julis Katonáné ... nagyotska orru [DLt 63 nyomt. kl]; 1815: Arko Antal ... nagyotska tompa orru [DLt 950 nyomt. kl]; 1829: Kereszter György ... nagyotska orru [DLt 505 nyomt. kl] * szájú 1846: Müller Vincze ... nagyocska száju [DLt 1114 nyomt. kl]; 1848: Páskuly György ... nagyocska száju [KLev.] * szarvú 1757: Egy Bogyán nagyotska szarvu kik
9 es(zten)dŏs tavallyi és idei ünő borjaival [Mezőpagocsa MT; Berz. 3. I/9].

10. elég jól fejlett 1815: Pujka Fiu nagyotska 12 [Majos MT; Told. 35].

11. eléggé magas növésü 1800: Gautieur Friedrich August, Komoediás, nagyotska Személy [Dés; DLt nyomt. kl].

12. serdülő 1782: egy Kalotaszegi, Monostori nagyotska Léányt ... tartván maga Házánál [Koronka MT; Told. 20].

II. fn meglehetősen nagy dolog 1792: Etzetes Általagok, mellyek égy Nagyotskán kivül mind kissebbek [CU].

nagyocskaszerü nagyobbfajta 1791: Egy nagyotska szerŭ Kávé ŏrlŏ avatég [Mv; MvLev.].

nehezecskén 1. üggyel-bajjal, döcögve 1790: A' Szarvas Marhák itt mostis dŏglenek, és tilalom alatt vagyunk ... melly miá az ott valo oeconomia nehezetskén foly [Sztrézakercesora F; TL. Wesselényi Dániel gr. Teleki Józsefhez].

2. kínosan 1755: Klmes Asz(onyo)m eo Excellya ... egyedúl lévén, mostanáb(an) ide bé, nehezetskén tőlti idejit [Ks 96 Baló Antal lev. Nsz-ből].

nehezedke sutácska, ügyetlenke 1796: Zsuzsi Urnaptol fogva a Gyapot mivelésel bajlodik, de nehezetke a' keze, hanem idǒvel tsak meg tanul [IB. Molnár György héderfáji ref. pap lev.].

népecske kis tömeg, csoportosulás 1710 k.: (Audenciakor) A házában ... egy darab által volt rekesztve ... aranyos fa orsókkal, övig ... ő azon belől állott ... a rekesszel ellenben seregel a sok supplicans ... aki mikor érkezett ... aszerént szólították, és elément a rekeszen belöl; ki csak supplicatiót adott s elment, némely ... beszéllett is, de nem igen nagyon, úgy hogy az ... ott jelenlévő népecske nem hallotta [BÖn. 593-4].

nótáriusocska (jelentéktelen) jegyzőcske 1773: Gr. Bánffi Dénes tudna az igaz, de az is nagyon fractus: mely szerént tudom aféle nótáriusocskákkal, procuratorocskákkal fogják kipótolni a fogyatkozást, az aféle pedig maga ellen nem ír [RettE 304]. 
nőcske nőstényke 1884: Tavaszi Józsinak meghalt a felesége. Március végén új aszszonyt visz a házhoz ... (Zárjel közt ide írom, hogy a tavaly a fecském elvesztette a feleségét, amelyikkel együtt rakták a fészket, egy hét múlva más nőcskét hozott a házacskába) [PLev. 110 Petelei István Jakab Ödönhöz].

nyáraska kis nyárfaerdő 1800: A Nyáraska (sz) ... szomszédgya égy felŏl ... az ŏ Natsága allodialis erdeje [Jedd MT; EHA].

nyársacska kis hússütő nyárs 1750: egj vas kalány, vas fogó s egj kis Nyársotska [Szamosfva K; JHbK LVIII/4. 2]; 1787: Egy hoszszúkó füles csésze ... Egy csésze alá való tangyérocska ... Egy Nyársottska [Kv; Ks 73/55 Oszt. 110]; 1787/1788: Egy Nyársotska [Kv; Ks 88 Oszt. 126].

nyelecske kis nyél 1714: Kristalyomos Kalán, meg aranyozott ezüst nyeletskével Türkes kövötskekkel ki rakott [AH 18].

nyelvecske kis nyelv 1759: az nap kezdett gyengén észre venni az Gyermeknek nyelvecskéin szájánis hasanlo mozgást, ugyan tsak ezek mellett az gyenge étkecskéit meg ette, mulatott, jádzott [M.csesztve AF; Ks Mikes Antal lev.].

nyelvesecske meglehetősen nyelves 1794: Muntyan Gligort jol esmérem ... éppen távol vagyon attol, hogy roszra valo hajlandoság volna ö benne, hanem minthogy Szomszédjai is Nyelvesetskék, az Felesége pedig Annál nagyobb Ördög, nem enged ö senkinek [Déva; Ks].

nyergecske kis nyereg 1688: Egy kis olah nyergecske pusztán, nintsen semmj szerszam rajta [Beszt.; Ks S. Misc. 27].

nyersecskén meglehetős gorombán 1855: Én se kértem ... nyersecskén nyilatkozni [ÚjfE 283].

nyilacska 1. (közföldből kiosztott) nyílföldecske 1635: Ezekbe(n) senkinek Eóreókeós feölde nem volt, hanem ez falu forgo Nyla vala ... Tudom ... az eok Nilaczkayokot, az többit nem tudom [Kál MT; Berz. 2. 40/82]; 1680: az Karolyb(an) vagjo(n) egj kaszálo rét ... az Lokőtő helj előt valo nyilakb(an) is egj nyilaczka [Backamadaras MT; Ks 15. XLVI. 15]; 1692: Az Vizelben egy Nyilatska Mester szamára valo
[Várfva TA; EHA]; 1730 k.: A Kozma kerte vigibe a Kutnál egy nyilatska [Pinárd MT; MMatr. 432]; 1751: égy darabotska hely Harmintz nyilotskákra valo capit Metr circiter 60 [Nagyercse MT; Told. 36]; 1775: a Járai Vŏlgybe ... a' Kis András ... Nyilatskája [Telek MT; TGsz 59]; 1777: három Nyilotska a verő fényb(en) [Bos MT; Berz. 15. XXXIV/16]; 1802: Kaszálok ... Szŏllŏk alatt a Karolyi Delniczék kŏzt 3 Nyilatska [Bürkös NK; RLt 1]; 1807: Vóltanak még ... néhai Mlgs Szalkai Antal Urnak résziben jutott öt nova Sessioi, vagy-is nyilatskái [Mezőbánd MT; TSb 47]; 1809: Vagyon a' Falunak kŏzŏnséges osztatlan hellye ... mindenik Colonus kapott belŏlle egy két vékára valo Nyilatskát [Csicsógyörgyfva SzD; Ks 76/56 Conscr. 83]; 1834: A kintsesi Veszszős Erdőből adtam el 4 Nyilatskát [Hosszúaszó KK; Born. F. 1a Bod Péter tt lev.].

Hn. 1748: Ugyanabban a Lábban egy nyilatska (k) [Udvarfva MT; Told. 79]; 1794: a' Hideg Vólgyben ... az Aprobb Nyila kőzőtt egy nyilatska (k) [Mezőbánd MT; EHA]; 1803: A' Bakotsban égy Nyilatska (sz) [Csókfva MT; EHA]; 1816: egy kŭs Nyilatska a' Bŭdŏs kutnál (k) [Iszló MT; EHA]; 1834: A' Nyilatskában [Gombás AF; EHA].

Szk: fertálynyi 1760: azon Josika és Szilvási részekre sorte divisionaria esendö Fertállynyi nyilatskat ... az őtódik Atyafinak cedálak [Runk TA; Ks 89 Vall.] * kicsi/ kis 1788: a' Hallogosban egy kis nyilatska [Melegföldvár SzD; SLt XLI]; 1803: Különős erdeit ... a Tekintetes Exponens Aszszonynak ezen az határon tsak a' Magos Sármás nevezetü helyb(en) levő kitsi nyilatskáját tudom [Berekeresztúr MT; BetLt 5 Mart. Sinka (50) ns vall.]; 1803: Az Ugy Neveztetett Bakots rétin égy küs Nyilatska [Csókfva MT; EHA] * pázsitos 1702: Pasitos nyilocska [Fejér m.; Kath] * törökbúzás 1797: egy Tőrők buzás Nyilatska [Balavásár KK; Hr].

2. vhány nyilacskányi (vmilyen) földterület XVIII. sz. köz.: Puszta Erdeje egj nyilacska [Udvarfva MT; Told. 18]; 1761: (Az erdő) a patakra megyen véggel tsak apro bokros tsere fákbol állo és kitsin helyen 
fekŭvŏ egj Nyilatska [Pókafva AF; JHbK LXVIII/1. 724]; 1818: égy Kis nyilatska Csere bokros erdő [Jedd MT; LLt].

Szk: erdő 1757: égy égy nyilatska Erdő [Mezőcsávás MT; Hr 6/26]; 1761: egy nyilatska erdŏ ès kaszállo [Szava KK; Lészai lev. V. 27]; 1815: edgy Nyilatska Erdejét ... meg jártuk [Kissáros KK; DLev. 2. XI A. 14]; 1828: vettünk meg ... a Vŏltsi ${ }^{a}$ Határon ugy nevezett fundu Szekerilor neuŭ Tábla erdŏbŏl égy nyilatska erdŏt [ELt. - aSzD]; 1832: Három nyilatska Erdŏk [Etéd U; NkF]; 1860: egy nyilatska erdö ... a' Budai lakosoknak el van adva [Szomordok K; BetLt 2] * fuszulykaföld 1774: egy nyilatska fuszujka fŏld [Aranyosgerend TA; $\mathrm{UC}]^{*}$ fü 1648: Az Patak foliasban Egy Nylaczka fü [Berkes TA; Berz. LXIV/11] * kaszáló 1774: nyilatska kaszállo [T; CU]; 1792: A Patákon tul a' Szegény Szérb(en) egy nyilotska kászálo [Náznánfva MT; EHA]; 1807: Egy Nyilotska ... kaszaloja [Mikháza MT; Sár.] * kaszálórét 1787: egy nyilatska kaszalo réttye [Kibéd MT; NkF] * kenderföld 1811: vagyon égy nyilatska kender Fŏld [M.gyerőmonostor K; HG Conscr. 308] * szántóföld 1721: Az also vŏlgy fŏn egy nyilacska szanto fŏld [Körispatak Hsz; Told. 19] * szénafú 1678/1741: A somodi Erdo alatt ... egy kis njilotska szena fŭ [Nagylak AF; DobLev. I/27a]; 1782: adott a Toháti egy Nyilatska Szénafüvet [A.detrehem TA; Born. IX. 52 David Nemes (56) ns vall.]; 1842: vagyon két nyilatska Széna fŭvem [Kv; Pk 3] * szőlő 1828: A Falu szŏlŏ hegyében ... égy Nyilatska szölöje [Mohaly SzD; WassLt]; 1847: ezen vitzinált hellyet Kontz János ifju Legeny ... által adá ... Vas Jánosnak örökös Cserébe mellyért Vas János is ada ... egy Küs nyilatska Szöllöt [Bözöd U; Borb. II].

nyílföldecske kisebb nyilas föld 1651: egy küs darab nyl foldeczke [Vadad MT; Berz. 11. 84/4]; 1743: Az Mikosban két nyil földecske, édgy más mellett [Sajósztandrás SzD; JHb XXIX/16]; 1752: a' Falubol rákos patakban le follyo patakb(an) rug veggel égy nyil földetske [Komjátszeg TA; EHA]; 1778: ada eő Kegyelme Zálogba ... Szánto Sándor Ur(amna)k ... három kis darabots- ka nyil füvetskéket [O.déllő TA; DobLev. III/522].

nyomorúcska soványka, véznácska 1768: azon Csikkot mikor edgyüt teleltünk volt tavasz felt be hozták Moldovába meg pokrotzal takarták volt bé hogy Nyomorutska volt [Kovászna Hsz; SzentkGy Stojka Ráduly (40) zs vall.].

nyomósocska nyomatékos, határozott 1816 : méltoztassék Kedves Sogor Vr ... ezen kérdezett környülállásoknak közelvalo 's immediatus tudoja lévén ... nékem egy nyomosotska Utasitó Informatiot kúldeni [Kv; DobLEv. V/1000 N. Sz. Szigethi György lev.].

nyoszolyácska ágyacska 1694: Ebben az hazba(n) va(gyo)n egy nyoszolyacska labostol es egy sing vason allo zőld mazu kemenczeje [Kővár Szt; JHb Inv.].

nyugodalmacska nyugalmacska, kevéske nyugalom 1779: hogy nekem is Excellentiád kegyelmessége után nyugodalmatskám lehessen ... azon Fundust instálom [Déva; Ks 73. IV. 59]; 1811: Körül keritik a' kitsin udvarotskát, Rajtok a' sétáló kap nyugodalmotskát [ÁrÉ 106].

nyulacska kis nyúl 1705: Ma voltam kinn nyulászni Disznód felé lovon ... egy nyulacskát is fogatánk [WIN I, 114]; 1750: ezen Talyigán két Zsák szárnyas majorságnak valo buza rostaalyát kŭldöttem bé, Holnapi Napra penig, őtt Csirkécskét, két Pipét, két ifju Nyulacskát és ez oráig Anynyát szopo két kis Báránykát [O.csesztve AF; Ks 83 Szabó István lev.].

nyusztocska kis nyusztprém 1743: Egy Rokas Téli Súveg. Egy Nusztotska [O.fenes K; JHbK XXIX/28].

óborocska 1595: Biro Wram Adot egy Oh Boroczkat: 50: vedrest ... Eyttelet p(er) d 6 ... f 22 [Kv; Szám. 6/XVIIa. 219]; 1748: Idai Ujj hegjben termet o Borotska Vas. 1 urnar. 07 [Koronka MT; Told. 11/95].

odrocskájú kis odorral ellátott 1722: egy közönséges két odrocskáju Csür [HSzj odor al.].

odvasocska meglehetősen odvas 1769/1802: Buda Juonnez ... egy felett (!) Udvasotska nagy bủk fában mutatott régi kereszt formát [Torda; TJkT III. 19]. 
officiumocska tisztségecske 1741: pro Harmonia Christiana, azt cselekütt, az ŏ kglmek $^{\mathrm{a}} \mathrm{p}$ (rae)tensiojok felett, hogj 'e szegény Városb(an) lévö Officiumocskákra ... Catholicus atyánkfiait admittaltuk [Dés;

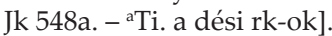

oklocska aklocska, (állattartó) szálláshelyecske 1767: egy kis oklocskában tartván ${ }^{a}$ [Mocs K; HG. Eszterházy lev. - 'A marhákat]; 1767: Mokányokkal hajtották béa ... egy szoros Kis oklocskában [Mocs K; HG. Eszterházy lev. - ${ }^{\mathrm{a} A}$ marhákat].

ólacska 1. gazdasági építményecske (háziállatok számára) 1743: Kriszta Iuon Teleke féle Puszta ... Ebbúl ... Toma Ignat elfoglalt volt, es oklot, s valami olatskátis épitett rá [Kincsi KK; SLt 8. K. 15]; 1746: Gabonás mellett két felöl vagjan Sővényből font s a kettő Négy Szakaszokra osztott, szalmával fedett Olacskák Kiknekis ketteje Szárnyas Majorság, ketteje jo Sertések számakra csináltattak [Ádámos KK; Ks 23. XXIIb]; 1753: Mindenféle Pajták, Csŭrŏs kertb(en) levŏ szinecske hizó ól és illyen ehez hasonló aprólek accidentiák mint a kapun kivüllis egj olacska [M.nádas K; RLt].

2. disznópajtácska 1729: Szurdokonis az Malomház mellet Csináltattam 3 sertes(ne)k valo oloczkát [Ruszkova Mm; TK1 Zólyomi János Teleki Pálhoz]; 1775: Rűdeg sertés hitván olotska [Kisillye MT; LLt].

Szk: lábas 1717: Ezek(ne)k az Istállok(na) $\mathrm{k}$ hátok meget ... vagjon ... egj kis udvarocska, mellyen vagjon két lábas olocska, edgjikben mostan van két kövér Sertés [Abafája MT; JHbK XXXIV/20. 7].

3. baromfiketrececske/ólacska1694:Vagjon ... Ennek vegib(en) egj rendib(en) ragasztatott, hasonlo Barona fákbol fel rotatott, Tjukok(na)k, Ludak(na)k, Réttzek(ne)k és egjeb apro majorsagok(na)k valo Olatskak is [Kisenyed AF; BfR néhai ifj. Bálpataki János urb.]; 1697: Ez Udvaron ... Vad(na) k szarnyas majorsag(na)k valo olacskák [Borberek AF; Mk Alvinczi Péter inv. 6]; 1741: A major ház véginél majorság(na)k sŏvénybŏl font négy szakaszu ollotskák majorság lud egy egyikb(en) 13 [Mezőbánd MT; LLt 146. B]; 1753: vagyon még ezen Circulusban egy Majorságnak való olotska [Karácsonfva AF; Told. 18].

Szk: lúdhizlaló 1636: E mellet egy lud hizlalo olaczka szalmas, egy aytoczka rajta [Siménfva U; JHb Inv.] * majorság hizlaló 1750: (Az) épület ... végibe ... majorság hizlalo két Rekeszbe lévő kis olacskák vagynak [Papolc Hsz; Hr]; 1809: egy majorság hizlalo olacska [Torda; KW] * majorság 1767: Majorság Olacska [Csapó KK; Berz. 3. 7. C. 6].

olcsóbbacska vmennyicskére olcsóbb 1739: Mlgs Gróff Fő- Ispán Urunk ő Ngának igért 50. Köböl Zabn(a)k penzen lejendö meg-vétettetésére, mig ólcsobbacska lészen a' zab, facultáltatik Hadnagj atyánkfia ő kglme [Dés; Jk 523a].

olcsócska az olcsónál is olcsóbb 1785: ez előtt ... oltsotska volt a rosz bor, de a millyen szúkség volt az idén ezen a fŏldŏn felejtették inya a parasztok $s$ még másokis [Bencenc H; BK. Bara Ferenc lev.].

oldalacska (lejtős) hegy/domboldalacska 1640: mentwnk ... egi oldaloczikara [Nyárádsztlászló MT; Sár.]; 1657: Az sereget ... rendben állítván magam felnyargalék egy oldalocskára [KemÖn. 203]; 1741: az Kornis rész kaszalonak felsö szeliben lévö oldalacskát ... dézmálta volt [Velkér TA; Ks]; 1745: A Kis Tekenyŏsben ... vicinussi egy felŏl mellette fekŭvŏ Falu kŏzŏnséges Erdellye, vagyis nagy bokros óldalotskája [Koronka MT; Told. 26]; 1746: (A méta) ŭtkŏzik ... Tziheres, bokros óldalocskáb(an) [Nagyida K; Told. 9]; 1751: A' Tsür helly nevezetü gődrős helly mind két felől mellette lévő erdős két óldalotskákkal együtt, azon két eletskéknek küzepéig hoszszára gondoltatván, keresztül két egyenlő részekre szakadott [Koronka MT; Told. 31/4]; 1767: haszantalan Semmire kellő forrásos oldalatskájak ... oldalos forrásos Sessiocska [Vajdasztiván MT; LLt Fasc. 129]; 1807: Dsiszán ... el foglalta a' fellyebb ki szomszédolt oldalacskát és magának réa szőlőt épített [Kersec H].

oldalasacska meredekecske 1767: a hoszszu lábban oldalasatska, de alkalmas jóságu helyen [Dányán KK; LLt Fasc. 129]; 1767: a hágoban oldalasacska ugyan, de jó ga- 
bonát termő helyen [Pócsfva KK; LLt Fasc. 129].

oldalbástyácska szélső bástyácska 1694: Az Kapun belől Balkez felől egj oldal Bastyacska va(gyo)n [Kővár Szt; JHb Inv.].

oldalföldecske lejtős/meredek földdarabocska 1694/1764: A Tőrvény fánál valo oldal főldetske [Abafája MT; EHA].

oldalházacska oldalszobácska 1725: Nehai $\mathrm{Ne}(\mathrm{me}) \mathrm{s}$ Szathmári Szabo János Ur(am) decessusa után ... gyermekire ... maradván eö kglmekre mind ketten itt $\mathrm{N}$ Enyeden ... edgy fedélnélkül valo romlondo kö házak egy oldal kamarácskával, egy oldal kis házacskával [Ne; DobLev. I/115]; 1742: Ezen Aszszony házából ugjan Eszakra, az Udvar felŏl keskeny hoszszu oldal házotska nyulik, mely keskeny ház kis Aszszony Házának tartatik [Gyeke K; Ks 4. VII. 1].

oldalka domboldalocska Hn. 1795: A' meleg oldalka [Szénaverős KK; EHA].

oldalkamarácska 1638: Az masik szobarais nilik hasonlo aito ... Ebböl nilik eggj oldal kamoraczkara egj felszer fa sarku aitŏ Benne vagjon az major eggjetmasa [A.porumbák F; UF I, 663]; 1656: az hatulso hazbolis nyilik más egy oldal kamaraczkara egy Ajto mellik [Doboka; Mk Inv. 4]; 1725: Nehai Ne(me)s Szathmári Szabo Janos $\operatorname{Ur}(\mathrm{am})$ decessusa után ... gyermekire ... maradván ... edgy fedélnélkűl valo romlando kö házak egy oldal kamarácskával [Ne; DobLev. I/115]; 1729: Vagyon egy szep proportioju rakó fabol epült házocska mellette lévő oldal kamarácskájával edgyütt [Buza SzD; JHbK V/2]; 1729: (A) két ház mellet két oldal kamarácska [Buza SzD; JHbK V/2]; 1732: Az ... Aszszony hazabol egj keskeny ... ajtotskan jarnak be az oldal kamaratskab(an) [Nagyida K; Told. 11/70]; 1732: az oldal kamaratskab(an) ... aprosag egjet mas conservaltatik [Nagyida K; Told. 11/70]; 1748: A' Sz. Jakabi udvarhazok háta meget van egj oldal kamarátska [Told. 11/95].

oldalszobácska 1830: Nyillik ezen szobábol égy ... ajto ... a hátulso oldal Szobátskába [Kv; Somb. II]. olló-bőröcske kecskegida-bőröcske 1706: Harom semmire kellŏ juh bŏr, kecske bŏr no 9 ollo bŏrecske no 2 [Görgény MT; Born. G. VII. 4].

ollócska 1671: Ket Aranyos oloczkakert egy forint [Gyf; UtI]; 1675: adtam az varróládába, az mátkájának elküldte ... két aranyos tallért ... másfél forint ópénzt ... egy ezüst mellfüzőt, egy ollócskát, egyéb dibdábot is [Kv; KvE 195 LJ]; 1692/1737: nékemis István Deák $\operatorname{Vr}(\mathrm{am})$ nevű Deákja ajándékozott papiros nyirő formáson ezüstbŏl kivert olocskát ... mely olotskát Tőkőlyi Imre Vram(na)k eŏ Nganak ajándekoztam [Szilágycseh/Nsz; EMLt Simeon Furenda Literati kezével]; 1775: 2 rosz aczel s egy ollótska [Déva; Ks 76. IX. 18 I/4].

ollótartó ládácska 1792: Gyüszö s' ollo tarto ládátska [TL Conscr.].

oltárocska 1732: Ezen kápolnában találunk, egj kicsinj arannjos oltárocskát, és erre függesztett aprolék pergament (!) ŭvegbe foglalt, aranyos rámás képeket tizennégyet, három ŭvegbe foglalt más képeket irottakot [Kv; Ks 40. XXVIIIc néhai gr. Kornis Zsigmond kv-i házának conscr.].

ón-gyertyatartócska 1732: Két ón magos Gyertya tartocska koppantoval vassal [Kv; Ks 31 Kornis Zsigmond lelt.].

ónkannácska ónból készült kannácska 1574: Kalara az nehay Hegedws Mathene ... vallia ... kyt $\mathrm{k}^{\mathrm{a}}$ eo ely adot es egy on kannachkat veot az arrawal [Kv; TJk III/3. 347. - ${ }^{\text {aEgy }}$ kristálypoharat]; 1747 e.: Tiszteletes Bölöni Sigmond Ur(am) adot a Böia Templom számára egj on kannácskát mint egj fertalyos [MMatr. 264. - ${ }^{\mathrm{a} M T}$ ]; 1797: Van egy Onn Kannacska [Nyárádsztlászló MT; MMatr. 106].

Szk: fedeles 1693: Mihoknak ... Egy fedeles ón kannácska [Ne; DobLev. I/38. 10]; 1736/1770 k.: Egy kis fedeles ón Kannátska Keresztelésre való [Hesdát SzD; SzConscr. 184] * keresztelő 1643: égy keresztelő ón kannátska [Sóvárad MT; MMatr. 207]; 1643/1687 k.: édgy keresztelő ón kannatska [Szentimre MT; MMatr. 234]; 1722: egj on tángjér egy keresztelő ón kannátska [Nagyercse MT; Told. 36]; 1728: Edgj keresztelő on kannatska [Angyalos Hsz; 
SVJk]; 1749: Egy keresztelő on kannátska [Kökös Hsz; SVJk].

ónkehelyecske kis ónkehely 1728: Egj on kehelyetske Brassai Kis Gjŏgjne Collatuma [Gidófva Hsz; SVJk].

ónpalackocska 1634: Egy ohn palaszkoczka [Kv; RDL I. 105].

ónpoharacska 1690: adott a kozmási templomba két kis ón poharoczkát bornak és viznek misére [SzO VI, 425].

Szk: keresztelő 1732: Vagjon ... egi keresztelŏ on poharocska [Szotyor Hsz; SVJk].

óntálacska 1627: Egi kis ón Talachka egi fontt szukon f. - d. 25 [Kv; RDL I. 131]; 1636: Nagy Mihaly ... egy kis on táláczykatis adot válá [Mv; MvLt 291. 65b]; 1673: Hét apró on talacska [Fog.; UtI]; 1737: Egjb(en) járó ón tálacska [Brassó; ApLt 5 Apor Péter inv.]; 1743: Apro ugorká(na)k valo on Talacska 3 [O.fenes K; JHbK XXIX/28]; 1744: Edgy lyukas ón tálatska [Szentdemeter U; LLt Fasc. 67].

óntányérocska 1738/1770 k.: adtak ... az Ur Asztalához egy szép ezűst Pohárt ... és egy ón Tányérotskát [Buza SzD; SzConscr. 96]; 1745: egy kopott on tányérotska [Sárd KK; UnVJk 115].

opiniócska szerény vélemény 1656: Az mely kérdésekre penig nagyságod az én opiniocskámat kivánja, látja Isten szívemet úgy kivánom nagyságodnak minden dolgaiba való boldog előmenetelit ... mint az idvességemet [RákDiplÖ 452 Rédei Ferenc II. Rákóczi Györgyhöz Husztról].

órácska 1. kis óra 1724: Intzedi Gergely Uram vett ... egj bontakozott óráttskát [Koronka MT; CsS]; 1724: vettŭnk ki ... egy bontakozott orácskát [Koronka MT; Told. 29/15].

Szk: nyakbavetố 1629: Egy kis nyakbaueteö Oraczika aestimaltuk tt f $25[\mathrm{Kv}$; RDL I. 132] * zsebbéli 1818: által adott ... égy régi 'sebbéli orátskát [Mezőbánd MT; TSb 35].

2. kb egy órányi idő 1786 : alkanyadat után mint egy orátskával Házamhoz jöve a' Falubol három legény [KLev.].

órapárnácska 1842: Csengettyű három rézbŏl valok, két párnátskával ... égj ora párnátska [Dés; Újf. 3 Újfalvi György hagy.]. órás tornyocska óratornyocska 1679: Harang láb avagi orás Tornyoczka. Felljeb irt kapu felet valo haz mellet vagyo(n) gerendakbol fel czinalva; oldalai gjalult fenyŏ deszkaval boritott ... az fele jo sindelyes [Uzdisztpéter K; TL. Bajomi János inv. 7].

oratóriumocska 1. kápolnácska/kis imaház 1803: béis gyülekezék az Ecclésia maga Templomáb(a), vagyis Orátoriumotskájáb(a) [Szőkefva KK; UnVJk]; 1834: Egy orátoriumotskát akarván a' Szamosfalvi Ekklesiánkban épitteni [KLev.].

2. ? házioltár 1782: Egy Kis Oratoriumatska ${ }^{a}$ [Nalác H; CsS. - ${ }^{a} \mathrm{~A}$ faportékák közt].

ordatömlőcske orda tartására való tömlőcske 1688: 1687ben valo Nyaron az Bucsumi határon holt meg Milliora Nō 1. Mely milliora(na)k bŏrit orda Tŏmlŏcske(ne)k csinálták [Bucsum F; MvRKLev.].

ormocska (domb)élecske 1718/XIX. sz. eleje: az oldalban lévŏ két ormocskán [Becski]; 1746: a describalt helység felsŏ oldalának vicinussa házának kapujanak also részitŏl fogva, egj essŏ csinálta árkacskán alol lévŏ kis Ormocskán le a fen álo kert Szegeleteig ... volt is valami kis káposztás kertecskéje [Monor BN; Ks 7. XX. 19].

ostáblácska kockajáték-táblácska 1804: Egy os-táblátska [Borosbenedek AF; SLev.].

ostorocska 1714: ostorocska ... arany s ezüst skofiummal boritott s aranj scofium apro gjöngjekkel ki rakot gombotskaval ekesitett fl. Hung 30 [AH 36].

oszlopocska 1850: a kissebb Lo Istáloba a Zablo hellyen vagyon a földbe ásva 3 kurta oszlopotska [Gyéressztkirály TA; DE 5].

osztovátácska 1793: egy prém szövö rosz osztovatatska [TL Conscr.].

otthonka háziruha XIX. sz. köz.: Küldök 14 Zsemlet ... a Marika rozsaszin otthonkáját hozzá valo darabakkal [BLt 11 Cserei Róza férjéhez, Béldi Alberthez]; 1859: M Ujfalvi Sándor Natsága Részére ... Egy Egy othonkát vásárolt $16 \mathrm{f}$ [Kv; Újf. 1].

öblöcske kis öböl 1777: Kretson Triful ... mingyárt mingyárt kapta fejszeit, és ide ezen a' bokros őblőtskén tul irtogatni kezdet 
[După Piatră H; GyK. Ádám Toma (70) jb vall.].

ökonómiácska 1. gazdaságocska 1743: mivel e nyári szoross idő s tsekély oeconomiatskánk lovainkot distrahállya, meltoztassék Nagysagtok egy szekér iránt parantsolni [Hatolyka Hsz; ApLt 5 Pótsa Lázár Apor Józsefhez]; 1775: Telék el az 1775-dik esztendő is. Istennek kegyelméből én reám s hozzám tartozóimra nézve tűrhető folyással ... Sőt mind oeconomiácskám, mind marhácskáim körül az ő szent felsége áldását tapasztaltam [RettE 361]; 1781: engedetlen Jobbágy embereim ... magokot nem jobbitották s szolgálatbeli restantiajokot szollitani nem igyekeztek sőt inkáb nevelték kitsin oeconomiatskam(na)k nagy hátra maradására s neveletlen árváimnak Nyilván valo károkra [BetLt 6].

2. kicsinyke/szerény gazdálkodás 1702: legyen kgld egy kis patientiával octoberig, mégh én-is kevés Oeconomiácskámat el végezem Novemberbe ... ā Capitalisrul-is contentalom [Ádámos KK; ApLt 5 Mikes Mihály Apor Péterhez]; 1757: A Gyogy vize mellyekin lévő Lakósokul mindnyájon Erdő hatságon nyomorgunk, Cultiválo Szanto és kászalo helyeinket erdőből kell írtás által tisztogatnunk, mely szerint ... ha ki mi kevés oeconomiatskát folytat, minden esztendőb(en) szűkségesen kívántatik hogy helyeit tisztogassa [Középalmás H; BK ad nro 144]; 1757: A mi Határunk erdős helyen fekszik, mindnyájunk(na)k irtás által kell segiteni mind szántó ugy kaszálo helyeinket kủlŏmb(en) oeconomiátskainkat nem folytathattyuk [Runksor H; BK ad nro 144].

ökörborjúcska 1757: Tavalyi de igen későn bornyuzott kitsin őkőr Bornyucskák egészségtelenek lévén dőglőtt meg ... Nro 2 [Kiskend KK; Ks 71/52 Szám.].

ökröcske kis ökör 1595: Jo eóchejm ket eòkrechket hizem adhattok tizen hat eŏkerbeól az gazda aszon(n)ak, de ne adgiatok az Joúaba, hane(m) adgiatok ket eókrechket [UszT 10/59]; 1604: Zola alard matene hog' uarna egj keueseg es meg agja mert hat ŏkrŏchykey uagjon es ha azt el uezj nem elhet el [UszT 20/207 farkas laky mihalj zent kiralj vall.]; 1708:
Kemecsei uram igen szegény-legény, négy ökröcskéje, vagy két tehene [SzZs 505]; 1748: vólt Ferenczi János Uram(na)k 6. ŏkrŏtskéje [Torda; Borb.]; 1757: két Ökrötskét vétettem Rhf. 20 xr. 20 [TL. Teleki Ádám költségnaplója 11a]; 1769: két őkrőtskét vet [Nagyercse MT; Told. 3a]; XIX. sz. eleje: Két rosz őkrőtském vagyon tsak [Zágor KK; Hr].

ölecske 1. egy négyszögölecskényi 1784: a nemes unitária religion lévő becsületes atyánkfiai megavult ... haranglábocskájok helyibe újat és nagyobbat is kivánnak épitteni ... avégre ... kértenek egy ölöcske földet pénzért a reformáta eklézsiától [Kőrispatak U; ETF 107. 34].

2. nyalábocskányi 1765: ő Naga emberei a Fejérvári Kristina Aszszony részében vágtanak vólt két vagy három őlecske vesszőt [Hosszútelke AF; JHb XXVII/25. 3]; 1817: A Gyogy viz meg Áradása Alkalmatosságával Lendvay kapitány Ur ... a gátbol embereivel Annyit le vétetett a mennyivel az exundatiotol a maga Udvarát és Csürit Securizálhassa ... azon Nyitott rést két Őletske vesz(sz)övel bè is lehetet csinálni [Algyógy H; Born. Vegyes X. 81 Zsuzsian Gavrila (40) vall.].

ölecskényi egy négyszögölecske nagyságú 1784: installunk az Urnakis hogy a sz: Eccla tsak egy ŏlŏtskeni szelessegŭt ${ }^{a}$ penzŭnkert adgyon [Kőrispatak U; Pf. ${ }^{\mathrm{a} T i}$. földet].

öregecske nagyocska 1685: Egy ŏregecske Réz ŭst [UtL]; 1713: Egy elŏ párta aranbol, rubintos, őregecske jo fele győngy kőzbe 13 boglárbol állo [WassLt id. Wass Györgyné Nemes Mária hagy.].

örökségecske birtokocska, jószágocska 1660: Sas Balasnenak egy Darab eöreöksegeczkeje, itt Szárhegyena, az Eőttsiuel, Orsolyaual Edgyütt [LLt Fasc. 152. - ${ }^{\mathrm{a} C s]}$; 1666: leven ... Fianak ... eggy pusztulasra jutott, ēs tőbbire sorvadolag veszŏ félben levő őrőksegetskeje Mező Bándon ... kerek ... Kovats Istva(n) Uramot, hogy ... venné meg az denotalt pusztulasra jutott, ès tőbbire sorvadolag veszŏ és dőlő félben levő örökseget [Mv; MbK]; 1737: itt Kémeren vagyon kevéss őrőkségecském [Kémer Sz; Ks 99]; 1756: ŏs Elejekrŏl deveniált 
ŏrŏkségetskét ... tserelte volt idegeneknek [Kibéd MT; NkF].

Szk: belső 1799: Sztán Mageránnak szakasztott ... Főldős Ura egy kis Belső őrőkségetskét [A.árpás F; TKl IV/5 sub BB].

ős-erdőcske vérségi felmenőktől törvényesen örökölt kis erdő 1750: a' Maros Vásárhelyi szálas Erdő kőzőtt fekvő allodialis öss Toldalagi Jusson forgó Erdőtskék [Koronka MT; EHA].

ősjószágocska ősöktől örökölt jószágocska/ birtokocska 1663: Egyébaránt is tudván Nagyságod az én igen elfogyatkozott állapotomat, minden kevés ős jószágocskámnak elveszését, legyen minden kegyelmességgel, had maradékim is érezhessék magokon Nagyságtok fejedelemségének hasznát [TML II, 591 Teleki Mihály Bornemisza Annához].

ösvényecske kis ösvény 1769/1802: Szakatura Burgyin alol egy ösvenyetske mellett lévő udvas fákban tanaltatott egy kereszt [BSz; JHb LXVII/3. 45].

ösvényke kis ösvény 1751/1753: a' Falu azon két ŏsvenyke nélkül kŏnnyen el lehet [Koronka MT; Told. 78].

őzecske őzike 1785 k.: Elég légyen ez néhány versecske; Néked írom te dali őzecske [EM XX. 501 Balás kódex. - A vén lány panasza].

őzollócska őzgidácska 1731: János Albert ... egy őz vagy Szarvas ollócskát vett volt [Gysz; LLt].

özvegyasszonyka 1758 k.: Lévén pedig Gyulatelkén egy özvegyasszonyka, Pekri Gábor leánya ${ }^{\mathrm{a}}$... elmentem nézésére [RettE

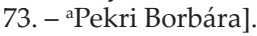

padlásocska 1702: Ezen kis Házból ... nyilik edgy ... oldal kamarára ... három fennyü gerendákbol állo s fennyŭ deszkával padolt padlásocskája vagyon [O.brettye $\mathrm{H}$; Born. XXIX. 4. 7].

padocska kis pad 1669: ezen léányok hazaban vagyon, égj kis padoczka [Királyhalma NK; Ks 67. 46. 24a]; 1736: Tüzhellyen allo padocska, egy kis üst rudacska [HSzj tüzelö-ház al.].

Szk: cseber alá való 1813: Kis Désátska 1 ... Egy tseber alá valo padotska 1 [Veresegyháza AF; Told. 18 Toldalagi Kata lelt.]
* fedeles 1809: Egy Kenyér tartó festett Fedeles Padotska [Mv; MvLev.] * tányérszárasztó 1788: Tángyér szarasto kis padatska [Mv; TSb 47].

padszékecske padformájú kisszék 1746: Vagyon Kis Pad Székecske ... A Palotán Kis pad székecske jeges vizet tartó 1 [Marossztkirály AF; Told. 14].

pajtácska 1. kisebb gazdasági épület 1581: Vegezte eo kegmek hogy az mely paytachykat Barbely Mihalnak engedet eó kegmek ... chyak durante beneplacito Ciuitatis ... legien eowe [Kv; TanJk V/3. 243b]; 1654: Hancz Janos ... Csüre fedetlen, haro(m) pajtacskaja oldala nelkül, fedelyeis mindenek(n)ek rosz [Kétely SzD; Ks Bánffy Anna urb.]; 1736: kis Sövényből font pajtátska [Bongárd $\mathrm{BN}$; $\mathrm{CU}$ ]; 1778: Hogy egyebet azon Ház kőrül épitettek vólna, egy egy Pajtátskánál, nem jut eszemben [Pósa SzD; Ks 34. VI. 1]; 1801: Edgy Pajtátska, veszszöböl font roszsz szalmás [TL]; 1805: A Káposztás kert kulsü bŭtŭjinél egy pajtátska [Makfva MT; DLev. 1. VIIIA. 29]; 1825: A' Serház Udvarának végében lévén egy kisded Pajtátska [Dés; Dlt 595].

2. istállócska, ólacska 1654: Rét György ... Egy Istaloja, Pajtácskaja [Szásznádas KK; Ks Bánffy Anna urb.]; 1753: jobb kézre a Sessionak Nap nyugati résziben találtatik egy Pajtácska Agasakra Sóvenybŏl font, jo szalma fedéll alatt Sővénybŏl fontt jászlaval együtt [Sajókeresztúr SzD; JHbK XXIX/7]; 1774: egy kis Pajtacskát, vagy is Istállot, az mely régen ház volt ad fh 2 ... aestimaltak [Kászonújfalu Cs; BCs]; 1786: A fejös Bihalyok(na)k ... az udvarba lévő egygyik istállot igazitottuk meg, a bornyaik(na)k pedig kŭlŏn jo pajtatskát banyalitottunk [Bencenc H; BK. Bara Ferenc lev.]; 1797: Cserefa ágasokra csinált Sŏvény oldalu pajtátska [Bözödújfalu U; Pf]; 1814: Zilahinénak ertében volt egy pajtácskája, melyben egy két Tehenet tartott [Dés; Ks 79. 29. 793].

Szk: hármas 1728: vagyon egy fedél alat harmos Pojtacskák harom Ajtokkal mellyek majorsagnak rendeltettek [Ludvég K; Told. 29/19] * két szakaszos 1803: sŏvénybŏl font két szakaszos Pajtátska 
[Csokfva MT; UnVJk 231] * majorságtartó 1812: Majorság tartó pajtátska [Sorostély AF; Born. XXXV. 66] * mezôségi 1783: Hátulsó Ház ... Valami alacson Mezöségi Pajtátska is vagyon mellette [Mocs $\mathrm{K} ; \mathrm{JHbK}$ XXXI/1. 13].

pakkocska kis csomag 1839: Dánielnének ezen pakotskát ... kérem, sietve juttassa át [Kv; Pk 7].

pakocs csomagocska 1850 k.: piskota, makaroni pakocsban [Pk 2].

palackocska 1. kis palack 1730: Egy szentelt Viznek valo Palaczkocska [Kv; Ks 15. LVIII. 6]; 1755: Fertályosnál kissebb kigyo köből faragott fedél nélkül egy palaczkocska [Szentdemeter U; LLt Fasc. 152].

Szk: hatszegletes 1754: Ezŭst Portékai ... Hat szegeletes Palatzkotskát Lot 50 konting 2 [Nsz; Told. 19].

2. vhány palackocskányi 1759: Dindár vram ... kéván pénzért egy butelia, vagy egy palatzkotska aszszu szőllő borát (!) [Déva; Ks 94. 24. 2].

3. lőportartó 1714: Egy körökös Kapszátskáb(an) foglaltatnak ... Porn(a)k való Palatzkotska fekete börrel boritott s meg aranjozott [AH 35]; 1759: szállittasson el ... Egy kis puska por hordozo kerek palatzkotskát [Sárd AF; TSb 51].

palánkocska deszkakerítésecske 1676: Ezen udvarnak ... bik fa kapuja és kétt felől az kapu mellett tőlgy fa sas fakban fenyü gerendakkal fel rott kétt darab palankocska desz(ka) [Fog.; UF II, 748].

palástocska kis palást 1710: Egy olajmagszín Lengyel palástocska [DanielAd. 90]; 1710: Egy hajszin atlasz palástocska [DanielAd. 96].

pálcácska 1. kis pálca 1599: az Vduaron faraczkal vala Deak Peter, egi palczachikat veon kezebe kj mene, de azt ne(m) latta(m) mjkor verthe [UszT 14/39]; 1654: Egi kis Palczaczika [Csapó KK; LLt 100. C]; 1714: Avram Csilye, Eszt monda en csak Evel az küs palczacskaval vagyok nem ugy jöttem hogy harczallyak, nem is vala nagy bott hanem csak Edgy küs palczaczka vala kezeben [Tamáspatak H; BK sub nro 261 Aramia Koszteszkuly (50) falusbíró vall.]; 1725: felem Jüvén eŏ kegjelme, egjéb nem vala eŏ Kegjelménél egj Pátzátskánál [M.köblös SzD; Becski]; 1748: Tasnádiné Aszszonyomot ... egy kis páltzátskával veri vala [F.karácsonfva KK; Told. 56]; 1761: Lupéj Vaszali őtőtis a' főldhőz tsapta, Blidár Gligoris oda jőtt, s kezéb(en) lévő páltzatzkával kétzer meg ütőtte Krisán Vonult, de el-választván őkőt egy mással meg békéllettek [Illyésfva Sz; BfR 45/9 Farkas Makari (46) zs vall.]; 1765: Varga György ... sokáig ment hátra kŏkkel, és ... Az keziben egy kis ujni pálczatska lévén azzal hadarázott maga elŏtt, oltalmazván magát [Szépkenyerüsztmárton SzD; Eszt-Mk Vall. 22]; 1796: Dáníel János István és ... Bálint Jánosnál vas villa volt a tőbbieknél egy egy páltsátska [Uzon Hsz; Kp IV. 288 Anna Nagy cons. Jos. Berbek (20) col. vall.].

Szk: vesszőszabású 1590: Lenart Vra(m) ... egy vekonj uezzeo zabasu palczaczkat hoza kj kezeben [Kv; TJk V/1. 3 Musnai Georgj vall.].

2. díszes (séta)botocska 1714: Paltzatska kigjo börrel boritott, ezüst almával, alsó részen ezüstel boritott fl. Hung. $6[\mathrm{AH}$ 37].

3. szk-ban: jának felemelitésével repellál 1766: Király Biro uram meg indula ... hogy bé menjen a kapun és a Deliberatumok szerint ... az Exponens Aszszonynak executioni mediante contentumot tehessen, de a kapun belŏl álván ... Bŏlŏni Ferentz nevŭ Udvari Birájok egy páltzátskájának melj keziben vala fel emelitésevel repellála [Msz; Ks 20. XIV].

pálcika kicsiny pálca 1584: Sos Jstwan ... wallia ... hallek kialtast ... Hatra tekintek es hat Dauid Ianos es Sardi Ianos Ieo vtanna(m) Ez zora kialtasra felele igy Sardi Ianos, Jhol Neste lelek Curwa fy lasd meg Minemeo palczika vagion en Nallam [Kv; TJk IV/1. 348]; 1629: ez az Andras sokat kesek borertt Uram megh uere egj palczikaval [Mv; MvLt 290. 156a]; 1647: latua(n) hogi balta va(gyo)n kezeben ugi mente(m) kj egi palczikaual, hogi jncziem hogi mennien tovab [Kv; TJk VIII/4. 236]; 1725: nem vala eŏ kegjelménél egjéb egj Páltzikánál [M.köblös SzD; Becski]; 1755: verni kezdék Lázár Jánost, akinékis csak 
egy kis palczika vala kezében [Ribice H; Ks 112 Vegyes ir.]; 1765: Varga Gyŏrgy ... kezében lévŏ kis ujjomni pálczikával maga elŏtt Czivészlett, hogy valamiképpen belé ne szaladgyon Szabaszlai Ur(am) és meg ne foghassa [Szépkenyerüsztmárton SzD; Eszt-Mk Vall. 13].

pálcikó pálcácska 1733: Bricz Stéphán főbe üte egj patzikoval Gligort [Szentmargita SzD; Ks 15. LXXVIII. 6]; 1749: Palffi Ferenc Uramnál égj kitsin Paczikot láttam [Tarcsafva U; Pf]; 1763: én nálla Sem láttam egy kis paczikonál egyebet a verekedéskor [Nagyida K; Told. 9]; 1765: az midŏn Varga Gyŏrgy az emlitett patzikoval hadarászot és hátra felé ment volna, Szabaszlai uram beléje szaladván, akkoron érte azon pálczával az karját egyszer [Szépkenyerüsztmárton SzD; Eszt-Mk Vall. 13]; 1783: égy sebet ejtven Kálo Miskán, egy Pátzikoval, mellyet kutya ŭtni vett volt kezéb(en) [Koronka MT; Told. 19/81]; 1825: találtam Molnár Lászlónét egy küs páltzikoval [Havad MT; CsS].

pálinkafőző üstöcske 1801: pálinka főző üstetske, egy Szakáts Asztalkával egyűtt [BLt II/11].

pallosdarabocska pallosról letört fémdarab 1598: Varga gaspar zolgaia ... wallia. Semmit en abban ne(m) thúdok ki ewteotte Thot Itsúant agion hane $(\mathrm{m})$... kewlde Biro $\operatorname{vra}(\mathrm{m})$ az Darabos korchiomaiara hogi megh erchiem ki bantotta, ot enneke(m) mutatanak egj kis pallos darabochkat ... ot azt mondak hogi pallos lapossaúal ewteottek s az az darabia [Kv; TJk VI/1. 205].

pallosocska kisebb pallos 1656: hagiom az vertyse Lovamot, uy kŏves partai legh szeb szerszámommal, orraba valojaval, fek emleivel, zabolajaval, kŏves veres Barsonios pallosoczkaval [Ádámos KK; BálLt 93].

pántlikácska szalagocska 1759: (Az úri aszszonyok) Melltartót, vagy amint most hívják laszli, vagy maszli vagy mi-ördög, nyakszorítót tudom mikor senki sem viselt, hanem 1733 tájban kezdének csak igen keskeny nyakszorítókat vagy pántlikácskákat az ifjú leányok és asszonyok viselni [RettE 91]. pántlika-rózsácska szalagcsokrocska formára készült ékszer 1719: Három smaragdu és három szem gjŏngju pántlika rosáscka (!) [WassLt Wass Daniel inv.].

pántocska vmit összekapcsoló/megerősítő kis pánt $1780 \mathrm{k} .:$ Az béres szekérre egy Lántz szemet és egy horgat xr. 06. - tíz kís pántotskát xr 06 [Szászváros; BK].

Szk: foglaló 1680: Pincze tokokrol le szedet harom darab foglalo Pantocskak [A.porumbák F; ÁLt Inv. 17].

papírdarabocska 1710 k.: Így szépen, rendesen két columnába írván a questiót és responsiót ... fedje bé papirdarabocskával a responsiocolumnát, és kezdje úgy repetálni, garagyolni, mint a vocabulát vagy

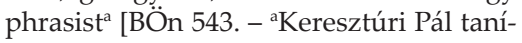
tási módszere szerint].

papiroska papírdarabka 1710 k.: A responsiót bétakartuk papiroskával, melyet kezünkkel alá s fel vontunk, mint szintén a vocabulák tanulásában ${ }^{\mathrm{a}}$ [BÖn 538 . - ${ }^{\mathrm{a}} \mathrm{Ke}-$ resztúri Pál tanítási módszere szerint].

papirosocska papírdarabocska 1710 k.: Hozta a város pecsétit is kettős papirosocska között zöld viaszra ütve [BÖn 970]; 1746: Egy papirosacskában krispány [Vargyas U; DanielAd. 255].

paplanka kisméretű paplan 1737: egj kis paplanka [Brassó; ApLt 5 Apor Péter inv.].

paplanocska kisméretü paplan 1693: egyeb supellitelekbŏl Mihok reszt nem vett, egy uj Paplanocskat adtunk neki [Ne; DobLev. I/38. 3].

papocska lekicsinylően: jelentéktelen kis pap 1772: ki szalada ... Popa Juanne Tamas Maria ... teli tarakkal kiáltván vár meg te Papotska mért te vével Túzet, es Fel Gyujtád az Popa Házát [Ludvég K; KLev.].

parasztablakocska egyszerü/közönséges (festetlen) kis ablak 1694: ezen Haznak Pitvara(n) va(gyo)n ket felszer Ajtó mindenik vas nelkúlt valo jo tapaszos fa Kemennye, ennek az haz(na)k pitvarkaja es hatulso Hazacskajais van, kibenis egy sing Rud vason, es Vas Labocskan allo paraszt Kemenczecske van, Ket paraszt Ablakocskaja annakis [Kővár Szt; JHb Inv.]. 
Szk: lantornás 1681: vagyon két lantornás paraszt ablakocska [CsVh 95] * üveges 1679: Onban foglalt, kivül vas keresztes, paraszt ŭveges ablakocskaja nro. 2 [Uzdisztpéter K; TL. Bajomi János inv. 26].

parasztajtócska egyszerü/festetlen kis ajtó 1736: Elébb azon gyalog ajtonál van egy földbe vert karokra veszszővel font tapasztatlan Szalma fedelü paraszt pajtátska, melly Bihalok számára való ennekis fenyő deszkábol valo paraszt ajtotskája van [Várhegy MT; CU XIII/1. 115].

parasztalmáriumocska festetlen kis almárium 1737: Egy földőn állo paraszt $\mathrm{Al}$ máriumotska, mellynek is vagjon két rekeszsze, elé s hátra huzogato deszkájával [Csákigorbó SzD; JHbK XXVI. 13. 6].

parasztasztalka egyszerü/festetlen kis asztal 1680: Vagjon ezen házban ... egy hosszu paraszt Asztalka. Harom darab paraszt fogas [A.porumbák F; ÁLt Inv. 5]; 1681: Majorház ... Szobája ... Vagyo(n) eze(n) Szabab(an) ... Paraszt Asztalka Nro 2 [Vh; VhU 566].

parasztcsüröcske kis paraszti csür 1827: van egy szalmás fedelü paraszt tsüretske [Somkerék SzD; Ks 73/55].

parasztfogasocska festetlen/paraszti kis fogas 1720: Egj keskény paraszt fogasocska [Szentimre Cs; Hr]; 1763: a Provisoralis Házba ... három paraszt Fogasotskák, és egy kisded Táltartotska fenyŏ deszkábol [Hortobágyfva Szb; Born. XXIXa. 19 néhai Hortobágyi Gergély György conscr. 12-3].

parasztházacska (jobbágytelekhez tartozó) kis falusi ház 1763: belső antiquă Colonialis Sessio ... Vagyon a' Falu kòzepiben, hajdon Kosztándin Bárb Jobbágy Mosiájanak hivattatot, melyen egy paraszt Házatska lévén; lakik benne egy Alexandru Muntyán nevü Sellér [Rákovica Szb; Born. XXIXa. 19 néhai Hortobágyi Gergély György conscr. 58]; 1814: paraszt Házotska [HG].

parasztházikó falusi házacska 1774: Zŏld Uram aban az Ŭdŏben a Falun kivŭl egy oldalban az Uraság fŏlgyin egy paraszt Hazikot epitetett [Mocs K; Ks Conscr. 31]. parasztkapucska falusi/gyalulatlan/ácsolt kiskapu 1681: az patak felől mégyen bé az barom okolra egy fenyő fábul csinált, fedetlen és ajtó nélkül való paraszt kapucska [CsVh 96].

parasztkemencécske falusi/paraszt kis kemence 1694: ennek az haz(na)k pitvarkaja es hatulso Hazacskajais van, kiben egy sing Rud vason, es Vas Labocskan allo paraszt Kemenczecske van [Kővár Szt; JHb Inv.].

parasztocska parasztforma 1823-1830: Vettem volt már egy lovat ... E parasztocska kanca volt, de fiatal, sebes és iramló [FogE 282].

paraszt-padocska falusi/paraszt módra készült kispad 1798: Az hátulsó kissebb házban vagyon ... két kiss paraszt padotskák két puszta fa rostéllyos ablak [Vályebrád H; Ks 76. IX. 27].

paraszt-pajtácska falusi/paraszt módra készített kis pajta 1736: Elébb azon gyalog ajtonál van egy földbe vert karokra veszszővel font tapasztatlan Szalma fedelü paraszt pajtátska, melly Bihalok számára való ennekis fenyő deszkábol valo paraszt ajtotskája van [Várhegy MT; CU XIII/1. 115].

parentációcska rövid gyászbeszéd 1796: A koporsom tsinálására, és a" Sirások(na) k munkálkodásokra, ugy eltemettetésem után, ha talám a' Barátim akarnák, vagy lehet, volt más jo akaroim is kivánnák, egy akármely bizonyoss napon tartando Parentatiotskára hagyok ötven Forintokat ... Getse Beniámin mp. [Déva; Ks 73. 74. VII. 126].

parlagocska kis parlag 1695: az Olt vize mentib(en) va(gyo)n egy darab Parlagocska [Kilyén Hsz; LLt]; 1720: edgy jó darab Szőlő ... nyúl ... eo Nacsága Parlagocskájára [Kide K; EHA].

párnácska 1. kis vánkos 1816: A' Cselédek 2. pokrotza és 4. párnátskája ... $6 \mathrm{Rf}[\mathrm{Kv}$; Born. IV. 41]; 1817: 7. Kissebb és Nagy párnátskák hajastol [Varsolc Sz; Born. IV. 41]. Szk: tarka 1733: Edgj kis tarka párnátska [Marossztkirály AF; Told. 2]. 
2. oltárra való kis párna 1732: ezen oltáron vagjon két kŏnyv alá valo kicsinj párnácska, edgj oltár takaró csipkés gyólcs egy abrasz [Kóród KK; Ks 12. I].

3. csengettyű́párnácska 1842: Csengetytyü három rézből valok, két párnátskával [Dés; Újf. 3 Újfalvi György hagy.].

párpisztolyocska páros pisztolyocska 1782: Dámának valo par Pistolyotska [Mv; CsS].

pártácska kis párta 1674: Egy haj fono kórŭl valo keskeny Gyenge Partatska el bontani valo [Tövis AF; Kath.]; 1709: 1 kis pantikara tsinalt Partatska talam van kilenc arany bene [WassLt Árva Matskási Ersebet inv.]; 1781: Egy kitsin gyenge pártátska rész szerint pedig apro Gyöngyőkkből tsinálva, két kitsín Arany Boglár benne [Nsz; Told. 3].

Szk: gyöngyös 1673: egj hajfono körül valo késkény gjőngjös pártácska [Tövis AF; BálLt 93].

pártaövecske (ékköves) kis öv 1588: Az Orsik Reze. Wagion egy kisded partha eowechke fekete visselt Mayczon Niom Maiczostol, 16 boglar rayta, M 1 p. 16 [Kv; KvLt Vegyes I/2. 23]; 1602: Honesta Martonra Catharina Rlcta Ioanis Kadas ... fassa est ... Tudom azt hogy az Thamas deak vram felesege Catha azzony ott az Annyanal lakott gyermek volt ... Ruhazattia feleol pedig, azt tudom hogy eggy zoknyaczkaya, es eggy kis parta Eowechkeys volt az Leannak [Kv; TJk VI/1. 606b]; 1629: Egy kis párta Eöuetczke az mely nyom m. 1. p. 45. aestimáltuk tt f. 48 d. $40[\mathrm{Kv}$; RDL I. 132]; 1638: egj kis parta eöueczkeje volt az mostis jelen vagjon az Aszonnal [Mv; MvLt 291. 144b]; 1693: Edgy párta Eŏveczke hét Gerezdes Tall - - 8// 1/2 [Ne; DobLev. I/37].

Szk: fekete majcos/majcú 1589: Ket O keosseonthiwchke, egy fekete Mayczw parta Eowechke [Kv; KvLt Vegyes I/2. 33]; 1676: Adott ... Egy fekete maiczos rövid czattu, 14 ezűst boglaru párta öveczkét, mely szijjával, maiczával együtt ... f. 12 [Kv; RDL I. 155a] * meró ezüst 1596: Egy mereo ezewst partha eowechke n 1 p 6 [Kv; RDL I. 65$]$ * remekes $~ 1625$ : Wagyon mas egy gyermeknek walo ezűst remekes parta eo- weczke nyom ez m. O. p. 32 er ezis f. 12 [Kv; RDL I. 126].

partikulácska 1. területecske 1735: (A fundusából) hasitottak volt ki azon kitsiny partikulatskat mellyet most Mathe Janosne Buzzoganyi Borka Aszszony bir [Kissolymos U; Márkus lev.]; 1747: kŏzŏs Jószág lévén, még pedig tsak egy kis Partikulátska [Vaja MT; Sár.]; 1780: Beretzkis Lŏrintz Nóva Sessioja ... a Falutol vásárlott particulátskával [Harasztkerék MT; Told. 86 Conscr. 6]; 1814: az nemes hütösség elejiben azért jöve híre (!), hogyha magáénak elnyerhetnéa azon kicsin munkás elfoglalt partikulácskát [Szárhegy Cs; RSzF 139. aCzimbalmos Albert gy. kat.].

Szk: zálogos 1759/1766: ha azon Portiokbol valamely Zálogos Particulátska relualtatik a' Zálog Summát végye fel Kemény Kristina Aszszony [Mv; DobLev. II/372. 2a].

2. kis részlet 1732: Raczkevi János $\operatorname{Vr}(\mathrm{am})$ eǒ Kglme Relatiojábol értettem hogj az Mgs Ur(am) neve alatt expedialtatott Instructio(na)k valamelly particulácskájában kivánná az Ur csekélly succursusomat [Mezőbánd MT; WassLt Szodos György Wass Lászlóhoz]; 1742: Mi azert primo is az Assumptiorol Junior Bekesi Istvăn Vrammal egy kis Particulăcskāt Sub Sigillo et subscriptione concipiălvăn alázatoson ell kŭldŏttŭk Ngod(na)k [Kovászna Hsz; ApLt 4 M. Sándor Deák Apor Péterhez]; 1772: Fassiomban az mingyárt emlitett ki maradott particulatskát inseralták [Drág K; TSb 21].

3. jelzői haszn-ban: részecske, kicsinyke 1731: Sz Imren Bedecs falva kőzőt egy kis particulacska joszagok [Szentimre Cs; EHA].

pászmácska (szőlőből) keskeny darabocska/ pászta 1757: egy darabotska szegeletenn két három Folthi embernek lévenn egy egy pászmátska szőlejek [Danulest $\mathrm{H}$; BK ad nro 144]; 1792: adom által ... az Agyagos n. hegyben lévŏ egy pászmátska szölöt és Gyümöltsösseit [Kide K; BHn 96]; 1840: Vagyon K. Okloson egy paszmátska Szőllő [Kv; Ks 100 Nyilak könyve 40]. 
paszomántövecske zsinórövecske 1788: Egy ezŭst kaptsos állott paszamánt ŏvetske [Mv; TSb 47].

paszulyka (szemes) bab, fuszulyka 1792: Malé szemül 9 Köb ... Paszujka 1 Köb [H; JF 36 LevK 12]; 1806: már a Szalonnát Fuszujkát, aszu gyümőltsőt hogy mennyi légyen nem mondották hanem azt monda, hogy a Paszujka mind nálla maradot [Szentkirály K; KLev.].

patakfolyásocska kis patak, vízfolyás 1727: Szüntelen volt ... egj Makai István nevü halászsza aki is nyárb(an) mind ott Lakat az To kőzőtt egj Csupan ... Es az eleven halakat ott tartotta holmi annak valo patak fojásacskáb(an) [Mezősámsond MT; Berz. 14 XVIII/19]; 1744: a Gát ... haromszor szakadott él, tudom két rendben hala vizevel edgyütt el fojt, tsak egy kis patak fojásotska maradott [Tóhát TA; JHb XI/17. 13].

patakocska 1. kis patak 1680: az Patakocskán tuul tiz oltovanyok vad(na)k ... szepen meg fogantak [A.porumbák F; ÁLt Inv. 10]; 1681/1748: A Falu felső Porgolát kapuján kivűl valo patakoczkán felyül [KvAkKt Mss lat. 236]; 1784: ezen Vala Unguruj Nevü hellytŏl, szakasztya meg a' Pojána Boldisoit égy Patakotska [M.gorbó SzD; JHbK LIX/4. 40]; 1803: az Abrahám hegye alatt lévő patakotskán ment volna [Aranyosrákos TA; Borb.]; 1815: A' Kosesdi Posta Stātiohoz tartozo erdŏ Napkeletre az ohábai határ felől határozodik a' vále Szereturi nevü patakotskával [Kosztesd H; Ks 112 Vegyes ir.]; 1826: ez a' patakotska váloszsza el a' Bontznyiresi Határt a' Vasas Szentiványi Határtol [Szék SzD; WassLt]; 1838: Pap erdeje alatt (sz) (szomszédja) egy patakocska [Báboc K; BHn 18].

Hn. 1681/1748: A Falu felső Porgolát kapuján kivúl valo patakoczkán felyül [KvAkKt Mss lat. 236]; 1740: A Patakocskáknál (sz) [M.gyerőmonostor K; EHA]; 1756: Máty éj nevü patakotska szomsz(édságában) [Celna AF; EHA]; 1760: az Sámsondi utt mellett valo patakotska mellett az felhágoban (sz) [Mezőbánd MT; EHA]; 1780: Vér Völgy patakotskája [Bonchida K; BfN]; 1816: Csulakally patakotskája [Kelementelke MT; EHA].
Szk: árka 1700: vicinussi ${ }^{\text {a }}$... alol oldalul Gyalakuta között le foljo patakocska árka [LLt 65/17. - ' ${ }^{\text {TTi }}$ egy belső örökségnek]; 1766: az Hendistotsabol le fojo patakotska árka [Szásznyíres SzD; Ks 33 Szásznyíres II. 16]; 1772: A' Malom árkára óldalaslag follyó patakocskának árka a ŏl számra három singes öllel 39 [JHbK II/17. - ${ }^{\text {a Kisfe- }}$ nes és O.léta (TA) határán] * kis 1639: Koronka fele azon ut mellet vagion egi kvs Patakocsika [Nyárádbálintfva MT; EHA]; 1736: Bartok András ... kere ... egj darabb gaz erdŏt ... az ŏ kegjelme kevansaganak mŭis engedelmeskedtŭnk es az magunk hatarunkan adank ŏ kegyelmenek egj darabocska gaz erdŏt ... az also hatara egj kŭs patakacska [Gyertyános TA; Bosla].

2. kis patak vize, kis vízfolyás 1674: azon viszszá folyo lókon nevü helyröl le folyo patakotskának mind ket felin [Tekerőpatak Cs; LLt Fasc. 69]; 1680: az havasrol le follyo patakocskán vagyon egy kötörö malom [A.porumbák F; ÁLt Urb. 674]; 1714: Csak nem meszsze a faluhoz kezdŏdvén eredeti a nagj vadon erdŏk kozŏt két setét kietlen vŏlgjekbŭl le folyo két patakocskáknak melyben Pisztrángok teremnek [Sztanisa H; JHb XXXVII. 7]; 1724: az falun le fojo patakocska felŏl el kezdődvén felyül a szeljesedés huszon két ŏlnyivel, fecske farkulag széljesedett [Derzse SzD; JHb III/67]; 1745: a Tyira Patakjárol le folyó patakocskáig [Nagyida K; EHA]; 1756: az Hámorok vize tsak egy patakotska [Torockó; TLev. 9/8. 1a]; 1759: A Malom innen egy patakotskán két őlős ág tőltés és a kőzepén Bodon vagy is üres Tőke [Csákigorbó SzD; JHbK XL/8]; 1763: Az Arpastoi hatar szelib(en) patakotska folyt [Felör SzD; Torma]; 1768: egy patakotska foly le benne [Buzásbesenyő KK; BálLt 1].

Szk: alájáró 1607: az zenafiue(m)nek zelen ala jaro patakoczika, melj az zena fiue $(\mathrm{m})$ zelen valo kèrtbol jndul megh [UszT 19/103] * folyó 1637: Vagyon szep folyo patakoczykaya kiben rak keŏj hal terem [Lupsa F; UC 14/42. 191]; 1641: ezt az kis folljo patakoskatt ... melljet Zaraz pattaknakis hinak ... azt Csokmanj hattarnak tudom [Csokmány és Turbuca között SzD; $\mathrm{JHbK} \mathrm{VIII/8]} \mathrm{*} \mathrm{kicsid/kis} \mathrm{1669:} \mathrm{Halaszo} \mathrm{Vi-}$ 
zek nincsen egyeb égy kis patakocskánal ... de abban sem foghatni igen sokat bár akar ki probállya megh [Tormás H; BfN Székely László lev.]; 1700: Patakjok vagyon kicsid Kicsid patakocskayok van [Doboka; OL Gub. Közig. összeírások]; 1744: Két rendben tudom, hogj a Gát el szakadot, és Vizével edgyütt hala is el ment, és mind a kétszer szarazon maradott a Tho hely, tsak valamely kis patakotska maradott [Tóhát TA; JHb XI/17. 11]; 1811: Lisztelő Malmát is tudjuk lenni ... a' Springi és Vingárdi kis Patakotskák égy be Szakadásokon [Spring AF; KvAkKt Mss hung. 6] * közönséges 1632: a falu keözöt ala folio keözeőnseges Patakotska [Pókafva AF; Sár.] * rákos 1674: Ez hataron foly egy Lajta nevú rakos patakocska, mellyet az mint az boerok es az esküttek hitek utan referalljak még az elejek vette volt meg az boeroknak az Kerczesoriaktol egj lovon, tizen két kőből buzan [A.porumbák F; UF II, 636] * rövid futású 1864: Ágypataka vagyon rövid futásu patakotska [Szu; Pesty, MgHnt 41. 577a] * tilalmas 1680: Vagyon az Falunak apro halos Tilalmas patakocskája is, mely az halos toba mégyen [Szaráta F; ÁLt Urb. 64].

3. kis patak medre 1672: magyar nádas feleol ... az hol égy nagy keo pincze és To helyis vagyon azon az helyen égy Erdős Borbára nevú nemes Asz(on)nak vala nemes udvarháza ... seot ott az házánál égy nagy veteményes kertis vala, és abban be veotték vala az patakocskát, és az ott léveo To helyis oda valo vala [Méra K; EHA].

patakocskaforma 1 . kis patakhoz hasonló 1812: ez előtt is volt az én értekemre egy kis patakotska forma kis Maros Ág, de ez olly kítsín volt, hogy által lehetett lépni [Koppánd AF; DobLev. IV/943. 18a Petrutz György (70) jb vall.].

Szk: porondos 1812: értem az elöttis a' mostani Marosnak follyamattya helylyin egy kis porondos patakotska formát [Nagylak AF; DobLev. IV/143. 37b Marsínán Juon (42) jb vall.].

2. kis patak medréhez hasonló 1812: Tudok ... egy kis patakotska forma Árkotskát, vagy vgy szolván egy kis porondot azon Maros mostani follyamattya hellyin (: melly a Víznek sokszori ki ütése Áradása alkalmatosságával let vala :) de az ollyan kítsin volt, hogy a két Berket tellyességgel mint most ketté nem vágta [Nagylak AF; DobLev. IV/943. 28b].

patikaládácska kis méretü patikaláda 1698 : Patika ládácska vagy iskatulya [MNy XXXVIII, 206].

patyolatkeszkenőcske finom gyolcsból készült kendőcske 1576: Wagion wyselth pattyolat kezkenyechke parazth [Szamosfva K; JHbK XVIII/7. 15].

pénzecske 1 . kis pénzösszegecske 1722: ki $\operatorname{adta}(\mathrm{m})$ kevés pènzetskémet dolog feiben, az által folj az oeconomia(m), amaz nagy szŭksegben szèpecskén adta(m) el Gabonácskát, abbol teremptettem vala pénzetskét, de aszt ki rívá az szegénj oláh tŏllem [KJ. Rétyi Péter lev. Fog-ból]; 1743: én egy kevés pénzetskét .... Borbol Congeráltam s pálinkábol [A.árpás F; TKl Váradi Zsigmond Teleki Ádámhoz]; 1748: hallottam masoktol kŏz beszedben hogj mi keves Penzecskeje volt az Matye Felesegenel tartotta volna [A.jára TA; Borb. I.]; 1763: a' mi pénzetskét gyưjtegethettem a' Joszág proventussábol, ha késécskénis, el indultam, és ide Szökefalvára le hoztam [Szőkefva KK; BálLt 1]; 1776: B. Bálintitt János Ur ... méltoztatott nékem meg-kŭldeni Flor. hg. 257 Dr. 50 ... Allvan penig ezen Pénzetském nevezett Mlgs őtsém Uramnál Tiz Holnapokig [Moson MT; BálLt 92]; 1782: Fattyu Todor ... az mikor ... valami pénzecskèt hozhatott az házbol abbol részesitette Bocska Gligort és Annyát mint Szúléit [Sólyomkő K; Eszt-Mk].

Szk: semmi 1830 k.: lèszen Ur Bátyam oly Jo hogy meg nem Neheztel reám hogy alkalmatlan lészek ezen Semmi Pénzetskémért [Mocs K; BetLt 1 Henter Farkas Vajna Istvánhoz].

2. elegy-belegy értéktelen pénzérmecske 1720: Vagyon Egy Csomoba füzue egy pár Palastra valo kapocz es ket ezüst gombocska ... ket kis boglárocska ... Valami elegy belegy pénzecskék [Kv; Pk 6].

perselyládácska pénz gyűjtésére/tárolására szolgáló záros ládika 1728: Egi kis persely ladátska [Sszgy; SVJk]; 1728: Persely Ladacska nro 1 [Szotyor Hsz; SVJk]; 1728: 
Persely ladacska jo szoros nro 1 [Uzon Hsz; SVJk]; 1752: Egy persely ládátska [Bikfva Hsz; SVJk].

pesztonka 1822: Szarvadi Ur ... mikor ötet meg zabolázni kéntelenittettem ... több izben meg vert; mellyet meg bizonyit az akkori Inassa, Kotsissa ... égy szolgáló, égy pesztonka [KLev. Gergelyfi Béniámin (28) kibédi ns vall.].

piacocska terecske 1783: mingyárt ország uttyán kívűl vólt edgy Piatzotskát mutató puszta helly, melly ... az Fogadonakis prospectust és diszt adott, és a' Fogado elött Innep napokon mulatni kiváno ifiuságnakis mulato hellye volt [Bergenye MT; LLt 38/13].

pikszisecske szelencécske Szk: hajkenőnek való 1714: egy haj kenönek valo Pixisetske $[\mathrm{AH} 55] *$ rezes $\sim 1714$ : Tojas formara tsinált rezes Pixisetske [AH 35].

pilivánkosocska pehelypárnácska 1749: két kis pili vánkosocska [Szárhegy Cs; LLt Fasc. 116].

pillangócska 1. lepke alakú ékszer 1716: Egy pár öreg győngy Fülben valŏ Egy pillangocska. Egy kis gyemántos egy szem győngyü tollacska [WassLt].

2. (repdeső) pontocska 1710 k.: Az aer másként láthatatlan, de mikor a nap valamely kisded lyukon vagy nyíláson bésüt, ha oldalfél állasz, szemeddel is meglátható apró fényecskemorzsáknak, pillangócskáknak, melyek atomusoknak neveztetnek a physica scholában, azoknak számtalan sokaságából álló nagy test, halom vagy rakás [BÖn. 448].

pincécske kis pince 1637: Vagyon ugyan az kemencze mellett egy kws pinczeczyke; abban apro muskataly alma cubul. nr. 6 [Fog.; UF I, 422]; 1652: (A péncének) Job kéz feleol valo szegeletiben egy kis keskény Pinczécske fokhagymát tartottak ezeleot benne [Görgény MT; Törzs.]; 1748: Vagyon Szalma fedél alat egy kisded pintzétske [Nyárádsztbenedek MT; Told. 79]; 1796: a Néhai Groff Ur Eŏ Nagysága ... épittetett egy jo Fogadot ... két házatskát, az édjik ház vége alá egy kis fábol epŭlt Pintzéstskét [Szentgothárd SzD; WassLt]; 1825: egy kis kőből rakott Péntzécske és a felett egj kis Padlásos és Simpla reteszes ajtoju Kamarátska van [Szárazpatak Hsz; SzentkZs Conscr. 381].

pincetokocska kis rekeszes ládácska 1697: veres Pincze tokocska [KGy]; 1744: Edgj hitván régi Ládátska $\mathrm{s}$ edgj parányi bé zárt régi Pintze Tokotska [Szentdemeter U; LLt Fasc. 67].

Szk: rozsolisos 1732: Vagyon egy kis Rézzel boritot, Vás pántokkal foglalt Rosolisos Pincze tokocskáb(an) 6. üvegecske on srofos [Kv; Ks Kornis Zsigmond lelt. 25].

pintyőke pinty 1766: Az új esztendő oly iszonyú hideggel köszöne be s oly hosszason tarta egész martiusig, hogy soha keményebb telet a mostani ember nem ért ... szememmel láttam a pintyőkét halva azon helyt, az hová hálni elült volt [RettE 195].

piroska pirosas, pirozsgás, Szk: ábrázatú 1846: teli piroska ábrázatu [KLev.]; 1847: Bogdanel Dumitrŭ... teli piroska ábrázatu [Dés; DLt 201]; 1817: Mŭller János ... pirossotska ábrázatu [DLt 366 nyomt. kl]; 1822: Gramma Thodor ... kerek pirasatska ábrázatu [DLt 242 nyomt. kl]; 1826: Zaharie Brod ... egy keveset Pirossotska hoszszuko ábrázatu [DLt 120 nyomt. kl].

pisztolyocska kis pisztoly 1780: magam is láttam nálla a kŏzelebb mult télen ollyan forma pistolyotskákot [Grohot H; Ks 113 Vegyes ir.].

pitvarocska 1. pitvarka 1629: (A) két ház mellet, két oldal kamarácska, a' ... megh irt három házok végiben egj pitvarocska [Buza SzD; JHbK V/2]; 1629: (Vagyon) Azon pitvarocskából a folyósóra egy kis béllet festett ajtó, záratlan [Szu; SzO VI, 96]; 1654: Roska Demeter ... kis hazacskaja pitvarocskaja [Liget MT; Ks Bánffy Anna urb.]; 1752: (A) Specificált Házak kőzőtt vagyon egy kisdék Pitvarocska ... festett bérlett jo záros ajtajaval egyűtt [Pókafva AF; JHb XXV/73]; 1777: vagyon elŏl kŏ lábokan álló Tornátz, azon belől egy kis pitvaratska [Megyesfva MT; LLt 28/531]; 1781: járnak bé egy kis Pitvarotskán [Backamadaras MT; Hr]; 1783: az két Ház között lévö Pitvarocskában ... fenyö Deszkábol csinált paraszt ajton mennek bé [Mocs $\mathrm{K} ; \mathrm{JHbK}$ XXXI/1]. 
2. elöterecske, ereszecske 1676: Ezen házbol nyilik ismét az Tómlőcz bástya felet lévő ház előtt valo pitvarra ... béllet régi ajtǒ... Ezen pitvaroczka boltásos [Fog.; UF II, 725]; 1743: majorság ol ... közepin egj kis pitvaracskával [Boroskrakkó AF; BfR dobozolt anyag VI]; 1747: Ezen bolt mellett vagjon egj Pitvaracska mellete S: V. kamara Szek [Aranykút K; Ks 73/55].

plántácska növényecske 1803: szép ágas plántátska [Harangláb KK; UnVJk].

pléhecske 1. bádogedényecske 1733: Méts(ne)k valo pléhetske [Marossztkirály AF; Told. 2].

2. kolbásztöltő 1788: olosz Kolbász tŏltŏ kítsin pléhetske [Mv; TSb 47].

pléhpalackocska bádogpalackocska 1816: Egy Pléh, Szŭk száju palatzkotska [Csíksztmárton MT; UnVJk 150].

pléhtányérocska bádogtányérka 1788: Konfect alá valo ezŭstŏs pléh Tángyérotskák Tíz [Mv; TSb 47].

pléhtölcsérecske bádogtölcsérecske 1804: Egy Pléh Tőltséretske [Hoszszútelke AF; Kath.].

pogácsácska kicsiny pogácsa 1723: ma Szintén Uram eő kgme fel menvén ... a Mlgos Vajdanét kőszőntötte ... hozodott elé Kgd Atyafiságos io akarattyábol mely szép fejedelmi czipokkal szokott volt Kgd Uram eő kgmének kedveskedni ... és mely Szép gyenge pogácsácskákot kalácsokat s tőbb afféle gyenge sütőgeteseket Szokott Kgd készittetni [ApLt 5 gr. Ferratiné gr. Kálnoki Ágnes Apor Péterné Kálnoki Borbárához Jászvásárból].

poharacska 1. kis (nemesfém) pohár 1611: Egy sellek pohar ... Mas egy kwsseb poharochka vgia(n) azo(n) formara valo ... 6/25 [Kv; RDL I. 88]; 1630: Húshagyó ked tájatt az czéh dutkáját adtuk az ötves kezéhez, hogy egy poharacskát csináljon belőle [Mv; EM XVIII, 57]; 1635/1650: Az Iffiú Mesterek keozeonsegessen ennek eleotte czinaltak volt magok számokra egy Cristal forma mereo(n) aranyozot poharoczkat ... az vtolsó az ki ideieben az pohar keszwlt, az Kolczyos mester tisztit el erte [Kv; ÖCJk]; 1638: nemis volt egjeb egj poharoczkajanal az Aszonnak [Mv; MvLt
291. 144b]; 1645: egj kiczin poharoczkatis ... czinjaltam, de en nem Tudom miczoda eszustőth adott az czinjalasara [Szárhegy Cs; LLt Fasc. 120]; 1700: apro Poharotskak [Hr I/20].

Szk: A. aranyos 1628/1635: Kett egj forma aranios poharoczkak, hetue(n) ket nehezek [Bodola Hsz; BLt 5 néhai Béldi Kelemen inv.] * fedeles 1651: Edgy kús Kristaly formara czinalt kúvúl belól Arannyos Fedeles poharoczka [WassLt Wass Judit kel.] * fehér 1589: egy feyer poharochka [Kv; KvLt Vegyes I/2. 64] * lábas 1694: Egy kis lábos holyagos Pohárocska [Kv; Berz. 2 29/76]; 1695: Egy kis labos holyagos poharoczka [Berz. 2. 27/29] * tarka 1674: Négy ezüst párta eővek, eggyik(ne) k lánczais vagyon; a láncza egy tarka pohárotskáb(an) vagyon [Szászvárosi ref. 1t. Halics Mihály lelt.]. B. rozsolisos 1801: Hét Rosolisos kisded virágos poharotskák [LLt 106/1] * szalamiás 1682/1722 k.: egy zomanczos szalamias Poharoczkais [Ludvég K; GörgJk 97].

2. úrvacsora-osztó kelyhecske 1798: Nékünk ... vagyon egy kitsiny Poharatskánk, a' mellyböl a' Pap a' Bort szokta a' Sakramentomok(na)k administratiojakor ki osztani, de tellyesseggel nem tudhatyuk, oné? ezüst é? ... vagy pedig Compositio [M.bikal K; RAk 30].

3. poharacskányi 1753: mikor sok Buzát mértem fel véle olykor olykor egy egy kis pohárocska pálinkát adott [Szentbenedek SzD; Ks Varia Paskuly (46) jb vall.].

pohárka 1. poharacska 1650: az ezüst poharaim kőzőtt vagyon egy tőrpe szeles poharka aztis agyak az monostori Pater kezében az teóbbiuel egyűtt [Kv; JHb III/7]; 1749: Husz darab Üveg Cre(de)ntia Nro 20 Hozza valo Nagyobb s kisebb pohárkáji és kantsotskaji Nro 32 [Told. 19].

2. keresztelő 1728: Egy keresztelŏ plehbŏl valo poharka [Eresztevény Hsz; SVJk].

pohárszék-almáriumocska kis pohárszék 1839: Egy kis diofa pohárszék almáriumatska [Kv; Ks 73/55].

pohárszékecske kis pohárszék 1679: Pohár székeczke nro 1. Ennek also részenek ajtoja, csiklos hevederes pléhes nro 1 [Uzdisztpéter K; TL. Bajomi János inv. 108]; 
1681: Egi kis pohar szekeczke [HSzj pohárszék al.].

Szk: festett 1694: A' falon is vannak itt katona fogasok ... Item egj kis festett Pohár székecske [Borberek AF; BfR néhai ifj. Bálpataki János kúrialeír.].

pojánácska kis erdei tisztás, erdőből irtott kis szántóföld 1746: a' Bŭkkŏsb(en) az Erdŏ kŏzŏtt lévŏ Polyánocska a vulgo Pável Polyánnya a Néhai Zaharia Gábor kalibájánál lévŏ két Pojánocskábol a Kis Polyánb(an) bé járó útonn feljŭl az Erdŏ kŏzŏtt [Nagyida K; Told. 9]; 1747: a' Meta ... nyulik a kis és nagy Bŭkkŏs kŏzŏtt valo életskére, mig egy Árkotskán által menvén ezen specificált Pojánatskákan feljŭl terminálódik [Nagyida K; Told. 27]; 1825: soha is az ők ki irtva lévő kevés pojánátskaikal meg nem elégedtek, hanem ... mindig bejebb, bejebb ... irtogattak es harapoztak [Kötelesmező SzD; TSb 47 Veszutz Todor (50) gr. Kornis Ignác szolgáló embere vall.].

pojánka kis erdei tisztás, erdőből irtott kis szántóföld Hn. 1781: Az alsó pojánkán (sz). A Közepső pojánkán (k) [Szárazpatak Hsz; EHA]; XVIII. sz. v.: a' Pojánka (sz) [Zabola Hsz; EHA]; 1825: az also Pojankánn (k). A Felsŏ Pojankann (sz) [Szárazpatak Hsz; EHA].

pojenica kis erdei tisztás 1782: azt tudom hogy égy hellyetskét a Gorbai határon in vállyá Unguruluj nevezetü vőlgyben Pojáná Boldizsojénak hivják melly Pojenitzát én tudom, hogy olly kitsiny helly volt tsak az én emlekezetemre is, hogy alig termett meg rajta égy szekeretske széna ... de ezen Pojenitzát miért hivják annak, nem tudom [Paptelke SzD; JHbK VIII/18 Petrán Togyér Senior (72) jb vall.].

polcocska kisebb polc 1746: Paraszt Fogas 1 Potzoska 1 [Borsa K; Told. 49]; 1797: rŏvid gyalulatlan polczotska [Körispatak U; Pf]; 1798: egy darabotska Deszkabol egy kis potzoska [Vingárd AF; KCsl 5].

ponkocska halmocska 1798: a Doduj szöllöje ... amaz ponkatskán elé, és szakadásos oldalon fel, viszont erre a Vaczkor fa felé feküdt [Nagykristolc SzD; JHb Bornemisza Annamária lev.]. pontocska 1826: viselt ... fejér tsikos bö nadrágot, fekete pontotskákkal tellyes sárga Lájblit, fejér pontotskákkal tellyes tégla szinü Nyakravalót [DLt 1126 nyomt. kl].

porceláncsebrecske porcelánedényke 1846: Két nagyobb és égy kissebb aranyos szélü porczellán csebrecskék [SLt 17].

porcelánkancsócska 1791: Két portzellán fertállyos Kantsotskák [Mv; MvLev.].

porcelántálacska 1763: Hat fejèr Kafes Fingsia talatskaival es hat tarka gyŭmŏltshoz valo Porcellein talatskak s egy fedeles tseszetske [Hsz; Ks 23. XXIIb].

Szk: aranyosszájú 1849: egy aranyos szaju portzellán hoszszuko tálatska [Somkerék SzD; Ks 73/55] * kávészín 1755: Ugorkának való Kávé szin Portzellán Tálotska 1 [Batiz H; BK sub nr. 1020] * kínai 1846: Két égy forma gazdagon aranyozott Chinai porczellán tálatska [SLt 17].

porcika darabka 1842: Portzika Gligor [DLt 240 nyomt. kl].

porciócska 1. részjószágocska 1638: ualamikor eő naganak arra ualo kglms akarattya lészen, és én teőlem ki akaria uáltani, le tétetuén ... más féll ezer forintott ... az megh irt Eőrkei portioczkatt, kezembeől minden teőrueny és imide amoda ualo halogatás nelkwl, ki eresztem [Bszt.; Ks 901]; 1659: az mely keues portioczykáia uolna eö kegnek [Szárhegy Cs; LLt Fasc. 157]; 1662: Kun Gergelj vram Algiogon a es ott kőzel léuö két három falukban levŏ husz ház iobbágiocskámot Ngodtol ... megh kérte uolna, melj portiocskát ... conferált volt [KJ. - $\left.{ }^{\mathrm{a}} \mathrm{H}\right]$; 1666: birok ... Sz: Margita $^{\mathrm{a}}$ nevü faluban egy Portiocskát [KGy. aSzD]; 1716: Budosban a melly portiocskat bir Somodi Istvanne Aszszonyom, edes Attyarul Csonka Gyŏrgj Urunkrul állo (!) portio [Dés; Ks 26. XIII]; 1722: hogy én az Runki maga(m) illető kevés porcziocskamat hogy él ata(m) volna ... aban $\mathrm{Na-}$ csagos Uram Sémi Sincs bénne [Kéménd H; JHb XIII/39 Váradi András br. Jósika Imréhez]; 1760: Az Száraz Pataki és Kantai Kitsind portiotskák még inventálatlan vadnak [Feltorja Hsz; LLt]; 1833: N Lakon bízonyos Portiotskajak lévén nállam el adva ... azon Portiojakért ... fizetnem is 
kell 300 ... Rftokat [Nagylak AF; DobLev. $\mathrm{V} / 1197]$.

2. osztályrészecske 1693: Lűn ... ilyen vegezesek és kőtesek Doboka varmegyebeli Solyomkűi és Uyfalvi Csegezi Susanna Aszszony reszire jutott portiocskai vegett [Kv; RLt 1]; 1792: biztam vala a' Feleségem képében Testvér Bátyámra Dévai Istvánra azt hogy Mbándi kevés minket illetô portiotskánkat ki vévén onnan az hol eddig volt és jobbatskán el adván a mit abbol kaphatunk, tehát ... follyo Caussáinknak le őrlésére forditanok [Kük.; MbK XII. 84].

3. jelzői haszn-ban; a. vhány porciónyi vmilyen takarmányból; Szk: vhány izék 1843: a' pajtám hijjára felhaigált 8 . portiocska ízéket [Dés; DLt 316] * vhány széna 1808: égy Nehány Portiotska széna termŏ helly [KLev.]. b. vhány adagocskányi; Szk: vhány pálinka 1796: Ezekre sem költ ... a Mlgos Uraság Semmit egy kis kenyéren és egy egy portiocska pálinkán kivül [Verebes Cs; Berz. 7. 66. V. 1].

porocska kis orvosságpor-adag 1735: kültem az ŏ Ngă számára valami apro Porotskákat ... be kell adni tsets téjben ŏ Nganak [Ks Borosnyai N. Márton lev. Nsz-ből].

Szk: vitális 1759: egj kis nyavalya tőres ellen valo port adott ... már ma vitális porocskát tókéllették el hogj az Gyermeknek adgyanak [M.csesztve AF; Ks Mikes Antal lev.].

porondhordó-szekérke homokszállító kiskocsi 1849: Vagyon egy porond hordo Szekérke vasas kerekekkel kerék szeg 's tengelly vég szegek nèlkúl [Somkerék SzD; Ks 73/55].

porondocska porondszigetecske 1812: Értem ... ennek az ágnak folyamattya hellyén egy kis porondotskát, mellyet a Viz Áradása okozott volt, de nagyon kitsi és száraz kopatz porondu hellyetske volt [Káptalan AF; DobLev. IV/943. 16a].

portékácska (személyes) holmicska/kisebb házi berendezési tárgy 1591: Minden egieb partekachkamat marhamat valahol my lezen Nenem es Ewchem zerezzek ewzze [BálLt 93]; 1670: Huszton nyomorgó leányomért is ez mai nap expediáltam. Tudom, elég nehézségére leszen szegénynek, hogy az maga kevés portékácskája sem adatik ki [TML V, 348 Tököly István Teleki Mihályhoz]; 1693: hirem s akartom (!) ellen azon sákb(an) kötöt portekacskaimat ki oldotta, és kirakogatta [Dés; Jk]; 1759: hozott egy Ládában holmi portékátskákat [Backamadaras MT; CsS]; 1777/1785: akinek házánál meg hal, nem tartozik (azo)n Édes Anyarol maradando portékátskákrol és penzrúl a Töb Atyafiak(na)k számadolni [Vajdasztiván MT; MbK X. 48].

Szk: apróság 1765: Egyéb minden nevel nevezendŏ aproság portekatskaim maradgyanak Ferkŏnek [Torda; Pk 2] * deáki 1823-1830: midőn Aprilisbe a' Kolégyombol ki jöttem, Könyveimet, 's Deáki Portékátskáimat kotyavetyéztettem [FogEK 185] * dibdáb 1733: Edgj Varro ladatskáb(an) recze kŏteshez valo botokák, és ugjan holmi dib dáb portekátskák [Marossztkirály AF; Told. 2] * házi 1831: minden Házi portékátskáim minden nap ázik és rothad [Dés; DLt 665] * nyillhúzás által esett 1754: Nyil huzás által esett portekátskái [Nsz; Told. 19].

posztócska posztódarabka 1628: Egy Uerez fonallal szeot Uankos heyban ... valami dirib darab poztoczkak [Gyalu/Kv; JHbK XII/44. 13]; 1756: Holmi dirib darabb posztótskák [Nagyrápolt $\mathrm{H} ; \mathrm{JHb}$ XXXV/35. 21].

posztódarabocska kis posztódarab 1732: sok dirib darab hánt vetet poszto darabocskák, kapczák Salavárí ŏvek, és egyéb materiák [Kv; Ks Kornis Zsigmond lelt. 9].

posztómagyarka posztóból készült magyaros kabátféle 1850/1851: Egy fekete poszto fél viseltes magyarka [Kv; EMLt].

pótlásrétecske kiegészítésül adott rétecske 1841: A' tanorakba lévö kis potlás rétetskéért [Nagyernye MT; MRLt].

potykácska kis ponty 1597: kwltem Aiandekot az debre(cze)ny Byraknak ... 1 pogykaczkat ... / 80 [Kv; Szám. 7/XIV. 13 Masass Tamás sp kezével].

pökölőládácska köpőládácska 1849: Vagyon ezen szobába két fekete színre festett harom labon állo pőkő ládátskák [Somkerék SzD; Ks 73/55]. 
prédiumocska kisebb birtok 1755: Nemes B Szolnok V(á)r(me)gyéb(en) Csűrfalva nevű Praediumocskát kit az Oláhok Súrény nevezettel neveznek Tudjaé ... a Tanu hogy azon Praediumocskát is akkor apprehendálta a Mgos Csáki Familia midőn Szurdokot? [BSz JHbK XXX/5 vk]; 1808: az Ördengesbéli praediumatska [Msz; Berz. 17].

Szk: puszta 1656: (A) Szentgeorgi, s kereszturi puszta praediumoczkakot, atta volt ... Felesegemnek ... Kosztesden valami portioczkakot ... adva(n) neki [Ádámos KK; BálLt 93].

prémecske szegélyecske 1714: Minium szin Brokad szoknja ... előkelö tenyérnyi széles, Vallon aranjos s ezüst kisebb primetskék f. Hung. 104 [AH 3].

Szk: arany-ezüst 1714: Férfi gjermeknek való Vörös Bársony Mente köröskorül keskeny aranj ezüst prímetskével [AH 24].

pretenziócska kisebb követelés 1733: nem sok adósságocskám lévén hátra ... tehát azokat fizesse meg az Vr Battyám vram ... ugy osztán én-is minden praetensiocskákrul a mellyek talan lehettek volna le mondok [TKl Teleki Sámuel lev.].

prokurátorocska jelentéktelen kis ügyvédecske 1773: Gr. Bánffi Dénes tudna az igaz ${ }^{a}$, de az is nagyon fractus; mely szerént tudom aféle nótáriusocskákkal, procurátorocskákkal fogják kipótolni a fogyatkozást, az aféle pedig maga ellen

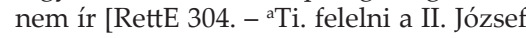
kérdőívében szereplő pontokra].

promóciócska szerény előmenetel/előléptetés 1758: azon gondolkoztam, hogy s mint lehetnék katonává valami kevés promotiócskával [RettE 66].

proventusocska jövedelmecske 1741: a Malombol is a' mi proventusocska jö, azt, az egész Város közönséges hasznára egjenlŏ képpen sine respectu Religionis fordittattuk [Dés; Jk 547b]; 1742: Pénzes kenyerrel 's eledellel kelletvén magunkat Szolgainkot, és házunk nepeit tartanunk, ami proventusotska ingredial, tsak arra sem elég [Torockó; TLev. 9/2. 2a]; 1756: Mivel a' Torotzkoi vas csinálás mások elŏtt szokatlan munka, ahoz képest proventusotskánkrol nétalám lehet oly velekedés is; hogy a' Vas csinálás mellett egyéb vas portéka keszittesbŏl is volna valami proventusunk, holott mi csak szintén vasat veretŭnk száljában, és azon tul abbol egy szeget sem tudunk csinálni [Torockó; TLev.].

Szk: vásári 1782/1799: (Városunk) Szombati Vásári proventusotskáit eleitől fogva ... hellységünk birái Szedték bé 's a' Városnak ottan ottan kővetkezett szűkségire kőltőtték [Torockó; TLev. 5/16 Transm. 348].

pugilláris könyvecske jegyzetkönyvecske 1714: Egy körökös kapszátskáb(an) foglaltatnak ... Csontbul vallo Pugillaris Konyvetske tengeri kis Compassal és magnetica tövel [AH 35].

punktumocska 1. kisebb feltétel 1668: Ez feljebb specificált punctumoknak megállására igírje magát ilyen formán, hogyha csak az kisebb punctumocskát által hágná is, tehát énnekem se püspököt, se ecclesiát ne kellessék érette keresnem, hanem lehessen szabados elválásom tőle [TML IV, 402 Szalánczy Krisztina Teleki Mihályhoz].

2. kicsiny pontocska/részecske $1710 \mathrm{k} .:$ a lineát helyesen ... definiálják a mathematicusok, hogy sok punctumocskáknak öszvekötött lánca avagy kötele [BÖn. 449].

3. átv jelentéktelen részecske 1782: Meltosagos Liber Báró és Gyeneralis Branyicskai Josika Joseff Ur ... meg emlekezvén ez boldog, és boldogtalan őrőkkevaloság kőzzé helheztetett, kitsiny Punktumotskánok az az ennek az Eletnek bizontalan voltarol ... Testamentumot tett $[\mathrm{Kv} ; \mathrm{JHb}$ $\mathrm{V} / 9]$.

pusztácska 1. kis puszta telek 1722: A Hid elöt a' Viz mellet ... kisded pusztácska [Barátos Hsz; SzentkZs]; 1751: A rét szélben aloll égy kis pusztátska [Nagyercse MT; Told. 36]; 1763: A Grope Gávrilla pusztátskája ... Vagyon ismét más pusztátska a La Podur [Garbonácfva SzD; TGsz 70]; 1767: ottan mindenkor birtak az ... eo Nga cseledi egy egy pusztácskát hol kertel hol penig ekivel [Hídvég Hsz; Eszt-Mk]; 1798: égy Gyűmőltsős helyetske és Pusztátska ... tőrókbuzás és káposztás főldetske [Kv; Pk 6]; 1803: Hasongardban eddig birt egj 
fertályni pusztátskáját ŏrŏk áron meg vásárlotta [Kv; Pk 3].

Hn. 1731/1802: A Nyárád partyán égy Pusztátska [Nyárádgálfva MT; EHA]; 1798: vagyon edgy kis pusztátska (szö) [Dés; DLt 12/1806].

2. kis erdei tisztás 1761: midŏn Pipei Szász István orotni kezdette tsak ă kŏzepin volt egy kevés pusztátska, kŏrŭl mind Erdő vólt [M.zsákod U; Told. 69].

puszta házacska puszta zsellérházacska 1756: Elek István ... egy Puszta házotskában mene lakni [Burjánosóbuda $\mathrm{K}$; JHbK XLIII/27].

pusztásocska eléggé kopár, elhanyagolt 1769: hogy ha munkát tétet eő Nagysága azon szőlöb(en) (: mint hogy pusztásotska ${ }^{a}$ :) verificalodvan, menyi munka ment reá; aztis a szőlő mellé todván tartaz(z)am meg forditani éő Nagyságának [Ádámos KK; MbK IX. 39. - ' Tollvétség pusztásocska h.].

puszta szessziócska elhagyott jobbágytelkecske 1732: Vagyon egy puszta mocsáros Sessíocska ... ezen Sessiotska ... minden külsŏ appertinentia nélkül vann [Göcs MT; Ks 17/LXXXIII]; 1767: ezen puszta Sessiotskát ... által adta volna hoszszas szolgálataiért [F.gezés NK; Berz. 3. 7. C. 6]; 1783: Czerjék Ferencz vr(am) mind két ágon s életb(en) Lévő edes Gyermekei meg edgyezett kőz akaratbol egy más kŏzött kivánván ... mint (!) két agat illető rész Portiojokat meg osztani ... Nyil Vonás szerént ... ugy hogy ki menvén az irt osztozo Atyafiak mérjék el, nem kŭlőmben azon puszta Sessiotskat is ... hat fele mérvén kinek kinek Cincus szerint való része a fenn irt Numerus szerint jutott [Zoltán Hsz; Borb. II]; 1817: Vagyon ... égy el súlylyett puszta Sessiostkaja [Buza SzD; LLt Csáky-per 28. L. 2].

Szk: nova 1775: Nova Puszta Sessiotska [LLt Csáky-per 107. L. 14].

puszta telkecske kis puszta jobbágytelek 1830: egy benn való puszta telketskét [Etéd U; NkF].

putinkaforma kis putinához hasonló 1755: Putinka forma otska általag No 3 [Batiz H; BK sub nro 1020 Naláczi conscr.]. puttonyka kis puttony 1638: Vagyon ... eggj palinka feözö hazis ... Vagjon benne ket kad, eggj putton, es eggj altalagoczka. Meghint eggj puttonka [A.porumbák F; UF I, 665]; 1758: Egy putonka káposztának valo valora den. 36 [HSzj puttony al.].

rabka fonókerék 1820 u: Egy len fono kerék vagy rabka kéz orsojával [Mv; MvLev.].

rációcska kis/rövid számadás 1664: alázatos könyörgésünk mellett való rátiocskánkat ez levelünk ... nemzetes Ugrai Gergely uram ő kegyelme által Kegyelmednek igen nagy bizodalommal in scriptis el küldöttük [TML III, 296-7 Boldai Márton Teleki Mihályhoz]; 1681: Eszt ... percipiálván Páter János uram gondviselője Jenei István uram kezébül, adtuk inventáriumban mostani tiszt Endes Miklós uramnak, eő nagysága részire való lüvén ez. Ezeken kívül ... Endes uramnak maga pecséttye alatt költ hiteles diariumbul álló ratiocskát adott mi előttünk [CsVh 94].

rajzocska rajzolatocska 1881: Kétségbe vagyok esve, Ödön! Nem tudok bár egyetlen vidám rajzocskát írni. Nem fog a pennám [PLev. 89 Petelei István Jakab Ödönhöz].

rakásocska 1. kis rakás, halmocska 1763: Lattam Bereczki Gábornális Farkas Dombi fát jo rakásotskát egy vagy két teréből állót [Zágon Hsz; Szentk. Sam. Domokos (58) pp vall.].

2. jelzői haszn-ban; vhány rakásocskányi/ halmocskányi 1633: az en felesegemnek ... hagyok ... az Mayorban egy Rakasotska fatt [Kv; RDL I. 101]; 1772: A Csürős kertben egj rakasocska buzaszalma [Tarcsafva $\mathrm{U} ; \mathrm{Pf}]$.

rámácska (ablak)keretecske 1656: Az fal mellett egi darab deszka polcz jvegh ablakhoz valo ramaczkák nro 6 [Fog.; UF II, 162]; 1789: A' Laboratoriumbol ezen Házban bé járo Ajtonak felsŏ része kŏzepén egy Rámátskába tsinalt onos Ǔveg ablak Rft - xr 15 [Mv; ConscrAp. 42].

ráta-porciócska birtokrészecske 1734: Conrád Andrásnē Dési Christina Aszszony Contractusa az ... Zutorja rata portiocskájárúl [SL. $\left.-{ }^{\mathrm{a}} \mathrm{K}\right]$. 
reditusocska jövedelmecske, bevételecske 1733: Malom vagjon a Berekb(en) a Dobokai Patakonn két kövű ... mikor szárazság nintsen, akkor vagjon reditusocskája, de ha az vagyon mint a Njáronnis nem forog és oljkor semmi proventus nem redundál belöle [Doboka; DHn 11]; 1737: Mint hogj I(ste)n ő Sz: Felsége kglmességéből szintén el-kőzelget az az idö, mellyb(en) a Nms Város Privilégium szerint való Három Hónapi Kortsomája bé állyon ... a meg-iható Dési borok szedettessenek bé a kortsomákra mas felével 1:/:1 m. forinton(n) ... Borbirák atyánkfiai ... ez után(n) ne expondállyanak a borok(na)k kortsomákra való vecturáztatásokért: hanem minden betsülletes atyánkfiai magok vecturáztassák boraikat a kortsomákra; ha ki pedig maga nem vecturáztathatná, valamelly rationabilis ok miatt, tehát mikor borok árrát bé fizetik Borbirák atyánkfiai, akkor az ollyan magok vecturáért remittállyanak 12:/:12 hogj ezen reditusotskával is angeáltathassék Nms Városunk Proventussa [Dés; Jk 476].

régebbecskén kissé régebben 1761: Galambadon a menyi Drágány vagyon mind edgy féle, ennek az itt valonak Szamontzája ... régebbetskén jőttek volt Galambadra, mert ez sokat budoklott imit, amot [Mezőcsávás MT; TL. Burdusán Gligor (60) jb vall.]; 1767: Az ide valo Possessor Urak közűl mostanában, vagy régebbetskenis a kőzőnséges falu főldibŏl ... mennyit fogtanak fel? [K; JHbK XLVIII/1. 8 vk].

régecske 1 . meglehetősen régen 1827: (A) rectificatiot tárgyazo Perfolyásátt nekem meg mutatta, de ... hogy menyibe lett, effectum azt nem tudom ... mint hogy már régetske a meg mutatas idejenek [Albis Hsz; BLev.].

2. meglehetősen régóta 1806: A mostani jó vásárhoz képest, mellyhez hasonlóba régetske hogy nem voltam, mondhatom, hogy ... ŏ Klmének ... igen sok kára kŏvetkezett [Torda; UszLt ComGub. 1753u]; 1814: ezen barátsága ... már régetske hogy foly [Ne; TSb 12].

régecskén elég régen 1712: nem emlekezem jol rea mivel regeczken volt [Dés; Hr 6/28]; 1743: fa Záros régecskén csinált ... ajtaja
[Boroskrakkó AF; BN dobozolt anyag VI]; 1778: a melly Recruta Transportok az Eszterházibol és Gyulaiboll már régecskén itt által mentek az Ármáda felé, azok ezenn két három napok alatt meg ... itt lésznek [Dédács H; Ks 96 Gyulay Ferenc lev.]; 1793: régetskén vivén Bort a' Falukra, vagy két hejt fogyatékján tudom lenni a bort [Hadad Sz; JF 36 LevK 294 Benkő Elek lev.]; 1796: láttam már régetskén, hogy egy Lakadalmi alkalmatassággal egy Kamarában egygyütt ittak szerelmeskedtek [Kv; AggmLt D. 15]; 1813: Groff Korda Anna Vr Aszszony ... fogattatott fel egy jo darab fiatalos Erdŏt ... ugy hallottam, hogy az akkori Udvari Tiszt az eŏ Nga emberei által fogattatta fel már régetskén ... imitt amott a régi fogásnak jelei és valoságos kereszt jegyei a Fákon találtatnak [F.berekszó Sz; BfR III. 12/9 Fluerás Mikás Vonucz (40) col. vall.]; 1824: a' már régetsken vólt [Szentdemeter U; Told. 40].

régicske 1. meglehetősen régen épült 1771/1817: Cseléd ház ... fedele régitske [Kardicsfva U; Mk Török-Rhédei transmiss.]; 1825: egy régitske fenyö Boronábol épült Ház [Csomakörös Hsz; SzentkZs Conscr. 317]; 1837: Egy borona Sertés ol ... régicske [Várfva TA; Borb.].

2. meglehetôsen ócska 1788: Palatsinta sŭtŏ vas égy, régitske [Mv; TSb 47].

3. meglehetősen régen learatott 1755 : eresztett ... a' Buzánakis kalongyája edgy vékát, s többecskètis; hanem az edgyik buza asztag régitske Lévén két kalogyais alig adott abból edgy vékát [Gernyeszeg MT; TGsz 35].

4. elég régen történt 1749: arrol éppen bizonyost mondani nem tudunk ... minthogy régitske a dolog [Koronka MT; Told. 29/42]; 1808/1809: Már most nem emlekezem régitske lévén a' dolog, a' kérdett rendelés publicaltatott volte, vagy nem [UszLt CombGub. 1753u].

5. idősecske, meglehetősen idős 1761: Én jóllehet régitskének látatom lenni Esztendeimre nézve [LLt 38/18]; 1793: ez iránt ámbár régitske szolgája vagyok Nagyságodnak Parantsolattyát nem tuttam mivel az én Idŏmben Istené a' ditsősség ollyas 
Marha dőgi nem volt [Drág K; JF 36 LevK 261 Tollas György lev.].

regisztrumocska lajstromocska 1768: kérem ezen emberem által, ezen acludalt registromacska szerent valo leveleket kŭlgye el öcsém Uram [Marossztgyörgy MT; Ks 61 Kornis István lev.].

rejtek-boltocska boltos rejtekhelyecske 1681/1748: be menvén két kis graditson, vagjon két alatt valo rejték boltocska [Balázsfva AF; KvAkKt Mss lat. 236].

rejtekecske rejtekhelyecske 1726: jó épp, hideg pintze ... az nagy ház alatt lévö harmadik pintzébŏl bé járó kis rejtékecske ajtó mellyék nélkül [Ne; DobLev. I/124].

rejtek-kamarácska titkos kamrácska 1694: Ebbŏl a Hazacskabol nyilik mas hasonlo Ajto mas hazacskara ... keorös kŏrnyűl Zőlden festet sima Fogasocskák vad(na)k benne az oldalan ... egy rejtek Kamaracskajais va(gyo)n ennek az haznak [Kővár Szt; JHb Inv.].

rekeszecske 1 . vmely helyiségből elkülönített kis rész 1632: Az Koniha feleől ... valo also rend hazban ... egy dezkabol czinalt rekeszeczke kiben vagion valami romladozott Iuegh [UC 14/38 Kománai urb. 121]; 1692: 5 . Haz ... most premendas haznak mondatik ... vagyon ebben egy fenyő deszkabul csinalt rekeszecske, fenyő deszkakkal be padolva [Görgénysztimre MT; JHb Inv.]; 1767: ā Tarnátzában Dél felől vagyon egy kis rekeszetske [Csapó KK; Berz. 3. 7. C. 6]; 1781: Élés Ház Melybe járnak ... egy hítvány vas Sarkokon forgó vas reteszszel járo ajton, egy kis rekeszetskén által, mely rekeszetskének bal felŏl valo részében vagyon egy deszkával el rekesztett kamaratska [Pálos NK; Hr]; 1781: vagyon ... egy kissebb Gabonás, melybe járnak bé az ... Tornátzból egy kis rekeszetskén által [Petek U; Hr].

Szk: parasztablakú 1699: nyilik bé ... ajto ... egy két kőtésséken alló előé három Nyar, cserefa sasokba rakot egy paraszt ablaku rekeszecskeben [Szentdemeter U; LLt] * párkányos 1692: ebben az hazban ... o fenyő deszkabul csinalt parkanyos rekeszecske [Görgénysztimre MT; JHb Inv.].
2. kis ól/istálló 1679: Bialy borjuk(na) k valo rekeszecske [Uzdisztpéter K; TL. Bajomi János inv. 117]; 1792: majorságnak meg kévántato rekeszetskékis voltanak [Recsenyéd U; Pf].

Szk: rostélyos ajtajú 1820 k.: vagyon ... a Tornátz alatt egy Majorság tarto rostélyos ajtaju rekeszetkeis [Dés; RLt].

rekeszke kis rekesz 1694: Ezen Folyoso vagy Tornacz vegen viszont van egy Kis Rekeszkeis, kinek sem Ajtaja, sem egjeb nincsen semmis benne [Kővár Szt; JHb Inv.].

rekesz-kertecske kis elrekesztő kerítés 1710 k.: Egy kis rekesz kertecske volt az ablak alatt, mely miatt az ember az ablakhoz nem mehetett [BÖn. 562].

remekecske kis ékszerdarab 1700: Egy rubintos nyakravalo huszonnégy kerek remekecskéje huszon kettŏdik az fityegŏje két két rubintocska, az kŏzte valo remeken ollyan hoszszuko remeke 19. az fityegǒjének az Pántlikáján egy Rubint [Hr 1/20].

reménységecske reményecske 1670: Gábor, hogy értett Ádámtúl, nem kétlem, mert éjjel-nappal csak együtt beszéltek, de nem hiszem, hogy az mi levelünk meritumát egészlen megmondhatta volna Ádám is, mivel bizony maga sem tudta, az modalitások mutogatásául mit írt Rottel, kihez képest Kegyelmednek is csak in generalibus terminis kell nekik mondani, hogy vagyon nyujtva valami jobb reménségecske most, mint eddig volt [TML V, 376 Bánfi Dienes Teleki Mihályhoz].

remeteházacska a magányos fülemüle fészke 1811: Pusztájában vólt e' Remete házatska, Miglen találkozott égy szarándokotska, Mely lakást választott annak a környékin, 'S járkál a' sürü fák' zőld ág boritékin ... Itt' változtattya száz formákra, tilile - Hangját e' Remeté a' kis Filemile [ÁrÉ 106].

részecske I. fn 1. darabocska 1656: az kemenj alliara nilik be vas sarkon panton forgo vas pantos pleh ajtó forditojaval faragott kö mellyekeuel ... Felseö resze ... küleömb külömb fele viragokkal ki csinalt mesz metczesses, meli mesz metczeseknek az jstalo feleöl valo reszeczkeje az viz rea csepegven, meli miatt egy kiczin hellien megh bontakozott [Fog.; UF II, 131]. 
2. rekeszecske 1712: Ezek vétettek ki egy régi két felé nyiló ládából ... az felső skatulyából, bal kéz felől az hátulsó részszecskéjéből [Ebesfva; CsVh 104].

3. folyószakaszocska 1765/1770: (A föld) innét ezen uthon kőzel lévő két füzfa kőzül ... a' Küküllő follyamatyának egy reszetskéjin keresztűl nézvén ... a' kőzepsotől harom olynyire ... határozodik [Széplak KK; SLt évr. Transm. 191].

4. mezőgazdasági területecske, (erdő/ föld/szőlő stb.) darabocska 1592: Az S. egihaz mellett uagio(n) falnúl egy darab mezeonk, kiben kerteltette(m) ez idey haznaerth be egy reszechket [UszT 11/61]; 1596: egy keóz erdeónkbe, mellyet eó kgmeis keoznek mondott az eleott ... az megh Irt keóz erdeóben egy reszeczket az en reszem zerenth epetettem [UszT 11/24] 1626: Az berek Elót valo ret hatara feleól az min vezekettek nagj Gergelljel az vezekedeó rezeczjket ket fele merjek es fele Nagj Janosnak fele Ozdj Gergeljnek maradgion [Bálintfva MT; Sár.]; 1696: vagjon egj Darab szenafü Templum szamara ... mikor niomasban esik egj kís reszecskeje, es egesszen egy irant nem kaszalhattyak Taxaja harom forint [Alfalu Cs; GyHn 16]; 1721: az ő kglnél zálogb(an) lévő részecskéjét azon gjŭmőlcsős(ne)k meg ereszté [Ne; DE 2]; 1737: informáltattunk vala ... Határunk egj(gj) rèszetskéjen(e)k a kozárváriak által lőtt el-foglaltatása iránt [Dés; Jk 485-6]; 1739: (A szőlő) nagjob reszét az Dumitru Ignát Fiai kezdették birni, s, egj rèszetskéjét en magam, minthogj verség szerent ket reszre kellenek oszlodni [Sáldorf NK; JHb XXIII/49. 15]; 1745: ezen szánto főldnek edgy kevés Ingoványos részecskéje [Fejér m.; Kath.]; 1748: az Füves kert nevü Telekbeli részetském [Komjátszeg TA; AbN]; 1777: (Az) irtásnak egy részecskéit ... az erdő ujjolag bé fogta [Dupapiatra H; GyK]; 1787: Ezen Fiscalis Tiburtzi határnak a' melly Dimensuraltatott egy részetskéje ... kaszáltatik [Kajántó K; KmULev. 2].

5. birtokrészecske, részjószágocska 1602: Gergh Seifner ... vallja En az Job apamrol ream marat darab zeoleochket mind az hugomrol ream marat kichin rezechkeúl vgy attam Veimerer Martonnak hogy ha Ieowendeoben el Adnays en hyremnekeol el ne Adhassa [Kv; TJk VI/1. 591]; 1606: Az melj keves rezecziket Keczietj Gaspar Erezteth wolt Kezemben azt kez wagiok ozlasra keozre bocziattany [UszT 20/47]; 1712: Lévén egj Kis részecskéje az emlitett R(eformátus) Parochia mellett valo Fundusnak Zalagban [Mikeszásza K; MúzRadák]; 1758: az Relicta ... azzal nem Contentalodik, ha nem továb mégyen ... az Ŏss Joszágbol estimalni kell Dosához illendő jövedelmű részeczkét, és a Férje Házában meg kell hadni [Asz; Borb. I]; 1769: az utrizalt erdŏhöz közelis kivált amelly szomszedcságában volna éppen nem bir Barótzi Uram, hanem tavolyatskán tölle a Bagyoni Sandor Uram részét birja ö kglme zálogban, melly a Béldi részbŏl szakadott $\mathrm{ki}$, de ez is igen kitsiny részetske [Ispánlaka AF; JHb XXVIII/53]; 1795: Groff Széki Teleki Kata Aszszony ŏ Nsága ... igen kevés héjjával egész Bányabükkit birván, és igy az én részecskémis ŏ Nsgának keze ügyiben esvén, tehát én azon Bányabükki Jószágbéli részetskémet minden belső és külső hozzá tartozoival egyetemben adom által ... örőkős cserében ... Groff Teleki Kata Aszszony ŏ Nságának [Kv; JHb XIII/19]; 1816: Atyafi Babos Ur itten járván, minthogy kedve vala a kotsárdi Részetskénket kivenni, tehát azt általis adtuk árendába [Kv; DobLev. V/1000]; 1822: Balog Márton ... az Orbán István és János reszetskéjeketis meg Vásárlotta [Szentimre MT; BalLev.].

Szk: belső 1681: az Beres pataka felŏll ualo belsò reszecskeje marada Marko Borbara fiaczkaianak Istoknak [Homoródsztmárton U; Borb. II]; 1791: ezen Adámoson lévŏ Solymosi részből jutott, osztály szerint, kevés belső és külső reszetkéjeket ... adák által ... eŏ Excelentiájának [Ádámos $\mathrm{KK}$; JHb XIX/33].

6. töredék országrész 1662: a hatalmas nemzet minden tanácsát arra kezdé forditani, hogy ... Erdélynek ... nyakát kedve szerint megnyomhassa, s Magyarországnak megmaradott kevés részecskéjének holdoltatásához és foglalásához is nagyobb kaput nyithasson [SKr 531]. 
7. megyei részterület 1661: Zaránd vármegyének részecskéjét szüntelen fenyegetvén, holdolásra kénszeriti [KemIr. 343].

8. kis örökrész 1629: Az Eötueos Nagi Mathe vram leaniat is, Nagi Margit Aszszont egy reszeczike illette, melliet Inuentariumba(n) irtunk; az myk az Szabo Nagi Ferencz iouaibol iutottak $[\mathrm{Kv}$; RDL I. 143].

9. járandóságocska 1782: Minthogy a fübéli kár is prétendáltatik, illő, hogy a határpásztoroknak füből is legyen valami részecske falu közönséges helyéből [Oroszfalu Hsz; RSzF 151].

Szk: pénzbeli 1674: Fimbriger Márton szeoleje félébenis vagyon az városnak vallami pénzbeli részecskéje [Kv; Szám. 34/L. 23].

10. hányadocska 1649: az mivek(ne)k kik feleŏl az per va(gio)n ighen keczin (!) reszeczikeje volt tizen ket lottos [Kv; TJk VIII/4. 376].

11. kb. mértékecske 1710 k.: Bízom Istenben, avagy csak mi részecskéjében elmondhattam volna Job. 31:33-36 [BÖn 933].

Szk: kicsiny ben 1673 k./1681: kivaltkepen valo tekéntetem lévén, az I(ste)n hazaban hűsegel forgolodó Egyhazi szolgakra ... hogy holtom utanis jo emlekezetem mindeneknél fen maradgyon, kivantam ha czak mi kicziny részecskeben is, jo indulatomnak kész voltat, az érdemeseknel irasban hadni [VhU 317 Thököly Imre ad. lev.].

12. kis csoport, töredék 1678: egy részecskéje az magyar nemzetnek akár mint erőlködjék is, de az többi nélkül félő, markába ne szakadjon, akármikor fog is [TML VIII, 157 Haller János Teleki Mihályhoz].

13. részletecske 1590: ha mit Ebben tagadnal wagj walami rezeczkejet tagadnad az my lehet bizonittok az mellet az teorwint is kerem tudomant tezek hogy zawa halwa ez dolognak minden rezejhez zabad leg(je)n teobet zolno(m) [UszT].

II. jelzői haszn-ban; részecskényi 1766: egj kis részetske főld [Hr 10/3]; 1860: meg vásárolta ... egy másfél öl Széles és 28 öl hoszszu részetske belsö birtokát [Mv; $\mathrm{DE}$ 2].

részecske-birtok részjószágocska 1864: Kegyelmednek egyezesünk szerént a' Gagyi részetske birtokunkért fizetnem kell vala ez elŏtt egy holnappal [Újszékely U; Pf Révai Dénes lev.].

reszelőcske 1656: Ezen saffar hazban vagyon egy negy szegre csinalt asztalos miszerszam tarto lada, kiben vagyon miveleö ezköz ez szerint ... Reszeleöczke nrŏ 2 . Veseö 2 [Fog.; UF II, 114].

részerdőcske részjószághoz tartozó erdőcske 1775/1802: Doszu Nadosuluj nevezetü Erdöbeli resz Erdötske ... azon kis resz Erdötske, oly kitsiny extensioju, hogy respective Erdőnek sem lehetne mondani [Bsz; JHb LXVII/3. 6-7, 96].

részföldecske részbirtokocska/jószágocska 1717: a kérdésb(en) specificalt resz fŏldetske ... Nagy Istvanek sessiojahoz jutott [M.csesztve AF; JHb XXVIII/21].

részfüvecske részszénafüvecske/kaszálócska 1728: Az érb(en) egj resz fŭvecske, a Kese fiak oszlo füvei kŏzŏtt [Lisznyó Hsz; SVJk].

részjószágocska részbirtokocska/porciócska 1582: Az eo Rez Ioszagoczikajat ... Varadi Pal deaknak es $\mathrm{Az}$ eo felesegenek ... ada eoreok aro(n) [Mv; BálLt 55]; 1584: yelenthethem wala few okath oda menisemnek hogy ha weselenj wramthwl ez kjs riz yozagocykath ... kólcygem athaljs meg zabadithatna(m) [Komlód K; WLt Petrichewich Kozma foly.]; 1618: az minemw rezz Jozagoczkat Niarlo Kekessen Doboka Varmegieben Coloswari Barbelly Martonne Azzoniom birt, ahoz en nekem bizonios Competentiam leuen Vrunk eò Naga kgmessege utan [Kv; RDL I. 105 Kowachoczy István nyil.]; 1623/1624: Mivelhogy az mi kiczin Jouaim, Jozagoczkam, es egieb keresmeny(m) uadnak, azokat en tulaidon iambor zolgalathommal kerestem ... mind az Olah Peterlakj Feieruar megiebeli rész Joszagoczkamat ... mind penigh minden egyeb kwlseő es belseő iauaimat ... hagiom es uallom Testamentomban az en szerelmes Felesegemnek, Lőrincz Judithnak eöreökben mindenek ellen [Medvés/Gyf AF; KCs IV/103]; 1782: 
az egész rész Joszágotska a Néhai Atyafi által ell volt 2180 Forintig kötve [Ne; DobLev. III/570]; 1805: Bartos Sara Asszony itt az Albisi rész joszagotskáját el adá őrőkősőn ... őtse Uranak Bartos Samuel Uramnak 100 - szász Magyar forintokert, mely joszágotska vagyon itt Albisban Felszegb(en) [Albis Hsz; BLev.]; 1810: Küküllő Vármegyében Kis Szőllösi, és ... Kővár vidékin Borkuti Rész Joszágatskák ... sem égyszer, sem mádszor meg nem voltanak osztva [Kv; Ks 89]; 1819: Dombóház Kőzél levén a' Tekintetes Ur Ádámosi rész Joszágatskája [Dombó KK; Pk 5].

reszketőtű́cske rezgő díszes kisékszertű 1749: Egy kis arany boglárból, jó féle gyŏngyel gombos tŭre tsinált reszketŏtŏtske [Koronka MT; Told. 12/14]; 1786: Egy Galamb formára Csinált reszkető tőtske 1 nagyobb rubintal, és három kisebb 13 szem joféle győngyel [Nsz; Ks 74/56].

Szk: gyémántos 1758: Egy Gyémántos, Rubintos, és Győngyős Médály, melyben vagyon ... nagyotska Rubint 8 ... Más gyémántos, s Samaragdos reszkető Tőtske, melyben van 5. Smaragd s 10 gyémánt [Nsz; TSb 21].

részporciócska részjószágocska 1662: Fejérvár megyében egy Tohát nevŭ faluban vagyon egy kis réssz portiocska ... Kŏnyŏrgŏk alázatossan Nsgod(na)k mint Keglmes Ur(am)n(a)k meltoztassék Nsgod az megh emlitet rész portiocskát Jus regiummal megh adni [JHb XXVI/71]; 1761: Lévén Sáljiban lako Menasági Josef nevŭ Nemes embernek Veszszŏdŏn bizonyos rész Portiocskája, asztat ŏ velle Nehai Mlgs Josika Josef Generalis vr el tserélvén adott azért itten ... egy Vlád Andréka nevŭ Jobbágyot [Pagocsa K; JHbK LXVIII/1. 31]; 1783: Lévén ... Szilágyi Sándor ö klmének ... Csekelakán bizonyos rész portiotskája ... édes Annyának abbol a Dos ki nem fizetődőtt [Mezőbánd MT; MbK XI. 69].

rész-szessziócska részjószághoz tartozó telkecske 1747: egy darab rész Sessiótska [Mv; Told. 43/36].

rétecske 1. kaszálócska, legelőcske 1599: 1 Zakaz Zena niolcz eol. Az hawason es az reteczken eot boglia [Kv; Szám. 8/XV. 18]; 1622: Szena Meszeő labian vagi(on) egi
Reteczke [Felőr SzD; SzJk 14]; 1634: Ez mult 1633 eztendeoben menek az holt Marosban egy kis reteczykem latnia, hat ot az maros mellet jar az menes [Mv; MvLt 291. 29b]; 1675: mivel már itt Fogarasban telepedtem megh, itt vagyon valami hitván házam, de hozzája valo majorkodásra valo kŭlsŏ alkalmatosságom csak egy talpallatni-is nincse(n) hanem hogy ha valakitől kaphatok á-beli szűksegemre drága pénzemen egy darab magh ala valo földet es egy kis retecsket neha neha egyŭttis másuttis [Fog.; Törzs. Fogarasi János portai posta lev.]; $1687 \mathrm{k} .:$ Malom szegb(en) vagyon égy darab rétecske Benedekfi György házára járo az hasznáért ad ā Templomnak d 25 [Seprőd MT; MMatr. 238]; 1719: A' szena Fúven ket Rit ... Pereczen fele ... Egy darab Riteczke Vagion egy darab pusztas Szőlő is [Varsolc Sz; Ks 83]; 1724: azon erdŏn alóll egy retecskét meg kaszáltatott volt edczer egy Vingárdi Uszkai János nevű Gondviselŏ [Gergelyfája AF; JHb XXVII/2]; 1754: Reszkota nevezetű helyben lévő rétetskét az Vtrizáltakat értem tisztitani mint Husziai határban levő helyet [Hosszúújfalu Sz; WLt Nagy Gyermán (44) jb vall.]; 1796: Ezen ket utolso rétetske a Falu kŏzŏnséges réttyébŏl jár a házok utan [Szentgothárd SzD; WassLt]; 1804: Hány esztendeje annak is hogy ezen rétetske fel hagyatott? [Kiscég/Kissáros K; RLt O. 4 vk]; 1824: a szomszédalt két Rétetskék ... 10 ... öt Esztöndökik kiválthatatlanok légyenek. 20 És mivel Ezüst Hüszasakban mégyen most a' Pénz ezekben légyen a kiváltásis [Asz; Borb. I].

Szk: allodiális 1747: Kender fŏldei és a Nagy Patak kŏzŏtt fekűvő Allodialis Rétetske [Nagyida K]; $\quad$ 1748: A Szoka (!) Rétén is Vagyon egy darab Allodialis Rétecske [Koronka MT] * közönséges 1745: a ... Falu kŏzŏnséges oszló Nyilas Rétetskéjéb(en) [Nagyida K] * majorság 1733: edgy darab Majorság Sáros Retecske [Sólyomkő K; SLt GH. 43]; 1795: Sztolnán adatik egy két Szekér Szénát termö Majorság Rétecske [Kv; JHb I/36] * nemes 1766: Vagyon ... igen jo Nemes Rétecske ... melly régenten az Néhai Diosi Ferencz Nemes kaszálloja volt [M.köblös SzD; 
RLt] * vhány buglyára való 1699: A Kis lakon edgj bugjara valo rétecske [O.zsákod KK; LLt]; 1733: Vagjon ott fennyeb az Ér mellett egj darabocska egy Bugjára valo Retetske [Vaja MT; Sár.] * vhány rúdnyi 1641: uagion ... hatt rudni Reteczike [Csepőmacskás K; SLt AM. 19] * vhány szekér szénára való 1681/1748: 3 szekér szénára valo rétecske [KvAkKt Mss lat. 236]; 1766: (Az iskolamesternek) Vagyon fél szekér szénára valo Retetskéje [M.goroszló Sz; SzVJk 172]; 1766: Colal Pataki István Uram ... egy szekér szénára Valo Rétecskét [M.köblös SzD; RLt]; 1793: a Communitás erdejéből egy darabotska mintegy egy szekér szénára valo rétetskét mi irtottunk az Atyámmal [Kalotasztkirály K; KHn 54] * vhány szekér szénát termő 1791: Lévén ... egy Kis Joszagotskája nevezet heljetskék ègy fél Szekér Szénát termő Retetske [Vaja $\mathrm{MT}$; VH].

2. irotványrétecske 1784: Egy irotványból készült Rétetske [Diós K; BHn 69].

3. mocsaras, zsombékos helyecske; Szk: sétás 1766: 1 szekér szénára Valo Satés Retecskét ... Tokai Ferencz Uram Miron Nevü Jobbágyais bir [M.köblös SzD; RLt]. Hn. 1678: kis Reteczke [Vadad MT; VK]; 1700: egj rétecske az Csernyicz Pataka mellett (k) [Abrudbánya; EHA]; 1717: az Gatok kózót ... reteczke [Gyulatelke K; EHA]; 1722: Az Pap Szököllejenél égy Küs Rétetske (sz) [Váralmás K; KHn 311]; 1737: A Vár Rétecske (k) [Nagyida K; EHA]; 1742: A Pásintos kutnál edgy rétetske [Mezőbánd MT; EHA]; 1747: A Tormás Gátján alol való kis Rétetske [Nagyida K; EHA]; 1748: A Vágás alat egy darab rétecske vi(cinusa) fellyŭl az erdŏ [Koronka MT; EHA]; 1753: a felsö Nádasban lévö rétetske [Szováta MT; Told. 3a].

reteszecske riglicske 1638: az ablakan vagjon két vas sarkoczka pantostol, eggj retezeczke fejesteöl [A.porumbák F; UF I, 656].

rézágyúcska 1667: Felsö Czejt haz ... Nyeregben valo réz agyucska nro. 1 [Fog.; UF II, 338].

rezecske rézdarabocska 1737 k.: 2. darabb vasacska ... 2 darab rézecske [Brassó; ApLt 5 Apor Péter inv.]. rézfazakacska 1673: egi Kis rez fazakaczka [WassLt Borsai István hagy.]; 1685 e.: Szász Sebesen Piheni (!) Peter Uram Házánal vadnak ... Kis réz fazakacska Nro. 1 [Borberek AF; MvRKLev. Urb. 18-9].

Szk: kávés 1837: Kávés réz fazakotskák 8 [Szentbenedek SzD; Ks 88 Oszt. 11] *úti 1823: Úti réz fozokatska [LLt Csáky-per 601. L. 1].

rézfillérke réz-aprópénz 1710 k.: ha ki a te sátorodhoz egy marok kecskeszőrt vagy a te házad ládájába két rézfillérkét adott, nem utáltad meg, hanem kedvesen vetted [BIm. 1002].

rézgombocska kis rézgomb 1755: Sára Aszszony az maga kertébe hiván Palko társammal, mondgya: fogjátok pázmára fiaim a Tőrők buzát, mert itten bizonyoson tanalunk valamit ... tanáltunk egy kiss vászon Zacskocskát ... benne két kis réz gombocskát, és egy gyŭrüben valo kóvet [Déva; Ks 101].

rézharangocska rézcsengő 1632: Az kapu felet valo porkolab ház Az foliosoian uagion ... Egy kis réz harangoczka ... N. 1 [Fog.; UF I, 131]; 1652: Egy kis agoson valo rez harangocskais kivel az kapu betételre és be eresztesre szoktak csengetni [Görgény MT; Törzs.]; 1714: Egj Theca, mellyb(en) következendö mobiliak vann(a)k ... Egynehany réz harangotskak ${ }^{\mathrm{a}}$ [AH 10-1. aFels-ból kiemelve].

rézibrikecske rézfindzsácska 1733: Réz Ibriketske [Marossztkirály AF; Told. 2].

rézkalánocska kis rézkanál 1742: egj réz Kalányotska [Pókafva AF; JHb XXV/58].

réz-kásztrolocska rézláboska 1791: Egy réz kasztrolotska [Déva; Ks 108 Vegyes ir. Grék Mihucz kereskedő hagy.].

rézkondérocska kis rézüst 1729: Egy káposztás Uti réz Kandérotska [CsS].

rézládácska kis rézláda 1765: Egy Rez Ladacska [Kóród KK; Ks 19/I. 6hoz].

rézláncocska rézből való kis lánc 1666: Viszki Paál ez szerént Harminczadoltatta ki hozot jováit ... maszkaras Tŭkŏrt. Jo fele tŭkŏrt, Kep iro Aranyat ... Rez Lanczoczkakat [UtI]; 1849: Vagyon égy mettzett üveg Lúszterhez három réz lántzatskákon igen ékes rézből készitett három férfi 
fők a' lántz vegeken [Somkerék SzD; Ks 73/55].

rézlombikocska rézből való kisebb pároló edény 1723: edgy kis réz lombikocska [Görgény MT; Born. G. VII. 24].

rézmozsárocska 1733: Réz mosároczka Tŏrǒjével 1 [Marossztkirály AF; Told. 2].

rézpléhecske rézlemezecske 1789: 3 Por tŏltŏ réz Pléhetske Rft - xr 5 [Mv; ConscrAp. 44].

rézserpenyőcske lapos rézedényecske 1627: Egy rez serpenieoczke ... Egy Kis fel fwgeszteő wsteoczike hitua(n) szabasu aestim: f. - d. 50 [Kv; RDL I. 133].

rézskatulyácska 1829: Edgy bors tarto réz Skatulyátska [Mv; MvLev.].

réztálacska 1729: Egy rez talacska tangjer hellyett [Erősd Hsz; SVJk].

Szk: megaranyozott 1714: Confectnek való meg aranjozott réz Tallotskak No. 12 2//40 [AH 46].

réztekenőcske hosszúkás rézedényecske 1715: A Réz edényt fel osztván ... jutot ... Pongrácz Andrásné Asz(szonynak) edgy tőredezet tekenőcske [WassLt].

réztököcske '?' 1714: egj Sakotskab(an) réz Tókötskek No 20. Mas Sakotskab(an) rez Tőkőtskek No 11 [AH 11].

rézüstöcske 1. rézkondérocska 1638: Vagion azon megh irt pitvarban ... Egj rez üsteöczke [A.porumbák F; UF I, 657]; 1673: 1 Réz Ǔstŏcske készségéuel [Gyf; UtI]; 1687: vŏttŭnk ... Egy réz ŭstŏcskét Segesvárrul pro f. 1//75 [UtI]; 1711: Egy Réz ŭstŏcske [MúzBethlen].

Szk: fogantyús 1627: Egj fogantos rez osteoczke f-d. 20 [Kv; RDL I. 134]; 1736: Fél ejtelesnél kissebb fogontyus réz üstötske [Várhegy MT; CU] * hatkupás 1787: 6 kupás réz kis ústetske viseltes [Mv; MvLev] * kétfülü 1789: Egy két fŭlŭ réz Ǔstetske Rf - xr 6 [Mv; ConscrAp. 6] * vasfogantyús 1736: Vas fogantyus rosz rèz ŭstŏtske [CU].

2. templomi rézedény; Szk: keresztelő 1690: keresztelő-kőben levő réz-üstöcske [SzO VI, 424] * szenteltvíznek való 1752: (A templomban) egj pár onbol való ampolna paténajaval edgyutt, egy Szentelt viznek való réz üstőcske [Kóród KK; Ks 12. I]. ridegsertés-ólacska kis pajta nem hízlalt disznónak tartására 1775: Rűdeg sertés hitván olotska [Kisillye MT; LLt].

rigócska kis rigó XVII. sz. v.: Rigottskám, Rigottskám tsatsogo szajkotskám [ETF 20.7 Thoroczkay Zsigmond daloskönyve 13b].

rókácska kicsi rókabőr 1711: (A kászon újfalusiak) most is oda fogytok (!) Kegdhez egj rokaczkaval [Újfalu Cs; BCs].

romlottacska kissé hibás 1806: Weress Samuel Ur ... kéntelenittetett ... egy fél Arkus Albat Subscribálni, mellyet Déakul akarván meg tenni Nevének első Sillabáját az S. leis írta, a' midön mük meg szollitottuk, hogy ... Magyarúl kelletik Subscribalni, igy oztan az S böl romlottatska Vét tsinált [Szék SzD; RLt O. 2 Kasza József keze írása].

rongyocska rongydarabka 1733: holmi aprólékos rongjocskákkal egj viseltes és foldozot veres Csuitár [Hacasel $\mathrm{H}$; JHb]; 1805: égy kis darab ... rongyatskának az edgyik vége az Ajtohaz volt ${ }^{a}$ [Szamosfva K; BLt 9. - aPecsételve].

rongyollottocska kissé elrongyolódott 1849: karas székek sárgán poriturazva (!) massiv ... veres tarkájú massával bé huzva; de már rongyollattatskák [Szentbenedek SzD; Ks 73/55].

rongyosocska 1. kissé rongyos/szakadozott 1747: Egy Bibliaja magyar de Rongyosocska [LLt 3. B]; 1827: három bőr Táska ... de mind a' három rongyosotska [Koronka MT; Told. 34].

2. meglehetősen rossz állapotban lévő 1732: vagjon edgj kis rongjosocska hintó gjermek(ne)k való fa és vas appertinantiaival edgjűtt [Kóród KK; Ks 12. I]; 1829: A Veress Jánosné Aszszony felŏll valo kŏz kert rongyosotska [Torda; KW].

rostélyka kicsiny (fa)rács 1676: ajtófélfája ... szegeletesen kifaragott tölgyfából álló, az szemöldökfáján felyül hat darab szegeletes fácskakból csináltatott rostélyka [Galac BN; ETF 108. 8].

rostélyocska várkapu kis rácsa 1653: ha megviradott is, nem nyitották meg a kapukat mindjárt, hanem a közel való házakat ... megjártatták ... úgy nyitották meg osztán 
a kaput s a rostélyocskának az ajtaját [ETA I, $77 \mathrm{NSz}]$.

rosszabbacska kissé rosszabb 1735: Jo üres Meh Kosár nro 151 Roszszabbatska Meh Kosár nro 7 [Mezősztjakab TA; JHb XI/9. 10].

rosszabbacskán kissé rosszabbul 1728: Az Feleségem ... csak nem épülhet ki nyavalyájából, ha három négy nap jobbacskán vagyon, megint harom nap roszszabbul ... most megint tegnaptol fogva roszszabbacskán vagyon [ApLt 1 gr. Haller János gr. Kálnoki Borbárához Nsz-ből].

rosszacska 1. kissé rossz, eléggé megromladozott 1730: aszt Geczi Uramtol magatol hallattam az bepecsetlese után hogy monda en az palaczkamat ŭressen felejtettem volt egy hordonak minthogy raszszacska vala az Csopja be ŭtem s abbol meg tŏltem az palaczkamat [Abosfva KK; Ks 8. XXIX. 24]; 1764: régi roszatska Agy [Pókafva AF; Kath.]; 1784: Más Őkőr Szekér, mellynek minden része jő az egy Nyujto agoson kivül, mely roszotska [Rücs MT; Ks 21. XV. 22]; 1801: jászolly roszszatska [TL]; 1813: Egy rákász Hálo roszatska [Veresegyháza AF; Told. 18 Toldalagi Kata lelt.]; 1813: A' Malom jo állapottyába vagyon ... Három szüszék benne kettŏ zárral - roszatskák 3 [Veresegyháza AF; Told. 18 Toldalagi Kata lelt.]; 1864: két roszacska festetlen deszka ágy Négy rosszacska zsák [Mihálcfva AF; HG br. Gerliczy cs. lev.].

2. omladozó 1750: elébb menvén egy kisség jobb kéz felé találtatott egj alkalmas konyhátska régi sendellyezéssel ujj foldozással, sőt meg az falais egj felőll rosszatska [Szamosfva K; JHbK LVIII. 4]; 1771: az én Gyepüm ... a Bangordban roszatska lévén minden kárát ... nekem tulajdonitja ... hozzám jöve reggel 8 vagy 9 ora tájban Nagy Josefné az Palinka főző Ustömet Csebremet a két ujjával keresztül circálta s azután az én pálinkám olyan lett mint a Savo [Dés; DLt 321. 42a Catharina Fülöp cons Antonii Stikler ns vall.]; 1806: Kotyetz roszszatska, Kerittés pedig a Telek körül jotska [Nagymon Sz; BálLt 68].

3. kissé megromlott, gyengébb minőségű 1763: a' széna a' mint ők praetendálták roszszatska lévén azon ő Nga szénájábol vásárolni nem akartanak [Záh TA; Mk VII/1. 19 Marosán Nyikita (30) zs vall.].

4. nehezen fegyelmezhető, fegyelmezetlen 1806: delelőtt meg lehetős voltam a Letzkét ki véve e sovány volt, delután roszszatska voltam [Dés; KMN 193]; 1807: délelött meglehetősőtske Repetitiot mondottam, és olvastam, délután roszszatska voltam [Dés; KMN 233].

5. gyenge, tartalmatlan 1804: Dél előtt a Letzke roszszatska volt, az expositio hasonlokeppen [Dés; KMN 15].

rosszacskán rossz egészségi állapotban, betegecskén 1724: En is Isten engedelméből, holnap ki fogok menni, csak Köleséri Ur(a)m(ma)l conferalhassak, mivel az estve is roszszatskán vala ${ }^{a}$ ApLt 1. ${ }^{a}$ Ti. a felesége gr. Haller János anyósához Nsz-ből]; 1794: kitsin változása vagyon, roszszatskán van, de ugyan ezen Változásáért tsak meg nem holt volna ő mert ép egésséges embernek esmértném mindég őtet [Somlyó Sz; BfN dobozolt anyag VI]; 1797: Nagyságod roszotskán ... volt [Vaja MT; BLt II. 12]; 1809: Czitrom árulo Társa roszatskán lévén le fekszik [Dés; DLt]; 1817: roszszatskán lévén nem költem fel ágyambol [Ne; DobLev. 3. XXVIIIA]; 1829: erosen sajnálom Köpetzitŏl halván hogy Anyád roszatskán volt $[\mathrm{Kv}$; Pk 6 Pákei Krisztina férjéhez, Gál Miklóshoz].

rózsácska kis rózsa alakú ékszer/ékszerdísz 1694: győngyből és klarisból csinált rosácska [Homoródsztpál U; BálLt 71]; 1700: Egy Aszszony ember Suvegben valo virág három rosácskája edgyik egyik Rosacskájában negy Smaragd, egy Rubin és negy szem Gyŏngy [Hr I/20]; 1703: arany mirŏl le eset egj kicin fejèr zomancu rosacska [LLt Fasc. 115]; 1703: két arany boglárol le eset rosatskák; mindenikb(en) negy negy kicsin robintoskák [LLt Fasc. 115]; 1786: Egy Zamantzos bokretátska 7 rosátskával 4 rubint benne, és három jo féle győngy [Nsz; Ks 74/56].

Szk: briliántos 1768: Groff Haller Maria kis Aszszony eö Nsgának jutott ... Egy Brilliantos Rosátska Rh. flor 50 [Nsz; Ks 74/56] * gyöngyös 1768: 4 Győngjős Rosácskák hét hét arany szemmel $[\mathrm{Nsz}$; TGsz 51]. 
rozsasztagocska kis rozsasztag 1647: Egy Arpa Aztagh gel. No. 180./ - Egy Ros Aztagoczka gel. No 80./ Egy Alakor Aztagh gel. No 100/- [Drassó AF; BK 48/16].

rövidecske kissé rövid, rövidke 1730: A Lo kŭlŏmben szegeny Legenynek meg léhet. Csak rövidétske [Somlyó Cs; ApLt 2. S. János Deák Apor Péternéhez]; 1788: rŏvidetske farku ${ }^{\mathrm{a}}\left[\mathrm{Kv}\right.$; DLt. - $\left.{ }^{\mathrm{a}} \mathrm{Ló}\right]$; 1791: rŏvidetske dereku, tsinos fejŭ marha [DLt hiv. nyomt.]; 1794: Egy akaszto rövidetske Lántz [Gyalakuta MT; TSb 17]; 1811: Egy Lovát le-irom fülitől farkáig. Ilyen az, nem tartlak függőbe sokáig: Fülei nem hoszszak, inkább rövidetskék [ÁrÉ 155]; 1815: piroslo sima ŭgyes ábrázatŭ orra rŏvidecske [DLt nyomt. kl].

rövidke rövidecske, kurta 1887: Kegyeskedjék egy rövidke történettel megajándékozni a Kolozsvárt - ha csak lehet e hó 19-éig [PLev. 136 Petelei István Szilágyi Sándorhoz].

rubintocska kis rubin 1625: Wagyon egy rosas arany boglaroczka melyben vagyon kilencz rubintoczka [Kv; RDL I. 126]; 1652: Egy kigyo forma gyŭrŭ kinek ket szemei, két tŭrkesecske koszoruja egy kis gyemant; szajaba(n) egy rubintocska [Nsz; IB. I. Bethlen István ir.]; 1700: Egy rubintos nyakra valo huszonnégy kerek remekecskeje huszonkettŏdik az fityegŏje két két, rubintocska, az kŏzte valo remeken ollyan hoszszuko remeke 19. az fityegǒjének az Pántlikáján egy Rubint [Hr I/20]; 1758: Rubíntos apró boglárkák, nyakra valónak valók, 23 s egy egy szem Rubintotska benne [Nsz; TSb 21]; 1763: Egy nagy arany függő Medály ... Egy pár Fülbe való Rostélyos két szem jó féle győngy és két két Rubintotska rajtok [Nsz; Szer. özv. Harsányi Sámuelné Tisza Ágnes inv.]; 1786: Egy reszkető tő két gyémántotska benne 8 rubintotska kőzepibe egy nagyotska rubint két felŏll [Nsz; Ks 74/56]; 1791: Egy lántzon függö Zamántzos Madár, tizenkét Rubintotska benne, és három győngy fityegô [Mv; Told. 19].

Szk: val cifrázott kard 1732: Egy ezŭst arannyos elefánt csontbol valo markolatu két rubintocskával czifrázot régi modi kard Karmasin Szin vastag Selyem Sinor rajta [Kv; Ks Kornis Zsigmond lelt. 16] * kicsiny/kis/kisded 1647: egi kis rubintoczka araniban foglaluan [Brassó; LLt Fasc. 137]; 1703: két arany boglárol le eset rosatskák, mindenikb(en) negy negy kicsin robintoskák. Es ket arany szegetske egy egy kicsin robintoska az tetejekb(en) [LLt Fasc. 115]; 1758: 9. kisded Rosa forma boglárka, egy egy kisded Rubintotska mindenikbe [Nsz; TSb 21].

rudacska 1. Szk: kétágú 1842: egy két águ rudátskát találtam [Dés; DLt 916].

2. tartórudacska 1647: Egj mecznek valo Vas serpenyő negj rudaczkán [Marosillye $\mathrm{H} ; \mathrm{VLt} 55 / 5415]$.

3. kifeszítő feszítőrudacska 1595: Foldoztattam az Tanacz hazba(n) az also kemenczet ... az elsó kj fözzite rúdoczkát, mert egyben dölt vala, és az 5 . sing vassat haitotta megh fizettem töle d $16[\mathrm{Kv}$; Szám. 6/XVIIa. 122 ifj. Heltai Gáspár sp kezével].

4. szuperlátnyitó szuperlát megeresztő rudacska 1732: ezen házba találtunk ... egy ágj eleibe való szép virágos olosz falt ... egj Superlat njitó vad kecske szarvas rudacskát, más egj bé csinálót a melljel superlatot ki terjesztik [Kv; Ks 40 Varia XXVIIIc néhai gr. Kornis Zsigmond conscr.].

5. legyező-rudacska 1778: Zöld festékes rudacskával, varrott legyező [Csapó KK; Berz. 4. 8. C. 18].

6. órarudacska; Szk: verő vonító 1599: 9. Die Marty hogi az felseo oranak az vereo vonito rŭdochkaia el teoret volt, ahoz vettŭnk egi apro vasat $\mathrm{fl}-\mathrm{d} 12[\mathrm{Kv}$; Szám. 8/XVI. 28].

7. pénztartó rudacska 1644/1648 k.: Egy rudaczkaba(n) nyolcz belyegzett taller No 8 [Born. XXXVIII. 14 St. Bethlen felj.].

8. jelzői haszn-ban; rudacska alakú; Szk: ezüst 1793: 3 darab rudatska ezüst 13 probas [TL Conscr.].

rugó-zárocska rugóval működő kis zár 1694: az $\operatorname{Var}(n a) k$ masik Szegeletiben va(gyo)n egy Czeyt haz, ennek kúlső Ajtaja, felszer parkanyozott, vas Sarkos pantos, rugo zarocskaja van [Kővár Szt; JHb Inv.]. 
ruhácska 1. terítőcske 1790: Egy Csengetü ... Két oltárra valo ruhátska [Déva; Ks 76. IX. 24].

2. homlokkötő homlokkötő kendőcske 1788: 8. Slájer fŏkŏtŏ és négy homlok kŏtŏ ruhátska [Mv; TSb 47].

ruhaleszedő-rudacska ruhaleemelő rudacska 1585: Egy Ruha le zedeo rudachka [Kv; Szám. 3/XIX. 5 A Szent Mihály templom lelt.].

ruhazacskócska vászonzacskócska 1807: maga Fitori Péter is egynehány ízben egy ruhazacskócskában lopott búzát a' csürből [F.rákos U; RSzF 169].

rútacska csúnyácska 1806: Az írás rutatska volt [Dés; KMN 189].

sáfárházacska kis raktárház/helyiség 1753: Ezen árnyék szék mellett bal kézre vagyon egy Sáfár házatska melyben nyilik egy Vas Sorkokon és pántokon forgo deszka ajtotska [Marossztkirály AF; Told. 18].

sajtocska kis méretû sajt 1596: 1. Sajtoczkat vöttem vala $\mathrm{p}(\mathrm{er}) \mathrm{d} 14$ hogy az el kele hosszú Ianos Wram küldöt 1. Saitot [Kv; Szám. 6/XXV. 8]; 1609: veottem ... Egi Saitoczikat ... d 16 [Kv; Szám. 12b/IV. 296].

Szk: ôszi 1596: 1 öszi Saitoczkat vöttem, kibe(n) fel atta(m) p(er) d. 14 [Kv; Szám. 6/XVII. 13-4 ifj. Heltai Gáspár sp kezével]; 1716: elküldöttem két őszi sajtotskát [Méhes TA; ApLt 2 Makkai Mihály Apor Péterhez] * tavalyi 1660: Taualyi kis eószi sajtoczka nro 3 [Lázárfva Cs; LLt Fasc. 117].

sajtócska kis sajtolószerkezet 1788: Dio olaj sajtolo Sajtotska [Mv; TSb 47]; 1789: Wgy Fŭvek Sajtolásához alkalmaztatott fábol tsinalt Sajtotska pléh Fészkével 's Csatornájával Rft 2 xr [Mv; ConscrAp. 8].

Szk: paraszt 1736: Tserefábol készŭlt, nem is tzifra, hanem paraszt Sajtotska ... tsak akkora a' Kádja ... hogy alig jŏhet le belŏlle harom veder must Szŭrt bor [CU].

sajtószínecske kis sajtószín 1775: azon ... Allodialis Szőllő alatt egy jo forma Sajto Szinetske [LLt Csáky-per 106. L. 13]; 1797: tanáltatik egy Szalma fedél alat valo parasztoson készített épület, melynek a Kapu felől valo résziben vagy fenyő deszkákkal Csere gerendákra padolt Házacs- ka ... közepin ezen épületnek vagyon egy Sajto Színecske ... a tulso végiben ... négy Márhákra valo istállocska [Hosszúaszó $\mathrm{KK} ; \mathrm{JHb}$ XX/35].

salláriumocska fizetésecske 1664: ha kicsiny salariumocskánk kiszolgáltatása dolgába való supplicationkat ő nagysága méltósága előtt való törekedésével promoveálni igyekezi, Kegyelmednek mind a hárman megszolgálni igyekezünk [TML III, 184-5 Szalárdi János Teleki Mihályhoz].

sanyarúcska meglehetős kedvezőtlen 1834: A’ kerti Szőllő megszedésekor Anyám teméntelen vendéget hivott ... Az údő sanyarutska volta mellettís vigan múlattunk, a Tracta állot Czipoka, és lágy kenyérbŏl [Kv; Pk 7 Pákei Krisztina lev.].

sápadtacska kissé sápadt; Szk: ábrázatú 1833: Cservenka Jósef ... sáppadtska ábrázatú [DLt nyomt. kl].

sarjú-kalangyácska kis sarjú kalangya 1747 : A Lunkában Találtatik Szena Kalongya Numero 5. Ittem Sarju Kalongyácska Nro 1 [Királyhalma NK; Ks 23. XXIIb].

sarkocska kis (ajtó)sarok 1724: az ajtaja(n) Ket Sarkacska [Koronka MT; Told. 27]; 1775: vagyon az nagy Udvarház, az melynek Sktukaturos onba foglalt nyoltz Sarkatskákon forgo négy vas horgotskakal zárodo üveg karikaju két ablakokkal vilagoskodo Pitvarában, Kancellusos kŏ gráditson fel menvén vagyon bé menetel [Nagyiklód SzD; CU].

sarokpléhecske sarokfelerősítő pléhdarabocska 1695: ablakja ... sark vasacskai es plehecskei meg vadnak [Boroskrakkó AF; BfN dobozolt anyag VI].

sarokvasacska ajtó/ablaksarokra való csuklósan müködő vaspántocska 1699: ablakja ... sark vasacskai es plehecskei meg vadnak [Boroskrakkó AF; BfN dobozolt anyag $\mathrm{VI}]$.

sasocska kis horog 1842: (A konyhának) van három égy forma - két két fligelü ablaka melyben van két két vas sarok és égy égy bé horgolo kilints formáju sasotska [Oprakercisóra F; TSb 51].

sátorocska kisebb sátor 1657: itt az sátorocskám hol volt, oly számtalan volt az fülbenmászó féreg, hogy csudálkozásra mél- 
tó Isten providentiájából maradtam meg [KemÖn. 238-9].

Szk: árnyékszéknek való 1714: Pamuk vaszonybul arnyék székn(e)k valo Satorotska fl. Hung 20 [AH 47] * szecesszusnak való 1714: secessusn(a)k valo Török Satorotska, Pamuk Vaszonybul, már Szakadozott [AH 47].

savanyúcska savanykás 1715: tiszta izu savanyucska jo bor [Ebesfva; UtI]; 1735: az savanyutska étkek által hamarébb appetitusra kap az ember [Ks Borosnyai Nagy Márton lev. Nsz-ből]; 1763: a' Borok a' mostani üdő szerént Savanyucskák [Szőkefva KK; BálLt 1]; 1815: Allodialis Szŏlŏk ... A' bora Savanyutska, de jó iható [Bálványosváralja SzD; Ks 77. 19 Conscr. 849].

sebecske kis seb 1644: Az mint engemet Munkaczi Borbely Istua(n) el hiut vala, ennek az Baczio Ianos fejenek fel meczesere hogi sebes vala, ugia(n) en meczem fel az sebet, az melliet üteöttek volt ... hanem egi igen kiczinj sebeczike vala az fejen oldalt felt mint az körmöm feketeje [Mv; MvLt 291. 411b]; 1722: Az mely kis bür elmenes latczott az orczajan ... Nimeth Sigmondnak tudgyae az Tanu hogy ez igy tőrtént ... az nyavalya töres rea juven felen esven Sietséggel hogy meg nem tarthattak ugy ütötte meg valamiben az orczajat, s abbol esett rajta azon kis Sebecske [Kük.; Szent. vk]; 1749: a nyakán egj Sebetske lévén [Ohába AF; Told. 3]; 1756: a fejen volt egy Sebetske de ŏ attol meg nem halt volna, hanem ... a Nyaka töröt volt ki neki [Bencenc $\mathrm{H}$; BK Misc. 1143]; 1764: a bal felől valo vékonyán egy kis sebetske láttatott [Illyefva Hsz; HSzjP].

sebesecskén hadarva 1799: Pap István ... beszél sebesetskén Magyar, és oláh nyelvenis [DLt nyomt. kl].

sebforradásocska kicsiny heg/sebhely 1805 : a' bal Pofáján vagyon egy Seb forradásotska [DLt nyomt. kl].

selyemdolmányka 1710 k.: anno 1674 k.: Anno 1674. májusban Fejérvárott országgyülése alatt estve igen meghevülvén, egy pohárba bor közé jeges vizet tölték jegestől ... megivám ... és másnap felmenék a gyưlésbe reggel, csak egy vékony selyem dolmánykában [BÖn. 526-7]. selyemövecske 1599: Kalmandy Jaanos. Hozot Crakay Marhatt ... 17. Seliem Eoweczett $^{\mathrm{a}}$... - 180 [Kv; Szám. 8/XIV. 19.

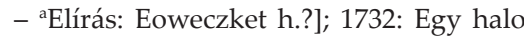
Jáponika ŏvezni valo Selyem ovecske ezŭst csat rajta [Kv; Ks Kornis Zsigmond lelt. 8].

selyemvesszőcske selyem csíkú hímzéselem 1714: Skofiumbul valo Tőrők Czafrang meg egyelitett Selyem veszötskékkel, Sarga Atlas beléssel fl. Hung. 60 [AH 4-5].

selymecske selyemdarabocska/fonalacska 1788: Egy tsomoba kŏtve dirib darab Sejmetskék, két kis hálo sapka, és vélle egyŭve kŏtve holmi apro patyolatok, és égy keszkenyŏbe virágoknak valo díríb darab matériák mind égyŭtt $[\mathrm{Mv} ; \mathrm{TSb}$ 47].

seregecske kis sereg/had 1657: izenék Daniel Jánosnak, hogy sietne az derék sereggel aláereszkedni; de az is késő vala, mert az magammal elöl vitt három seregecske, melyeknek egyike puskás, másikja kurtán, harmadikja az magam zászlója alatt lévők valának, már tovább az dolgot nem állhatja, és az általköltöző paraszt nem tarthatja vala [KemÖn. 234-5].

sereskádacska sörfőzésre használt kis kád 1638: Egy kis seres kadoczka [A.porumbák F; UF I, 659].

serlegecske kis serleg 1757: egy Sellegetskémet ugyan el lopták valá s el dugták vólt de az után meg tanáltam [Gyszm; DE 3].

Szk: halhajas 1655: Egy halhajas sellegetske 14 - p. 34 [Kv; RDL I. 29].

serlegpoharacska kis serlegpohár 1622: Egy kws sellek poharoczka nio(m)m. - p. 16 $1 / 2$ tt f. 4 d. 50 [Kv; RDL I. 119].

serpenyőcske kis serpenyő 1770: Kitsin Serpenyŏtske nro 1 [Királyhalma NK; Ks 23. XXIIb].

sertécske malac 1769: Vagyon Egy bornyus Tehen, kétt Sertécskéje [Marossztgyörgy MT; Ks 67. 48. 81].

sertésecske kis disznó 1721: alazatosan meg szolgalom az Mlgos Urnak ha nekem is eg sértesecskét küld ezen meszet le vivő talyigan tavaj ném busítotam az Melgos Urat mivél vot de most egyecskét őletem vot mind aprolikja mind szalonaja mind 
egy falatig el fogot [Szentpál K; TK1 Mihály Deák Teleki Pálhoz]; 1778: én tőllem vett hat Márjáson, egy jó Sertésetskét [Pósa Sz; Ks 34. VI/1]; 1851: Valami Sertésetskeim is vadnak el hozva [Széplak KK; SLt évr. Biró Sándor lev.].

sertésólacska disznópajtácska 1774: Egy Sertés olatska Vastag Cserefákbol egy rodalt Szalma fedél alatt [Hosszútelke AF; Kath.]; 1817: Ezen Molnár Ház kőrúl vadnak aproság Epületetskék kisded sővény Pajta és egy Sertés olatska, és égy Tơrőkbuza Kas mellyek a fel adás szerént a molnárnak Tulajdonai, maga tévén réájak a kőlcséget, és fáradtságat [Ördöngösfüzes SzD; ÖrmMúz. 8].

sertéspajtácska 1763: (A konyha) véginél négy fa lábra epittetett, és szalmával fedetett egy Sertés pajtatskais van bé fervén beleje s. v. Sertes Nro 2 [Hortobágyfva Szb; JHb XXIXa. 19 néhai Hortobágyi Gergély György conscr. 13].

sikátorocska keskeny köz, ösvény 1767: ezen Joszág mellet béjaro sikatorotska [Mezőbánd MT; MbK]; 1775: Colonicalis Sessio ... vicinussa ... Nyugotrol más kis Sikatorotska [Buza SzD; LLt Csáky-per 107. L. 14]; 1779: a Templomba járo Sikátorotska [Szövérd MT; Told. 25].

skarlát-subica skarlátposztóból készült kis suba 1560: Rwha Nemw Marha ... Egy Skarlath Swbycha weres kamuka az galleran [JHb QQ Temeswary Janos reg.].

smaragdocska kis smaragdkő 1697: Gyŭrŭ, melyben vagyon négy rubintocska, és az közepin egy kis Smaragdocska [Kgy]; 1786: Arany portéka ... 14 Smaragdotska és tizen négy rubintotska benne [Nsz; Ks].

smukládácska ékszerdoboz 1752: egy Üres Schmuk Ládácska [Eszt. gr. Pekriné lelt.].

sógorka fiatal sógor 1717: most ujjolag el kủldőttem edgy gyalmoczkámot Méhesre ha valamit tehetnének vélle, hogy Sogorkáimnak is succurálhatnék a bőjtre, itt pedig eppen Szűkösök vagyunk friss hal dolgabol [Darlac KK; ApLt 2 Haller János Apor Péterhez]. sokacska I. $m n$ 1. meglehetősen nagyméretü 1847: a' játzintok elvitelével nem akartam alkalmatlankodni, mert sokatska pak, hanem mihelyt lesz kitől, elküldőm [Kv; Pk 7].

2. meglehetősen nagy összegü 1814: kenyérrel sokatska költségem vagyon [NkF]; 1828: oda küldhető emberem nincsen addig a meddig oda bé valo kevés joszágotskáimbol viszszá nem jön praefectusom ... 's ha ollyan joságu, 's akkora ki terjedésű hellyel teszszűk a Cserét, a mostani pénz szűkibe a kévánt fellyűl fizetés talám sokatska is lenne $[\mathrm{Kv}$; RLt O. 1 Béldi István lev.].

II. $f n$ meglehetősen nagy összeg; Szk: $\sim b a$ kerül 1844: biz e' sokatskába fog kerŭlni [Széplak KK; SLt évr. Menyhárd Péter P. Horváth Ferenchez] ${ }^{*} \sim t$ költ 1788: négy béres ŏkret vettŭnk hogy a dolog jobban foljon a puszta bé keritésére is sokotskát kŏltettŭnk s még adob(an) is sokat kell adni [Bencenc H; BK. Bara Ferenc lev.].

III. hsz-szerü haszn-ban; $\sim t$ meglehetősen sokáig 1861: Mult év utolso holnapjában irott Levelét ez év elejével tiszteltem; mert a' postán ugy láttzik sokatskát ült [Komolló Hsz; BetLt 4 Sylvester Dávid lev.].

sokacskán meglehetősen sokan 1738: ittenis hagymázban sokacskán kezdettek betegeskedni egy nehanyon holtakis meg [Gyeke K; Ks 99 Kornis Antal lev.].

somfapálcika somfavessző 1823-1830: privatus praeceptorom volt Szigeti Mihaly uram ... Igaz, hogy kemény ember volt, kisujjamnyi somfa pálcikával vert engemet is, mást is [FogE 80].

sóőrlö-malmocska kis sódaráló malom 1835 : A' Hinto Szinben ... Egy so örlő Malmocska [F.zsuk K; SLt Vegyes perir.].

sorocska 1. rövid levél 1880: Emlékezel-e arra, mikor Klasszit felküldtem a Főv. Lapoknak, s onnan írták azt a gonosz három sorocskát [PLev. 83 Petelei István Jakab Ödönhöz].

2. kisebb göngyfüzér 1848: 3 sor aprobb gránát gyŏngy 1 sorocska felfüzve [Pk 2].

sótartócska kis sótartó; Szk: aranyos 1651: Edgy nedgy szegŭ Arannyas So tartoczka [WassLt Wass Judit kel.] * kerek 1711: 
Kis kerék sotartocska [Told. 19]; 1730: egy dupplás fedelü kerek Sotartoczka [Kv; Ks 15. LVIII. 6].

soványka meglehetősen gyengén termő 1746: égy soványka Domb [Nagyida K; Told. 9]; 1794: Soványka föld [Marosjára MT; PfM].

soványocska 1 . meglehetősen gyengén termő 1720: Az Udvarház mellett edgy láb fŏld ... soványocska [Gorbó SzD; JHbK XXVI/2]; 1780: egy Láb Föld ... a' Felső Része soványotska [Nagyercse MT; Told. 79]; 1794: Soványotska föld [Marosjára MT; PfM]; 1794: Soványotska helly [Marosjára MT; PfM].

2. átv gyengécske 1807: dél előt kulőmbe(n) meg lehetős uoltam tsak a Letzke soványocska volt [Dés; KMN 224]; 1807: 7 után tanultam a Letzkét de soványotska voltam [Dés; KMN 361].

sötétebbecske kissé sötétebb 1807: Az Harmadik Kantza setétebbetske Pely [DLt 234 nyomt. kl].

sötétecske 1. kissé homályos 1771: mikor égy alkalmatossággal hozzám szállot volt Halász Hadnagy, tŏrténik hogy bé jŏve Szabo Ferkŏne is a házomba részegen és a mint a házom Ablaka papyrosbol volt csinálva Setétetske volt a Házom [Dés; DLt 321. 39].

2. a kelleténél kissé sötétebb árnyalatú 1850: a' Szővetet Schindler megfesté ... csakugyan ha setétetske is, de használhato lesz [Kv; Pk 7].

sövényajtócska vesszőből font ajtócska 1753 : az Udvar háznak szarvazatjáig belöl vagyon egy darab jó Leszas Tamaszos kert melyre szolgál az ház szegeletitől be egy söveny ajtotska [Karácsonfva AF; Told. $18]$.

sövényházacska kis sövényfalú ház 1726: találánk ot egy sövény házacskát [Esztény SzD; Told. 29]; 1760: egy kis hitván kunynyo Forma Sŏvény hitvány házatskánál Semmi egyéb épület rata (!) nem vólt [Mv; Told. 15/44]; 1786: adám által ... Kis Petri Curialisomat égy kitsid komorával ... s ... két kis Sövén Házatskákkal [Kispetri K; RLt O. 4]. státuácska szobrocska 1732: Vagyon egy Mariaczeli B: S. M: Statuácskája, kis Jézuskával rajta Lévö Sárga Vont arany materiaval [Kv; Ks Kornis Zsigmond lelt. 30]; 1760: a' Frontispicium Tetein lèszen Gombok helyett három kisded Statuátska [Kv; Told. 26]; 1779: Egy kis sz. János Státuátskaja [Nsz; CsS].

stelázsicska kis állvány 1789: A' belsŏ Patika Hazbol által járo Ajto felett két oszlopokon állo Stellasitskában melly(ne)k felsŏ fele réz Pléhekkel vagyon bé boritva találtattak illyen Portékak [Mv; ConscrAp. 66].

stompocska kisebb érczúzó malom 1642: Aztis ugy tudom, hogy az mely hat nyilu stompoczjkat mely puszta uolt, adott Fodor Pal az Vaczi Benedek fiainak ... Isten neuiert atta nekiek, hogj gonoszt holta vtan ne mongianak [Abrudbánya; Törzs. Rapolti Andras (70) városi rend vall.].

strázsaházacska őrházacska 1694: Külső Vár ... az Also Kaputol fel nyulo Kőfal mellet az leővő Bástya szegeletib(en) va(gyo)n egy fa Labokon allo eoszve bardolt fakbol csinalt Strasa Hazacska [Kővár Szt; JHb Inv.]; 1807: a midőn azon hely még szabad hely volt, egy kis Strázsa házatska volt réá építve [Apahida K; RLt O. 5 Moga Von (50) col. vall.].

subica kissuba 1529: Cui dedi pro expensis fl. octo ac pro dolman Swpicza caligis et calceis ac sartori quinque et denarios 90 [Vh; MNy XXXI, 125]; 1531: panum michi pro una supicza seu tunica parva purgamal emere feci pro fl II 1/2 [Vh; DomH 112]; 1572 k.: Kys Myhal zolgalta barat Istwant ... zolgalatomert ados mynd Enye ydeigh fl 12 d 50, es 2 nadragh kysnycher, 1 fodor Jgler keccher swbyccha, ket Ing ket gatya es egy szwr es egy sywegh [Kv; TJk III/3. 262f].

subika kissuba XVIII. sz. v.: Egy veres Subika ... Egy ramas Aszony Embernek valo Czima (!) [Borb.].

sugárocska elég jól sikerült/fényes 1806: dél elöt jol ment a dolog, délután is estvíg akkor sugárotska Letzkét mondottam [Dés; KMN 174]. 
summácska I. fn (pénz) összegecske 1613: mely Summaczykanak hatra maradot Tizen hat forintiat my eleottwnk veüe fel ... es igy Aztalos Miklos vallast teon my eleottwnk, hogy Radnothy Jstua(n) vram Jmmar Egy penzeuel sem uolna eó nekj ados [Kv; RDL I. 92]; 1823: meg esmérem hogy N Laki gazdaságom jobban folyhatása tekintetéből vásároltam légyen hitelbe Tks Doboly Sigmond Uram Bátyámtol ... egy pár járomra valo bihaj tulkokat 60 - Hatvan Rh forint valto czédula, forintokban ('́gy!) ily feltételek alat ... Hogy ... a minket Komaromianusokat illetö negyed részböl ... jöhetö részt által engedem Kökösi Idösb Dobolyi Sigmond Vram Bátyámnak hogy abbol ezen Summátskát ki vonván ... engem ki fizessen [Nagylak AF; DobLev. V/1072 Horváth Elek kezével]; 1842: kötelesek ... a fenn irt sum(m)átskát Czéhbe állásokkor mindjárt le-fizetni [Kv; ÖCLev.]; 1846: a' legénytől le-huzzák, 's a' kőnyvbe bé-nem irják, s irattyák azon bé-fizetni, vagy fizettetni kelletô sum(m) átskát [Kv; ÖCLev.].

II. jelzői haszn-ban; vmekkora kis összegú/summájú 1772: bizonyos summátska pénzt kinek kinek annak érdeme szerént adott [Drág K; TSb 21].

sutucska tokocska 1798: beretva kés xr 2. Kisded sututska xr. 6. Kis furutska xr. 1 ... egy pár beretva tokostol xr. 20 ... nagyobb sutu xr 34 [Kv; Pk 6 Rázmány Sámuel hagy.].

süketecske kissé süket 1794: maga Hajda és Felesége mutatták Festeken a' kékséget, 's láttam mely erőssen meg-verettettenek ... ennél tőbbet nem láttam nem hallottam, mivel sűketetske lévén nem hallottam mindent [Ne; DobLev. IV/728. 3a]; 1799: Rajka Mihálly ... kevéssé siketetske [Dés; DLt]; 1830: Nutza Sófi ... kevéssé sűketetske Fejérnép [DLt 1025 nyomt. kl].

süldőcske kis süldő 1692: Három süldöcske [HSzj süldô al.]; 1736: vehessen Discretioban egjgj 5 vagj 6 Máriásos sűldőtskét [Dés; Jk]; 1757: Sűldŏtskék találtattanak Nro 7 [Pusztasztmiklós TA; Berz. 3. I/9]; 1765: Sŭldotske melly actu hizlaltatik [Esztény SzD; Told. 29]; 1818: Legfelylyebb Tsŏtŏrtŏkŏn vagy Pénteken bizonyosonn le inditom azon Pénzt a milyen
Szalonatska s hájja létt két süldötskéknek aval együtt [Galac BN; WLt Kováts Mihály gondv. lev.]; 1840: vásároltam volt a Nagyságod sertés nyájábol ket kŭs Süldőtskéket [Vécke U; Told. 39]; 1841: Egy süldötske [Kissármás K; KLev.].

Szk: idei 1674: Disznok ... Hizo Galla nro 5. Az idei süldöcskék nro 50 [Radnót KK; UtI] * nyári 1741: két kiss nyári sűdőtskét vetettek bé hizlalni [Mezőbánd MT; LLt 146. B].

süldődisznócska növendéksertés 1587: Maradott Nyolcz dizno Swldeo dezmaban. Mindenesteol fogua az harom faluban iutott dezmaban Swldeo diznochka 16 ... Ezekben az Dizno Swldeochkekben attunk el 8 fl. 3 d. 62 [Kv; Szám. 3/XXXII. 7].

sümölcsöcske kis szemölcs 1801: az állán egy kisded sŭmŏltsŏtskéje [DLt nyomt. kl].

sürǘske meglehetősen sürü 1754: (Az erdő) mind jókora Tőlgyfából áll sürütskeis noha sokatis ki vagtak imitt amott benne [Uzdisztpéter K; CU].

sütőházacska kis sütőház; Szk: zsindelyes 1793: Egy sendelyes Sütő Házacska egy árnyékkal valet 10 Rf [HSzj árnyék al.].

sütőtekenőcske kis dagasztó tekenő 1747: Egy Sŭtŏ Tekenŏcsket is ada a Relicta Janosnak [Kőrispatak U; Pf]; 1776: ezen Pinczében vagyon ... cserefa Lijju 1 ... két csebrecske Cir. egy egy vedresek egy fejér Sŭtŏ Tekenocske, egy kőz Czipo Sŭtŏ Tekenő egy más Csonka Tekenő, Sajtár 2 [Mezőméhes TA; WassLt].

szádok-budunka hársfából készült bödön 1840: Juh fejő 2. Krinta 1 és 2 Turos Désa R. for. 3. ... 2. Zádag vagy hársfa Budunka R. for. 2 [Várhegy MT; TLt Közig. ir. 1042 Bencze Illyés lelt.].

szájacska kis száj, gyermekszáj 1759: az midőn le akartunk volna takaradni jobbanis ell álmosodván az Gyermek, azon szájocskája nyelve reszketése erőssebben réá jőtt [M.csesztve AF; Ks Mikes Antal lev.].

szajkócska nép mátyásmadárka 1695 k.: Rigottskám Rigottskám tsatsogo szajkotskám [Thoroczkay Zsigmond daloskönyve 13b. - A virágének id. sora: ETF 20. 7; az egész ének: Haja, haja virágom 94]. 
szakácskönyvecske 1802: Egy kis szakáts kőnyvetske fél börbe de A(nn)o 1785 [Ne; DobLev. IV/858. 6b].

szakadékocska folyóágacska 1760: el kezdvén a mérést a Maros felŏl valo felsŏ részin, a hol a Marosbol egy kis Szakadekotska ered, a kotsárdi ... nagy Berek also veginél be jŏvŏ utig huszon két kőtelnek talaltuk [Székelykocsárd TA; LLt 1/11].

szakaszocska 1. rekeszecske 1680: Majorhaz ... az hazban kŏrŏs kŏrnyŭl kotlo Tyukok Pujkak, es Ludak alá valo fabol csinalt szakaszocskak vad(na)k [A.porumbák F; ÁLt Inv. 28-9].

2. kazlacska 1819: 1817 beli Zab Szalma egy Szakaszotskaba [Baca SzD; TSb 6]; 1848: A hatodik Szakaszotskába volt 17 kal(angya) dézma Zabszalmát Consumálták a Tiszt marhái [Bezdéd SzD; LLt].

3. jelzői haszn-ban: vhány szakasz vmiből. Szk: vhány rozs 1814: Szakaszotska Magnak valo Ros [Told. 43] * vhány sarjú 1802: Egy Szakaszotska Sarju melyben vagyon három Szekeretske [MkG]; 1819: 1818ba termet és Szalmával őszve rázatt egy szakaszatska sarju [Baca SzD; TSb 6] * vhány szalma 1782: három kalangyátska széna, és két szakaszatska szalma maradván [M.fodorháza K; RGyLt VII. 27 Pop Togyer (33) zs vall.].

szakasztócska rekeszecske 1767: A Pitvarban vagyon, egy felyől deszkábol, tsinált szalonna szakaszotska, melynek egyik oldalának két deszka hijja vagyon [Nagyernye MT; LLt Fasc. 129].

szálacska I. fn (vékony) szálfa 1731: Fát tudom hogy Kolosvárra ... Sz. Pálrol, és Vajdaházárol hordatott a Nagy Ura, innen minden nap két szekérrel vittenek, mely miá nehány kor nagy tsonkulásais esett a Gazdaság folytatásban, az eŏ Nga kủlőnŏs Joszágábol pedig még tsak edgy szálatskát sem vittenek egyszeris [Szentpál K; TKl. - ${ }^{a}$ Gr. Teleki Pál Bara András (94) jb vall.].

II. jelzői haszn-ban: 1. vhány szálacskányi (fa/deszka) 1763: két hárón (!) szalatska fának le vágásáért [Udvarfva MT; Told. 44/13]; 1797: kétt szálatska deszkából állo polcz [Kőrispatak U; Pf]; 1797: 51. Szálotska bűkfa deszkák [Kőrispatak U; Pf];1799:
Két szálatska Deszkábol valo Pad Tzővekeken [F.zsuk K; SLt Vegyes perir.]; 1807: három Szálatska fát vágtak az Groff erdejiben [Udvarfva MT; Told. 44a].

2. vhány darabka (vasrúd/vessző) 1736: edgyik edgyik ablak hat szalatska vas vesszőkkel van meg erőssitve és négy nagy Fijokjai két vas Sorkotskákon forognak [CU].

szalmaládácska szalmából font doboz 1763: Három Lántz végire valo Kapots Ugy holmi aprosag kapsotskák nro 24 ... öt Kitsid szalma Ládátskákb(an) [Nsz; Szer. özv. Harsányi Sámuelné Tisza Ágnes inv.]; 1768: Nehai Mlgos Gróf Kis Aszszony Ládája 1 szalma Ládátska 1 [Mezősztgyörgy K; Ks 23. XXIIb].

szalmapántlika szalmából font pántlika 1711: 12 Vég Szalma Pántlika ... 8 // 16 [ApLt 5 Apor Péter inv.]; 1788: Egy iskatulyába színes Szalma pántlikák 12 darab [Mv; MT TSb 47]; 1788: Szalma bandlika (!) [WLt Cserei Heléna jk 16a].

szalonnácska kis szalonna 1589: Ket Zalonnachka, es egy darab [Kv; KvLt Vegyes I/2. 70]; 1591: Az Ispannok hozttanak az falûkbol 11 Tawaly Baranyt egy kis zalonachykatt [Kv; Szám. 5/I. 57]; 1729: ā 1mā May szalonnátskát egjebet is a mi vagyon adott jó akaratyából mivel az Katona is kért [Sövényfva KK; TSb 51]; 1775: Borsai Nagy István Uram ... felesége ... a Jobbágy Aszszonyoknak is, sző és fon lisztetskeért, turotskaért, szalonnátskáért, egy szoval ... nagy kuldussággal élnek [Peselnek Hsz; HSzjP]; 1818: Legfelyebb Tsŏtŏrtŏkŏn vagy Pénteken bizonyosonn le inditom azon Pénzt a milyen Szalonatska s hájja lét két süldötskéknek aval együtt [Galac BN; WLt Kováts Mihály gondv. lev.]; 1839: Egy szalonnátskánok fele [Kv; Ks 73/55]; 1854: 2 és $1 / 2$ Szalonnátska ezek felett 6 pár Sertés Láb [Sárd KK; WassLt].

Szk: aprólék 1687: Voltanak az Kamaraháznál ... egy nihány igen avasos husas aprolek szalonnácskák [Sziget Mm; Törzs].

számtartóházacska a számtartó kis háza 1694: az Pincze Tornattza kőzőt va(gyo)n egy szamtarto hazacska [Kővár Szt; JHb Inv.]. 
szánacska 1. egylovas szán 1849: Egy, egy lonak valo szánatska két rudjával [Somkerék SzD; Ks 73/55].

Szk: vhány ra való 1778: szokot ugjan ö Nsga nékünk maga embereinek kủlőn-külőn minden Gazdának két-két szánatskára valo fát adatni [Bányabükk TA; BLt 11].

2. jelzői haszn-ban: vhány szánacskára való vmiből 1684: Fogarasban ... Vettünk egy szánacska szénát fl. 1/40 [SzZs 260].

szánka kisebb, lovas szán 1595: 1. zankaia eleiben, adot Biro Wram 4. loat [Kv; Szám. 6/XXVIIa. 38 ifj. Heltai Gáspár sp kezével]; 1596: fat vettunk egy kis zankaŭal ... d 16 [Kv; Szám. 7/II. 18]; 1756: hirtelenséggel Balog Uram Pistolyal az ablakon ki lőve a szánkájáb(an) lévő gazban mely meg is Gyuladot allovak (!) az szánkát el ragatták [Remete Szt; TKl].

szánocska szánka. Szk: ra való fa 1778: szokott ... eŏ Nga nékünk ... két két szánotskára valo fát adatni [Bányabükk TA; MkG] * deszkás 1761: Alkalmas Deszkás szanocska kassával s Rudgyaval égybe [Kémend $\mathrm{H}$; JHb XXXV/39. 34].

szántócska szántóföldecske 1787: parlagban hagyott egy Szántotska [Désakna; Hr $1 / 22]$.

szántóföldecske kis szántóföld 1654: Azon küuöl ket darab szanto földecske ket forintba vet volt Zaloghba(n) az maga Jobbagyatul [Szásznádas KK; Ks Bánffy Anna urb.]; 1715: Vagyon ... a Kŏszŏrŭ patak alatt edgy szanto Földetske ... melylyet is Sztojka Gergely fogott volt fel a falu kŏzŏnséges fŏldibŏl [Nagyercse MT; WH]; 1717/XVIII. sz.: Vagjon ... egj darab szántó földecske [Benedekfva Sz; Berz. 7. 68/1]; 1728: Tudok az Pojenb(en) egy darab kaszálot kŏrŭlette harom szánto fŏldetskéket [M.újfalu K; RLt Goron Páskul (70) jb vall.]; 1741: ugy vélem hogy Szilágyi János vramé fogott lenni azon szántó főldecske [Nyárádsztbenedek MT; Told. 22]; 1782: azon Szánto főldecskéjeket ... Vásárolván Zálog titulussal [M.köblös SzD; RLt]; 1792: a Zugonál lévő Szánto Foldetske ... mint hogy meg ugaroltatatt volt név szerént kineveztetvén viszsza adatatt a Melgos Urnak [Msz; MbK XII. 87]; 1823: méltoztassanak ... nékem meg- engedni, hogy ezt az oláh Templomnál lévő szántofŏldecskémet ... vehessem 's vétethessem keritésbe [M.köblös SzD; RLt Incze István lévita-lelkész kérv.].

Szk: allodiális 1777/1780: vagyon ... Allodialis Szánto Főldetske, melly a Praebendásoknak szokott ki osztatni [Alparét SzD; JHbK LII/396]; 1802: egy allodialis Szanto földetske [Mezőpagocsa TA; Berz. 5. 38. P. 14] ${ }^{*}$ fecskefarkú 1722/1814: Az ország uttya és a' ... Lonai Patak kőzőtt egy Darabotska Fetske farku Circiter három köblös Szánto Főldetske hagyattatott az Reformata Ecclesia számára [Kisjenő SzD; BetLt 1] * nemes 1766: az Pataki Istvá(n) Ur(am) Málé Főldének az Végiben az Vancsa Gligorek által Csinált Irotvány Kosztájok alat, mindgyárt Vagyon az Kántor részen égy Nemes szánto Főldecske [M.köblös SzD; RLt] * nyíl 1766: egy kis nyil szánto Földetském [Szásznyíres SzD; Ks 33. II. 16].

szappanozótekenőcske 1699: Szappanozo tekenőcskék Nro 3 Üress hitvan ládácskák Nro 2 [O.csesztve AF; LLt Gyulafi László inv.].

szapulókádacska kis szapulókád 1770: Szapullo kádatska [Esztény SzD; Told. 29].

száraz liktáriumtartó ládácska aszalt gyümölcsből készített lekvárt tartó ládácska 1788: Úvegnek valo kitsin tojokás Ferslog ... Száraz Lictárium tarto kítsin reteszes Ládátska [Mv; TSb 47].

szárika kb. (posztó)guba, suba 1739: Szárikámot az nyakambol kivetvén, mondám az Öcsemnek, Lőjjed ... mert el kell vesznünk [Kézdisztlélek Hsz; HSzjP St. Hodor (49) pp vall.]; 1758: Egy szárika valora flor. Hung 1. den. 24 [Páké Hsz; HSzjP]; 1801: Georgie N. mint egy 20. esztendős ... sárga haju, az Oláh Országi modra fésülve ... egy kurta rongyos Olah bundát, s' azon felyül egy uj, ugy nevezett zárikát ... viselvén [DLt nyomt. kl]; 1801: Szávu Popa mint egy 24. esztendös ... fēkete szemü és haju, az Oláh Országi modra fésülve ... egy nagy Oláh bundát és azon felyül egy régi ugy nevezett zárikát viselvén [DLt nyomt. kl]; 1808: Felsŏ Porumbáki ... Gyitza Pap János ... visel szŏrŏs Oláh bubot vagy szárikát [DLt 171 nyomt. kl]; 
1811: hegyi Tolvajok ... vittenek el ... Három ujj által vetöt ... Egy ujj szárikát ... Egy Puskát [DLt 629 nyomt. kl]; 1819: aprobb panaszokbol világosságra jŏvén az, hogy egy uj szárika az eö kegyelme házánál tanáltatott meg [Bereck Hsz; HSzjP]; 1826: a' Nyakamba levő szárikámat ki huzta és el vitte [Lisznyó Hsz; HSzjP Karátson Gyurka (36) prov. vall.]; 1829: Tudom azt nyilván mivel szemeimmel láttam, hogy Hoszszu Péternek egy szárikáját el vette [Bodzaforduló Hsz; HSzjP Bulárka Thoma (40) vall.]; 1839: Majláth Jeremiás ... visel ... fekete zekét, vagy is sokszor csak szárikát [DLt 1355 nyomt. kl].

Szk: comközépig éró 1817: Egy Szilágyi modi fekete váslott Czomb kŏzépig érŏ szárika, vagy Gubába [DLt 70 nyomt. kl] * szürke 1752: Edgy Szürke Szárika [Szászvesződ NK; JHb XXIII/27] * viseltes 1803: Bochoday András ... őltőzete vólt egy viseltes Szárika, egy viseltes fekete Bárány - bőrrel prémezett, és zöld posztóju Süveg [DLt nyomt. kl].

szárikás kb. gubás, subás 1796: jöttenek hozzá oda ki valo szárikás isméretlen emberek [Hidvég Hsz; HSzjP Támpa István (60) col. vall.]; 1873: néhány ... vámhivatalnok lakik itt ${ }^{\mathrm{a}}$ a nagyszerü magányban, heteken át alig látva mást, mint egy-egy nyájai után szamáron haladó nagy sárikás ${ }^{\mathrm{b}}$ és kucsmás juhászt [Orbán, SzfLeír. VI. 77. - ${ }^{\mathrm{A}} \mathrm{A}$ brassói Királyhegyen lévő határállomáson. b'́gy! Lapalji jegyzetben: Lombos suba, melyet a hétfalusiak $(\mathrm{Br})$ viselnek. Ez az értelmezés nem a szárm-ra, hanem az alapszóra vonatkoztatható].

szarvacska kis szarv 1697: Tinŏ... Tavaly Kek Barna fel allo szarvacskai [Almakerék $\mathrm{NK}$; UtI].

szarvasborjúcska 1759: méltóztassék ... valami szarvas bornyutskákkal szigoru szegénységemben fel emelni [Szőkefva KK; Ks 72. 54].

szarvasmarhácska marhácska 1765: az Béres Ŏkrŏkre, Magam Lova Birák lovaj és tŏb szarvas Marhácskákra ... Széna [Nagybarcsa H; Ks 71. 52 Szám.].

szarvasocska szarvaska (figura) 1594: Az Varbeli hazakban ualo Inuentarium ... Az Azzoni Thar hazaban ... vagion fabul csi- nalt szaruasochka is No. 1 [Somlyó Sz; UC 78/7. 22].

szarvasollócska ?szarvasborjúcska 1731: János Albert ... egy őz vagy Szarvas ollocskát vett volt [Gysz; LLt].

szarvazatocska alacsony fedélszék 1736: Ezen Filegoriátskának tsak kitsin Szarvazatotskája van [CU].

szebbecske meglehetôsen szép 1747: a Hámbárnak edgyik rekeszszében találtunk ... szebbetske buzát Cub: 3 metr. 3 [Spring AF; JHb XXV/88. 5]; 1821: több a bük fa benne $^{a}$ - ís szebbetske [Ködmönös SzD; LLt. - ${ }^{\mathrm{a}} \mathrm{Az}$ erdőben]; 1822: valami igen apró körtvél tizenkettő vala nagyobb ezis tsak bé lévén hányva ${ }^{a}$ öszve romlott, de az Idegen Uraságok ki katzagtak hogy fejül egynehány szebetske volt [Mv; IB. gr. Korda Anna lev. - ${ }^{a} \mathrm{~A}$ kosárba].

szebbecskén vmivel szebben 1748: miolta Ferenczi Uramhoz ment férihez, az ólta maga szebbetskén jár, mint az elŏtt [Torda; Borb.].

szebbedkén kibetűzhetőbben 1670: Uram, én nem bánnám, bár maga írna, mert talám még valamivel kevesebbet írna, csak írna egy kevéssé szebbedkén, ne kelletnék oly főtöréssel elolvasnom [TML V, 5 Naláczi István Teleki Mihályhoz].

szegecske kis szeg Szk: rezes 1714: Ló szerszám barsonnjal buritott ès atzéljos halhéval rezes szegetskékkel, harom darabbul állo fl. Hung. 12. - [AH 22].

szegelet-asztalocska sarokasztalka 1819: egy szegelet cserefa kis asztalacska, rajta lévő kétfelé nyilo ajtajuk kitsi tékátskával [Baca SzD; TSb 6].

szegeletecske 1. szélföldecske 1643 u./1770 k.: A' szőlő alatt való kútnál vagyon egy szegeletetske [SzConscr.]; 1667: az Kapolnan kűűl, az ket vt kózőtt valo szegileteczike ez marada közre [Imecsfva Hsz; LLt]; 1676/1687 k.: volt Pápai Péter Vr(amna)k égy űlés helye rajta valo épúleteivel édgyưtt ... égy kis szegeletecske, mellyet ö kglme ada a' megyének őrőkősőn hogy legyen a Schola Mester lako helye [Mező́csávás MT; MMatr. 412]; 1739: adattatott égy darabotska rét, égy Szegeletetske, minthogy a jŏvŏ jároktol Semmiképpen azon 
szegeletetskét meg nem tarthattuk ... azon Vámosok vagy Révészek usualtak eddigis [Dés; Ks 28. V]; 1757: Vagjon egy kis szegeletetske mint egy Fertály szekér szenára válo [Szentmihály Cs; SándorConscr.]; 1782: azon ... retnek tsak egy szegeletecskéjére tétetet az eŏ Naga Malma [Torockósztgyörgy TA; Thor. XX/2 Ványa Gergely tt lev.]; 1796: Vagyon még más Káposztás Kertnek usualt egy Kis Szegeletetske [O.solymos KK; Told. 39/30]; 1826 k.: a Kelementelki Csulak agy nevü Patak ... a Gyalakuti határunknak csak egy szegeletetskéje mellett a téren follyván ... a Természettol jo ágyába ... Nap nyugot felé folly [Gyalakuta MT; GyL]

Szk: bokros 1733: Az Nyárád marton egj kis bokros Szegeletecske [Lőrincfva MT; EHA] * kopaszos 1768/1801: egy kis rővid suhartzos kopatzos szegeletetske [Timafva U; Pf] * puszta 1780: vett Cserében ... Buzás Besenyőben ${ }^{\mathrm{a}}$ egy puszta szegeletetskét [DobLev. III/550. 1a. - ${ }^{\mathrm{a} K K}$ ] ${ }^{*}$ telekbéli 1776: a' Porondi felső sikátorb(an) ... lévő kis Telekbéli szegeletecske részecske [Ne; DobLev. II/484. 1b].

2. (erdő)szélecske 1785: Az Sorostelyi Erdŏbŏl Farkas el adott egy szegeletecsket $55 \mathrm{M}$ forinton [Nsz; TSb 13 Bethlen Zsuzsánna lev.].

szegeletecske-erdő szélerdőcske 1775: Maradat Magyar Peterlaka felŏl egy kiss szegeletetske erdŏ [Körtvélyfája MT; LLt]; 1818: a mostani vágás alatt lévö Táblában fel járo uton alol lévő szegeletetske erdö adattassék által, ugy mindazonáltal hogy az a helybéli Ispány által mutattassék ki a Bácsiaknak [Kv; KmULev. 3]; 1823: a' kitsin szegeletetske erdőnek fele [Kakasd MT; DLev. 1. II. 19].

szegeletecske-föld szélföldecske 1845: a' Sospatak hidja végénél lévő Szegeletetske főld [Dés; DLt 657]; 1848: égy darabatska Füzessel bé nőt Szegeletetské főld [Dés; DLt].

szegeletecske-hely szélföldecske 1716: egy küs szegeletecske helyet adtak [Erdőcsinád MT; Told. 52]; 1758: egj kis szegeletetske tizen négj őlni helj vagjon [Nyárádkarácsonfva MT; Berz. XXVII/11]; 1852: égy Szegeletetske heljet két kupa tőrok- buzát vetett [Magyaró MT; LLt]; 1852: az malam ösvenye mellett égy Szegeletetske helj [Magyaró MT; EHA].

szegeletecske-jószág szélbirtokocska 1810: azon Kŭs Szegeletetske joszág [Tarcsafva $\mathrm{U} ; \mathrm{Pf}]$.

szegeletecske-szénafü szél-szénafüvecske 1717: egy kŏblŏs fŏldecskéjét ... és három szegeletecske szena fŭvetis [Pálos NK; $\mathrm{Hr}$ $1 / 42]$.

szegeleterdőcske szélerdőcske 1756: engedŏk az Néhai Horváth Bodisar Posteritási rész nyilnak ... az felsŏ bŭtŭin az bérczen az ket utak kŏzŏtt lévŏ három szegü kis szegelet erdŏtskét [Széplak KK; SLt 20 Sz. 14]

szegeletföldecske szélföldecske 1751: a' Szölőre ki járó úton alól lévő szegelet Főldetskével együtt [Koronka MT; EHA].

szegelethelyecske sarkon/szélen levő földdarabocska, szélföldecske 1727/1790: tudgyaé a Tanŭ... hogy az mely kủs Szegelet helyetske vagyon olahok Templomán alol ... ezen kis helyetskére ... kis engedelméből csinált egy kis házat egy Gyermány nevü Ember [Ádámos KK; MvLev. vk]; 1803/1804: Hát azon kis uttzatska, melly a' Refor(matum) Templom alatt lévő Kolosi Farkas Ur veteményes kertye és a' kérdésb(en) ki tett Szegelet helyetske kőzőtt megyen fel; falu uttzája volt é eleitől fogva ...? [Kv; RLt vk].

szegelet-jószágocska széljószágocska/birtokocska 1803: áltăl adom ŏrŏkŏs birtokába Tks Dosa Gergely Urnak ... azon kis szegelet joszágotskámot [Kakasd MT; DLev. 1. I. 6].

szegeletkemencécske sarokkemencécske 1697: Melly házban vagyon egy zőld tserépból kerekdeden tsinált szegelet kemetzétske az elsŏ része egy vas lábonn áll az Szemoldokeis vas [O.brettye H; Born. XXIXa. 2 néhai Bodoni Balázs conscr.].

szegeletkertecske szélső kertecske 1775: szegelet Kertetske [Dés; Pat.].

szegélyke szélföldecske 1758: ada ... ket darab Szanto fŏldnek a lábján egy kitsin Szegeljket [Hsz; Hr 194].

szegényecske 1. kevéske 1758: monda Udvar Istvánné Aszszonyom: Iuana ha sŭtŏttél vólna adnál nékem egy Kis kenyeret ... 
mellyre én mondék: Jó szivel én Aszszonyom, tsak hogy bizony szegényetske $a^{\prime}$ kenyerem [Bethlensztmiklós KK; BK. Farkas Juana cons. providi Vintilla Petre (32) vall.].

2. a szokottnál kisebb 1807: dél előt szegényetske Repetitiot mondottam [KMN 220].

szegényke 1. sajnálni való (kis)gyermek 1662: ez a gyermek oly nagy szopható, hogy ugyan mód nélkül vagyon. Egyébaránt nem aránszom szegénykének semmi nyavalyáját [TML II, 242 Veér Judit Teleki Mihályhoz]; 1670: Az én fiam, Uram igen elnyomorodék ... jártányi ereje sincs ... sőt az sárgaság is látszik rajta ... ha az Isten nem könyörül szegénkén, én nem tudom, hova leszen [TML V, 407-8 Bánfi Dienes Teleki Mihályhoz]; 1717: En ... Tednap (!) del után erkeztem haza bekével másként bizony igen vekony egéssegbén hattam lègfőkepén Josephet, Jankoczka Ugyan jobbáczkán vagyon Istennék hálá elég nagy Sirva maradának el Szegenkék [Altorja Hsz; ApLt 2 Kálnoki Borbára férjéhez, Apor Péterhez]; 1851: kitsi Titi is mostanság mind beteg volt el van pusztulva, féltŭnk hogy el veszessük szegénykét [Kv; Pk 6 Pákei Krisztina férjéhez].

2. halott gyermekre von. 1660: Én, édes Sógor uram, szegény édes kis fiacskám halála történvén ... tegnap temettetém el szegénkét [TML I, 555 Bánfi Dienes Teleki Mihályhoz]; 1705: Ugyan a szegény kisleánykám testét bétöttük a több testekhez az Ötves házába, holott is már négy koporsó vagyon téve: Székely Ádámné asszonyom teste kisgyermekestül, az úr kisfia teste, a Józsefé, és az enyémé, szegénykéé [WIN I, 565]; 1777: Ez igen okos gyermek volt szegény ... Nem hihetni el micsoda sírást és szomorúságot vittek végbe szegénykének az halálán [RettE 375]; 1777: Mi itt kesergünk felette szegénykének, ő pedig, tudom, a mennyeknek országában örvendez [RettE 376].

székecske 1631: azon beleöl uagyon ... egy szekecsyke [Fog.; UF I, 401]; 1637: Beczy vas zaros sarkas pantos aytó egy hazban; egy aztal labastol benne, egy festet karos szek, kett kws szekecsyke [Fog.; UF
I, 408]; 1637: Onnatt bellyeb jeöuen ... az hazban ... harom aztal labastol, ket eczel szek, ket kar szek, kett nyoszolya, egy kws hituan szekecsyke [Fog.; UF I/409]; 1749: Kett Fejer Székecske [Királyhalma KK; Ks 33. XXIIb].

Szk: láb alá való 1748: Lább alá valo kicsiny Szekecske [Ks 8. XXVIII. 5]; 1756: Láb alá való széketske [Nagyrápolt $H$; JHb XXXV/35. 27]; 1805: Egy Kis láb alá valo Széketske [Szamosfva K; BLt 9] * pástétom alá való 1679: Pastetom alá valo Labas apro szekecskék nro 26 [Uzdisztpéter K; TL. Bajomi János inv. 55-6].

szekerecske 1. 1748: volt két Lova, s, egy szekeretskéje [Torda; Borb.]; 1750: Egy küs Szekeretske Nr 2 [Gyeke K; Ks 83].

Szk: bánátusi 1812: egy Bánátusi szekeretskét német hámokkal maga után hagyván el szŏkŏtt [DLt 383 nyomt. kl] * egylovú 1582: Hallottam Zaiabol ez Ersebet Azzonnak, Mondwan ... ot a Zamos mellet, Veres Lukach Masod magawal eg lowo Zekereczkewel vagion, es azon tolnak eg wst penzt fel a zekerre $[\mathrm{Kv}$; TJk IV/1. 50] * fahordó 1735: két alacson fa hordo Szekerecskébe való kerekek [Kv; Ks 40 Varia XXVIIIc] * lován, jén visz 1597: Zeifner Georgi Egy Loan zekerechikeien vit egj berbentzet Egresre (!) [Kv; Szám. 7/ XII. 55 Filstich Lőrinc sp kezével].

2. vhány szekerecskényi mennyiség 1782 : széna három kalangyátska maradott ... mindenik kalangyában volt négy négy szekeretske [M.fodorháza K; KvRLt VII. 27 Sztánka Tyifor (26) jb vall.]; 1802: Egy Szakaszotska Sarju melyben vagyon három Szekeretske [MkG]; 1831: a Széna Termést két Bugjába raktam, a mely átaljában, 2 Ŏkŏr után 3: Szekeretske lehetne [O.kocsárd KK; Pf Duka Szimion lev.]; 1840: akkoron oda állitott öt Kaszásim édgy Szekeretskénél tŏbb Sarjut édgybe nem gyüjthettem [Dés; DLt 983]; 1847: Széna a' két réten lett ... 3 szekeretske $[\mathrm{Kv}$; Pk 7].

Szk: vhány vel ad 1805: a Falus Biro edgy edgy Szekeretskével adnak ${ }^{a}$... Négy Négy Sustákon [Ózd AF; MúzRadák. - ${ }^{\mathrm{a} F a ́ t]}$ * vhány vel vitet 1829: a Falus Biro egy egy Szál Gyűmőlts Fát le vágotatt $\mathrm{s}$ vitetett 
Rectificator Urhoz ... egy egy Szekeretskével [Mezőkölpény MT; TSb Fartzádi Márton (46) vall.].

3. jelzői haszn-ban 1621: veottwnk ... Egj Zekereczke Zekelfóldi sendelt 3 Ezert 6 Zazaual p(ro) fl. 1 tt fl. 5 [Kv; Szám. 15b/ IV. 21]; 1729: hoztam ... harom szekerecske aszu fat [A.karácsonfva MT; Told. 31]; 1759: tett a' viz mint egy szekeretske széna kárt [M.zsombor K; SL]; 1778: Szokott ... B. Alvintzi Gábor Ur ő Nsga a' maga embereinek, az alább valo erdőből adatni két szekeretske fát annuatim egy-egy Gazdának [Bányabükk TA; BLt 11 Molduán Ignát (60) zs vall.]; 1820: (A) kaszálo mind addig mig el nem suvadozott két szekeretske szénát meg termet [Firtosváralja U; Pf].

4. területnagyságra von.: vhány szekerecskényit termő 1727: az emlitet irotvány ... oly nagy mint most nem volt, mert akkor csak akkora volt hogj fél Szekerecske Széna termet rajta [Középlak K; SLt 29. J. 26 Joh. Molduván (60) jb vall.]; 1770: Vagyon még ... ezen patak(na)k két felén és ezen Tanya kőrül ... egy darabotska kaszálo hellyetskéje ... mint egj szekeretske szénát termő hellye [Berekeresztúr MT; BetLt]; 1782: azt tudom hogy égy hellyetskét ... in vállyá Unguruluj nevezetű vőlgyben Pojáná Boldizsojenak hivják, melly Pojenitzát én tudom, hogy olly kitsiny helly volt ... hogy alig termett meg rajta égy szekeretske széna [Csákigorbó SzD; JHbK VIII/18]; 1798: egy Szekeretske málét termő (föld) [Dés; DLt]; 1804: Van 2 szekeretskére valo kaszállo is ezen fordulon, de ... ez a kaszállotska nem volt el foglalva a Fŏ Ispány Ur számára [Szásznyíres SzD; Ks 101 Jó János ref. pap kezével]; 1856: egy fél szekeretske széna hely [Csekelaka AF; KCsl 6]; 1864: egy szekerecske szénát termő hely [M.bikal K; RAk 250].

szekérke 1. kicsi szekér 1679: Kőzőnséges, deszkas, Karika Kerekü, gyermek(ne)k valo kis szekerke nŏ 1 . Ugian illyen, romladozot, regi szekerke hatulso tengelje, egj kerekével no. 1 [Uzdisztpéter K; TL. Bajomi János inv.].
2. jelzői haszn-ban: szekérkényi 1730: egj szekérfáért Den. 69 ... ismét 2 szekerke fáért Den. 90 [Kv; Szám. 56/XIX. 24].

szekérszínecske kocsiszínecske 1825: egy kis Szekér Szinetske [M.felek K; SzentkZs Conscr. 13].

szekrényecske szekrényke 1700: fel kez kád nro 2. Tekenyőczke 1. Desa nro 1. Egi kis szekrenyeczke [Csicsó Cs; BálLt 71].

szélecske 1. kis földszél 1607: Tudok egi zelieczket az to mellet [Szacsva Hsz; BLt].

2. jelzői haszn-ban: szélecskényi 1803: ègy szeletske hoszszu rojtos végü Kendő [Harangláb KK; UnVJk].

szélesebbecske kissé szélesebb, szélesebbke 1754: az egész épűletnek hoszsza $161 / 2$ Szeless 3 ôl és helyenn szelesebbetskeis [Uzdisztpéter K; CU]; 1808: A lábost szélesebbecske dészkára teszik száradni [Dés; MNy XXXIV, 12].

szélesebbecskén kissé szélesebben, szélesebbkén 1733: Minthogy az hegy teteje felé meg rŏvidult az láb, potoltuk azzal hogy szelesebbetsken mertük fellyŭl, mint aláb [Kiskerék AF; JHb XXVI/44].

szélesecske 1. széleske 1661: én ott lételemkor amaz négyélű igen könnyű szélesecske hegyestőr vasakot árúltanak [TML II, 81 Rhédei Ferenc Teleki Mihályhoz]; 1813: szélesetske vékonyabb patyolat [Asszonynépe AF; UnVJk].

2. széleske területü. Szk: föld 1751: $\mathrm{A}^{\prime}$ Bordás Hegynek verő fényes oldalán alól egy szélesetske főld [Koronka MT; Told. 31/4] * gyepú 1800: az uton fellyúl az szőlőig az p(rae)tendalt Cziher széllyesetske gyepú [Ádámos KK; JHb XX/19] * gyümölcsös 1844: a Szamos vize a Szász fenesi határban levŏ Sodo (!) réthez lassan lassan közelgetett, és a' Monostori Szőllőkhez is, a' hol az alyba Szelesetske gyümölcsös volt [Szászfenes K; KmULev. 1. Nagy Josef (65) col. vall. - 'Elírás Sodró h., de ma is hallható a fenti alakban].

széleske I. mn szélesecske 1710 k.: én Istenem! ... csudálatos szózat és sugallás által a te dicsőséges jöveteledről nékem hírt adtál, kiváltképpen való gyönyörűséges jó illatnak nagy bőségét bocsátád magad előtt, mellyel, mint valami drága olaj- 
jal, engemet felkenél és eltöltél, és ottan mindjárt szép, jó hosszúka, széleske, mindenik felől béírt levélnek látható formáját szállítád az én fejemre [BIm. 1007].

II. fn '?' Hn. 1835: A' Széleskékben a' Tatrang között (sz) [Keresztvár Hsz; EHA].

szelídecske I. 1. mn szelídded XIX. sz. eleje: Mondám néki szelidetske Léány vagy e vagy menyetske Én sem Léány sem menyetske vagyok oh te szelidetske [AbN].

2. szelídke 1811: Te pedig Gazdádhoz hív oh Szelidetske Házam eszterhájján hangitsáló Fetske! [ÁrÉ 108].

II. fn szelídke személy XIX. sz. eleje: Mondám néki szelidetske Léány vagy e vagy menyetske Én sem Léány sem menyetske vagyok oh te szelidetske [AbN].

szellőcske szelecske 1777: az Haztol az Istallora lengedezŏ szellŏtske [Majos MT; Told. 26/21].

szemecske kis gabonaszem 1722: rettenetes roszszak azok az kgd Sertéssi, most edgy néhányat kŭlŏn választattam, és szemecskével tartatom [Fog.; KJ Miss].

szénácska kevés széna 1595: en Magamra Lowamra ... attam vallami zenachykatis ... keolteotem f 1 d 50 [Kv; Szám. 6/XV. 99].

Szk: t csinál 1777: egy Nállunk valo bohokás Ember ... irtogatni kezdvén Szénácskátis tsinált itten [Konkolyfva SzD; JHbK LVIII/28] * kis szekér 1618: egy küs szekér szénácskát hoztak [BTN 81, BTN² 83] * társzekérnyi 1797: kèretett egy egy Tár Szekérnyi Szenátskát [Mv; Told. 42/1].

szénafiók szénaboglyácska 1824: edgy Széna fiok alatt vártuk az esső elmulását [M.légen K; KLev. 9].

szénafü-helyecske kaszálócska 1648: adának ... egi darab szena fv helieczket [Hatolyka Hsz; BálLt 1].

szénafü-részecske kaszálórészecske 1665: ádá ... Damokos Mihály, al(ia)s Pal Mihaly, az ö reszit az malomhelybol ... mely malom hely, és szenafü reszeczke vagyon ... Jakab falvaban [Impérfva Cs; BCs].

szénafüvecske kaszálócska 1592: egy kis szena fweczykeie vala ott fanczialy Leurinczynek [UszT]; 1600: En mindenkor azt a darab zena fwwechket Fekete Balaseknak hallotta(m), en masenak ne(m) hallotta(m) [UszT 15/87 Miklos Ferencz Kaidichfalui Lofeö ember vall.]; 1665: ada ... az feljel mégh neuezet szena füeczket [Impérfva Cs; BCs]; 1696: Az Apro fŭn is van egy darab Szena Fuvecske [Szotyor Hsz; LLt]; 1716: Vagyon a Határ vegb(en) ... más szena füvecskeis [Bürkös NK; TGsz 51]; 1723: Bohus nevü szena fŭben valo darab szena fŭveczke [Mezősámsond MT; Berz. 5. 42. S. 35]; 1758: Argyeus Veszelie ... azon Szénafüvetskéje ... Csáki rész Széna füvével ... vicinálodik [Mocs $\mathrm{K}$; JHbK XLVII/18]; 1770: adot volt kétt szena füecsket [Köpec Hsz; Köpeci lev.]; 1812: Álapos (!) árkában egy széna füvetske [Bordos U; EHA].

Hn. 1730: Az Szenafŭvecskeben (sz) [M.décse SzD; EHA].

szénarétecske kaszálócska 1577: vagyon ... ismett egy kis Zena retechyke [Mv; BálLt 79]; 1675: vettem bizonyos summa pénzen ... egy darab szanto fŏldet, es mellette egy kis szena retecsket ... örök árron megh hihatatlanol [Fog.; Törzs. Fogarasi János portai posta a fej-hez]; 1713: Vettem ... égy széna Rétecskét a mellyen kétt szekér széna Terém rajta [F.gezés NK; JHb XXIV/14]; 1722: az utrumb(an) fel tőtt darab széna rétecské(ne)k helljén ... ez előtt mintedgy 36 esztendővel a Maros vize fojt és rend szerint járt [Algyógy $\mathrm{H}$; JHb XXXII/41]; 1723: Ada ... egj darab ... széna rétecskét [Mikháza MT; Lok.]; 1725: a Gŏncz kutytyán fellyúl egy darab szena retecske [A.jára TA; EHA]; 1762: Tudgya é a' Tanŭ. sŭrŭ erdŏbŏl ki irtott és pacifice birt Széna Rétetskét, azon ki irtott Hellyetske jutott é valamelly bizonyos Paraszt Ház-helly után, avagy nem? [Cege SzD; WassLt vk]; 1790: házom után ... mind darab széna rétetskét, mint $\mathrm{p}(\mathrm{e}) \mathrm{d}(\mathrm{i}) \mathrm{g}$ osztot darab törökbuza földetskék is voltak [Déva; Ks 75. VIII. 154].

szépecske 1. meglehetősen szép 1758: Ezen mostani feleségemet ... minden ember bátorkodott kérni, azon okból hihető, hogy szépecske is volt [RettE 75]; 1758: Minthogy szépecske volt, kapott a szem rajta [RettE 75]; 1771: Tanulógyermek koromban egy Komjátszegi Sámuel nevü 
unitárius ember gazdám lévén, szépecske felesége volt [RettE 249].

2. meglehetősen mutatós 1795: Kriska kisasszony adott 6 Rf. 40 xr hogy vegyek ... 4 v. 5 szem szépetske Gránátot [ETF 182. 26 Gyarmathi Sámuel felj.]; 1796: Egy szépetske Rotgüldenért Rfl 1 [ETF 182. 74 Gyarmathi Sámuel felj.].

3. meglehetősen fejlett/nagy 1757: Egy 5: esz(ten)dŏs Magyar Országi Szépetske

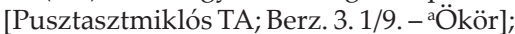
1760: mikor halásztunk, és valami szépetske halat fogtunk, azt mondotta hogy ezt a Nénémnek küldöm Sz: Miklosra [Gyeke K; Ks 92 Peszkár Von (40) vall.].

4. meglehetősen jó minőségü 1786: Borso szepetske Metr. 7 [Nagyalmás K; JHbK XXIX/38].

5. meglehetősen nagy összegü 1788: Ha az Ur I(ste)n Békességet parantsol, reménlyhettyŭk az Aszszu - szŏlŏ Borának arrábol ... a' Nyereség ... szépetske lenne [Kercsesora H; TL. Málnási László ref. konz. pap gr. Teleki Józsefhez].

szépecskén 1. elegendő számban/mennyiségben/bőségben 1680: ennek az Tonak szŭksseges az Tisztitás olt(na)k szamos hala az Praedecessor R(ationi)sta(na)k relatioja szerint szepecsken vagyon benne [A.porumbák F; ÁLt Inv. 33-4]; 1710 k.: Az kész pénzen külis hólmi naturálétok gyült öszve nállam szépetskén [CsV]; 1722: ki $\operatorname{adta}(\mathrm{m})$ kevés pénzetskémet dolog feiben, az által folj az oeconomia(m), amaz nagy szŭkségben szépecskén adta(m) el Gabonácskát, abbol teremptettem vala pénzetskét [KJ. Rétyi Pál lev. Fog-ból]; 1748: Bora, buzájais szépetskén maradott ŏ kglmé(ne)k [Torda; Borb.]; 1774/1778: Joszag szépetsként lévén kezében [Msz; DE]; 1799: már az Szent Ur Isten azokra is réá segitett és már ollyan állapotban hoztam a Joszágotskáimat hogy már ŏnként is szépecskén hoznak bé [Ne; DobLev. IV/810 Szántó Sándor fiához].

2. elég nagy összegben 1754: vagyon erdő árrábol gyüldőgelt penze ${ }^{\mathrm{a}}$ szepetskén [Dés; DREmLt Conscr. III. 51. - ' $\mathrm{A}$ ref. eklézsiának]. szepetecske ládikácska 1669: Vagjon egj ŏregh szepet ... Ezen szepetben vagjon egj kis szepeteczke, kiben Veres minium Vagjon [Kőhalom NK; Ks 66. 46. 24a].

szerviánka rövid női kabát, ujjas 1849: 12. sing kartont ... Egy Szerviánka ... égy fel duczet kés, és villa [Dés; DLt].

szessziócska úrbéri telkecske 1727: Lévén Kézdi Székben Száraz Patakon egy küsded darabotska szessiotskám [Kilyén Hsz; HSzjP]; 1732: Egj Sessiocska van Poka Kereszturon [Ks 12. I]; 1747: azon kis Sessiótska [Vaja MT; Sár.]; 1747: egj Váradi nevü Tisztartója ... egj belső fundusocskát két felé szakasztott felit Porcsiren (!) Juon nevü Sellérinek atta ... meg halván ... az emlitett ... Sellér az emlitett Sesziócskátis, vagjis inkáb huruba helyecskét az ... M. B. Kemén Samuel Ur részire szakasztatott helyhez foglalták el [Mezősályi TA; Ks 7. XV. 20 Molduvan Iefftin (50) jb vall.]; 1756: az ... Eclesia Parochialis fundussának vicinitásokban lévö Sessiotskákot ... Mikola Lászlo Ur ő Nga birta [Burjánosóbuda; JHbK XLIII/27]; 1771: Vagyon a Sz. Katolnai Praediumban egy más mellet két Sessiocska, de egy Antiqua Sessióbol áll [Mezőköblös SzD; RLt]; 1798: ezen a' Sessiotskán lakott ... Bába On [Buza SzD; Conscr.]; 1801: a patak által el szakasztatott Sessiotskának [Nagynyulas K; DLev. 5].

Szk: bennvaló 1746: egj ben valo Sessiocska [Bibarcfva U; Berz. 16. XLIX. 23]; 1776: Vagyon Marus Székben Csejden egy benn valo Sessiotska [Told. 8] * fél antikva 1802: a Falu közepetáján lévén ezen fél Antiqua sessiotska [Topasztkirály $\mathrm{K} ; \mathrm{JHb}$ LXXI/2. 12] * nova 1782: igért volt ... nova Sessiocskát [Buza SzD; LLt Csáky-per 168. L. 32] * oldalos 1767: haszantalan Semmire kellő forrásos oldalatskájak oldalos forrásos Sessiocska [LLt Fasc. 129]; 1767: oldalos forrásos Sessiocska vagyon a felszegybe [Vajdasztiván MT; EHA].

szigetecske szigetke, kis sziget 1572: az kys zewgetechketys twggia hogy Desy hatar Byzonnyal [Dés; DLt 184]; 1590/1593: ide altal az peres zygeteczkere ne hajcziak barmokat itatnj [Bálványosváralja SzD; Ks]; 1592/1593: mikor az zent Benedeki- 
ek marhayok altal zaladot neha az Kys zamoson ... nem hadtak azon az zygeteczken iarnj [Bálványosváralja SzD; Ks]; 1592/1593: az viznek nagj volta miat azt az Zigeteczket keorniwl folta ${ }^{a}$ [Bálványosváralja SzD; Ks. - ${ }^{\mathrm{a}} \mathrm{A}$ Kisszamos]; 1685: az Molnar Albert szigeten alul való fellyul az Réven, az két Viz kőzőt valo szigetecsket adtuk Pacsai Ferencz vram eo k(e)g(ye) 1(méne)k [Dés; EHA]; 1676: az Nyárádon lévŏ hidon fellyel egy szigetetskét adott érette [Nyárádsztbenedek MT; Told. 37]; 1783: tul a Maroson az által járo rév hajon aloll égj füzes Szigetetske [Branyicska H; $\mathrm{JHb}$ XXXI/28].

szíjacska szíjdarabka 1719 k.: szerszámhoz valo darab szijatskak [LLt Fasc. 115].

szíjácska szilácska, vékony forgácska 1756 : szoktak ... fizetni Maruson tul lévő Dobraiak ... szijácskáért [Déva; Ks 101].

szikrácska átv a vonzódás, ragaszkodás szikrácskája 1758: Kérem is az én Istenemet, hogy ennek utána is tartsa meg én bennem azt a kicsiny szikrácskát ${ }^{a}$, sőt nevelje [RettE 80. - aA ref. valláshoz való ragaszkodást].

szilvafácska szilvacsemete 1648: (A kertnek) Az közepin egj wltetet szilva faczka [UF I, 893].

szilváskertecske kis szilvás kert 1783: Vagjon gyümöltsös Szilvás, és veteményes kertecske [Nagyrápolt $\mathrm{H}$; JHb XXXI/28].

szilvásocska szilváskertecske 1717/XVIII. sz.: Ezen Udvarház hellyen alóll egj kis Sylvasocska [Benedekfva sz; Berz. 7. 68/1].

színecske 1. fészerecske 1742: egj Sendelyel fedett Szinetske ülés kedviért csinálva [Pókafva AF; JHb XXV/58]; 1758: egy kis szinetske Fenyő Deszkákbol bé padolva [HSzj padol al.]; 1777: egy deszka fedelŭ kis Szinetske [Meggyesfva MT; LLt 28/531]; 1780: egy szinetskéböl ... el lopták ... egy pánt vasat [Grohot H; Ks 113 Vegyes ir.]; 1807: Vagyon édgy rongyos ágasokon álló pajta és Színetske Szalma fedél alatt [Szentmargita SzD; Ks 76/56 Conscr. 8]; 1830: Egy szinetske ... vagyon az udvar napkeleti oldalába $[\mathrm{Kv}$; Somb. II]; 1849: Ezen szinhez ragasztva égy tarto Színetske vas sarkos, reteszes ajtojaval [Somkerék SzD; Ks 73/55].
2. árusító bódécska 1893: Fel olvastatik az ide valo Dévai Fazakos Czehnek Instantiaja, mellyben panaszolják, hogy özvegy Tekintetes Szeredai Domokosné aszszony, a' Dévai piatzi kapu elött lévö kis Szinetskéért, hogy alatta árulgatnak Szambatonként őket nagyon Taxálni kivánnya [Déva; Ks 91. C. 12].

szipka fúvóka 1823: Egy pár ezŭst aranyozot trombita kővekkel ki rakva veres sejem sinorral, égyik Szipka nélkül [Szentbenedek SzD; Ks 38. V Clenodia fam.].

szitácska kis szita 1794: vettem ... A konyhára egy szitátskát [Gyalakuta MT; TSb 17].

szívecske kis szívalakú ékszer 1714: Sziv formára futralyb(an) találtatnak: Kisetske Vidlatska, szivetske, gyüszü, Lantzotska, mind ezustbül [M.köblös SzD; RLt O. 1 Rettegi Miklós lev.]; 1714: egy haj kenönek valo Pixisetske, egj haj Tó egy szivetske ezüstes [AH 32, 55].

szkédácska cédulácska 1600: Die 18 Decembris exhibealt egy schedachkat (!) kiben mutogat regestumanak be Adassa vthan valo buza ky oztast Cub 51 1/2 tt az Arra fl 257/50 [Kv; Szám. 9/IX. 14].

szkófiumgombocska 1714: Zőld virágos Bársonj Dolmánj, nagjob reszrül Brokad bélléssel, a' mellyén jókora 15. s az uyan 16. kissebb skofium gombotskakkal fl. Hung. 70 [Kv; AH 7].

szobácska kis lakószoba 1590: Az Varosban ualo haznak pinczejeuel egietembe ualo Beri ez rend zerenth ... Az Haz beer ... Nagi Jlona az Hatulso Zobachkatol fl. 6 $\mathrm{Az}$ Kohnia mellet valo Zobachkatol fl. 3 [Kv; Szám. 4/XIX. 4]; 1602: Czementes Kadar Mihaly ... vallya ... Zeoch Andrasne ... az Zakach Jstwan Zobachkajabol Ieo ky, vgy kezde mondany ${ }^{\mathrm{a}}[\mathrm{Kv}$; TJk VI/1.

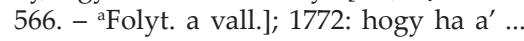
Konyha mellett, félben-lévŏ Téglábol indult Szobátska, el készittenék ... ugy 600 MForintokot meg-érne az el-betsŭlt helly, és épŭletek [Mv; DLev. 5. XVII. 4]; 1894: Én vettem Szovátán egy fészket. Ne félj, szegényes székely házikó. Mindenestől együtt pár száz forint. Én ott lakom nyáron. Csak 3 szobácskám lesz, de ott neked is van helyed [PLev. 167 Petelei István Jakab Ödönhöz]. 
szócska 1. 1665: Naláczi uram ő kegyelme jelenté, Uram, nekem, hogy nehezen esett volna Kegyelmednek egy szócska az aszszonyunk ő nagysága levelében, melyben írja ő nagysága, hogy ajándék nélkül nem volt az Kapi uram ő nagysága dolga stb., alítván, hogy Kegyelmedet értené ő nagysága [TML III, 541 Székhalmi András Teleki Mihályhoz]; 1739: Noha egj szócskának nem hejesen való tétettetéséért láttatik kevés difformitásnak lenni [Dés; Jk 295b-296a].

2. mutató mutató névmás 1710 k.: ez a mutató szócska "az", valósagot tészen s mutat, semmit pedig senki sem mutat meg [BÖn. 438].

szodomika fajtalankodó 1683: eo kglme Felesegevel nem az tiszta Szent hazassagnak rendi szerent élt, hanem tilalmas sodomika eletet Kővetet [Dés; Jk].

szokatlanocska kissé szokatlan 1798: Szokatlanotska a dologa [MNy XLVI, 157. Gyarmathi Sámuel Aranka Györgyhöz Göttingából - ${ }^{\mathrm{a}} \mathrm{Az}$ ifjú gr. Bethlen Elek hirtelen házassága].

szoknyácska kis szoknya 1602: Honesta Matrona Catharina R(e)l(i)cta Ioannis Kadas ... fassa est ... Ruhazattia feleol pedig, azt tudom hogy eggy zoknyaczkaya, es eggy kis parta Eowechkeys volt az Leannak [Kv; TJk VI/1. 606b]; 1778: Szokmányamán és rajtam levő hitvan szoknyatskaman kivül mindeneket az Udvarb(an) bě. vittek [Agárd MT; Told. 8]; 1839: két esztendős Papp Nyikuláj ... viselt ... egy hasonló szinü spanyolett szoknyátskát [DLt 132 nyomt. kl].

szolgácska 1. kics szolga 1596: Orozhegy Zaz Pal zabaditattia egy zolgachkaianak nalla ualo lakasath [UszT 12/93]; 1631: im egj kis szolgaczka(m) vagjon ugj mond $\mathrm{s}$ mindgjart ki hajtatom vele az mezeore ${ }^{a}$ [Mv; MvLt 290. 232b. - ${ }^{\mathrm{a}} \mathrm{Az}$ ökröket]; 1778: egy kis szolgatskáját is tudom [KLev.]; 1806: Nosa Luka Szolgátskájais az Erdőn volt [KLev.].

2. átv levélzáradékban: vkinek híve 1740: maradok G(róf) U(ramna)k alazatos szegeny szolgátskaja Mohaj Moses mpr [TK1 Mohai Mózes Teleki Ádámhoz]. szolgálatocska szolgálattételecske 1668: kicsin sok rendbeli szolgálatocskáimnak, ha sokat nem is, mindazáltal talám valami kis effectumát érezhették is mind ő nagyságok $\mathrm{s}$ mind az szegény haza [TML IV, 341 Baló László Teleki Mihályhoz].

szolgaleányka cselédleányka, szolgálócska 1599: el kyldem egy zolga leankamoth hogy rakia el onna(n) rúlla chak zepen es hozza el rekezthessem be marhamoth [UszT 14/41].

szolgálócska 1. szolgálóleányka 1629: Baczi Gyeorgynel lako egy Zolgaloczika mondot volt ... reaja ualamit [Kv; TJk VII/3. 117]; 1761: A' Gyermek dolga arant ... az Edes anya ugyan semmit nem kevánván az egy Gyermek mellett levö kis szolgálócskának fizetésén kivül [Kv; SRE 196]; 1785: egy szolgálotskának is bére értetŏdik [Dés; DLt].

2. udv levélzáradékban 1712: Nságtok(na)k s kglmeteknek, Szomoru árvaságb(an) megh keseredett alázatos Szolgálocskai Arva Bealis Boricza, Annis és Jutka [ApLt 2]; 1739: Az kís Arvácskam Exc(ellent) iád engedelmes Szolgálocskaja Leanyi alazatossagal kŏszŏnteti Exc(ellent)iadot [Moha NK; Ks 99 Nagy Boldisár lev.].

szolgálóleányka szolgálóleányocska 1583: Nag kialtassal ki futa Biro Mihal felesege, es monda hogy Az vra az eo Zolgalo leankayat Eolebe Zoritotta volt, es gonossagra fogta volt, kyn Rajta kapta [Kv; TJk IV/1. 141].

szopókancsócska kis csecses/szívókás kancsó 1678: Die 15 July Eperjesi által vásaroltatván az Uj Keresztenyektül vinczi edenyeket ez szerent: ... Szopo kansocska két har(om) har(om) penzen egyet egyet facit $\mathrm{f}-/ / 2$ [UtI].

szopókás csecses/szívókás Szk: üvegkancsó 1679: Szopokas ŭvegh kancso nro. 2 [Uzdisztpéter K; TL 29 Bajomi János inv.].

szorítószíjacska lábbeli szíjacska 1729: $\mathrm{Az}$ árvák számára valo három szorito szijacskák(ér)t d 9 [Szentbenedek SzD; Ks 26. XIV. 1]

szorosocska keskenyecske 1760: Jollehet szorossotska az Falunak hatara mindaz altal adaequate sufficial az Incolak Marhá- 
joknak pascuatiojara [Csehtelke K; BLt]; 1766: Ha a' Fundus szorosotskais, tsak addig kell terjeszkedni kinek kinek, amig határa engedi [Torda; TJkT V. 321].

szőkécske kissé szőke 1813: Rákosi Hodra Danilla ... szŏkétske [DLt 890 nyomt. kl].

szőlőcske 1. szőlősöcske 1583: Barbara hozzw Georgne vallia ... vagion eg kis Darab Zeóleochkem [Kv; TJk IV/1. 179]; 1593: Nemety Jstua(n) vallia, Zayabol hallotta(m) Kosa Mihaltol (!) ezt, Am az en Margitomnak eegj zeoleochket Attam [Kv; TJk V/1. 419]; 1641: uagion egj kis Szŏlŏczke [Inó Sz; GyK X. 30/8]; 1703: Egj kis darabaczka szőlőczke [Ádámos KK; Pk 7]; 1728: egy Kis szőlötske vagyon Cir 40 „, vagy 50 , veder bort termő ... Kelementelke felé [Balavásár KK; Ks 13. XV]; 1746: jutottanak vagy 5 darab aproság szŏllŏtskei [Buza SzD; LLt Fasc. 177]; 1749: vettük pénzen ... az Dési Lakatos Péter háza félétt ... az felette valo egy hasáb szőlőtskével kilenczven két Forinton [Ne; DobLev. I/234]; 1763: vagyon ... egy szőlőcske [Felör SzD; Torma]; 1767: vólt mint egy fél-holdné Szŏllŏtskéje [Nyárádsztbenedek MT; Told. 37]; 1774: 20 Tőből állo szŏlőttske [T; EMLt Conscr.]; 1817: két rongyos szőllőtskéje a miveletség (!) mián 20 vedret sem terem [M.igen AF; KmULev. 3]; 1822: Egj kis darabotska szŏlotske [Kv; Pk 7].

Szk: fecskefarkú 1759: egy kis Fecske Farku szöllöcske [Backamadaras MT; JHbB B. 2] * puszta 1625: hittuk az ket huteos feoldmereot Zenfner Matiast es Cati Mihalt felseo Lombra, egy puzta zeoleoczke zalua(n) a Varosra, hogy meg estimalliak [Kv; Szám. 16/XXXIII. 23]; 1667: az Isputalihoz tartozo egy fertalnj kis darab puszta szőlöcziket ... töredtem es uöttem fel giepúből magam szamomra [Kv; RDL I. 31].

2. szőlőtőkécske 1818: Kőtőlős leszen az Arendator Ur ... az Hataron levŏ erdŏmet ugy Conservalni hogy abban semi tetemes kár ne essék ottan lévő Kevés szŏllŏtskemnek karozására appelacidalok (!) az erdŏ tisztitásabol anyit a menyit az embereim jó Lelekkel meg esmernek [Nagylak AF; DobLev. V/1016]. szőlő-hasábocskakaró hasogatott szőlőkarócska 1804: Portsahalmi Ur is égy Szölö hasabotska karoval oda nyargalván, a Sertéseket ütni kezdette [Dés; DLt 82/1810]; 1810: égy Szölö hasabotska karo [Dés; DLt 82].

szőlőhegyecske kis szőlőhegy 1794: vagyon egy Szőlő hegyetske vagy is darabotska Szölö [Marosjára MT; Pf]

szőlőhelyecske szőlősöcske, szőlőföldecske 1703: Az Falu felett egj darab szŏlŏ heljecske [F.tök SzD; RLt].

Szk: puszta 1745: egj puszta Szŏlŏ helylyecske [Hosszútelke AF; Kath.].

szőlőnyilacska sorshúzással kiosztott kis darab szőlőföld 1767: egy Kis darabotska Szőllő Nyilatska [Buza SzD; LLt].

szőlőske kis szőlős Hn. Szöllöske [Vaja MT; HbEk].

szőnyegecske kicsi asztalterítő 1733: Ur Asztalára valo Seljem materiából csinált edgj szŏnjegecske [Marossztkirály AF; Told. 18]; 1752: Egy Ur Asztalához valo Sellyem Materiábol csinált Szőnyegetske [Nsz; Told. 2].

szubszidiumocska segélyecske 1605: Bocsatottuk Pettky János uramat, tanácsunkot is kegyelmetek között valo generalisunkot, azonképpen Zuhay Gáspár uramot, magyarországi főhívünket ... hogy az mely kevés subsidiumocskát és ajándékot kegyelmetek maga szabad akaratjából most először minekünk igért, azt kegyelmetek felszedessék és ... kezünkhŏz szolgáltassék (!) az rendelés szerént [Barabás, SzO 355 fej.].

szubsztanciácska javacska 1720: mihent anynyira valo állapotban lészek hogy excurralhassak, ha semmissé maradokis, kevés joszágocskámat és egjéb Substantiácskámatis pinzé tészem [Borosbocsárd AF; Ks 95 R. Boér Sámuel lev.].

szupulyka, szupujkó 1. karcsúan elvékonyodó 1823-1830: a prussus huszároknak a csákójok is alol széles, a teteje szupujko volt [FogE 203].

2. lapos 1792: a' Székelyeknél ... szupulyka orru, az az lapos orru [MNy LXIX, 283]. 
szurdi-burdi kis termetü 1758: Maga ${ }^{a}$ is hozzám eljött volna, de a leveleimet mind elfogták, még csak egy sem ment kezébe, amint annak utána maga, minekutána már Fosztó Zsigmondhoz ment volna, mondotta, ki is egy szurdi-burdi, kopasz

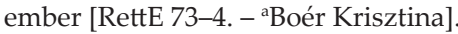

szúrósocska csalán 1726: (Az ördög harapás ${ }^{a}$ ) Levele hoszuko mint egy petyegetet, a koroja magassan nő fel, a tetein vagyon kék virágja, akkora mint egy egy poltura kerek s mint egy Szurosocska [Fog.; LLt Miss. - aSuccisa pratensis].

szuszékocska kis szuszék 1741: szŭksége lévén a Falunak egj szuszekotskara, melyben a kaplárnak holmi egjet mását tedgjuk [Mezősályi TA; Ks]; 1748: vólt ... buzájais két szuszékotskával, hány véka lehetett, nem tudom [Torda TA; Borb.]; 1799: Vagyon más Szuszékotska melyben vagyon Faszujka Metr. 9 1/2 [F.zsuk K; SLt Vegyes perir.]; 1831: Két Szuszinkotska 1 Rf. 50 kr [Szászfenes K; KLev. 18].

Szk: kicsiny/kisded 1791: A Vár mellett ... Vám tartó kisded szúszékotska Nro 1 [Nagyalmás K; JHbK XXIX/37]; 1811: égy kitsiny szuszékotska fenyő fából [Mezőőr K; MkG] * liszttartó 1798: Egy Liszt tarto Szuszekotska [Vingárd AF; KCsl. 5] * szekrényforma 1699: edgj kisded szekrény forma szúszékocska négj kŏblŏs [Andrásfva U; LLt 116 Inv.].

szűkecske kicsi kiterjedésű 1818: Kibédi lako Szűkőtske Joszágát pénz által ki Szélesithetné [NkF]; 1820/1852: A legelő helyünk is szükecske [Ispánlaka F; MkG].

szürkécske 1. szürkés 1673: gyermek Lovak ... 2 Deres, edgyike Fejer Deres ... 2 Fejer. 1 Babos ... 2 vércse ... 16 Fejer 1 Fejer kékek ... 2 Szŭrkecske ... Szegek: 2 Szegh ló. 1 Szepe ábrázatu [UtI].

2. őszes 1822: Pipa Antal ... szŭrkétske himlŏhelyesetske ábrázatu [DLt 73 nyomt. $\mathrm{kl}]$.

szürőkádacska borszürésre való kádacska 1793: Nyomo kádok és approbb Szürö kádotskák No 5 [Kettősmező $\mathrm{Sz} ; \mathrm{JHb}$ XLVI/8]. szürőszitácska kis szürőszita 1778: Kerek Szürő Szitátska [Csapó KK; Berz. 4. 8. C. 18].

táblácska 1. számvető kis számolótábla 1804: Egy Szám vető tablátska [Borosbenedek AF; SLev.].

2. vmilyen tok/tartó 1801: Egy Spádéra valo Táblatska [Medgyes; CsS].

3. kis ablakvédő tábla 1692: ezen egyik ablak(na)k két felŏl való mellyékit két kis Almarium formára csinált vak ablakok (így!), az egyik ablaka, az egyike nincsen jelen, ezeknek fŭresz Deszkakbol való totyogato kiss parkanyzatos Táblacskái, avagy aitaj egy hijaval [Mezőbodon TA; BK 9 Inv.]; 1702: ezen oldal kamarának vagyon egy kis ablakja ... belŏl Vas Sarkokon forgo vastag Cserefából Csinált Táblácskája is vagyon [O.brettye H; Born. XXIX. 4]; 1849: A Szobának két ablakaiba három táblátska el van hasadva [Somkerék SzD; Ks 73. 55].

4. ablakszemecske 1798: az Hét Házokban két két ablakok vagynak ... ki tőredezve találtattak 6 Táblátskák, mellyek papirossal vagynak ki fóldozva [Vályebrád $\mathrm{H}$; Ks 76. IX. 27]; 1814: kis ablak, kilentz kis Tablátska kettő el van belőlle tŏrve [Mezősályi TA; RLt]; 1827: a' Kert felől valo ablakotskának két Táblátskái ki vagynak tőrve [Koronka MT; Told. 34].

Szk: ablak i 1756: Ezen Ház ... belsŏ Rámáján két két Vas Sarkokon forduló kisded Vas karikákkal ki Nyitó és Vas Horgokkal be záro kisded Üveg karikákkal On közé foglalva rakot Ablak Táblátskái vadnak Négj részekben szakasztva [Branyicska $\mathrm{H}$; JHb LXX/2. 18-9].

5. asztalocska 1788: Két kis avatég Tábla ... Két ennél nagyobb Táblátska [Mv; TSb 47].

6. kis földterület/darab 1766: ezen Táblátskát megszakasztván az emlitett nagy árok [Dob.; Mk]; 1800: A La Kályá Boilor lévő Táblátska [Szomordok K; BetLt 2].

Hn. 1767: a verőfényben egy Kis Táblátska [Mezőbodon TA; EHA].

Szk: ra feloszt 1746: ezen alól maradott részt a Mlgs $B$. $\operatorname{Vr}(a) k$ kŏzt fel osztván négj táblátskára, fellyủl a Gróff mellett a meleg 
oldal felől Valo táblátska és tul a patak felől lévő ... táblátska ... jutott Mlgs B. Josika Mojses Vr ő Ngn(a)k [Mezőbodon TA; $\mathrm{JHb} \mathrm{XI/22.} \mathrm{6]} \mathrm{*} \mathrm{kiszakasztott} \mathrm{1786:} \mathrm{Ezen} \mathrm{ki}$ szakasztott Szegeletes Táblátska mellett [Mezőbánd MT; TSb 51].

7. jelzői haszn-ban 1797: Szokolba van egy Tablatska veszŏ vagyis ollyas mező Cseplesz erdŏ (így!) Amellyet negyedik otodik esztendŏben el szoktan(a)k volt adni ugy Fŭlpesenis ez ugyan jobbatska karon(a)k valois van benne [Banyica K; IB. Gombos István lev.]; 1798: Egy Tablácska Széna füvet ... adtam egy ujj Selérnek mellynek nem volt nyila [Mezőbodon TA; IB].

táblácskaforma kis négyszögü minta 1787: Vr Asztalára valo elegyes Sejemmel aranynyal Ezüstel Táblatska formákra varrott Abrasz [M.fodorháza K; RLt].

tafotaszoknyácska selyemszoknyácska 1628/1635: Egj veres tafota uiselt zokniaczka az kws leanioke [Bodola Hsz; BLt 5 néhai Béldi Kelemen inv.]; 1761: Egy kis tarka tafota szoknyátska [Koronka MT; Told. 8].

tafotavánkosocska selyempárnácska Szk: tengerszín 1700: Egj Kis Kopot, Tengerszin Tafata vankosocska [Ebesfva; UtI].

tálacska 1. kis tál 1584: Nagy Antal vallia ... a' zegeny fazakasne ezt kialta vala $\mathrm{Az}$ vargane Anniara ... Im vgmond az Eyel a' Bozorkany essez Curwa ennem hozot vala egy talachkaba [Kv; TJk IV/1. 280]; 1623: ket kis vy kannaczka es egj Talaczka niomnak Lib. 8 [Kv; RDL I. 121]; 1659: Ladányi Györgytől izentem volt valami tálacskák felől, Kegyelmed csináltassa meg, mindjárást kiváltom [TML I, 444 Vér Zsigmond Teleki Mihályhoz]; 1737: Tokbéli kis tálacska [Brassó; ApLt 5 Apor Péter inv.]. Szk: apró 1630: Apro talaczikak [Kv; RDL I. 147]; 1633: 3 Apro Talaczikak [Kv; RDL I. 103] * aranyozott szájú 1846: Két égy forma nagyságu de külőmbozö virágu aranyozott Száju Confectnek valo tálotskák [SLt 17] * bécsi 1615/1628: Het Beczi talaczikak Czifrások mustarnak ualo [Kv; RDL I. 96c] * bőrös 1714: bőres talatska Indiai figurákkal ékesitett [Kv; AH 18] * kék mázas 1615: Egj kek mazos kws talochka iratos f - d. 25 [Kv; RDL I. 97 Junck
Andr. kezével] * kerek 1786: Egy kerék tálatska ... Két kissebb kerek tálatska [Nsz; Ks 74/56. 74 Conscr.] * sima (aranyos szélü) 1658: Kistin (!) sima talaczkak [Kv; KJ]; 1801: Hat Chinai modra festett Sima aranyos Szélŭ ép Tálotskák [LLt 106/1].

2. szk-ban: borotválkozni való 1736: Veres, és Arannyos Fenekü szegeletre mettzett virágos beretválkozni valo tálotska [CU] * méreg ellen való 1732: Egy Indiai fŏldbŏl valo méreg ellen valo tálacska $[\mathrm{Kv} ; \mathrm{Ks}$ Kornis Zsigmond lelt. 25].

tálka tálacska 1812: Két kis Talka fŭles Segesvari Csesze xr 4 [Mv; MvLev. Szürtei József hagy. 7-8].

tallérocska tallér 1671/1681: az Talleroczkak(na)k halyaga annjira fogta volt el az eő kglmek szemek fényét hogi az Instructiot abban ă részb(en) nem lattak olvasni [Vh; VhU 677]; 1704: még lévén száz tallérocskám, abból vöttem ki tízet [WIN 225].

talpacska 1584: Takach Ieremias vallia Egy giermekemnek a' talpachkaia fel fordula az vargane Annia hat be keoteotte $[\mathrm{Kv}$; TJk IV/1. 258].

talpfácska kis talpfa 1623: Mely allasfakott az gerendakb(an) kelletik be vesny es zegezny, fen alatt meghint talp faczykab(a) mellyet az feoldb(e) kell le swllyezteny [BGU]; 1676: Vagyon az Vár kapuján kivúl kett felől egy egj kőrtvély fa, az job felől valonak ágai léczekre vadnak terjesztve. Vagyon alatt avatagh talp faczkakon egj szineczke [Fog.; UF II, 698].

Szk: tölgy 1804: A pintze torka felet vagyon vékony tőlgy talp fátskákra épitett fedél [Marossolymos H; Ks 108 Vegyes ir.].

táltartócska kisebb táltartó 1736: a Provisoralis Házba ... egy kisded Táltartotska fenyŏ deszkábol valok [Hortobágyfva Szb; Born. XXIXa/19. 12-3 Néhai Hortobágyi Gergely György conscr.].

tanorocska kicsi, bekerített kaszálócska 1600: az Kikelon thwl az Warosnak semmi byrodalma ne $(\mathrm{m})$ wolt hane $(\mathrm{m})$ az baratoknak wolt egy kichin tanorochkaiok [UszT 15/263 Demien Peter Zenth Thamassi Zabad Zekely (56) vall.]. 
tanorokocska bekerített kaszálócska 1744: A Kovats Sigmond szilvása mellett egj kis Tanorokotska [Bordos U; LLt Fasc. 67]; 1781: Lévén ezen Falunak Ádámosnak Felsŏ végin, éppen a Ngod Tanorokja mellett eddigis némellyikŭnktől gyepŭvel békerittett Tanorotskánk, mellyb(en) ... tŏbbetskét birtunk [Ádámos KK; Pk 7].

tanulóházacska kis tanulószoba 1803: égy Classis(na)k való kisded kamarátska vagy Házatska égy kis Tanulo Házatska vagy Kamarátska [Désfva KK; UnVJk 183].

tanulókamrácska kis tanulószoba 1803: égy Classis(na)k való kisded kamarátska vagy Házatska égy kis Tanulo Házatska vagy Kamarátska [Désfva KK; UnVJk 183].

tanulókönyvecske tankönyvecske $1710 \mathrm{k}$.: Ezt a nyavalyás árvát még csak a tanulókönyvecskéitől is s alkalmatosságaitól is mint fosztották meg [BIm 1001].

tanulóleányka 1609: Az dominus Martinusnak Aytaiara ahol az tanulo leankak ky iarnak ket vas pantot sarkostol attham $\mathrm{f}$ d 12 [Kv; Szám. 12b/IV. 107].

tányérasztalka ?kerekasztalka 1832: Egy kis kerek oszlopon állo Tányér asztalka [Sáromberke MT; TSb 26].

tányérocska tányérka 1737: Egy Ezűs Aranyos Tánygyérotska 1 [Nsz; Told. 2]; 1787: Egy csésze alá való tangyérocska [Kv; Ks 73. 55. 110].

tarackocska rövid csövű tábori lövegecske 1594: Az Varbeli hazakban ualo Inuentarium ... Az Azzoni Thar hazaban ... Egi kis tharachkochka meli az kis vre volt No. 1 [Somlyó Sz; UC 78. 7/22. 33-4]; 1620: Az Chyath hazban Taraczkochyka No. 1 [Kövár Szt; Borb. II]; 1662: Mindenestül való is harcra való emberem, négy vagy ötezer emberem ha lehetett ... Tarackocska négy [SKr 381]; 1664: Rettenetes keménységgel és vehementiával vagyon az németség, az magyar fizetett katonák is egyetértvén velek. Még azt mondják, hogy míg csak az hídat egészlen megcsináltatja is az ország (mivel ezen egy üres szekér is alig mehet ki s bé, nem hogy csak egy taraczkocskát is kivehetnének rajta) az idő alatt is azon dolgokat promoveálhatja ő felsége az török előtt [TML III, 288 Stepan Ferencz Teleki Mihályhoz]. targonca-szekerecske kétkerekű szekerecske 1822: a' Tisztelt Grof ur ŏ Nsága ... erdeib(en) az ö Nsága N Adorjáni erdő Pásztora által meg találtatván ket tehennel, egy Torgantza Szekeretskével fiaival [LLt].

tartóládácska kis tartóláda 1850 k.: 1 ezüst szinü tarto ládácska 12 pengoért csinálták [Kv; Pk 2].

tatárka Fagopyrum tataricum 1592: Tatarka chepelwe cb 7 1/4 [Kv; Szám. 5/XI. 15]; 1623: Moldouaboll az Neszter és Prwt melleöll, hauaselfeoldebeöll az Duna melleöl jgen jo fele eoregh zeöke disznokott vetessen 200 tenezteny valokot ... ha pedigh mak mikor sohont nem lenne thehat ollyankor tatarkauall zabbalis ketelen $\mathrm{kj}$ teleltettny [BGU 121]; 1736: Tatarka nr. 1 [Mikefva KK; CU XIII/1. 173]; 1744: Meg veszett Tatárka 27 [Marossztkirály MT; Told. 18]; 1745: Haritska Met. 11. Tatárka fél véka [Marossztkirály MT; Told. 18]; 1756: Törŏk Buza Met. 3. Tatárka Met. 2 1/2 [Piskinc H; JHb XXXV/35. 34]; 1763: Istennek hala, minden fele gabana Borso lentse tatárka len mag arpa alakar Zabotska Istennek hala minden vagyon [Kóród KK; Ks CII. 18 Szarka József tt kezével]; 1773: Ficzko Legénykorunkban lattuk ... hogy ... Szabo Ferencz egyszer bé keritette vala azon meg nevezett pusztát Uraság számára és kukuruzát s Tatárkát vétettek beléje [Ádámos KK; JHb XIX/15]; 1774: Kŏlest, Arpát, Alakort, Tőnkőlt, Tatárkát, és Haritskát ... nem szoktanak vetni [Szentdemeter U; LLt Vall. 14]; 1783: Teremiből ... A Tatárkát is el hozták ... a Tatárkát ezen Holnapnak vége felé lészen jó vetni, most nem bátorságos, gyenge Portéka lévén ... A Tatárka ... szapora Gabona, Sertések(ne)k igen jó, csak jó főldben vessék [JHb Árkosi Ferenc Csáki Katalinhoz]; 1823: Tatarca, harisca, Tragum, gi, m. 2 [Borb. II. 446].

tatárkavetés 1736: Vetések ... Tatárka vetés nr 2 [Mikefva KK; CU XIII/1. 175].

tavaszbúza-asztagocska tavaszbúzából rakott kis asztag 1812: Egy Tavasz Buza Asztagotska [M.gyerőmonostor K; KCsl 11]. 
távolabbacska messzebbecske 1810: Margita esik mint egy' őkőr szekérrel négy ora alat meg járhato tavulságra, más hely Tasnádon (!), mely távulabbacska vagyon [Pacal Sz; Ks 76. 444 Conscr.]; 1820: Thorda harmadfél postányi Kolosváron tul rakott uttal járhat, vagyon Gyalu távulobbatska [Bács K; KmULev. 2].

távolacska 1. kissé messzebb 1728: mihelylyen az Vrfi ... Czirmai nevŭ Szolgája, és iffiabbik Szotyori Ferencz Vram érkeztek, mindgjárást ă Sertéseket lŏdŏzni kezdették, s még akkor az vrffi távullocska volt [Hidvég Hsz; Mk I Joan. Barabás (56) jb vall.]; 1749: en mint hogj tavulotska voltam nem ŭsmerhettem kik légjenek [Balavásár KK; Ks 15. LXXVIII. 17]; 1767: Midőn Bukur Jánost az Utrizált Tanorok széllyin a határ kőzőtt meg támodták s verték ... magamis távulocska voltam onnan [Betlensztmiklós KK; BK]; 1769: házoktol távolotska széna kalangyái voltak [Bukuresd H; Ks]; 1779: mentek volt ki a Falubol ... az Expon(en)s Aszszony Malom főldére hatalmosul Csegzi Győrgyre Varga Peter s Varga Tamás az Exp(one)ns Aszszony Jobbagyi, kiket én a' szavokbol ismértem meg távulotska léven az aratoba [Berekeresztúr MT; BetLt 6]; 1784: Vagyon égy bor, vagy inkább gyümőlts 's Vetemény tarto Főldbe ásott szalmával fedett pintze az Udvar Háztól távulatska [Burjánosóbuda; JHbK 9. LX. 18]; 1794: Ezen kivül tőbbet nem tudunk se nem láttunk, mivel távolatska lakunk [Déva; Ks]; 1800: tavulotska lévén és a Szászok őszve tsoportozván nem láthottam [O.solymos KK; Ks 67. 47. 27]; 1810: a' Vintzellér Társának puskáját, távolatska lévén tŏlle fel tamosztva el vettem [Görgénysztimre MT; Born. G. XIV. 1 Pap Danyila (43) vall.]; 1827: égy kicsit Tavulatska husztom volt meg magamat az Malamtol [Szind TA; EMLt Mészkői cs. lev.].

Szk: kevéssé 1841: kevéssé tavulatska, égyszer tsak látom hogy a' fŏldbŏl hirtelen kék lang jŏnn fel [KLev. 11].

2. $n$ kissé távolabb/messzebb 1754: láttam az embereket ez előtt mint egy három hetekkel ... ott rokásban láttam őket de távulatskán lévén tőllek mindeniket nem ismerhettem meg [Tóhát AF; JHb Dumitru Csuka (60) zs vall.]; 1756: tavullatskán állok állok (így!) vala [Bencenc H; BK 1143 Tot Marián (37) jb vall.]; 1759: mind kettenn távolatskán voltunk nem láthattuk [Árpástó SzD; BK. Füldrán Márkony (44) és Joh. Szász (35) zs-ek vall.]; 1765: az elegett epŭleten kivŭl meg fedelmé kert volt azis nem éppen a pajta mellett hanem tavolatskan [Pálos NK; Hr 1/29]; 1769: az utrizált erdŏhöz közelis kivált amelly szomszédcságában volna éppen nem bir Barótzi Uram, hanem tavolyatskán tölle a Bagyoni Sandor Uram részét birja ŏ kglme zálogban [Ispánlaka AF; JHb XXVIII/53]; 1770: háttal állottunk arrol ameröl ... Tiszt Ur(am) jött, én még távollocskán felénk jövén meg Látván a kalapomat le vettem [Konkolyfva SzD; Ks 20. XII. 10]; 1771: a' Gyermekek két Fejér haju Gyermekek valá(na)k de távulocskán lévén világosson meg nem ismérhettem s nem vallhatom ki tseledgyei volta(na)k [Berekeresztúr MT; BetLt 7 Lad. Siklodi (33) vall.]; 1792: Midőn az Utrumban Specificált Juhok bé hajtattak ... távoltaskán lévén lát(t)am hogy tulajdon a' mi Galgai határunkon legelnek a' buza főldeinken [Galgó Sz; JHb I/22].

távolkán kissé távolabb 1657: Erre én a fejedelemmel ugyan pirongató kemény szókkal is írattam, de addig halogatá, hogy az ellenség is megértvén ugyan az én szerencsi földvárnál lételemet is, igyekezik vala reám jüni, de azonban nyelvet fogván az Ibrányi hadából, minden állapotjának végére ment, mind az helynek alkalmatosságának, rossz vigyázásának és tőlem is távolykán lételének [KemÖn. 257].

távolkábban kissé távolabb 1663: Kérem, tovább is ha mit érthet, tudósítson, távulykábban lételemben is [TML II, 614 Teleki Mihály Kászoni Mártonhoz]; 1702: ŏ kglme egj kitsineg tavolkábban ült [Tarcsafva U; Pf]. 


\section{SUFIXELE DIMINUTIVE ALE LIMBII VECHI DIN TRANSILVANIA}

Cercetarea sufixelor diminutive, respectiv a cuvintelor derivate cu ajutorul acestora nu a stat în centrul atenției ştiințifice.

Sufixele diminutive constituie o grupă aparte a afixelor denominative. Rolul lor constă nu în formarea unor cuvinte noi, ci în nuanțarea semnificațiilor cuvintelor - astfel ele nu pot fi numite sufixe tipice. Formarea, respectiv apariţia lor îşi are rădăcina în atitudinea vorbitorilor, respectiv în necesitatea de a evita monotonia folosirii aceloraşi expresii. Particularitatea diminutivelor se regăseşte în caracterul lor ludic.

Astfel diminutivele apar în majoritatea limbilor ca un fel de exprimare a sentimentelor, dar frecvența, productivitatea şi sistematizarea lor diferă în funcție de fiecare limbă. În limba engleză sufixele diminutive apar într-un număr mai mic în comparație cu celelalte limbi europene (cum ar fi limba spaniolă, italiană, rusă), dar de exemplu în limba suedeză nu există aproape nici un sufix diminutiv cu excepția unor derivate lexicalizate. Limbile diferă şi în ceea ce priveşte sistemul sufixelor diminutive: în limba maghiară şi germană există doar una sau două variante (-cskal-cske, -kal-ke; -lein, -chen) în comparație cu limba rusă unde sufixele diminutive formează un sistem complicat, sistem din care vorbitorii aleg varianta cea mai potrivită în baza caracteristicilor semantice şi pragmatice (Bronislava 1987, Dahl 2006: 594).

Pe lângă nenumăratele modificări, categorira sufixelor diminutive arată o relativă constanță: chiar dacă de-a lungul istoriei limbii au apărut noi elemente pentru exprimarea lingvistică a diminuării (deci volumul sufixelor existente a crescut), semantica lor a rămas neschimbată, putând fi depistate doar nuanțări semantice. O altă trăsătură importantă a acestei grupe de sufixe este că formele arhaice nu au dispărut nici ele, câteva forme se regăsesc şi în prezent în diferitele dialecte ale limbii maghiare. Funcția sufixului -csa/-cse din a doua parte a perioadei denumite epoca maghiarei vechi s-a redus la formarea unor substantive proprii cu sufix diminutiv (de ex. Ancsa, Borcsa, Julcsa - nume proprii), dar în dialectul slavonic acest sufix a rămas principalul sufix diminutiv până la începutul secolului 20. (de ex. aprócsa, egércse, küszöbcse / în traducere: micuță, şoricel, prăguleț/), acesta apărând chiar şi în adverbe (de ex. nagyszerücsén / în traducere: formidabiluț) (Zsilinszky 2003: 181). 
Obiectivul cercetării a fost analizarea sufixelor diminutive şi a elementelor lexicalizate formate cu ajutorul acestor sufixe din perioada secololelor 16-19., ce apar în Dicționarul istoric al limbii maghiare din Transilvania. Am ales această temă, deoarece ca şi redactor al Dicționarului istoric mi-am dat seama că această operă lexicografică este foarte bogată în date lingvistice. Cercetarea perioadei şi regiunii alese precum şi baza de date analizată se încadrează perfect în rândul cercetărilor din domeniul istoriei limbii, totodată îmbogățind aceste cercetări, deoarece nu s-a elaborat până în prezent nici un studiu privind acest subsistem al sufixelor denominative.

Studierea sufixelor diminutive constituie un fragment foarte mic al cercetărilor lingvistice, fragment despre care aparent - precum şi văzând numărul mic al lucrărilor publicate în domeniu - nu se pot spune multe. Totuşi, cu ajutorul unor analize mai detaliate observăm că, prin folosirea mai multor puncte de vedere şi metode de cercetare, vom obține multe date privind utilizarea şi frecvența acestor sufixe în limba maghiară din Transilvania a secolelor 16-19. Rezultatele cercetărilor se referă la limbajul comun regional folosit în Transilvania în secolele menționate mai sus (ele din punct de vedere al istoriei limbii sunt epoca medie şi epoca nouă), aşa cum acest lucru reiese şi din titlul dicționarului, care arată că datele conținute sunt date lingvistice ale regiunii orientale ale teritoriului lingvistic maghiar.

Caracterul specific al subiectului necesită aplicarea mai multor puncte de vedere în cursul efectuării cercetărilor. Astfel a fost necesară lărgirea orizontului analizei morfologice aplicată de regulă în cursul analizării sufixelor, cu alte aspecte lingvistice relevante. Punctele de vedere şi metodele folosite în gramaticile descriptive clasice sunt îmbogățite prin utilizarea unor puncte de vedere ce se bazează pe detalii sociolingvistice şi pragmatice, respectiv pe aspecte din domeniul geolingvisticii.

Studiul nu se extinde asupra sufixelor diminutive sau a celor denominale existente în limba maghiară contemporană (din Transilvania sau din Ungaria).

Scopul acestei lucrări este descrierea sistemului sufixelor diminutive existente în limba maghiară folosit în Transilvania din perioada secolelor 16-19, precum şi stabilirea regulilor de sufixare, descrierea trăsăturilor morfologice, sintactice, morfopragmatice, prezentarea caracteristicilor sociolingvistice şi geolingvistice. 


\section{ABSTRACT}

\section{DIMINUTIVE SUFFIXES IN THE OLD HUNGARIAN IN TRANSYLVANIA}

The analysis of diminutive suffixes and the diminutive derivatives has been marginalized in the linguistic descriptions.

Diminutive suffixes form a special group of denominal nominalizing suffixes. Their primary role is not the creation of new words but the expressions of semantic nuances, and that is why they cannot be considered typical suffixes. Their formation, their apparition is rooted in the attitudes of the speakers, in the linguistic ambition to avoid plainness in phrasing. The most important characteristic of diminution lies in its playfulness.

As a result of this, diminutive suffixes have significantly spread in the different languages, nevertheless their frequency, productivity, their systemic nature differs in all these languages. In English, for example, there are relatively few diminutive suffixes in comparison with other European languages (Spanish, Italian, Russian), while in the Swedish language except for some lexicalized derivatives there are no diminutives at all. On the other hand there are differences in complexity of the systems between the different languages. In the Hungarian and German languages there are only a few formants available to the speakers (-cskal-cske, -kal-ke; -lein, -chen), while in Russian diminutives form a complex system, and speakers can choose the most appropriate one according to their semantic and pragmatic features (Bronislava 1987, Dahl 2006: 594).

The category of diminutive suffixes shows a certain kind of consistency throughout the history of the language: although during the periods of the history of the language some new elements appeared to express diminution, their group thus being enlarged, their meaning basically stayed the same, the modifications add nuances only. Another particular characteristic of this group of suffixes is that the ancient formants have not disappeared, they still exist in a few derivatives and in some dialects. The function of -csa/-cse from the second half of the Old Hungarian period was limited to the creation of pet names (e.g. Ancsa, Borcsa, Julcsa), in the Slavonian dialect this was the most frequent diminutive at the beginning of the $20^{\text {th }}$ century (e.g. aprócsa, egércse, küszöbcse), moreover it was not rare in adverbs, either (e.g. nagyszerücsén) (Zsilinszky 2003: 181).

The subject of this research was the analysis of the $16-19^{\text {th }}$ century diminutives in the Transylvanian Hungarian Historical Dictionary (THHD), as well as that of the diminutive derivatives (which may be lexicalized). I chose this particular subject 
because as an editor of the THHD I realized that this dictionary provides extremely rich linguistic data. The analysis of the determined period and region based on the marked data constitutes an organic part of other researches in language history, completing them, as such an extensive analysis has not been carried out on this group of the denominal nominalizing suffixes.

The analysis of diminutive suffixes represents a small fraction of the linguistic research, in connection of which - mainly based on the bibliography - one cannot say much. Nevertheless during the more thorough analysis it became obvious that applying several aspects we can get a detailed picture of the use of diminutives in the Old Hungarian language in Transylvania. The results of the analysis refer to the Transylvanian regional standard of the period stated above (from the point of view of language history the Middle and New Hungarian period), because as the title of the THHD suggests, it contains the linguistic data of the Eastern Hungarian speech area.

Due to the specific nature of the subject it was a requirement to perform a thorough analysis from as many perspectives as possible. As a result of which I enlarged the traditional description of diminutives - which is based on morphological aspects -, and I took into consideration their sociolinguistic determination, pragmatic character, geographic distribution.

The research was not extended to the present day diminutives (from the Transylvanian or Hungarian dialects), nor to other denominal nominalizing suffixes.

The aim of this work is the presentation of the diminutive suffixes used in the Old Hungarian language in Transylvania (16-19 $9^{\text {th }}$ century), as well as the description of their connection rules, morphological, syntactic, morphopragmatical, semantic features, their sociolinguistic determination and geographic distribution. 

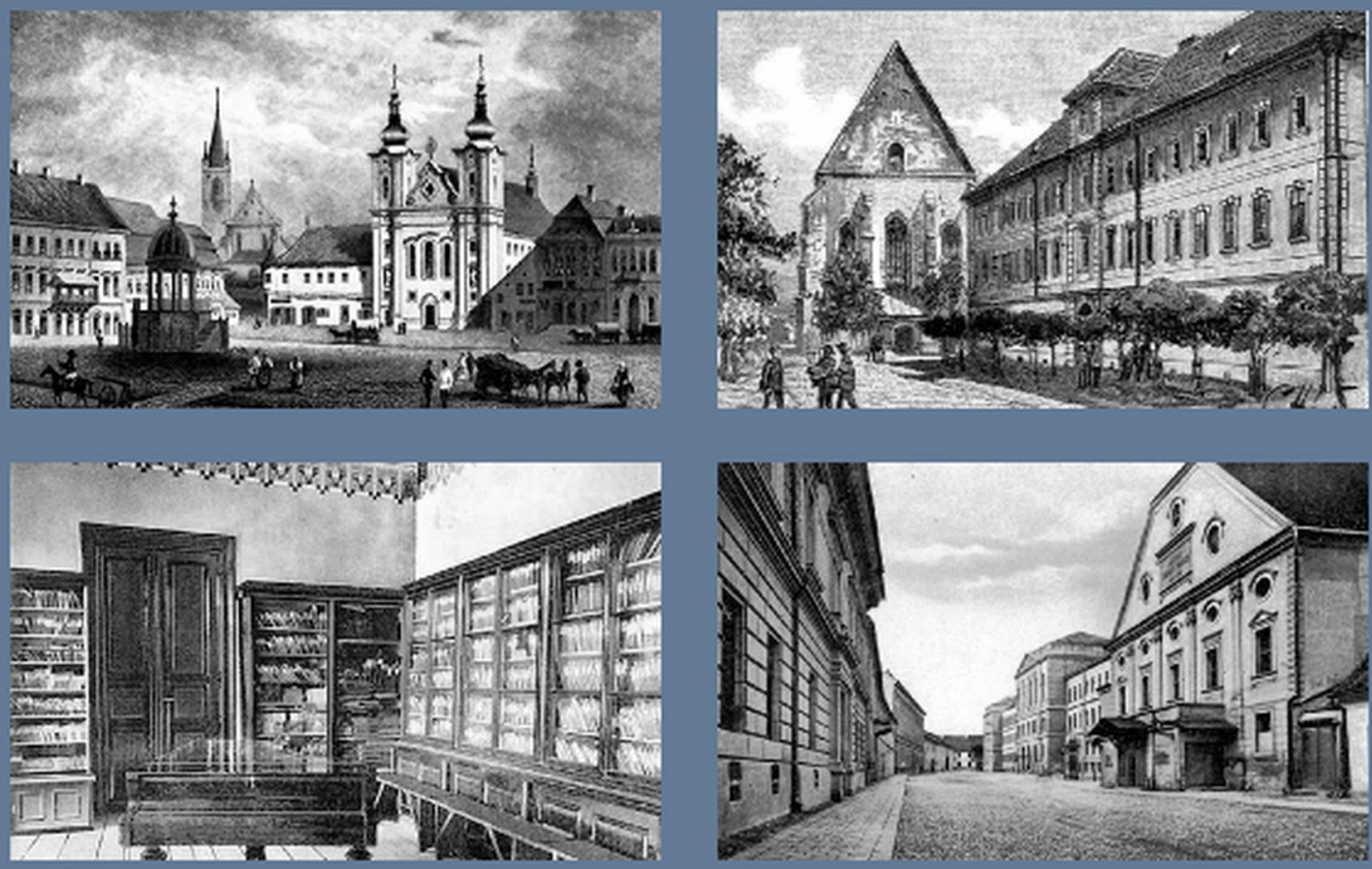

A kicsinyítő képzők vizsgálata a nyelvészeti kutatások igen kis szeletét képezi, hiszen látszólag a funkciójuk „csupán” abban merül ki, hogy az alapszót a 'kis, kicsi' jelentésjeggyel kiegészítsék. Az alaposabb vizsgálatok azonban azt mutatták, hogy több elemzési szempont figyelembevételével részletes képet kaphatunk a denominális névszóképzők ezen részrendszeréről. A kutatások az Erdélyi magyar szótörténeti tár 16-19. századi adatai alapján történtek. Az elemzés eredményei az említett időszak (nyelvtörténeti szempontból közép- és újmagyar kor) erdélyi regionális köznyelvére vonatkoznak.

ISBN 978-606-8178-24-0

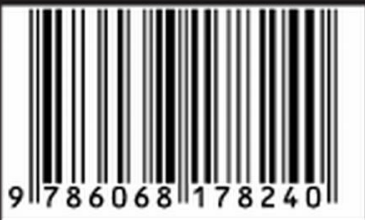

